\title{
The Morgan Hill, California, Earthquake of April 24, 1984
}

\section{U.S. GEOLOGICAL SURVEY BULLETIN 1639}




\section{The Morgan Hill, California, Earthquake of April 24, 1984}

Seena N. Hoose, Editor 


\section{DEPARTMENT OF THE INTERIOR DONALD PAUL HODEL, Secretary U.S. GEOLOGICAL SURVEY \\ Dallas L. Peck, Director}

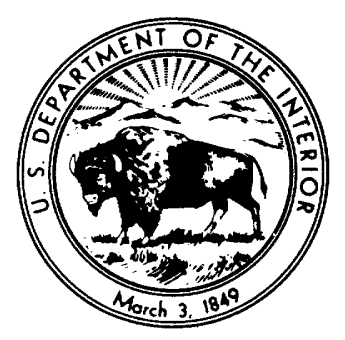

For sale by the Books and Open-File Reports Section U.S. Geological Survey Federal Center, Box 25425

Denver, CO 80225

Library of Congress Cataloging-in-Publication Data

Main entry under title:

The Morgan Hill, California, earthquake of April 24, 1984.

(U.S. Geological Survey Bulletin 1639)

1. Earthquakes-California-Morgan Hill. I. Hoose, Seena

N. II. Series: United States. Geological Survey. Bulletin 1639.

QE75.B9 no. 1639

[QE535.2.U6]

$557.3 \mathrm{~s}$

86-600306

$557.3 \mathrm{~s}$
$\left[551.2^{\prime} 2^{\prime} 079473\right]$


Chapter 1. The Morgan Hill earthquake: An overview, by Seena N. Hoose 1

2. The earthquake and its aftershocks, April 24 through September 30,1984 , by Robert S. Cockerham and Jerry P. Eaton 15

3. Location, focal mechanism, and magnitude of the main shock, by Jerry P. Eaton 29

4. Source parameters for two aftershocks, by Ralph J. Archuleta, John Watson, Jon B. Fletcher, and Eugene Sembera 33

5. Processing of strong-motion recordings from the main shock, by A.G. Brady, R.L. Porcella, G.N. Bycroft, E.C. Etheredge, P.N. Mork, Barry Silverstein, and A.F. Shakal 53

6. The search for surface faulting, by Katherine K. Harms, Ma l colm M. Clark, Michael J. Rymer, Manuel G. Bonilla, Edwin L. Harp, Darrell G. Herd, Kenneth R. Lajoie, James J. Lienkaemper, Scott A. Mathieson, James A. Perkins, Robert E. Wallace, and Joseph I. Zi ony $\quad 61$

7. Surface displacement near Hollister, California, by Jon S. Galehouse and Beth D. Brown 69

8. Earthquake-triggered lands lide at La Honda, Cal ifornia, by Gerald F. Wieczorek and David K. Keefer $\quad \mathbf{7 3}$

9. Near-surface geology and seismic-wave velocities at six strong-motion stations near Gilroy, California, by Thomas E. Fumal, James F. Gibbs, and Edward F. Roth 81

10. Ground-failure damage and liquefaction near Morgan Hill, by T. Leslie Youd $\mathbf{8 9}$

11. Structural damage near Morgan Hill, by Scott A. Mathieson 93

12. Distant resonance effects of the earthquake--a preliminary study, by Mehmet Celebi 105

13. Response of U.S. Geological Survey creepmeters near Hollister, California, by Sandra S. Schulz 111

14. Alignment-array measurements in the San Felipe Valley, California, by Beth D. Brown 117

15. Theodolite measurements, by Jon $S$. Galehouse 121

16. Tiltmeter observations, by C.E. Mortensen and R.P. Liechti 125

17. Magnetic-field measurements, by R.J. Mueller and M.J.S. Johnst on 129

18. Ground-water observations, by Chi-Yu King and David Basler

19. Computer plots of strong-motion results from the main shock, by A.G. Brady, R.L. Porcella, G.N. Bycroft, E.C. Etheredge, P.N. Work, Barry Silverstein, and A.F. Shakal 139

PLATE

1. Sites of investigation for ground rupture following the April 24, 1984, Morgan Hill, Cal i fornia, earthquake In pocket 
Any use of trade names and trademarks in this publication is for descriptive purposes only and does not constitute endorsement by the U.S. Geological Survey. 


\title{
The Morgan Hill Earthquake: An Overview
}

\author{
By Seena N. Hoose
}

\section{CONTENTS}

\author{
Introduction 1 \\ Geologic and tectonic setting \\ Seismologic setting 5 \\ Postearthquake observations 7 \\ Seismologic observations 7 \\ Geologic observations 10 \\ Engineering observations $\mathbf{1 0}$ \\ Geodetic observations $\mathbf{1 1}$ \\ Conclusions and implications 12 \\ References cited $\mathbf{1 2}$
}

\section{INTRODUCTION}

The Morgan Hill earthquake, a moderate-size $\left(M_{s}=6.1, M_{L}=6.2, M=6.2\right)$ event, was felt throughout central California on April 24, 1984. The epicenter of the earthquake was located near Halls Valley southwest of Mount Hamilton, and the event is presumed to have occurred on the Calaveras fault. Damage, however, was concentrated near the south end of the Anderson Reservoir and in the town of Morgan Hill. A preliminary assessment by the California Office of Emergency Services estimated damage to private property at $\$ 7.0$ million and to local-government facilities at $\$ 0.5$ million, for a total of $\$ 7.5$ million in damage.

Acknowledgments.--I appreciate the helpful suggestions of Joseph I. Ziony and Robert D. Brown, Jr. These studies were aided by the generous cooperation of the many landowners who permitted access to their properties.

\section{Geologic and Tectonic Setting}

The Calaveras fault is one of many active faults in the complex San Andreas fault system, the transform plate boundary between the Pacific and North American plates in the San Francisco Bay region. The San Andreas fault system also includes the Hayward, Sargent, San Gregorio, Silver Creek, and many other faults (fig. 1.1). The Calaveras fault diverges from the east side of the San Andreas fault

south of the town of Hollister. The Hollister and Santa Clara Valleys lie between the San Andreas and Calaveras faults.

The overall sense of plate motion is right lateral, and both the San Andreas and Calaveras fuults are right-lateral strike-slip faults. The orientation of the San Andreas fault ranges from N. $35^{\circ}$ to N. $37^{\circ} \mathrm{W}$., believed to generally parallel the plate boundary. The orientation of the Calaverus fault is N. $27^{\circ} \mathrm{W}$., and individual segments deviate as much as $24^{\circ}$ from the general fault direction.

Relative motion between the Pacific and North American plates is $5.6 \pm 0.3 \mathrm{~cm} / \mathrm{yr}$ (Minster and Jordan, 1978), accommodated in a broad zone between the continental slope and the Sierra Nevada, but primarily concentrated along the San Andreas fault system. Within this fault system, transform plate motion is recognized by geodetic measurements, observed creep, seismicity, and offset geologic units.

Using geodetic methods, Prescott and others (1981) measured $1.22 \pm 0.39 \mathrm{~cm} / \mathrm{yr}$ of right-lateral deformation in a zone a few kilometers wide along the San Andreas fault on the San Francisco peninsula, although the fault itself is not creeping. Aydin and Page (1984) determined approximately $0.7 \mathrm{~cm} / \mathrm{yr}$ of movement across the Hayward fault zone and 0.7 $\mathrm{cm} / \mathrm{yr}$ across the Calaveras fault zone, using techniques similar to those of Prescott and others. Geologic evidence indicates 0.01 to $0.07 \mathrm{~cm} / \mathrm{yr}$ of movement on the Greenville fault (Sweeney, 1982; Wright and others, 1982). Offset marine terraces along the San Gregorio-Hosgri fault indicate an average slip rate of about $0.6 \mathrm{~cm} / \mathrm{yr}$ during the past 
200,000 years (Weber and Lajoie, 1977). Aydin and Page (1984, p. 1308) concluded, "Thus the aggregate dextral motion rate across the area shown in Figure 1 [1.1] is probably on the order of $3.6 \mathrm{~cm} / \mathrm{yr}--\mathrm{a}$ result consistent with an earlier geodetic determination of $3.2 \pm 0.5 \mathrm{~cm} / \mathrm{yr}$ " (Savage and Burford, 1973).

Some plate motion is accommodated by creep along active faults. South of Hollister, the San Andreas fault is creeping at a rate locally as high as 20 $\mathrm{mm} / \mathrm{yr}$, but more commonly from 8 to $13 \mathrm{~mm} / \mathrm{yr}$
(Nason, 1973). The San Andreas fault is locked from near San Juan Bautista northward through the peninsula and into Marin County. The San GregorioHosgri fault is also locked through the peninsula. Just south of Hollister, creep along the San Andreas fault transfers to the Paicines-Calaveras fault. The creep rate along the Calaverus fault in and near the town of Hollister is from 9 to $13 \mathrm{~mm} / \mathrm{yr}$ (see chap. 5), decreasing northward. Apparently, the segment of the Calaveras fault that includes the aftershock zone of

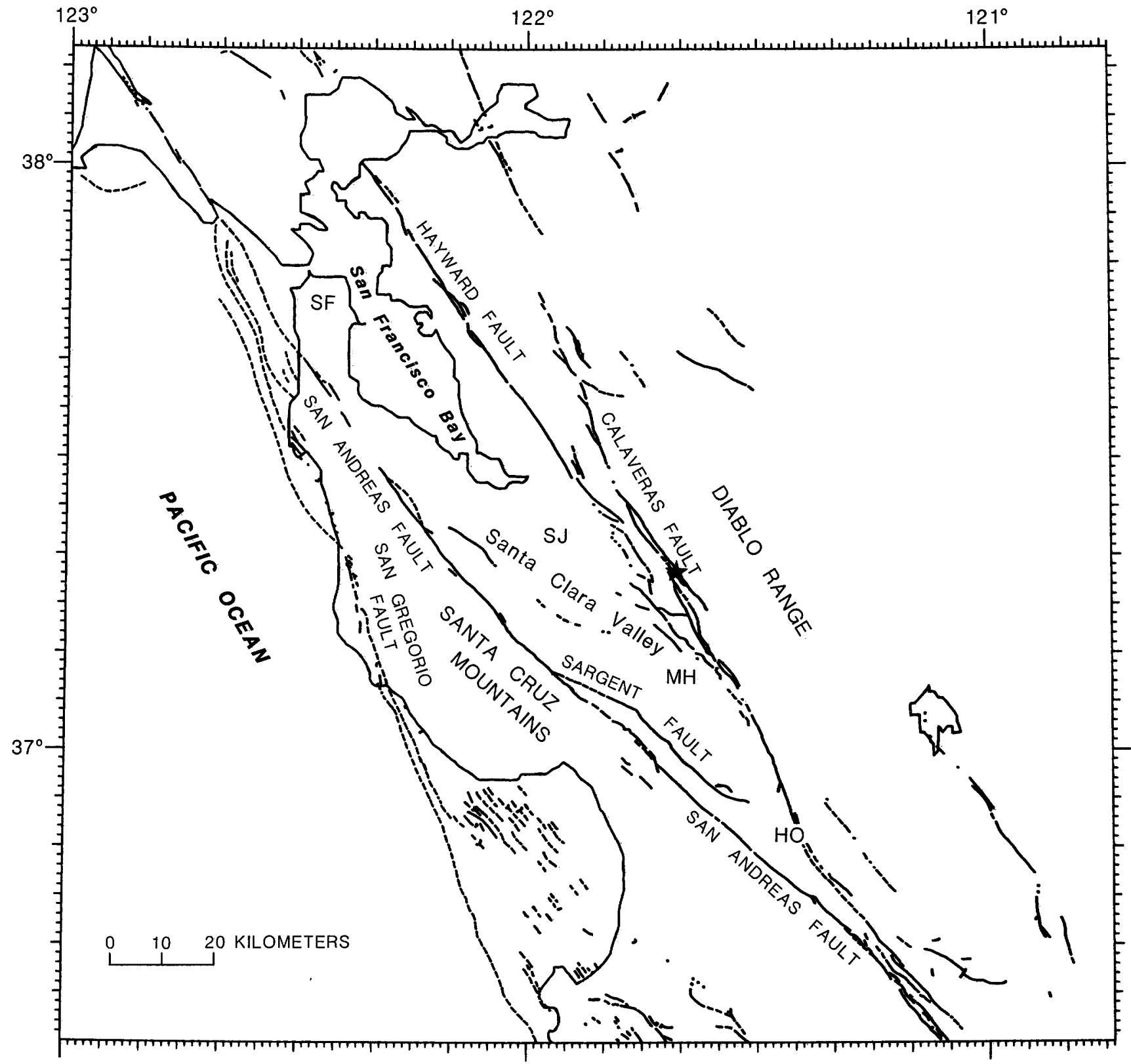

Figure 1.1. San Francisco Bay region, showing locations of active faults (dashed where inferred) and epicenter of the Morgan Hill earthquake (star). HO, Hollister; MH, Morgan Fill; SF, San Francisco; SJ, San Jose. From Jennings (1975). 
the Morgan Hill earthquake was not creeping before the earthquake. All of the creep and much of the seismicity on the Calaverus fault are transferred to the Hayward fault from the vicinity of the Calaveras Reservoir northward (Page, 1984, p. 116).

Plate motion not accounted for by creep is accommodated by regional struin and by slip on faults during earthquakes. Seismicity is associated with active faults throughout the bay region, although seismicity is not entirely confined to recognized faults. The seismologic setting is discussed below.

The summury of bay-region tectonics by Aydin and Page (1984) presents the regional geology, as shown in figure 1.2. The San Andreas fault separates two fundamentally different terranes that have been brought together by right-lateral movement along the transform fault during Cenozoic time (Dibblee, 1980). West of the San Andreas fault zone, the Salinian block (Ross, 1978; Page, 1982a) basement is composed of the granitic rocks of Montara Mountain and the Ben Lomond Quartz Diorite (Baldwin, 1967) and associated metamorphic rocks of Cretaceous age. East of the San Andreas fault, the basement is the late Mesozoic Franciscan Complex (Bailey and others, 1964; Berkland and others, 1972). The Franciscan Complex includes coherent blocks of sundstone, greenstone, and chert, and a melange of highly sheared shale and serpentinite enclosing blocks of graywacke, basaltic greenstone, chert, and other rocks. This subduction-zone complex is partially metamorphosed and severely deformed.

West of the San Andreas fault, a thick sequence of Paleocene and Eocene marine sedimentary rocks is in depositional contact with the underlying Salinian basement. East of the Sun Andreas fault, Upper Jurassic to uppermost Cretaceous marine sandstone and mudstone of the Great Valley sequence are in fault contact with the Franciscan basement.

Miocene deposits are similar on both sides of the San Andreas fault and include deep-water marine clastic sedimentary rocks, siliceous mudstone, and porcellanite, such as the Monterey Formation. These Miocene deposits locally include mafic and intermediate volcanic rocks. Semiconsolidated Pliocene sedimentury rocks unconformably overlie older rocks and include marine-shelf deposits and some nonmarine sandstone.

Pliocene and Pleistocene nonmarine unconsolidated sediment, such as the gravels of the Santa Clara Formation, is found in many parts of the bay region. The Santa Clara and Hollister Valleys are covered with Holocene alluvial deposits, and the San Francisco Bay is underlain by Pleistocene and Holocene estuarine and alluvial deposits, as much as a few hundred meters thick. Coastal marine terraces are covered with a thin deposit of Quaternary sediment.

Folds, thrust faults, and normal faults are related to strike-slip faulting throughout the bay region. Pliocene and Pleistocene nonmarine sediment is folded and faulted, as are all the older rocks. In many places, Holocene deposits have also been of fset by faulting. Deformation indicates that some of these structures began to form during the middle or late Miocene and that nearly all have been active during Pliocene and Quaternary time (Aydin and Page, 1984, p. 1308). Pre-Miocene deformation is related to subduction processes, and some of these structures may be reactivated by transform tectonics.

The East Bay Hills structural domain of Aydin and Page (1984; see Aydin, 1982; Page, 1982b, c, 1984) lies between the Diablo Range and the Santa Clara Valley. The boundaries of the East Bay Hills domain are the Culaveras fault zone on the east and the Hayward fault zone on the west, and a series of thrust faults continuing southward from the Hayward fault zone (fig. 1.3). The region affected by the Morgan Hill earthquake is in the southern part of the East Bay Hills domain, where the west boundary of the domain is a series of thrust faults dipping northeast, toward the Calaveras fault zone.

Geologic maps of the Calaveras fault zone (see chap. 6; pl. 1) show a complex zone of discontinuous fault strands. In some areas, the fault is obscured by landslides, recently deposited alluvium, and reservoir waters. Fault strands are straight to curvilinear, and there is no clear, consistent echelon pattern to the left and right stepovers between fault strands. The fault is near-vertical. In map view, the Calaveras fault zone is angular, with several bends in its strike. Various segments of the fault deviate from the general strike of the fault zone by as much as $24^{\circ}$, and the angle between adjacent fault segments ranges from $3.5^{\circ}$ to $22^{\circ}$ (Page, 1984, p. 112).

Echelon folds and thrust and reverse faults are common in the East Bay Hills domain, as elsewhere in the Coast Ranges. "The trends of the fold axes are similar to those of the reverse faults, that is, most are oblique to, but some are parallel with, the main strikeslip zones" (Aydin and Page, 1984, p. 1309). Several faults, such as the Silver Creek and Coyote Creek faults, that trend parallel to the major strike-slip faults curve abruptly and connect with the strike-slip faults. Aydin and Page (1984, p. 1313) attributed the relation between the folds, the reverse and thrust faults, and the strike-slip faults to compression of the entire East Buy Hills domain due to the left stepover between the Calaveras and Hayward-Rodgers Creek faults (inset, fig. 1.3).

Stepovers between discontinuous fault strands in a right-lateral fault system behave differently, depending on the direction of the stepover. Rightstepping discontinuities cause tension, whereas leftstepping discontinuities cause compression (Rodgers, 1980; Segal and Pollard, 1980). This difference is expressed as pullapart basins at right stepovers, such as Halls and San Felipe Valleys, and Coyote and San Felipe Lakes; and as uplift at left stepovers, such as the foothills ridge between Anderson Lake and the Santa Clara Valley.

Fault complexities observed at the surface (bends, changes in strike, left and right stepovers, related reverse and thrust faulting, and other discontinuities) appear to exist at depths where earthquakes are generated along the Calaverus fault zone (Bakun, 1980; Reasenberg and Ellsworth, 1982). Mavko (1982) proposed that different segments of the fault would have a different likelihood of producing earthquakes, depending on the geometry of the fault and the forces acting on a particular fault segment. Fault complexities and segments of the fault where slip is difficult may become the loci of repeated eurthquakes 


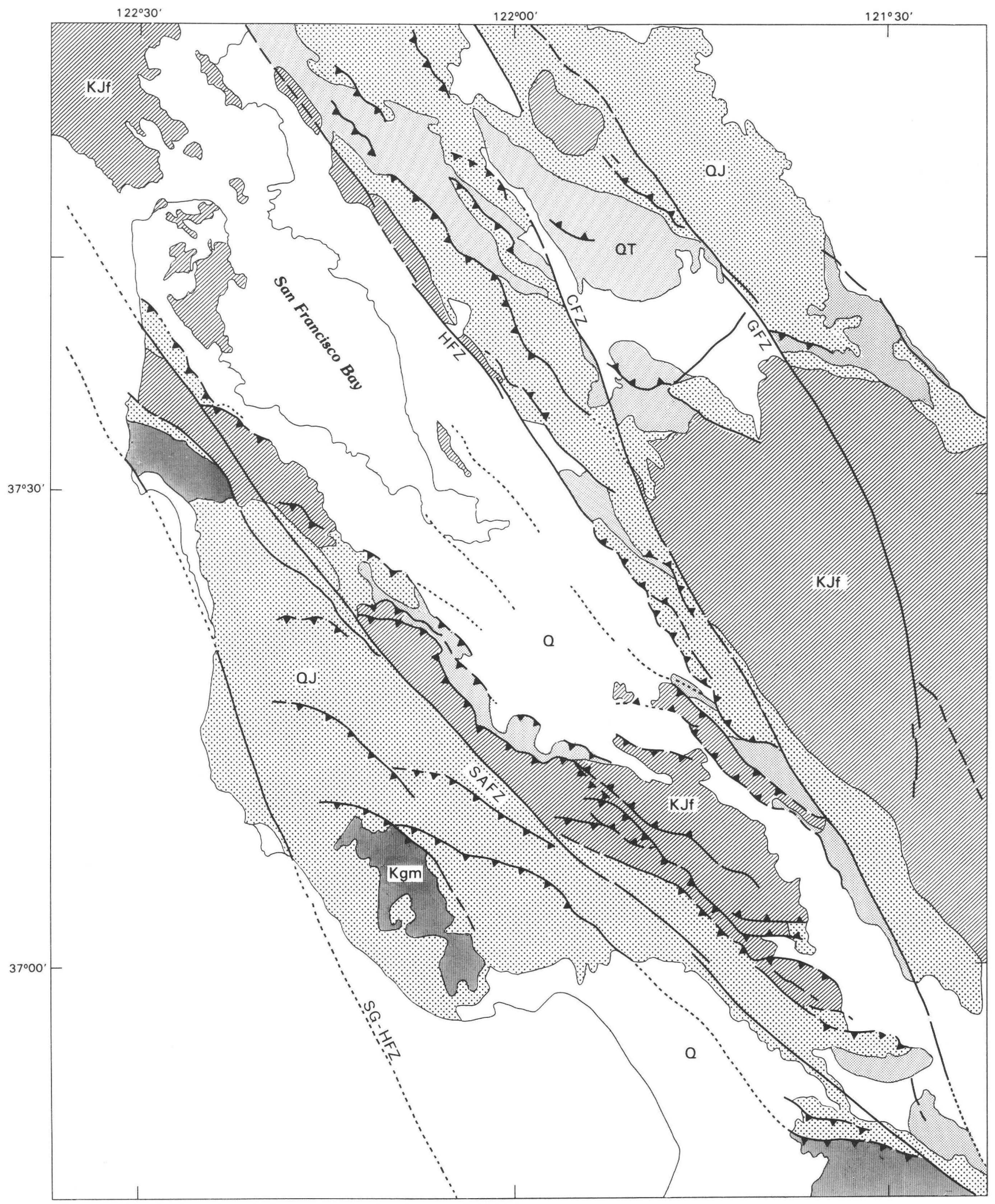

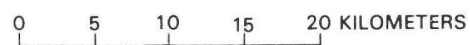

Figure 1.2. Simplified geologic map of the San Francisco Bay region, modified from Aydin and Page (1984, fig. 2). Fault zones: CFZ, Calaveras; GFZ, Greenville; HFZ, Hayward; SAFZ, San Andreas; SG-HFZ, San GregorioHosgri. 
in the Calaveras fault zone (Bakun, 1980). These fault complexities appear to have influenced the locations of the Morgan Hill and Coyote Lakes earthquakes and their aftershocks.

\section{Seismologic Setting}

Earthquakes of $\mathbf{M}>5$ occurred along the south half of the Calaveras fault in 1897, 1911, 1949, 1955, 1979, and 1984. On June 20, 1897, an $\mathbf{M}=6$ earthquake occurred along the same segment of the Calaveras fault system as the August 6, 1979, Coyote Lake earthquake, on the basis of an analysis of historical accounts and intensity data by Toppozada and others (1981). "If the 1979 earthquake represents a repeat of the 1897 event, then it is possible that the hypocentral region of the fault was locked for as much as 82 years between events" (Reasenberg and Ellsworth, 1982, p. 10652).

An instrumentally recorded earthquake of $\mathbf{M}=6.6$ occurred on July 1, 1911 (Richter, 1958, p. 469; Toppozada, 1984), near Mount Hamilton. If the epicenters of aftershocks of that earthquake are constrained to the Calaveras fault, published information is adequate to locate them. The 1911 aftershock epicenters plot within a 20-km-long zone from near Mount Hamilton southeastward to the 1979 Coyote Lake main-shock epicenter (Bufe and others, 1979). This zone, which is basically equivalent to the

\section{EXPLANATION}

\section{Q}

Quaternary sedimentary rocks, mainly flat lying

\section{ar}

Quaternary to upper Miocene sedimentary rocks, folded

\section{QJ}

Quaternary to Upper Jurassic marine sedimentary rocks, folded

\section{$\mathrm{Kgm}$}

Cretaceous granitic plutons and metamorphic rocks (Salinian basement)

$$
\text { Kust }
$$

Cretaceous and Jurassic Franciscan Complex (includes ophiolite); oceanic and terrigenous rocks, highly deformed

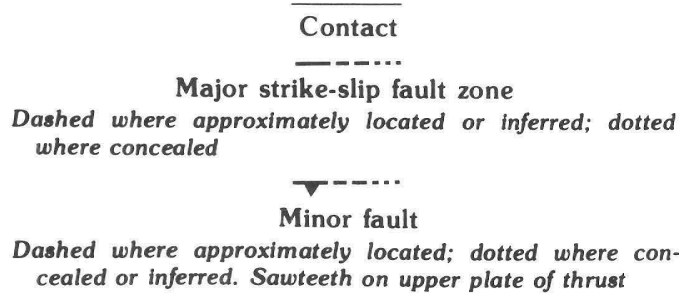

Figure 1.2. Continued aftershock zone of the Morgan Hill earthquake (fig. 1.4), indicates a recurrence interval of 73 years for that segment of the fault. In 1980, it was recognized that a repeat of the 1911 event might reasonably be expected. No short-term precursors were noted, however, and the time of the Morgan Hill earthquake was not predicted, although both its magnitude and location had been anticipated in 1980 (Bakun, 1980; Bakun and others, 1984).

The 1979 Coyote Lake earthquake $\left(\mathrm{M}_{\mathrm{L}}=5.9\right)$ occurred on the section of the Calaveras fault immediately to the southeast of the Morgan Hill earthquake rupture zone (Bakun, 1980; Reasenberg and Ellsworth, 1982). The $1949 \mathrm{MI}_{\mathrm{L}}=5.2$ shock was located in the southeastern part of the 1979 Coyote Lake aftershock zone (Bufe and others, 1979).

During the past 6 years, several $\mathrm{M}_{\mathrm{L}}=3-4$ earthquakes have occurred immediately to the northwest of the Morgan Hill earthquake rupture zone, including

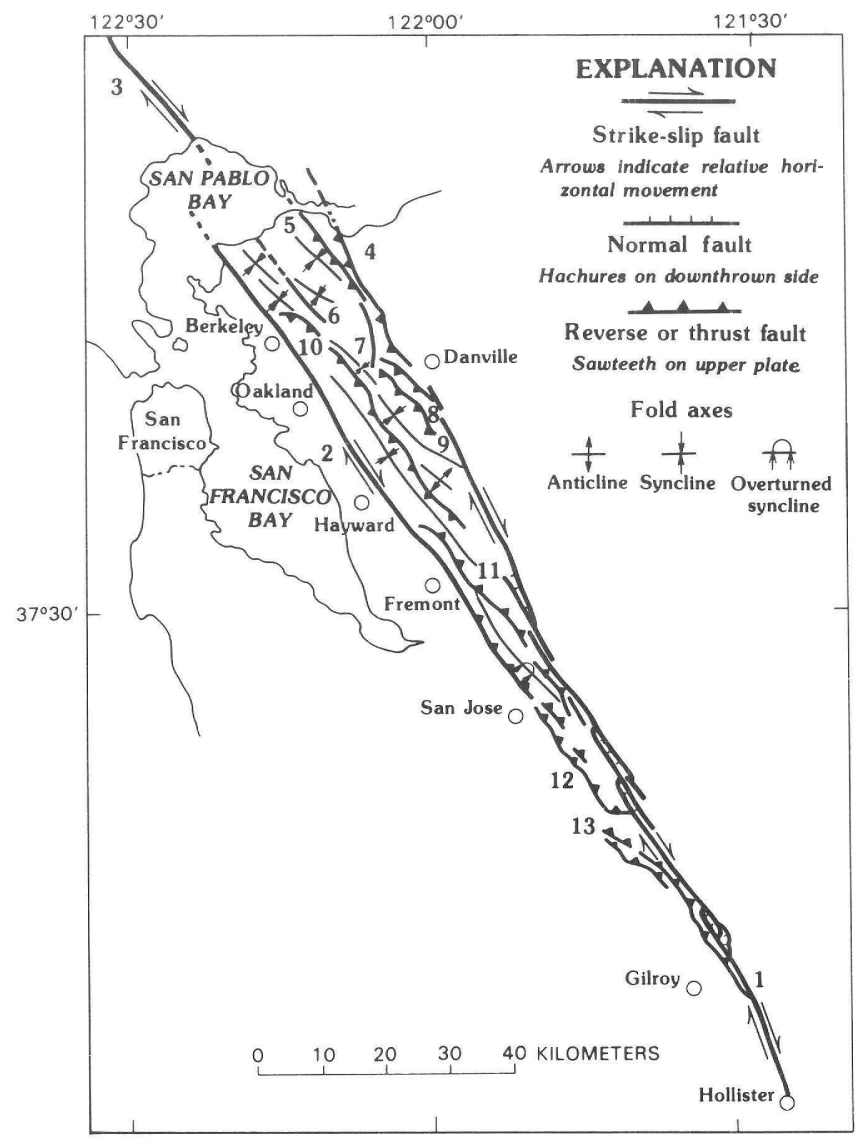

Figure 1.3. Simplified structural $\mathrm{map}$ and hypothetical model for the East Bay Hills compressional domain between the left-step from the Calaveras to the Hayward and Rodgers Creek fault zones (from Aydin and Page, 1984, fig. 7). Major faults: 1, Calaveras; 2, Hayward; 3, Rodgers Creek; 4, Southampton; 5, Franklin; 6, Pinole; 7, Lafayette; 8, Las Pampas; 9, Bolinger; 10, Moraga; 11, Mission; 12, Evergreen; 13, Silver and Coyote Creek. 


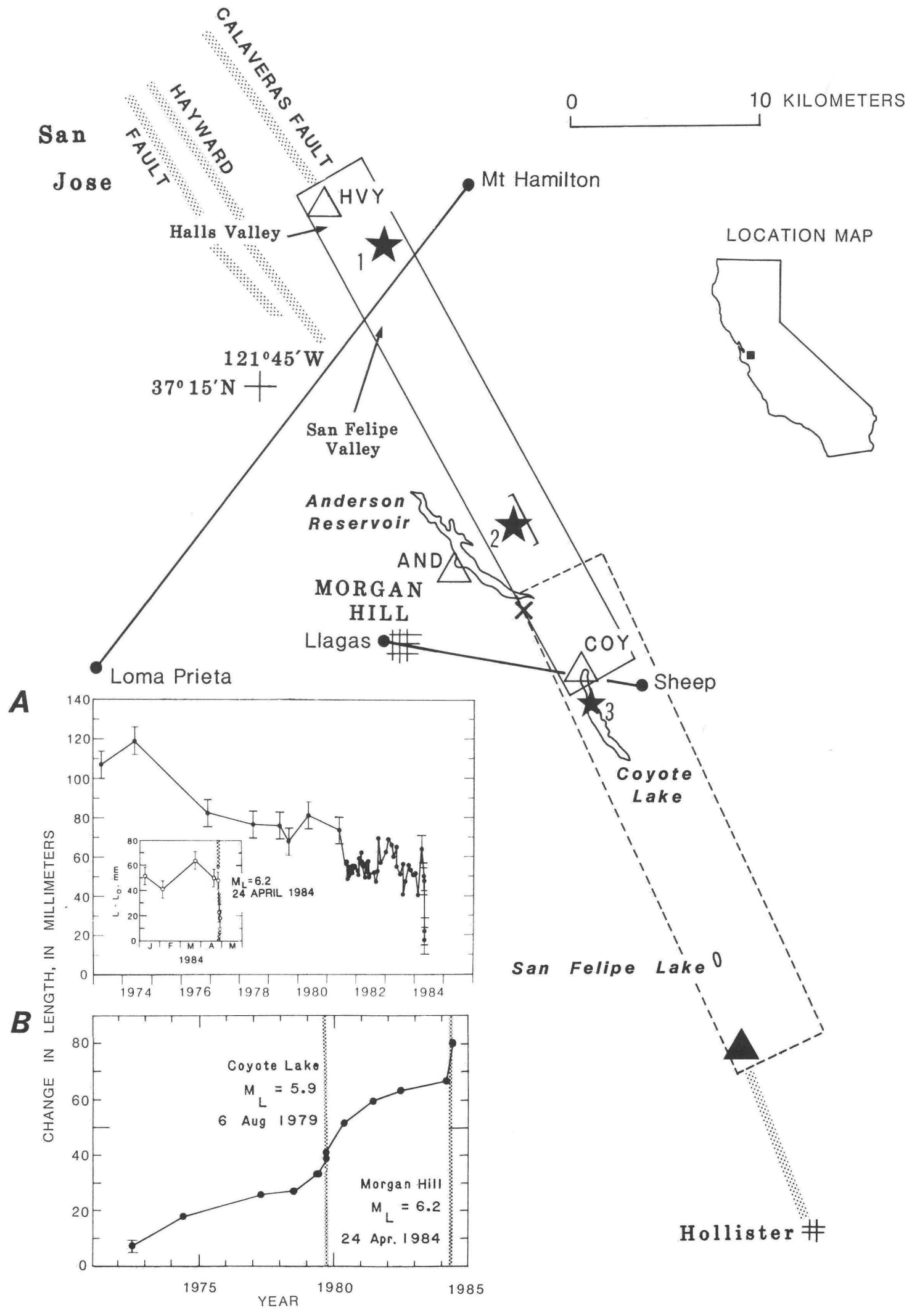


earthquakes near Halls Valley on January 15, 1981 $\left(\mathrm{M}_{\mathrm{I}}=4.8\right)$, and on October $23,1983\left(\mathrm{M}_{\mathrm{I}}=3.8\right)$ (Bakun, 1980; Bakun and others, 1984). In 1955, an $\mathrm{M}_{\mathrm{L}}=5.5$ shock occurred about $10 \mathrm{~km}$ northwest of Mount Hamilton (Bufe and others, 1979).

No clear changes in the pattern of seismicity immediately before the Morgan Hill earthquake have been identified that would have permitted prediction of the earthquake. The Morgan Hill earthquake rupture zone lies within a dense network of seismographic stations operated by the U.S. Geological Survey (USGS) in central California, so that all earthquakes of $\mathrm{M}_{\mathrm{L}} \geq 1.5$ in the vicinity are recorded and located. During the 24 hours before the main shock, only two small earthquakes occurred on April 24, at 0341:37.0 G.m.t. (coda-duration magnitude, 0.7) and 1811:37.7 G.m.t. (coda-duration magnitude, 0.4), both located at the main-shock epicenter (Bakun and others, 1984). For comparison, more than 150 earthquakes (coda-duration magnitude, $\geq 1.0$ ) occurred within the rupture zone during the 12 months before the main shock. An increase in earthquake activity did occur near the two ends of the rupture zone during the 16 months before the Morgan Hill earthquake (fig. 1.5C); this pattern of precursory seismicity near the ends of the rupture zone is consistent with seismicity observed near the ends of rupture zones before large earthquakes on plate boundaries (Kelleher and Savino, 1975) and before $M_{1}=4-6$ earthquakes on the San Andreas fault system (Bakun, 1980; Bakun, and others, 1980).

\section{POSTEARTHQUAKE OBSERVATIONS}

\section{Seismologic Observations}

Seismologic observations included the determination of: aftershock patterns; location, focal mechanism, and magnitude of the main shock; and source parameters of the two largest aftershocks, as

Figure 1.4. Calaveras and Hayward fault zones (stippled bands) outside rupture $z$ one of the 1984 Morgan Hill earthquake (solid box) and aftershock zone of the 1979 Coyote Lake earthquake (Reasenberg and Ellsworth, 1982) (dashed box), relative to locations of selected geophysical instruments. Stars denote epicenters: 1, main shock; 2, delayed source; 3, 1979 Coyote Lake main shock. Open triangles, strongmotion accelerographs: Halls Valley (HVY), Anderson Dam, downstream (AND), and Coyote Lake Dam abutment (COY or CYC). Solid triangle, Shore Road creepmeter. $\mathrm{X}$, locus of severe damage in the unincorporated Jackson Oaks area of Morgan Hill. A, Length of the line Loma Prieta-Mount Hamilton as a function of time. Insert shows recent measurements at an expanded time scale; error bars are $\pm \sigma$. B, Length of the line Llagas-Sheep. From Bakun and others (1984, fig. 1). well as a presentation of strong-motion records from the main shock.

The Morgan Hill earthquake of April 24, 1984, occurred at 2115:18.78 G.m.t. (1:15 p.m. P.d.t); its epicenter was near Halls Valley along the Calaverus fault zone east of San Jose, Calif. (fig. 1.1). This moderate earthquake had a surface-wave magnitude $\left(\mathrm{M}_{S}\right)$ of 6.1 and a body-wave magnitude $\left(m_{b}\right)$ of 5.7 , according to the U.S. National Earthquake Information Service in Golden, Colo. A local magnitude $\left(\mathrm{M}_{\mathrm{L}}\right)$ of 6.2 was measured by the University of California, Berkeley, Seismographic Station from seismographs north and northwest of the epicenter. A moment magnitude (Hanks and Kanamori, 1979) of 6.2 was calculated by using a geodetic moment of $1.9 \times 10^{25}$ dyne-cm (Prescott and others, 1984). The relatively small $m_{b}$ of 5.7 reflects the size of the initial source; the larger $\underline{M}_{s}$, moment magnitude, and $\underline{M}_{L}$ estimates reflect the extended source, including an energetic source 16 to $20 \mathrm{~km}$ southeast of the main-shock epicenter near the end of the earthquake rupture zone (Bakun and others, 1984).

The Morgan Hill earthquake ruptured a 26-kmlong subsurface segment of the Calaveras fault zone to the east and southeast of San Jose, Calif. The af tershock hypocenter distribution (figs. 1.4, 1.5B) is used to define the subsurface "rupture zone" of the earthquake, although rupture during the main shock probubly did not extend over this entire length. The epicenter (lat $37^{\circ} 18.56^{\prime} \mathrm{N}$., long $121^{\circ} 40.68^{\prime}$ W.) of the main shock was located near the Calaveras fault zone, $5 \mathrm{~km}$ west-southwest of Mount Hamilton and about 65 $\mathrm{km}$ northwest of the junction of the Calaveras and San Andreas faults (see chap. 3). Nearly all the aftershocks locate on the 26-km-long section of the Calaveras fault zone southeast of the epicenter of the main shock; aftershocks were concentrated near the San Felipe Valley and the Anderson Reservoir (fig. 1.5). The distribution of aftershocks in space and time suggests that the source mechanism of the earthquake can be described by a unilateral rupture propagating to the south-southeast from the main-shock epicenter to the south end of the Anderson Reservoir.

An anulysis of more than 1,000 aftershocks of $M \geq 0.5$, plotted on a map view, reveals a central band of aftershocks parallel to the Calaveras fault, less than 1 $\mathrm{km}$ wide and more than $30 \mathrm{~km}$ long (see chap. 2). The aftershock pattern is simpler than the mapped strands of the Calaveras fault in the aftershock region. Longitudinal cross sections showing the hypocentral locations of aftershocks show two quiet zones in the aftershock pattern on the inferred fault surface. These quiet zones are represented as adjacent 3- by $10-\mathrm{km}$ and $5-$ by $13-\mathrm{km}$ patches that are believed to be devoid of aftershocks because they broke during the main shock. The transition between these quiet patches coincides with a $6^{\circ}$ change in strike of the inferred fault surface. Selected transverse stereoscopic plots of aftershock locations show a conspicuous group of aftershocks southwest of the principal band of aftershocks that appear to be bounded by the Calaveras fault on the northeast and by the Silver Creek (or a related, reverse) fault below and on the southwest. These aftershock patterns suggest that the Morgan Hill earthquake was accompanied by, 
or stimulated movement on, one or more nearby reverse faults.

The results of analyses of the hypocentral location, focal mechanism, and magnitude of the main shock, based on records from the USGS northern California seismograph network and the USGS/California Institute of Technology (CIT) southern California seismograph network, are reported in chapter 3. The hypocentral location was calculated by using three different crustal models. All three locations fall to the east of mapped traces of the Calaveras fault. The epicentral region is geologically complex, and the crustal-velocity structure is poorly understood there. One possible explanation for the hypocentral location east of the fault is that the crustal velocity at depths of 6 to $10 \mathrm{~km}$ is substantially higher east than west of the fault. First-motion plots for all three hypocentral solutions are almost identical and indicate right-lateral strike-slip movement on a fault plane striking N. $33^{\circ}$ W. and dipping $84^{\circ}$ SW. Magnitude calculations from northern California stations $\left(M_{L}=6.2\right)$ and southern California stations $\left(\mathrm{M}_{\mathrm{L}}=6.5-6.7\right)$ differ significantly; this difference may be due to a strong directional variation in the energy radiated by the earthquake.
Unilateral rupture propagation toward the southsoutheast from the main-shock epicenter, and an energetic late source of seismic radiation located near the southeast end of the rupture zone, contributed to the highly focused pattern of strong motion, including an exceptionally large horizontal acceleration of 1.29 $\mathrm{g}$ at a site on the Coyote Lake Dam abutment near the southeast end of the rupture zone. Strong-groundmotion recordings (see chap. 5) show that ground accelerations were generally larger south of the rupture zone than to the north. For example, peak horizontal accelerations were 5 to 8 times higher to the southeast of the rupture zone than to the northwest at distances of 25 to $50 \mathrm{~km}$ from the ends of the rupture zone. Severe damage was limited to the vicinity of Morgan Hill (see chap. 11), and the largest horizontal accelerations were recorded near there as well (fig. 1.6). These observations are consistent with pronounced focusing of seismic energy to the southeast of the rupture zone, caused by the predominantly unilateral southeastward rupture expansion. A large, late pulse on some of the strong-motion records, such as the pulse $11 \mathrm{~s}$ after triggering on the station HVY accelerogram, shows the existence of an energetic source of seismic radiation (fig. 1.6) near the southeast

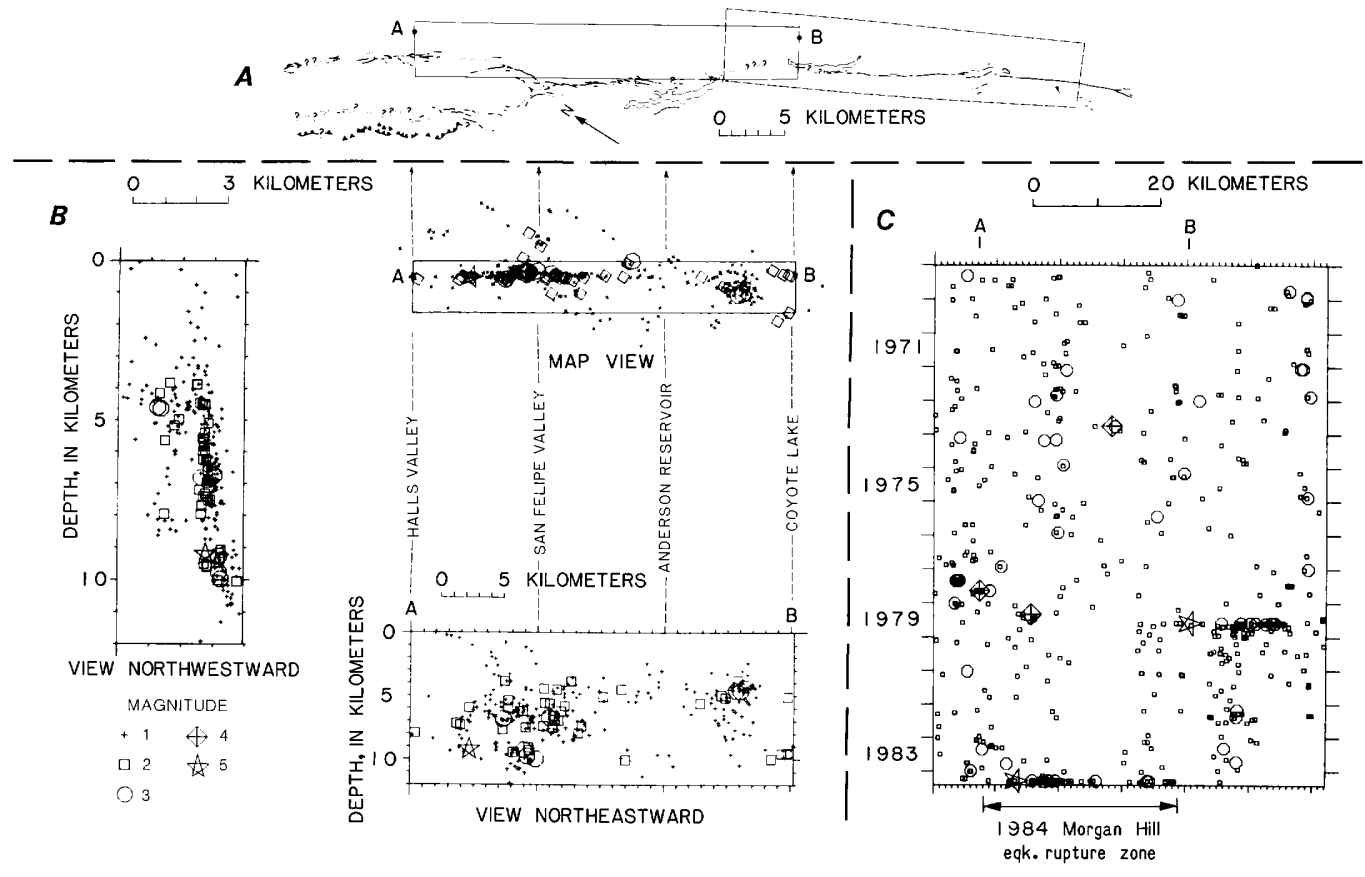

Figure 1.5. Seismicity of the Calaveras fault zone. A, Traces of the Calaveras fault (D.G. Herd, unpub. data, 1982) relative to the 1984 Morgan Hill and 1979 Coyote Lake earthquake rupture zones (fig. 1.4). Solid lines, fault traces; dotted where inferred, queried where questionable. Sawteeth, thrust faults; barbs on upper plate. B, Map and cross sections of seismicity $(2115$ G.m.t. April 24 to 0000 G.m.t. May 11, 1984) along the 1984 Morgan Hill earthquake rupture $z$ one. Only epicenters within the box (map view) are shown on the cross sections. Star, hypocenter of main shock. Hypocentral locations were obtained by using a regional velocity model (Ellsworth and Marks 1980); displacement of epicenters off the fault traces may be due to a poorly constrained crustalvelocity model. $C$, Space-time plot of seismicity $\left(M_{L} \geq 2\right)$ along the Calaveras fault zone. From Bakun and others (1984, fig. 2). 
end of the rupture zone. The timing of $S$ waves from this source is consistent with a location near the Anderson Reservoir (fig. 1.5B) that is noticeably deficient in located aftershocks (Bakun and others, 1984).

Six General Earthquake Observation System (GEOS, a microprocessor-based digital recorder) strong-motion-recording instruments were deployed within 8 hours of the main shock. Each instrument was attached to a three-component force-balance accelerometer and a three-component velocity trunsducer. From 6 to 13 GEOS stations collected data for more than a month after the earthquake. As of May 30, 1984, a total of 126 aftershocks had been recorded by 4 or more GEOS stations. As many as 11 GEOS stations recorded some of the larger

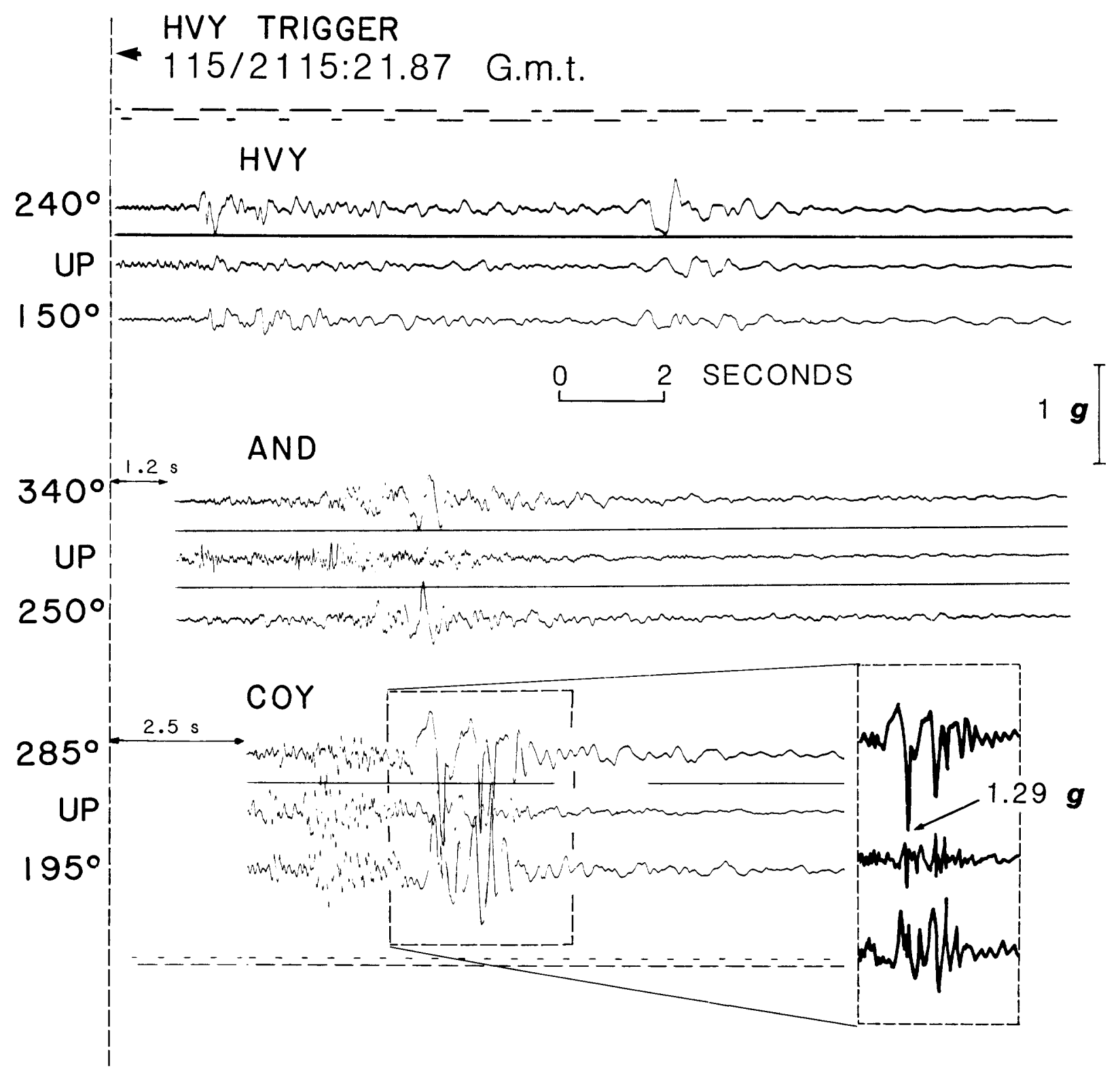

Figure 1.6. Strong-motion accelerograms recorded at Halls Valley (HVY), Anderson Dam-downstream (AND), and Coyote Dam abutment (COY or CYC) stations. Traces are aligned on a common absolute time base. Dashed vertical line at left marks trigger time of station HVY recorder. Delays in trigger times at the other sites are indicated. $U p$ on the records corresponds to ground-motion directions indicated at left. Inset, tracing of station COY accelerograms near the 1.29-g peak acceleration toward $105^{\circ}$. Straight horiz ontal lines between accelerogram traces are reference marks. Station HVY and COY traces were recorded on California Division of Mines and Geology instruments. From Bakun and others (1984, fig. 3). 
aftershocks. Source parameters calculated for two of the largest aftershocks include seismic moment, corner frequency, source radius, and stress drop (see chup. 4). These two aftershocks occurred on April 29 (Julian day 118) at 1648 G.m.t. and on May 5 (Julian day 124) at 1307 G.m.t. S-wave moments of $1.2 \times 10^{22}$ and $6.2 \times 10^{22}$ dyne-cm were obtained for these two events. Source radii ( $\underline{S}$ waves) of 0.4 and $0.6 \mathrm{~km}$ yielded similar stress drops of 12.2 and $14.6 \mathrm{MPa}$. Pwave moments were smaller than $\underline{S}$-wave moments $\overline{b y}$ factors of 4 and 6 . These stress drops are considered high in comparison with the norm for California data.

An important set of strong-motion records was collected from the main shock of the Morgan Hill earthquake by the permanent accelerograph networks of both the USGS and the California Division of Mines and Geology (CDMG). About 75 stations within the combined networks were triggered at epicentral distances ranging from 4 to $100 \mathrm{~km}$. Chapter 5 provides information for readers wishing to obtain copies of these records, as well as a summary of information from 25 USGS stations, including the maximum acceleration for euch component and the duration (in seconds) for which the acceleration reached amplitudes greater than $0.1 \mathrm{~g}$. Digitizing and processing of film records for five stations has been completed, and chapter 19 presents computer plots of data collected from strong-motion seismographs, including: (1) uncorrected accelerograms; (2) corrected acceleration, velocity, and displacement; (3) relative-velocity-response spectra plotted on linear scales; (4) response spectra plotted on tripartite scales, (5) Fourier-umplitude spectra plotted on linear scales; and (6) Fourier spectra plotted on log-log scales.

\section{Geologic Observations}

Geologic observations sought to identify and measure possible surface fault rupture associated with the earthquake, to measure postearthquake surface displacement on the fault zone southeast of the af tershock zone, and to document earthquake-induced ground failure.

No unequivocal evidence of surface faulting was found during an intensive investigation of abundant ground cracks associated with the main-shock and aftershock zones of the Morgan Hill earthquake. Cracks at two localities in the San Felipe Valley were aligned with Quaternary fault traces but did not show convincing evidence of tectonic origin, nor did they show measurable postearthquake displacement. Cracks near the southeast end of the Anderson Reservoir are within an area of extensive landsliding; some of these cracks could be tectonic, but their absence of consistent slip direction and orientation suggests a nontectonic origin (see chap. 6).

On the day after the earthquake, ground cracks with recent surface displacement were found along a $5.8-\mathrm{km}$-long segment of the Calaveras fault from 48 to $54 \mathrm{~km}$ southeast of the epicenter, beyond the aftershock zone. These fresh cracks were found at Shore Road and at three localities near San Felipe Lake where the Calaveras fault trace was mapped by
Radbruch-Hall (1974). This surface displacement may have occurred shortly before, during, or shortly after the earthquake. However, the creepmeter at Shore Road recorded an of fset shortly after the earthquake. On August 10, new cracks were found where the Calaveras fault crosses California Highway 25 near Hollister. This new set of cracks indicates continued movement and the possible development of a new surficial fault trace at California Highway 25 (see chap. 7).

A large landslide in the central Santa Cruz Mountains near the town of La Honda, Calif., $53 \mathrm{~km}$ northwest of the epicenter, was probably triggered by the Morgan Hill earthquake (see chap. 8). This translational block slide occurred in an area of prehistoric deep-seated landslides. The basal shear zone of the landslide is in material that was probably weakened by previous landslide movement. Winter rains, which contributed to a perched water table within the old landslide, provided optimum conditions for renewed landslide movement. The La Honda landslide is at about the maximum distance from the epicenter where an $M_{S}=6.1$ earthquake is likely to cause a block slide in highly susceptible material, on the basis of earthquake-magnitude relations determined from a worldwide data set for coherent slope failures (Keefer, 1984).

\section{Engineering Observations}

Engineering reports include: a discussion of seismic velocities in relation to local geology; an assessment of the influence of ground failure on damage and the occurrence of liquefaction; $a$ description of the damage in Morgan Hill and Jackson Oaks, near the Anderson Reservoir; and a discussion of the response of two buildings in San Francisco to the Morgan Hill earthquake.

Interpretation of the strong-motion data from five stations in the Gilroy strong-motion array and the Coyote Lake Dam, South Abutment, station requires information about the geologic materials underlying each site, including the shear-wave velocities. Geologic and $\mathrm{P}$ - and S-wave-velocity logs from borings are provided for these six stations, which extend a distance of $10 \mathrm{~km}$ from sandstone of the Franciscan Complex on the southwest, across alluvium of the Santa Clara Valley, to Tertiary sandstone on the northeast. The Coyote Lake Dam instrument pad is located on or partly on a mass of silica-carbonate rock and serpentine embedded in sheared rock of the Franciscan Complex, which composes the western dam abutment. The USGS borehole, $70 \mathrm{~m}$ to the southwest of the instrument and across a fault strand, penetrated only sedimentary rocks, and so the relatively low sheur-wave velocities $(250-480 \mathrm{~m} / \mathrm{s})$ measured in the borehole should not be used to characterize the Coyote Lake Dam instrument site nor to interpret the $1.29-\mathrm{g}$ horizontal acceleration recorded there (see chap. 9).

Several houses were damaged in the Jackson Oaks area on the southwest side of the Anderson Reservoir (see chap. 10). A conspicuous east-west fissure along Oak Ridge Court cracked driveways and the street, and broke pipes. Although this fissure 
probably marked the head of an incipient slope failure, the fissure had no detectable direct influence on the damage to houses in the vicinity. Damage to the Cochrane Bridge across the Anderson Reservoir may huve been caused by deep-seated landslide movement. Dunne Road was damaged by landslides. Details of the various cracks are described in chapter 6. Liquefaction effects were found at only one locality on the east shore of the Anderson Reservoir, where sand boils and fissures a few centimeters wide occurred.

Unreinforced-masonry buildings sustained the most external damage in downtown Morgan Hill (see chap. 11). Some windows were broken, and in many places items were thrown from shelves and knocked over, commonly falling to the north. At the Emilio Guglielmo Winery, damage included the shifting of both empty and full 10,500-gal stuinless-steel tanks. Water tanks were also damaged during the earthquake. Damage at the Madrone Mobile Estates was confined to one small section of the park, where many trailers were twisted or toppled from their post foundations. Other mobile-home parks in the vicinity were not dumaged. Five wood-frame homes in the Jackson Oaks subdivision were abandoned immediately after the earthquake, owing to damage presumably related to strong ground shaking.

Chapter 12 evaluates the significance of minor damage to two buildings on the southwest side of San Francisco, approximately $100 \mathrm{~km}$ from the epicenter of the Morgan Hill earthquake. These buildings are 8 and 9 stories tall and are connected by walkways at the third and sixth floors. People in the buildings experienced strong shaking during the earthquake. Nonstructural cracks occurred in both buildings, particularly on the fif th and sixth floors. At least 16 and possibly as much as $29 \mathrm{~m}$ of moist sandy sediment overlies bedrock at the building site. The strong similarity of the fundamental frequencies of the structures and the soil indicates a probable resonance between the buildings and the underlying soil. Preliminury amplification ratios determined for the site also indicate a strong probability for amplification of ground motion at the building site: This combination of resonance and amplification factors may explain the minor damage at such a great distance from the earthquake.

\section{Geodetic Observations}

Geodetic investigations included measurements of creepmeter response and alignment arrays, Theodolite measurements, tiltmeter measurements, magnetic-field measurements, and determinations of ground-water response.

Earthquake-triggered creep at Shore Road, one of the more unusual phenomena of the Morgan Hill earthquake, is discussed in chapter 13. The USGS creepmeter at Shore Road (sta. SHR1, fig. 1.4) recorded $12.9 \mathrm{~mm}$ of afterslip within the first 18 hours after the earthquake. The Shore Road creepmeter, which crosses the Calaverus fault $50 \mathrm{~km}$ southeast of the epicenter, was the closest creepmeter to the earthquake. Ground breakage was associated with postearthquake creep. The afterslip at Shore Road is the largest creep event recorded in the 13-year history of this creepmeter. On May 26, an additional creep event of $7.9 \mathrm{~mm}$ occurred at Shore Road. Three creepmeters in downtown Hollister showed only normal activity after the earthquake, and so the creep at Shore Road did not propagate so far south as Hollister. In comparison, the slip at Shore Road in the 24 hours after the 1979 Coyote Lake earthquake was $8.3 \mathrm{~mm}$ (Burford and Schulz, 1984). The Coyote Lake earthquake ended a 3-year creep lag at Shore Road (Raleigh, 1979; Schulz and others, 1983). The Morgan Hill earthquake was preceded by an 18-month creep lag at Shore Road.

A small-aperture alignment array in the San Felipe Vulley, well within the aftershock zone, provided no evidence of afterslip associated with the earthquake (see chap. 14). The San Felipe Valley array, $4 \mathrm{~km}$ south of the epicenter, was installed 2 days after the earthquake to monitor possible afterslip. This array crosses the Calaveras fault traces identified by Radbruch-Hall (1974) and D.G. Herd (unpub. data, 1982). Measurements of the array indicated $1.8 \mathrm{~mm}$ of left-lateral movement and 0.5 and $0.4 \mathrm{~mm}$ of right-lateral movement, with error bars of as much as $\pm 1.0 \mathrm{~mm}$, during the 2 months after the earthquake. Therefore, the cumulative total slip after four remeasurements of the urray does not indicate appreciable postearthquake movement beyond the error limits.

Data from three Theodolite triangulation sites on the Calaveras fault (two near Hollister and one near San Ramon) indicate no significant change in longterm creep rates before the earthquake, nor was any surface displacement observed after the earthquake (see chap. 15). The San Ramon site has had a creep rate of $1 \mathrm{~mm} / \mathrm{yr}$ for the past 3.75 years, and three measurements after the earthquake were all normal relative to the overall average at the site. At Wright Road, $1.5 \mathrm{~km}$ north of Hollister, the slip has averaged $13 \mathrm{~mm} / \mathrm{yr}$ for the past 4.5 years. Five remeasurements, including one on the day after the earthquake, showed a net right-lateral slip of more than $13 \mathrm{~mm}$ in the 3.5 months after the earthquake. This slip is nearly $1 \mathrm{~cm}$ greater than the average rate, but similar slip occurred at Wright Road in 1981 without an earthquake. At Seventh Street in downtown Hollister, the overall average rate of rightlateral movement has been $6.5 \mathrm{~mm} / \mathrm{yr}$ for the past 4.5 yeurs. At the time of the iVlorgan Hill earthquake this site was in a left-lateral phase, but during the 3.5 months after the earthquake a net right-lateral movement of $10.5 \mathrm{~mm}$ occurred. This slip exceeds the long-term rate at Seventh Street by $9 \mathrm{~mm}$; however, a similar change in direction and amount of creep occurred during 1982 without an earthquake. Three other sites on the Hayward and San Andreas faults were also remeasured, but no anomalous movement was detected.

The rupture zone of the Morgan Hill earthquake also lies within a frequently measured, dense geodetic network, and so regional displacements associated with the earthquake are relatively well determined. Baselines range from 12 to $43 \mathrm{~km}$ in length, and coseismic changes associated with the Morgan Hill 
earthquake average a few centimeters (Prescott and others, 1984). Selecting a 25-km-long rupture length and using the 4- to $10-\mathrm{km}$ depth range of the main shock and aftershocks as the rupture width, the observed line-length changes are consistent with a right-lateral displacement of $42 \pm 4 \mathrm{~cm}$ over a surface $25-$ by $6-\mathrm{km}$ in area. This analysis allows the calculation of a geodetic moment of $1.9 \times 10^{25}$ dyne-cm (Prescott and others, 1984). For comparison, the geodetic moment of the 1979 Coyote Lake earthquake was $1.6 \times 10^{25}$ dyne-cm.

Observations of the $32-\mathrm{km}$-long Loma PrietaMount Hamilton geodetic line (fig. 1.4) limit the amount of any preearthquake slip that might have occurred during the week before the earthquake to less than $7 \mathrm{~cm}$, if this slip occurred over the entire rupture area (Prescott and others, 1984). A small-aperture geodetic network at Grant's Ranch in Halls Valley, 5 $\mathrm{km}$ northwest of the main-shock epicenter, showed no anomalous deformation 2 weeks before the earthquake, nor was any coseismic fault slip observed at Grant's Ranch (Prescott and others, 1984).

After the 1979 Coyote Lake eurthquake, significant postseismic slip occurred along the $20-\mathrm{km}-$ long section of the Calaveras fault south of Coyote Lake (Michael Lisowski and N.E. King, unpub. data, 1979); this afterslip probably accounts for all the accelerated extension of the Llagas-Sheep geodetic line (fig. 1.4). During this same 4-1/2-year period, three $\mathbf{M}=4.5$ shocks (fig. $1.5 \mathrm{C}$ ) near Halls Valley and Coyote Lake may have increased the shear stress on the fault segment along which the Morgan Hill earthquake and its aftershocks occurred (Bakun and others, 1984).

A bubble-level tiltmeter located near Mount Hamilton, $1.5 \mathrm{~km}$ east of the epicenter of the Morgan Hill earthquake, indicated a tilt change of about 9 microradians down to the east-southeast between April 5 and 24. This tilt change is similar to tilt events of short duration preceding the earthquakes on August 29, 1978, and January 5, 1981. In contrast, no precursory tilt was observed for an earthquake on May 8, 1979, which had an epicenter very near the epicenter of the Morgan Hill earthquake. However, Mortensen and Liechti (see chap. 16) found that tiltmeter response before the April 24, 1984, earthquake correlated well with rainfall and so could not be attributed to the earthquake.

The USGS operates a network of magnetometer stations in central California to detect local magneticfield perturbations generated by changes in tectonic stress. A comparison of the magnetic-field differences after the earthquake with those 16 months earlier indicated no significant variations greater than $0.75 \mathrm{nT}$. Variations in magnetic-field differences were less than $1.0 \mathrm{nT}$ during the 12 days after the main shock and were not clearly related to aftershock activity (see chap. 17).

A large increase in the flow rates of two springs along the Hayward fault at Alum Rock Park was observed on the day after the earthquake (see chap. 18). The spring water carried an abnormally high amount of suspended sediment, although the increase in flow was not due to rainfall. These springs are located within the compressional quadrant of the earthquake. An anomalous change in water quality began 2 years before the earthquake. The springs, which have been monitored since 1975, showed a gradual decline in salinity and conductivity by 40 percent since the end of 1981 .

\section{CONCLUSIONS AND IMPLICATIONS}

1. The aftershock distribution shows activity on both the Calaveras and Silver Creek faults (see chap. 2). This seismologic finding provides support for the contention by Page (1984, p. 113) that the foothills ridge between the Calaveras fault and the edge of the Santa Clara Valley near Morgan Hill is "a rootless prism undercut by thrusts." These findings demonstrate the active relation between strike-slip and thrust movements in the Calaveras fault zone.

2. A horizontal acceleration of $1.29 \mathrm{~g}$ was measured at the Coyote Lake Dam, South Abutment, strongmotion seismograph. This instrument is located partly on artificial fill and partly on a prominent outcrop of silica-carbonate rock incorporated within the dam abutment. Fault strands occur in the Franciscan Complex on both sides of the silicacarbonate rock outcrop. Thus, local topographic and site effects may strongly influence the records from this instrument.

3. A $13-\mathrm{mm}$ creep event occurred within the first 18 hours after the earthquake at a creepmeter $50 \mathrm{~km}$ south of the aftershock zone. Fresh ground cracks found along mapped traces of the Calaveras fault on the day after the earthquake at localities 48 and $54 \mathrm{~km}$ southeast of the epicenter are presumed to have formed concurrently with this postearthquake creep event.

4. The search for surface fault rupture within the af tershock zone was largely inconclusive. Ground cracks in line with mapped fault traces did not show offset, and where of fset was present, so were landslides.

5. Distant effects of this earthquake included a landslide near La Honda, $53 \mathrm{~km}$ from the epicenter, and minor building damage in San Francisco, 100 $\mathrm{km}$ from the epicenter.

\section{REFERENCES CITED}

Aydin, Atilla, 1982, The East Bay Hills, a compressional domain resulting from interaction between the Calaveras and Hayward-Rodgers Creek faults, in Hart, E.W., Hirschfeld, S.E., and Schulz, S.S., eds., Conference on Earthquake Hazards in the Eastern San Francisco Bay Area, Hayward, Calif., 1982, Proceedings: California Division of Mines and Geology Special Publication 62, p. 11-21.

Aydin, Atilla, and Page, B.M., 1984, Diverse PlioceneQuaternary tectonics in a transform enviromnent, San Francisco Bay region, California: Geological Society of America Bulletin, v. 95, no. 11, p. 1303-1317. 
Bailey, E.H., Irwin, W.P., and Jones, D.L., 1964, Franciscan and related rocks and their significance in the geology of western California: California Division of Mines and Geology Bulletin 183, 171 p.

Bakun, W.H., 1980, Seismic activity on the southern Calaveras fault in central California: Seismological Society of America Bulletin, v. 70, no. 4, p. 1181-1197.

Bakun, W.H., Clark, M.M., Cockerham, R.S., Ellsw orth, W.L., Lindh, A.L., Prescott, W.L., Shakal, A.F., and Spudich, Paul, 1984, The 1984 Morgan Hill, California, earthquake: Science, v. 225, no. 4659 , p. 288-291.

Bakun, W.H., Stewart, R.M., Bufe, C.G., and Marks, S.M., 1980, Implication of seismicity for failure of a section of the San Andreas fault: Seismological Society of America Bulletin, v. 70, no. 1, p. 185-201.

Baldwin, A.D., Jr., 1967, Geologic and geographic controls upon the rate of solute erosion from selected coastal river basins between Half Moon Bay and Davenport, California: Stanford, Calif., Stanford University, Ph.D. thesis, $182 \mathrm{p}$.

Berkland, J.O., Raymond, L.A., Kramer, J.C., Moores, E.M., and O'Day, Michael, 1972, What is Franciscan?: American Association of Petroleum Geologists Bulletin, v. 56, no. 12, p. 2295-2302.

Bufe, C.G., Bakun, W.H., and McEvilly, T.V., 1979, Historic seismic activity and the 1979 Coyote Lake sequence [abs.]: Eos (American Geophysical Union Transactions\}, v. 60, no. 46, p. 891.

Burford, R.O., and Schulz, S.S., 1984, Retardations in aseismic slip rate on the Calaveras fault at Shore Road, 1975-1984: Precursors of regional moderate earthquakes: Eos (American Geophysical Union Transactions), v. 65, no. 45, p. 852.

Dibblee, T.W., Jr., 1980, Geology along the San Andreas fault from Gilroy to Parkfield, in Studies of the San Andreas fault zone in northern California: California Division of Mines and Geology Special Report 140, p. 3-18.

Ellsworth, W.L., Lindh, A.G., Prescott, W.H., and Herd, D.G., 1981, The 1906 San Francisco earthquake and the seismic cycle, in Simpson, D.W., and Richards, P.G., eds., Earthquake prediction: An international review (Maurice Ewing series 4): Washington, American Geophysical Union, p. 126-140.

Hanks, T.C., and Kanamori, Hiroo, 1979, A moment magnitude scale: Journal of Geophysical Research, v. 84 , no. B5, p. 2348-2350.

Hill, M.L., 1971, A test of new global tectonics: Comparisons of northeast Pacific and California structures: American Association of Petroleum Geologists Bulletin, v. 55, no. 1, p. 3-9.

Jennings, C.W., 1975, Fault map of California, with locations of volcanoes, thermal springs and thermal wells: California Division of Mines and Geology California Geologic Data Map 1, scale $1: 750,000$.

Keefer, D.K., 1984, Landslides caused by earthquakes: Geological Society of America Bulletin, v. 95, no. 4, p. 406-421.

Kelleher, John, and Savino, John, 1975, Distribution of seismicity before large strike slip and thrusttype earthquakes: Journal of Geophysical Research, v. 80, no. 2, p. 260-271.

Mavko, G.M., 1982, Fault interaction near Hollister, California: Journal of Geophysical Research, v. 87 , no. B9, p. 7807-7816.

Minster, J.B., and Jordan, T.H., 1978, Present-day plate motions: Journal of Geophysical Research, v. 83, no. B11, p. 5331-5354.

Nason, R.D., 1973, Fault creep and earthquakes on the San Andreas fault, in Kovach, R.L., and Nur, Amos, eds., Proceedings of the conference on tectonic problems of the San Andreas fault system: Stanford University Publications in the Geological Sciences, v. 13, p. 275-285.

Page, B.M., 1982a, Migration of Salinian composite block, California, and disappearance of fragments: American Journal of Science, v. 282, no. 70 , p. 1694-1734.

-1982b, Modes of Quaternary tectonic movement in the San Francisco Bay region, California, in Hart, E.W., Hirschfeld, S.E., and Schulz, S.S., eds., Conference on Earthquake Hazards in the Eastern San Francisco Bay Area, Hayward, Calif., 1982, Proceedings: California Division of Mines and Geology Special Publication 62, p. 110.

1982c, The Calaveras fault zone of California-an active plate boundary element, in Hart, E.W., Hirschfeld, S.E., and Schulz, S.S., eds., Conference on Earthquake Hazards in the Eastern San Francisco Bay Area, Hayward, Calif., 1982, Proceedings: California Division of Mines and Geology Special Publication 62, p. 175-184.

1984, The Calaveras fault zone of California, an active plate boundary element, in Bennett, J.H., and Sherburne, R.W., eds., The $1 \overline{984}$ Morgan Hill, California, earthquake: California Division of Mines and Geology Special Publication 68, p. 109-122.

Prescott, W.H., Lisowski, Michael, and Savage, J.C., 1981, Geodetic measurement of crustal deformation on the San Andreas, Hayward, and Calaveras faults near San Francisco, California: Journal of Geophysical Research, v. 86, no. B11, p. 10853-10869.

Prescott, W.H., King, N.E., and Guohua, Gu, 1984, Preseismic and coseismic deformation associated with the 1984 Morgan Hill, California, earthquake, in Hoose, S.N., compiler, The Morgan Hill, California, earthquake of April 24, 1984 (a preliminary report), volume I: U.S. Geological Survey Open-File Report 84-498-A, p. 50-59.

Radbruch-Hall, D.H., 1974, Map showing recently active breaks along the Hayward fault zone and the southern part of the Calaveras fault zone, California: U.S. Geological Survey Miscellaneous Investigation Series Map I-813, scale $1: 24,000,2$ sheets.

Raleigh, C.B., Stuart, W., and Harsh, P.W., 1979, 
Creep on the Calaveras fault near Coyote Lake Calif. [abs.]: Eos (American Geophysical Union Transactions), v. 60 , no. 46 , p. 890 .

Reasenberg, Paul, and Ellsworth, W.L., 1982, Aftershocks of the Coyote Lake, California, earthquake of August 6, 1979: A detailed study: Journal of Geophysical Research, v. 87, no. B13, p. 10637-10655.

Richter, C.F., 1958, Elementary seismology: San Francisco, W.H. Freeman, 768 p.

Rodgers, D.A., 1980, Analysis of pull-apart basin development produced by en echelon strike-slip faults, in Ballance, P. F., and Reading, H.G., eds., Sedimentation in oblique-slip mobile zones: International Association of Sedimentologists Special Publication 4, p. 27-41.

Ross, D.C., 1978, The Salinian block--a Mesozoic granitic orphan in the California Coast Ranges, in Howell, D.G., and McDougall, K.A., eds., Mesozoic paleogeography of the western United States: Pacific Coast Paleogeography Symposium 2: Los Angeles, Society of Economic Paleontologists and Mineralogists, Pacific Section, p. 509-522.

Savage, J.C., and Burford, R.O., 1973, Geodetic determination of relative plate motion in central California: Journal of Geophysical Research, v. 78 , no. 5, p. 832-845.

Schulz, S.S., Burford, R.O., and Mavko, Barbara, 1983, Influence of seismicity and rainfall on episodic creep on the San Andreas fault system in central California: Journal of Geophysical Research, v. 88, no. B9, p. 7475-7484.

Segall, Paul, and Pollard, D.D., 1980, Mechanics of discontinuous faults: Journal of Geophysical Research, v. 85, no. B8, p. 4337-4350.
Sweeney, J.J., 1982, Magnitudes of slip along the Greenville fault in the Diablo Range and Corral Hollow areas, in Hart, E.W., Hirschfeld, S.E., and Schulz, S.S., eds., Conference on Earthquake Hazards in the Eastern San Francisco Bay area, Hayward, Calif., 1982, Proceedings: California Division of Mines and Geology Special Publication 62, p. 137-146.

Toppozada, T.R., Real, C.R., and Parke, D.L., 1981, Preparation of isoseismal maps and summaries of reported effects for pre-1900 California earthquakes: California Division of Mines and Geology Open-File Report 81-11 SAC, 182 p.

Toppozada, T.R., 1984, His tory of earthquake damage in Santa Clara County and comparison of 1911 and 1984 earthquakes, in Bennett, J.H., and Sherburne, R.W., eds., The 1984 Morgan Hill, California, earthquake: California Division of Mines and Geology Special Publication 68, p. 237-248.

Weber, G.E., and Lajoie, K.R., 1977, Late Pleistocene and Holocene tectonics of the San Gregorio fault zone between Moss Beach and Point Ano Nuevo, San Mateo County, California [abs.]: Geological Society of America Abstracts with Programs, v. 9, no. 4, p. 524 .

Wright, R.H., Hamilton, D.H., Hunt, J.D., Traubenik, M.L., and Shlemon, R.J., 1982, Character and activity of the Greenville structural trend, in Hart, E.W., Hirschfeld, S.E., and Schulz, S.S., eds., Conference on Earthquake Hazards in the Eastern San Francisco Bay Area, Hayward, Calif., 1982, Proceedings: California Division of Mines and Geology Special Publication 62, p. 187-196. 


\title{
The Earthquake and its Aftershocks, April 24 through September 30, 1984
}

\author{
By Robert S. Cockerham and Jerry P. Eaton
}

\section{CONTENTS}

\author{
Abstract 15 \\ Introduction 15 \\ Seismic network 15 \\ Data selection $\mathbf{1 6}$ \\ Crustal-velocity model $\mathbf{1 6}$ \\ The main shock 17 \\ Spatial distribution of af tershocks $\quad 18$ \\ Discussion 23 \\ Acknowledgments $\quad 26$ \\ References cited $\mathbf{2 6}$
}

\section{Abstract}

Aftershocks of the earthquake clearly outline a near-vertical fault surface that is parallel to, but much simpler in structure than, the mapped strands of the Calaveras fault in the aftershock area. A central quiet $z$ one in the aftershock pattern on this inferred fault surface marks out adjacent $3-$ by $10-\mathrm{km}$ and $5-$ by $13-\mathrm{km}$ patches that are believed to outline the rupture region of the main shock. The transition between these patches coincides with a $6^{\circ}$ change in strike of the inferred fault surface. A conspicuous group of aftershocks southwest of the principal band of aftershocks appears to be bounded by the Calaveras fault on the northeast and by the Silver Creek (or a related, reverse) fault below and on the southwest. These aftershocks suggest that the Morgan Hill earthquake was accompanied by, or stimulated, movement on one or more nearby reverse faults.

\section{INTRODUCTION}

At 2115:18.8 G.m.t. April 24, 1984, an $\mathrm{M}_{\mathrm{L}}=6.2$ earthquake occurred on the Calaveras fault about 20 $\mathrm{km}$ east of downtown San Jose, Calif. (fig. 2.1A). This earthquake was felt throughout central California (Bakun and others, 1984). Because of the concentration of damage in a suburb of the town of Morgan Hill, the event has been called the Morgan Hill earthquake (Bakun and others, 1984).

The work reported in this chapter is based primarily on duta recorded by the U.S. Geological
Survey (USGS) northern California seismic network and processed by a computer-assisted system for analysing seismic datu. For the main shock, however, $\mathrm{P}$-wave onset times and first-motion directions, as well as maximum amplitudes and associated periods, were read from magnetic-tape playbacks from both the northern and southern California network stations. The principal objectives of this chapter are: (1) to develop a one-dimensional velocity model and associated station corrections for use in locating earthquakes in the Morgan Hill area; (2) to determine the hypocenter, local magnitude, and fault-plane solution of the main shock; and (3) to determine the distribution of af tershock hypocenters.

\section{SEISMIC NETWORK}

The USGS seismic network in the Morgan Hill area consists primurily of high-gain, short-period, vertical-component seismic systems (fig. 2.1A). Several low-guin seismic systems at the north and south ends of this network wrote unclipped records of the main shock from which maximum amplitudes and associated periods were measured. During the first 2 days after the main shock, additional seismic stations (fig. 2.1B) were installed in the aftershock area to augment the network.

The progress of aftershock activity was monitored in Menlo Park, Calif., by means of locations provided by an Allen/Ellis real-time processor (RTP; Allen, 1978). The RTP located several hundred earthquakes, with 30 to 40 reporting stations per 
event, during the first 72 hours of the aftershock sequence. During the early hours of this sequence, the rapid locations provided by the RTP allowed selection of the most critical sites for portable stations while field crews were still on their way to the epicentral region.

\section{DATA SELECTION}

The telemetered data were digitized and analyzed by an improved online/offline, computerassisted seismic-anulysis system based on an original design by Johnson (1983). The incoming signals were digitized at 100 sumples per second; automatically detected seismic events were saved and demultiplexed for offline analysis. For analysis, which was interactive, seismograms were displayed on a highspeed graphics terminal. $\underline{P}$ - and $\underline{S}$-wave onsets were picked and timed to $0.01 \mathrm{~s}$, and coda lengths were measured for magnitude determinations. All hypocenter determinations were carried out with the HYPO71 program (Lee and Lahr, 1975).

\section{CRUSTAL-VELOCITY MODEL}

The station traveltime corrections (table 2.1) and the P-wave crustal-velocity model (table 2.2 ) used in this study were obtained by a full inversion of P-wave arrival times from 40 af tershocks of the earthquake, using the procedure of Roecker and Ellsworth (1978) and following the method of Crosson (1976). The events used in this inversion were all of $M>2.0$ and were recorded by 30 or more stations, including 10 or more temporary stations. These events were distributed along the entire length of the aftershock zone.

The starting model for the velocity inversion was based on the results of Blumling and others (1985), whose crustal model for the Morgan Hill area was determined from explosion data recorded within and
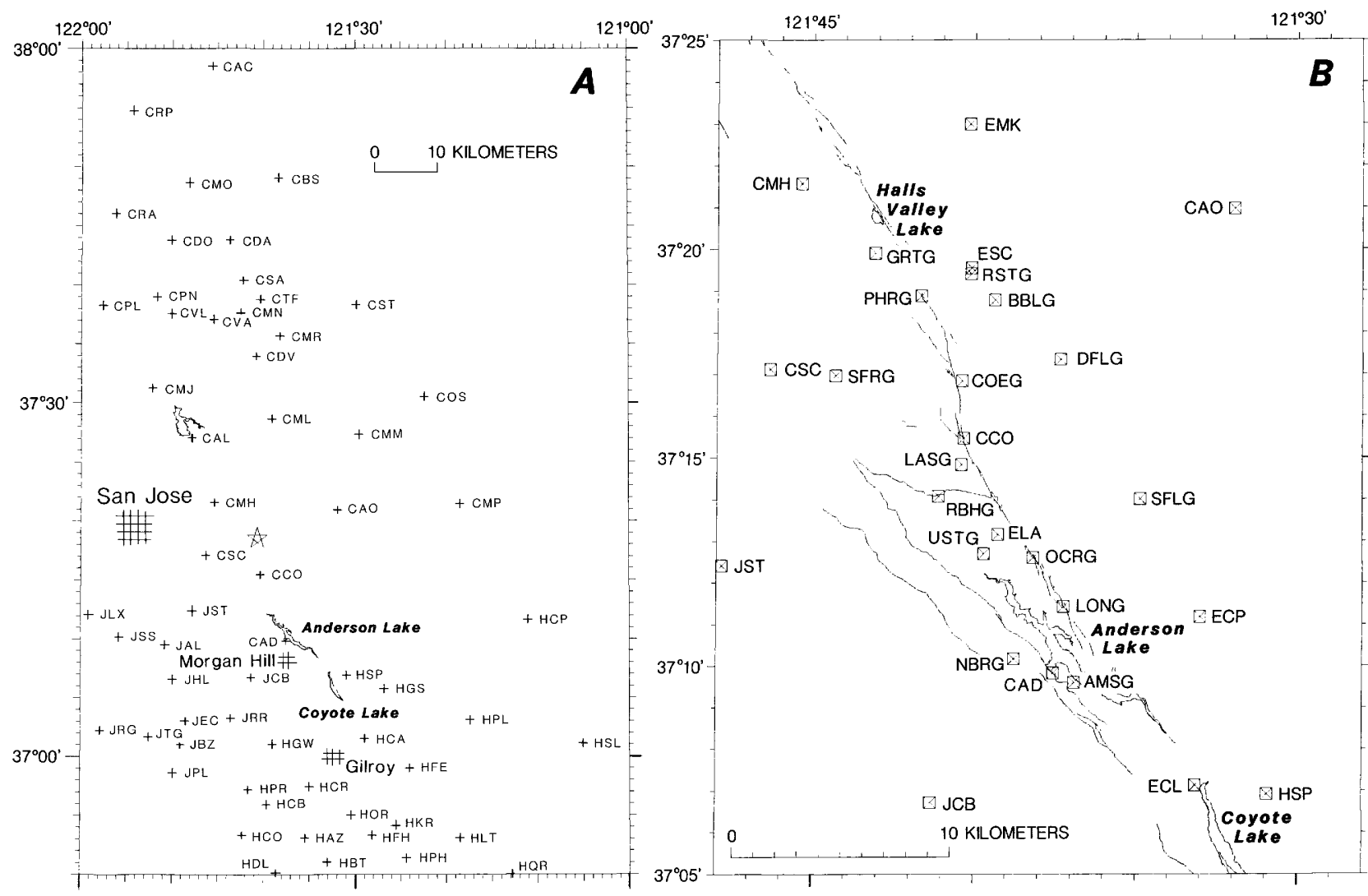

Figure 2.1. Sketch maps of Morgan Hill, Calif., area. A, Locations of epicenter of the earthquake (star), stations in northern California telemetered seismic network (crosses), and physiographic features and localities mentioned in text. B, Locations of strands of the Calaveras fault and nearby reverse faults (from D.G. Herd, unpub. data, 1982), augmented seismic network used to study aftershocks (squares), and physiographic features mentioned in text. Station types are indicated by station codes: three-letter codes beginning with $\mathrm{C}, \mathrm{H}$, or $\mathrm{J}$ are permanent network stations, three-letter codes beginning with $\mathrm{E}$ are portable analog 5-day tape-recorder stations, and four-letter codes are digital General Earthquake Observation System (GEOS) stations. 
Table 2.1. Locations and delay times for stations used in locating aftershocks of the earthquake

\begin{tabular}{|c|c|c|c|c|c|c|c|}
\hline \multirow{4}{*}{\multicolumn{4}{|c|}{$\begin{array}{l}\text { [Delay times calculated using the VELEST program } \\
\text { (Roecker and Ellsworth, 1978). Asterisks denote } \\
\text { temporary stations installed to augment the per- } \\
\text { manent network immediately after the April } 24 \\
\text { main shock] }\end{array}$}} & \\
\hline & & & & Station & Latitude N. & Longitude w. & Delay (s) \\
\hline & & & & $\mathrm{CSH}$ & $37^{\circ} 38.88^{\prime}$ & $122^{\circ} 02.57^{\prime}$ & .81 \\
\hline & & & & CST & $37^{\circ} 38.35^{\circ}$ & $121^{\circ} 29.89^{\prime}$ & .39 \\
\hline \multirow{3}{*}{ Station } & \multirow{3}{*}{ Latitude N. } & \multirow{3}{*}{ Longitude w. } & \multirow{3}{*}{$\operatorname{Delay}(\mathrm{s})$} & CVA & $37^{\circ} 37.10^{\prime}$ & $121^{\circ} 45.49^{\prime}$ & .18 \\
\hline & & & & $\mathrm{CVL}$ & $37 \circ 37.58^{\prime}$ & $121^{\circ} 50.14^{\prime}$ & .31 \\
\hline & & & & HAZ & $36^{\circ} 53.08^{\prime}$ & $1211^{\circ} 35.45^{\prime}$ & .37 \\
\hline & & & & HBT & $36^{\circ} 51.01^{\prime}$ & $121 \cdot 33.04^{\prime}$ & .46 \\
\hline BAV & $36^{\circ} 38.75^{\prime}$ & $121 \circ 01.79^{\circ}$ & -0.18 & $\mathrm{HCA}$ & $37 \circ 01.52^{\prime}$ & $121^{\circ} 29.02^{\prime}$ & .01 \\
\hline BEM & $36^{\circ} 39.68^{\prime}$ & $121^{\circ} 05.76^{\prime}$ & .15 & НСВ & $36^{\circ} 55.88^{\prime}$ & $121^{\circ} 39.63^{\prime}$ & .26 \\
\hline BHR & $36^{\circ} 43.67$ & $121015.83^{\prime}$ & -.02 & HCO & $36^{\circ} 53.311$ & $121^{\circ} 42.34^{\prime}$ & .39 \\
\hline BHS & $36^{\circ} 21.35^{\prime}$ & $121^{\circ} 32.39^{\prime}$ & -.44 & $\mathrm{HCP}$ & $37 \circ 11.67^{\prime}$ & $121^{\circ} 11.08^{\prime}$ & -.20 \\
\hline $\mathrm{BJC}$ & $36 \circ 32.82^{\prime}$ & $121^{\circ} 23.53^{\circ}$ & -.36 & $\mathrm{HCR}$ & $36^{\circ} 57.46^{\prime}$ & $121035.01^{\prime}$ & -.01 \\
\hline BJO & $36^{\circ} 36.65^{\prime}$ & $121^{\circ} 18.81^{\prime}$ & -.20 & HDL & $366^{\circ} 50.12^{\prime}$ & $121^{\circ} 38.64^{\prime}$ & .16 \\
\hline $\mathrm{BPC}$ & $36 \circ 34.32$ & $121^{\circ} 37.56^{\prime}$ & -.09 & HFE & $36^{\circ} 59.00^{\prime}$ & $121^{\circ} 24.09^{\prime}$ & -.15 \\
\hline BSL & $36^{\circ} 46.53^{\prime}$ & $121^{\circ} 20.96^{\circ}$ & .12 & $\mathrm{HFH}$ & $36^{\circ} 53.29^{\prime}$ & $121^{\circ} 28.13^{\prime}$ & .36 \\
\hline BSR & $36^{\circ} 39^{\circ} .99^{\prime}$ & $121 \circ 31.12^{\prime}$ & -.15 & HFP & $36^{\circ} 45.22^{\prime}$ & $121^{\circ} 29.43^{\prime}$ & .24 \\
\hline BVY & $36^{\circ} 44.96^{\prime}$ & $121 \circ 24.80^{\circ}$ & .55 & HGS & $37^{\circ} 05.75^{\prime}$ & $121^{\circ} 26.83^{\prime}$ & -.15 \\
\hline CAD & $37009.83^{\prime}$ & $121 \circ 37.55^{\prime}$ & .39 & HGW & $37 \circ 01.02^{\prime}$ & $121^{\circ} 39.02^{\circ}$ & .09 \\
\hline CAI & $37^{\circ} 51.68^{\prime}$ & $122^{\circ} 25.77^{\circ}$ & -.52 & HJG & $36^{\circ} 47.88^{\prime}$ & $\left.12^{\prime}\right|^{\circ} 34.43^{\prime}$ & .16 \\
\hline CAL & $37 \cdot 27.07$ & $121^{\circ} 47.95^{\prime}$ & .00 & HJS & $36^{\circ} 48.99^{\prime}$ & $12 \| \bullet 17.92^{\prime}$ & -.03 \\
\hline CAO & $37 \circ 20.96^{\prime}$ & $121^{\circ} 31.96^{\circ}$ & -.10 & HKR & $36^{\circ} 54.10^{\prime}$ & $12^{\prime} 1^{\circ} 25.56^{\prime}$ & .42 \\
\hline CBS & $37^{\circ} 49.06^{\prime}$ & $121^{\circ} 38.43^{\prime}$ & .68 & HLT & $36 \circ 53.07^{\prime}$ & $12.1^{\circ} 18.49^{\prime}$ & -.19 \\
\hline $\mathrm{Cco}$ & $37^{\circ} 15.46^{\circ}$ & $121^{\circ} 40.35^{\prime}$ & .41 & нмо & $36^{\circ} 36.03^{\prime}$ & $12^{\prime} 1^{\circ} 55.06^{\prime}$ & -.29 \\
\hline $\mathrm{CCY}$ & $37 \circ 33.10^{\prime}$ & $122^{\circ} 05.45^{\prime}$ & -.32 & HOR & $36^{\circ} 55.03^{\prime}$ & $121^{\circ} 30.46^{\prime}$ & .05 \\
\hline $\mathrm{CDA}$ & $37^{\circ} 43.80^{\circ}$ & $121^{\circ} 43.70^{\circ}$ & -1.03 & $\mathrm{HPH}$ & $36^{\circ} 51.38^{\prime}$ & $121^{\circ} 24.37^{\prime}$ & .65 \\
\hline $\mathrm{CDO}$ & $37 \circ 43.80^{\circ}$ & $121^{\circ} 50.12^{\prime}$ & .93 & HPL & $37^{\circ} 03.13^{\prime}$ & $121017.40^{\circ}$ & -.28 \\
\hline $\mathrm{CDV}$ & $37^{\circ} 33.98^{\prime}$ & $121 \cdot 40.81$, & .02 & HPR & $36^{\circ} 57.19^{\prime}$ & $121^{\circ} 41.70^{\circ}$ & .32 \\
\hline CMC & $37^{\circ} 46.88^{\prime}$ & $122^{\circ} 10.55^{\prime}$ & .05 & $\mathrm{HQR}$ & $36^{\circ} 50.02^{\prime}$ & $121012.76^{\circ}$ & -.25 \\
\hline СМH & $37 \circ 21.57$ & $1211^{\circ} 45.38^{\prime}$ & .29 & $\mathrm{HSF}$ & $36^{\circ} 48.72^{\prime}$ & $121^{\circ} 29.977^{\prime}$ & .74 \\
\hline $\mathrm{CMJ}_{\mathrm{J}}$ & $37 \circ 31.25^{\prime}$ & $121^{\circ} 52.23^{\prime}$ & .10 & HSL & $37^{\circ} 01.16^{\prime}$ & $121005.13^{\prime}$ & -.05 \\
\hline CML & $37028.64^{\prime}$ & $121^{\circ} 39.09^{\circ}$ & .12 & HSP & $37 \circ 06.91^{\prime}$ & $121 \circ 30.94^{\prime}$ & .09 \\
\hline CMM & $37^{\circ} 27^{\circ} 34^{\prime}$ & $121^{\circ} 29.62^{\prime}$ & -.01 & JAL & $37 \circ 09.50^{\prime}$ & $121^{\circ} 50.82^{\prime}$ & .17 \\
\hline CMN & $37 \circ 37.65^{\circ}$ & $121^{\circ} 42.50^{\circ}$ & .14 & $\mathrm{JBC}$ & $37^{\circ} 09.62^{\prime}$ & $122^{\circ} 01.571$ & .23 \\
\hline Смо & $37 \circ 48.68^{\prime}$ & $121^{\circ} 48.15^{\prime}$ & 1.02 & JBG & $37^{\circ} 20.52$ & $122^{\circ} 20.34^{\prime}$ & .03 \\
\hline CMP & $37^{\circ} 21.46^{\circ}$ & $121^{\circ} 18.51^{\prime}$ & -.24 & JBL & $37007.67^{\prime}$ & $122^{\circ} 09.98^{\prime}$ & -.17 \\
\hline CMR & $37 \cdot 35.68^{\circ}$ & $121^{\circ} 38.22^{\prime}$ & .00 & JBM & $37019.09^{\prime}$ & $122^{\circ} 09^{\prime} 16^{\prime}$ & .01 \\
\hline $\cos$ & $37^{\circ} 30.51^{\prime}$ & $121 \circ 22.44^{\prime}$ & .00 & JBZ & $37 \circ 01.07^{\prime}$ & $121^{\circ} 49.15^{\prime}$ & .46 \\
\hline $\mathrm{CPL}$ & $37^{\circ} 38.25^{\prime}$ & $121^{\circ} 57.64^{\prime}$ & .09 & $\mathrm{JCB}$ & $37^{\circ} 06.71^{\prime}$ & $12 \|^{\circ} 41.33^{\prime}$ & .16 \\
\hline CRA & $37^{\circ} 46.03^{\prime}$ & $121^{\circ} 56.25^{\prime}$ & 1.07 & JEC & $37^{\circ} 03.04^{\prime}$ & $121^{\circ} 48.56^{\prime}$ & .23 \\
\hline $\operatorname{CSA}$ & $37^{\circ} 40.42^{\prime}$ & $121^{\circ} 42.25^{\prime}$ & .27 & JEG & $37^{\circ} 30.84^{\prime}$ & $122^{\circ} 27.74^{\prime}$ & -.37 \\
\hline $\csc$ & $37 \circ 17.11^{\prime}$ & $121^{\circ} 46.35^{\prime}$ & .68 & JHL & $37^{\circ} 06.56^{\prime}$ & $121^{\circ} 49.95^{\prime}$ & .18 \\
\hline
\end{tabular}

\begin{tabular}{|c|c|c|c|}
\hline Station & Latitude N. & Longitude $w$. & Delay(s) \\
\hline JHP & $37^{\circ} 26.65^{\prime}$ & $122 \circ 18.09^{\prime}$ & -.18 \\
\hline JLT & $37^{\circ} 21.22^{\circ}$ & $122^{\circ} 12.25^{\prime}$ & -.06 \\
\hline JLX & $37^{\circ} 12.11^{\prime}$ & $121^{\circ} 59.17^{\prime}$ & .03 \\
\hline JPL & $36^{\circ} 58.62^{\prime}$ & $121^{\circ} 49.93^{\prime}$ & .56 \\
\hline JPP & $37 \circ 15.811$ & $122^{\circ} 12.78^{\prime}$ & .13 \\
\hline JPS & $37^{\circ} 11.94^{\prime}$ & $122^{\circ} 20.90^{\prime}$ & -.09 \\
\hline JRG & $37^{\circ} 02.22^{\prime}$ & $121^{\circ} 57.86^{\prime}$ & .23 \\
\hline JRR & $37^{\circ} 03.27^{\prime}$ & $121^{\circ} 43.61^{\prime}$ & .12 \\
\hline JSA & $37034.95^{\prime}$ & $122^{\circ} 25.03^{\prime}$ & -.44 \\
\hline JSC & $37^{\circ} 17.07^{\prime}$ & $122^{\circ} 07.42^{\circ}$ & .01 \\
\hline JSF & $37^{\circ} 24.31^{\prime}$ & $122^{\circ} 10.55^{\prime}$ & -.02 \\
\hline JSG & $37016.96^{\prime}$ & $122^{\circ} 03.00^{\prime}$ & .52 \\
\hline JSJ & $37^{\circ} 20.03^{\prime}$ & $122^{\circ} 05.48^{\prime}$ & .42 \\
\hline JSM & $37012.74^{\prime}$ & $122^{\circ} 10.06^{\circ}$ & .14 \\
\hline JSS & 37010.17 & $121^{\circ} 55.84^{\prime}$ & .09 \\
\hline JST & $37012.41^{\prime}$ & $121^{\circ} 47.84^{\prime}$ & .22 \\
\hline JTG & $37^{\circ} 01.71^{\prime}$ & $121^{\circ} 52.58^{\prime}$ & .46 \\
\hline JuC & $37^{\circ} 00.07$ & $122^{\circ} 02.91^{\prime}$ & .02 \\
\hline AMSG* & $37^{\circ} 09.60^{\prime}$ & $121^{\circ} 36.90^{\circ}$ & .41 \\
\hline BBLG* & $37^{\circ} 18.78^{\prime}$ & $121^{\circ} 39.40^{\prime}$ & .07 \\
\hline $\operatorname{COEG} \mathrm{G}^{\star}$ & $37^{\circ} 16.84^{\prime}$ & $121^{\circ} 40.40^{\prime}$ & .35 \\
\hline $\mathrm{DFLG} *$ & $37^{\circ} 17.35^{\prime}$ & $121^{\circ} 37.35^{\prime}$ & -.02 \\
\hline GRTG* & $37^{\circ} 19.90^{\circ}$ & $121^{\circ} 43.11^{\prime}$ & .20 \\
\hline UTSG* ${ }^{\star}$ & $37^{\circ} 12.70^{\prime}$ & $121^{\circ} 39.72^{\prime}$ & .74 \\
\hline LASG* & $370^{\circ} 14.84^{\prime}$ & $121 \circ 40.41^{\prime}$ & .62 \\
\hline LONG* & $37^{\circ} 11.43^{\circ}$ & $121^{\circ} 37.24^{\prime}$ & .57 \\
\hline NBRG* & $37010.17^{\prime}$ & $121^{\circ} 38.76^{\prime}$ & .45 \\
\hline OCRG* & $37012.60^{\prime}$ & $121^{\circ} 38.18^{\prime}$ & .53 \\
\hline PHRG ${ }^{\star}$ & $37 \circ 18.88^{\circ}$ & $121^{\circ} 41.67^{\prime}$ & .17 \\
\hline RBHG* & $37 \circ 14.071$ & $121^{\circ} 41.13^{\prime}$ & .71 \\
\hline RSTG* & $37^{\circ} 19.41^{\prime}$ & $121^{\circ} 40.13^{\prime}$ & .04 \\
\hline SFLG* & $37^{\circ} 14.01^{\prime}$ & $121^{\circ} 34.89^{\circ}$ & .09 \\
\hline SFRG* & $37^{\circ} 16.96^{\prime}$ & $121^{\circ} 44.32^{\prime}$ & .67 \\
\hline ECL* & $37^{\circ} 07.12^{\prime}$ & $121^{\circ} 33.14^{\prime}$ & .27 \\
\hline ECP* & $37011.18^{\prime}$ & $121^{\circ} 33.01^{\prime}$ & .09 \\
\hline $\mathrm{ECW}^{\star}$ & $37^{\circ} 17.46^{\prime}$ & $121^{\circ} 27.75^{\prime}$ & -.13 \\
\hline ELA* & $37013.16^{\prime}$ & $121^{\circ} 39.28^{\prime}$ & .54 \\
\hline EMK* & $37^{\circ} 23.00^{\prime}$ & $121^{\circ} 40.17^{\prime}$ &. .08 \\
\hline ESC* & $37 \circ 19.35^{\prime}$ & $121^{\circ} 40.12^{\prime}$ & -.02 \\
\hline
\end{tabular}

Table 2.2. $\quad \mathrm{P}-$ wave - velocity model used in this study

$\underline{\underline{\underline{V}}} \underline{\mathrm{p}}_{\mathrm{p}}, \underline{\mathrm{p}}$-wave velocity; $\underline{\underline{Z}}$, depth to top of layer]

\begin{tabular}{lr}
\hline$\underline{\mathrm{v}} \underline{\mathrm{v}}_{\mathrm{p}}$ & $\underline{\mathrm{zm}}$ \\
\hline 3.67 & 0.0 \\
4.80 & .5 \\
5.27 & 2.0 \\
5.76 & 4.2 \\
6.05 & 10.0 \\
6.20 & 14.0 \\
7.60 & 25.0 \\
\hline
\end{tabular}

transverse to the Calaveras fault zone. Their final crustal model for this area has several wedges of sedimentary material that cannot be taken into account by the location program. A composite onedimensionul model embodying the principal features of their model was used as a starting model in the inversion procedure for the aftershock data.

We compared the hypocentral determinations bused on our final model with those based on two other models. Mayer-Rosa (1973) derived a model for this section of the Caluveras fuult from explosion data recorded at short distances; however, his model extends only to shallow depths (approx $6 \mathrm{~km}$ ). The second model used, which was developed by Ellsworth and Marks (1980), is generalized for the region east of the San Francisco Bay and was derived from explosion

and earthquake data in the Livermore area. The focal depths computed with Mayer-Rosa's model are somewhat shallower, and the locations computed with the Ellsworth and Marks' model somewhat more scattered, than those obtained with our model based on the pattern of aftershocks. Although the overall hypocentral-distribution patterns produced by these three models are nearly identical, we believe that the absolute locations based on the aftershock model are superior to those based on the other two models because the aftershock model was determined from a more comprehensive local set of traveltime observations.

\section{THE MAIN SHOCK}

The Morgan Hill earthquake occurred on the Calaveras fault in a region of great geologic complexity. In this region, the band of frequent small earthquakes believed to be associated with the Calaveras fault is located, according to the model and station corrections routinely used for central California by the USGS, about $3 \mathrm{~km}$ east of the surface expression of the fault. In a preliminary study of the earthquake (Eaton, 1984), three different models were used to locate the hypocenter of the main shock so as to assess the model dependence of this location. The different models and associated station corrections used were: (A) the standard USGS model and station corrections for the central California Coast Ranges, (B) the east-bay-regionul model of Ellsworth and Marks (1980), and (C) station corrections based on $\mathrm{P}_{n}$ timeterm differences in the central California Coust Ranges (J.P. Eaton, unpub. data, 1980) and a crustal 
model designed to minimize the root mean square (rms) of traveltime residuals of the main shock. The hypocenters calculated from these three models were within $1.5 \mathrm{~km}$ of each other in both epicentral location and focal depth, but all three lay east of the surface expression of the Calaveras fault. Distances to the nearest mapped strand of the Calaveras fault from the three epicenters were $1.8,1.1$, and $0.8 \mathrm{~km}$ for models $\mathrm{A}, \mathrm{B}$, and $\mathrm{C}$, respectively.

The hypocenter of the main shock calculated with the model and station corrections derived for the present study is almost identical to that from model C: only $0.3 \mathrm{~km}$ shallower and $0.1 \mathrm{~km}$ due east. We interpret this close agreement between the results of these two models, derived by very different procedures, as support for the validity of our result. P-wave first motions of the main shock are plotted in figure 2.2. Nodal plane I strikes N. $34^{\circ} \mathrm{W}$. and dips $84^{\circ}$ SE.; nodal plane II strikes N. $57^{\circ}$ E. and dips $80^{\circ}$ NW. Nodal plane I can be confidently identified as the fault plane because it parallels the long narrow band of aftershocks as well as the Calaveras fault.

The most seriously discordant points in figure 2.2 are for stations $\operatorname{CCO}(\Delta=5.8 \mathrm{~km})$ and $\operatorname{CiNH}(\Delta=8.9 \mathrm{~km})$, both of which lie just west of the Calaveras fault but recorded first motions more appropriate for the east side of the fault. These discordant first motions, as well as the apparent mislocation of the main shock and its aftershocks about $1 \mathrm{~km}$ east of the surface

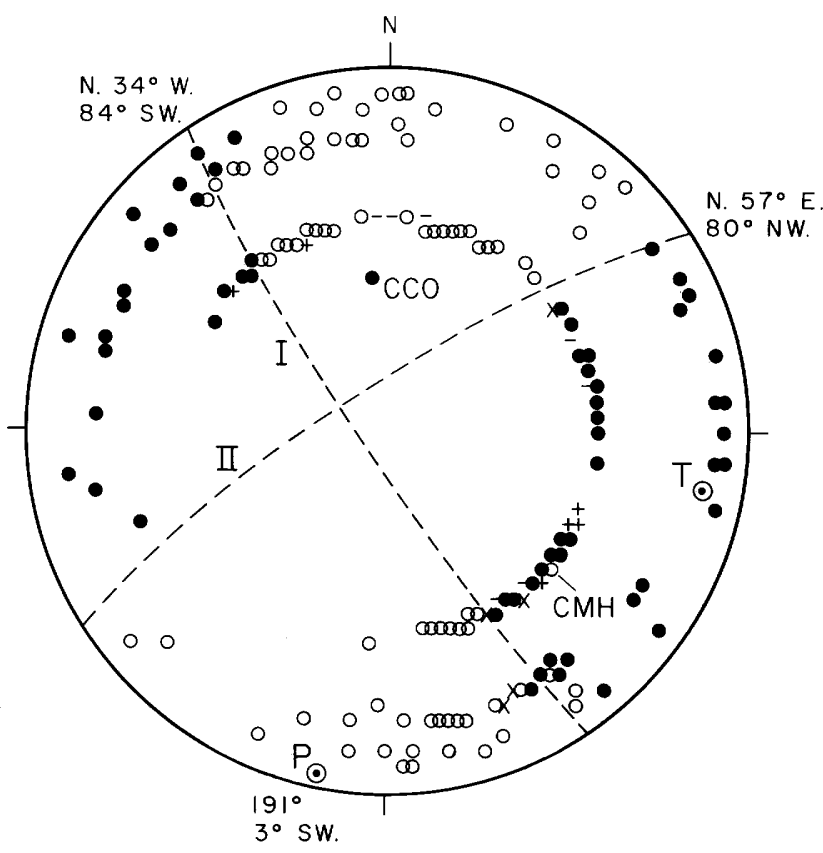

Figure 2.2. Equal-area lower-hemisphere first-motion plot, showing focal-plane solution for the main shock. Dots and crosses, certain and questionable compressional first arrivals, respectively; circles and dashes, certain and questionable dilatational first arrivals, respectively; $X$ 's, conflicting first arrivals; $P$ and $T$, inferred axes of maximum and minimum compression, respectively; I and II, nodal planes; $\mathrm{CCO}$ and $\mathrm{CMH}$, discordant first-motion readings. expression of the Calaveras fault, suggest that $P$-wave velocities at upper-crustal and midcrustal depths are somewhat higher east than west of the fault.

A total of 3 low-gain horizontal-component seismometers in northern California and 10 low-guin vertical-component seismometers in southern California produced records from which maximum amplitudes and associated periods could be measured. Table 2.3 lists the distance and azimuth of each of these stations from the epicenter, as well as the magnitude computed for the main shock. The average $\mathrm{M}_{\mathrm{L}}$ for the three northern California stations is 6.17; the $10 \mathrm{M}$ values from southern California average 6.74, substantially larger than the northern California average. A correction of +0.25 has been added to the magnitudes computed from a vertical-component instead of a horizontal-component seismometer to compensate for the average ratio of horizontal to vertical maximum amplitudes. This correction, which was determined from a limited number of small to moderate earthquakes recorded at distances less than $200 \mathrm{~km}$ in central California, may be inappropriate for larger earthquakes recorded at much greater distances.

We also note the rather narrow range in azimuth of the stations reporting magnitudes in northern California $\left(328^{\circ}-353^{\circ}\right)$ and southern California $\left(125^{\circ}\right.$ $\left.134^{\circ}\right)$. The difference in northern and southern California magnitudes may arise from the northwestto-southeast direction of rupture propagation in the event (Bakun and others, 1984). Chapter 3 summarizes the parameters for the main shock.

\section{SPATIAL DISTRIBUTION OF THE AFTERSHOCKS}

Figure 2.3 shows the locations of the earthquake and its aftershocks from April 24 through September 30,1984 . The primary feature of the aftershockdistribution pattern is a narrow central band of aftershocks that parallels the trend of the Calaveras

Table 2.3. Local-magnitude determinations for the main shock

[Average magnitudes: northern California, 6.17 ; southern California, 6.74-(0.00-0.25)= $6 \cdot 5-6 \cdot 7]$

\begin{tabular}{lccc}
\hline Station & $\begin{array}{c}\text { Distance } \\
(\mathrm{km})\end{array}$ & $\begin{array}{c}\text { Azimuth } \\
\left({ }^{\circ}\right)\end{array}$ & $\begin{array}{c}\text { Magnitude } \\
\text {-L }\end{array}$ \\
\hline LTCN & 324 & 353 & 6.2 \\
KMPN & 405 & 328 & 6.0 \\
KMPE & 405 & 328 & 6.3 \\
RLBZ & 459 & 131 & 6.7 \\
RBRZ & 481 & 132 & 6.6 \\
RGAZ & 525 & 134 & 6.4 \\
RBIZ & 548 & 127 & 7.0 \\
RRFZ & 571 & 129 & 7.0 \\
RPBZ & 590 & 133 & 6.5 \\
DCUZ & 607 & 125 & 6.8 \\
REWZ & 609 & 128 & 6.9 \\
ECYZ & 656 & 132 & 6.8 \\
ICWZ & 663 & 127 & 6.7 \\
\hline
\end{tabular}




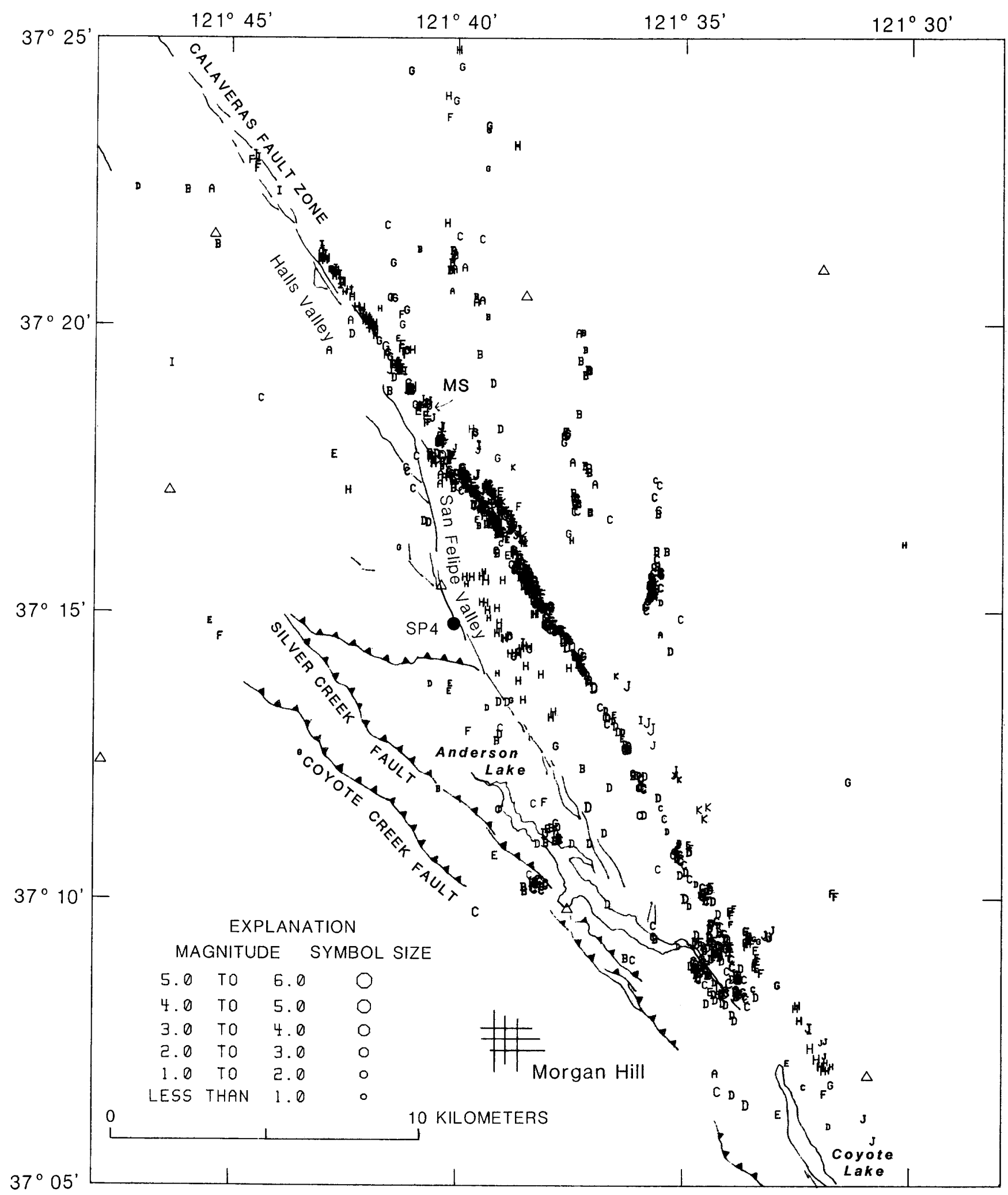

Figure 2.3. Sketch map of Morgan Hill, Calif., area, showing locations of epicenter of April 24 main shock (MS) and its aftershocks through September 30, 1984. Magnitudes and focal depths ( $\mathrm{H}$, in kilometers) are indicated by symbol size and letter: $A, 0<\underline{H} \leq 1 ; B$,
$1<\mathrm{H} \leq 2 ; * * * \mathrm{~K}, 10<\mathrm{H} \leq 11 \mathrm{~km}$. Solid lines, fault traces from D.G. Herd (unpub. data, 1982). Saw teeth, thrust faults; barbs on upper plate. Triangles, seismic stations in permanent network. SP4, refraction shotpoint of Blumling and others (1985). 
fault zone from Halls Valley on the northwest to the north end of Coyote Lake on the southeast. This band is generally less than $1 \mathrm{~km}$ wide and more than $30 \mathrm{~km}$ long. Notable secondury features of the aftershock distribution include: (1) three 5- to 7-km long northsouth-trending alignments of shallow earthquakes that lie east of the northwest half of the central band, (2) a 6-km-long alignment of hypocenters at a depth of 7 to $8 \mathrm{~km}$ that parallels the central section of the central band southwest of the San Felipe Valley and is offset 1.5 to $2 \mathrm{~km}$ southwest of it, and (3) a dense, 2-km-wide by $3-\mathrm{km}$-long cluster of shallow aftershocks just west of the central band at the south end of Anderson Lake.

At its northwest end, the central band of af tershocks is locuted about $0.5 \mathrm{~km}$ east of mapped strands of the Calaveras fault. In its $30+\mathrm{km}$ extension to the southeast, this central band curves very gently to the west. Nowhere does it depart more than about $1 \mathrm{~km}$ from the straight line striking $\mathrm{N}$. $33^{\circ} \mathrm{W}$. that joins its end points. At the south end of Anderson Lake, the central band lies 1 to $1.5 \mathrm{~km}$ east of the principal mapped strand of the Calaveras fault. The mapped strands of the Calaveras fault between Halls Valley and Coyote Lake suggest a more complex structure there than does the central band of aftershocks. Between San Felipe Valley and the center of Anderson Lake, mapped strands of the fault are of fset 1.5 to $2 \mathrm{~km}$ southwestward of a line joining strands of the fault at Halls Valley on the northwest and Coyote Lake on the southeast. This offset is adjacent to the Silver Creek fault and related faults (Page 1982a, b), which strike more east-westerly than the Calaveras fault and appear to terminate at or near the Calaveras fault between the San Felipe Valley and Coyote Lake. This of fset also has the same sense and size as the of fset of the alignment of the 7 to $8-\mathrm{km}$ deep aftershocks southeast of the San Felipe Valley from the central band of aftershocks. Although we note a possible systematic mislocation of the main shock and its aftershocks, as well as a biasing of the dip of the fault surface corresponding to the central band of aftershocks that would result from $\mathrm{P}$-wave velocities higher east of the fault than west of it, we believe that the hypocenters presented herein (fig. 2.3) are not systematically mislocated toward the east between San Felipe Valley and the south end of Anderson Lake. In fact, using $P$-wave arrival times from a refraction shot (SP4 of Blumling and others, 1985) and the crustal-velocity model and station delay terms reported herein, the computer location of the shotpoint is less than $0.5 \mathrm{~km}$ both laterally and vertically from the actual shotpoint. This shotpoint is located $1.3 \mathrm{~km}$ south of seismic station CCO (fig. 2.3) within the mapped fault strands of the Calaveras fault.

Figure 2.4 compares the map pattern of aftershocks at all depths (fig. 2.4A) with those for the depth intervals $\mathrm{H}<2.5 \mathrm{~km}$ (fig. $2.4 \mathrm{~B}$ ), $2.5 \leq \underline{\mathrm{H}}<7.5 \mathrm{~km}$ (fig. $2.4 \mathrm{C}$ ), and $\overline{\mathrm{H}} \geq 7.5 \mathrm{~km}$ (fig $2.4 \mathrm{D}$ ). In the pattern of shallow events (fig. 2.4B), the central band of aftershocks is visible, though no more conspicuous than the alignments of shallow af tershocks that lie east of the northwest half of the central band and west of the southeast half of the central band. In the pattern of intermediate-depth af tershocks (fig. $2.4 \mathrm{C}$ ), the central band is well developed and is flanked by scattered events to the east along its northwest half and by a more concentrated band of aftershocks to the west along most of its length, particularly from the southwest end of San Felipe Valley to the southwest end of Anderson Lake. In the pattern for deep events (fig. 2.4D), the central band consists of several very narrow segments that can be grouped into northwest and southeast halves with average strikes of $\mathrm{N} .35^{\circ} \mathrm{W}$. and N. $29^{\circ}$ W., respectively. Similar changes in the strike direction of the central band occur at shallow (fig. 2.4B) and intermediate (fig. 2.4C) depths. Below 7.5-km depth, a subparallel band of aftershocks lies opposite and about $2 \mathrm{~km}$ southwest of a gap in the central band between its northwest and southeast halves, just southeust of San Felipe Valley.

The root of the aftershock zone is narrow and simple below $7.5-\mathrm{km}$ depth. The central band of af tershocks and the af tershocks southwest of that band are best expressed in the depth range $2.5-7.5 \mathrm{~km}$. The pattern of aftershocks above $2.5-\mathrm{km}$ depth and its relation to mapped strands of the Calaveras fault suggest that these aftershocks are concentrated on local shallow structures bordering the Calaveras fault and that the Calaveras fault does not cut cleanly through this shallow region, above the principal trace of the fault at depth, over much of the break associated with the April 24 earthquake. A small but clear change in the strike of the central band of af tershocks apparently occurs about $5 \mathrm{~km}$ southeast of San Felipe Valley, from N. $35^{\circ} \mathrm{W}$. in the northwest to N. $29^{\circ} \mathrm{W}$. in the southeast.

The longitudinal cross sections of the aftershock zone in fig. 2.5 are projected onto a vertical plane through the line $\mathrm{R}-\mathrm{R}^{\prime}$ (azimuth $327^{\circ}$, fig. 2.4D). In figure 2.5A, aftershocks within $10 \mathrm{~km}$ of line $R-R^{\prime}$ are included in the plot; in figures $2.5 \mathrm{~B}$ and $2.5 \mathrm{C}$ only aftershocks within a $2.1-\mathrm{km}$-wide band along line $\mathbf{R}-\mathbf{R}^{\prime}$ are included to permit aftershocks along the principal fault to be separated from those bordering the fault.

Figure 2.5B shows a central quiet zone surrounded and almost completely outlined by aftershocks. The main-shock hypocenter lies within this quiet zone at its northwest end. We interpret this quiet zone to be the section of the fault that slipped during the main shock, and the surrounding zone of aftershocks to be the subsequent extension of this slipped section on the fault surface. Reasenberg and Ellsworth (1982) found a zone of subdued aftershock activity around the main shock of the 1979 Coyote Lake, Calif., earthquake, which occurred on the Calaveras fault just southeast of the Morgan Hill aftershock zone. King and others (1985) presented evidence that the main shocks of the 1981 Corinth, Greece, earthquake sequence lie between clusters of af tershocks and suggest that $" * * *$ de-stressed regions associated with the main event faulting are relatively free from aftershocks compared to regions where the motion on the main fault planes increased stress." Figure $2.5 \mathrm{C}$ shows that af tershocks of $M \geq 2.0$ generally show the same pattern as those in figure $2.5 \mathrm{~B}$, but with poorer definition. These $\mathbf{M} \geq 2.0$ aftershocks are most numerous in the distance range $1-7 \mathrm{~km}$ along the profile, which is the region just southeast of San Felipe Valley with the alignment of $7-$ to $8-\mathrm{km}$-deep earthquakes southwest of the central band. Figure 

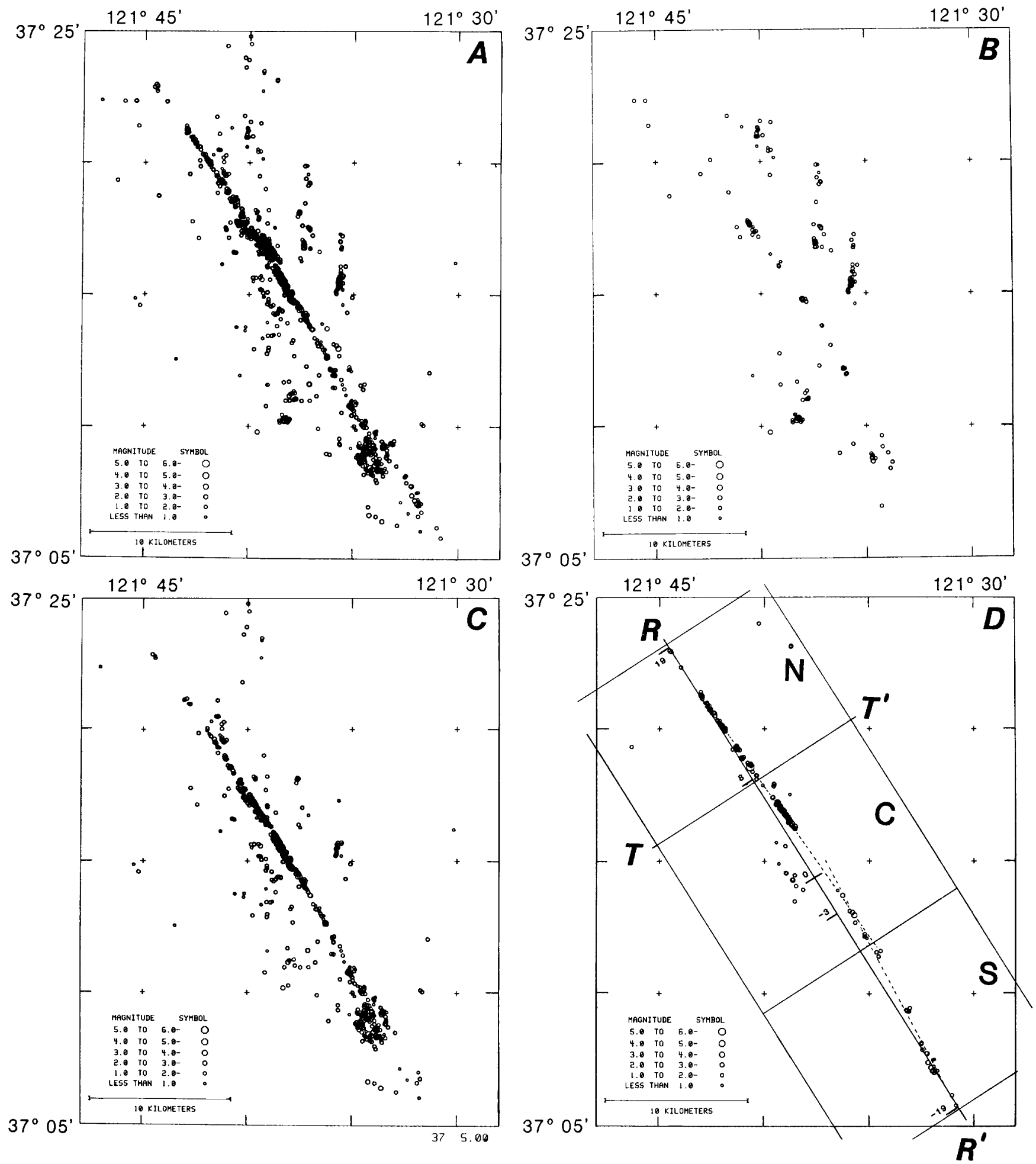

Figure 2.4. Sketch maps showing aftershock pattern as a function of focal-depth (H) range. $A, H \geq 0 \mathrm{~km}$. $B, H \leq 2.5$ $\mathrm{km}$. $\mathrm{C}, 2.5 \mathrm{~km}<\mathrm{H} \leq 7.5 \mathrm{~km}$. $\mathrm{D}, \underline{H}>7.5 \mathrm{~km}$. Lines $\mathrm{R}-\mathrm{R}^{\prime}$ and $\mathrm{T}^{\prime} \mathrm{T}^{\prime}$ are longitudinal and transverse section lines, respectively. Frames N, C, and $\mathrm{S}$ are subregions for which separate plots were constructed. 

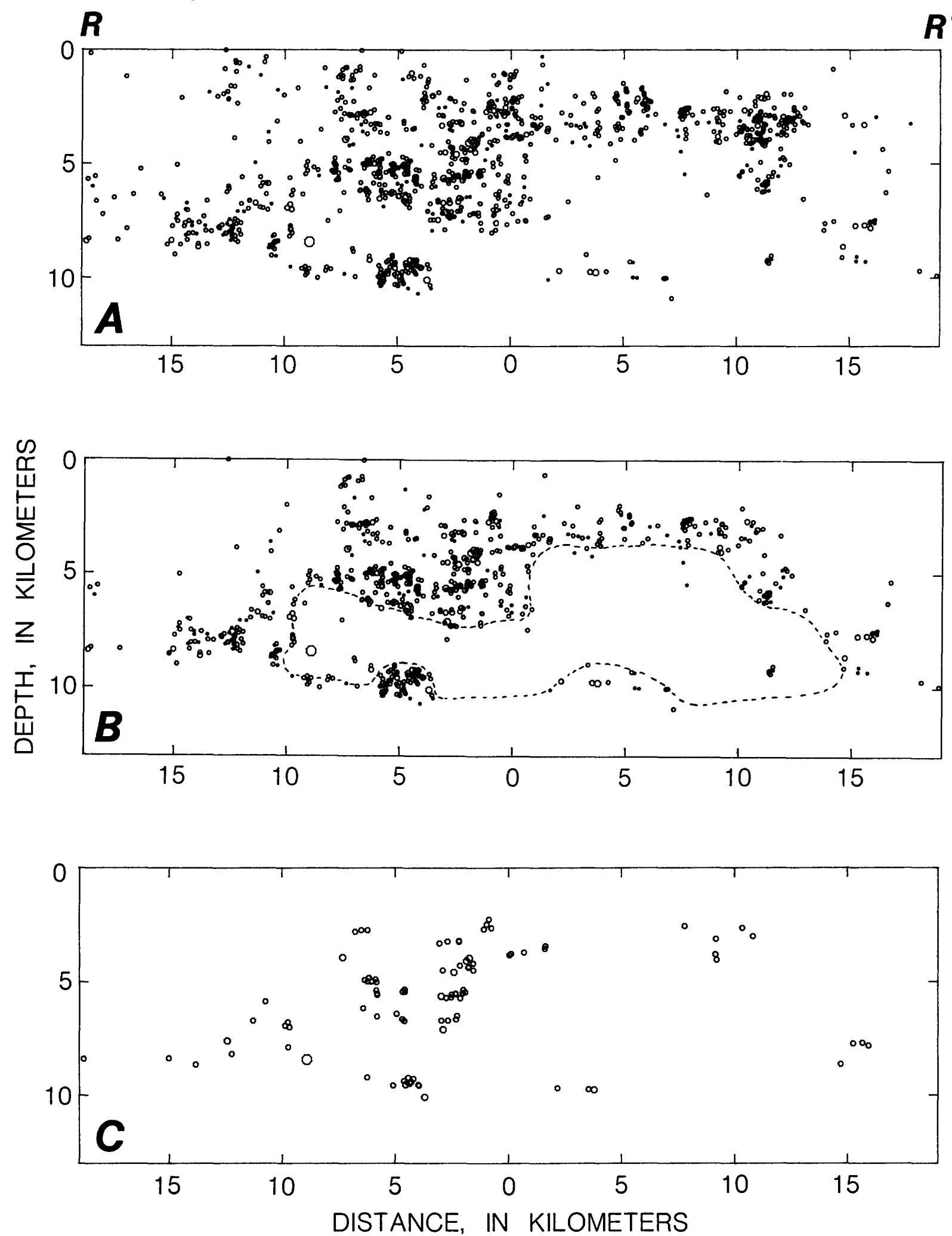

Figure 2.5. Longitudinal sections of aftershock distribution along line $\underline{R}-\underline{R}$ ' (fig. 2.4D). A, All events within $10 \mathrm{~km}$ of line $\underline{R}-\underline{R}^{\prime}$. $\underline{B}$ and $\underline{C}$, Events within $1.3 \mathrm{~km}$ nor theast and $0.8 \mathrm{~km}$ southwest of line $\underline{R}-\underline{R}$, respectively. All events plotted in figure 2.5 $\underline{\mathrm{C}}$ are of $\mathrm{M} \geq 2.0$. 
$2.5 \mathrm{~A}$, in comparison with figure $2.5 \mathrm{~B}$, shows that the off-fault aftershocks are predominantly shallow.

Transverse cross sections of the aftershock zone (fig. 2.6) are projected onto a vertical plane perpendicular to the average trend of the central band of aftershocks (azimuth $327^{\circ}$ ) and parallel to line $\mathrm{T}-\mathrm{T}^{\mathrm{t}}$ in figure $2.4 \mathrm{D}$. In figure $2.6 \mathrm{~B}$, for aftershocks with $\mathbf{M} \geq 2.0$, the fault surface appears as a very narrow zone of aftershocks, dipping about $85^{\circ} \mathrm{NE}$. and passing through the main shock. Most of the of $f-f$ ault aftershocks are 2 to $4 \mathrm{~km}$ deep and lie southwest of the fault. The fault zone appears to be complex between 8- and 11-km depth, centered on the main shock. In figure $2.6 \mathrm{~A}$, which shows the entire set of aftershocks, the nearly vertical fault is the most striking feature, but the off-fault features of the pattern are also well defined. The shallow alignments of aftershocks northeast of the principal fault are well separated from it. A diffuse horizontal zone of aftershocks at 5 - to $8-\mathrm{km}$ depth extends outward to

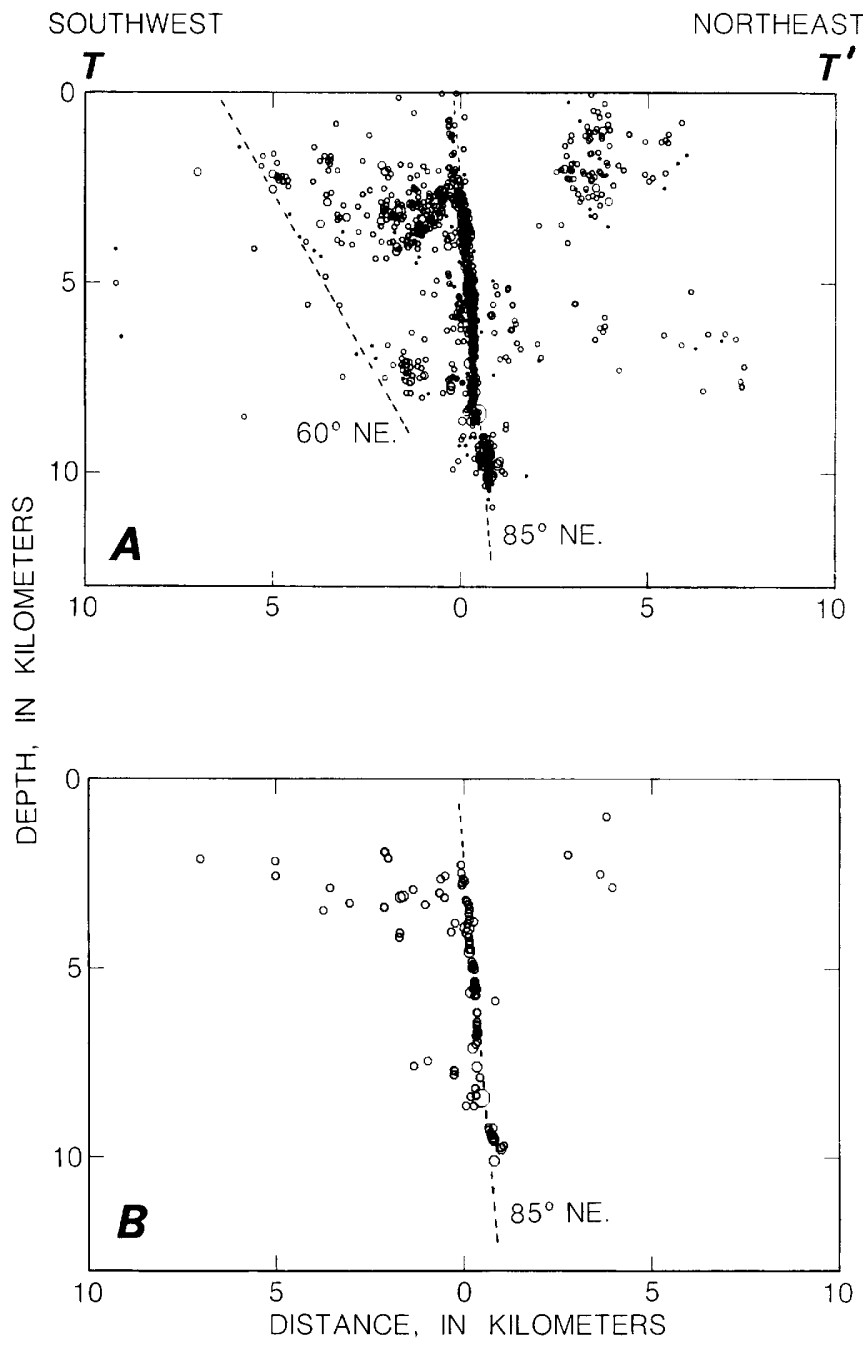

Figure 2.6. Transverse sections of aftershock distribution along line $T-T^{\prime}$ (and perpendicular to line $R-R^{\prime}$ ) for all events between points $R$ and $R^{\prime}$ (fig. 2.4D). A, All events. $B$, Events of $\underline{M} \geq 2 . \overline{0}$. about $8 \mathrm{~km}$ northeast of the fault. Aftershocks southwest of the fault are much more numerous than those northeast of it. Most of these events are concentrated in two groups, at $2-$ to $4-\mathrm{km}$ depth and at 6 - to $8-\mathrm{km}$ depth; they appear to be bounded on the southwest by a line that dips about $60^{\circ} \mathrm{NE}$. and which would outcrop about $7 \mathrm{~km}$ southwest of the central band of aftershocks near the Silver Creek fault.

Figure 2.7 shows transverse sections for three zones along the fault (fig. 2.4D): $N(8 \mathrm{~km}<\mathrm{R}<19 \mathrm{~km})$, $\mathrm{C}(-3 \mathrm{~km}<\mathrm{R}<8 \mathrm{~km})$, and $\mathrm{S}(-19 \mathrm{~km}<\mathrm{R}<-3 \mathrm{~km})$. Sections $\mathrm{N}$ and $\mathrm{C}$ are perpendicular to azimuth $327^{\circ}$ (same as in fig. 2.6), but section $S$ is perpendicular to azimuth $331^{\circ}$, reflecting the gradual change in strike of the central band of aftershocks from north to south. In all three sections, the fault appears as a very narrow zone of aftershocks, but its dip changes progressively from north to south: $88^{\circ} \mathrm{NE}$. in section $\mathrm{N}, 84^{\circ} \mathrm{NE}$. in section $C$, and $81^{\circ} \mathrm{NE}$. in section $\mathrm{S}$. In section $\mathrm{N}$, the locations of aftershocks nearest to the main shock, at depths of 7.5 to $9 \mathrm{~km}$, suggest that this part of the fault surface may dip very steeply southwest, in agreement with the main-shock fault-plane solution.

Maps and cross sections fail to show adequately the spatial relation of the structures defined by concentrations of hypocenters in the Morgan Hill aftershock sequence. These relation are shown more clearly by selected stereoplots that view the af tershock distribution from favorable directions. The stereoplot program was provided by Paul Reasenberg (oral commun., 1984), who had extended an earlier program by German and Johnson (1983). Each of the stereoplots in figures 2.8 through 2.10 is enclosed in a frame whose central axis parallels the central band of aftershocks (azimuth $327^{\circ}$ ). In figure $2.8 \mathrm{~A}$, the aftershock region is seen from below. Most features of the aftershock distribution described above are visible here, including the change in strike direction of the central band of aftershocks southeast of San Felipe Valley. In Figure $2.9 \mathrm{~A}$, the shallow clusters northeast of the fault are clearly sepurated from aftershocks along the fault, but the scattered deeper events at the far end of the plot (north-west) appear to approach the fault. In figure $2.9 \mathrm{~B}$, most of the off-fault events southwest of the fault are enclosed in a triangular prism with its bot tom edge near the fault at a depth of about $8 \mathrm{~km}$. One upper edge is along the fault (at approx 2-km depth), and the other is at about the same depth and $7 \mathrm{~km}$ southwest of the fault. In figure $2.10 \mathrm{~B}$, the off-fault earthquakes southwest of the fault appear to be bounded on the southwest by a northeastdipping plane that intersects the fault at a depth of 8 $\mathrm{km}$ or more. In figure $2.10 \mathrm{C}$, the principal concentration of off-fault aftershocks is only 2 to 4 $\mathrm{km}$ deep and lies directly against the fault on its southwest side. Here and in figure $2.7 \mathrm{C}$, the northeast edge of this shallow cluster appears to be bounded by a curved surface that dips about $40^{\circ} \mathrm{SW}$. at its lower end and merges with the main fault (dipping about $80^{\circ} \mathrm{NE}$.) at its upper end.

\section{DISCUSSION}

The earthquake and its aftershocks are of great importance to our understanding of tectonic processes 
along and east of the Calaveras and Hayward faults in central California. These events occurred at the south end of the East Bay Hills (Aydin, 1982), where the Hayward and Calaveras faults approach each other and where clear examples of other structures characterizing the tectonics of the region are found (Page, 1982a, b), including pullapart valleys (Halls
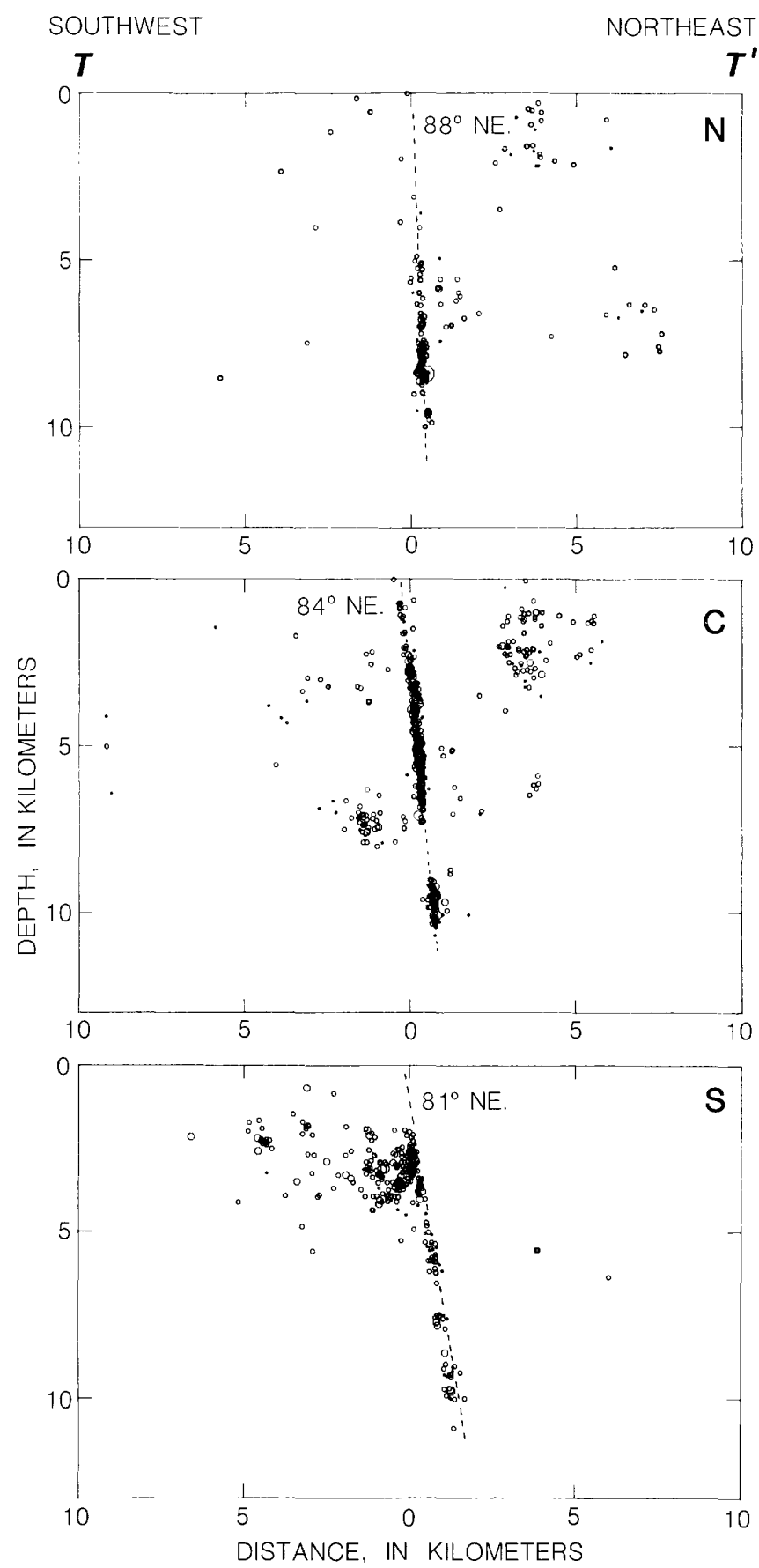

Figure 2.7. Transverse sections of events in frames $\mathrm{N}$, $\mathrm{C}$, and $\mathrm{S}$ (fig. 2.4D). Sections $\mathrm{N}$ and $\mathrm{C}$ are perpendicular to azimuth $327^{\circ}$ (line $R-R^{\prime}$, fig. 2.4D); section $S$ is perpendicular to azimuth $331^{\circ}$.
Valley, San Felipe Valley, and Coyote Lake) along the Calaveras fault and high-angle reverse faults (Silver Creek and Coyote Creek faults) that appear to be associated with the Calaveras fault. Complexities in the aftershock pattern appear to be associated with some of these structures.

In comparing the locations of the aftershocks with mapped surface features, we should allow for a possible systematic mislocation of the aftershocks by about $1 \mathrm{~km}$ toward the northeast. The occurrence of higher crustal velocities northeast of the fault than southwest of it, as was suggested by the mainshock first-motion plot, could lead to such a mislocation. The most intriguing feature of the uftershock distribution is the large quiet zone outlined by aftershocks in the longitudinal sections (see fig. 2.5B). We argue that this zone, which contains the main-shock hypocenter at its northwest end, represents the area on the fault surface that slipped during the main shock and remained quiet thereafter. The encircling band of aftershocks represents the subsequent extension of the slipped zone on the fault surface. This quiet zone can be divided into two sections on the basis of the depth to its top. The $10 \mathrm{~km}$-long northwest section averages about $3 \mathrm{~km}$ in height and extends from about 6- or 7to about $10-\mathrm{km}$ depth; the $13-\mathrm{km}$-long southeast section averages about $5 \mathrm{~km}$ in height and extends from about 4 - to about $10-\mathrm{km}$ depth. The boundary between these two sections is approximately at the change in strike of the central band of aftershocks. Bakun and others (1984) interpreted a conspicuous late pulse on strong-motion records of the main shock as a second, delayed source of the earthquake. This pulse appears to have originated $5 \mathrm{~s}$ after and 16 to $20 \mathrm{~km}$ southeast of the initial source. In figure 2.5, this second source would plot between -7 and $-11 \mathrm{~km}$ on the distance axis, in the southeast half of the southeast section of the quiet zone. Where the aftershock area bounding the quiet zone descends below about $11 \mathrm{~km}$, this area disappears. We take that depth to be the base of the seismogenic layer in the area.

The most conspicuous group of aftershocks outside the central band (fig. 2.3) lies southwest of the central band from San Felipe Valley to the southeast end of Anderson Lake. The lower limit of these af tershocks appears to be a northeast-dipping surface that would crop out in the region of the Silver Creek and Coyote Creek faults, if projected to the Earth's surface, and intersects the central band of aftershocks at a depth of 8 to $10 \mathrm{~km}$ near the southeast end of San Felipe Valley. These aftershocks are concentrated at depths of 7 to $8 \mathrm{~km}$ near the central band, just southeast of San Felipe Valley. At the southeast end of Anderson Lake, they are concentrated at depths of 2 to $4 \mathrm{~km}$ and are immediately adjacent to the central band. From their spatial distribution, these aftershocks suggest that movement on the Silver Creek or nearby related reverse faults either accompanied or was stimulated by the earthquake.

The mapped strands of the Calaveras fault step to the right about $2 \mathrm{~km}$ as they traverse San Felipe Valley. No such offset is seen in the fault surface outlined by the central band of aftershocks at this locality. However, from the southeast end of San Felipe Valley to the northwest end of Anderson Lake, 
the offset mapped strand of the Calaveras fault is mimicked by the 7- to $8-\mathrm{km}$-deep alignment of af tershocks that is offset about $2 \mathrm{~km}$ southwest of the central band.

Although the structure of the fault surface suggested by the spatial distribution of aftershocks in the central band is simple in comparison with that of mapped strands of the fault, several important changes occur along the central band, including a small but clear change in strike (N. $35^{\circ}$ to $29^{\circ}$ W., from northwest to southeast) about $5 \mathrm{~km}$ southeast of San Felipe Valley, and a progressive change in dip from the northwest end $\left(88^{\circ} \mathrm{NE}\right.$.) to the southeast end $\left(81^{\circ} \mathrm{NE}.\right)$ of the aftershock zone.

A closer examination of the relation of aftershocks of the earthquake to the Calaveras fault
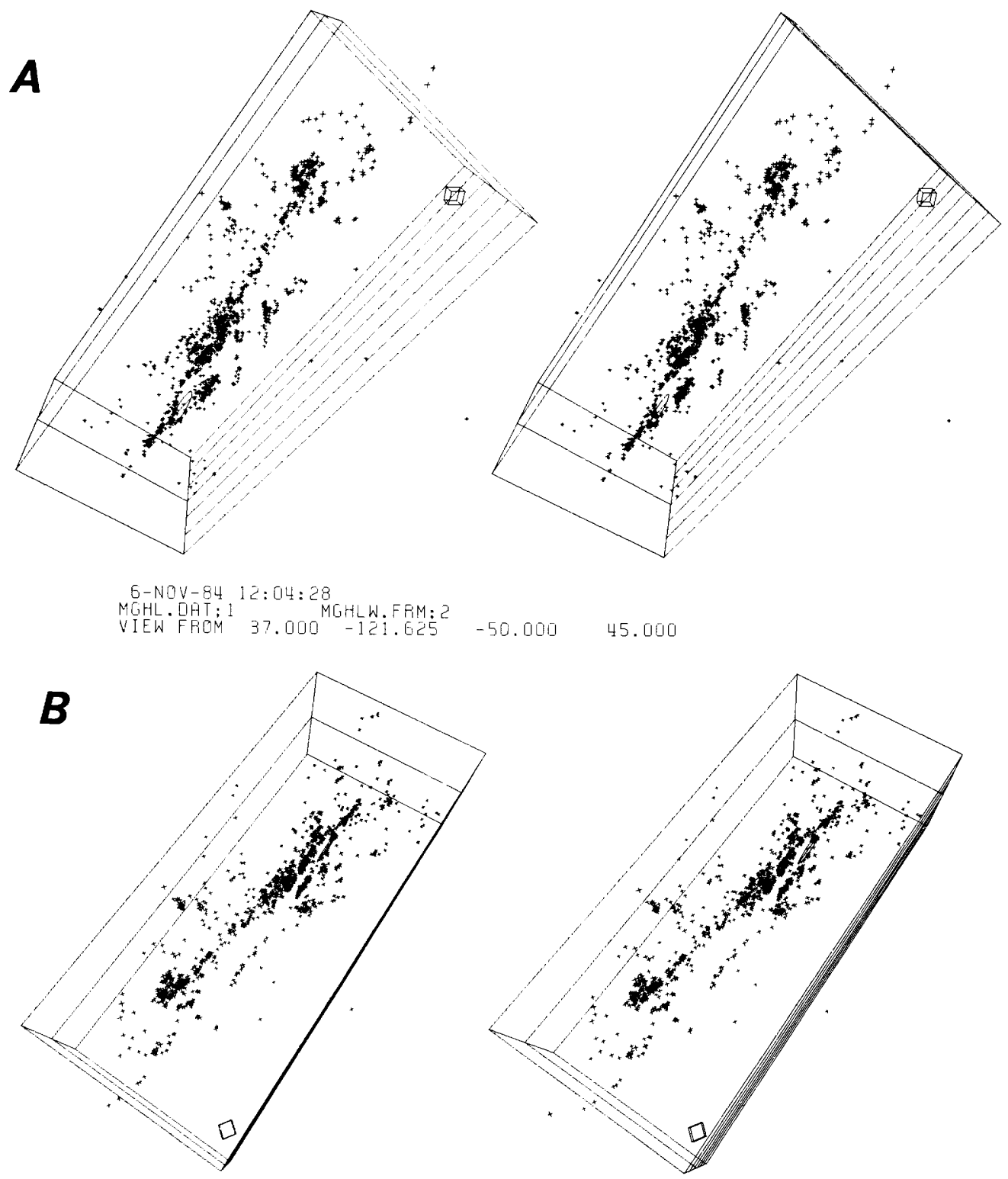

$$
\begin{gathered}
E-N O V-84 \text { ] } 2: 0 E: 59 \\
\text { MGHL. DAT } 19 \text { MGHLW. FRM: }
\end{gathered}
$$$$
30.000 \quad 47.500
$$

Figure 2.8. Stereopairs of the earthquake and its aftershocks from below (A) and above (B). Main shock is plotted as a circle lying in the fault plane deduced from focal-plane solution; aftershocks are plotted as crosses and are scaled weakly according to magnitude. In figure $2.8 \mathrm{~A}$, viewpoint is $50 \mathrm{~km}$ deep, approximately below southwest corner of frame. In figure $2.8 \mathrm{~B}$, viewpoint is $30 \mathrm{~km}$ above the Earth's surface and approximately above southeast corner of frame. In both figures, area is combined frames $\mathrm{N}, \mathrm{C}$, and $\mathrm{S}$ in figure 2.4D; the frames are $12 \mathrm{~km}$ high, with 2-km intervals marked on one face. A $1-\mathrm{km}$ reference cube, with its edges oriented $\mathrm{N}-\mathrm{S}$. and $\mathrm{E}-\mathrm{W}$. , is shown in southeast corner of both frames. 
and related structures will require the determination of a substantial number of aftershock focal mechanisms.

\section{ACKNOWLEDGMENTS}

We acknowledge the indispensible contributions to this chapter from Carl Johnson, Sam Stewart, and Peter Johnson, who developed and implemented the digital-data-acquisition and interactive-analysis systems, and from Shirley Miarks, Mike Stephens, and Gail Nishioka, who analyzed the aftershocks on those systems.

\section{REFERENCES CITED}

Allen, R.V., 1978, Automatic earthquake recognition and timing from single traces: Seismological Society of America Bulletin, v. 68, no. 5, p. 1521-1532.

Aydin, Atilla, 1982, The East Bay Hills, a compressional domain resulting from interaction between the Calaveras and Hayward-Rodgers Creek faults, in Hart, E.W., Hirschfeld, S.E., and Schulz, S.S., eds., Conference on Earthquake Hazards in the Eastern San Francisco Bay Area, Hayward, Calif., 1982, Proceedings: California Division of Mines and Geology Special
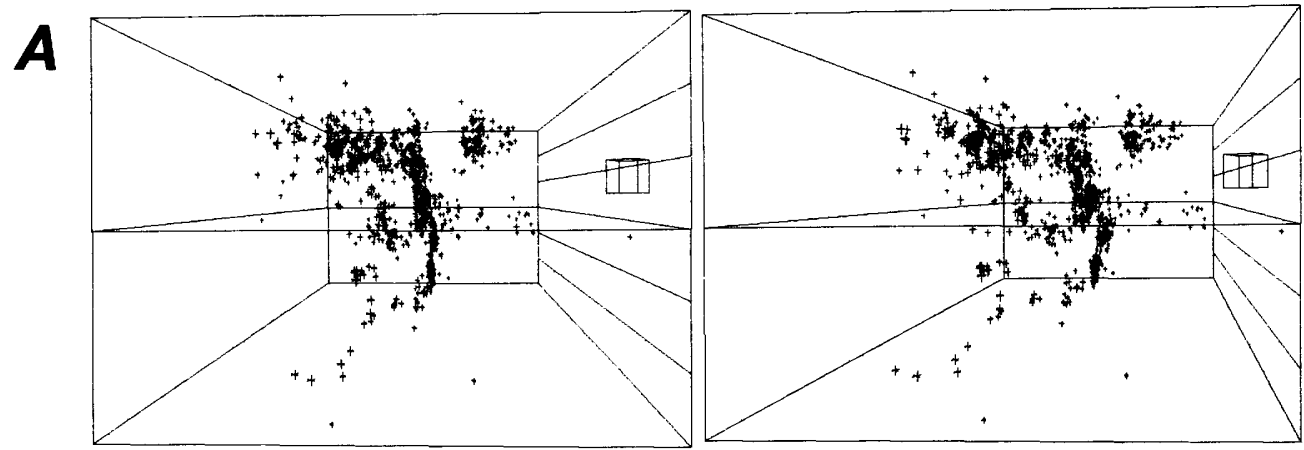

10-NOV-84 08:37:07

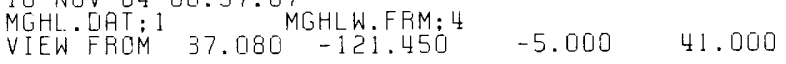

$\boldsymbol{B}$
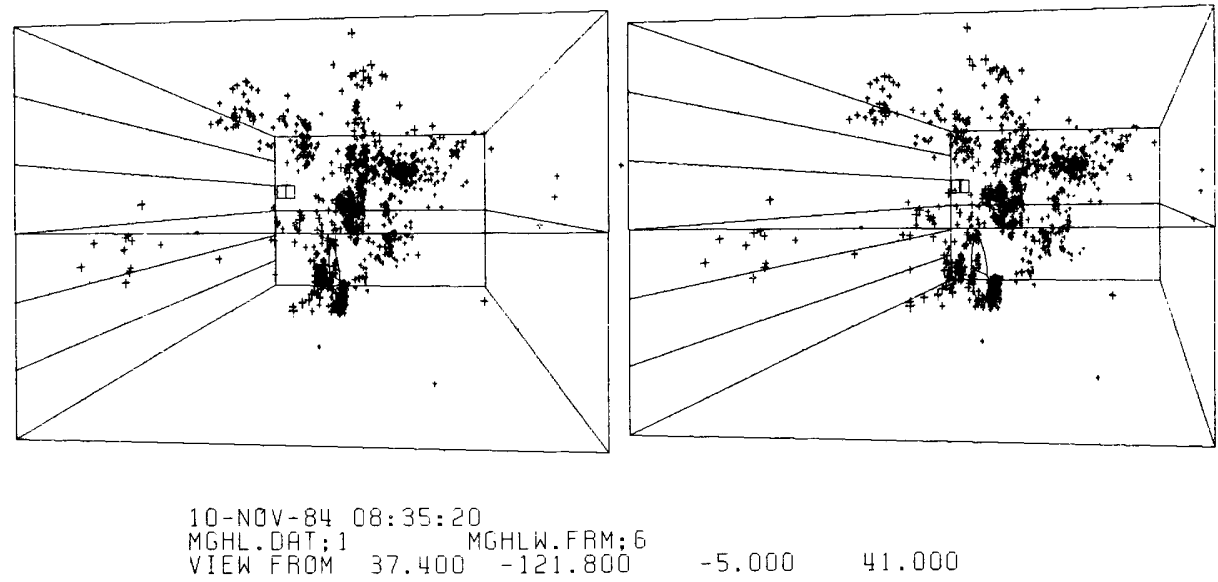

$-5.000 \quad 41.000$

Figure 2.9. Stereopairs of the earthquake and its aftershocks from the southeast (A) and northwest (B). Main shock is plotted as a circle lying in the fault plane, with a diameter showing direction of slip; aftershocks are plotted as crosses and scaled weakly according to magnitude. In figure $2.9 \mathrm{~A}$, viewpoint is $5 \mathrm{~km} \mathrm{deep}$, and line of sight is toward the northwest along northeast side of fault surface. In figure $2.9 \mathrm{~B}$, viewpoint is $5 \mathrm{~km}$ deep, and line of sight is toward the southeast along southwest side of fault surface. In both figures, area is combined frames $N, C$, and $S$ in figure 2.4D; the frames are $12 \mathrm{~km}$ high, with $2-\mathrm{km}$ intervals marked on one face. A $1-\mathrm{km}$ reference cube, with its edges oriented N-S. and E-W., is shown in southeast corner of each frame. 

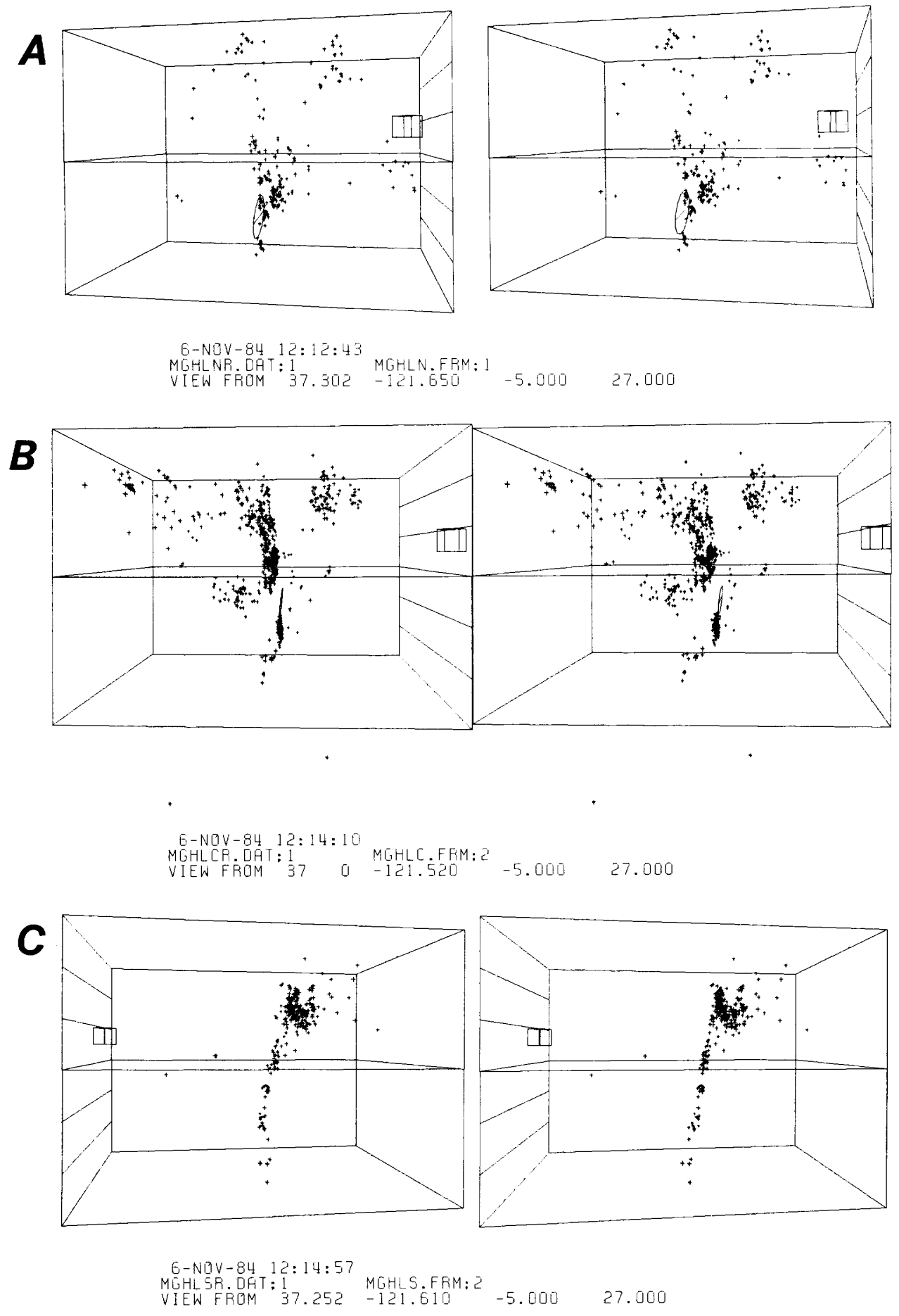

Figure 2.10. Stereopairs of events in frames N, C, and S (A, B, and C, respectively) of figure 2.4D. Main shock is plotted as a circle lying in the fault plane, with a diameter showing direction of slip; aftershocks are plotted as crosses and are scaled weakly according to magnitude. Areas that correspond to frames $\mathrm{N}, \mathrm{C}$, and $\mathrm{S}$ in figure 2.4D are all $12 \mathrm{~km}$ high, with $2-\mathrm{km}$ intervals marked on one face. In figure $2.10 \mathrm{~A}$, viewpoint is $5 \mathrm{~km}$ deep, and line of sight is toward the southeast along nor theast side of fault. A $1-\mathrm{km}$ reference cube, with its edges oriented N-S. and EW., is shown in southeast corner of each frame. 
Publication 62, p. 11-21.

Bakun, W.H., Clark, M.M., Cockerham, R.S., Ellsworth, W.L., Lindh, A.G., Prescott, W.H., Shakal, A.F., and Spudich, Paul, 1984, The 1984 Morgan Hill, California, earthquake: Science, v. 225, no. 4659, p. 288-291.

Blümling, Peter, Mooney, W.D., and Lee, W.H.K., 1985, Crustal structure of the southern Calaveras fault zone, central California, from seismic refraction investigations: Seismological Society of America Bulletin, v. 75, no. 1, p. 193-209.

Crosson, R.S., 1976, Crustal structure modeling of earthquake data, 1. Simultaneous least squares estimation of hypocenter and velocity parameters: Journal of Geophysical Research, v. 81 , no. 17, p. 3036-3046.

Eaton, J.P., 1984, Location, focal inechanism, and magnitude of the Morgan Hill earthquake derived from CALNET records, in Hoose, S.H., compiler, The Morgan Hill, California, earthquake of April 24, 1984 (a preliminary report), volume I: U.S. Geological Survey Open-File Report 84-498-A, p. $10-17$.

Ellsworth, W.L. and Marks, S.M., 1980, Seismicity of the Livermore Valley, California, region, 19691979: U.S. Geological Survey Open-File Report $80-515,42$ p.

Ellsworth, W.L., Olson, J.A., Shijo, L.N., and Marks, S.M., 1982, Seismicity and active faults in the eastern San Francisco Bay region, in Hart, E.W., Hirschfeld, S.E., and Schulz S.S., eds., Conference on Earthquake Hazards in the Eastern San Francisco Bay Area, Hayward, Calif., 1982, Proceedings: Calif ornia Division of Mines and Geology Special Publication, 62, p. 8391.

German, Peter, and Johnson, Carl, 1983, STEREO: A computer program for projecting and plotting stereograms: U.S. Geological Survey Open-File Report 82-726, 56 p.

King, G.C.P., Ouyang, E.X., Papadimitriou, P., Deschamps, A., Gagneposin, J., Houseman, G.,
Jackson, J.A., Soufleris, C., and Virieux, J., 1985, The evolution of the Gulf of Corinth (Greece): An aftershock study of the 1981 earthquake: Royal Astronomical Society Geophysical Journal, v. 80, p. 677-693.

Johnson, C.E., 1983, I. CUSP--automated processing and management for large regional networks: U.S. Geological Survey Earthquake Notes, v. 54, p. 13.

Lee, W.H.K. and Lahr, J.C., 1975, HYPO71 revised: A computer program for determining hypocenter, magnitude, and first motion pattern of local earthquakes: U.S. Geological Survey Open-File Report 75-311, 113 p.

Mayer-Rosa, Dieter, 1973, Travel-time anomalies and distribution of earthquakes along the Calaveras Fault zone, California: Seismological Society of America Bulletin, v. 63, no. 2, p. 713-729.

Page, B.M., 1982a, Modes of Quaternary tectonic movement in the San Francisco Bay region, California, in Hart, E.W., Hirschfeld, S.E., and Schulz, S.S., eds., Conference on Earthquake Hazards in the Eastern San Francisco Bay Area, Hayward, Calif., 1982, Proceedings: California Division of Mines and Geology Special Publication 62, p. 1-10.

$1982 \mathrm{~b}$, The Calaveras fault zone of California-an active plate boundary element, in Hart, E.W., Hirschfeld, S.E., and Schulz, S.S., eds., Conference on Earthquake Hazards in the Eastern San Francisco Bay Area, Hayward, Calif., 1982, Proceedings: California Division of Mines and Geology Special Publication 62, p. 175-184.

Reasenberg, Paul, and Ellsworth, W.L., 1982, Aftershocks of the Coyote Lake, California, earthquake of August 6, 1979: A detailed study: Journal of Geophysical Research, v. 87 no. B13, p. 10637-10655.

Roecker, S.W., and Ellsworth, W.L., 1978, VELEST Fortran program: Menlo Park, Calif., U.S. Geological Survey. 


\title{
Location, Focal Mechanism, and Magnitude of the Main Shock
}

\author{
By Jerry P. Eaton
}

\section{CONTENTS}

$\begin{array}{ll}\text { Abstract } \quad \mathbf{2 9} & \\ \text { Data and models } & \mathbf{2 9} \\ \text { Discussion } \mathbf{3 1} & \\ \text { References cited } & \mathbf{3 1}\end{array}$

\section{Abstract}

Records of the main shock from the entire northern California U.S. Geological Survey (USGS) and southern California USGS-California Institute of Technology (CIT) networks were analyzed to determine its hypocenter, focal mechanism, and magnitude. Although some problems in the determination of each of these parameters are still unresolved, the preferred solutions are:

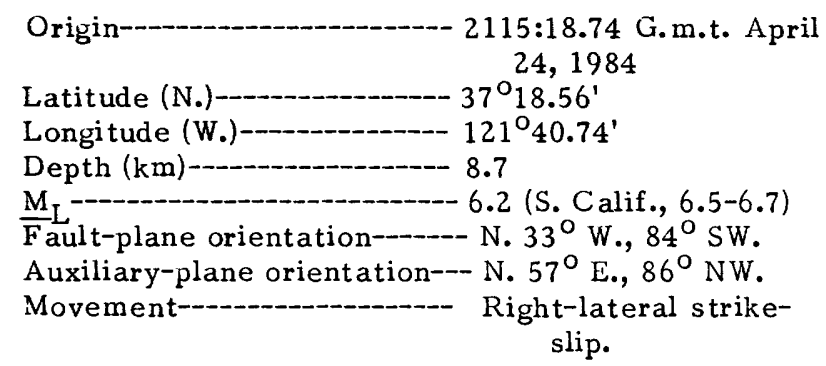

\section{HYPOCENTRAL LOCATION AND FOCAL MECHANISM}

Seismograms of the main shock were played back from magnetic tupe for both the northern and southern California networks (Calnet). P-wave onset times and first-motion directions, as well as maximum amplitudes and associated periods, were read from paper playbacks. The hypocenter was calculated from severul different crustal models (with associated station delays), and first-motion plots were made for each solution. Magnitudes based on peak amplitudes were calculated from available unclipped records.

The epicentral region of the earthquake is geologically complex, and its crustal-velocity structure is poorly understood. The complexity of this region is illustrated by a map of $\underline{p}_{n}$ time-term differences (fig 3.1), which shows several basin-shaped areas with anomalously large values (low-velocity region), superposed on a regional trend of increasing values from west to east across the Coast Ranges (J.P. Eaton, unpub. data, 1980). The band of persistent microearthquakes located by stundard Calnet procedures, which apparently is associated with the Calaveras fault, is of fset several kilometers eastward of the fault zone mapped at the surface. This offset is probably an artifact of the crustal model and station delays, but substantially higher velocities at midcrustal depths $(6-12 \mathrm{~km})$ east of the fault than west of it would be required to move the microearthquake hypocenters on to the fuult.

Hypocentral solut ons of the April 24 main shock, based on three different crustal-model/station-delay sets (fig. 3.2), all lie east of the principul strunds of the Caluveras fault mapped by D.G. Herd (unpub. data, 1982). First-motion plots for all three solutions are almost identical as to the strikes and dips of the nodal planes, but they differ in the number and degree of misfit of discordant observations. The three crustal models were: (A) the standard northern California model and station-delay set, (B) a model and station delays developed by Ellsworth and Marks (1980) by inversion of explosion and local earthquake arrival times in the east-bay area, and (C) station delays derived from the $\underline{P}_{n}$ time-term-difference map by subtracting the regional trend $(0.0$ near the coast to +1.0 at the edge of the Great Valley) from individual station values, and a crustal model developed from the standard northern California model by an iterative process in which layer velocities and depths were modified to minimize the root mean square ( $\mathrm{rms}$ ) of onset-time residuals and to permit separation of compressional and dilatational first motions is to 
different fields. Tuble 3.1 lists the crustal models, and table 3.2 lis ts the corresponding station-delay sets for stations at epicentral distances less than $35 \mathrm{~km}$ (stations beyond $35 \mathrm{~km}$ were not used in the solution). In figure 3.2 , the hypocenters are labeled $\mathrm{A}, \mathrm{B}$, and $\mathrm{C}$, corresponding to the crustal models used to obtain them.

Figure 3.3 shows first-inotion plots for these three models. The nodal planes in all three solutions are nearly identical. Solutions B and C are preferred to solution A because they have fewer discordant points, but otherwise there is little basis for choosing between solutions $\mathrm{B}$ and $\mathrm{C}$. In all three solutions, the two stations nearest the epicenter, $\mathrm{CCO}$ and $\mathrm{CMH}$, are seriously discordant; this result suggests that the epicenters are too far eust. Accordingly, a trial

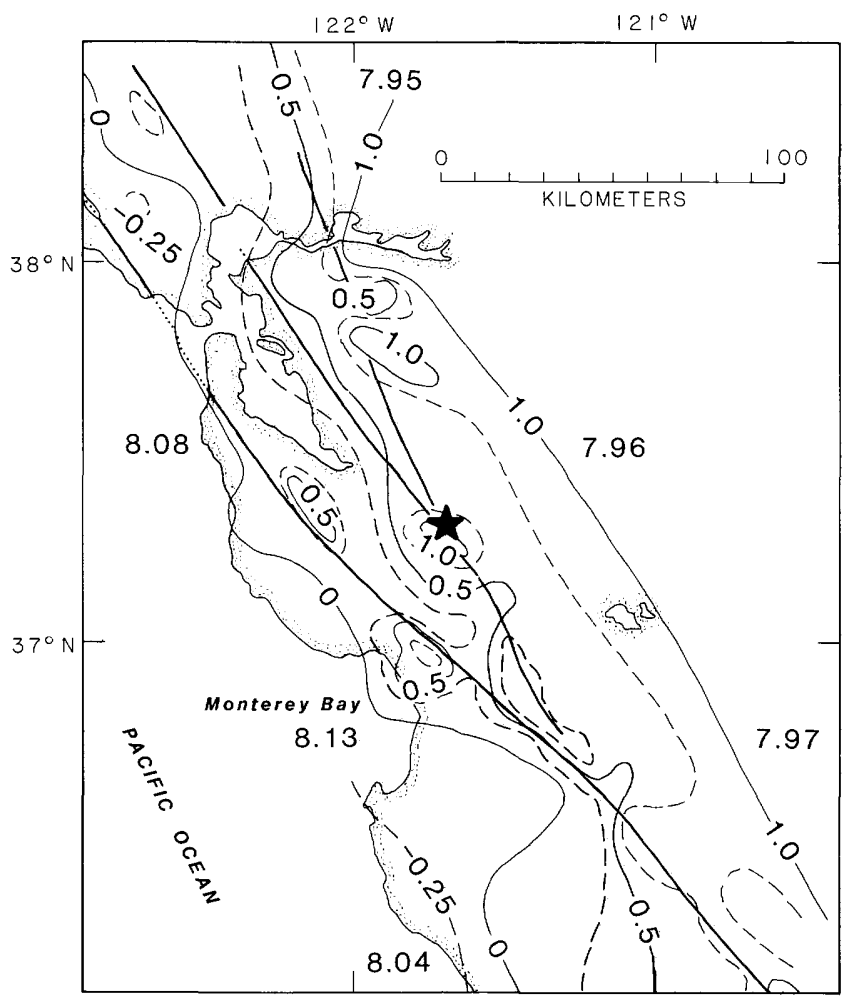

$$
\begin{aligned}
& \text { EXPLANATION } \\
& \text { Major fault } \\
& \text { Dotted where concealed } \\
& \text { - } 0.5-\ldots \\
& \text { Contours showing } \overline{\boldsymbol{P}}_{\boldsymbol{n}} \text { time-term difference, in seconds } \\
& \text { Dashed contours at half interval } \\
& 7.97
\end{aligned}
$$

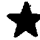

Figure 3.1. $\quad \underline{P}_{n}$ time-term-difference map for the Calaveras fault area. hypocenter for another first-motion plot was obtained by moving hypocenter $\mathrm{C} 2.6 \mathrm{~km}$ southwestward to $\mathrm{D}$ (about $1 \mathrm{~km}$ southwest of the principal mapped trace of the fault). The nodal planes of the first-motion plot for this trial hypocenter are the same as for solution $\mathrm{C}$, and the plotted points for stations $\mathrm{CCO}$ and $\mathrm{CMH}$ have moved much closer to concordant sectors of the plot. An additional shift of several hundred meters southwestward would be required to move stations $\mathrm{CCO}$ and $\mathrm{CMH}$ into appropriate fields.

An alternative explanation of the discordant points for stations $\mathrm{CCO}$ and $\mathrm{CMH}$ is that the average crustal velocity just east of the fault is several tenths of a kilometer per second higher than just west of the fault, and that the first arrivals at those stations left the focus along paths east of the fault and were then refracted across the fault. For a focal depth of $9 \mathrm{~km}$, a fairly modest velocity contrast brings such refracted waves to the surface as first arrivals considerably west of the fault: for $\underline{V}_{e}=5.7$ and $\underline{V}_{w}=5.5$, refracted waves from the region east of the fault would be first arrivals as far as $2.5 \mathrm{~km}$ west of the fault.

This brief analysis suggests the range of uncertainty in the location of the earthquake, but it

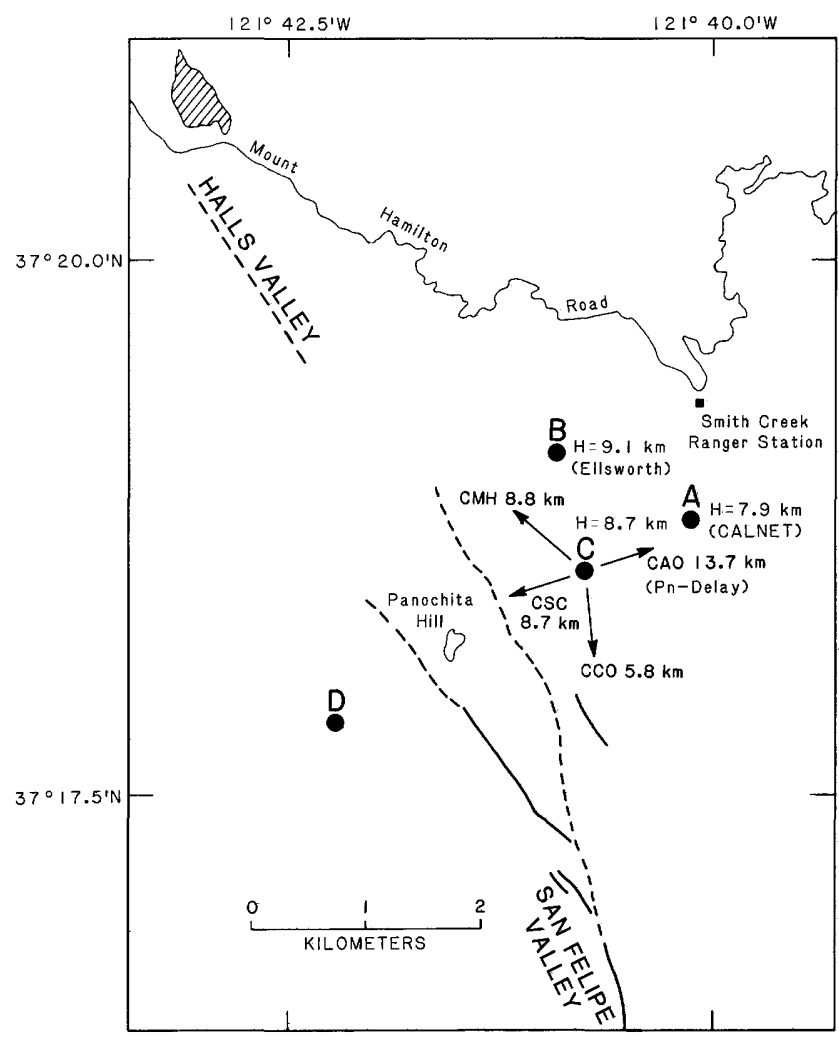

Figure 3.2. Sketch map of epicentral region of the earthquake. Epicentral designations (dots A-D) correspond to model used to determine them (see fig. 3.3). Directions and distances to nearest stations are indicated for epicenter C; $\mathrm{H}$, hypocentral depth. Solid lines, traces of the Calaveras fault (from D.G. Herd, unpub. data, 1982); dashed where inferred. 
Table 3.1. Crustal models

\begin{tabular}{|c|c|}
\hline $\begin{array}{l}\text { Velocity } \\
(\mathrm{km} / \mathrm{s})\end{array}$ & $\begin{array}{r}\text { Depth } \\
(\mathrm{km})\end{array}$ \\
\hline \multicolumn{2}{|c|}{ Model A } \\
\hline 4.00 & 0.00 \\
\hline 5.90 & 3.50 \\
\hline 6.80 & 15.00 \\
\hline 8.05 & 25.00 \\
\hline \multicolumn{2}{|c|}{ Model B } \\
\hline 3.40 & 0.00 \\
\hline $\begin{array}{l}4.70 \\
5.20\end{array}$ & $\begin{array}{l}1.00 \\
3.00\end{array}$ \\
\hline 5.60 & 5.00 \\
\hline 5.70 & 7.00 \\
\hline 5.80 & 9.00 \\
\hline 6.00 & 11.00 \\
\hline 6.80 & 13.00 \\
\hline 8.00 & 28.00 \\
\hline \multicolumn{2}{|c|}{ Model C } \\
\hline 3.50 & 0.00 \\
\hline 5.20 & 1.00 \\
\hline 5.50 & 3.00 \\
\hline 5.70 & 7.00 \\
\hline 6.10 & 9.00 \\
\hline 6.50 & 15.00 \\
\hline 8.00 & 28.00 \\
\hline
\end{tabular}

Table 3.2. Station corrections for stations less than $35 \mathrm{~km}$ from the epicenter of the April 24 earthquake

\begin{tabular}{|c|c|c|c|}
\hline \multirow{2}{*}{ Station } & \multicolumn{3}{|c|}{ Mode 1} \\
\hline & A & B & $\mathrm{C}$ \\
\hline $\mathrm{CcO}$ & +0.31 & +0.13 & +0.50 \\
\hline СMH & +.16 & +.02 & +.20 \\
\hline $\csc$ & +.27 & +.43 & +.50 \\
\hline $\mathrm{CAO}$ & -.01 & -.29 & .00 \\
\hline $\mathrm{JST}$ & -.10 & -.15 & +.30 \\
\hline$C A D$ & -.09 & -.04 & +.10 \\
\hline $\mathrm{CML}$ & .00 & -.09 & -.10 \\
\hline CAL & -.01 & -.11 & .00 \\
\hline CMM & .00 & -.26 & -.10 \\
\hline $\mathrm{JCB}$ & -.07 & -.29 & +.10 \\
\hline JAL & -.11 & -.22 & .00 \\
\hline HSP & .00 & -.37 & -.10 \\
\hline JHL & -.15 & -.27 & .00 \\
\hline $\mathrm{CDV}$ & .00 & -.18 & +.10 \\
\hline JSS & -.09 & -.13 & +.10 \\
\hline $\mathrm{CMJ}$ & -.10 & +.04 & .00 \\
\hline JRR & -.20 & -.38 & +.10 \\
\hline JLX & -.07 & -.31 & +.10 \\
\hline CMR & -.06 & -.02 & -.10 \\
\hline HGS & -.07 & -.56 & -.10 \\
\hline JEC & -.04 & -.25 & +.50 \\
\hline CMP & .00 & -.58 & -.10 \\
\hline HGW & -.24 & -.39 & -.20 \\
\hline $\cos$ & .00 & -.31 & .00 \\
\hline JSG & +.15 & -.01 & +.50 \\
\hline CVA & .00 & .00 & -.10 \\
\hline CMN & -.10 & .00 & -.10 \\
\hline
\end{tabular}

Table 3.3. Magnitude determinations for the April 24 earthquake

[Average magnitude: northern California stations, 6.17; southern California stations, 6.74]

\begin{tabular}{|c|c|c|c|}
\hline Station & $\begin{array}{c}\text { Distance } \\
(\mathrm{km})\end{array}$ & $\begin{array}{c}\text { Azimuth } \\
\left({ }^{\circ}\right)\end{array}$ & $\begin{array}{c}\text { Magnitude } \\
\left(\underline{M}_{L}\right)\end{array}$ \\
\hline \multicolumn{4}{|c|}{ Northern California } \\
\hline LTCN & 324 & 353 & 6.2 \\
\hline KMPN & 405 & 328 & 6.0 \\
\hline $\mathrm{KMPE}$ & 405 & 328 & $6 \cdot 3$ \\
\hline \multicolumn{4}{|c|}{ So uthern California } \\
\hline RLBZ & 459 & 131 & 6.7 \\
\hline RBRZ & 481 & 132 & 6.6 \\
\hline RGAZ & 525 & 134 & 6.4 \\
\hline RBIZ & 548 & 127 & 7.0 \\
\hline RRFZ & 571 & 129 & 7.0 \\
\hline RPBZ & 590 & 133 & 6.5 \\
\hline DCUZ & 607 & 125 & 6.8 \\
\hline REWZ & 609 & 128 & 6.9 \\
\hline ECYZ & 656 & 132 & 6.8 \\
\hline ICWZ & 663 & 127 & 6.7 \\
\hline
\end{tabular}

does not resolve this uncertainty. Hypocentral solution $\mathrm{C}$ and first-motion plot $\mathrm{C}$ are tentatively adopted for the earthquake, with the caution that some evidence supports a location $2 \mathrm{~km}$ or more farther southwestward.

\section{MAGNITUDE}

A group of 3 low-guin horizontal-component seismometers in northern California and 10 low-gain vertical-component seismometers in southern California produced records from which maximum amplitudes and associated periods could be measured. Table 3.3 lists the distance and azimuth of each station from the epicenter, as well as the calculated magnitude. The average $\mathrm{M}_{\mathrm{L}}$ of the three northern California stations is 6.17 . The $10 \mathrm{M}_{\mathrm{L}}$ 's from southern California average 6.74 , substantially larger than the northern California average. A correction of 0.25 is added to magnitudes calculated from a verticalcomponent instead of a horizontal-component seismometer to compensate for the average ratio of horizontal to vertical maximum amplitudes. This correction was determined from a limited number of recordings of small to moderate earthquakes recorded at distances of less than $200 \mathrm{~km}$ in central California, and so it may be inappropriate for larger earthquakes recorded at much greater distances.

We also note the rather narrow range in azimuth of the stations reporting magnitudes in northern California $\left(328^{\circ}-353^{\circ}\right.$ and southern California $\left(125^{\circ}\right.$ $\left.134^{\circ}\right)$. The difference between the northern and southern California $\mathrm{M}_{\mathrm{L}}$ 's may arise from a strong azimuthal variation in the energy radiated by the earthquake.

Allowing for the uncertainty in the magnitude correction applied to the vertical-component seismometers, the $\mathrm{M}_{\mathrm{I}}$ determined from the northern California station data is 6.2 , and from the southern California station data 6.5-6.7.

\section{REFERENCE CITED}

Ellsworth, W.L., and Marks, S.M., 1980, Seismicity of the Livermore Valley, California, region, 19691979: U.S. Geological Survey Open-File Report $80-515,42$ p. 


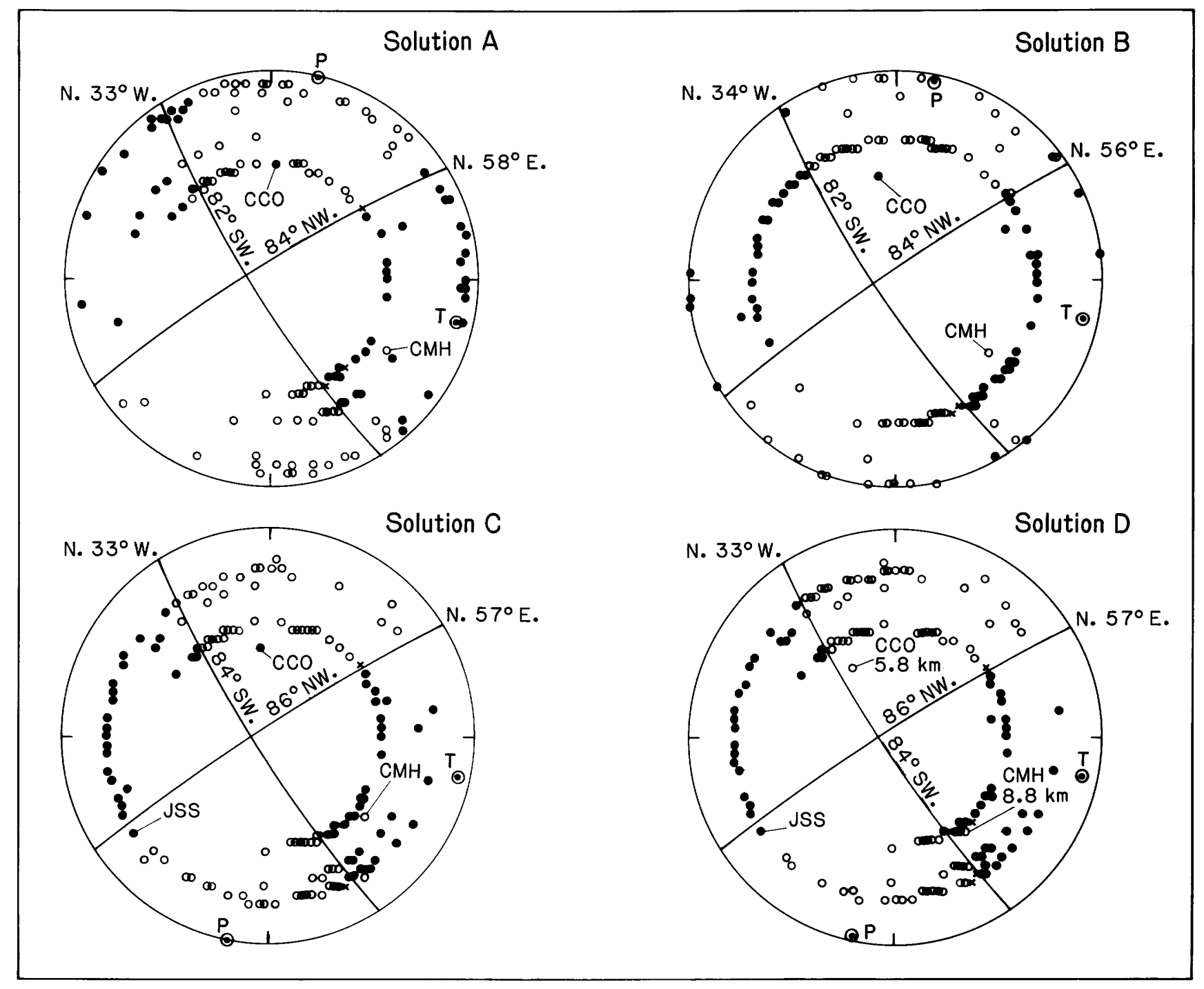

Figure 3.3. First-motion plots for different hypocentral solutions of the earthquake (A-D, fig. 3.2). Circles, dilatational first motions; dots, compressional first motions; circled dots, pressure (P) and tension (T) axes; X's, conflicting first motions. Points for discordant stations $\mathrm{CCO}, \mathrm{CMH}$, and JSS (see fig. 2.1) are labeled. 


\title{
Source Parameters for Two Aftershocks
}

\author{
By Ralph J. Archuleta, John Watson, Jon B. Fletcher, and Eugene Sembera
}

\section{CONTENTS}

Abstract $\quad 33$

Field procedures

Instruction 34

Data 34

Acknowledgments $\mathbf{3 4}$

References cited $\mathbf{3 4}$

\section{Abstract}

In this chapter, we present a tabulation of nearsource digital seismograms for selected aftershocks of the April 24, 1984, Moryan Hill, Calif., earthquake. For two of the larger aftershocks, we estimate their source parameters: seismic movement, corner frequency, source radius, and stress drop.

\section{FIELD PROCEDURES}

Within hours of the main shock, we began the deployment of General Earthquake Observation System (GEOS; Borcherdt and others, 1985) recorders with three-component force-balanced accelerometers and three-component velocity transducers into the area near the epicenter and along the assumed rupture zone of the Calaveras fault (fig. 4.1). Because of the dense coverage of this area with standard U.S. Geological Survey (USGS) California network (Calnet) seismometers, location of aftershocks was not a primary concern. Our principal objective was onscale recording of all large $(M>3.0)$ aftershocks, with a special emphasis on possible aftershocks of $\mathbf{M}>\mathbf{5 . 0}$. Thus, we placed most of our instruments in the immediate vicinity of the Calaveras fault trace. Although many of the aftershocks (fig. 4.1) appear to lie east of the Calaveras fault (locations from USGS Calnet; R.S. Cockerham, written commun., 1984), this is probably an artificial result of the location programs, which do not properly account for the differences in velocity structure east and west of the fault.

In the first 8 hours after the main shock, six GEOS recorders were placed in the area; seven more were added during the next week. During the aftershock period, the number of GEOS recorders in the field has ranged from 9 to 13 . The locations of the recorders and their duys of operation are listed in table 4.1 .

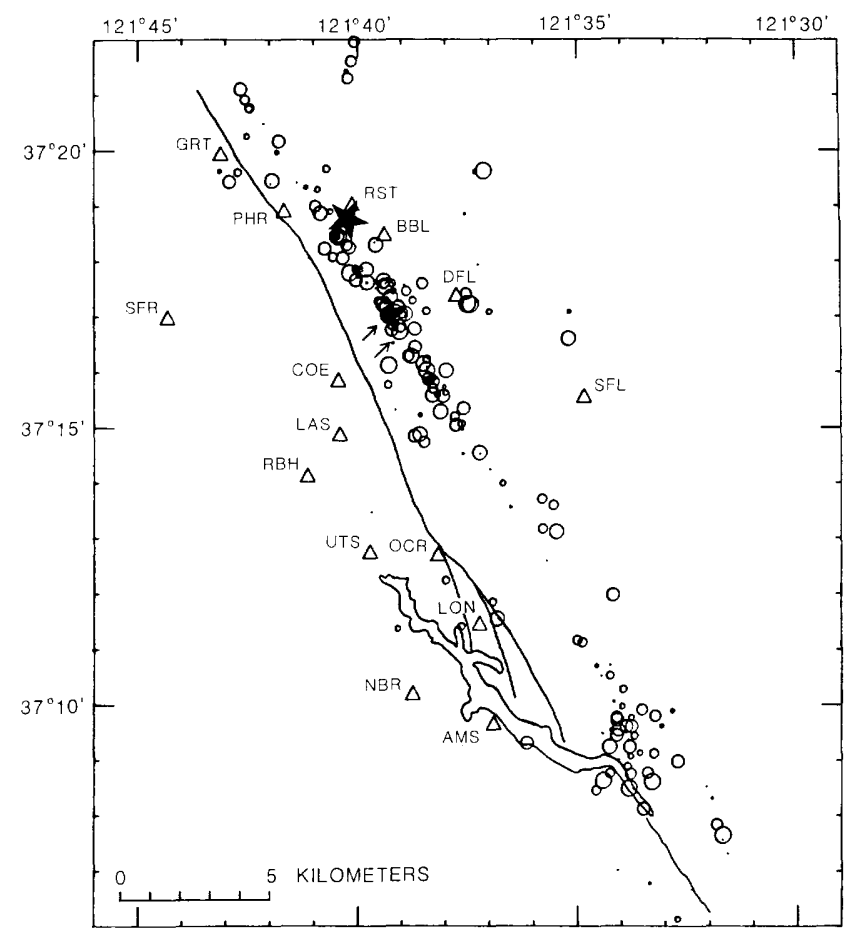

Figure 4.1. Sketch map of earthquake source region, showing locations of main-shock epicenter (star), GEOS stations (triangles), epicenters of events of $M \geq 1.5$ recorded by one or more GEOS stations (circles, size proportional to magnitude), and approximate surface trace of the Calaveras fault (heavy diagonal line). Arrows point to epicenters of two events for which source parameters were calculated. 
Table 4.1.- Locations and days of operation for GEOS stations

[April 24 is Julian day 116]

Station Latitude N. Longitude $w$. $\begin{gathered}\text { Operating interval } \\ \text { (Julian days) }\end{gathered}$

\begin{tabular}{lccc}
\hline & & & \\
AMS & $37^{\circ} 9.63^{\prime}$ & $121^{\circ} 36.92^{\prime}$ & $117-140$ \\
BBL & $37^{\circ} 18.46^{\prime}$ & $121^{\circ} 39.49^{\prime}$ & $116-117$ \\
COE & $37^{\circ} 15.82^{\prime}$ & $121^{\circ} 40.45^{\prime}$ & $116-157$ \\
DFL & $37^{\circ} 17.36^{\prime}$ & $121^{\circ} 37.76^{\prime}$ & $118-156$ \\
GRI & $37^{\circ} 19.91^{\prime}$ & $121^{\circ} 43.11^{\prime}$ & $116-154$ \\
LAS & $37^{\circ} 14.85^{\prime}$ & $121^{\circ} 40.41^{\prime}$ & $116-150$ \\
LON & $37^{\circ} 11.43^{\prime}$ & $121^{\circ} 37.24^{\prime}$ & $116-129,135-143$, \\
& & & $153-156$ \\
NBR & $37^{\circ} 10.17^{\prime}$ & $121^{\circ} 38.76^{\prime}$ & $130-152$ \\
OCR & $37^{\circ} 12.67^{\prime}$ & $121^{\circ} 38.19^{\prime}$ & $116-118,129-157$ \\
PHR & $37^{\circ} 18.88^{\prime}$ & $121^{\circ} 41.67^{\circ}$ & $116-127$ \\
RBH & $37^{\circ} 14.10^{\prime}$ & $121^{\circ} 41.15^{\prime}$ & $116-127$ \\
RST & $37^{\circ} 19.00^{\prime}$ & $121^{\circ} 40.13^{\prime}$ & $116-129$ \\
SFL & $37^{\circ} 15.54^{\prime}$ & $121^{\circ} 34.86^{\prime}$ & $116-119$ \\
SFR & $37^{\circ} 16.95^{\prime}$ & $121^{\circ} 44.32^{\prime}$ & $116-128$ \\
UTS & $37^{\circ} 12.72^{\prime}$ & $121^{\circ} 39.74^{\prime}$ & $116-152$ \\
\hline
\end{tabular}

\section{INSTRUMENTATION}

The GEOS instrument is a microprocessor-based digital recorder, capable of sampling at 1,200 sumples per second with a 16-bit analog-to-digital converter. For each of the six components of ground acceleration and velocity, the sampling rate is 200 samples per second. Variable gain settings $(\max 60 \mathrm{~dB})$, coupled with different types of sensors, allow onscale recording of a wide range of seismic events. For af tershocks, we set the recorders in a trigger mode that is based on the ratio of the short-term-average (STA) signal to the long-term-average (LTA) signal. The gains were deliberately set low to ensure against clipping for events with accelerations less than $1 \mathrm{~g}$. The velocity transducers and force-balanced accelerometer had nutural periods of 2 and $80 \mathrm{~Hz}$, respectively. The horizontal components were oriented at azimuths $000^{\circ}$ and $090^{\circ}$ for both sensors.

\section{DATA}

As of May 30, we had recorded more than 126 aftershocks at 4 or more stations (table 4.2). For events 1181648 and 1241307, we computed source parameters by the method of Brune $(1970,1971)$. Figures 4.2 through 4.11 show the three components of particle velocity and their respective displacement spectra, from which we determined a long-period level $\Omega_{0}$ and a corner frequency $f_{c}$ for event 1181648 . Figures 4.12 through 4.16 show similar plots for event 1241307. The spectral parameters and derived seismic parumeters for both of these events are listed in tables 4.3 and 4.4. An average value of the source parameters was obtained by the method of Archuleta and others (1982). Hypocentrul distances are based on depths of 9.97 and $9.76 \mathrm{~km}$ for events 1181648 and 1241307 , respectively. In our calculations of the source parameters, we used a density of $2.8 \mathrm{~g} / \mathrm{cm}^{3}$, a shear-wave velocity of $3.3 \mathrm{~km} / \mathrm{s}$, and a.P-wave velocity of $5.8 \mathrm{~km} / \mathrm{s}$. The $\underline{\mathrm{P}}$ - and $\underline{\mathrm{S}}$-wave parameters calculated from these physical values are listed in table 4.5.

For both events, the seismic moment and the source radius determined from the $\underline{P}$-wave spectra are significantly smaller than those determined from the S-wave spectra. Although the recorders were very close to the source, it is clear from the curvature of the spectrum that attenuation is influencing the ground motion. We did not consider any at tenuation for these preliminary calculations. The net effect of whole-path attenuation would be to give lower corner frequencies and consequently lower stress drops (Archuleta and others, 1982). These events were assigned coda magnitudes of 3.1 and 3.7 by the USGS real-time processor used to locate the events. However, if we apply the relation of Bakun (1984) that $\log \underline{M}_{0}=1.2 \underline{M}_{D}+17.0$ for central California earthquakes,

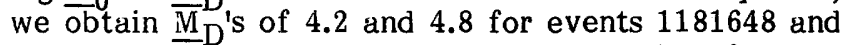
1241307 , respectively. Further analysis of more af tershocks may show that these two events are the exceptions rather than the rule.

\section{ACKNOWLEDGMENTS}

We thank Chris Dietel and Cohen Criley for their assistance in maintaining the instruments, and R.S. Cockerham for providing us with the locutions of af tershocks.

\section{REFERENCES CITED}

Archuleta, R.J., Cranswick, Edward, Mueller, Charles, and Spudich, Paul, 1982, Source parameters of the 1980 Mammoth Lakes, Calif ornia, earthquake sequence: Journal of Geophysical Research, v. 87 , no. B6, p. 4595-4607.

Bakun, W.H., 1984, Seismic moments, local magnitudes, and coda-duration magnitudes for earthquakes in central California: Seismological Society of America Bulletin, V. 74, no. 2, p. 439458.

Borcherdt, R.B., Fletcher, J.B., Jensen, E.G., Maxwell, G.L., VanSchaack, J.R., Warrick, R.E., Cranswick, Edward, Johnston, M.J.S., and McClearn, R., in press, A General Earthquake Observation System (GEOS): Seismological Society of America Bulletin.

Brune, J.N., 1970, Tectonic stress and the spectra of seismic shear waves from earthquakes: Journal of Geophysical Research, V. 75, no. 26, p. 49975009.

-1971, Correction: Journal of Geophysical Research, v. 76, no. 20, p. 5002 . 
Table 4.2. Aftershocks of the earthquake

[First three digits of origin time are the Julian day, next two are the hour, and last two are the minute. Letters, which are used for computer-file identification, denote recording of a particular event by a station. Only events recorded by four or more GEOS stations are listed]

\begin{tabular}{|c|c|c|c|c|c|c|c|c|c|c|c|c|c|c|c|c|}
\hline \multirow{2}{*}{$\begin{array}{l}\text { Origin } \\
\text { time }\end{array}$} & \multirow{2}{*}{$\frac{\mathrm{M}}{(\operatorname{coda})}$} & \multicolumn{15}{|c|}{ Station } \\
\hline & & AMS & BBL & $\mathrm{COE}$ & DFL & GRT & LAS & LON & NBR & $O C R$ & PHR & $\mathrm{RBH}$ & RST & SFL & SFR & UTS \\
\hline 1160416 & 2.7 & -- & --- & $\mathbf{R}$ & -- & $\mathrm{R}$ & $\mathrm{R}$ & -- & --- & -- & $\mathrm{R}$ & --- & $\mathrm{C}$ & -- & -- & $-\infty$ \\
\hline 1160435 & 1.7 & --- & --- & $\mathrm{G}$ & --- & --- & G & --- & --- & --- & $\mathrm{G}$ & --- & $\mathrm{G}$ & --- & --- & -- \\
\hline 1160518 & 2.4 & - & -- & $\mathrm{P}$ & -- & -- & $\mathrm{P}$ & --- & --- & -- & $Q$ & $\mathbf{P}$ & $\mathbf{P}$ & -- & -- & $\mathrm{P}$ \\
\hline 1160733 & 1.7 & -- & --- & $\mathrm{K}$ & -- & --- & $\mathrm{K}$ & -- & --- & --- & -- & $\mathrm{K}$ & $\mathrm{K}$ & $-\infty$ & --- & $\mathrm{K}$ \\
\hline 1160744 & 1.7 & --- & --- & $\mathrm{S}$ & --- & --- & $-\cdots$ & -- & $\rightarrow-$ & -- & $\mathrm{S}$ & $-\cdots$ & $\mathrm{s}$ & --- & -- & $\mathrm{T}$ \\
\hline 1161204 & 1.8 & --- & --- & $I$ & -- & --- & $I$ & -- & --- & --- & --- & -- & $I$ & --- & --- & I \\
\hline 1161414 & 2.0 & -- & --- & -- & -- & 2 & $\mathrm{P}$ & --- & -- & --- & $\mathrm{P}$ & -- & $Q$ & --- & -- & $\mathrm{P}$ \\
\hline 1161837 & 1.7 & --- & -- & --- & --- & $\mathrm{K}$ & $\mathrm{K}$ & --- & --- & -- & $\mathrm{K}$ & -- & $\mathrm{K}$ & -- & -- & $\mathrm{L}$ \\
\hline 1162026 & 2.4 & $\cdots$ & $-\cdots$ & --- & $\rightarrow$ & $\mathrm{T}$ & $\mathrm{s}$ & --- & --- & -- & $\mathrm{T}$ & --- & $\mathrm{s}$ & --- & $\mathrm{T}$ & $\mathbf{T}$ \\
\hline 1162102 & 2.0 & --- & -- & $\mathrm{F}$ & --- & G & $\mathrm{F}$ & --- & --- & --- & $\mathrm{G}$ & --- & $-\infty$ & -- & G & G \\
\hline 1162214 & 1.6 & --- & --- & $\mathrm{H}$ & -- & --- & $\mathrm{H}$ & --- & --- & --- & -- & $\mathrm{H}$ & -- & --- & $\mathrm{H}$ & $I$ \\
\hline 1162256 & 1.8 & --- & --- & $M$ & -- & --- & M & --- & --- & --- & M & M & M & --- & $M$ & M \\
\hline 1170042 & 3.1 & $I$ & $\mathfrak{J}$ & $\mathbf{J}$ & --- & $\mathrm{K}$ & $\mathrm{J}$ & --- & --- & I & $\mathrm{J}$ & $\mathrm{J}$ & $\mathrm{J}$ & --- & $\mathrm{J}$ & $\mathrm{J}$ \\
\hline 1170050 & 2.6 & $A$ & A & A & --- & A & A & --- & --- & A & A & A & A & --- & A & A \\
\hline 1170111 & 1.5 & -- & $\mathrm{N}$ & -- & -- & -- & $\mathrm{N}$ & -- & --- & --- & -- & $\mathrm{N}$ & $\mathrm{N}$ & --- & $\mathbf{N}$ & -- \\
\hline 1170214 & 1.8 & $s$ & $\mathrm{R}$ & -- & -- & $\mathrm{s}$ & $\mathrm{R}$ & -- & -- & $\mathrm{s}$ & --- & $\mathrm{R}$ & $\mathrm{R}$ & --- & $\mathrm{S}$ & $s$ \\
\hline 1170227 & 1.8 & --- & --- & --- & --- & $-\infty$ & $\mathrm{P}$ & --- & --- & --- & -- & $\mathrm{P}$ & $P$ & --- & $P$ & $P$ \\
\hline 1170329 & 2.0 & $\mathrm{H}$ & $\mathrm{H}$ & -- & --- & -- & $\mathrm{H}$ & --- & -- & $\mathrm{H}$ & -- & $\mathrm{H}$ & $I$ & --- & I & $\mathrm{H}$ \\
\hline 1170410 & -- & --- & --- & -- & --- & -- & $-\infty$ & --- & --- & -- & -- & $Q$ & 2 & --- & 2 & $Q$ \\
\hline 1170515 & 2.1 & --- & $\mathrm{C}$ & --- & -- & $\mathrm{D}$ & --- & --- & --- & $\mathrm{D}$ & -- & $\hat{\mathrm{B}}$ & $\tilde{B}$ & --- & B & $\hat{\mathrm{D}}$ \\
\hline 1170629 & 3.3 & $\mathrm{R}$ & $\mathbf{S}$ & -- & --- & $S$ & --- & -- & --- & $R$ & $\mathbf{S}$ & $\mathrm{R}$ & $\mathbf{S}$ & --- & $\mathrm{S}$ & $\mathbf{R}$ \\
\hline 1170659 & 2.4 & G & G & --- & -- & G & --- & --- & --- & G & G & $G$ & G & --- & $G$ & -- \\
\hline 1170752 & 2.6 & B & A & --- & --- & $B$ & --- & --- & --- & A & A & $\mathrm{B}$ & A & -- & B & A \\
\hline 1171532 & 1.9 & -- & $\mathrm{T}$ & -- & -- & -- & -- & --- & --- & -- & A & $T$ & $T$ & --- & -- & $\mathrm{T}$ \\
\hline 1171535 & 2.4 & $J$ & I & $-\infty$ & -- & I & --- & --- & -- & --- & I & $I$ & I & --- & --- & -- \\
\hline 1171600 & --- & $T$ & $T$ & -- & --- & $\mathrm{T}$ & --- & $\mathrm{T}$ & --- & --- & $\mathrm{T}$ & $T$ & $T$ & --- & -- & $\mathrm{T}$ \\
\hline 1172059 & $2 \cdot 3$ & $\mathrm{H}$ & $\mathrm{H}$ & -- & --- & $\mathrm{H}$ & --- & -- & --- & --- & $\mathrm{H}$ & G & -- & -- & -- & $\mathrm{H}$ \\
\hline 1180312 & $2 \cdot 2$ & $s$ & --- & $\mathrm{S}$ & $s$ & $\mathrm{~S}$ & $\mathrm{~s}$ & -- & --- & -- & $\mathrm{s}$ & $\mathrm{S}$ & $\mathrm{S}$ & $s$ & $\mathrm{~S}$ & $\mathrm{~s}$ \\
\hline 1180410 & 3.0 & I & --- & I & $I$ & $\mathrm{~J}$ & $I$ & --- & --- & -- & I & $I$ & $I$ & $I$ & I & $\mathrm{J}$ \\
\hline 1180721 & 1.4 & --- & -- & $\mathrm{K}$ & $\mathrm{K}$ & -- & -- & --- & --- & --- & -- & --- & $\mathrm{K}$ & $\mathrm{K}$ & $\mathrm{K}$ & --- \\
\hline 1180725 & 2.2 & $\mathrm{H}$ & -- & $I$ & $I$ & --- & --- & --- & -- & --- & --- & $I$ & --- & $\mathrm{H}$ & $I$ & $I$ \\
\hline 1180748 & 1.0 & --- & --- & $-\cdots$ & $\mathrm{H}$ & -- & -- & --- & --- & --- & --- & --- & $\mathrm{H}$ & I & $\mathrm{H}$ & -- \\
\hline 1180910 & 2.0 & --- & --- & $\mathrm{T}$ & $\mathrm{T}$ & --- & --- & -- & --- & --- & --- & --- & $\mathrm{T}$ & $\mathrm{T}$ & $\mathrm{T}$ & $T$ \\
\hline 1181024 & 1.3 & --- & --- & $I$ & I & --- & --- & --- & --- & --- & -- & I & --- & I & I & --- \\
\hline 1181048 & 1.1 & --- & --- & --- & $s$ & -- & --- & --- & --- & --- & -- & $S$ & $\mathbf{S}$ & $\mathrm{s}$ & $\mathrm{s}$ & -- \\
\hline 1181108 & 1.2 & --- & --- & -- & $\mathrm{C}$ & --- & --- & -- & --- & -- & --- & $\mathrm{D}$ & C & $\mathrm{D}$ & $\mathrm{D}$ & -- \\
\hline 1181319 & 2.7 & $\mathrm{C}$ & --- & $c$ & $c$ & --- & -- & --- & --- & -- & --- & $c$ & $\mathrm{E}$ & --- & $D$ & $\mathrm{C}$ \\
\hline 1181605 & 1.8 & -- & -- & $M$ & $M$ & M & --- & -- & -- & -- & -- & $M$ & $M$ & --- & $M$ & $M$ \\
\hline 1181648 & 3.1 & L & --- & L & L & $\mathrm{L}$ & --- & -- & -- & -- & $\mathrm{L}$ & $\mathrm{L}$ & $\mathrm{L}$ & M & $\mathrm{L}$ & L \\
\hline 1181752 & 1.4 & $-\cdots$ & --- & $\mathrm{C}$ & $c$ & --- & -- & --- & $\rightarrow$ & -- & -- & $c$ & --- & $\mathrm{C}$ & $\mathrm{C}$ & -- \\
\hline 1181903 & 1.2 & -- & --- & --- & $E$ & --- & -- & -- & --- & --- & --- & $F$ & $E$ & $\mathrm{~F}$ & $\mathbf{F}$ & -- \\
\hline 1181955 & 1.7 & $c$ & --- & --- & --- & -- & --- & --- & -- & --- & -- & $\mathrm{D}$ & --- & C & D & $\mathrm{C}$ \\
\hline 1190000 & 1.6 & -- & --- & $\mathrm{C}$ & --- & --- & $\mathrm{D}$ & --- & -- & -- & -- & $c$ & $\mathrm{C}$ & C & $\mathrm{C}$ & -- \\
\hline 1190004 & 1.0 & -- & $-\cdots$ & -- & $\mathrm{K}$ & --- & -- & -- & --- & --- & $-\ldots$ & $\mathrm{K}$ & $\mathrm{K}$ & $\mathrm{K}$ & -- & -- \\
\hline 1190116 & 1.5 & --- & --- & $\mathrm{T}$ & $\mathrm{T}$ & --- & $\mathrm{T}$ & -- & -- & --- & -- & $\mathbf{T}$ & -- & $\mathrm{s}$ & $T$ & $\mathrm{~T}$ \\
\hline 1190143 & 1.2 & --- & -- & -- & $\mathrm{P}$ & --- & -- & -- & --- & --- & --- & $\mathrm{Q}$ & $\mathrm{P}$ & $Q$ & $Q$ & -- \\
\hline 1190354 & 1.3 & -- & -- & -- & D & --- & -- & --- & -- & -- & -- & $\bar{E}$ & $E$ & $E$ & $\mathrm{E}$ & $-\infty$ \\
\hline 1190443 & 1.3 & --- & --- & $I$ & $I$ & -- & --- & -- & $-\infty$ & -- & --- & --- & $I$ & -- & I & -- \\
\hline 1190718 & 2.6 & $F$ & -- & G & G & $\mathrm{H}$ & G & G & $-\ldots$ & -- & --- & -- & $\mathrm{H}$ & G & G & -- \\
\hline 1190826 & 2.2 & -- & --- & $\mathrm{K}$ & $\mathrm{k}$ & $\mathrm{K}$ & $\mathrm{K}$ & --- & -- & --- & -- & -- & $\mathrm{K}$ & $\mathrm{K}$ & $\mathrm{K}$ & -- \\
\hline 1190838 & 1.9 & -- & --- & Q & --- & -- & 2 & --- & --- & --- & -- & -- & $Q$ & $Q$ & $Q$ & -- \\
\hline 1191115 & 1.4 & --- & --- & --- & $\mathrm{N}$ & --- & -- & --- & --- & -- & -- & --- & 0 & $\mathrm{~N}$ & $\mathbf{N}$ & $-\infty$ \\
\hline 1191130 & 1.7 & --- & --- & $\mathrm{N}$ & M & --- & M & --- & -- & --- & --- & -- & --- & $\mathrm{M}$ & $\mathrm{N}$ & $\mathrm{N}$ \\
\hline 1191451 & 1.6 & --- & --- & A & A & --- & A & --- & --- & --- & --- & -- & A & --- & A & A \\
\hline 1191543 & 1.9 & $\mathrm{D}$ & $-\cdots$ & $\mathrm{D}$ & $\mathrm{D}$ & -- & $\mathrm{D}$ & --- & --- & --- & -- & --- & $D$ & --- & $D$ & $\mathrm{D}$ \\
\hline 1191612 & 1.9 & $\rightarrow$ & -- & 0 & -- & --- & 0 & --- & $\rightarrow$ & -- & -- & -- & 0 & -- & 0 & $-\infty$ \\
\hline 1191748 & 1.1 & --- & -- & $P$ & 0 & -- & --- & --- & -- & -- & --- & $P$ & -- & --- & P & -- \\
\hline 1191752 & 1.2 & $\rightarrow$ & --- & $\mathrm{C}$ & $\mathrm{C}$ & $--\infty$ & -- & $\rightarrow$ & --- & -- & -- & $c$ & -- & -- & $\mathrm{c}$ & --- \\
\hline 1191853 & 1.9 & --- & --- & Q & $Q$ & $Q$ & 2 & --- & --- & --- & --- & $Q$ & Q & --- & $Q$ & $Q$ \\
\hline 1192033 & 1.3 & -- & --- & $\tilde{A}$ & $\hat{T}$ & --- & -- & -- & --- & -- & --- & $\mathrm{A}$ & $T$ & -- & $\bar{A}$ & $-\infty$ \\
\hline 1192108 & $1 \cdot 3$ & --- & --- & $\mathrm{K}$ & $\mathrm{J}$ & --- & --- & -- & --- & --- & +-- & $\mathrm{K}$ & $\mathrm{K}$ & -- & $\mathrm{K}$ & $-\infty$ \\
\hline 1200103 & .6 & --- & --- & $M$ & $M$ & --- & --- & --- & --- & --- & --- & $M$ & L & --- & -- & $-\infty$ \\
\hline 1200143 & 1.9 & $\mathrm{C}$ & --- & B & B & $\mathrm{C}$ & -- & C & --- & --- & B & C & B & --- & -- & $\mathrm{C}$ \\
\hline 1200601 & 1.5 & -- & --- & A & A & -- & --- & -- & $\rightarrow$ & --- & -- & A & A & $-\cdots$ & -- & A \\
\hline 1201920 & 1.7 & --- & -- & $\mathrm{H}$ & $\mathrm{H}$ & I & $\mathrm{H}$ & --- & -- & --- & H & $\mathrm{H}$ & $\mathrm{H}$ & -- & I & -- \\
\hline
\end{tabular}


Table 4.2. Aftershocks of the earthquake--Continued

\begin{tabular}{|c|c|c|c|c|c|c|c|c|c|c|c|c|c|c|c|c|}
\hline \multirow{2}{*}{$\begin{array}{l}\text { Origin } \\
\text { time }\end{array}$} & \multirow{2}{*}{$\left(\frac{M}{c o d a}\right)$} & \multicolumn{15}{|c|}{ Station } \\
\hline & & AMS & BBL & $\mathrm{COE}$ & DFL & GRT & LAS & LON & NBR & $O C R$ & PHR & $\mathrm{RBH}$ & RST & SFL & SFR & UTS \\
\hline 1202358 & 2.6 & G & --- & н & $\mathrm{H}$ & H & $\mathrm{H}$ & $\mathrm{G}$ & --- & --- & н & H & H & --- & $\mathrm{H}$ & $\mathrm{H}$ \\
\hline 1210053 & 1.6 & $\cdots$ & -- & --- & --- & B & -- & -- & --- & -- & -- & B & B & --- & B & --- \\
\hline 1210113 & 1.9 & --- & -- & I & H & -- & $\mathrm{H}$ & -- & --- & -- & -- & I & H & --- & I & $\mathrm{H}$ \\
\hline 1210312 & 1.2 & --- & --- & --- & I & -- & -- & --- & $\cdots$ & --- & $-\cdots$ & $I$ & I & --- & I & --- \\
\hline 1210352 & 1.6 & --- & --- & -- & $\mathrm{N}$ & -- & -- & -- & -- & -- & 0 & 0 & 0 & -- & 0 & -- \\
\hline 1211128 & 1.0 & --- & --- & D & D & --- & $\cdots$ & --- & --- & --- & --- & D & D & --- & D & $\cdots$ \\
\hline 1211446 & 1.4 & --- & --- & A & A & --- & --- & --- & -- & --- & --- & A & A & $\cdots$ & A & $\cdots$ \\
\hline 1220220 & 2.3 & --- & -- & A & A & B & B & -- & --- & $\cdots$ & --- & B & B & --- & B & A \\
\hline 1220400 & 2.4 & --- & -- & D & c & D & D & -- & --- & --- & --- & D & D & -- & D & D \\
\hline 1221518 & 2.6 & $\mathbf{P}$ & -- & 0 & 0 & P & o & --- & --- & --- & --- & $\mathbf{P}$ & --- & --- & --- & P \\
\hline 1222323 & 2.6 & D & --- & D & D & D & D & D & -- & --- & --- & D & --- & -- & D & -- \\
\hline 1230444 & 2.7 & -- & --- & H & $\mathrm{H}$ & H & $\mathrm{H}$ & $\mathrm{H}$ & -- & --- & --- & $\mathrm{H}$ & --- & --- & $\mathrm{H}$ & -- \\
\hline 1231918 & 1.9 & --- & --- & D & c & --- & --- & --- & --- & --- & --- & D & --- & --- & D & -- \\
\hline 1230401 & 2.3 & --- & --- & Q & $\mathrm{P}$ & Q & $\cdots$ & --- & -- & --- & -- & $Q$ & --- & -- & -- & -- \\
\hline 1241050 & 1.8 & --- & --- & H & $\mathrm{H}$ & $\mathrm{G}$ & --- & --- & --- & --- & --- & H & --- & --- & --- & --- \\
\hline 1241302 & 2.0 & $\mathrm{R}$ & -- & $\mathrm{R}$ & 2 & $\mathrm{R}$ & --- & --- & --- & $\cdots$ & --- & $\mathrm{R}$ & -- & -- & -- & --- \\
\hline 1241307 & 3.7 & E & --- & E & D & D & --- & --- & --- & --- & --- & E & --- & $\cdots$ & -- & -- \\
\hline 1251842 & 2.7 & --- & --- & $T$ & $T$ & $\mathbf{T}$ & $T$ & --- & --- & -- & --- & $T$ & --- & --- & --- & -- \\
\hline 1260331 & $2 \cdot 2$ & --- & --- & $\mathrm{s}$ & $\mathrm{s}$ & $s$ & $\mathrm{~s}$ & --- & --- & --- & --- & $\mathrm{s}$ & $\mathrm{s}$ & -- & --- & -- \\
\hline 1260352 & 1.9 & --- & --- & D & D & E & D & --- & -- & --- & -- & E & D & --- & -- & --- \\
\hline 1260550 & 2.7 & --- & --- & $F$ & $\mathbf{F}$ & --- & $\mathrm{F}$ & --- & --- & --- & --- & F & --- & -- & --- & --- \\
\hline 1260632 & 1.7 & --- & -- & $Q$ & Q & $Q$ & $\mathrm{R}$ & --- & -- & --- & --- & $\mathrm{R}$ & Q & --- & --- & -- \\
\hline 1261142 & 1.9 & -- & --- & --- & B & --- & B & --- & --- & --- & --- & B & B & -- & --- & -- \\
\hline 1261501 & 1.8 & $\rightarrow-$ & --- & I & I & --- & I & --- & --- & --- & --- & --- & I & --- & -- & --- \\
\hline 1262330 & 1.7 & -- & --- & --- & $\mathrm{K}$ & $\mathrm{K}$ & L & --- & --- & -- & $\mathrm{x}$ & $\mathrm{K}$ & $\mathrm{K}$ & -- & --- & --- \\
\hline 1271129 & 2.5 & --- & --- & $\mathrm{C}$ & c & c & D & --- & -- & --- & D & -- & c & --- & $\cdots$ & --- \\
\hline 1281427 & 2.6 & --- & -- & G & G & G & --- & --- & --- & -- & --- & --- & G & -- & -- & $-\cdots$ \\
\hline 1291334 & 1.9 & --- & -- & C & c & --- & c & --- & -- & --- & -- & --- & c & --- & -- & -- \\
\hline 1310110 & $2 \cdot 1$ & --- & --- & $\mathrm{N}$ & $\mathrm{N}$ & -- & $\mathbf{N}$ & --- & N & $\mathrm{N}$ & -- & --- & -- & --- & -- & -- \\
\hline 1310307 & $2 \cdot 3$ & --- & --- & E & E & --- & E & --- & E & --- & -- & -- & --- & $-\cdots$ & --- & --- \\
\hline 1320025 & 2.1 & --- & -- & $\mathrm{R}$ & $\mathrm{R}$ & $\mathrm{s}$ & $\mathrm{s}$ & --- & $s$ & --- & $-\cdots$ & -- & --- & -- & --- & -- \\
\hline 1320044 & 1.5 & --- & --- & E & $\mathbf{E}$ & --- & $F$ & --- & --- & E & --- & -- & --- & -- & --- & --- \\
\hline 1320308 & --- & --- & --- & $\mathbf{J}$ & $\mathrm{J}$ & --- & --- & $\cdots$ & I & $\mathrm{J}$ & --- & -- & --- & -- & --- & --- \\
\hline 1320431 & --- & $\mathrm{J}$ & --- & $\mathrm{x}$ & $\mathrm{x}$ & --- & $\mathrm{K}$ & --- & $\mathrm{J}$ & $\mathrm{K}$ & --- & --- & --- & --- & --- & $\cdots$ \\
\hline 1322326 & $2 \cdot 3$ & --- & --- & B & B & c & c & --- & c & -- & --- & -- & -- & $-\cdots$ & --- & -- \\
\hline 1362252 & 2.2 & --- & --- & $\mathrm{J}$ & $\mathrm{J}$ & I & $\mathrm{J}$ & --- & --- & --- & -- & --- & -- & -- & --- & --- \\
\hline 1370745 & 1.9 & --- & -- & -- & M & M & $\mathrm{N}$ & --- & $\mathrm{N}$ & --- & -- & -- & -- & -- & --- & - \\
\hline 1371709 & --- & --- & -- & --- & $\mathrm{J}$ & $\mathbf{J}$ & $\mathrm{K}$ & --- & $\mathrm{x}$ & --- & $-\infty$ & --- & -- & $-\cdots$ & -- & -- \\
\hline 1380843 & 3.0 & B & -- & -- & A & B & B & B & B & B & -- & -- & $\rightarrow--$ & -- & -- & +- \\
\hline 1381557 & 2.1 & --- & --- & --- & $P$ & $\mathrm{P}$ & $Q$ & --- & $\mathbf{P}$ & --- & $\cdots$ & -- & --- & -- & -- & -- \\
\hline 1390207 & $2 \cdot 0$ & --- & -- & --- & --- & I & I & --- & I & I & -- & --- & -- & -- & --- & -- \\
\hline 1391417 & 2.8 & F & --- & --- & --- & F & F & --- & F & E & --- & --- & --- & -- & -- & $\cdots$ \\
\hline 1391930 & 2.4 & -- & --- & --- & -- & I & I & --- & I & -- & -- & --- & -- & -- & --- & $-\cdots$ \\
\hline 1401649 & 2.8 & -- & --- & $\mathrm{R}$ & $\mathrm{R}$ & Q & $\mathrm{R}$ & -- & $\mathbf{R}$ & --- & --- & -- & -- & --- & --- & --- \\
\hline 1410016 & 1.6 & -- & --- & G & G & G & H & -- & H & -- & -- & --- & --- & -- & --- & -- \\
\hline 1430254 & 2.4 & $\rightarrow$ & --- & $\mathrm{E}$ & E & E & F & -- & E & F & -- & --- & -- & --- & --- & --- \\
\hline 1441835 & 1.7 & --- & --- & $T$ & $T$ & $\mathbf{T}$ & $T$ & --- & --- & --- & -- & -- & -- & -- & --- & --- \\
\hline 1442141 & 2.3 & -- & --- & --- & $\mathrm{K}$ & $\mathrm{x}$ & $\mathrm{x}$ & -- & $\mathrm{K}$ & $\mathrm{k}$ & --- & --- & -- & -- & -- & --- \\
\hline 1482023 & 1.8 & --- & --- & $\mathbf{P}$ & P & $\mathrm{P}$ & P & -- & -- & --- & -- & $\cdots$ & --- & -- & -- & --- \\
\hline 1502132 & 2.3 & -- & -- & G & G & H & $\cdots$ & --- & G & G & -- & --- & -- & -- & --- & -- \\
\hline 1510328 & -- & --- & --- & F & E & F & --- & -- & $\mathbf{F}$ & $\mathbf{F}$ & -- & -- & --- & --- & --- & --- \\
\hline 1511238 & --- & --- & -- & D & D & D & -- & --- & D & D & -- & $\cdots$ & $\cdots$ & --- & $\cdots$ & --- \\
\hline
\end{tabular}

Figure 4.2. Three components of particle velocity for event 1181648 at station AMS, followed by their displacement spectra. Comp., component orientation; $\mathrm{H}$, horizontal component; V, vertical component. Threedigit numbers after $\mathrm{H}$ indicate compass heading of positive ground motion for that component. Trace amplitudes noted at left include a constant scale factor; for example, the initial $\underline{P}$ wave at $2.1 \mathrm{~s}$ would have an amplitude of about $3 \times 10^{-1} \mathrm{~cm} / \mathrm{s}$. Parameters to upper right of each trace, which are calculated over interval denoted by bar above each trace, are as follows: ARMS, root-mean-square acceleration; DUR, duration of window (in seconds); $t$-star, attenuation parameter; VIF, integral squared velocity. At top are instrument parameters: G, Geophone coil constant; gains, amplifier gains; filter, corner of antialiasing filter used. A value is given for each component. Spectra are spectral-density plots of ground displacement (velocity divided by $\omega)$. Picked values for asymptotic long-period level (level), corner frequency (corner, denoted by arrows), and weight (weight) are given in each plot. Below leftmost spectrum is additional information on corrections used in calculating each spectra: divided by $W$, Fourier spectra of velocity was divided by $\omega$ to determine displacement spectra; instr., response of Geophone was removed. FN, natural frequency of the sensor; damp, damping coefficient. Spectral parameters and derived source parameters are listed in table 4.3. 

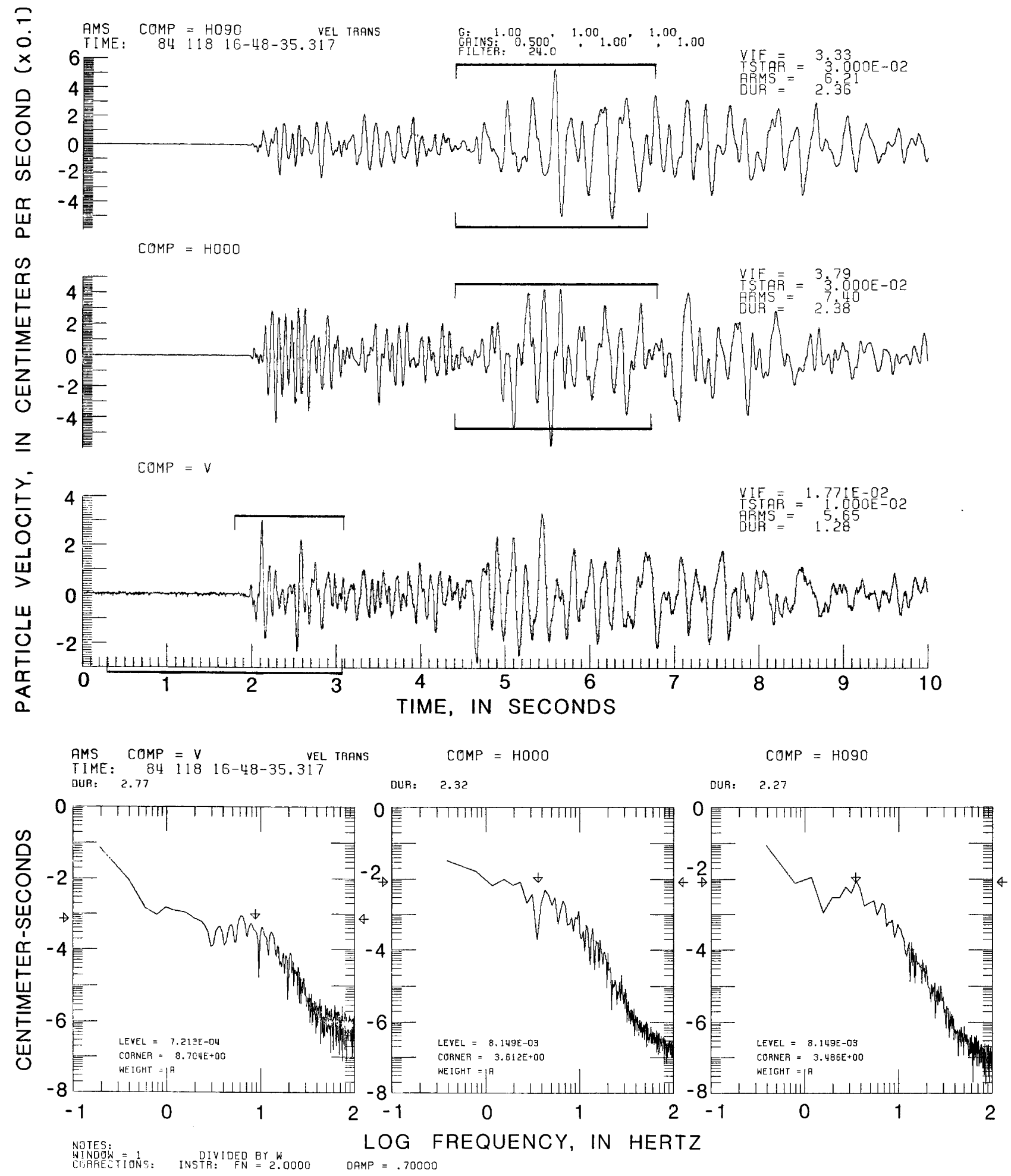

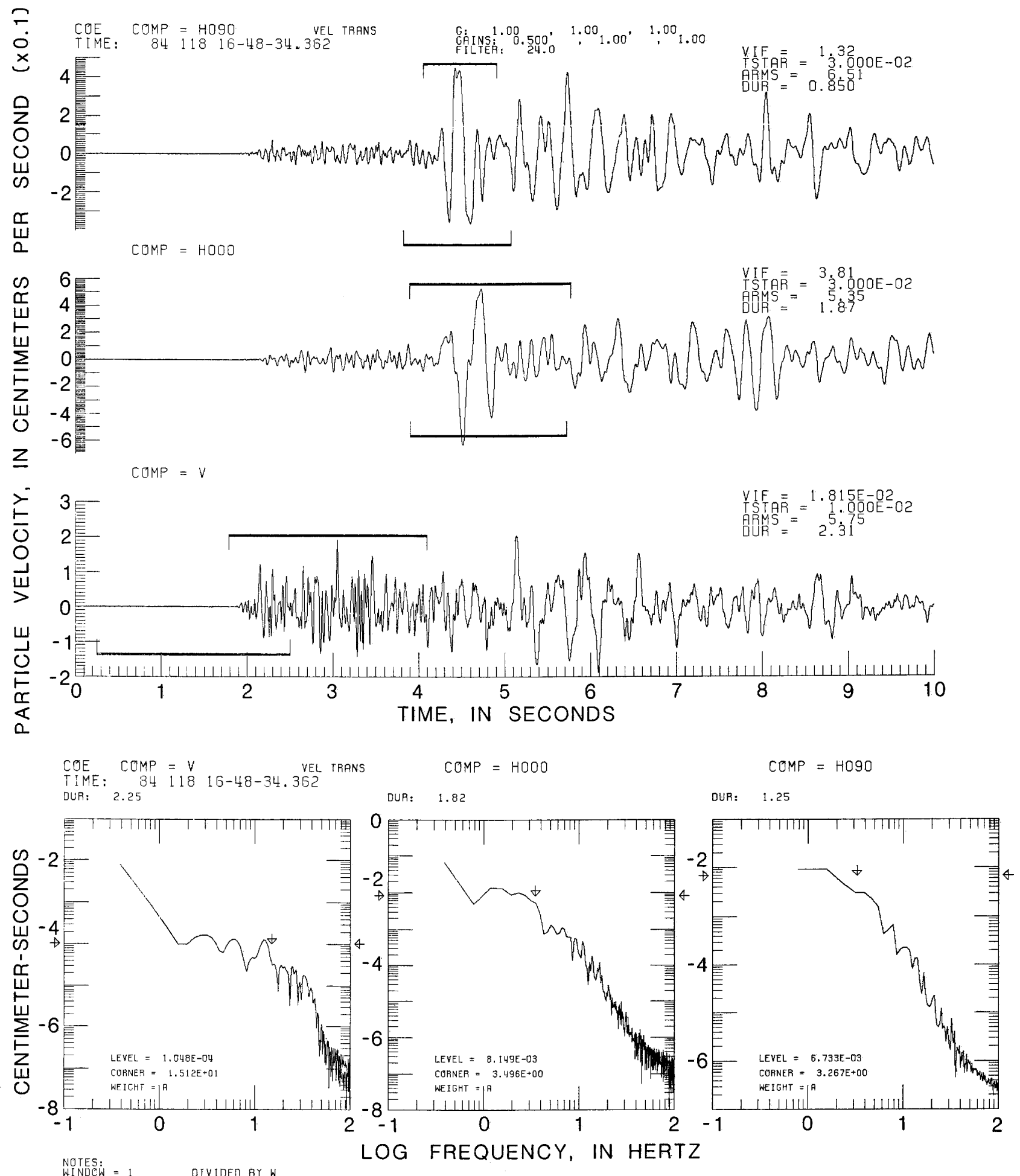

NOTES:
WINDEW
CORRECTIONS: INYIDED BY W

Figure 4.3. Three components of particle velocity for event 1181648 at station COE. Same conventions as in figure 4.2 . 


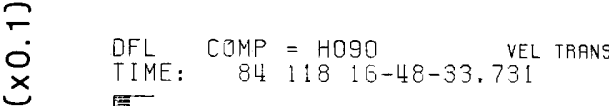
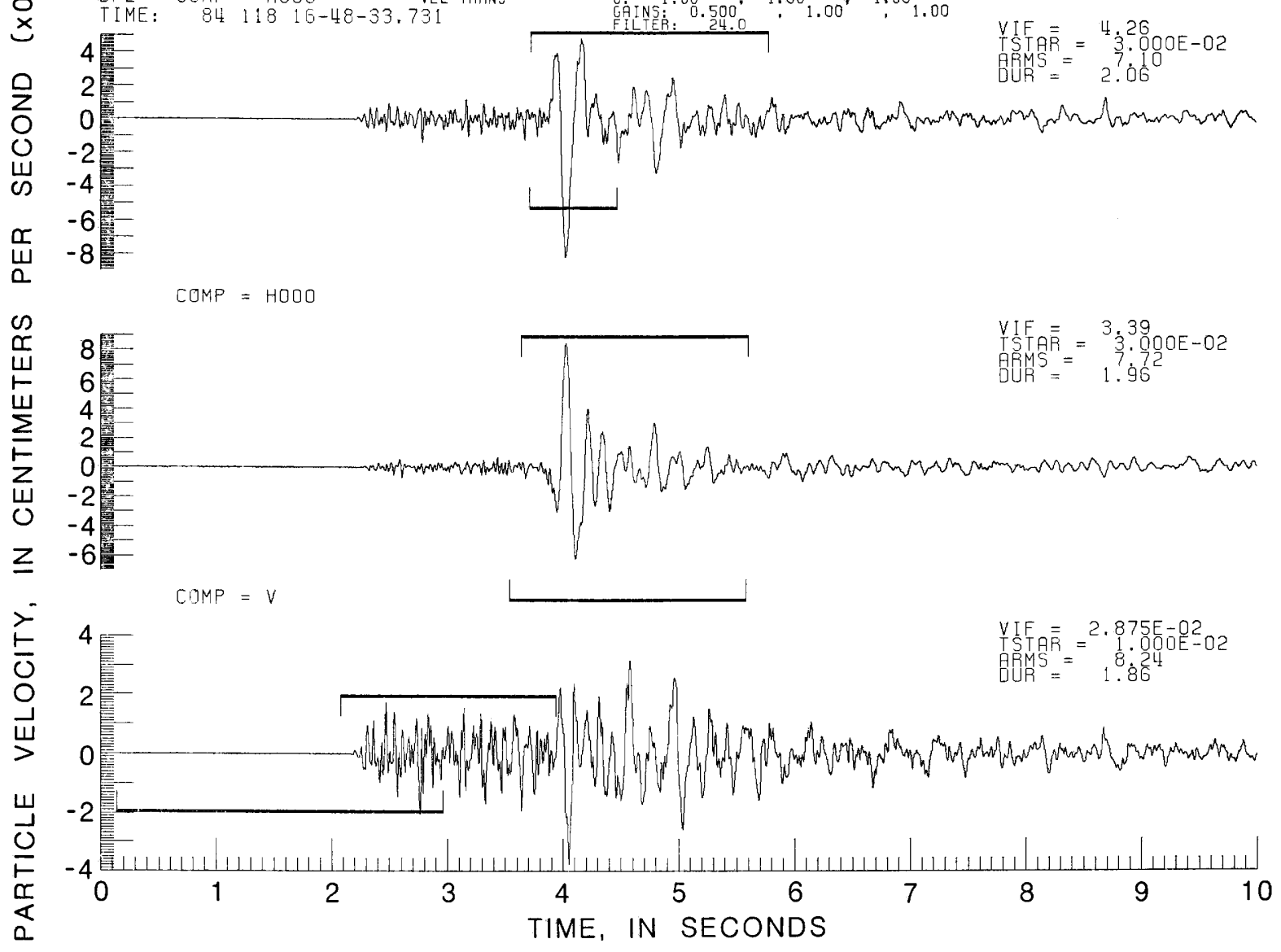

a
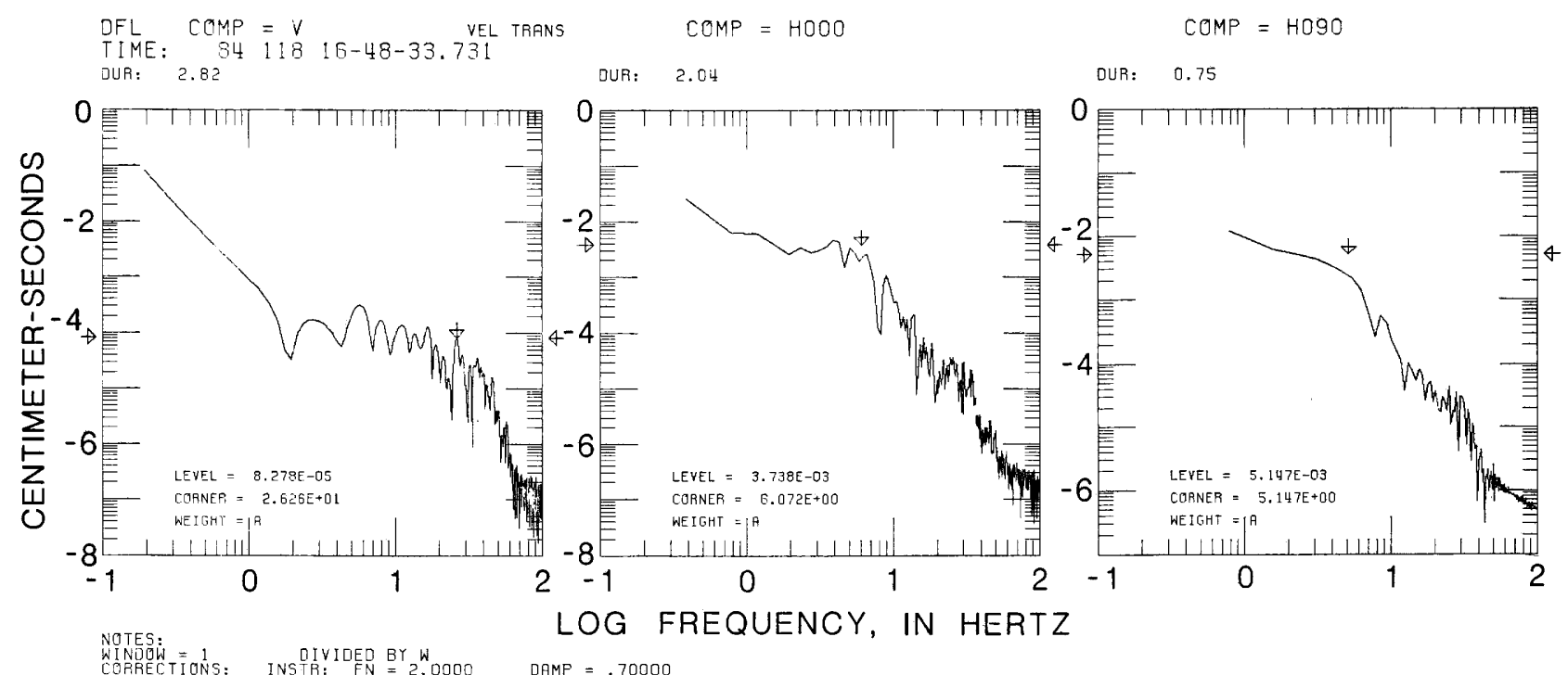

Figure 4.4. Three components of particle velocity for event 1181648 at station DFL. Same conventions as in figure 4.2 . 


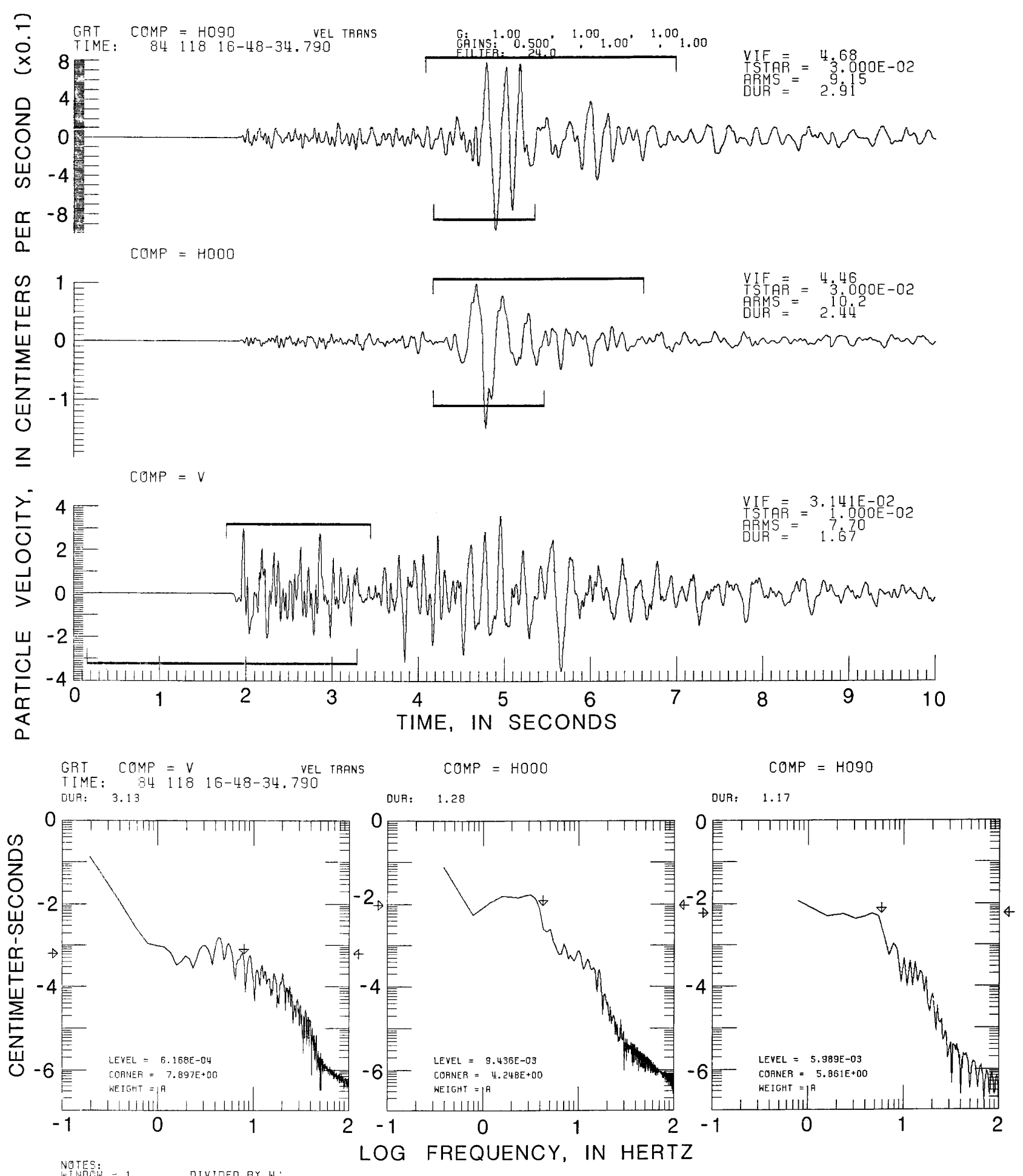

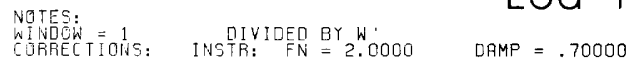

Figure 4.5. Three components of particle velocity for event 1181648 at station GRT. Same conventions as in figure 4.2 . 

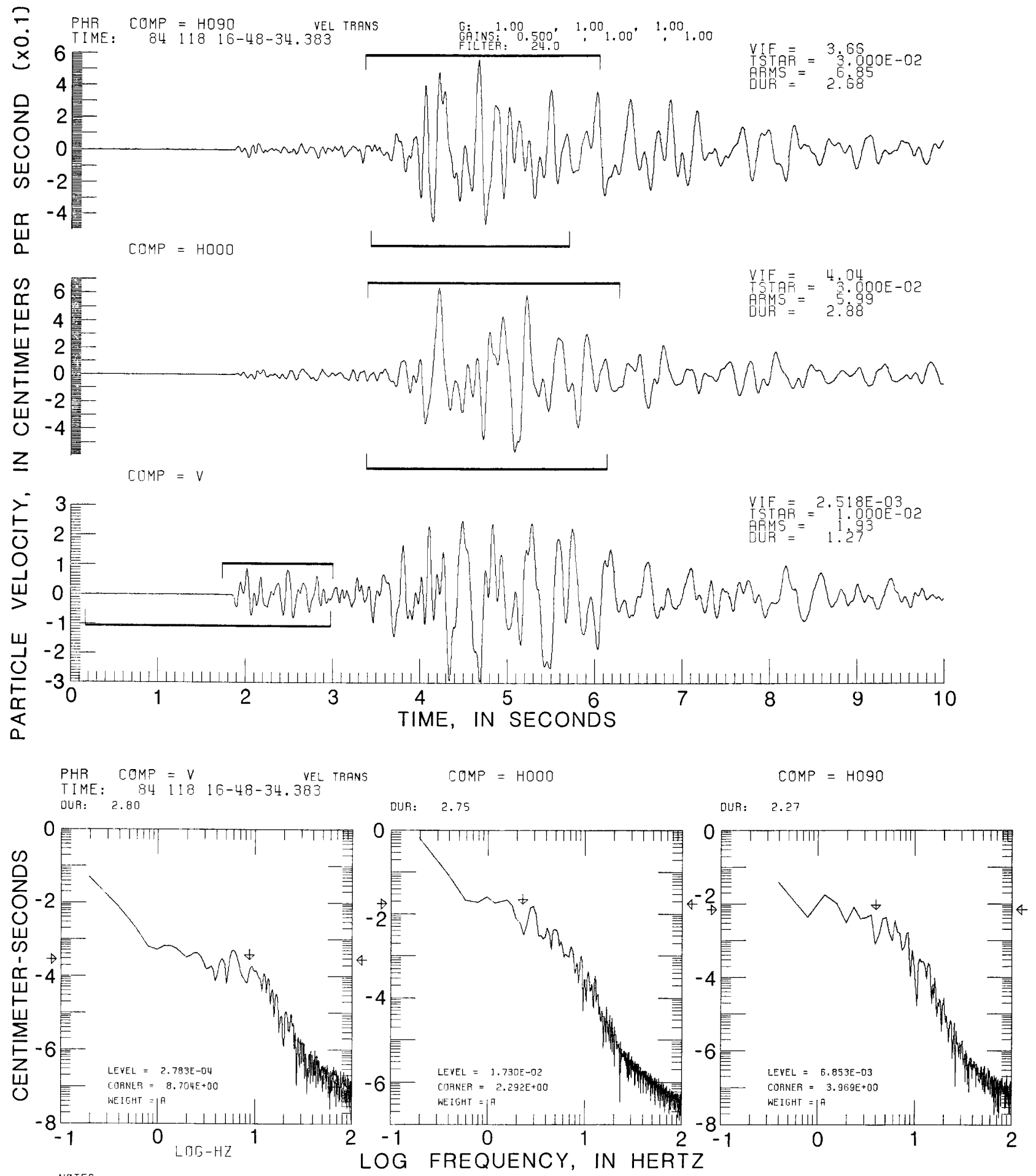

NOTES:
WIEDTE
CORRETTIONS:

Figure 4.6. Three components of particle velocity for event 1181648 at station PHR. Same conventions as in figure 4.2 . 


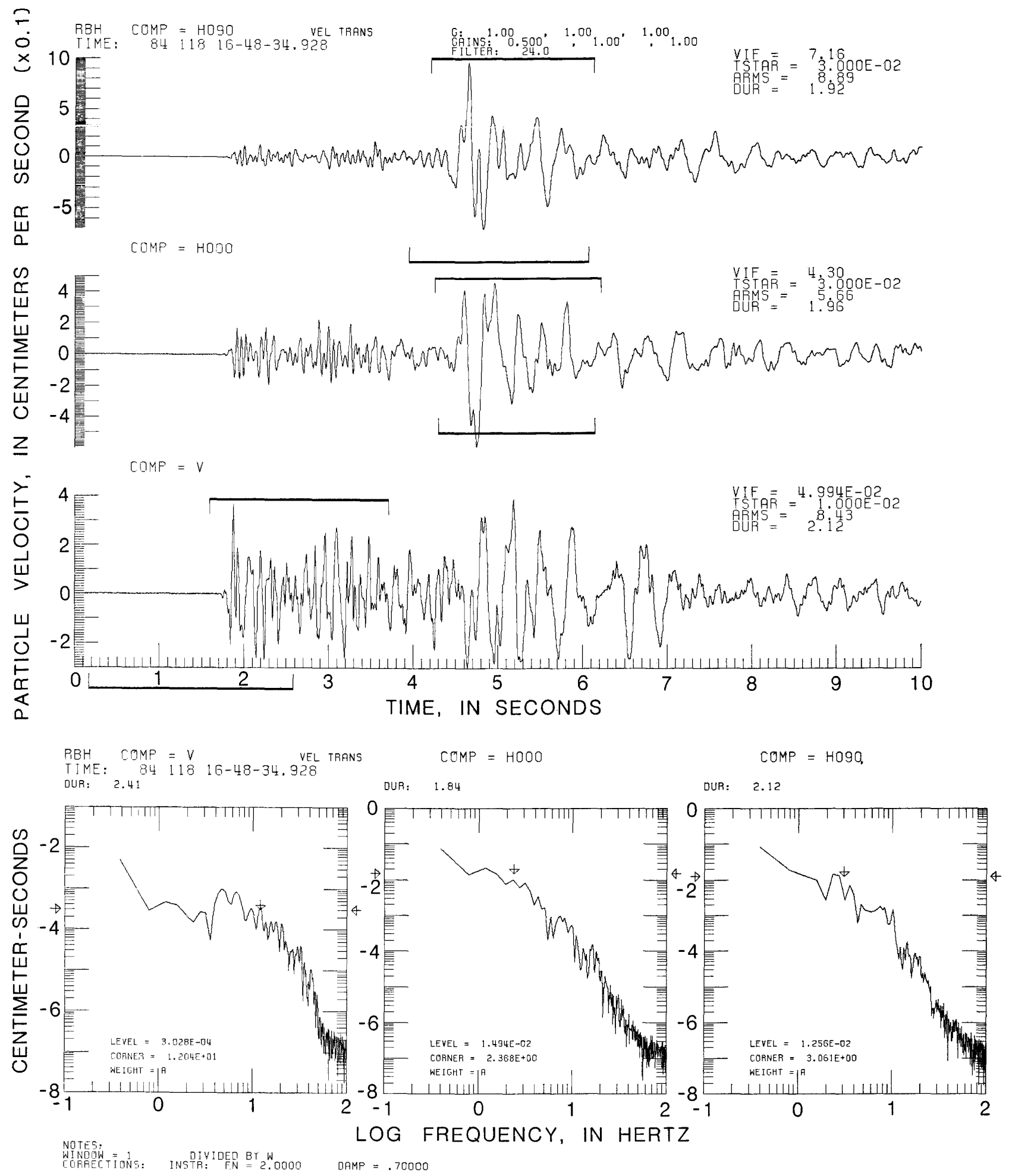

Figure 4.7. Three components of particle velocity for event 1181648 at station RBH. Same conventions as in figure 4.2 . 


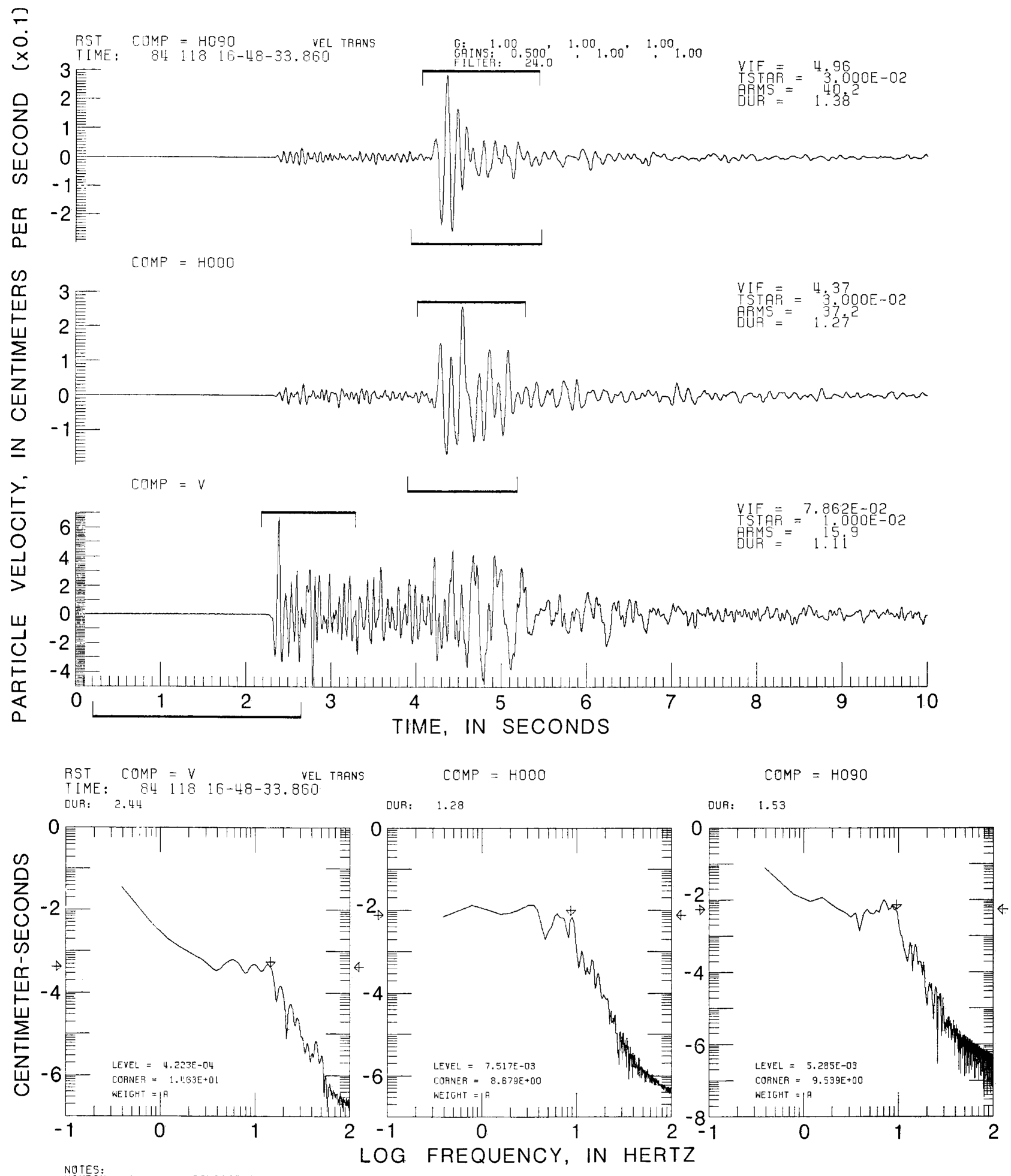

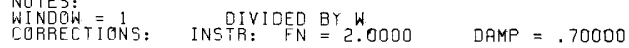

Figure 4.8. Three components of particle velocity for event 1181648 at station RST. Same conventions as in figure 4.2. 

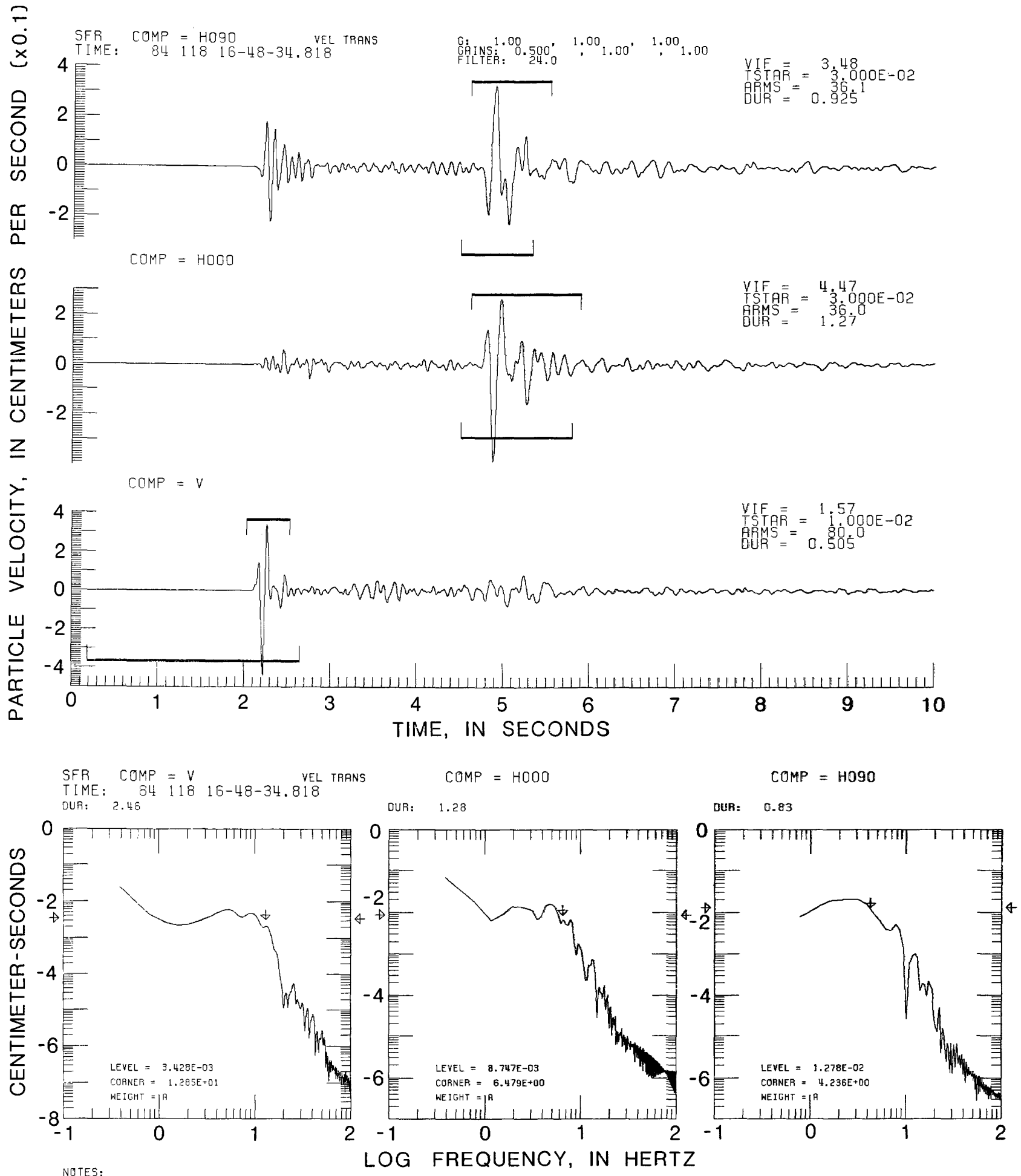

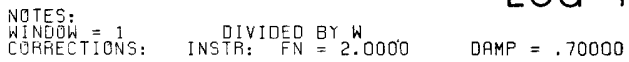

Figure 4.9. Three components of particle velocity for event 1181648 at station SFR. Same conventions as in figure 4.2 . 

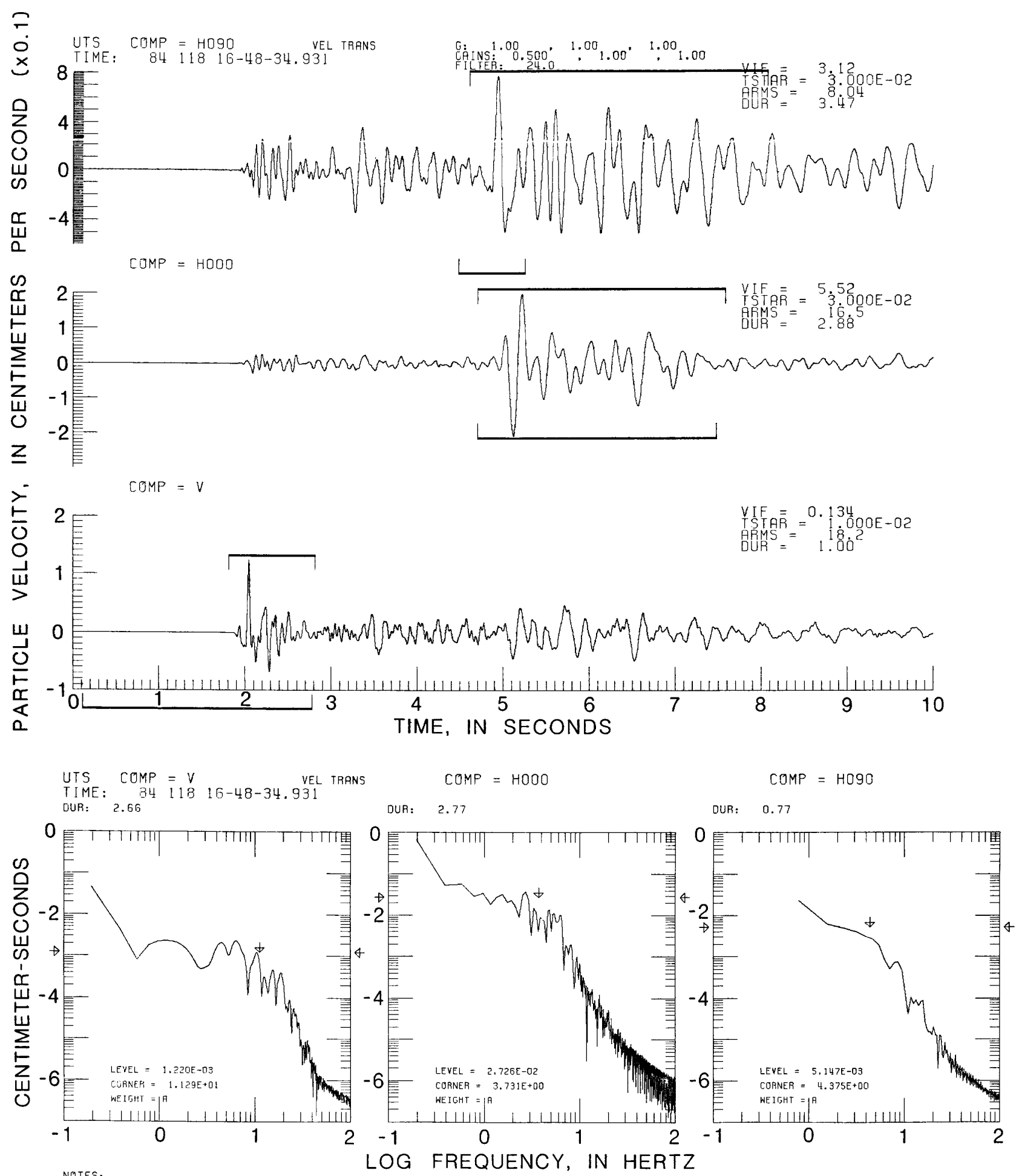

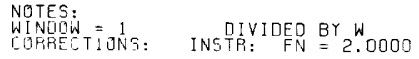

DAMP $=.70000$

Figure 4.10. Three components of particle velocity for event 1181648 at station UTS. Same conventions as in figure 4.2. 

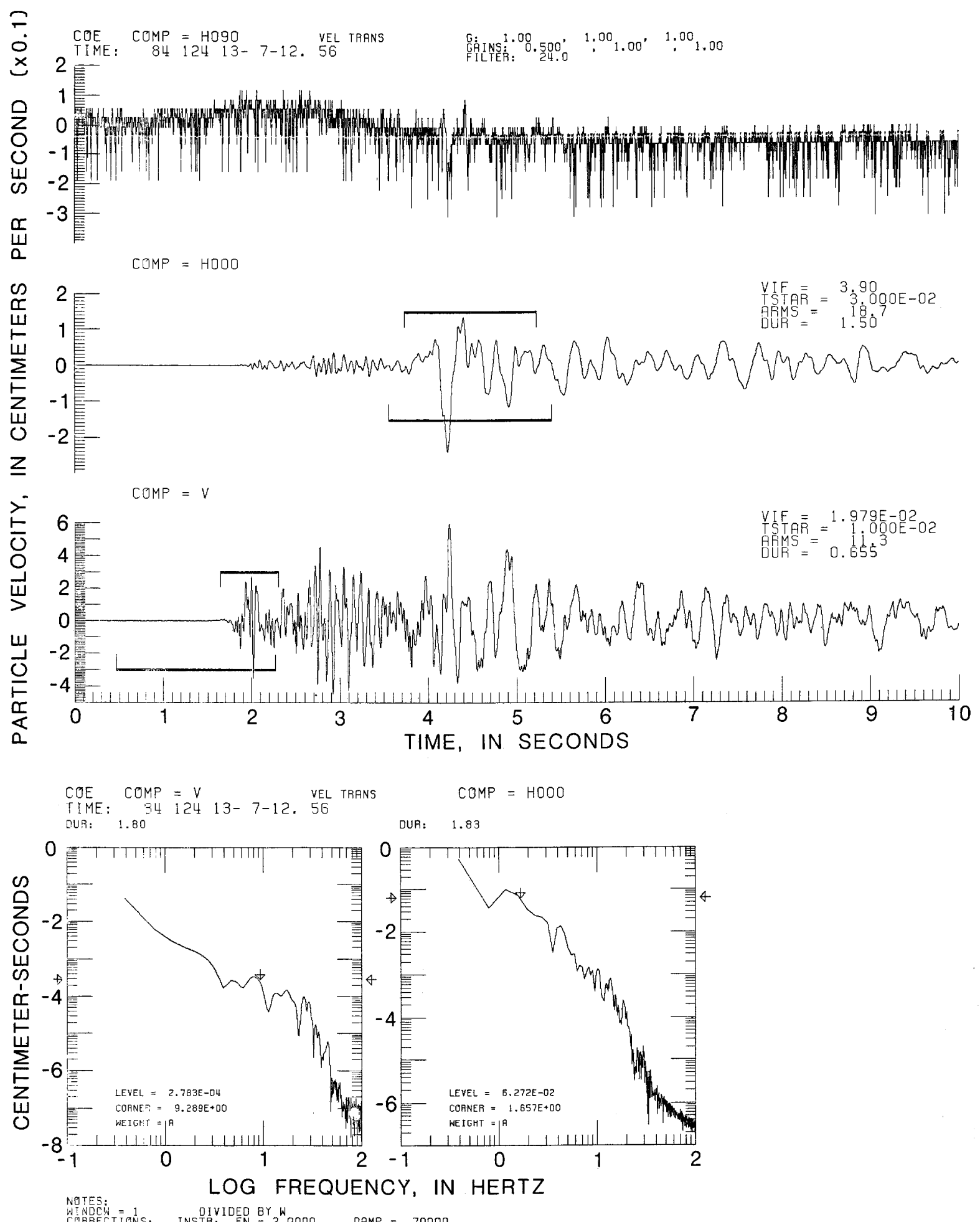

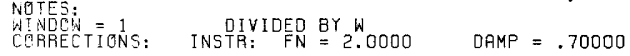

Figure 4.11. Three components of particle velocity for event 1241307 at station COE. Same conventions as in figure 4.2. 

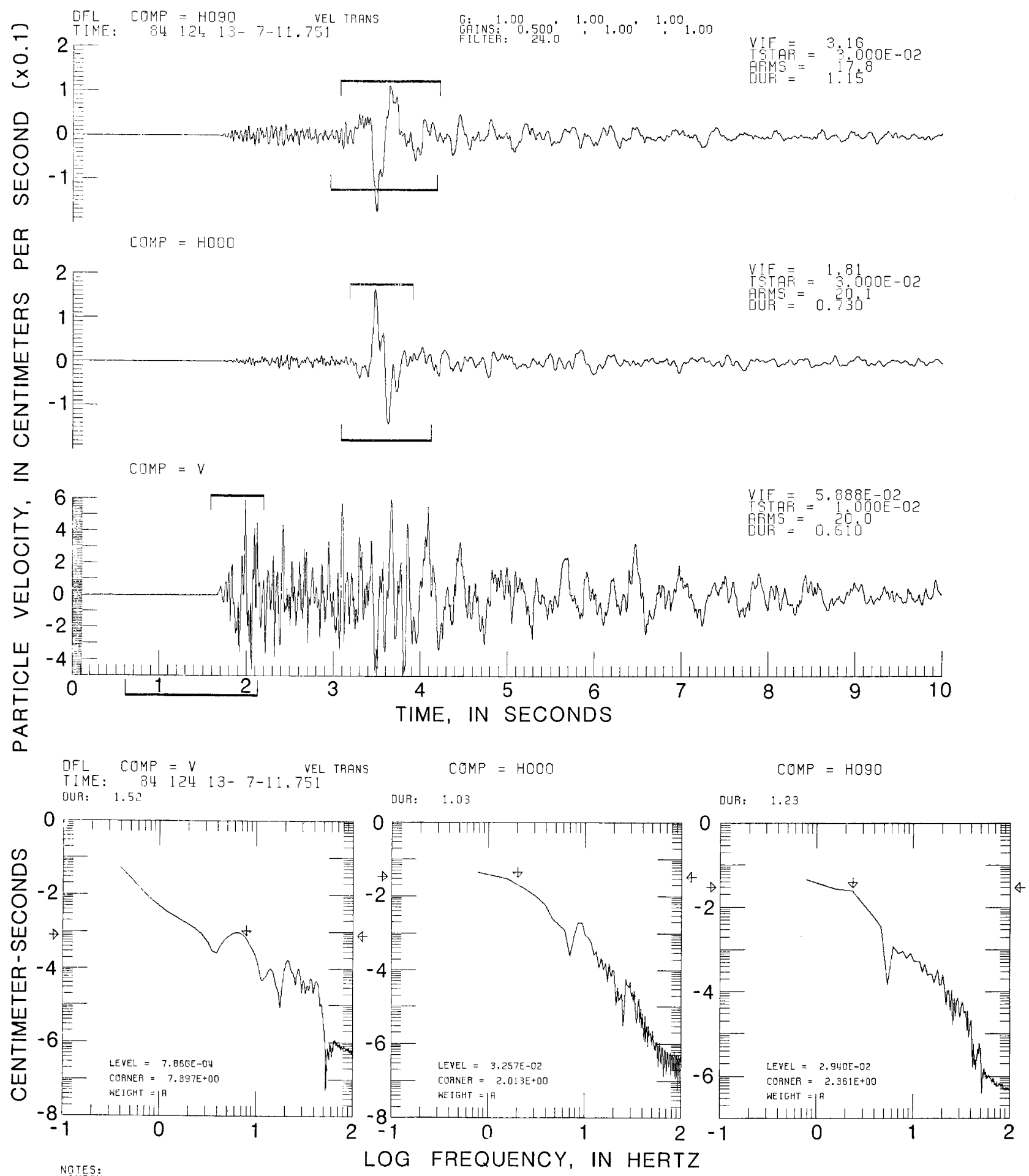

NGTES:
WINODW
CORRECTIONS: INSTIVIDED

Figure 4.12. Three components of particle velocity for event 1241307 at station DFL. Same conventions as in figure 4.2 . 


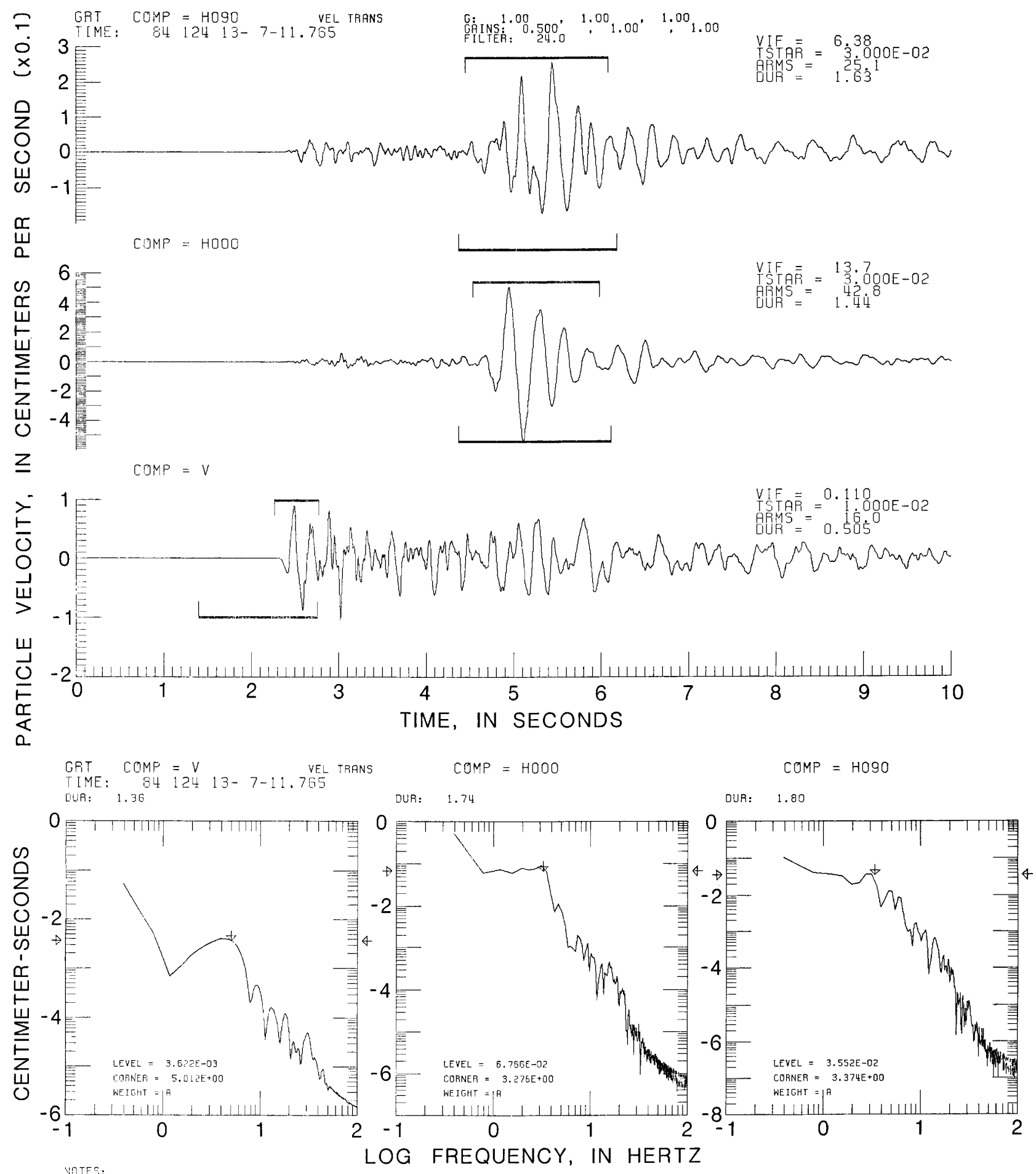

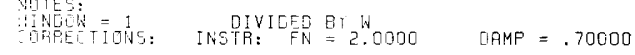

Figure 4.13. Three components of particle velocity for event 1241307 at station GRT. Same conventions as in figure 4.2 . 


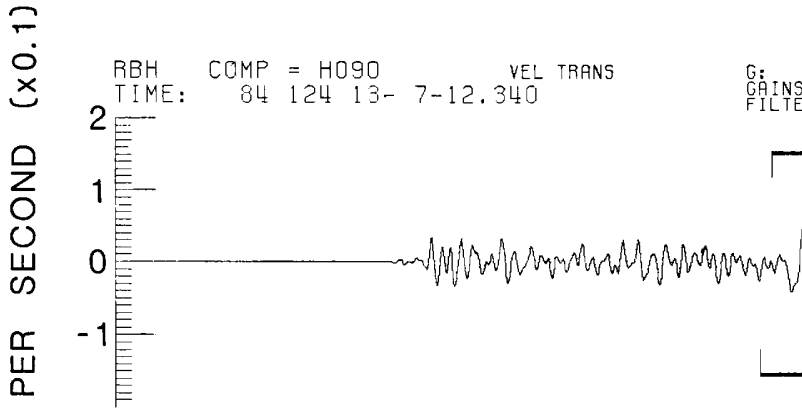

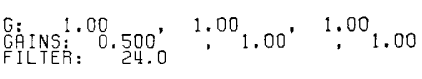
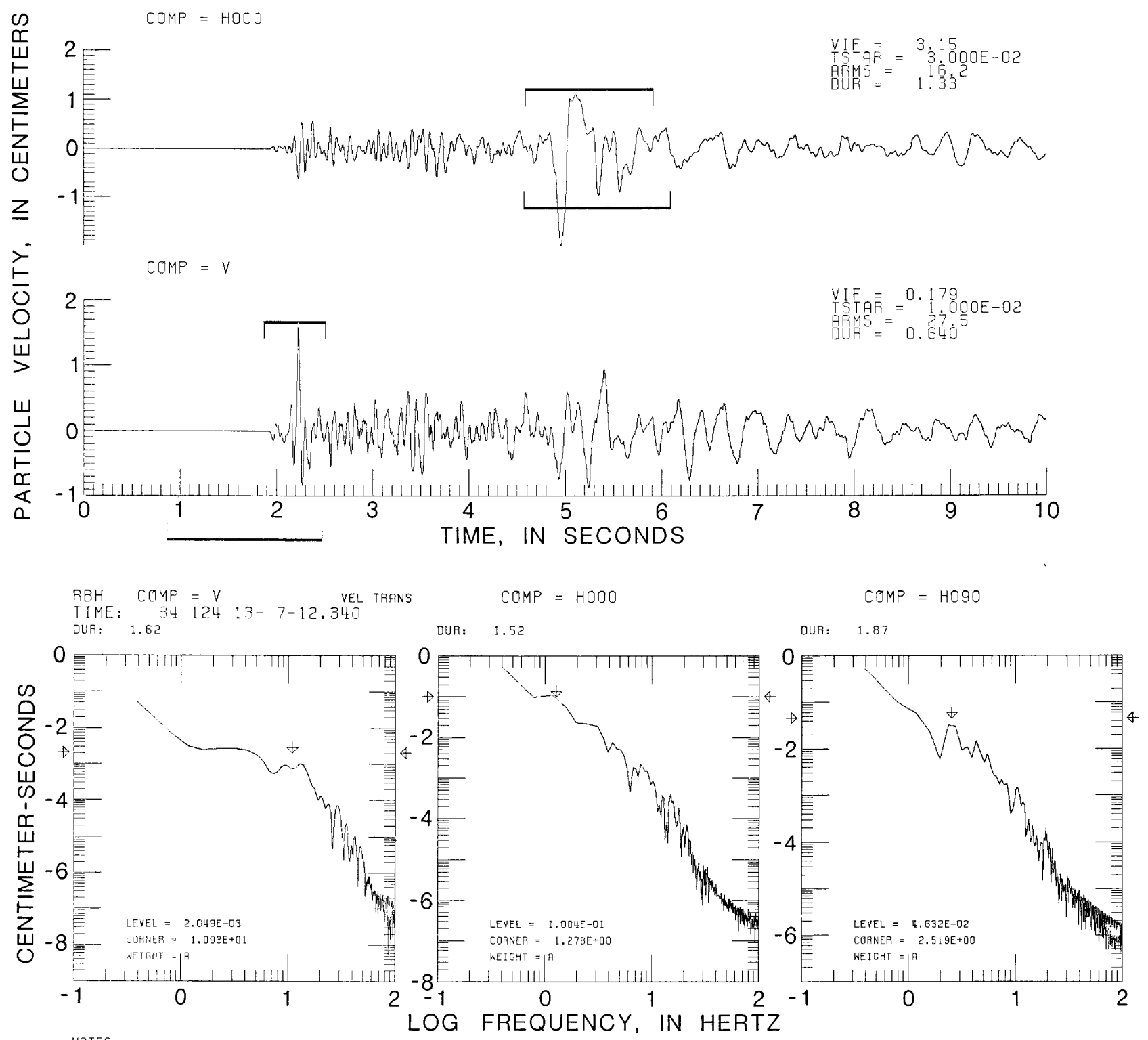

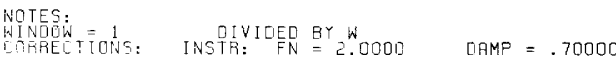

Figure 4.14. Three components of particle velocity for event 1241307 at station RBH. Same conventions as in figure 4.2 . 


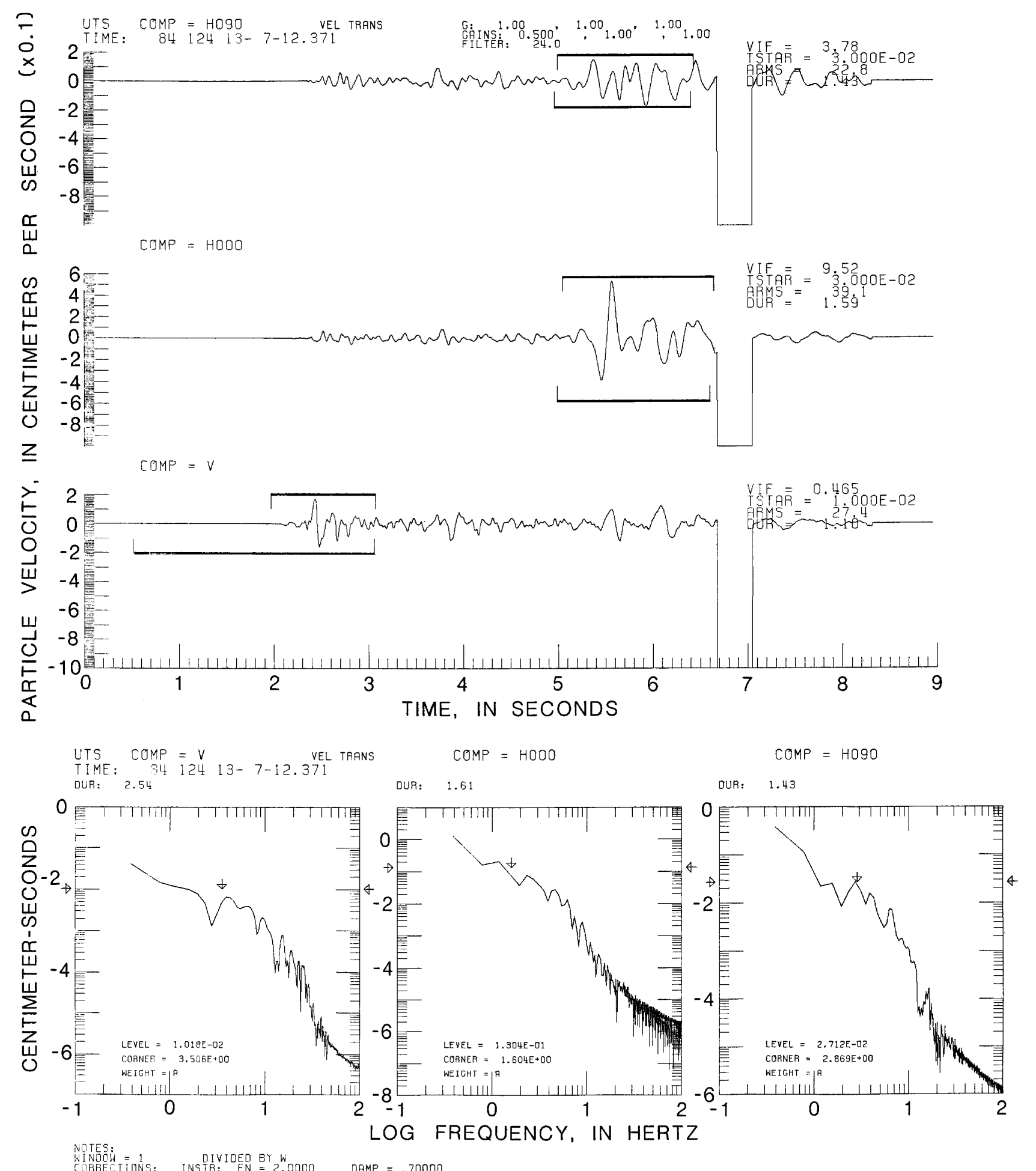

Figure 4.15. Three components of particle velocity for event 1241307 at station UTS. Same conventions as in figure 4.2. 
Table 4.3. Source parameters for event 1181648

\begin{tabular}{|c|c|c|c|c|c|c|c|c|c|c|c|c|c|}
\hline \multirow{2}{*}{\multicolumn{2}{|c|}{ Component---D--- }} & \multirow{3}{*}{$\begin{array}{c}\log \Omega_{0}(p) \\
(\mathrm{cm}-\mathrm{s}) \\
\underline{z}\end{array}$} & \multicolumn{3}{|c|}{$\underset{(\mathrm{cm}-\mathrm{s})}{\log \Omega_{0}(\underline{s})}$} & \multirow{3}{*}{$\begin{array}{c}\frac{\mathrm{f}}{(\mathrm{Hz})}(\mathrm{p}) \\
\underline{\mathrm{z}}\end{array}$} & \multicolumn{3}{|c|}{$\frac{f}{(H z)}$} & \multirow{3}{*}{$\begin{array}{c}\left(10^{\frac{\log }{21} \frac{M_{0}(p)}{\text { dyne-cm })}}\right. \\
\underline{z}\end{array}$} & \multirow{3}{*}{$\begin{array}{c}\left(10^{\log \frac{\mathrm{M}_{0}(\underline{s})}{\text { dyne-cm })}}\right. \\
\underline{\mathrm{H}}(\operatorname{avg})\end{array}$} & \multirow{3}{*}{$\begin{array}{l}\frac{r}{(k m)}(p) \\
\underline{z}\end{array}$} & \multirow{3}{*}{$\begin{array}{l}\underline{\underline{r}(\mathrm{~s})} \\
\underline{\mathrm{H}} \text { (avg) }\end{array}$} \\
\hline & & & \multirow{2}{*}{ H- 000} & \multirow{2}{*}{$\underline{\text { H090 }}$} & \multirow{2}{*}{$\underline{\mathrm{H}} \quad(\operatorname{avg})$} & & \multirow{2}{*}{ HO 00} & \multirow{2}{*}{$\underline{\mathrm{H}} 090$} & \multirow[t]{2}{*}{$\underline{H}(\mathrm{avg})$} & & & & \\
\hline Station & $\frac{R}{(k m)}$ & & & & & & & & & & & & \\
\hline $\mathrm{COE}$ & 10.3 & -4.00 & -2.092 & -2.174 & -2.133 & 15.1 & 3.5 & 3.3 & 3.4 & 20.770 & 21.903 & 0.14 & 0.42 \\
\hline DFL & 10.2 & -4.081 & -2.432 & -2.292 & -2.362 & 26.3 & 6.1 & 5.1 & 5.6 & 20.688 & 21.670 & .08 & 0.22 \\
\hline GRT & 13.3 & -3.208 & -2.027 & -2.229 & -2.128 & 7.9 & 4.2 & 5.9 & 5.0 & 21.673 & 22.019 & .27 & 0.24 \\
\hline PHR & 11.6 & -3.553 & -1.770 & -2.167 & -1.969 & 8.7 & 2.3 & 4.0 & 3.1 & 21.269 & 22.118 & .25 & 0.39 \\
\hline $\mathrm{RBH}$ & 11.8 & -3.523 & -1.824 & -1.886 & -1.855 & 12.0 & 2.4 & 3.1 & 2.7 & 21.306 & 22.240 & .18 & 0.45 \\
\hline RST & 11.4 & -3.377 & -2.125 & -2.277 & -2.201 & 14.6 & 8.7 & 9.5 & 9.1 & 21.437 & 21.879 & .15 & 0.13 \\
\hline SFR & 13.0 & -2.469 & -2.770 & -1.886 & -2.328 & 12.8 & 6.5 & 4.2 & 5.4 & 22.402 & 21.809 & .17 & 0.23 \\
\hline UTS & 12.6 & -2.921 & -1.569 & -2.292 & -1.931 & 11.3 & 3.7 & 4.4 & 4.0 & 21.937 & 22.192 & .19 & 0.31 \\
\hline AMS & 16.8 & -3.143 & -2.092 & -2.092 & -2.092 & 8.7 & 3.6 & 3.5 & 3.5 & 21.840 & 22.156 & .25 & 0.35 \\
\hline Average- & ------ & --n---n- & ------ & -------- & $\langle-2.111\rangle$ & ---- & $-\infty-\infty$ & $---n-\infty$ & $\langle 4.6\rangle$ & $\langle 21.480\rangle$ & $\langle 21.998\rangle$ & $\langle .19\rangle$ & $\langle .30\rangle$ \\
\hline Error-- & $-----\infty$ & - & $---\infty--$ & -------- & \pm .172 & ---- & ---- & $----\infty$ & \pm 2.0 & \pm .552 & \pm .194 & \pm .06 & \pm .11 \\
\hline
\end{tabular}

Table 4.4. Source parameters for event 1241307

\begin{tabular}{|c|c|c|c|c|c|c|c|c|c|c|c|c|c|}
\hline \multirow[b]{2}{*}{$\begin{array}{l}\text { Componen } \\
\text { Station }\end{array}$} & \multirow{2}{*}{$\frac{\mathrm{R}}{(\bar{k} \mathrm{~m})}$} & \multirow{2}{*}{$\begin{array}{c}\log \Omega_{0}(p) \\
(\mathrm{cm}-\mathrm{s}) \\
\underline{z}\end{array}$} & \multicolumn{3}{|c|}{$\underset{(\mathrm{cm}-\mathrm{s})}{\log \Omega_{0}(\underline{\mathrm{s}})}$} & \multirow{2}{*}{$\begin{array}{c}\frac{f}{f}(p) \\
(H z) \\
\underline{z}\end{array}$} & \multicolumn{3}{|c|}{$\frac{f}{(\mathrm{~Hz})}$} & \multirow{2}{*}{$\begin{array}{c}\left(10^{\frac{\log }{2} \frac{\mathrm{M}_{0}(p)}{\text { dyne-cm })}}\right. \\
\underline{\mathrm{z}}\end{array}$} & \multirow{2}{*}{$\begin{array}{c}\left(10^{\log } \frac{\mathrm{M}}{\mathrm{d}}{ }_{\mathrm{dy} e-\mathrm{sm})}^{\mathrm{s})}\right. \\
\underline{\mathbf{H}} \text { (avg) }\end{array}$} & \multirow{2}{*}{$\begin{array}{l}\frac{r}{(k m)}(p) \\
\underline{z}\end{array}$} & \multirow{2}{*}{$\begin{array}{l}\frac{r}{(\mathrm{~km})} \\
\underline{\text { 보 }} \text { (avg) }\end{array}$} \\
\hline & & & H000 & H090 & $\underline{\mathrm{H}}(\mathrm{avg})$ & & H 000 & $\underline{\text { H090 }}$ & $\underline{\mathrm{H}}$ (avg) & & & & \\
\hline $\mathrm{COE}$ & 10.1 & -3.553 & -1.201 & --- & -1.201 & 9.3 & 1.6 & --- & 1.6 & 21.208 & 22.826 & 0.23 & 0.76 \\
\hline DFL & 10.2 & -3.102 & -1.481 & 1.538 & -1.510 & 7.9 & 2.0 & 2.4 & 2.2 & 21.664 & 22.522 & .27 & .56 \\
\hline GRT & 14.0 & -2.444 & -1.167 & -1.444 & -1.306 & 5.0 & 3.3 & 3.4 & 3.3 & 22.459 & 22.717 & .43 & .37 \\
\hline $\mathrm{RBH}$ & 12.7 & -2.699 & -1.000 & -1.337 & -1.169 & 11.0 & 1.3 & 2.5 & 1.9 & 22.162 & 22.958 & .20 & .64 \\
\hline UTS & 14.3 & -2.000 & -.886 & -1.569 & -1.227 & 3.5 & 1.6 & 2.9 & 2.3 & 22.912 & 22.951 & .61 & .53 \\
\hline Average- & $-0-1$ & - & $-2-1-2$ & $-\cdots$ & $-1-1$ & $\ldots$ & $\cdots$ & 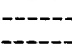 & 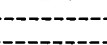 & $\langle 22.081\rangle$ & $\langle 22.795\rangle$ & $\langle .35\rangle$ & $\langle .57\rangle$ \\
\hline
\end{tabular}

Table 4.5. $\underline{P}-$ and $\underline{S}$-wave parameters for events 1181648 and $1 \overline{24} 1307$

\begin{tabular}{|c|c|c|c|c|c|c|}
\hline \multirow{2}{*}{ Event } & \multicolumn{2}{|c|}{$\begin{array}{l}\text { seismic moment } \\
\left(10^{21} \text { dyne-cm }\right)\end{array}$} & \multicolumn{2}{|c|}{$\begin{array}{l}\text { Source radius } \\
\text { (km) }\end{array}$} & \multicolumn{2}{|c|}{$\begin{array}{l}\text { Stress drop } \\
\text { (bars) }\end{array}$} \\
\hline & $\underline{P}$ wave & $\underline{s}$ wave & $\underline{P}$ wave & $\underline{S}$ wave & $\underline{P}$ wave & $\underline{\mathbf{s}}$ wave \\
\hline 1181648 & 3.0 & 9.9 & 0.19 & 0.30 & 191 & 161 \\
\hline 1241307 & 12 & 62 & .35 & .57 & 122 & 146 \\
\hline
\end{tabular}




\title{
Processing of Strong-Motion Recordings from the Main Shock
}

\author{
By A.G. Brady, R.L. Porcella, G.N. Bycroft, E.C. Etheredge, P.N. Mork, Barry \\ Silverstein, and A.F. Shakal'
}

\section{CONTENTS}

\author{
Abstract $\mathbf{5 3}$ \\ Strong-motion results $\mathbf{5 3}$ \\ Processing $\mathbf{5 3}$ \\ References cited $\mathbf{5 9}$
}

\begin{abstract}
The significant strong-motion records of the earthquake, from the permanent accelerograph networks of the U.S. Geological Survey (USGS) and the California Division of Mines and Geology, have been processed. This chapter describes the processing decisions and the resulting computer plots for the USGS records.
\end{abstract}

\section{STRONG-MOTION RESULTS}

The permanent accelerograph networks of both the U.S. Geological Survey (USGS) and the California Division of Mines and Geology (CDMG) have provided an important set of strong-motion records from the April 24 main shock. Altogether, about 75 stations were triggered among the combined networks, at epicentral distances ranging from about $4 \mathrm{~km}$ (Halls Valley, a CDMG-maintained station) to more than 100 $\mathrm{km}$.

The locations of the accelerograph stations in both networks at the time of the main shock are shown in figure 5.1, and the data for the USGS-maintuined stations are summurized in table 5.1. A comparuble list for the CDMG-maintained stations (Shakal and others, 1984) gives the maximum acceleration for each component scaled from the original records, together with the duration for which the accelerations reached amplitudes greater than $0.1 \mathrm{~g}$. Selected USGS and CDMG film records of the earthquake at various stations are shown in figure 5.2.

${ }^{1} \mathrm{Cal}$ if ornia Division of Mines and Geology, Sacramento, CA 95812 .
Information on both the $70-\mathrm{mm}$ film records and digitul records (Kinemetries DSA-1) is listed in table 5.1. For example, the entry "Hollister Dif ferential Array" refers to a film recorder included within the Hollister Digital Differential Array, which provided four digital records in addition to those from the listed film recorder. Also, a set of three digital records was obtained from various locations on a span of the San Jose Freeway Interchange. The details listed in table 5.1 for this station are from the film recorder, located within the bridge box girder but close to the abutment. The Palo Alto Veterans' Administration Hospital has two digital recorders located in separate buildings.

The film records have been digitized and processed for the following stations: Anderson Dum (crest and downstream), Hollister Differential Array, Hollister City Hall Annex, San Justo Damsite (right and left abutments), and San Jose Freeway Interchange.

Processing of corrected ground motions from the digital records at the Hollister Differential Digital Array (fig. 5.3) is included. The individual stations in the array are arranged along the two legs of a V: four stations along a $610-\mathrm{m}$ length, and two more along a $305-\mathrm{m}$ length at $33^{\circ}$ to the first. This urray is located at the Hollister Airport, $4 \mathrm{~km}$ north of the Hollister City Hall. At present, only the records from stations $1,3,4$, and 5 have been processed. Malfunctions in the other two recorders may limit the usefulness of their records.

\section{PROCESSING}

All the records (seven film, four digital) have been processed according to the descriptions in AGRAM (Converse, 1984). Chapter 19 presents 


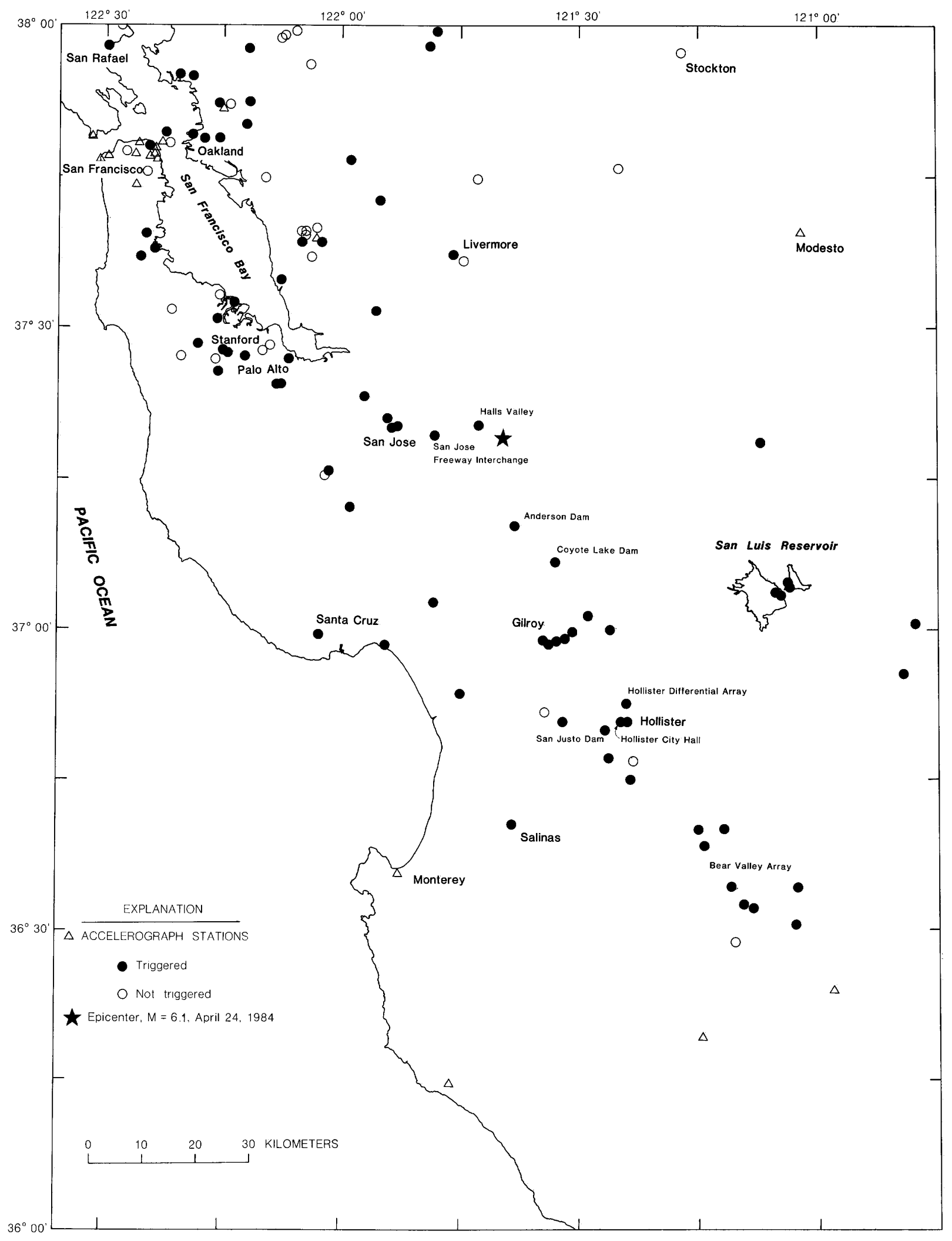

Figure 5.1. Locations of accelerograph stations in both U.S. Geological Survey and California Division of Mines and Geology permanent networks. Dots, triggered stations; circles, nontriggered stations. Named stations yielded significant records, shown in figure 5.2 . 
Table 5.1. USGS strong-motion data from the April 24 main shock

\begin{tabular}{|c|c|c|c|c|c|c|c|}
\hline \multicolumn{2}{|r|}{ Station } & \multirow{2}{*}{$\begin{array}{l}\text { Latitude } \\
(0 \mathrm{~N} .)\end{array}$} & \multirow{2}{*}{$\begin{array}{l}\text { Longitude } \\
\left(\circ \mathrm{W}^{-}\right)\end{array}$} & \multirow{2}{*}{$\begin{array}{l}\text { Epicentral } \\
\text { distance } \\
(\mathrm{km})\end{array}$} & \multirow{2}{*}{$\begin{array}{l}\text { Component } \\
\text { direction } \\
\left({ }^{\circ}\right)\end{array}$} & \multirow{2}{*}{$\begin{array}{l}\text { Maximum } \\
\text { acceleration } \\
(\mathrm{km})\end{array}$} & \multirow{2}{*}{$\begin{array}{c}\text { Strong }(>0.1 \mathrm{~g}) \\
\text { duration } \\
(\mathrm{s})\end{array}$} \\
\hline No. & Name & & & & & & \\
\hline 1652 & Anderson Dam, downstream--- & 37.165 & 121.631 & 16 & $\begin{array}{r}340 \\
\text { Up } \\
250\end{array}$ & $\begin{array}{r}0.301 \\
.201 \\
.409\end{array}$ & $\begin{array}{l}4.0 \\
5.2 \\
4.4\end{array}$ \\
\hline 1652 & Anderson Dam, crest--------- & 37.166 & 121.631 & 16 & $\begin{array}{r}340 \\
\text { Up } \\
250\end{array}$ & $\begin{array}{l}.386 \\
.202 \\
.634\end{array}$ & $\begin{array}{l}8.7 \\
3.3 \\
7.9\end{array}$ \\
\hline 1575 & $\begin{array}{l}\text { Hollister City Hall } \\
\text { Annex. }\end{array}$ & 36.85 & 121.40 & 55 & $\begin{array}{r}180 \\
\text { Up } \\
090\end{array}$ & $\begin{array}{l}.078 \\
.425 \\
.077\end{array}$ & $\begin{array}{l}--- \\
---\end{array}$ \\
\hline 1656 & $\begin{array}{l}\text { Hollister Differential } \\
\text { Array. }\end{array}$ & 36.888 & 121.413 & 51 & $\begin{array}{r}255 \\
\text { Up } \\
165\end{array}$ & $\begin{array}{l}.094 \\
.222 \\
.089\end{array}$ & $\begin{array}{l}--- \\
2.0 \\
---\end{array}$ \\
\hline 1655 & $\begin{array}{l}\text { San Justo Damsite, } \\
\text { right abutment } \\
\text { (dike). }\end{array}$ & 36.827 & 121.445 & 55 & $\begin{array}{r}360 \\
\text { Up } \\
270\end{array}$ & $\begin{array}{l}.059 \\
.060 \\
.076\end{array}$ & $\begin{array}{l}-- \\
---\end{array}$ \\
\hline 1655 & $\begin{array}{l}\text { San Justo Damsite, } \\
\text { left abutment. }\end{array}$ & 36.815 & 121.447 & 56 & $\begin{array}{r}360 \\
\text { Up } \\
270\end{array}$ & $\begin{array}{l}.074 \\
.034 \\
.038\end{array}$ & $\begin{array}{l}-- \\
-- \\
--\end{array}$ \\
\hline 1571 & $\begin{array}{l}\text { San Jose Freeway Inter- } \\
\text { change, U. } \mathrm{S.}-101 \\
\mathrm{I}-680, \mathrm{I}-280 .\end{array}$ & 37.340 & 121.851 & 12 & $\begin{array}{r}322 \\
\text { Up } \\
232\end{array}$ & $\begin{array}{l}.123 \\
.082 \\
.083\end{array}$ & 4 peaks \\
\hline 1227 & $\begin{array}{l}\text { Pa lo Al to veterans' } \\
\text { Administration } \\
\text { Hospital, basement. }\end{array}$ & 37.40 & 122.14 & 37 & $\begin{array}{r}302 \\
\text { Up } \\
212\end{array}$ & $\begin{array}{l}.022 \\
.018 \\
.022\end{array}$ & $\begin{array}{l}--- \\
---\end{array}$ \\
\hline 1277 & $\begin{array}{l}\text { Palo Alto Veterans' } \\
\text { Administration } \\
\text { Hospital, roof } \\
\text { 7th level). }\end{array}$ & 37.40 & 122.14 & 37 & $\begin{array}{r}302 \\
\text { Up } \\
212\end{array}$ & $\begin{array}{l}.084 \\
.034 \\
.089\end{array}$ & $\begin{array}{l}--- \\
---\end{array}$ \\
\hline 1226 & $\begin{array}{l}\text { Livermore veterans' } \\
\text { Administration } \\
\text { Hospital, basement. }\end{array}$ & 37.62 & 121.76 & 41 & $\begin{array}{r}128 \\
\text { Up } \\
038\end{array}$ & $\begin{array}{l}.022 \\
.011 \\
.016\end{array}$ & $\begin{array}{l}--- \\
---\end{array}$ \\
\hline & Roof (bldg. 62) & $-\ldots-$ & -------- & -...- & $\begin{array}{r}128 \\
\text { Up } \\
038\end{array}$ & $\begin{array}{l}.027 \\
.016 \\
.047\end{array}$ & $\begin{array}{c}-- \\
-- \\
--\end{array}$ \\
\hline 1610 & $\begin{array}{l}\text { Stanford University, } \\
\text { Quadrangle. }\end{array}$ & 37.429 & 122.169 & 41 & $\begin{array}{r}015 \\
\text { Up } \\
285\end{array}$ & $\begin{array}{l}.027 \\
.022 \\
.023\end{array}$ & $\begin{array}{l}-- \\
--- \\
--\end{array}$ \\
\hline 1602 & $\begin{array}{l}\text { Stanford University, } \\
\text { Stanford Li near } \\
\text { Accelerator Center, } \\
\text { Survey Hill. }\end{array}$ & 37.417 & 122.198 & 42 & $\begin{array}{r}360 \\
\text { Up } \\
270\end{array}$ & $\begin{array}{l}.027 \\
.020 \\
.016\end{array}$ & $\begin{array}{l}--- \\
--- \\
--\end{array}$ \\
\hline 1601 & $\begin{array}{l}\text { Stanford University, } \\
\text { Stanford Linear } \\
\text { Accelerator Center, } \\
\text { Test Laboratory. }\end{array}$ & 37.419 & 122.205 & 43 & $\begin{array}{r}360 \\
\text { Up } \\
270\end{array}$ & $\begin{array}{l}.031 \\
.022 \\
.032\end{array}$ & $\begin{array}{l}-- \\
-- \\
--\end{array}$ \\
\hline 1481 & $\begin{array}{l}\text { Bear valley sta. } 12, \\
\text { williams Ranch. }\end{array}$ & 36.658 & 121.249 & 82 & $\begin{array}{r}310 \\
\text { Up } \\
220\end{array}$ & $\begin{array}{l}.057 \\
.140 \\
.044\end{array}$ & $\begin{array}{c}--- \\
.6 \\
---\end{array}$ \\
\hline 1479 & $\begin{array}{l}\text { Bear valley sta. }{ }^{10,} \\
\text { Webb residence. }\end{array}$ & 36.532 & 121.143 & 99 & $\begin{array}{r}310 \\
\text { Up } \\
220\end{array}$ & $\begin{array}{l}.021 \\
.011 \\
.027\end{array}$ & $\begin{array}{l}--- \\
---\end{array}$ \\
\hline 1475 & $\begin{array}{l}\text { Bear Valley sta. } 6 \text {, } \\
\text { James Ranch. }\end{array}$ & 36.504 & 121.101 & 103 & $\begin{array}{r}310 \\
\text { Up } \\
220\end{array}$ & $\begin{array}{l}.024 \\
.005 \\
.016\end{array}$ & $\begin{array}{l}--- \\
---\end{array}$ \\
\hline
\end{tabular}


Table 5.1. USGS strong-motion data from the April 24 main shock-Continued

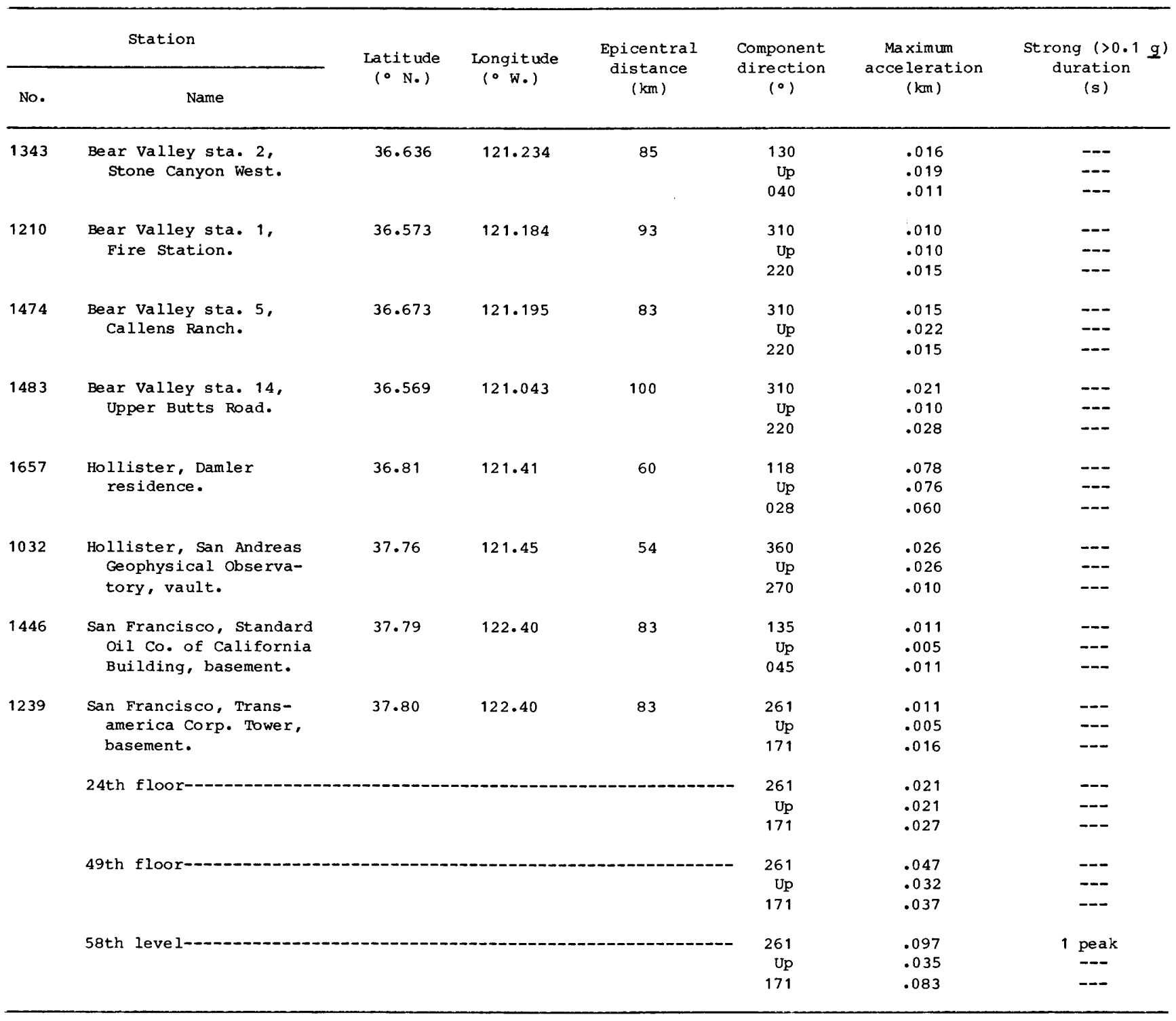

Figure 5.2. Film records of the main shock. A, Reproductions of original USGS film records from Anderson Dam (downstream and crest), Hollister (Differential Array and City Hall Annex), San Jose Freeway Interchange (I-680/280 overcrossing U.S.-101), and San Justo Damsite (right and left abutments). B, Reproductions of original CDMG film records from Halls Valley and Coyote Lake Dam (south abutment). C, Photographic enlargement of high-amplitude section of Coyote Lake Dain record shown in figure $5.2 \overrightarrow{\mathrm{B}}$. Peak value of $285^{\circ}$ component scales at $1.29 \mathrm{~g}$. 


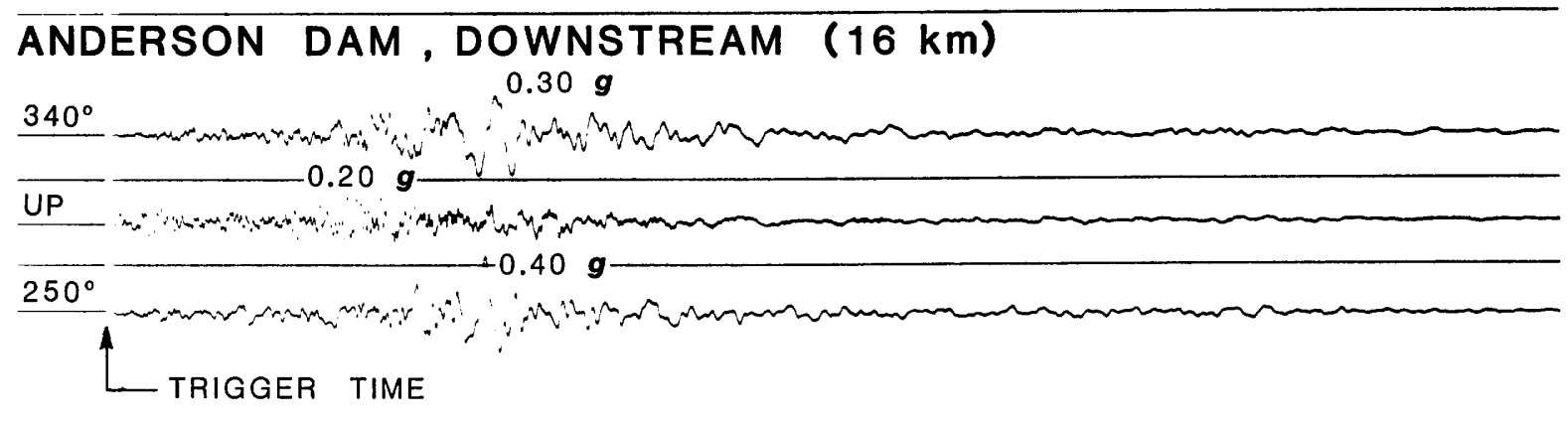

$\overline{A N D E} \bar{R} \overline{S O N} \overline{D_{A M}}-\overline{C R E S T}-\overline{(16} \overline{\mathrm{km}} \overline{-}--\ldots$ $\frac{250^{\circ}}{240^{\circ}}$ HOLLISTER DIFFERENTIAL $\overline{\text { ARRAY }} \overline{(51 \mathrm{~km})}-------$ UP

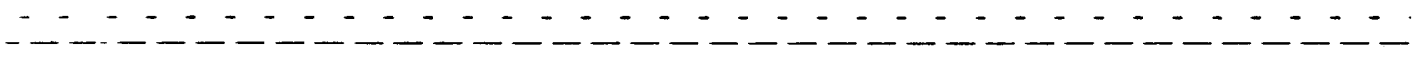

\section{HOLLISTER CITY HALL $(55 \mathrm{~km})$}
$360^{\circ}$
$0.08 \mathrm{~g}$

$270^{\circ}$

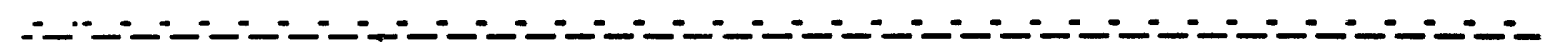

Figure 5.2A. 
FREEWAY $101 / 680 / 280$ INTERCHANGE (12 km) $322^{\circ}$

\section{Mnmm}

UP

$0.08 \mathrm{~g}$ $232^{\circ} 0.08 \mathrm{~g}$

(1)

LTRIGGER TIME

(1)

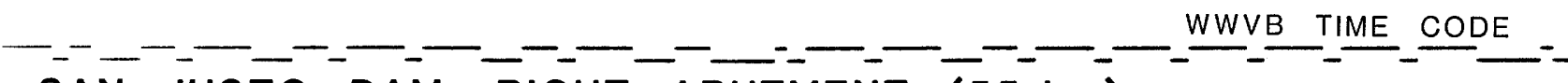

SAN JUSTO DAM, RIGHT ABUTMENT (55 km)

$360^{\circ}$

UP -0.06 (1) UP $-0.06 \mathrm{~g}$

$270^{\circ} \longrightarrow 0.08 \mathrm{~g}$

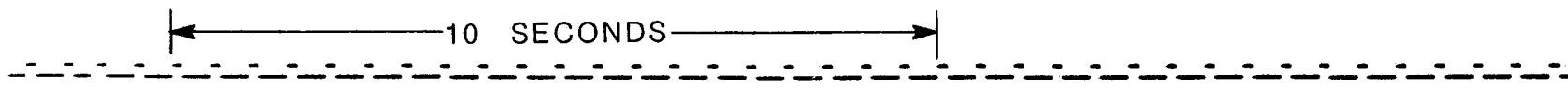

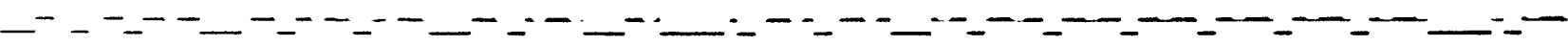

SAN JUSTO DAM, LEFT ABUTMENT (56 km)

$360^{\circ} \quad 0.07 \mathrm{~g}$

$\mathrm{UP} 0.03 \mathrm{~g}$

$270^{\circ}$

-

Figure 5.2A. Continued 


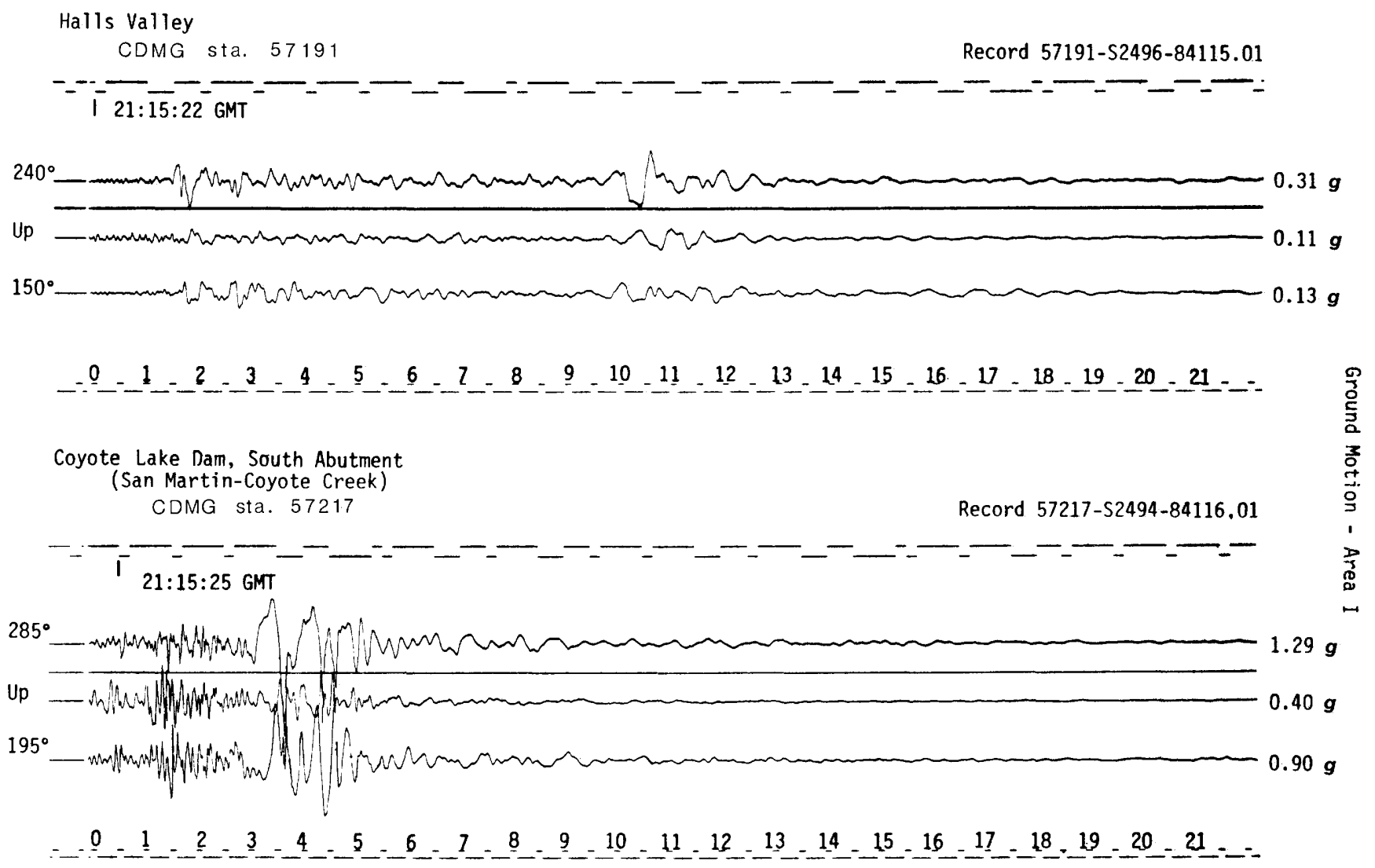

Figure 5.2B.

computer plots of these records. Briefly, the steps are as follows:

1. Digitization of the film records by a commercial digitizing firm (IOM-Towill of Santa Clara, Calif.) on a trace-following, computer-controlled laser scanner, using unequal time spacing at an average of 600 sumples per second.

2. Reassembly of the separately digitized 10-s frames, using specially inserted vertical lines, each digitized twice, once in each adjacent frame.

3. Preparation of uncorrected accelerograms by subtracting out the reference traces, using the time marks for the $\mathrm{x}$-coordinates, and subtracting the average value. Chapter 19 includes plots of the uncorrected duta.

4. Passing of the data from both film and digital recordings through a correction algorithm that applies a high-frequency $(50 \mathrm{~Hz})$, filter instrument corrections, and decimation to 200 samples per second. A low-frequency high-pass Butterworth filter $(0.25 \mathrm{~Hz}$, order 8) removes all periods longer than $4 \mathrm{~s}$ from the data. These parameters were chosen after consideration of: (i) the strongmotion duration of the records, (ii) any distortion during preevent memory on the digitals, (iii) displacements calculated at the Anderson Dam, and (iv) displacements of adjacent film and digital recordings on the Hollister Differential Array. Chapter 19 includes plots of corrected acceleration, velocity, and displacements for the three components of each recording.

5. Calculation of response speetra for oscillation periods as long as $4 \mathrm{~s}$. Chapter 19 includes linear plots of the relative-velocity-response spectrum and $\log -\log$ tripurtite plots of pseudovelocityresponse spectra.

6. Calculation of Foupier amplitude spectra by fastFourier-transform methods. Chapter 19 includes both linear and log-log plots of these spectra.

\section{REFERENCES CITED}

Converse, A.M., 1984, AGRAM: A series of computer programs for processing digitized strong-motion accelerograms. Version 2.0: U.S. Geological Survey Open-File Report 84-525, 98 p.

Shakal, A.F., Sherburne, R.W., and Parke, D.L., 1984, CDMG Strong-motion records from the Morgan Hill, California, earthquake of 24 April, 1984: California Division of Mines and Geology, Office of Strong Motion Studies Report OSMS 84-7, 101 p. 


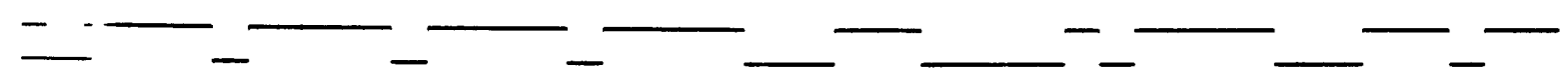

$285^{\circ}$
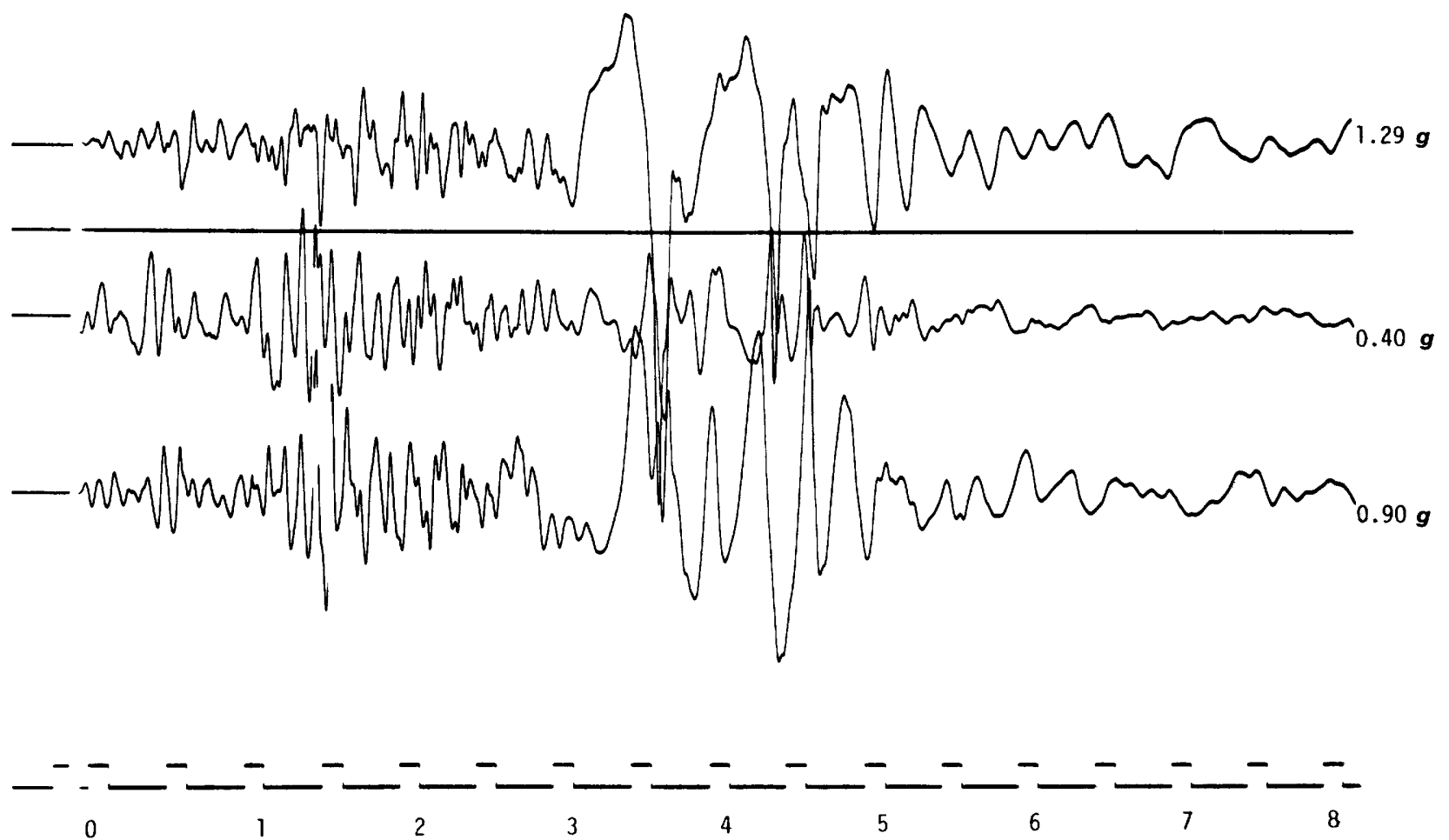

Figure 5.2C.

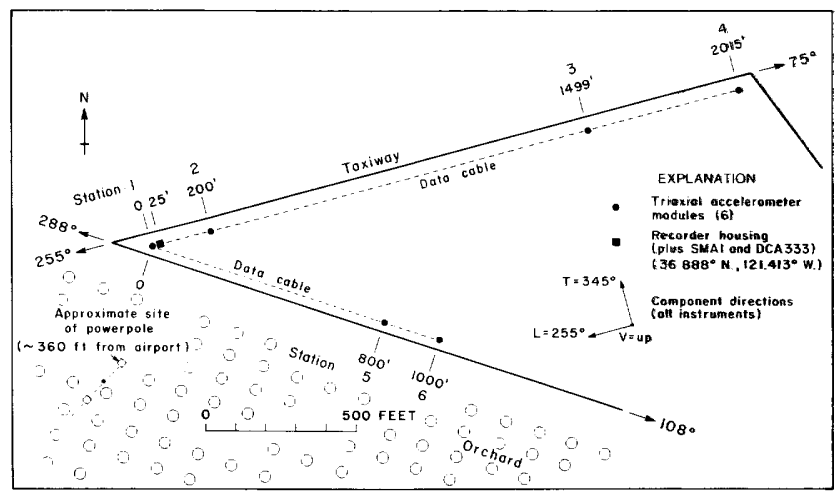

Figure 5.3. Locations of accelerograph stations in the Hollister Differential Digital Array. 


\title{
The Search for Surface Faulting
}

\author{
By Katherine K. Harms, Malcolm M. Clark, Michael J. Rymer, Manuel G. Bonilla, \\ Edwin L. Harp, Darrell G. Herd, Kenneth R. Lajoie, James J. Lienkaemper, Scott A. \\ Mathieson, James A. Perkins, Robert E. Wallace, and Joseph I. Ziony
}

\section{CONTENTS}

Abstract $\quad 61$ Introduction $\mathbf{6 1}$

Observations $\mathbf{6 1}$

Conclusions $\quad 67$

References cited

\section{Abstract}

Postearthquake investigation of abundant ground cracks associated with the Morgan Hill earthquake revealed no unequivocal evidence of surface faulting. Cracks in two places in the San Felipe Valley were aligned with late Quaternary fault traces but showed no tectonic displacement. Cracks near the southeast end of the Anderson Reservoir showed right slip of more than $0.1 \mathrm{~m}$ but were either in or near active landslides or in short zones that had no continuity of displacement or trend along strike in the fault zone. Although we conclude that the evidence does not demonstrate surface faulting, we cannot deny that some of the cracks may have been tectonic.

\section{INTRODUCTION}

This report summarizes our initial investigations to determine whether surface faulting accompanied the Morgan Hill earthquake. Our investigations started the day of the earthquake and continued daily through April 27 as we inspected traces of the Calaverus fault mapped by Dibblee (1972, 1973), and Radbruch-Hall (1974), and nearby traces of the Hayward fault (fig. 6.1). On May 2-4, we checked additionul recent truces mapped by D.G. Herd (unpub. data, 1982) in the epicentrul and aftershock zones. We reinvestigated in detail the area at the southeast end of the Anderson Reservoir on May 11 and 16. On April 10,1985 , we checked the easternmost fault mapped by Dibblee $(1972,1973)$ and the Madrone Springs fault, in response to concentrations of aftershocks located east of the most recently active traces of the Calaveras fault. Although we found no unequivocal evidence for surface faulting associated with the earthquake, we cannot eliminate faulting as the origin for some of the many cracks that we found.

To distinguish tectonic cracks from those formed by other processes, such as downslope movement, lateral spreading, or differential settling, we used two main guidelines: (1) displacement commonly lies in the plane of tectonic cracks, and (2) slip and trend show broad consistency or continuity along strike for tectonic cracks or zones of tectonic cracks. In addition, cracks that had a northwest-southeast orientation, or that were located along mapped or suspected late Quaternary traces, suggested a tectonic origin. Some cracks clearly displayed evidence for all these tectonic factors and also displayed characteristics of nontectonic processes; thus, their origin is uncertain. Afterslip in the plane of any of these cracks would have been strong evidence for tectonic origin, but absence of afterslip does not allow us to rule out such an origin.

\section{OBSERVATIONS}

Plate 1 shows our routes, sites of primary interest, and the fault-trace interpretations of Dibblee (1972, 1973), Radbruch-Hall (1974), and D.G. Herd (unpub. data, 1982). The faults mapped by Herd and Radbruch-Hall were primarily located from geomorphic evidence of recent displacement, whereas those mapped by Dibblee were also located from lithologic, stratigraphic, and structural evidence; thus, some of Dibblee's mapped faults show little evidence of recent slip. Our field observations are summarized in table 6.1, and the locations of the sites investigated outside of the area of plate 1 are shown in figure 6.1.

We interpreted most of the abundant cracks in the epicentral and aftershock zones to be caused by 


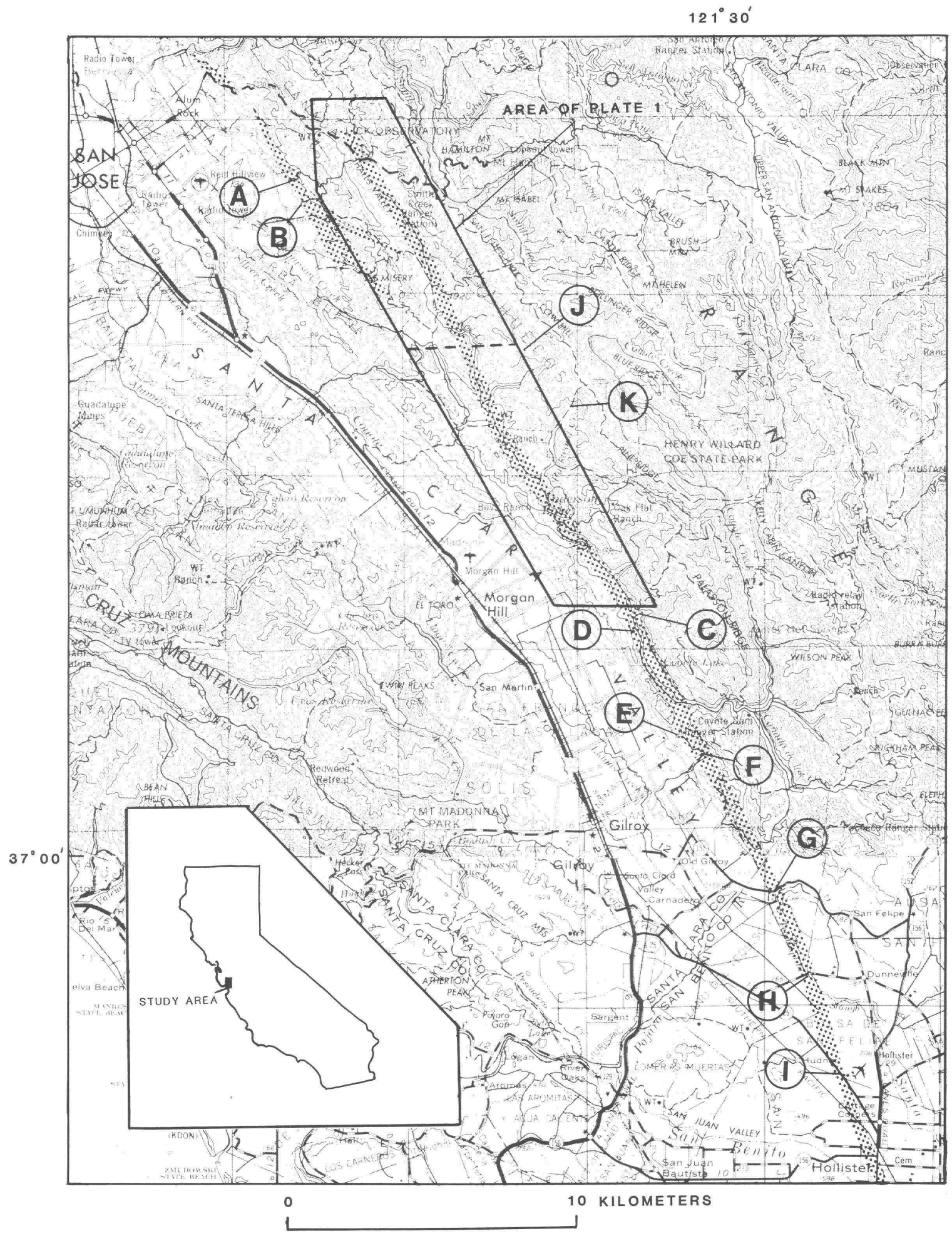

Figure 6.1. Santa Clara Valley, Calif., showing areas of the two maps on plate 1 and locations of sites (locs. A-K, table 6.1) that lie outside area of plate 1. Stippled areas, fault zones. Base from U.S. Geological Survey, 1:250,000 scale, San Jose, 1969, and Monterey, 1974. 
Table 6.1. Field observations after the Morgan Hill earthquake of April 24, 1984

[Data from Harms and others (1984); see plate 1 for localities 1 through 78, and figure 6.1 for localities A through K. Detection limit is minimum visible offset or opening of a crack. Investigators: MB, Manual Bonilla; MC, Malcolm Clark; KH, Katherine Harms; EH, Edwin Harp; DH, Darrell Herd; KL, Kenneth Lajoie; JL, James Lienkaemper; SM, Scott Mathieson; JP, James Perkins; MR, Michael Rymer; RW, Robert Wallace; and JZ, Joseph ziony. do., dittol

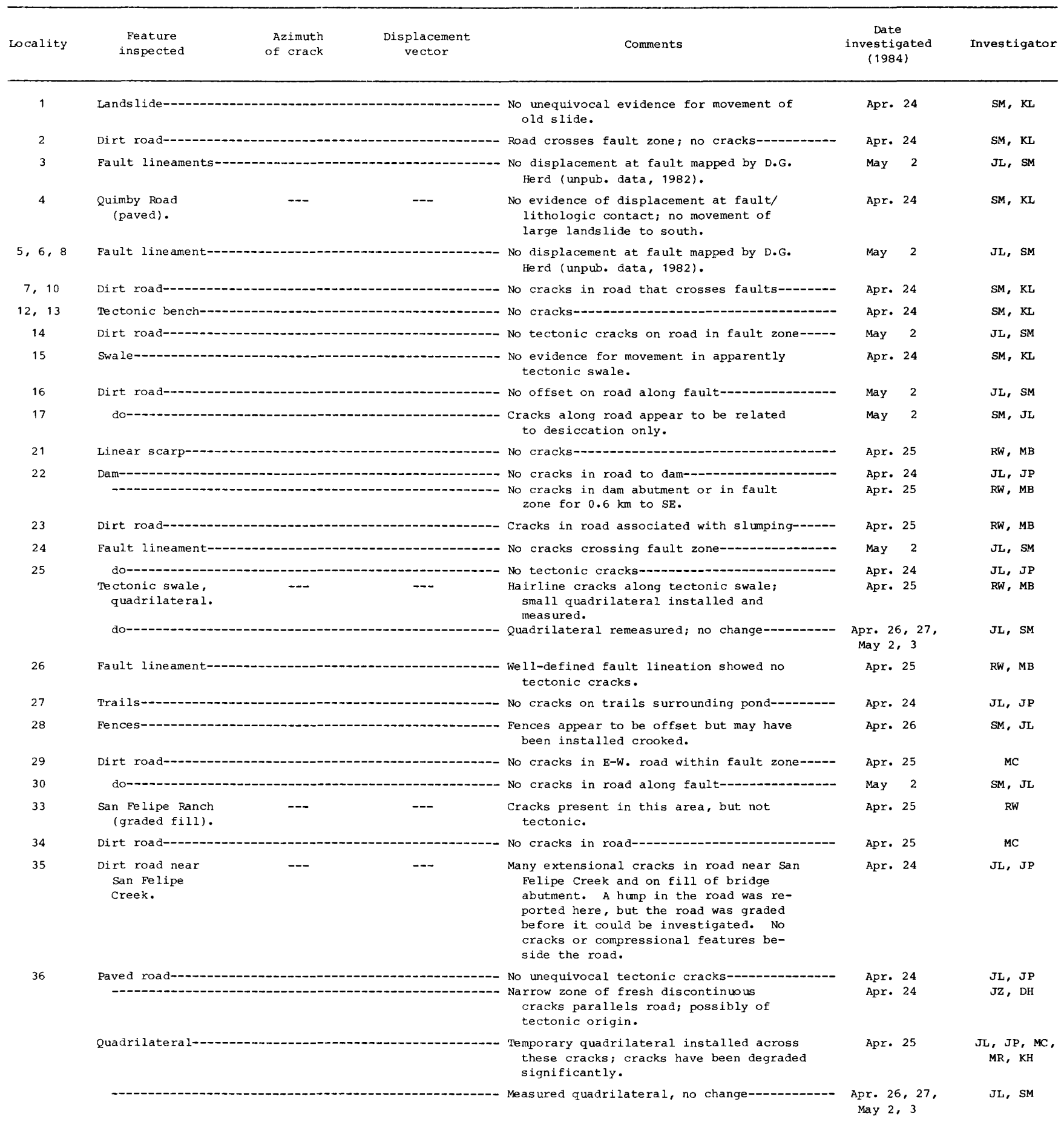


Table 6.1. Field observations after the Morgan Hill earthquake of April 24, 1984--Continued

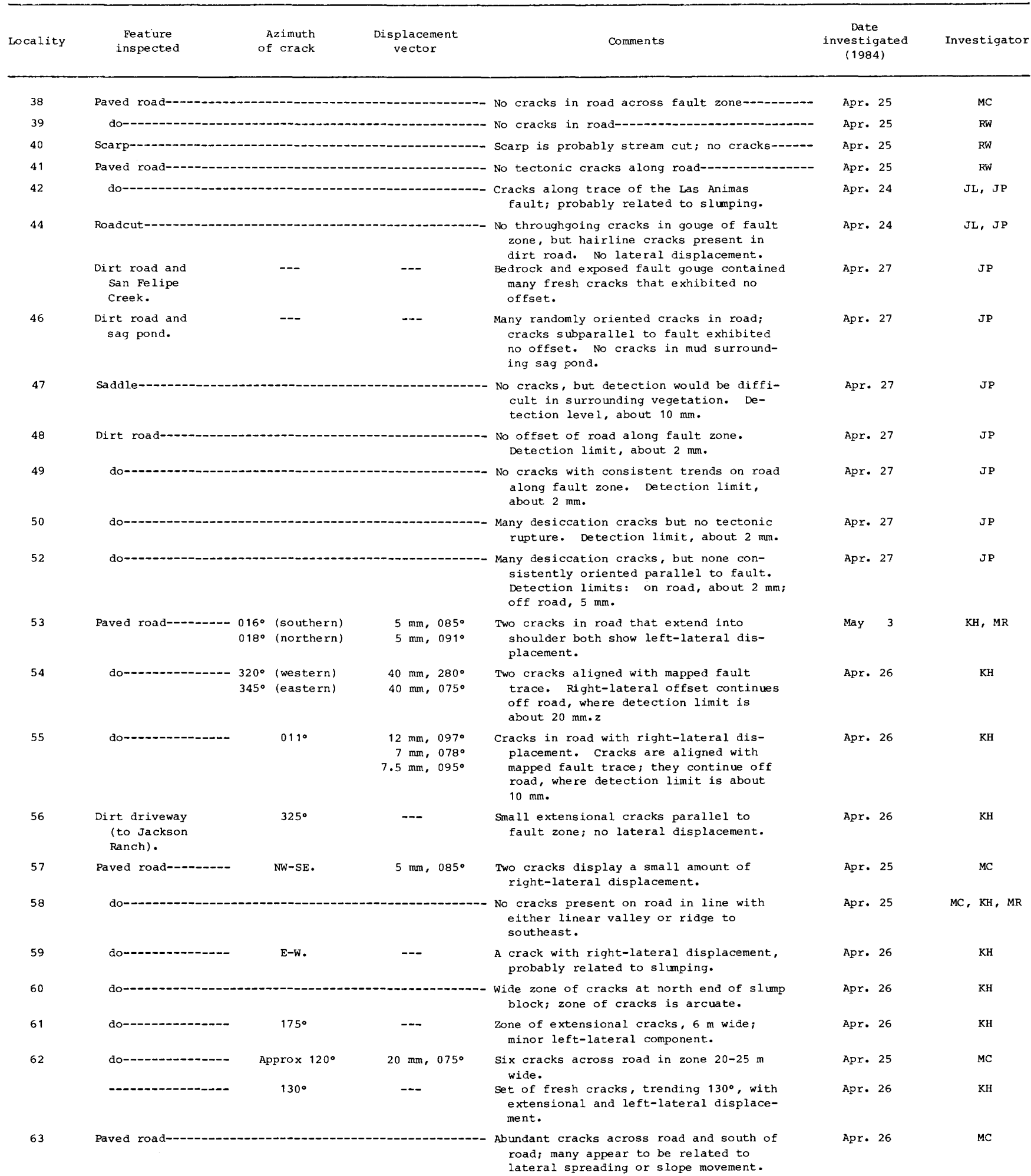


Table 6.1. Field observations after the Morgan Hill earthquake of April 24, 1984--Continued

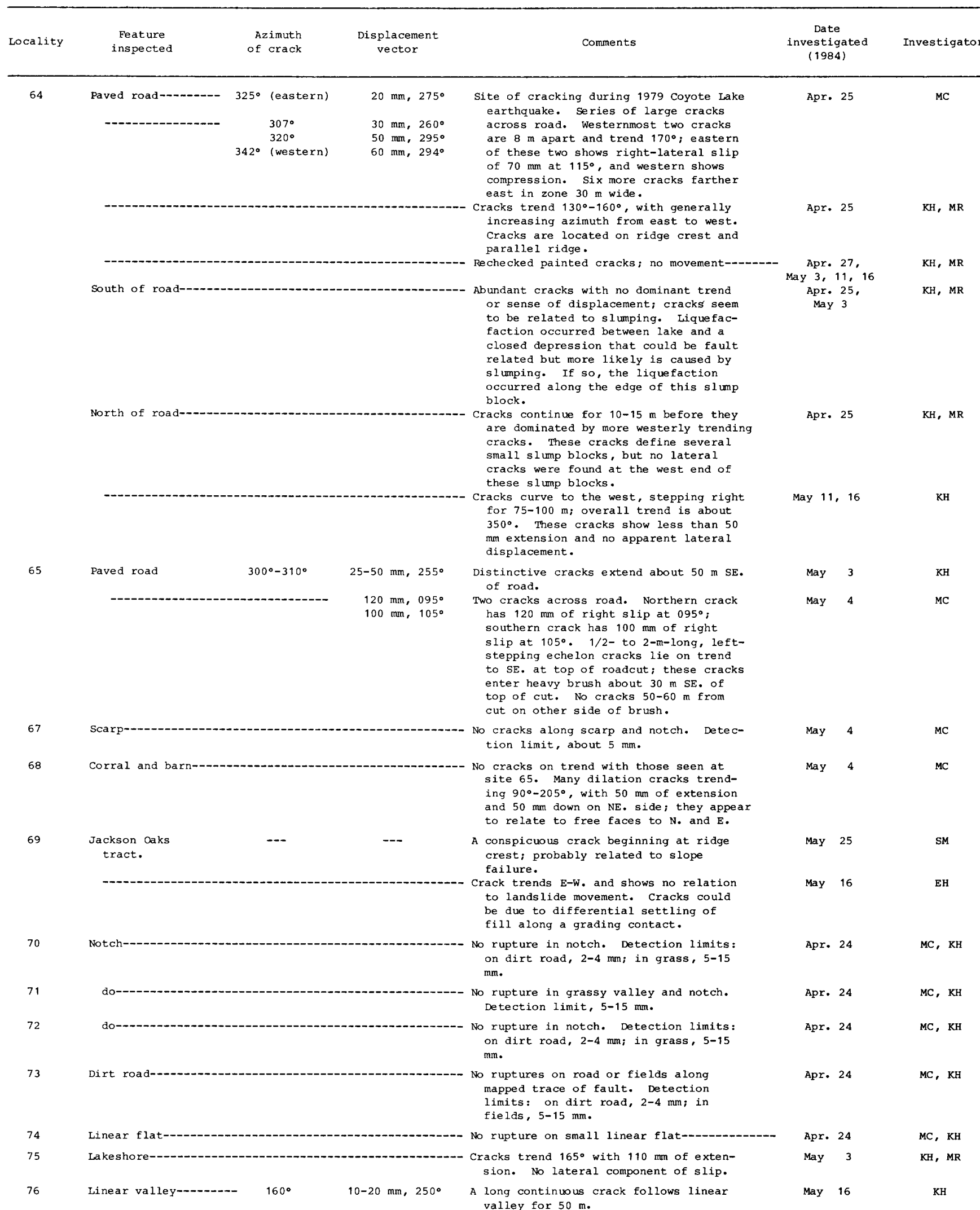


Table 6.1. Field observations after the Morgan Hill earthquake of April 24, 1984--Continued

\begin{tabular}{|c|c|c|c|c|c|c|c|}
\hline \multirow{2}{*}{ Locality } & \multirow{2}{*}{$\begin{array}{c}\begin{array}{c}\text { Feature } \\
\text { inspected }\end{array} \\
\text { inear valley--------- }\end{array}$} & \multirow{2}{*}{$\begin{array}{r}\text { Azimuth } \\
\text { of crack }\end{array}$} & \multirow{2}{*}{$\begin{array}{c}\begin{array}{c}\text { Displacement } \\
\text { vector }\end{array} \\
10 \mathrm{~mm}, 235^{\circ}\end{array}$} & \multirow{2}{*}{ Comments } & \multicolumn{2}{|c|}{$\begin{array}{l}\text { Date } \\
\text { investigated } \\
(1984)\end{array}$} & \multirow{2}{*}{ Investigator } \\
\hline & & & & & May & 16 & \\
\hline 78 & Lakeshore------------ & ------- & 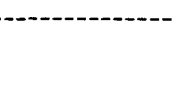 & $\begin{array}{l}\text { Cracks show } 35 \mathrm{~mm} \text { of left-lateral offset } \\
\text { and } 30 \mathrm{~mm} \text { of extension. This site is } \\
\text { part of a slump toward lake, on Nw. } \\
\text { side of a young fan deposit. }\end{array}$ & May & & $\mathrm{KH}, \mathrm{MR}$ \\
\hline 79 & Fault lineation------ & $---n--$ & $----n---1$ & $\begin{array}{l}\text { No evidence for recent ground rupture } \\
\text { along Iineation. }\end{array}$ & Apr. 10 & , 1985 & $\mathrm{MC}, \mathrm{KH}$ \\
\hline 80 & $\begin{array}{l}\text { Vegetation } \\
\text { lineation. }\end{array}$ & --- & --- & $\begin{array}{l}\text { No cracks observed at linear edge of } \\
\text { small hill. }\end{array}$ & Apr. 10 & , 1985 & $\mathrm{MC}, \mathrm{KH}$ \\
\hline 81 & Fault lineation & -+------ & $---n--n--1$ & No cracks along break in slope-1- & Apr. 10 & 1985 & $\mathrm{MC}, \mathrm{KH}$ \\
\hline 82 & 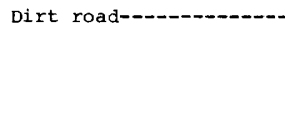 & ------- & 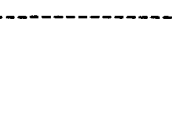 & $\begin{array}{l}\text { No evidence for recent movement on road } \\
\text { at Dibblee's (1972, 1973) eastern } \\
\text { mapped fault trace. No rupture in } \\
\text { notch to } \mathrm{SE} \text {. , where detection limit } \\
\text { is } 10 \mathrm{~mm} \text {. }\end{array}$ & Apr. 10 & , 1985 & $\mathrm{MC}, \mathrm{KH}$ \\
\hline 83 & $\begin{array}{l}\text { Dirt road and } \\
\text { creek. }\end{array}$ & --- & -- & $\begin{array}{l}\text { No evidence for recent movement on mapped } \\
\text { fault lineament. }\end{array}$ & Apr. 10 & , 1985 & $\mathrm{MC}, \mathrm{KH}$ \\
\hline 86 & Dirt road------ & --------- & 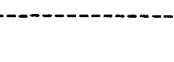 & $\begin{array}{l}\text { No evidence of recent ground rupture } \\
\text { along road. }\end{array}$ & Apr. 10 & , 1985 & $\mathrm{MC}, \mathrm{KH}$ \\
\hline 87 & Fault lineation--...- & $-\infty+\cdots---1$ & 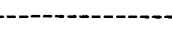 & 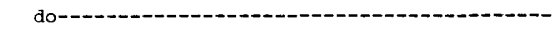 & Apr. 10 & , 1985 & $\mathrm{MC}, \mathrm{KH}$ \\
\hline 88 & 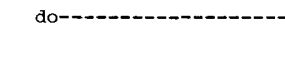 & $---n-\infty$ & 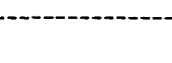 & $\begin{array}{l}\text { No evidence of movement on this possible } \\
\text { fault strand. }\end{array}$ & Apr. 10 & , 1985 & $\mathrm{MC}, \mathrm{KH}$ \\
\hline A & Paved road---------- & --------- & 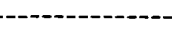 & No cracks on trace of Hayward fault--_- & Apr. & 25 & $\mathrm{KH}, \mathrm{MJ}$ \\
\hline B & do---n--------- & - & --- & 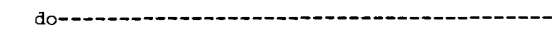 & Apr. & 26 & JL, SM \\
\hline $\mathrm{C}$ & 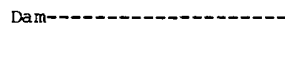 & --- & -n-m-n- & $\begin{array}{l}\text { Cracks due to slumping, but no tectonic } \\
\text { offsets. }\end{array}$ & May & & $J L, S M$ \\
\hline $\mathrm{D}$ & Fault lineation--.--- & --n--- & 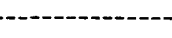 & No cracks. Detection limit, about $3 \mathrm{~mm}$ & May & 2 & $J L, S M$ \\
\hline $\mathrm{E}$ & Paved road----------- & ----- & ---------1 & $\begin{array}{l}\text { No fresh cracks on left-stepping echelon } \\
\text { cracks in road. }\end{array}$ & May & & JL, SM \\
\hline G & do--n-me-n--- & $146^{\circ}$ & $1 \mathrm{~mm}, 128^{\circ}$ & $\begin{array}{l}\text { Some fresh cracks at north side of road, } \\
\text { extending from older cracks. }\end{array}$ & Apr. & 27 & MR \\
\hline $\mathrm{H}$ & 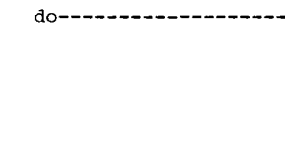 & ---- & ------ & $\begin{array}{l}\text { Fresh cracks on SE side of road with a } \\
\text { net right-lateral offset of } 3.5 \mathrm{~mm} \text {. } \\
\text { on } \mathrm{NW} \text {. side of road, fresh cracks show } \\
2 \mathrm{~mm} \text { of right-lateral displacement. } \\
\text { Creepmeter at this site showed } 13 \mathrm{~mm} \\
\text { of coseismic slip. }\end{array}$ & Apr. & 27 & MR \\
\hline I & 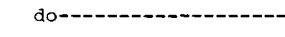 & - & $---1-\infty-1$ & No fresh tectonic cracks- & Apr. & 27 & MR \\
\hline $\mathrm{J}$ & 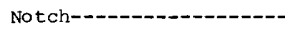 & ------ & ------- & No evidence of recent faulting-- & Apr. 10 & , 1985 & $\mathrm{KH}, \mathrm{MC}$ \\
\hline $\mathrm{K}$ & Fault lineation------- & 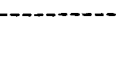 & 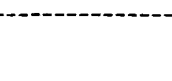 & $\begin{array}{l}\text { No evidence of recent faulting along the } \\
\text { Madrone Springs fault at road or in } \\
\text { Packwood valley. }\end{array}$ & Apr. 10 & , 1985 & $\mathrm{KH}, \mathrm{MC}$ \\
\hline
\end{tabular}

nontectonic, near-surface movement in young deposits or artificial fill. However, the origin of the cracks in two areas in the San Felipe Valley (sites 25, 36, pl. 1) and near the southeast end of the Anderson Reservoir (sites 64, 65, pl. 1) is equivocal.

The northern of the two sites in the San Felipe Valley (site 25) included very small extensional cracks that were aligned with clearly defined fault scarps to the southeast and northwest but displayed no recognizable tectonic displacement. We installed a temporary 5-m quadrilateral of spikes across the cracks on April 25 to help determine if they were of tectonic origin. Four unchunged remeasurements through May 3 across this quadrilateral suggested that the cracks were nontectonic.

North-northwest-trending cracks extended for approximately $10 \mathrm{~m}$ along the east shoulder of the paved section of San Felipe Road and for about $40 \mathrm{~m}$ along the unpaved section of the road about $1-1 / 2 \mathrm{~km}$ farther south in the San Felipe Vulley (site 36). The unpaved section of the road was cut in alluvium, with no fill added. At the north end of this unpaved section, the cracks were most abundant in the coarse alluvium (granule to pebble gravel) and ended at the north contact of this gravel with a finer deposit. We installed a $2-m$ quadrilateral of nails and stakes at this site on April 25, but it showed no movement through May 3. The absence of afterslip suggests that the cracks were nontectonic in origin.

Cracks of equivocally tectonic origin were also observed at site 64 , about $1 / 2 \mathrm{~km}$ northwest of the Cochrane Bridge near the southeast end of Anderson Lake. Cumulative right-lateral displacement was about $15 \mathrm{~cm}$ across five of these cracks in a zone 
about $30 \mathrm{~m}$ wide by only $5 \mathrm{~m}$ long. These breaks crossed Dunne Road at the crest of a ridge and showed generally increasing azimuth from east to west. South of the road near the lakeshore, the fractures were not continuous but merged with other randomly oriented cracks. These shore-zone cracks were dominantly extensional, with both minor left-lateral and rightlaterul components of slip, suggesting slumping or lateral spreading. North of the road, the crucks were extensional without clear evidence of right-lateral slip, and they merged with east-west-trending cracks related to slumping. Although locally or individually these breaks suggested a tectonic origin, they occurred within a broad zone of active landslides and slumps and showed little continuity of trend or displacement within, and none beyond, the landslide-slump area. This absence of continuity suggests a nontectonic origin for these cracks.

West of the Cochrane Bridge, on the south side of the Anderson Reservoir and on trend with the cracks at site 64, fractures extended about $50 \mathrm{~m}$ southeastward from Dunne Road (site 65) from about $20 \mathrm{~m}$ west of the side road up and beyond a steep embankment. These fractures exhibited dominantly right-lateral displacement with minor extension. Although the cracks were not clearly related to landslides, they were associated with steep topography. The southeast end of these cracks was hidden by a dense patch of poison oak, 20 to $30 \mathrm{~m}$ long. The cracks were not on the other side of the patch, nor on the benches and slopes farther to the southeast. Two fractures, each with more than $0.1 \mathrm{~m}$ of right-lateral displacement, that crossed Dunne Road on trend with these cracks may be related to them; however, these two fractures may also be related to local failure of the road fill. No cracks displaying lateral displacement crossed the unvegetated lakeshore on this trend northwest of the road, where they would have been easy to detect. This set of cracks showed the strongest evidence for a tectonic origin. Their trend and displacement were consistent along the length of the zone of crucks; however, the zone of crucks was short, with clearly unfaulted segments at each end. We believe that the absence of continuity implies a nontectonic origin.

\section{CONCLUSIONS}

From our evidence, the question whether surface faulting accompanied the April 24 earthquake is still unanswered. If present at all, tectonic ruptures were short and scattered, and showed only small of fset. Evidence favoring a tectonic origin for the surface breaks in the San Felipe Valley and near the southeast end of the Anderson Reservoir includes their northwest-southeast orientation, their position along mapped or suspected late Quaternary traces in the fault zone, and their definite or possible component of right slip. Evidence for a nontectonic origin, however, is that: (1) the cracks near or along fault trends in the San Felipe Valley displayed no lateral displacement and no af terslip, and those at the Anderson Reservoir lay in or near zones of active landslides or slope failure; (2) all four zones (sites 25, 36, 64, 65) were short, and both were internally discontinuous and had clear boundaries on strike, beyond which there was definitely no faulting; and (3) individual cracks lacked the continuity of displacement or trend found elsewhere for tectonic ruptures of small displacement (for example, Brown and Vedder, 1967, Allen and others, 1972; Clark and others, 1976; Fuis, 1982; Sieh, 1982). The balance of evidence convinced Hart (1984a, b) that the ruptures near the southeast end of the Anderson Reservoir were tectonic. Although we conclude that the evidence does not demonstrate surface faulting associated with the Morgan Hill earthquake, we cannot deny that some of the cracks may have been tectonic.

\section{REFERENCES CITED}

Allen, C.R., Wyss, Max, Brune, J.N., Grantz, Arthur, and Wallace, R.E., 1972, Displacements on the Imperial, Superstition Hills, and San Andreas faults triggered by the Borrego Mountain earthquake, in The Borrego Mountain earthquake of April 9, 1968: U.S. Geological Survey Professional Paper 787, p. 87-104.

Brown, R.D., Jr., and Vedder, J.G., 1967, Surface tectonic fractures along the San Andreas fault, in Brown, R.D., Jr., Vedder, J.G., Wallace, R.E., Roth, E.F., Yerkes, R.F., Castle, R.O., Waananen, A.O., Page, R.W., and Eaton, J.P., The Parkfield-Cholame, California, earthquake of June-August 1966--surface geologic effects, water-resources aspects, and preliminary seismic date: U.S. Geological Survey Professional Paper 579, p. 2-23.

Clark, M.M., Sharp, R.N., Castle, R.O., and Harsh, P.W., 1976, Surface faulting near Lake Oroville, California, in August 1975: Seismological Society of America Bulletin, v. 66, no. 4, p. 1101-1110.

Dibblee, T.W., 1972, Preliminary geologic maps of three quadrangles, Santa Clara County, California: U.S. Geological Survey open-file report, scale $1: 24,000$.

- 1973, Preliminary geologic maps of the Gilroy Hot Springs, Gilroy, Mt. Sizer, Mt. Madonna, and Morgan Hill quadrangles, Santa Clara and Santa Cruz Counties, California: U.S. Geological Survey open-file report, scale 1:24,000.

Fuis, G.S., 1982, Displacement on the Superstition Hills fault triggered by the earthquake, in The Imperial Valley, California, earthquake of October 15, 1979: U.S. Geological Survey Professional Paper 1254, p. 145-154.

Harms, K.K., Clark, M.M., Rymer, M.J., Bonilla, M.G., Harp, E.L., Herd, D.G., Lajoie, K.R., Lienkaemper, J.J., Mathieson, S.A., Perkins, J.A., Wallace, R.E., and Ziony, J.F., 1984, The April 24, 1984 Morgan Hill, California earthquake: The search for surface faulting, in Hoose, S.N., compiler, The Morgan Hill, California, earthquake of April 24, 1984 (a preliminary report), volume I: U.S. Geological Survey Open-File Report 84-498-A, p. 92-108. 
Hart, E.W., 1984a, Evidence of surface faulting associated with the Morgan Hill earthquake of April 24, 1984 in Bennett, J.H., and Sherburne, R.W., eds., The 1984 Morgan Hill, California earthquake: California Division of Mines and Geology Special Publication 68, p. 161-173.

$1984 \mathrm{~b}$, Surface faulting associated with the Morgan Hill earthquake of April 24, 1984: California Geology, v. 37, no. 8, 168-170.

Radbruch-Hall, D.H., 1974, Map showing recently active breaks along the Hayward fault zone and the southern part of the Calaveras fault zone, California: U.S. Geological Survey Miscellaneous Investigations Series Map I-813, scale 1:24,000, 2 sheets.

Sieh, K.E., 1982, Slip along the San Andreas fault associated with the earthquake, in The Imperial Valley, California, earthquake of October 15, 1979: U.S. Geological Survey Professional Paper 1254 , p. $155-160$. 


\title{
Surface Displacement near Hollister, California
}

\author{
By Jon S. Galehouse ${ }^{1}$ and Beth D. Brown
}

CONTENTS

Abstract $\quad \mathbf{6 9}$

Field observutions $\quad \mathbf{6 9}$

Wright Roud $\mathbf{6 9}$

McConnell Road $\quad 69$

California Highway $25 \quad \mathbf{6 9}$

Shore Roud $\mathbf{7 0}$

California Highway 152 (Pacheco Pass Road) 70

Summary $\mathbf{7 1}$

References cited $\mathbf{7 2}$

Abstruct

On April 25, 1984, just 1 day after the earthquake, the southeast limit of surface displacement along the Calaveras fault was within a 5.8-km-long segment of the fault, about 48 to $54 \mathrm{~km}$ southeast of the epicenter. About 3.5 months after the earthquake, however, a newly developed trace of the fault was observed in the asphalt of California Highway 25 near Hollister, $54 \mathrm{~km}$ southeast of the epicenter; and 9 months after the earthquake, yet another new trace had developed at this site.

\section{FIELD OBSERVATIONS}

During the late afternoon of April 25, 1984, we made field observations along five roads crossing the Calaveras fault north of Hollister (fig. 7.1), to determine any signs of surface displacement that may have been associated with the earthquake of the preceding day. In this chapter, we report our observations and interpretations at these five sites, progressing from Wright Road near Hollister northward to California Highway 152 , about $15 \mathrm{~km}$ northwest of Hollister.

${ }^{1}$ San Francisco State University, San Francisco,

\section{Wright Road}

We observed left-stepping echelon cracks crossing Wright Road about $1.5 \mathrm{~km}$ north of Hollister, at the approximate position of the fault as shown by Radbruch-Hall (1974). However, we had observed these cracks 3 months previously, and no significant changes were apparent. No cracks or mole tracks were seen in the fields to the north and south of the site. In addition, Theodolite measurements on April 25 in comparison with measurements made on January 28 also indicated no displacement associated with the earthquake at this site (see chap. 15).

\section{McConnell Road}

We found no evidence of displacement along McConnell Road about $4 \mathrm{~km}$ northwest of Hollister, or in the recently plowed and smoothed fields to the north and south.

\section{California Highway 25}

Two traces of the Calaverus fault (approx $6.5 \mathrm{~m}$ from one another) were evident in the asphalt of California Highway 25 about $4.2 \mathrm{~km}$ northwest of Hollister on April 25. Both traces show well-developed left-stepping echelon cracks. The more westerly trace extended only across the north half of the road, whereas the more easterly trace extended completely across it. Neither set of cracks showed unequivocal evidence of recent displacement, and no related cracking or mole tracks were found in the soil of fields adjacent to the road.

\section{CA 94132}




\section{Shore Road}

We found definite evidence of recent displacement along the trace of the Calaveras fault that crosses Shore Road, about $5.8 \mathrm{~km}$ north of California Highway 25 and about $48 \mathrm{~km}$ southeast of the epicenter as located by Bakun and others (1984). The well-developed left-stepping echelon cracks in the asphalt could be traced into fresh well-developed cracks in the soil on either side of the road (fig. 7.2). The fault trend measured from cracks in the soil on the south side of the road to those in the soil on the north side was N. $17^{\circ}$ W. A U.S. Geological Survey creepmeter (see chap. 13) showed more than a centimeter of right-lateral displacement at this site associated with the April 24 earthquake.

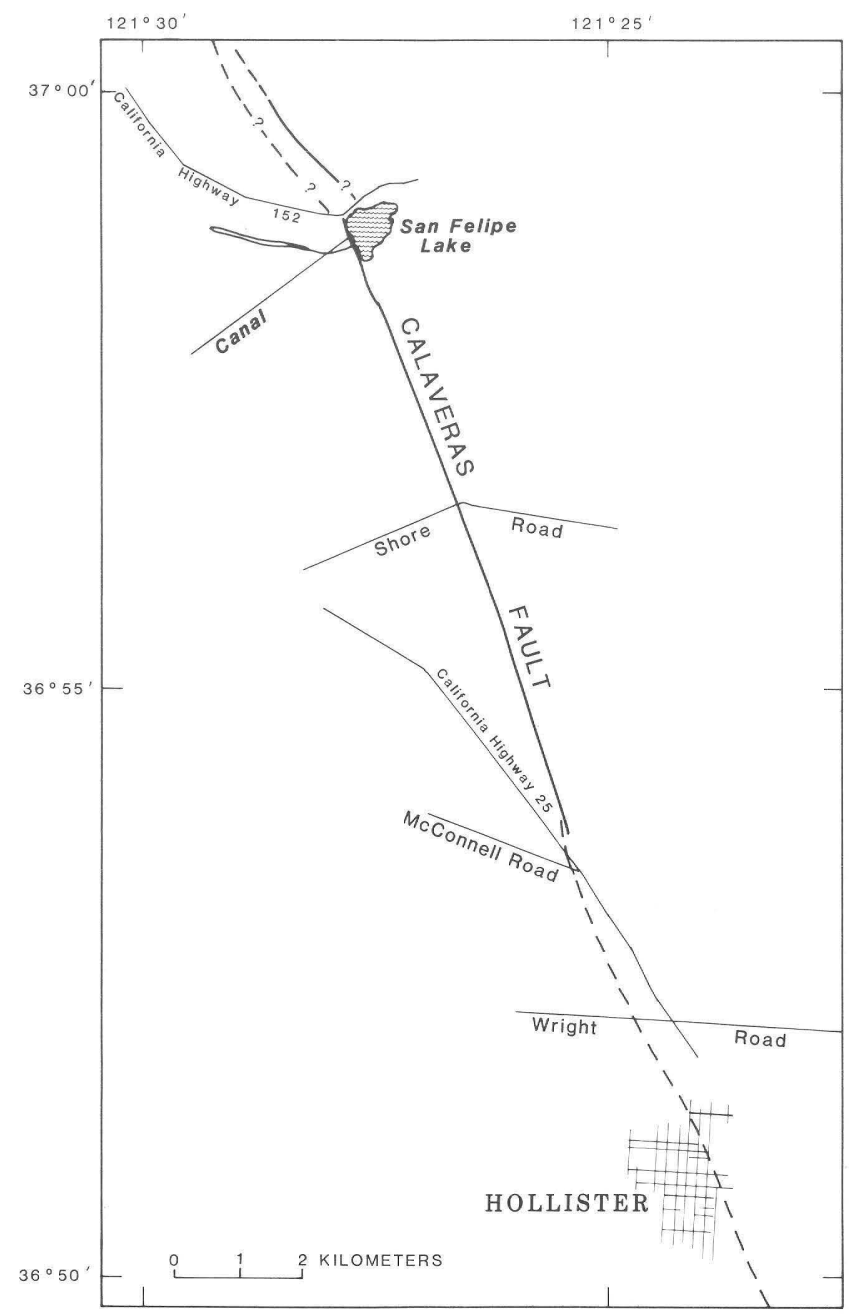

Figure 7.1. Sketch map of study area near Hollister, Calif., showing locations of roads crossing the Calaveras fault from Hollister northward to California Highway 152. Fault traces from Radbruch-Hall (1974).

\section{California Highway 152 (Pacheco Pass Road)}

We found evidence of fresh cracking in three different places near San Felipe Lake, about $40 \mathrm{~km}$ southeast of the earthquake epicenter. The trace mapped by Radbruch-Hall (1974) that continues southward of California Highway 152 (fig. 7.1) showed well-developed cracks in the asphalt that could be traced into poorly developed but fresh hairline cracks in the soil on both sides of the road. The fault trend measured from cracks in the soil on the south side to those in the soil on the north side was $\mathrm{N} .18^{\circ} \mathrm{W}$. The curb on the north side of the road was offset about $1 \mathrm{~cm}$ right laterally (fig. 7.3). This of fset, which was also visible in the soil, was almost certainly associated with the earthquake. There was no unequivocal way to determine whether this of fset occurred shortly before, during, or shortly after the earthquake, although it was probably shortly after the earthquake, similarly to the offset determined by the creepmeter at Shore Roud, about $5 \mathrm{~km}$ to the southeast (see chap. 13). We also

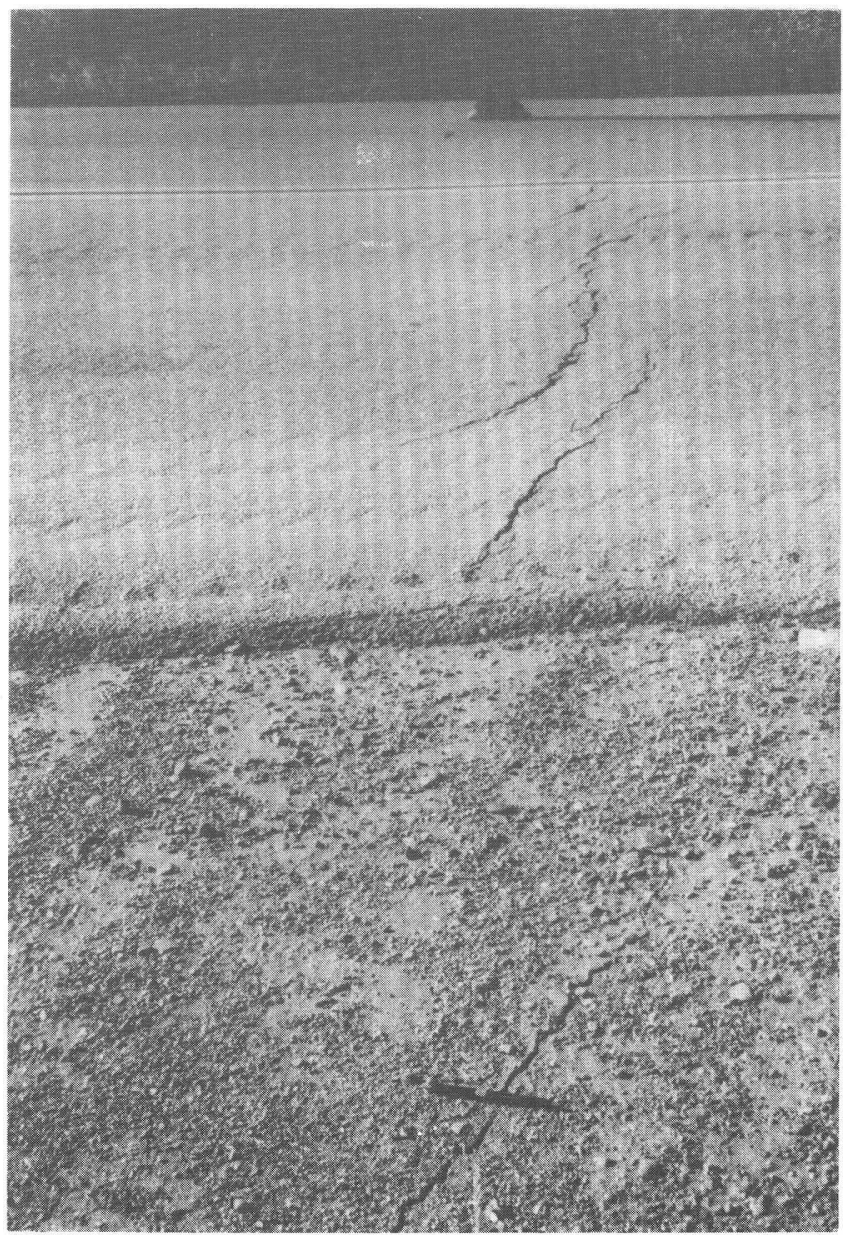

Figure 7.2. Calaveras fault at Shore Road on April 25, 1984. Left-stepping echelon cracks appear in the asphalt and also in the dirt. 
found two additional sets of fresh cracks about $4.6 \mathrm{~m}$ from one another, about midway between the two traces of the Calaveras fault that Radbruch-Hall (1974) mapped northwest of California Highway 152 (fig. 7.1). The more easterly of these unmapped sets of cracks trends about $N .35^{\circ} \mathrm{W}$. across the road (fig. 7.4), and the more westerly set about N. $40^{\circ} \mathrm{W}$. Both sets showed hairline cracks that extended from the asphalt into the soil on both sides of the road. Several other sets of northwest-trending cracks also crossed California Highway 152 in this area; none of these sets showed associated cracks in the soil bordering the highway.

\section{SUMMARY}

On April 25, 1984, just 1 day after the earthquake, the two northernmost of five roads

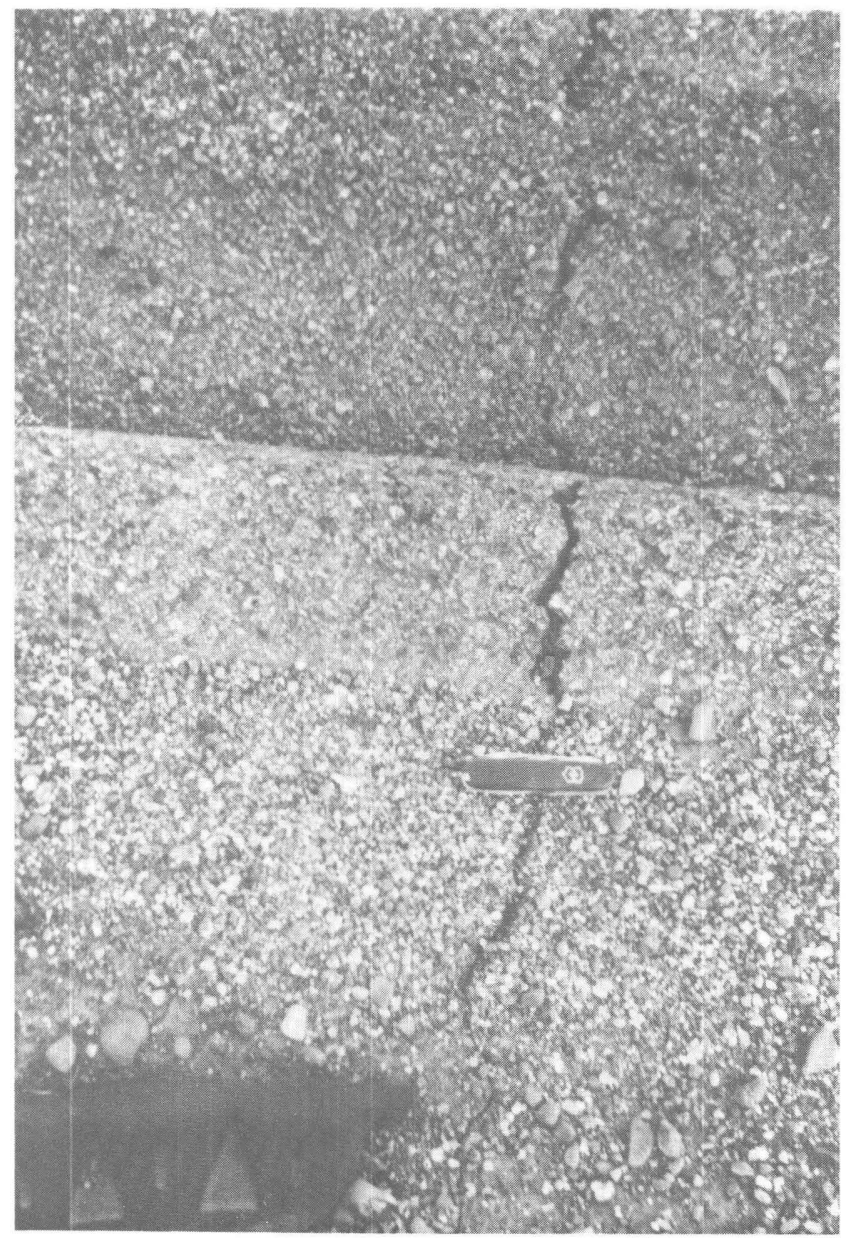

Figure 7.3. Calaveras fault at California Highway 152 (Pacheco Pass Road) on April 25, 1984. Crack in darker upper part of photograph is in asphalt of the road. Crack in lighter middle part above knife is in road curb, which is offset about $1 \mathrm{~cm}$ right laterally. Crack beneath knife in foreground, in dirt alongside the road, also shows right-lateral of fset. crossing the Calaveras fault north of Hollister showed strong evidence of recent displacement, whereas the three southernmost roads showed no unequivocal evidence of recent displacement. Thus, the southeast limit of surface displacement along the Calaveras fault associated with the April 24 earthquake appears to be along a $5.8-\mathrm{km}$-long segment of the fault between Shore Road and California Highway 25, about 48 to $54 \mathrm{~km}$ southeast of the epicenter.

On August 10, 3.5 months after the earthquake, we revisited the site on California Highway 25 where we found two active traces of the Calaveras fault on April 25. We observed three traces of the fault crossing the asphalt, all showing well-developed leftstepping echelon cracks (fig. 7.5). A third trace, to the southeast of the other two, had developed since April 25. On January 26, 1985, we revisited this site again and found a fourth, recently developed active trace of the fault approximately 1 to $2 \mathrm{~m}$ southeast of the third trace.

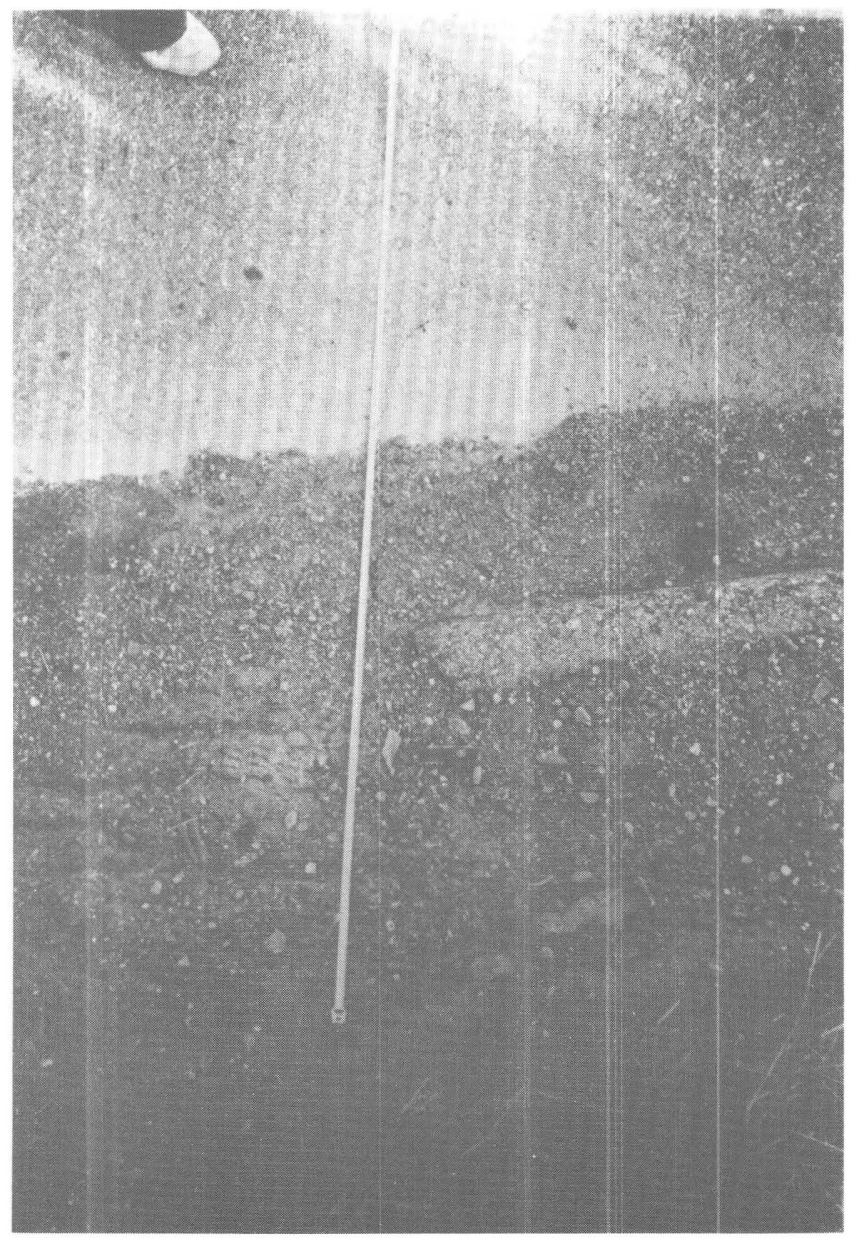

Figure 7.4. Calaveras fault at California Highway 152 (Pacheco Pass Road) on April 25, 1984. Crack is northeast of the one in figure 7.3. Crack in lighter upper part of photograph to right of tape is in asphalt. Crack in darker lower part is in dirt and runs from underneath knife downward and underneath tape, about 1.5 knife lengths from end of tape. 


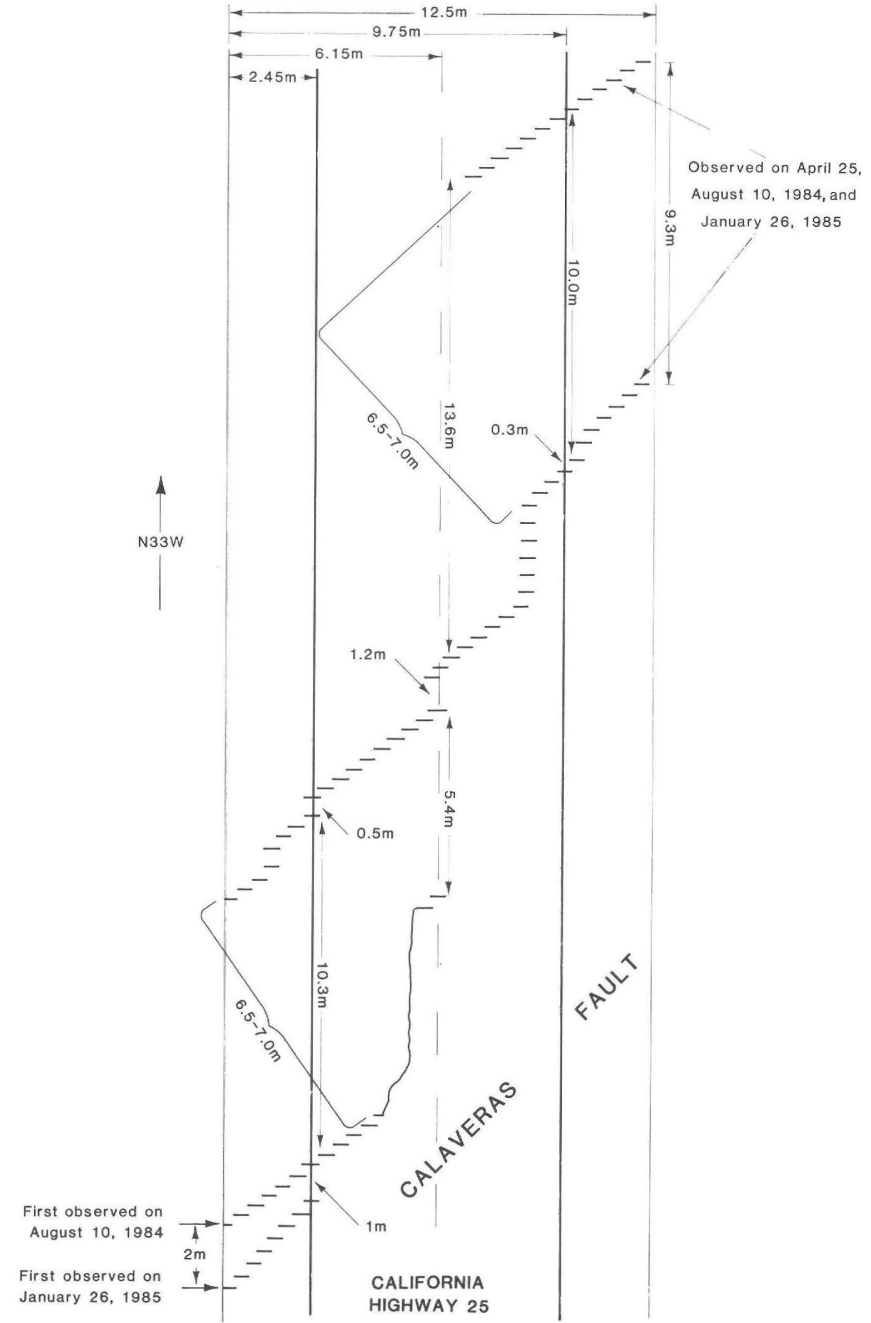

Figure 7.5. Sketch map of four traces of Calaveras fault crossing California Highway 25 in Hollister area on January 26, 1985.
Surface displacement to the southeast of the epicenter is consistent with the distribution of aftershocks (Bakun and others, 1984). Chapter 15 presents additional detailed evidence that increased rates of creep after the earthquake did not occur as far south as Hollister.

Shifting of fault movement from an older active trace to a newly developed one has serious implications regarding how fault movement should be monitored. A Theodolite triangulation site or an alignment array covering 50 to $250 \mathrm{~m}$ of a fault zone would have detected movement on the newly developed traces of the Calaveras fault crossing California Highway 25, whereas a creepmeter, monitoring a much narrower zone, probably would have missed it.

\section{REFERENCES CITED}

Bakun, W.H., Clark, M.M., Cockerham, R.S., Ellsworth, W.L., Lindh, A.G., Prescott, W.H., Shakal, A.F., and Spudich, Paul, 1984, The 1984 Morgan Hill, California, earthquake: Science, v. 225, no. 4659, p. 288-291.

Radbruch-Hall, D.H., 1974, Map showing recently active breaks along the Hayward fault zone and the southern part of the Calaveras fault zone, California: U.S. Geological Survey Miscellaneous Investigations Series Map I-813, scale 1:24,000, 2 sheets. 


\title{
Earthquake-Triggered Landslide at La Honda, California
}

\author{
By Gerald F. Wieczorek and David K. Keefer
}

\section{CONTENTS}

\author{
Abstruct $\quad 73$ \\ Introduction $\mathbf{7 3}$ \\ Description of the landslide $\mathbf{7 3}$ \\ Climatologic and hydrologic conditions $\quad \mathbf{7 4}$ \\ Earthquake magnitude and distance of the epicenter \\ from the landslide \\ Conclusions $\quad \mathbf{7 5}$ \\ References cited \\ 75 \\ 79
}

\section{Abstract}

A large, deep-seated translational landslide in the central Santa Cruz Mountains near the town of La Honda, Calif., was probably triggered by the earthquake. This landslide occurred approximately 53 $\mathrm{km}$ from the epicenter, which is the greatest epicentral distance at which an $M_{S}=6.1$ earthquake is likely to trigger a landslide of this type, on the basis of worldwide historical evidence. Earthquake triggering of this landslide probably involved one or more rather unusual conditions, such as significant focusing of seismic energy at the site, anomalous perturbations of the ground-water level by shaking, or a marginal stability of the hillside before shaking began.

\section{INTRODUCTION}

The Morgan Hill earthquake was felt strongly throughout the San Francisco peninsula and the Santa Cruz Mountains (fig. 8.1). A large landslide near La Honda, Calif., that was observed soon after the earthquake was probably triggered by the earthquake. This landslide, of approximately $67,000-\mathrm{m}^{2}$ area, was first noticed by Henry Cunha on April 25, the day after the earthquake, when he made a survey of his ranch. He observed fresh ground cracks, crevices, grubens, and other evidence of landslide movement. These landslide features were absent when he had previously traversed the area on April 20.

No nearby strong-motion records are available; the triggered strong-motion instrument nearest to the landslide, approximately $10 \mathrm{~km}$ to the east at Stanford University's Linear Accelerator Center (SLAC) Test Laboratory, recorded a maximum acceleration of 0.032 g (see chap. 5). The shaking in the La Honda area was insufficient to knock groceries from the shelves of a store $1.6 \mathrm{~km}$ southeast of the landslide but was so strong that one resident ran from a house $850 \mathrm{~m}$ southeast of the landslide; these obersvations suggest a modified Mercalli intensity (IVIMI) of V to VI.

\section{DESCRIPTION OF THE LANDSLIDE}

The maximum dimensions of the landslide are approximately $225 \mathrm{~m}$ wide by $430 \mathrm{~m}$ long. Its surface consists of a gently rolling headward part covered with grass and oaks (fig. 8.2A), and a steep frontal slope covered with thick brush. The average surface inclination of the headward part is approximately $3^{\circ}$ to $14^{\mathrm{O}}$, and that of the frontal slope $12^{\mathrm{O}}$ to $24^{\mathrm{O}}$. The morphology and predominantly translational movernent of the landslide indicate that it is a block slide, according to the landslide classification of Varnes (1978). At the head of the landslide is a conspicuous graben. The lateral margins of the landslide are marked by jugged lateral-shear surfaces. The toe of the landslide is marked in places by a low ridge, a few tens of centimeters high, that contains an underthrust shear surface where the landslide toe has been thrust $25 \mathrm{~cm}$ under the ground surface immediately downslope. The landslide exhibits internal cracking; however, most of the ground surface on the landslide is intact, and most trees on the surface are not tilted. The landslide thus moved largely as a single intact translational block. Figure 8.3 shows the amounts and directions of displacement.

The graben, the cracks along the lateral margins of the landslide, and most internal cracks do not conform to the topography but, instead, trend across 
topographic lows and highs. This nonconformity and the absence of surface disruption suggest that the landslide is deep seated. Along the southeast margin of the landslide, cracks as much as $5 \mathrm{~m}$ deep disrupt the surface of the ground at point A (fig. 8.3), which is $20 \mathrm{~m}$ lower in altitude than the top of the adjacent $\mathrm{r}$ ise at point $B$ (fig. 8.3). Drilling in the landslide at point $\mathrm{C}$ (fig 8.3) revealed a highly fractured zone at a depth of 15 to $17 \mathrm{~m}$, which we interpret as the basal shear zone of failure. A descriptive log of the borehole is presented in figure 8.4 .

The landslide occurred in an area of prehistoric deep-seated landslides; the relation of the present landslide boundaries to the previous landslide deposits is evident in figure 8.5. A basal shear zone is likely in material weakened by previous landslide movements.

\section{CLIMATOLOGIC AND HYDROLOGIC CONDITIONS}

Although landslides are common in this part of the Santa Cruz Mountains, most are triggered by intense storm rainfall in December, January, or February or by ground-water levels that gradually rise during the winter rainy season, which generally extends from October through April (Wieczorek, 1982). During winter 1983-84, intense storms terminated in late December 1983, and less frequent showers of more moderate intensity continued until March. Total 1983-84 seasonal precipitation before the earthquake was approximately 20 percent below normal. Some deep-seated landslides in the La Honda area moved during the very wet winters of 1981-82 and 1982-83 and showed signs of renewed activity in

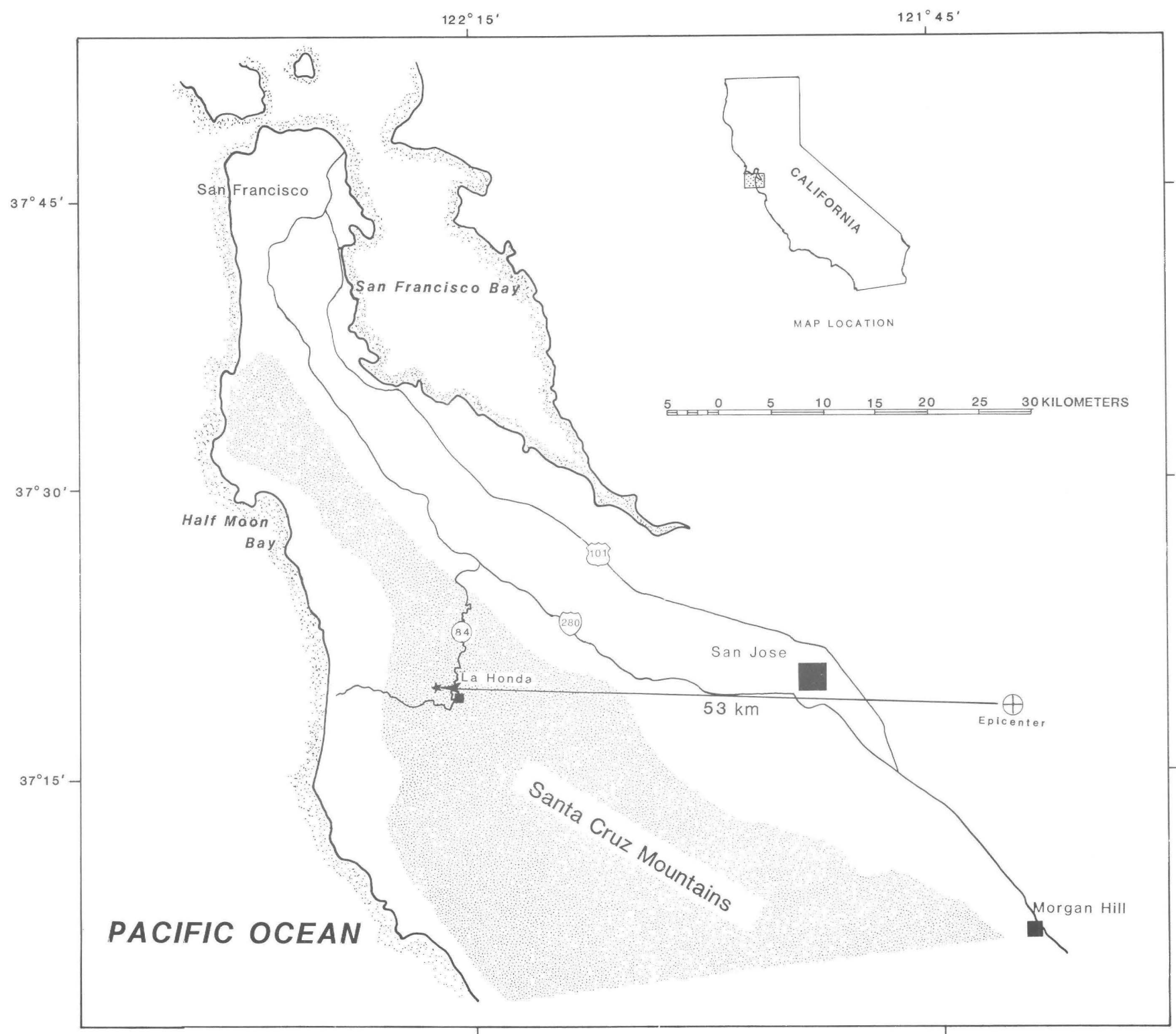

Figure 8.1. Santa Cruz Mountains area, Calif., showing locations of epicenter of the April 24, 1984, Morgan Hill earthquake (circled cross) and of landslide at La Honda (star). Arrow indicates distance from epicenter to landslide. 

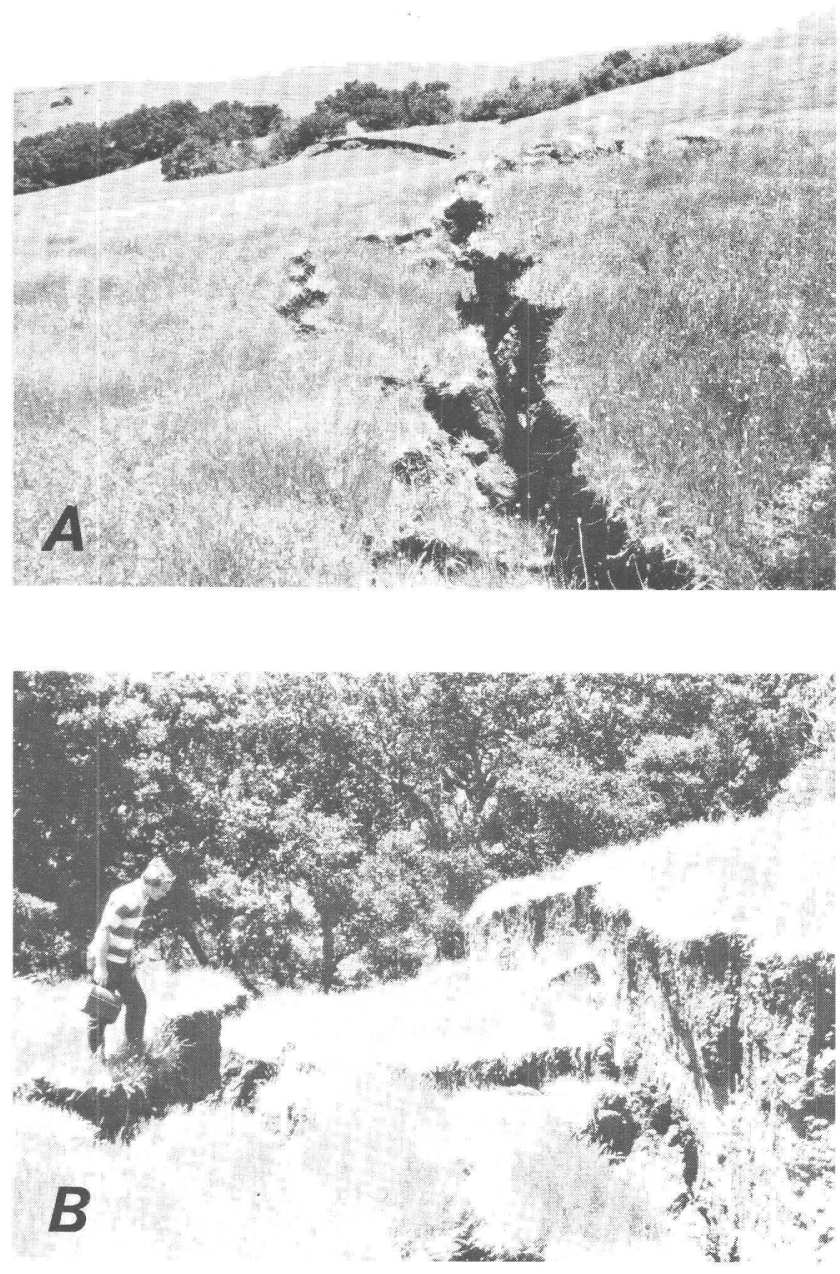

Figure 8.2. Landslide at La Honda, Calif., probably triggered by the earthquake. A, Scarp along northeastern part of landslide. View northward. B, Graben at head of landslide. Measurements across graben show $1.2 \mathrm{~m}$ of displacement toward the southwest.

November and December 1983 and (or) Junuary 1984. However, because of fewer late-winter storms and below-average annual rainfall, landslide movements ceased in January 1984 as ground-water levels in the hillside materials began to decline (G.F. Wieczorek, unpub. data, 1984). Henry Cunha observed no landslide movements on his ranch during the winter before the April 24 earthquake.

When we inspected the landslide on May 15 and 18, we observed no water standing in cracks and noted that the soil exposed in scraps and cracks was dry or only slightly moist. The bowl-shaped topography of the area upslope from the landslide (fig. 8.3) suggests that water infiltrates into the slopes above the landslide and flows toward the flatter lying area of the landslide, thus creating a body of perched ground water in the landslide. On the basis of (1) identification of a possible ground-water level from samples in the borehole, (2) measurements of groundwater level in the cased borehole during June, July, and August 1984, and (3) comparisons with the groundwater levels in several other cased boreholes in the vicinity of the landslide, we estimate that the groundwater level at point $C$ (fig. 8.3) in the landslide mass at the time of the earthquake was approximately $5 \pm 0.6$ $\mathrm{m}$ below the ground surface.

\section{EARTHQUAKE MAGNITUDE AND DISTANCE OF THE EPICENTER FROM THE LANDSLIDE}

The lundslide is $53 \mathrm{~km}$ from the epicenter (see chap. 3) of the earthquake (fig. 8.1), which had a Richter surface-wave magnitude $\underline{M}_{S}$ of 6.1 (see chap. 1). According to $a$ worldwide historical review of the relations between earthquake magnitude and epicentrul distance for different types of landslides (Keefer, 1984), this landslide is at approximately the maximum distance from the epicenter at which an $\mathrm{MI}_{\mathrm{S}}=6.1$ earthquake is likely to cause a block slide in a highly susceptible material. Figure 8.6 (point A) plots the distance of the block slide at La Honda from the epicenter $(53 \mathrm{~km})$. Other landslides presumed to have been caused by this earthquake, however, are within about $30 \mathrm{~km}$ of the epicenter (E.L. Harp and others, unpub. data, 1984). Thus, if the La Honda landslide was seismically triggered, it probably involved one or more rather unusual conditions, such as significant focusing of seismic energy at the site, anomalous perturbations of the ground-water level by shaking, or a marginal stability of the hillside before shaking began.

\section{CONCLUSIONS}

The below-normal seasonal rainfall before the landslide, the absence of other landslide activity in the La Honda area during the previous several months, and observations that conclusively bracket the landslide occurrence to a 5-day period that included the April 24 earthquake strongly suggest that the La Honda landslide was seismically triggered. The landslide occurred at approximately the maximum epicentral distance at which an $M_{S}=6.1$ earthquake is likely to trigger a landslide of this type, on the basis of worldwide historical evidence. However, the occurrence of most or all other landslides from this earthquake much closer to the epicenter suggests either that the landslide coincided with the earthquake or that some unusual conditions which aided seismic triggering were present at the La Honda site. 


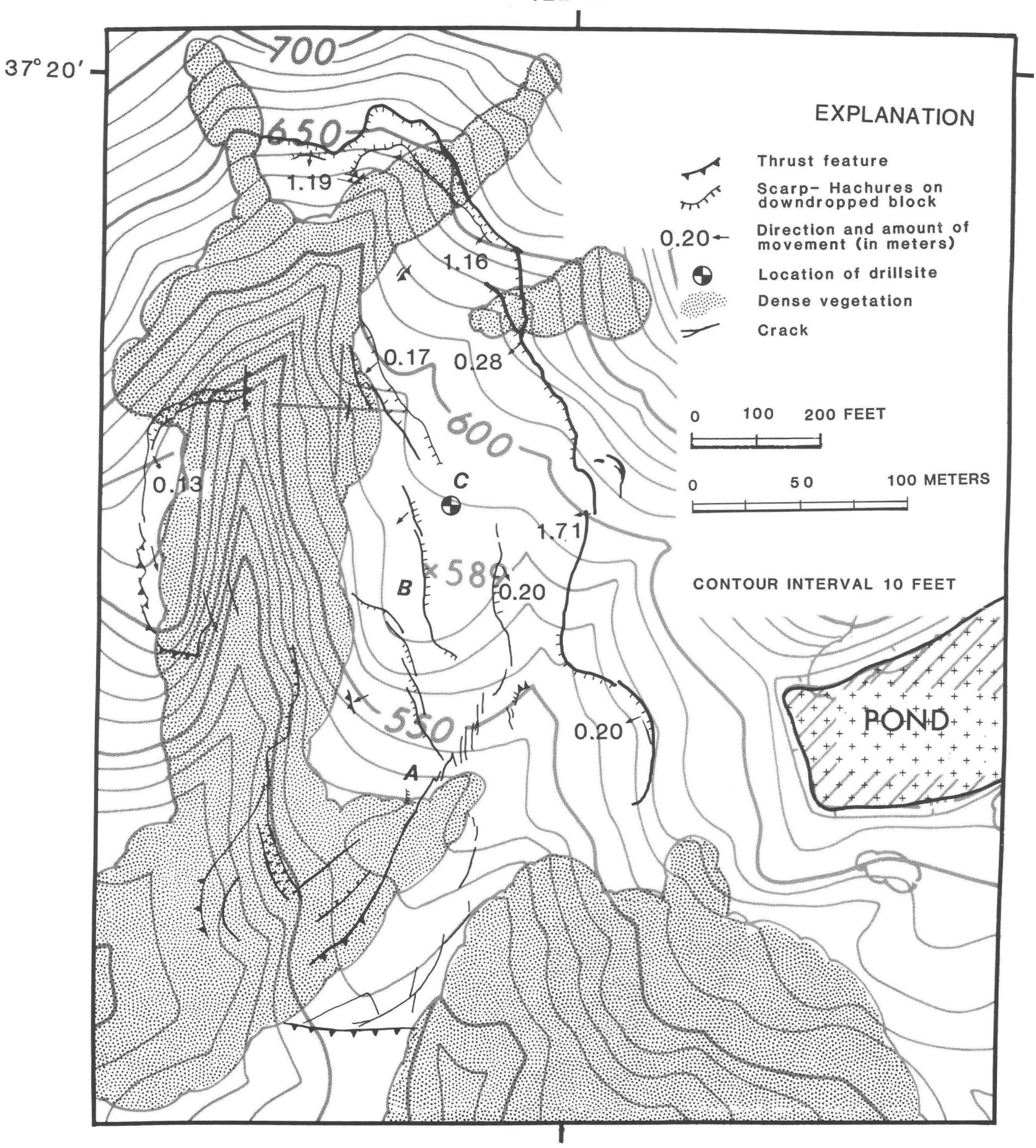

Figure 8.3. Landslide at La Honda, Calif., showing amounts and directions of displacement. 


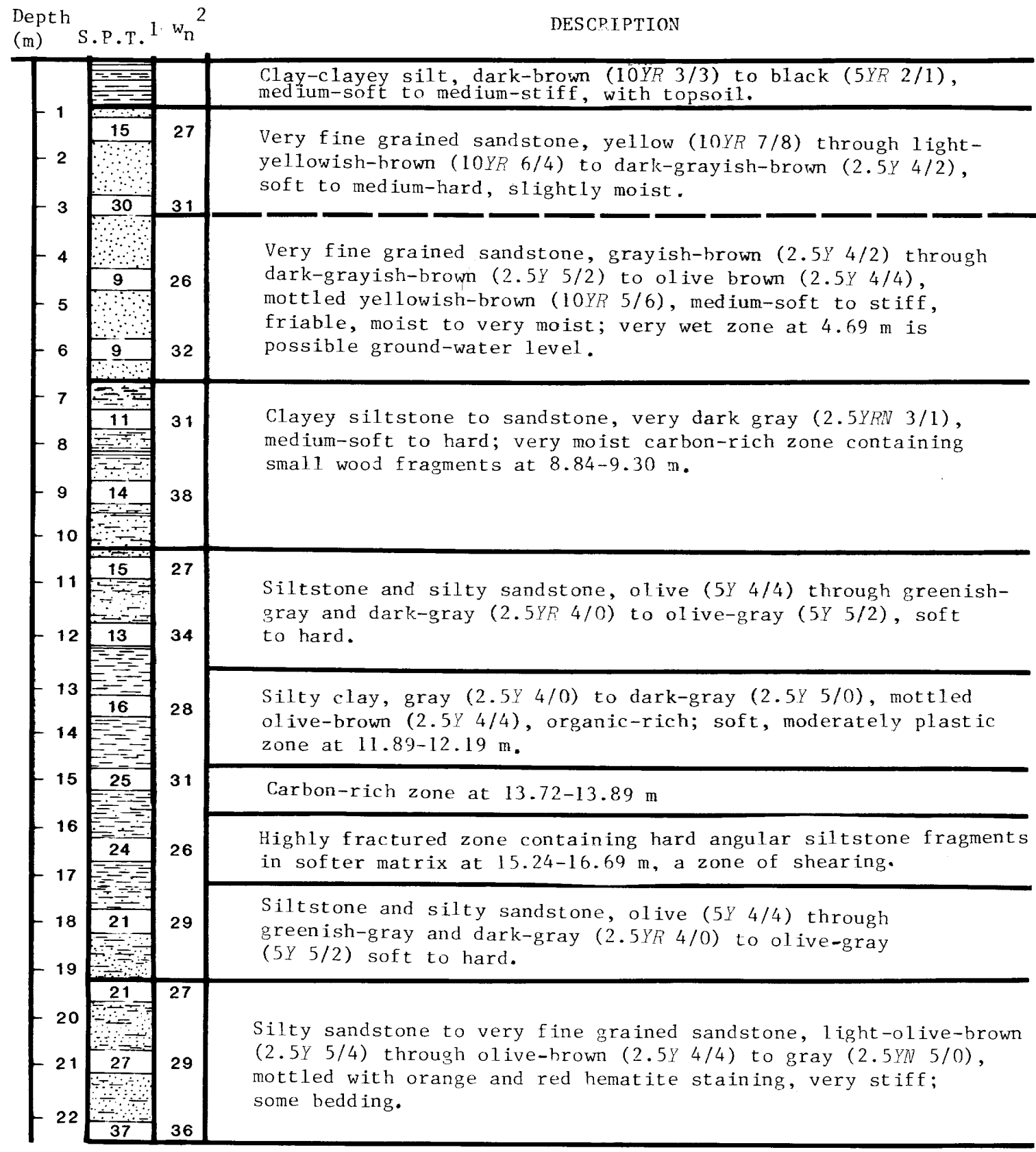

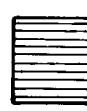

${ }^{1}$ Standard penetration test (blows/ft.)

Clay

2 Natural water content (pct)

Silt

Sand

Figure 8.4. Borehole log of soil and rock layers at point $\mathrm{C}$ (fig. 8.3) in landslide at La Honda. Color designations are according to Munsell soil-color chart. 


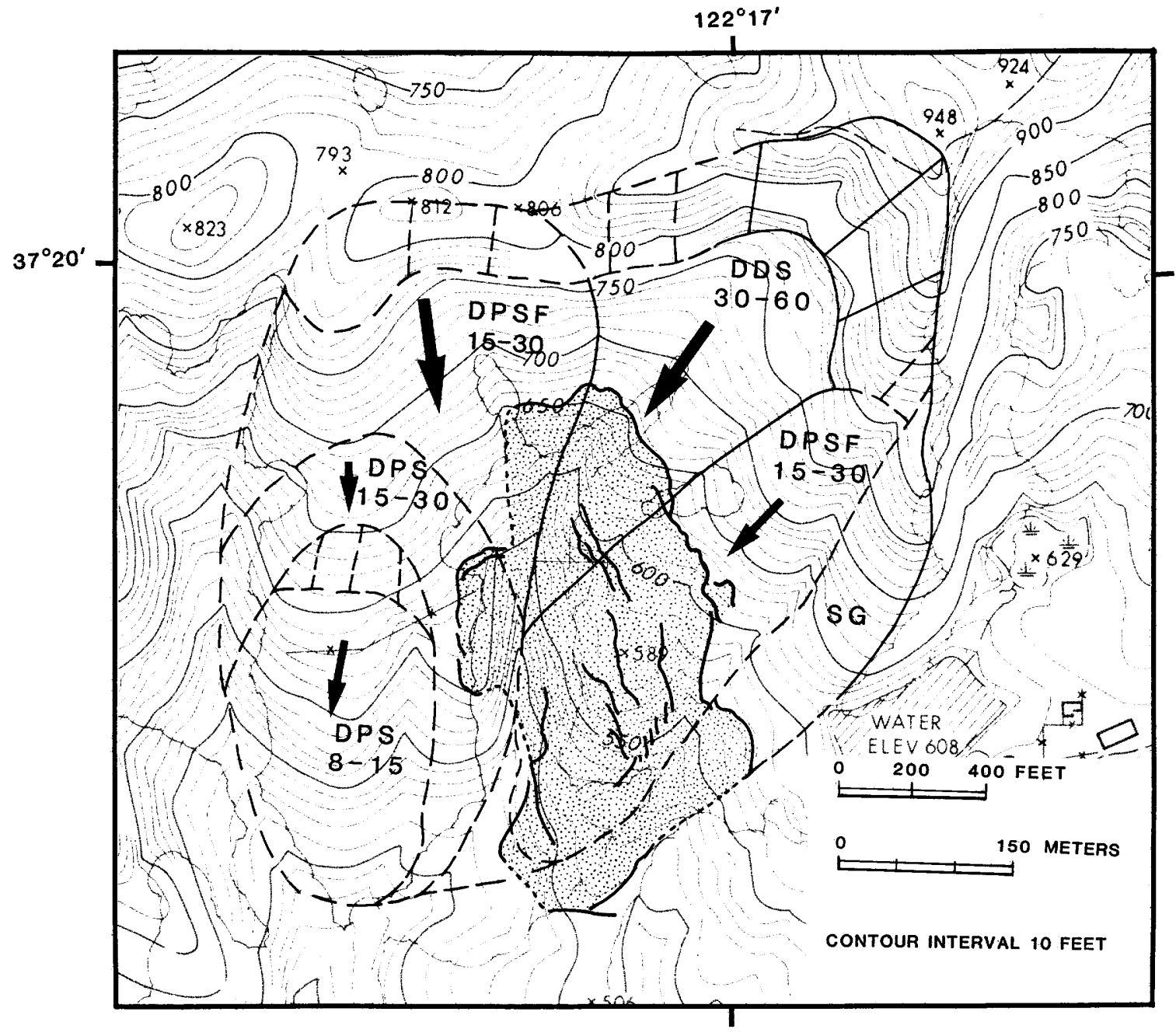

\section{LANDSLIDE CLASSIFICATION}

\begin{tabular}{|c|c|c|}
\hline $\begin{array}{l}\text { State of } \\
\text { activity }\end{array}$ & $\begin{array}{l}\text { Certainty of } \\
\text { identification }\end{array}$ & $\begin{array}{l}\text { Dominant type of } \\
\text { slope movement }\end{array}$ \\
\hline $\begin{array}{l}\text { A, Active or } \\
\text { recently active }\end{array}$ & $D$, Definite & $\begin{array}{l}\text { SF, Complex slump/ } \\
\text { earth flow }\end{array}$ \\
\hline SG, Stable ground & & S, Slump \\
\hline D, Dormant & & \\
\hline
\end{tabular}

aID Landslide scarp--Dashed where approximately located

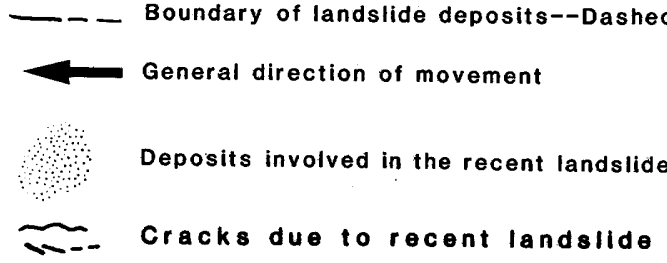

Figure 8.5. Landslide at La Honda probably triggered by the earthquake, with respect to boundaries of previous landslide deposits (Wieczorek, 1982). 


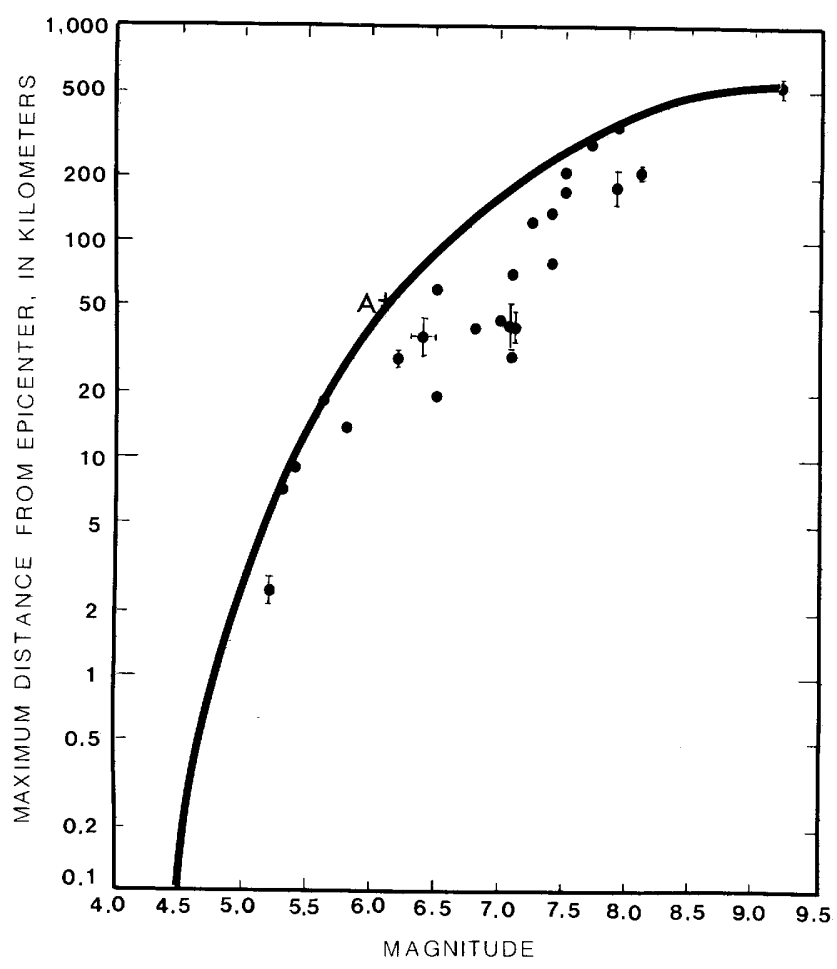

Figure 8.6. Maximum epicentral distance for block slides and related landslides as a function of earthquake magnitude for historical earthquakes. Dots represent historical earthquakes compiled by Keefer (1984). Solid line is approximate upper bound enclosing all historical data, as determined by Keefer (1984). Point A represents distance of landslide at La Honda from epicenter of April 24, 1984, Morgan Hill earthquake $\left(\underline{M}_{s}=6.1\right)$.

\section{REFERENCES CITED}

Keefer, D.K., 1984, Landslides caused by earthquakes: Geological Society of America Bulletin, v. 95, no. 4, p. 406-421.

Varnes, D.J., 1978, Slope movement types and processes, in Schuster, R.L. and Krizek, R.J., eds., Landslides: Analysis and control: U.S. National Academy of Sciences, National Research Council, Transportation Research Board Special Report 176, p. 12-33.

Wieczorek, G.F., 1981, Ground-water level and precipitation data for slopes near La Honda, California: U.S. Geological Survey Open-File Report 81-367, 25 p.

1982, Map showing recently active and dormant landslides near La Honda, central Santa Cruz Mountains, California: U.S. Geological Survey Miscellaneous Field Studies Map MF-1422, scale $1: 4,800$. 


\title{
Near-Surface Geology and Seismic-Wave Velocities at Six Strong-Motion Stations near Gilroy, California
}

\author{
By Thomas E. Fumal, James F. Gibbs, and Edward F. Roth
}

\section{CONTENTS}

\author{
Abstract $\quad \mathbf{8 1}$ \\ Introduction $\mathbf{8 1}$ \\ Data acquisition and processing \\ Results $\mathbf{8 2}$ \\ Acknowledginents $\mathbf{8 3}$ \\ References cited $\mathbf{8 3}$
}

\section{Abstract}

We present geologic and $\underline{P}-$ and $\underline{S}-$ wave-velocity logs from boreholes 20 to $60 \mathrm{~m}$ deep at five stations of the Gilroy strong-motion array and at the Coyote Lake Dam, south abutment, station (originally called San Martin-Coyote Creek when first installed by the U.S. Geological Survey). The geology at the Coyote Lake Dam site is highly complex. The instrument pad is located on or partly on a prominent mass of silicacarbonate rock and serpentine embedded in sheared rock of the Franciscan assemblage. Our borehole, 70 m to the southwest, penetrated only sedimentary rocks and is separated from the instrument site by a strand of the Calaveras fault zone. In view of this location, the relatively low shear-wave velocities $(250-480 \mathrm{~m} / \mathrm{s})$ measured in the borehole should not be used to characterize this site; further investigations will be necessary to determine the velocity structure underlying the strong-motion instrument at the Coyote Lake Dam.

\section{INTRODUCTION}

Significant records were obtuined at five stations of the Gilroy strong-motion array within $16 \mathrm{~km}$ of the Coyote Lake, Calif., earthquake (August 6, 1979; $\mathrm{M}_{\mathrm{L}}=5.9$ ) and within $40 \mathrm{~km}$ of the Morgan Hill, Calif., earthquake (April 24, 1984; $\underline{M}_{L}=6.1$ ). This array was installed by the U.S. Geological Survey (USGS) in 1971 and presently is operated jointly by the California Division of Mines and Geology. Records from the array are particularly useful for investiguting the effects of site conditions on strong ground motion because the subsurface geology changes significantly over a short distance. The array (fig. 9.1) extends from sandstone of the Franciscan assemblage on the southwest, across alluvium of Santa Clara Valley, to Tertiary sandstone on the northeast $10 \mathrm{~km}$ away. Interpretation of the strong-motion data from these stations requires information about the geologic materials underlying each site, including shear-wave velocities. After the Coyote Lake earthquake, the USGS began studying the near-surface geology and the compressional- and shear-wave-velocity structure at five of the Gilroy array stations and at the nearby Coyote Lake Dam station. The results of these investigutions, which were reported in detail by Fumal and others (1982), are summarized in this chapter.

\section{DATA ACQUISITION AND PROCESSING}

At each strong-motion station, rotary-wash equipment was used to drill a borehole 20 to $30 \mathrm{~m}$ deep at sites on bedrock and 30 to $60 \mathrm{~m}$ deep at sites on alluvium. An additional hole was drilled at the Mission Trails Motel (sta. 2) to find the depth to bedrock (180.5 $\mathrm{m}$ to Franciscan sandstone). The geologic and seismicvelocity logs from this deep borehole were presented by Joyner and others (1981).

Samples of each dominant type of material penetrated were recovered during drilling. Two to four samples were taken at each of four sites (stas. 2-4 and the Coyote Lake Dam); no samples were recovered at two of the bedrock sites--Gavilan water tank and Cañada Road, San Ysidro (stas. 1, 6). A geologic log, including soil texture and color and estimates of hardness and fracture spacing in the rocks, was compiled for each hole from descriptions of the samples and a field log made at the time of drilling. This field $\log$ was based on continuous monitoring of the drill cuttings and the roughness and rate of drilling, onsite inspection of samples, and inspection of 
nearby outcrops. Figure 9.2 shows simplified versions of the geologic logs.

Shear waves were generated at the ground surface by using a horizontal traction source similar to the one discussed by Warrick (1974). Compressionul waves were generated by using both a vertical hammerblow on a striker plate and a blasting cap. Recordings of the seismic signals were made in the boreholes with a three-component Geophone package, generally at depth intervals of $2.5 \mathrm{~m}$. P- and S-wave velocities were calculated from the measured traveltimes for depth intervals determined from changes in the slopes of traveltime curves. To minimize the effect of picking errors, these depth intervals are a minimum of $5 \mathrm{~m}$ (three traveltime measurements) for materials with shear-wave velocities $\left(V_{s}\right)$ lower than $350 \mathrm{~m} / \mathrm{s}$ and a minimum of $7.5 \mathrm{~m}$ (four traveltime measurements) for stiffer materials. Figure 2 shows the traveltime curves and calculated $\mathrm{P}$ - and $\mathrm{S}-$ wave-interval velocities.

\section{RESULTS}

The near-surface geology and shear-wave velocities at each strong-motion station can be summarized as follows:

Gavilan water tank (sta. 1).--Sandstone of the Franciscan assemblage (Dibblee, 1973a) and minor shule, hard; fracture spacing mostly very close to close in moderately weathered rock to $10-\mathrm{m}$ depth $\left(\mathrm{V}_{\mathrm{s}}=780\right.$ $\mathrm{m} / \mathrm{s})$ and close to wide in fresh rock $\left(\mathrm{V}_{\mathrm{s}}=2,230 \mathrm{~m} / \mathrm{s}\right)$.

Mission Trails Motel (sta. 2).--Alluvial-fan deposits of Holocene age (Helley and Brabb, 1971) to 8-m depth $\left(\mathrm{V}_{\mathrm{s}}=275 \mathrm{~m} / \mathrm{s}\right)$ over Pleistocene alluvium to $180.5-\mathrm{m}$ depth $\left(V_{s}=300-460 \mathrm{~m} / \mathrm{s}\right.$ to $40-\mathrm{m}$ depth, about $630 \mathrm{~m} / \mathrm{s}$ from $40-$ to $180-\mathrm{m}$ depth).

Gilroy Sewage Treatment Plant (sta. 3).-Inter fluvial-basin deposits of Holocene age (Helley and Brabb, 1971) to $6-\mathrm{m}$ depth $\left(\mathrm{V}_{\mathrm{s}}=165 \mathrm{~m} / \mathrm{s}\right)$ over Pleistocene alluvium to greater than $60-\mathrm{m}$ depth $\left(\underline{V}_{\mathrm{s}}=255-625 \mathrm{~m} / \mathrm{s}\right)$.

San Ysidro School (sta. 4).--Fluvial deposits of Holocene age (Helley and Brabb, 1971) to 9-m depth $\left(V_{s}=145 \mathrm{~m} / \mathrm{s}\right)$ over mostly fine gruined Pleistocene alluvium to greater than $30-\mathrm{m}$ depth $\left(\mathrm{V}_{\mathrm{s}}=285 \mathrm{~m} / \mathrm{s}\right)$.

Cañada Roud, San Ysidro (sta. 6).--Unnamed marine sedimentary rocks of early Eocene-Paleocene and (or) Late Cretaceous age (Dibblee, 1973a); deeply to moderately weathered sands tone with very close to close fracture spacing to $18-\mathrm{m}$ depth $\left(\mathrm{V}_{\mathrm{s}}=625 \mathrm{~m} / \mathrm{s}\right)$, over fresh hard shale with mostly close to moderate fracture spacing and some sheared zones $\left(V_{s}=690 \mathrm{~m} / \mathrm{s}\right)$.

Coyote Lake Dam (sta. CYC).--The geology at the Coyote Lake Dam site, located within the Calaveras fault zone, is highly complex. The strongmotion instrument is situated at the left (southwest) abutment of the dam, next to a prominent outcrop of silica-carbonate rock and serpentine. The concrete base for the instrument may rest on as much as $1.5 \mathrm{~m}$ of fill at the edge of a steep south-facing slope partly buried by the embankment of the dam (Tepel, 1984). The USGS drill hole was located about $70 \mathrm{~m}$ to the southwest of the accelerograph shelter in an area mapped as serpentine by Dibblee (1973b). Drilling,

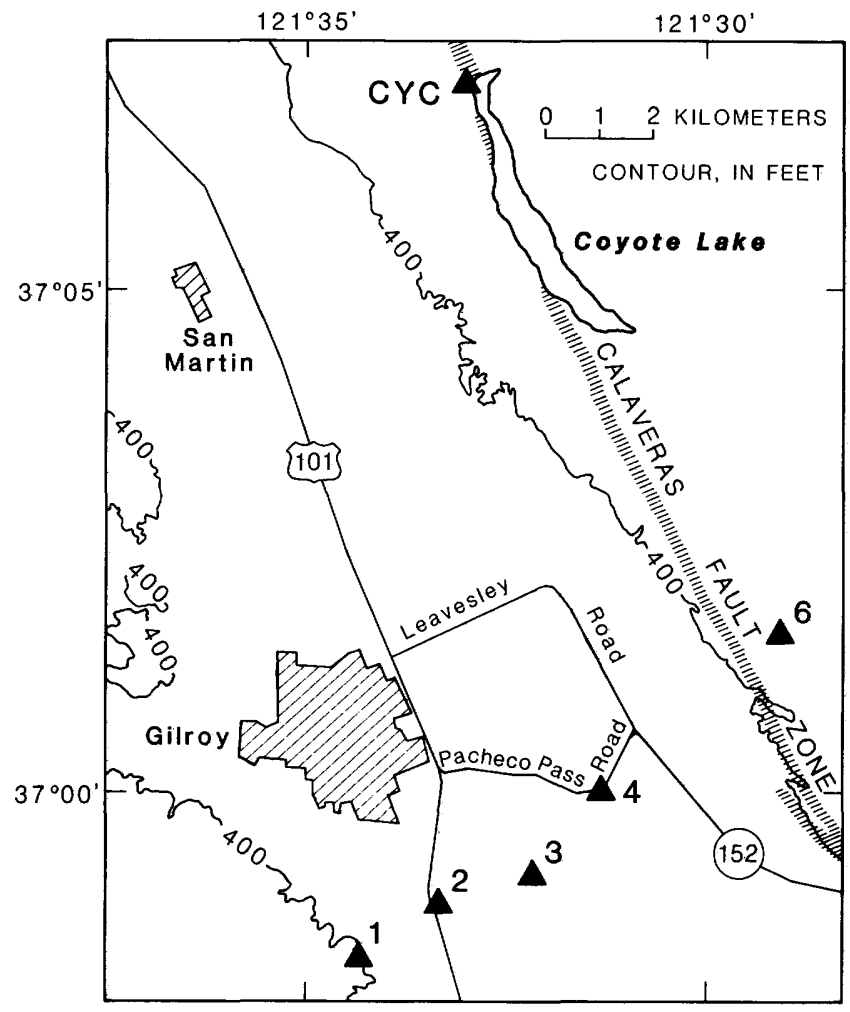

Figure 9.1. Sketch map of Gilroy, Calif., area showing locations of strong-motion stations where downhole seismic-velocity measurements were made. 1, Gavilan water tank; 2, Mission Trails Motel; 3, Gilroy Sewage Treatment Plant; 4, San Ysidro School; 6, Cañada Road, San Ysidro; CYC, Coyote Lake Dam.

however, revealed about $2.5 \mathrm{~m}$ of fill over a sequence of sof $t$ to firm mudstone and sandstone $\left(V_{s}=250-480\right.$ $\mathrm{m} / \mathrm{s}$ ). The report by Gulloway and others (1935) describing tunnels cut before dam construction indicates that these sedimentary rocks are in fault contact with serpentine that is, in turn, separated from the main serpentine mass by a zone of highly sheared rock, about $5 \mathrm{~m}$ thick. The sedimentury rocks are apparently part of a block of Pliocene and Pleistocene rocks within the Calaveras fault zone. This block is cut by several minor faults and includes a zone of volcanic breccia in fault contact with the sedimentary rocks. The serpentine knob on which the strong-motion instrument is located forms part of a disturbed zone developed in shale and sandstone of the Franciscan assemblage, extending beneath most of the valley floor. Several wide zones of highly sheared rock are present, increasing in abundance toward the left abutment. The disturbed zone crops out downstream from the serpentine knob and consis ts of large (max 10 $m$ diam) blocks of serpentine, sandstone, and shale in a matrix of highly sheared serpentine and shale.

Considering the geology in the vicinity of the Coyote Lake Dam strong-motion instrument, the 
TIME, IN MILLISECONDS
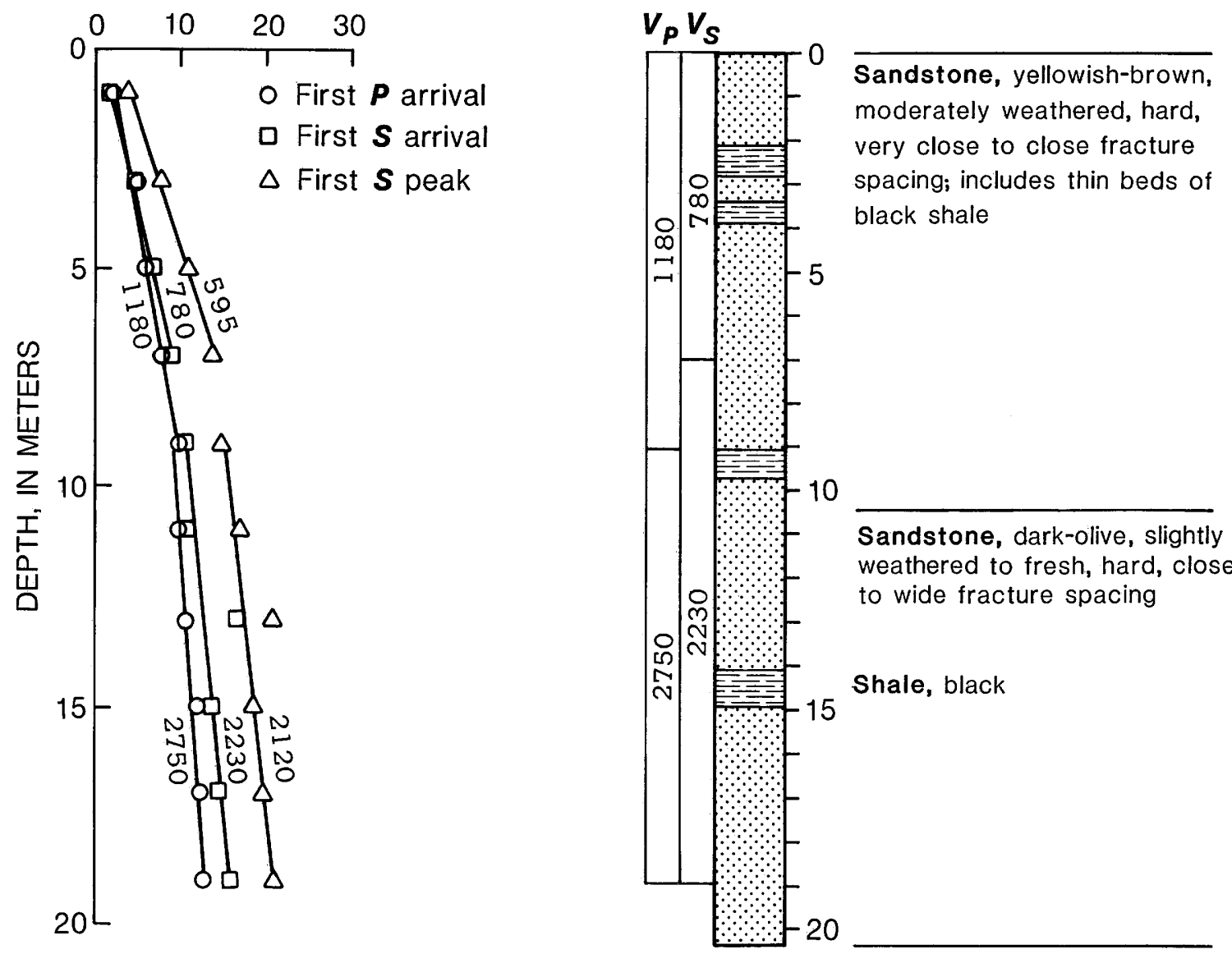

Figure 9.2. Traveltime curves, calcalated $\underline{\mathrm{P}}$ - and $\underline{\mathrm{S}}-\mathrm{wave}$ velocities $\left(\underline{\mathrm{V}}_{\mathrm{p}}\right.$ and $\underline{\mathrm{V}}_{\mathrm{S}}$, respectively) in meters per second, and simplified geologic logs at strong-motion stations where downhole seismic-velocity measurements were made. Values in parentheses are not well determined. A, Gavilan water tank. B, Mission Trails Motel. C, Gilroy Sewage Treatment Plant. D, San Ysidro School. E, Cañada Road, San Ysidro. F, Coyote Lake Dam.

relatively low shear-wave velocities measured in the USGS borehole $(250-480 \mathrm{~m} / \mathrm{s})$ should not be used to characterize the materials underlying the instrument pad. Shear-wuve velocites of 600 to $800 \mathrm{~m} / \mathrm{s}$ have been recorded in serpentine and sheared rock at several other sites investigated by the USGS elsewhere in northern Californiu. Future investigutions will be necessary to characterize with certainty the velocity structure underlying the instrument at this site.

\section{ACKNOWLEDGMENTS}

We thank all of the property owners who allowed access for drilling and making the velocity meusurements. R.E. Warrick and R.L. Porcella of the USGS helped with the seismic measurements at the Coyote Lake Dam station and provided helpful review comments.

\section{REFERENCES CITED}

Dibblee, T.W., Jr., 1973a, Preliminary geologic map of the Gilroy Hot Springs quadrangle, Santa Clara County, California: U.S. Geological Survey Open-File Report, scale 1:24,000.

- 1973b, Preliminary geologic map of the Gilroy Quadrangle, Santa Clara County, California: U.S. Geological Survey Open-File Report, scale $1: 24,000$.

Fumal, T.E., Gibbs, J.F., and Roth, E.F., 1982, In-situ measurements of seismic velocity at 10 strong motion accelerograph stations in central California: U.S. Geological Survey Open-File Report 82-407, 78 p.

Galloway, J.D., Herrmann, F.C., and Louderback, G.D., 1935, Report on the plans for the Coyote Dam: San Jose, Calif., Santa Clara Valley Water Dis trict report, $28 \mathrm{p}$. 

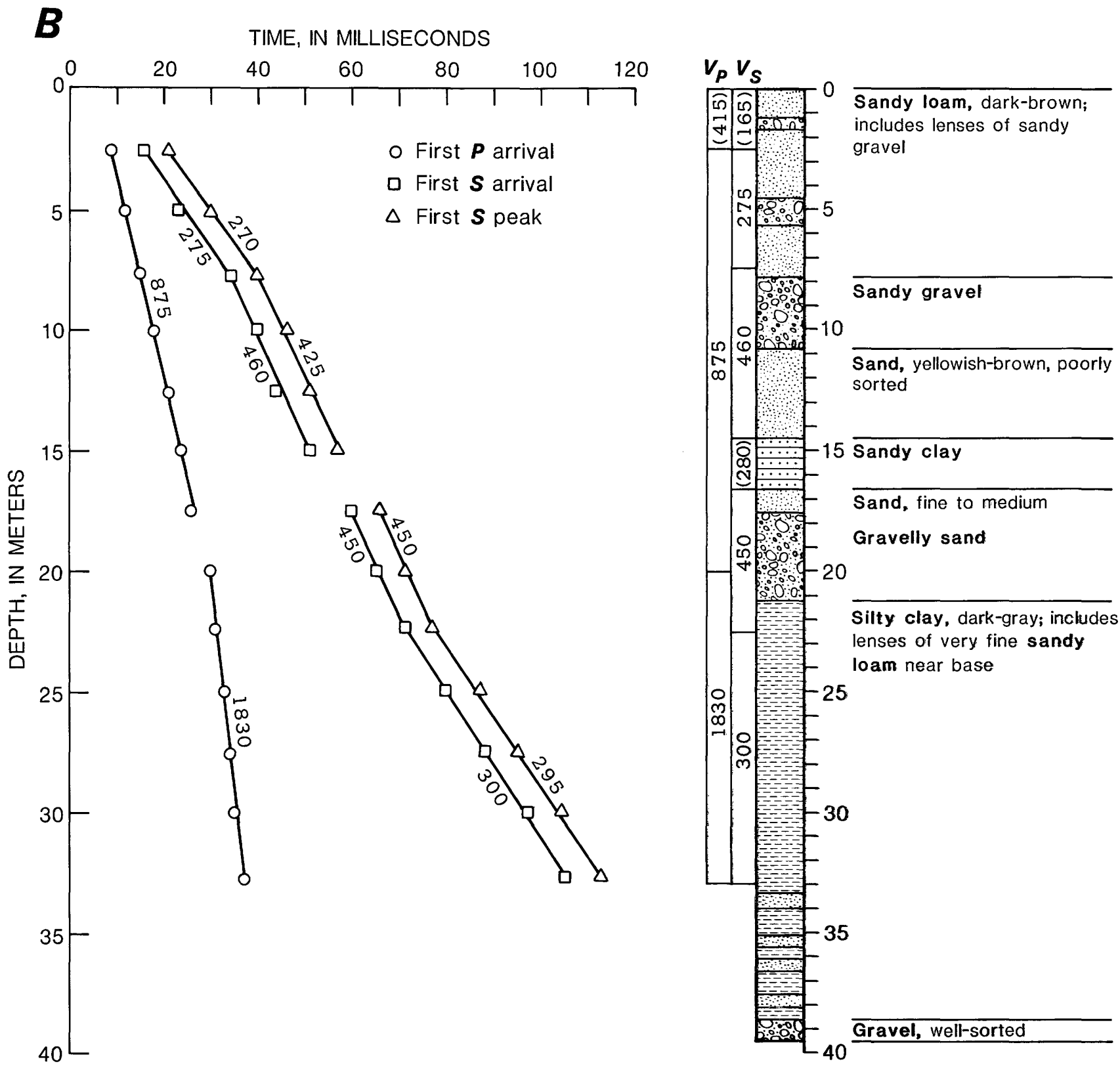

Figure 9.2. Continued

Helley, E.J., and Brabb, E.E., 1971, Geologic map of late Cenozoic deposits, Santa Clara County, California: U.S. Geological Survey Miscellaneous Field Studies Map MF-335, scale 1:62,500.

Joyner, W.B., Warrick, R.E., and Fumal, T.E., 1981, The effect of Quaternary alluvium on strong ground motion in the Coyote Lake, California, earthquake of 1979: Seismological Society of
America Bulletin, v. 71 , no. 4, p. 1333-1349.

Tepel, R.E., 1984, Evaluation of the effects of the Morgan Hill earthquake of April 24, 1984 at Coyote dam and spillway: San Jose, Calif., Santa Clara Valley Water District report, $45 \mathrm{p}$.

Warrick, R.E., 1974, Seismic investigation of a San Francisco bay mud site: Seismological Society of America Bulletin, v. 64, no. 2, p. 375-385. 


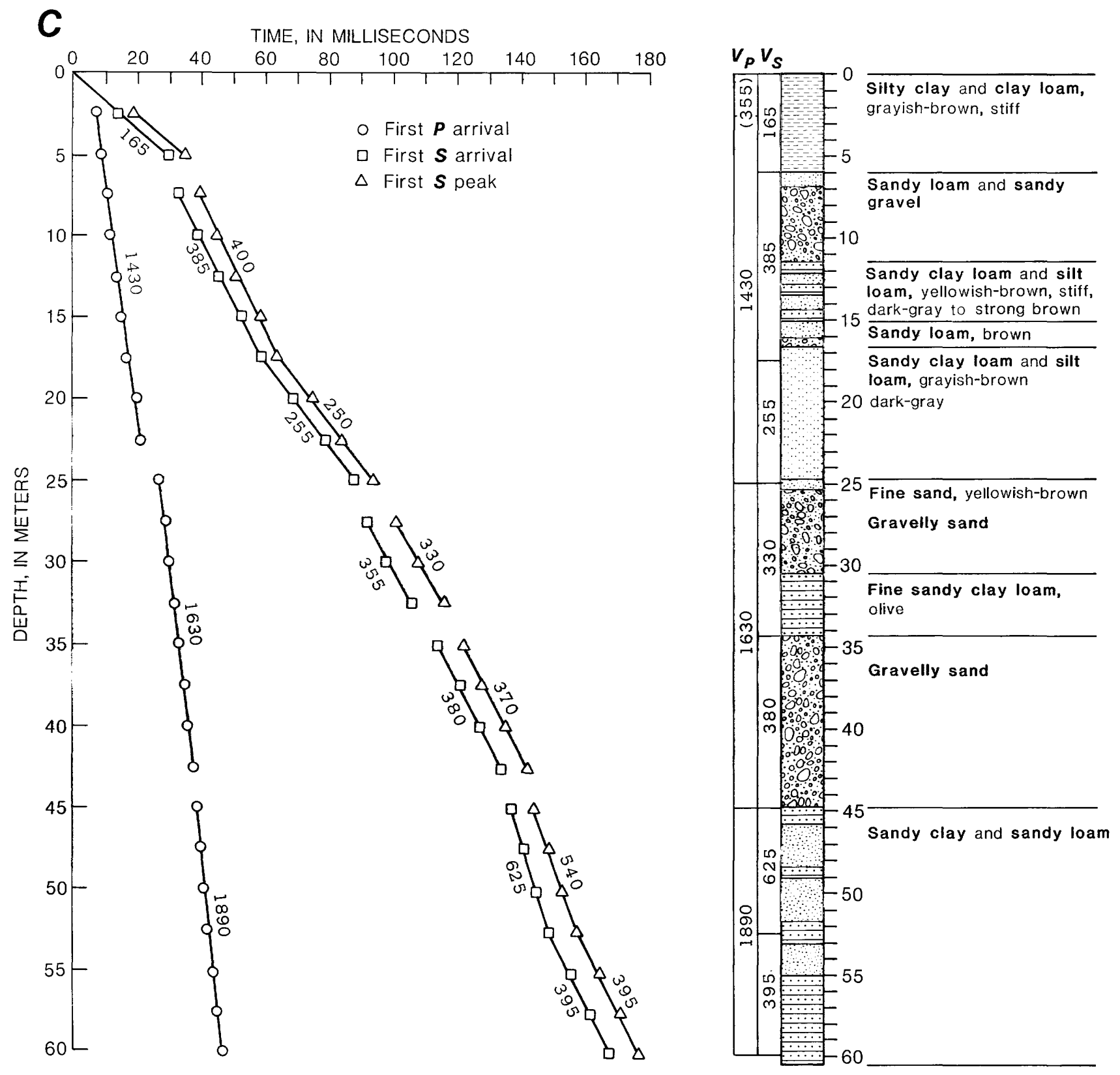

Figure 9.2. Continued 


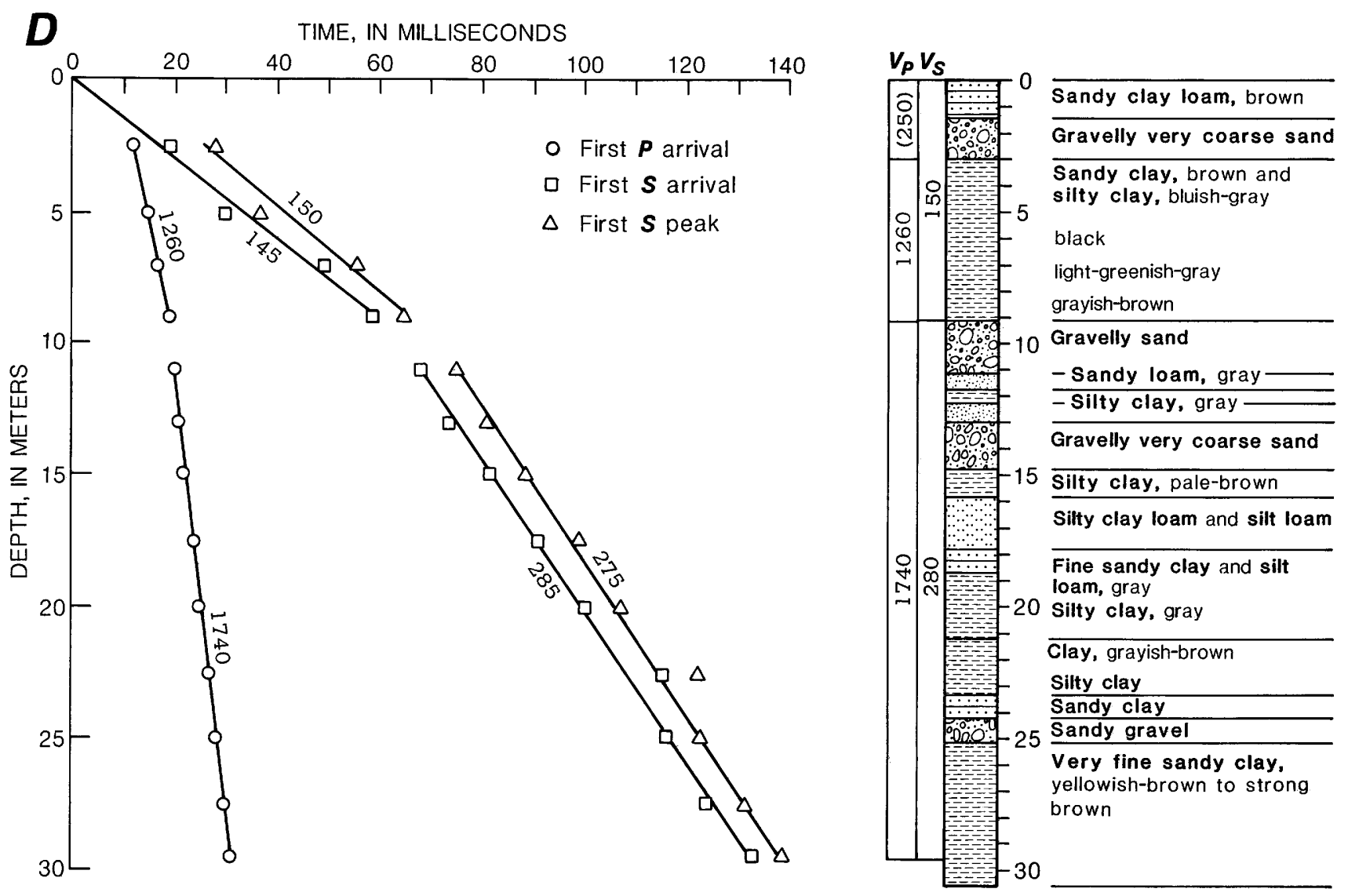

Figure 9.2. Continued 

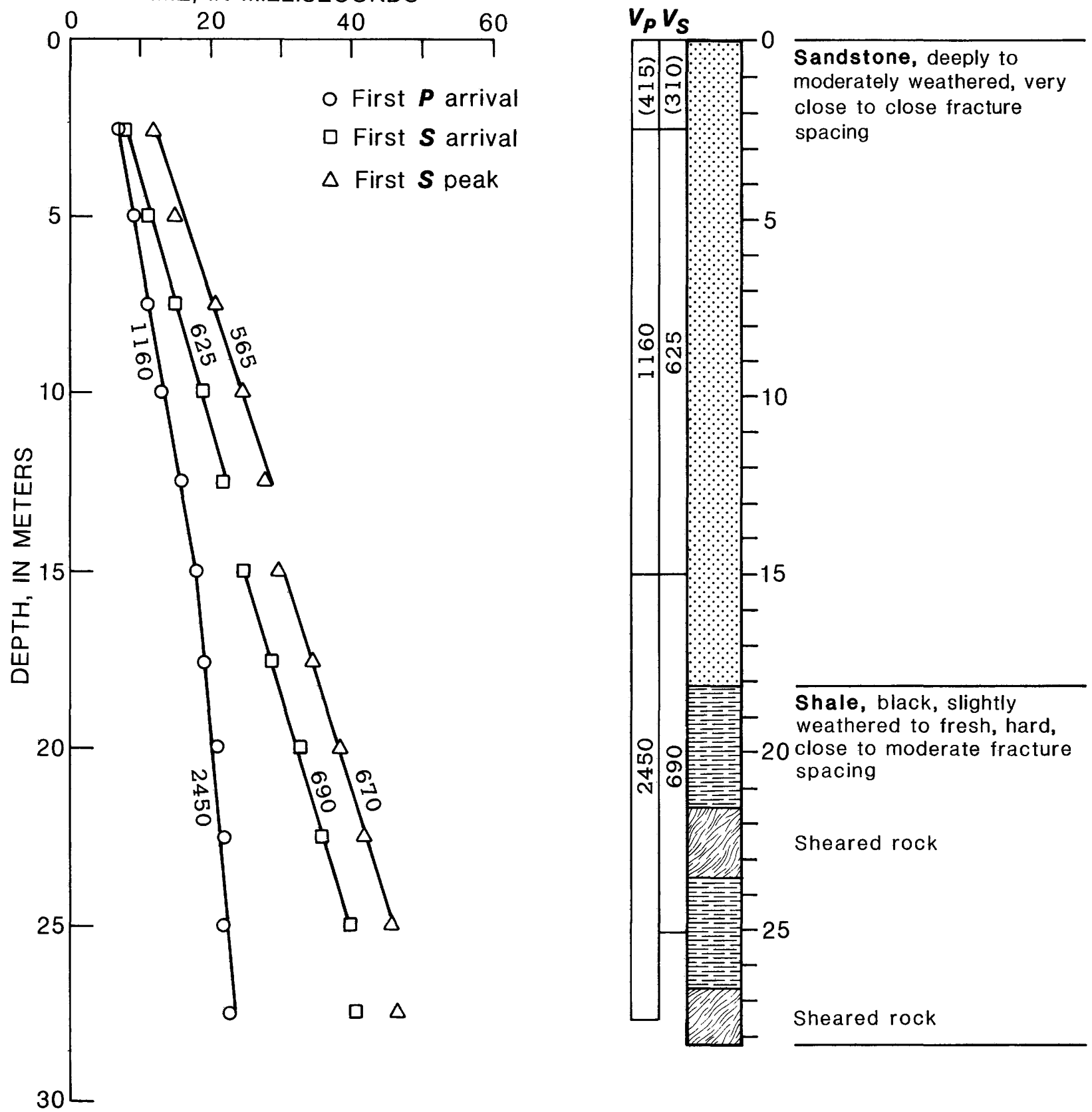

Figure 9.2. Continued 


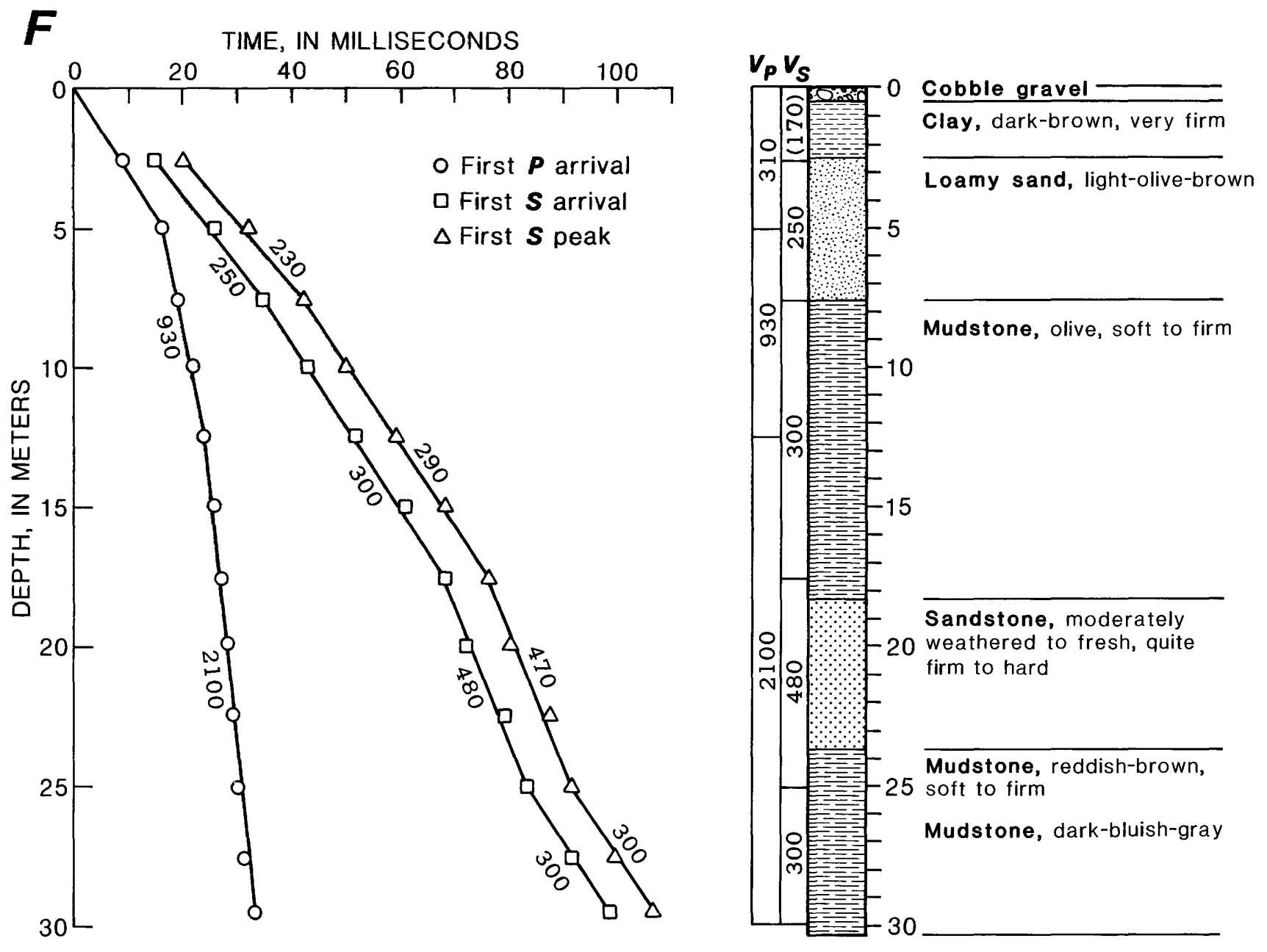

Figure 9.2. Continued 


\title{
Ground-Failure Damage and Liquefaction near Morgan Hill
}

\author{
By T. Leslie Youd
}

\section{CONTENTS}

\author{
Abstruct $\quad 89$ \\ Introduction $\mathbf{8 9}$ \\ Observations $\quad \mathbf{8 9}$ \\ Reference cited $\quad 91$
}

\section{Abstruct}

Several houses in the Jackson Oaks subdivision and the Cochrane Bridge near Morgan Hill, Calif., were damaged during the earthquake. The damage to houses was not directly related to ground failure, although a fissure, probably the head of an incipient slope failure, did cause pipeline breaks near the damaged houses. Damage to the south end of the Cochrane Bridge may have been due to movement of a deep landslide under the bridge abutment. Liquefaction occurred in one place near the east shore of the Anderson Reservoir, where sand boils and fissures due to lateral spreading were found.

\section{INTRODUCTION}

The earthquake caused severe damage to several houses and a bridge in the Morgan Hill area, and generated a few minor liquefaction effects. My study investigated the influence of ground failure on earthquake damage and the extent of the liquefaction effects.

\section{OBSERVATIONS}

Initial news reports from the Morgan Hill area noted that several houses were set "off their foundations" in the Jackson Oaks subdivision (fig. 10.1). This damage could have been caused by either ground shaking, faulting, or ground failure. I inspected the more severely damaged of these homes, however, and found that the perimeter and interior footings were not damaged by the earthquake. Thus, the damage was caused by ground shaking. The severe damage to structures was due to shear deformation within the wall immediately above the foundation. In most places, the exterior sheeting, either plywood or

fiberboard, provided inadequate shear resistance for these structures. Fracturing or pulling away of this sheeting from the wall during the earthquake allowed the walls to distort in shear. These distortions, in turn, caused the houses to shift "off" or away from their foundations (fig. 10.2; see figs. 11.8, 11.9, house $1)$.

A conspicuous east-west fissure cracked driveways and the street near the crest of the hill, along Ouk Ridge Court, upslope from the damaged houses described above (fig. 10.3; see front of house 3, fig. 11.8). This fissure, which was as wide as $50 \mathrm{~mm}$ and contained scarps as high as $150 \mathrm{~mm}$ down to the south, probably was caused by local ground failure and probably marked the head of an incipient slope failure. The fissure and accompanying minor downslope movement, however, had no detectable direct influence on damage to the houses, although one or more pipeline breaks occurred along the fissure.

A bent ${ }^{1}$ supporting the south end of the Cochrane Bridge (Dunne Avenue) was tilted and fractured by the earthquake (fig. 10.4). The cause of the damage to this bent may have been downslope movement of a deep landslide that pushed or carried the pier supporting the bent toward the reservoir.

Fissures caused by landslide movements fractured the pavement of Dunne Avenue on both sides of the Anderson Reservoir. Many of the fractures broke through recent patches in the road pavement. Interviews with local residents confirmed that landslides had considerably disrupted the road during the previous winter but that repairs had been made before the earthquake. Many of these landslides were

${ }^{1} \mathrm{~A}$ bent is a structural frame, generally trapezoidal, that provides vertical and lateral support to a bridge, building, or other structure. 


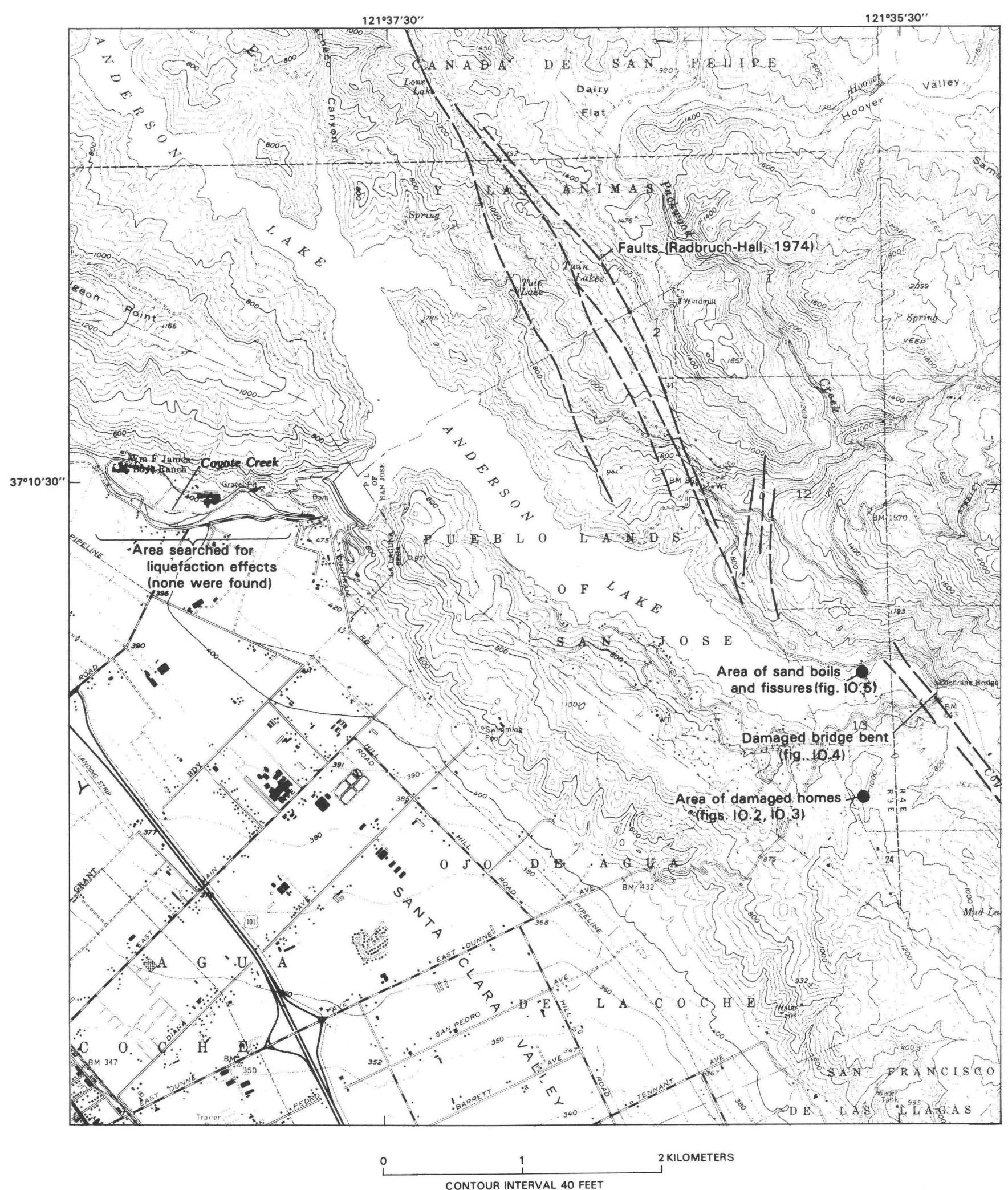

Figure 10.1. Area near the Anderson Reservoir, Calif., showing locations of earthquake effects described in this report. Topography from U.S. Geological Survey, Morgan Hill and Mount Sizer 7.5-minute quadrangles, photorevised 1980. 

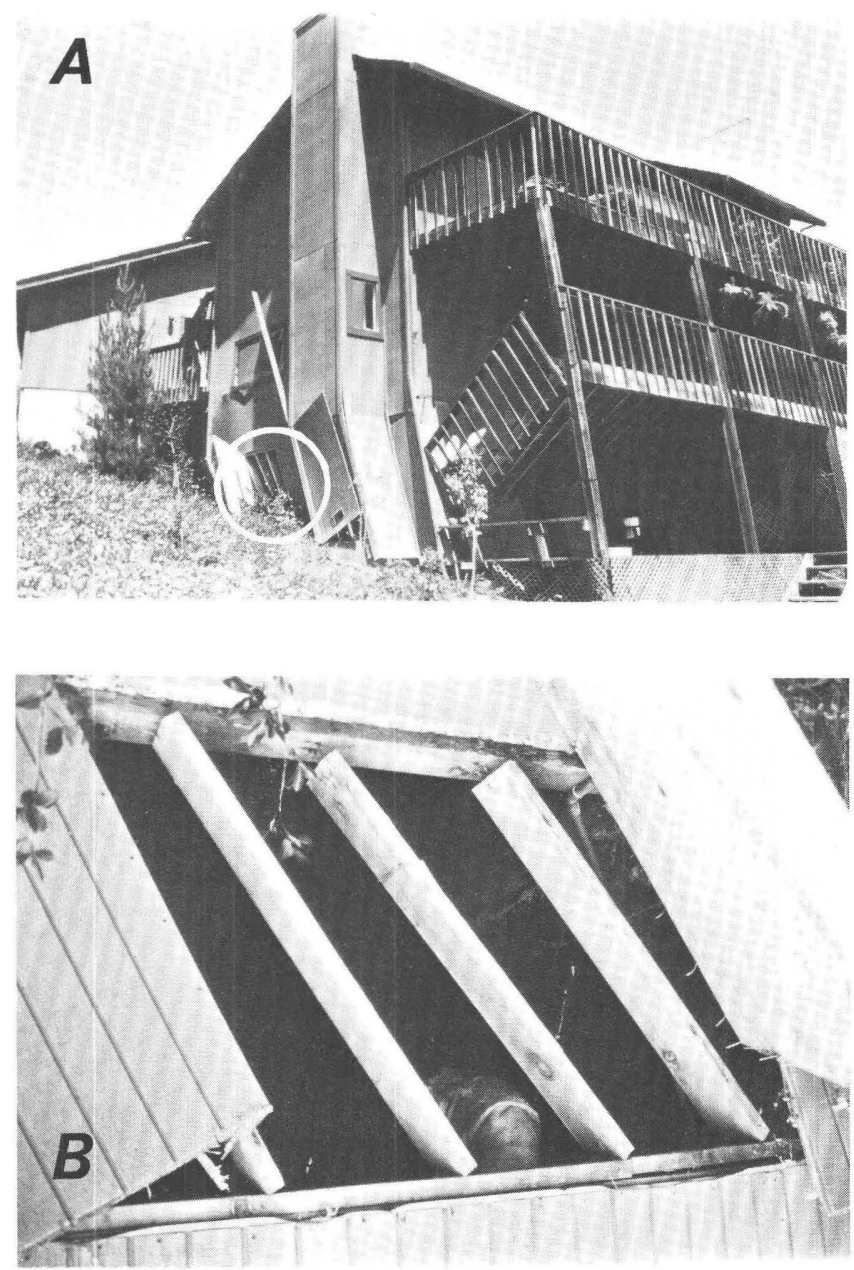

Figure 10.2. A house described as "off its foundation" in Morgan Hill. Perimeter and interior footings of house are intact and were undamaged by the earthquake. Lateral displacement of house and consequent damage was due to shear deformation within wall immediately above foundation. A, View of house from a distance, showing damage and distortion to structure. Unbroken rotated shear panels appear to have provided little shear protection. B, Closeup of circled area in figure $2 \mathrm{~A}$, showing skewed studs and siding ("shear panels") that pulled of from wall as the structure deformed.

reactivated by the earthquake. Chapter 6 presents more detailed descriptions and delineations of the fissures and landslides in these areas.

A search was made for liquefaction effects in the area surrounding the Anderson Reservoir and in the San Felipe Valley. The only sand boils discovered were at a single locality near the east shore of the reservoir (fig. 10.1). Most of these sand boils erupted through earthquake-generated fissures and deposited thin veneers of sand in generally circular areas surounding each vent (fig. 10.5). Sund-boil deposits were as large

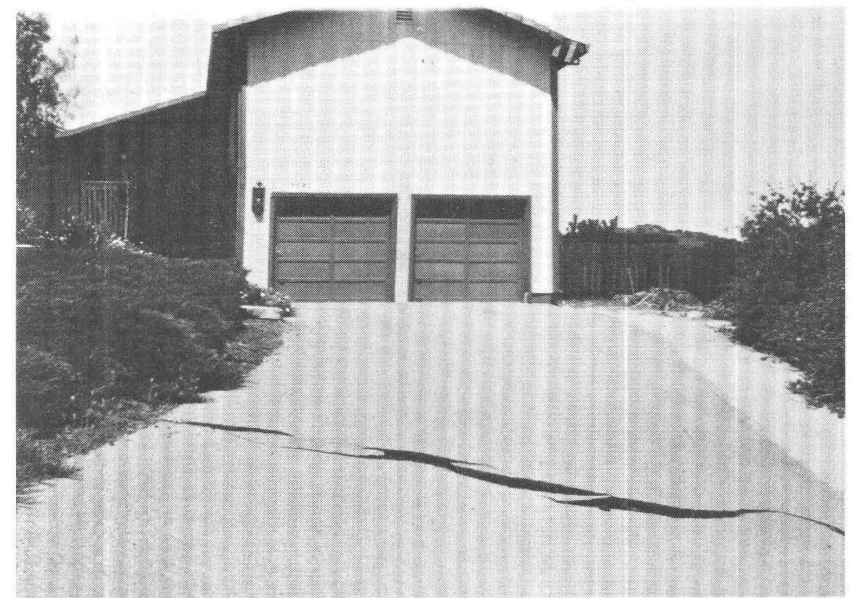

Figure 10.3. Conspicuous fissure in a driveway near crest of hill above house shown in figure 10.1. Fissure was caused by local ground displacement, probably an incipient slope failure, but had no direct influence on damage to houses in the area.

as $1 \mathrm{~m}$ in diameter but only a few centimeters thick. The arcuate fissures, which were as wide as a few centimeters, evidently were caused by minor lateral spreading due to liquefaction.

With the help of M.J. Bennett, I searched several other areas where geologic conditions appeared favorable for liquefaction. In particular, I searched the flood plain and nearby area along Coyote Creek west of the Anderson Reservoir (fig. 10.1), and the lowlands along San Felipe Creek in the San Felipe Valley. I found no sand boils or fissures along Coyote Creek and only a few millimeter-wide cracks along San Felipe Creek. Deltas at the north and south ends of the Anderson Reservoir could contain sedimentury layers susceptible to liquefaction; because of their inaccessibility, we did not search the deltas on foot, although I did view the delta at the south end from a hill about $1 \mathrm{~km}$ away with the aid of binoculars. I could discern no fissures or sand boils on that delta, nor did I hear any reports of fissures or sand boils from others who visited or flew over the deltas and other nearby areas.

The sediment along Coyote and San Felipe Creeks is coarse and contuins a large fraction of gravel and cobbles. This coarseness may render the sediment too permeable for buildup of pore-water pressure and the onset of liquefaction.

\section{REFERENCE CITED}

Radbruch-Hall, D.H., 1974, Map showing recently active breaks along the Hayward Fault zone and the southern part of the Calaveras fault zone, California: U.S. Geological Survey Miscellaneous Investigations Series Map I-813, scale 1:24,000, 2 sheets. 


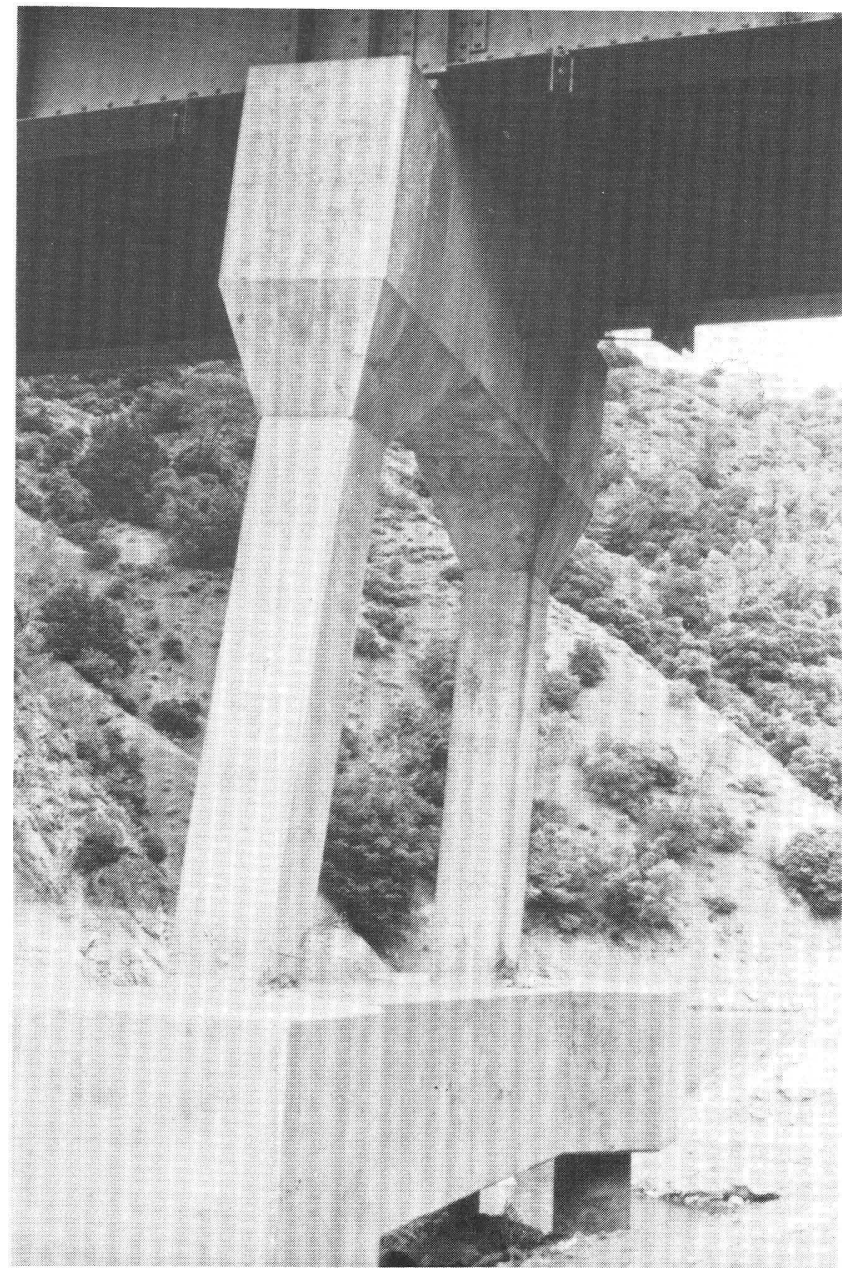

Figure 10.4. Tilted and fractured bent of the Cochrane Bridge. Tilting and fracturing of bent were possibly caused by deep-seated movement of a landslide that pushed or carried pier supporting bent toward the Anderson Reservoir (to left).

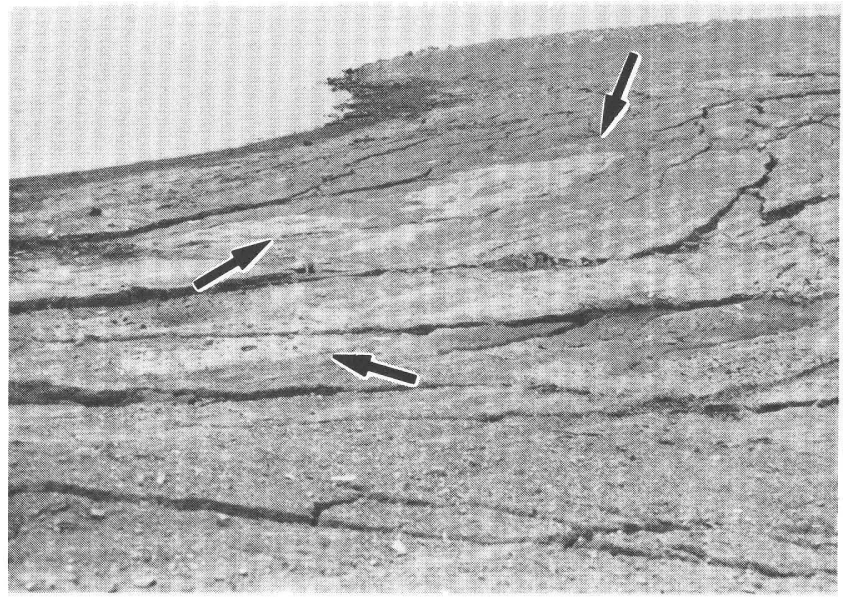

Figure 10.5. Sand boils (arrows) and fissures near shoreline on east side of the Anderson Reservoir. Liquefaction and minor lateral spreading caused these features. 


\title{
Structural Damage near Morgan Hill
}

\author{
By Scott A. Mathieson
}

\section{CONTENTS}

\author{
Abstract 93 \\ Introduction 93 \\ Summary of damage $\quad 93$ \\ References cited 101
}

\begin{abstract}
The earthquake caused approximately $\$ 7.5$ million in property damage in the town of Morgan Hill and the surrounding area. An unreinforced-masonry building underwent the most external damage in downtown Morgan Hill. Residential structures in the Jackson Oaks housing tract and the Madrone Mobile Estates park were the only ones that underwent more than superficial damage. The Cochrane Bridge was shortened and rotated during or shortly after the main shock, and was temporarily closed. Many items large and small, such as houses, trailers, water tanks, and potted plants, toppled northward; this observation suggests that the first strong ground motion during the main shock was toward the south.
\end{abstract}

\section{INTRODUCTION}

About $\$ 7.5$ million in property and structural damage occurred during the earthquake. Most of this damage was only light to moderate and occurred within an asymmetric zone, parallel to the Calaveras fault, extending from $3 \mathrm{~km}$ northward to $20 \mathrm{~km}$ southward of the main-shock epicenter (fig. 11.1). This chapter reports on all the earthquake damage to property or structures that I observed during postearthquake field investigations. Additional descriptions of much of the damage are given in chapters 6 and 11 (Mathieson, 1984; Harms and others, 1984).

\section{SUMMARY OF DAMAGE}

Exterior damage to commercial buildings within the town of Morgan Hill (fig. 11.2) during the main shock was limited to the unreinforced-masonry "1905" or South Coast Realty Building (fig. 11.3). A shattered plate-glass window was the only damage observed at the Corner Drug Store. At Pearson's Hardware and Supply (loc. 3, fig. 11.2), items stored outside, such as rolls of roofing and bags of fertilizer, toppled northward. Items inside, on north-facing shelves, were thrown to the floor (fig. 11.4). Items on south-facing shelves shifted but did not fall from shelves. Other businesses reported minor to moderate damage to their inventory but were not visited. Across the street at the Hammond Brothers Wholesale Lumber Co. (loc. 5, fig. 11.2), stacks of lumber as tall as $5 \mathrm{~m}$ did not shift. I visited the Emilio Guglielmo Winery (loc. 4, fig. 11.2). Damage to the winery buildings consisted of about $30 \mathrm{~m}^{2}$ of sheetrock that fell from the ceiling of a storage room adjacent to a reinforced cinderblock wall, $7 \mathrm{~m}$ tall (fig. 11.5). Damage inside the buildings included toppling of several 180 -gal wooden winestorage barrels stacked cannonball fashion, shifting of 8,000 -gal wooden storage barrels on their timber-andblock footings, and shifting of both empty and full 10,500-gal stainless-steel wine-storage tanks resting on concrete pads. Empty free-standing steel tanks were rotated clockwise $2.5 \mathrm{~cm}$ (fig. 11.6); southward shifting of full steel tanks $2.5 \mathrm{~cm}$ caused the tank bases to buckle inward and outward within consistent southern azimuthal ranges between $150^{\circ}$ and $210^{\circ}$.

Although exterior damage to residential structures was widespread, only the residences at Jackson Oaks and the Madrone Mobile Estates were damaged more than superficially. The Jackson Oaks housing tract lies immediately west of the main active trace of the Calaveras fault. Five wood-frame homes in this hilltop housing tract (loc. 6, fig. 11.7) were abandoned immediately after the main shock (figs. 11.8-11.10; see figs. 10.2, 10.3). Damage to these homes may have been due to high horizontal ground accelerations; a $1.29-\mathrm{g}$ peak horizontal acceleration was measured at the Coyote Lake Dam (sta. CYC), about $5.6 \mathrm{~km}$ south of the homesites (see chap. 5). Station CYC is too poorly located, on bedrock and soil (damfill), for accurate measurement of strong ground motion; the Anderson Dam, crest, station (1652), about 
$4 \mathrm{~km}$ northwest of the homesites, yields equal or better estimates of strong ground motion, between 0.2 and $0.6 \mathrm{~g}$. The high ground acceleration and the duration of strong ground motion may have contributed to the failure of shear and pony walls at the studsillplate contact (houses 1-3, fig. 11.8; fig. 11.10; see figs. 10.2, 10.3). Each of the five most severely damaged homes showed that strong ground motion was to the south. Lawn ornaments, fountains, and potted plants also toppled nor thward (fig. 11.9).

The Madrone Mobile Estates (loc. 7, fig. 11.2), near the center of the southern Santa Clara Valley, is $5 \mathrm{~km}$ west of the main active trace of the Calaveras fault. Many of the trailers in one small section of the park tilted out of plumb (fig. 11.11) or toppled northward (fig. 11.12) from their jackpost supports, observations suggesting that the greater intensity of ground acceleration in this area might be related to some localized subsurface condition. Two additional trailer parks were investigated near the Madrone Mobile Estates; neither of these other parks, nor the remaining two-thirds of the Madrone Mobile Estates, showed any evidence of permanent shifting or collapse. Potted plants toppled northward at the Madrone Mobile Estates, just as they did at Jackson Oaks.

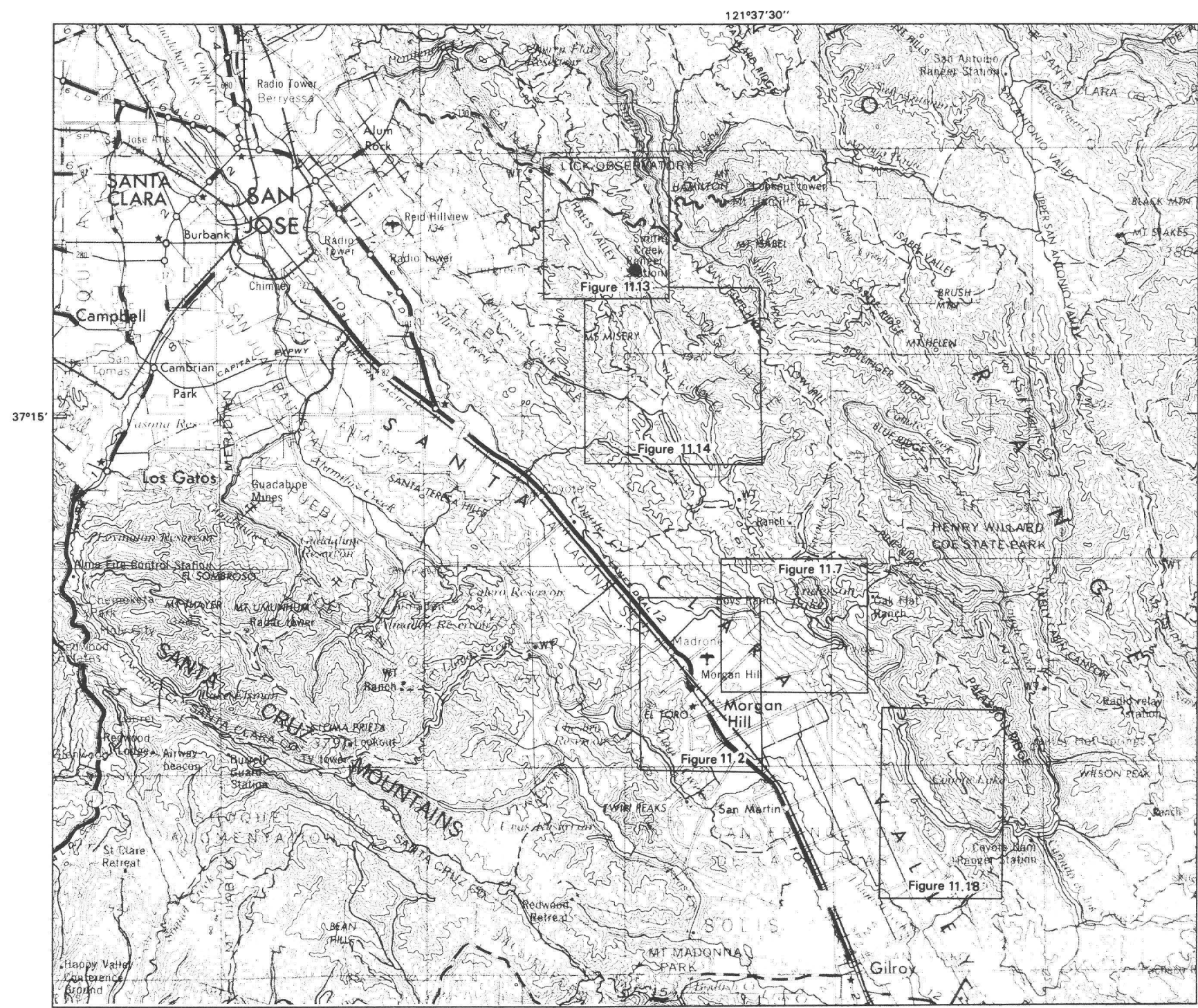

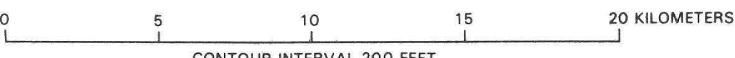

Figure 11.1. Santa Clara Valley, Calif., showing access routes, epicenter of the April 24 main shock (dot), and locations of figures $11.2,11.7,11.13,11.14$, and 11.18 . 


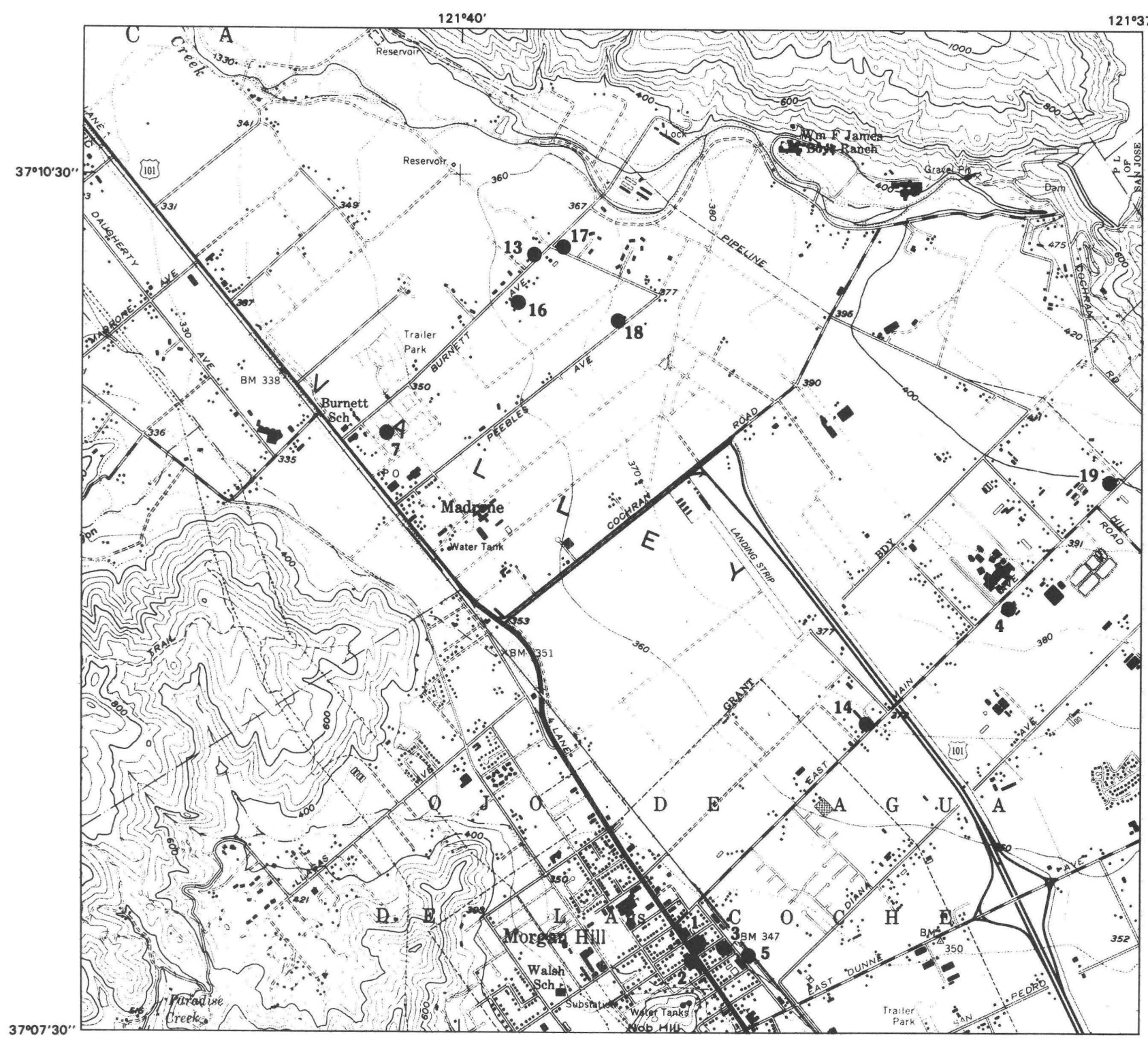

$\underbrace{1}_{\text {CONTOUR INTERVAL 40 FEET }}$ MILE

Figure 11.2. Morgan Hill, Calif., area, showing localities in vicinity of the downtown.

No external damage to any residential structures were found in Halls Valley (loc. 8, fig. 11.13), $5 \mathrm{~km}$ north of the main-shock epicenter. In contrast, homes in the San Felipe Valley (loc. 9-west, fig. 11.14), 5 to 7 $\mathrm{km}$ south of the main-shock epicenter, sustained minor foundation stemwall ${ }^{1}$ cracking (fig. 11.15) and separation and settlement of concrete slabs (fig.

${ }^{1}$ The stemwall of a foundation is the vertical concrete or cinderblock wall below the wooden sillplate and above the widened footing. The footing and part of the stemwall are generally buried beneath the ground.
11.16). Damage to the contents of many San Felipe Valley homes was reported by local residents (loc. 9). Most damage in the San Felipe Valley seems to be related to minor lateral spreading of Holocene and late Pleistocene valley-fill deposits adjacent to San Felipe Creek. Although barns have less shear protection than is normally found in homes, none of the barns investiguted in Halls Valley (loc. 10, fig. 11.13) or the San Felipe Valley (loc. 11, fig. 11.14) exhibited distortion or damage.

Wooden water tanks appear to be reliable qualitative indicators of ground shaking. The only earthquake-related damage discovered in Halls Valley was to a $3-\mathrm{m}$-tall by $3-\mathrm{m}$-diameter hooped water tank resting on the ground in a slight swale on a hillslope (loc. 12, fig. 11.13; fig. 11.17). The tank hoops shifted 


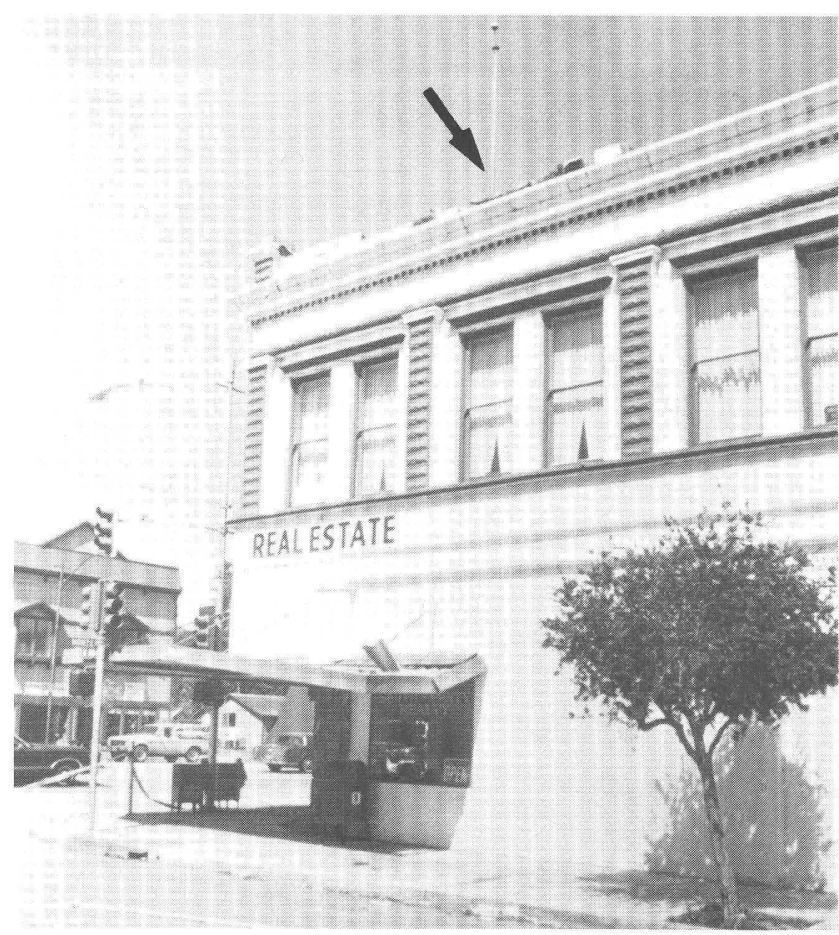

Figure 11.3. The 1905 or South Coast Realty Building (loc. 1, fig. 11.2). Tumbled part of roof cornice fell to north (arrow). Note partly collapsed awning near left corner of building that was struck by a heavy object, possibly a block from the cornice. View northwestward.

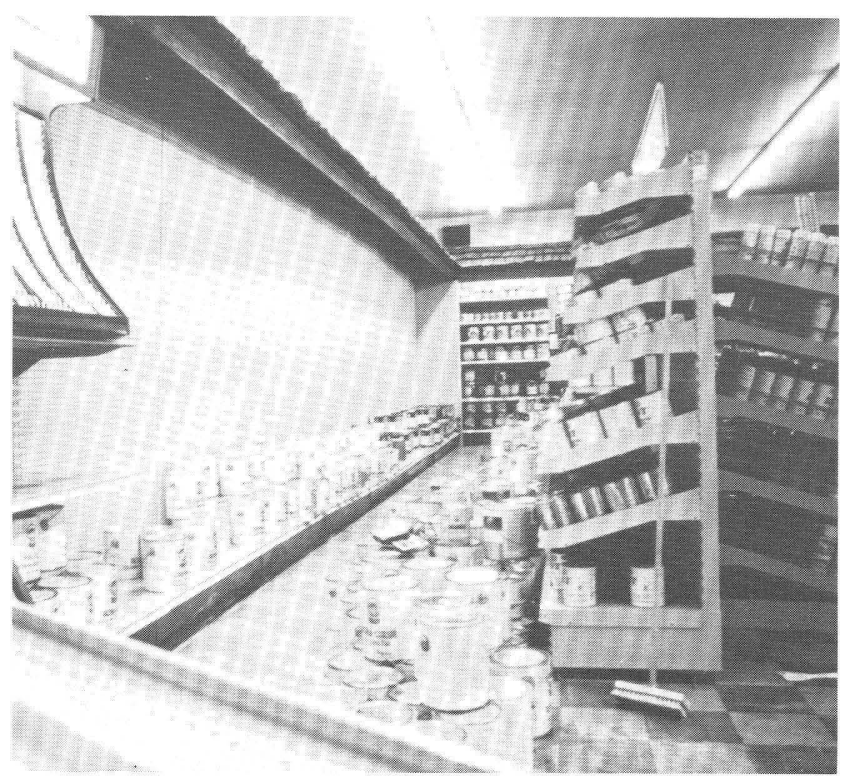

Figure 11.4. Inside of Pearson's Hardware at the corner of Second and Depot Streets (loc. 3, fig. 11.2). Paint cans on north-facing shelves were thrown into aisles; cans on south-facing shelves remained on the shelves. Paint in this area of the store was ankle deep. View westward; north is to right.

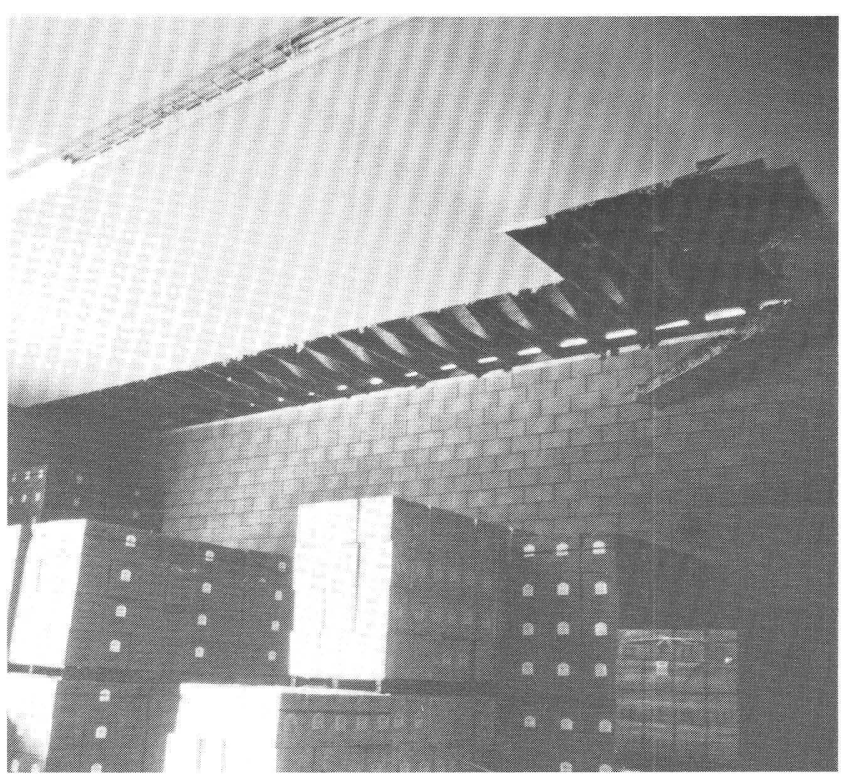

Figure 11.5. Sheetrock fell from ceiling adjacent to westernmost cinderblock wall at the Emilio Guglielmo Winery, 1480 Main Street (loc. 4, fig. 11.2). View westward.

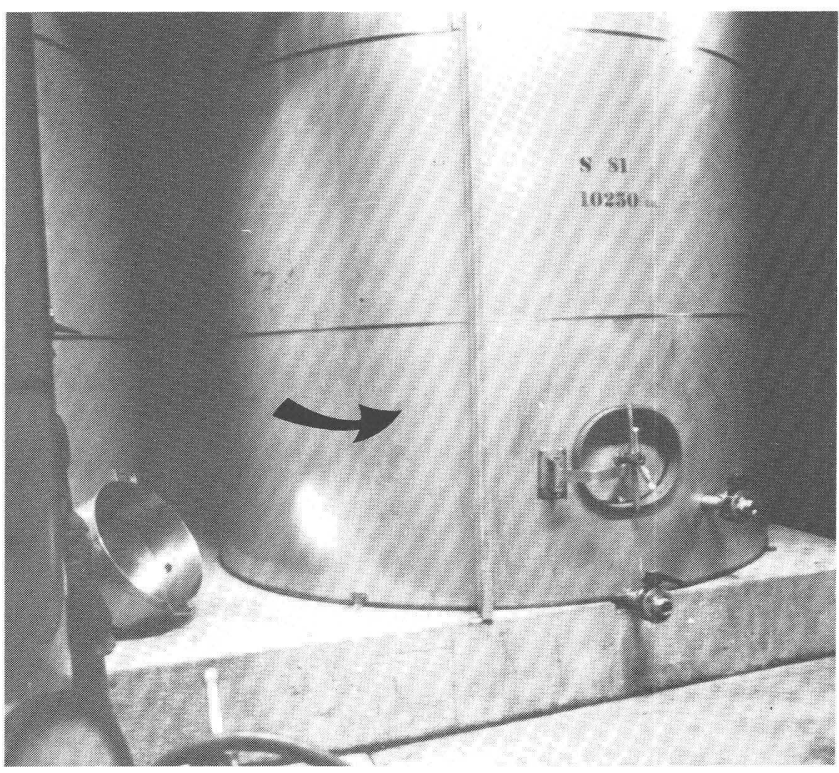

Figure 11.6. Inside of the Emilio Guglielmo Winery (loc. 4, fig. 11.2), showing 10,250-gal storage tank welded to a catwalk support, which, in turn, was bolted into the concrete pad. This stainless-steel tank rotated $2.5 \mathrm{~cm}$ counterclockwise (to right in direction of arrow), and the catwalk was twisted. The tank was empty. Tanks that were filled to capacity developed "elephant toe" bulges while shifting on the same concrete pad. View west-northwestward. 
systematically (down on the west), and staves were forcibly shifted both inward and outward. Throughout the affected area, water tanks on or near the ground tilted or toppled, generally to the north; shifting of hoops was common (loc. 12, 14, fig. 11.2). Water tanks on wood-frame towers (loc. 15, fig. 11.13; locs. 14-17, fig. 11.2) slid on their tower platforms in no apparently consistent direction; few hoops were shifted.

Dams observed included the Halls Valley Lake Dam (loc. 20, fig. 11.13), the San Felipe Ranch Dam (loc. 21, fig. 11.14), the Anderson Dam (loc. 22, fig.
11.7), and the Coyote Lake Dam and Spillway (loc. 23, fig. 11.18). Only the Anderson Dam sustained any significant damage: minor consolidation cracks formed in the damcrest (figs. 11.19, 11.20). These cracks ( $1 \mathrm{~mm}$ across, with vertical displacements of as much as $1 \mathrm{~cm}$ ) reflected settlement between the core and the upstream and downstream armoring layers. The concrete blockhouse adjacent to the upstream face of the dam, near the center of the dam, rotated toward the reservoir approximately $2.5 \mathrm{~cm}$. Damage to the Coyote Dam was limited to minor consolidation

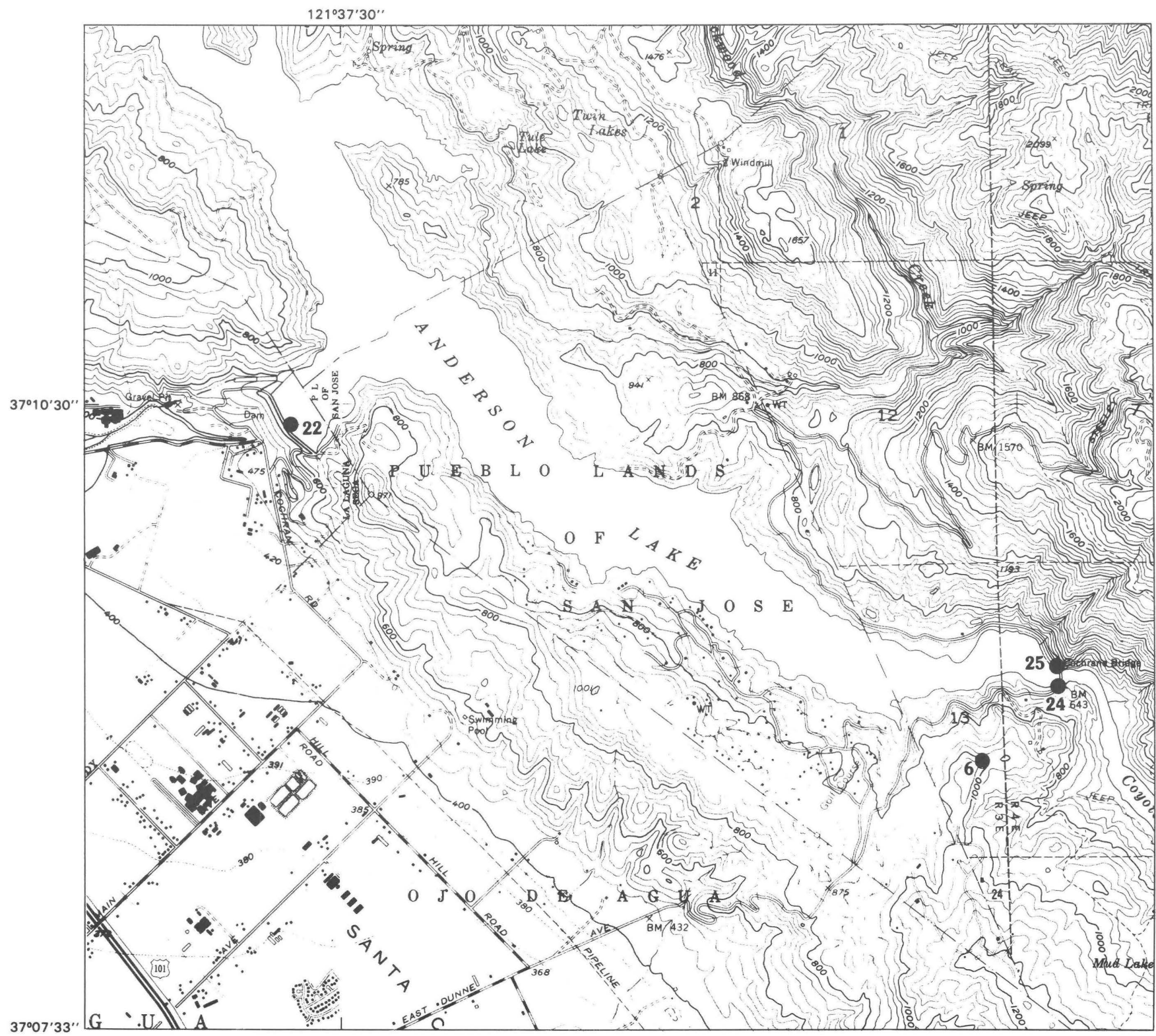

2 1 KILOMETERS

CONTOUR INTERVAL 40 FEET

Figure 11.7. Anderson Lake area, Calif., showing localities discussed in text in the vicinity of Jackson Oaks (loc. 6), the Cochrane Bridge, and East Dunne Avenue. 


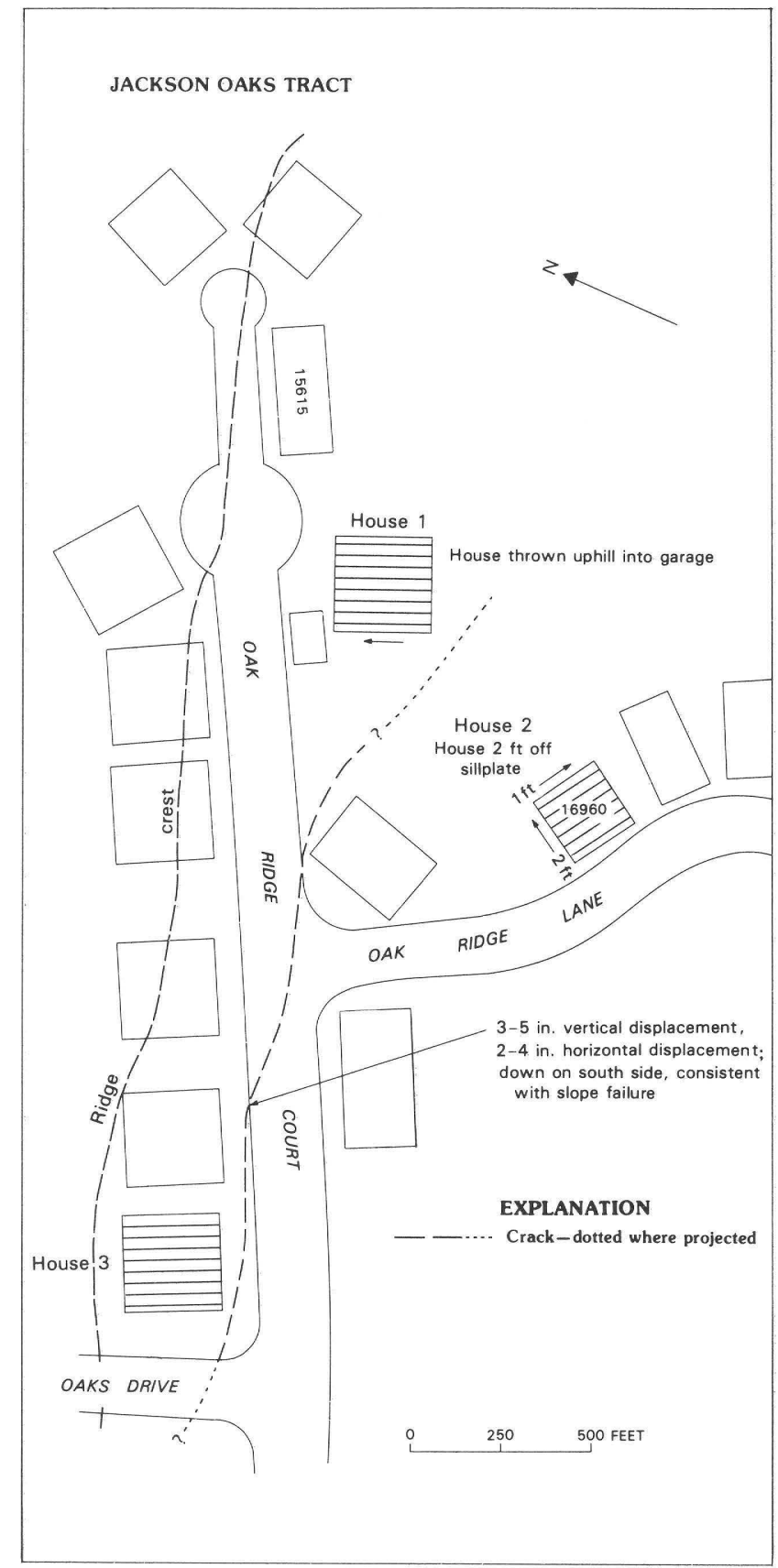

Figure 11.8. Sketch map of part of Jackson Oaks housing tract (loc. 6, fig. 11.7); five-digit numbers are house addresses.

Figure 11.10. House 2 along Oak Ridge Lane (loc. 6, fig. 11.8). Note sillplate (arrow) still secured to concrete perimeter foundation. Ripping of this house from its foundation sillplate suggests high horizontal ground accelerations. View southeastward.

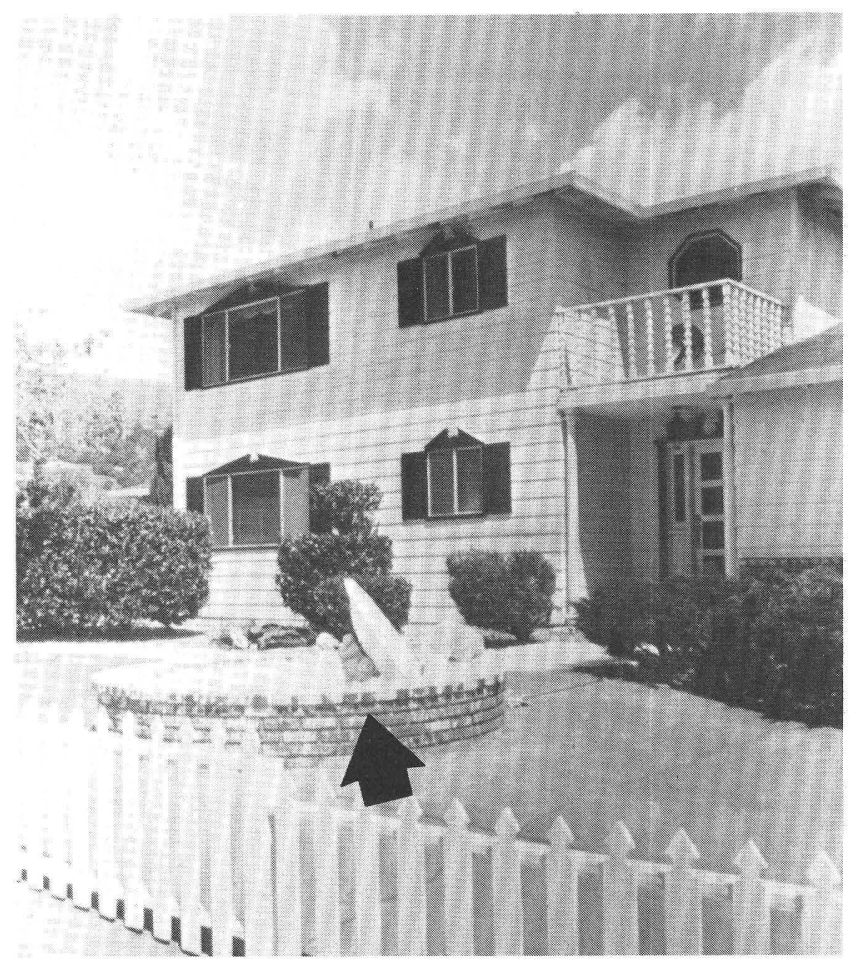

Figure 11.9. Fountain toppled in front yard of house in Jackson Oaks subdivision west of area shown in figure 11.8. View southeastward.

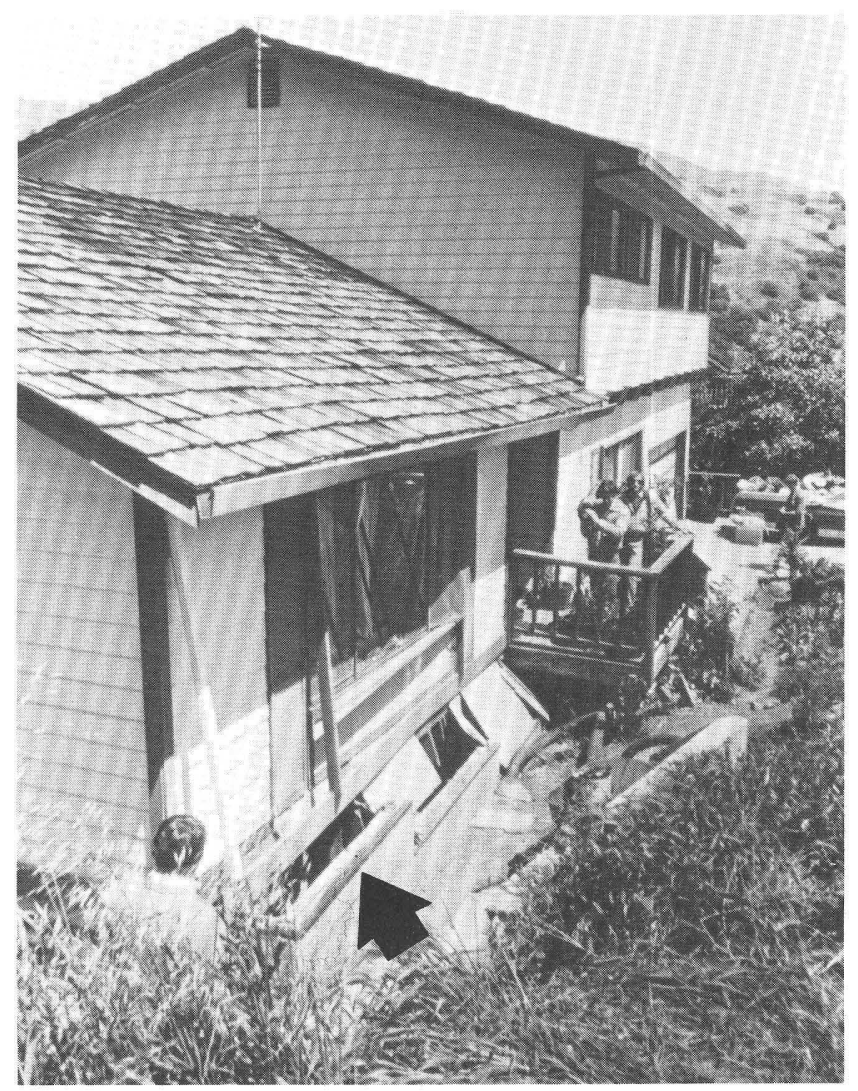


cracks. The general absence of damage to the spillway is noteworthy because the walls of this channel have numerous landslides that have failed repeatedly over many decades. The strong-motion accelerogruph in the Coyote Dam, abutment, recorded a $1.29 \mathrm{-g}$ peak horizontal component of ground acceleration during the main shock.

The Cochrane or Dunne Avenue Bridge (loc. 24, fig. 11.7) was displaced southward approximately 5 to $7 \mathrm{~cm}$ and rotated clockwise (viewed from above) 5 to 7

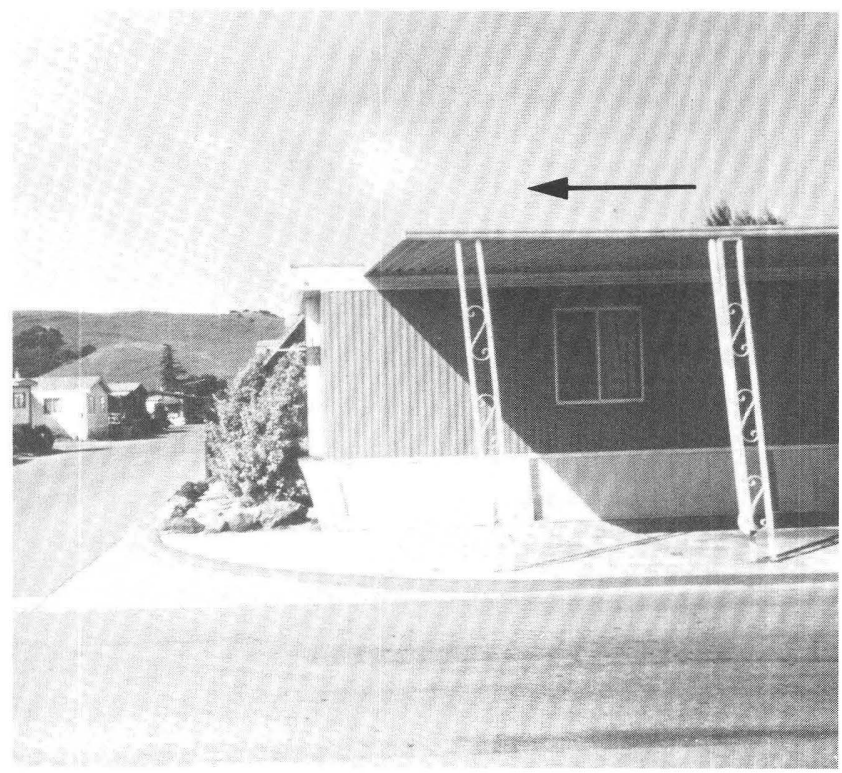

Figure 11.11. Partly collapsed mobile home in Madrone Mobile Home Estates (loc. 7, fig. 11.2). Carport supports were perpendicular to ground before the earthquake. Arrow shows direction of motion. View westward.

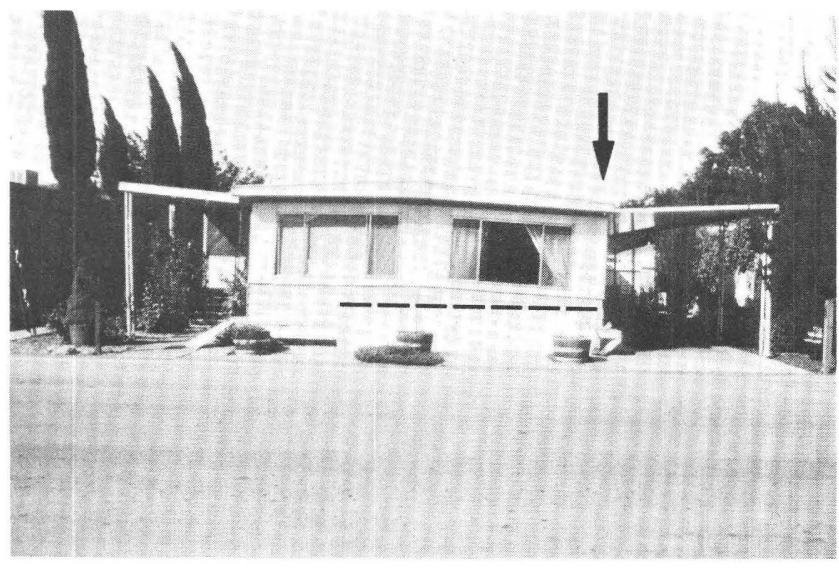

Figure 11.12. Completely collapsed mobil home in Madrone Mobile Home Estates (loc. 7, fig. 11.2). Carport roofs, which sloped away for drainage before the earthquake, now slope toward trailer. Bottom of trailer was at level of top of skirt (dashed line). Arrow shows direction of collapse. View westward. cm during the main shock (fig. 11.21). Because the south abutment of this bridge is actually incorporated into a large complex landslide (fig. 11.22), this abutment may have moved northward, instead of the bridge moving southward. As a result of displacement and rotation of the bridge during fault displacement and (or) landslide movement, the bridge was shortened, I-beam supports were tilted (fig. 11.23), rivets pinning steel I-beams together were torn free, and the concrete bent-bracing pillars spalled at their bases (fig. 11.24).

The only road closure associated with the earthquake occurred along both the north and south accesses to the Cochrane Bridge. Dunne Avenue, which parallels the sides of the Anderson Reservoir, underwent numerous fill and rock-cutslope failures (fig. 11.25). A 15 to $30-\mathrm{m}^{3}$ rock fall that was caused by this earthquake fell into the Dunne Avenue roadbed north of the Cochrane Bridge (loc. 25, fig. 11.7; fig. 11.23). No cracking was observed in any of the other

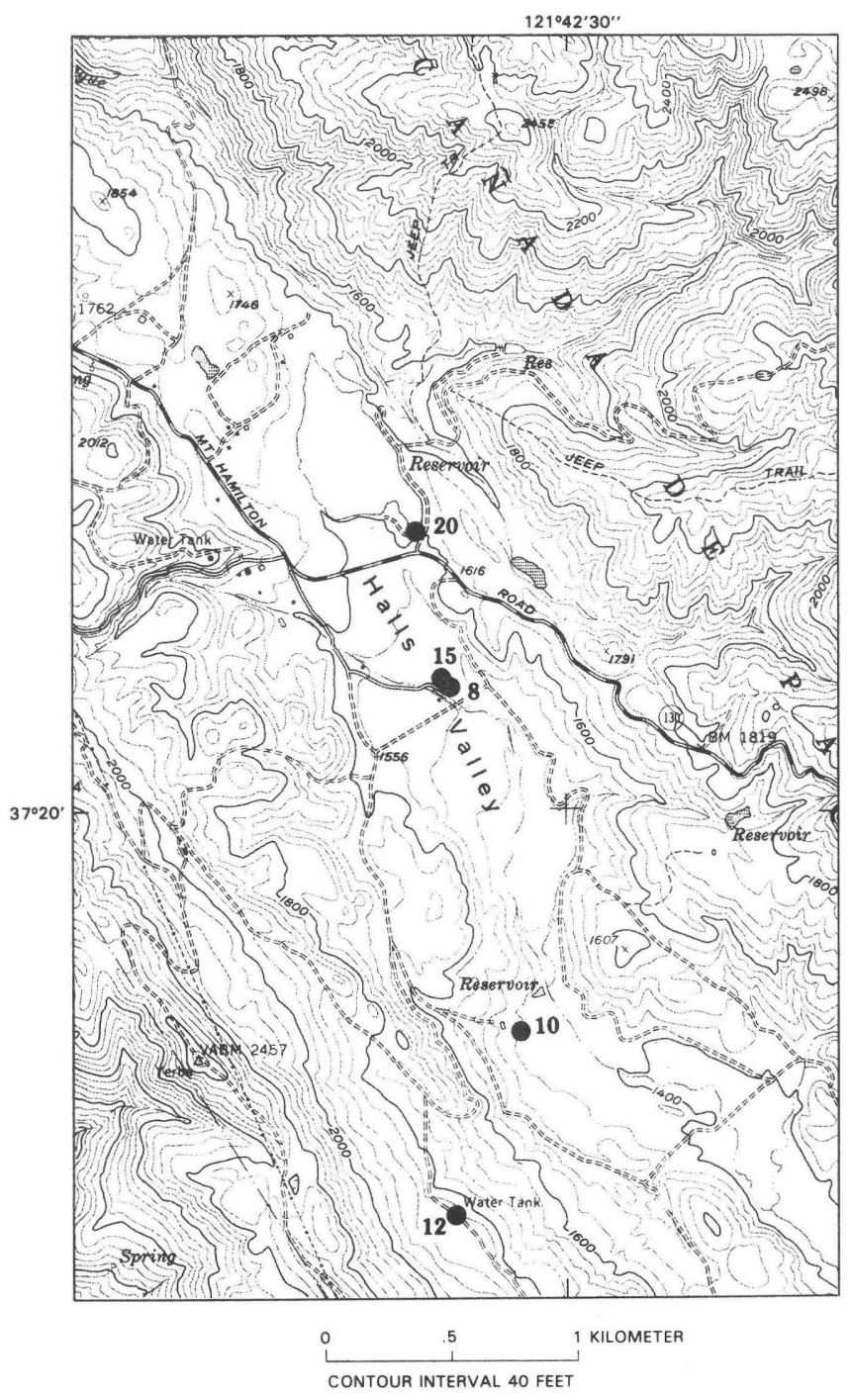

Figure 11.13. Halls Valley area, Calif., showing localities discussed in text. 
paved or unpaved roadways in Halls Valley or around the Coyote Reservoir. No recent cracks related to this earthquake were found on either Roop (loc. 26, fig. 11.20) or Leavsey (loc. 27, fig. 11.20) Roads, which cross and parallel the trace of the Calaveras fault. In the San Felipe Valley, minor cracks (1 $\mathrm{mm}$ wide) parallel to San Felipe Road 2 were discovered shortly after the main shock. Quadrilaterals (sets of survey monuments) were installed across these cracks, and for a period as long as 2 weeks after the earthquake, no movement was noted. The cracks are probably related to settlement of fill.

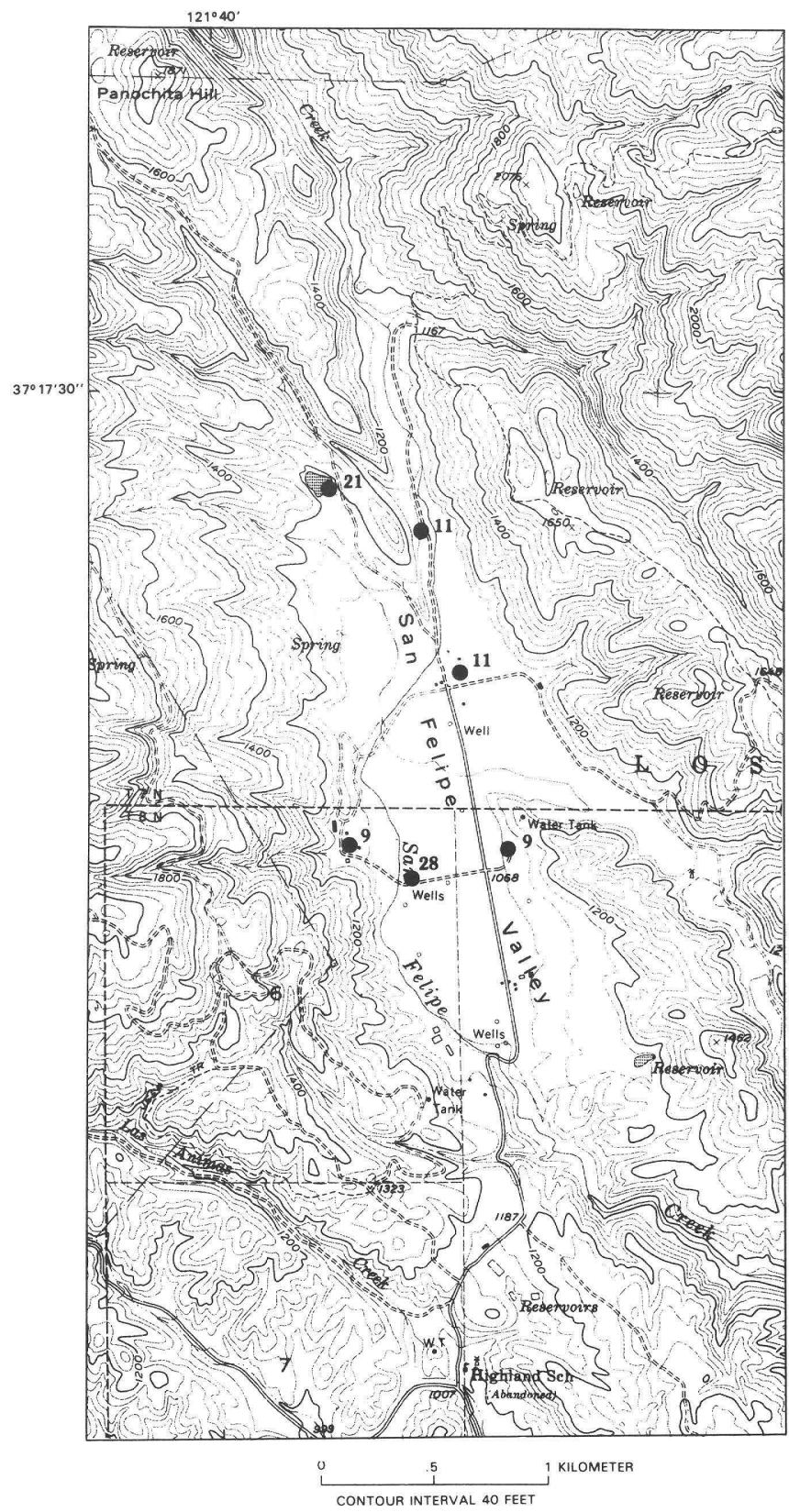

Figure 11.14. San Felipe Valley area, Calif., showing localities discussed in text.

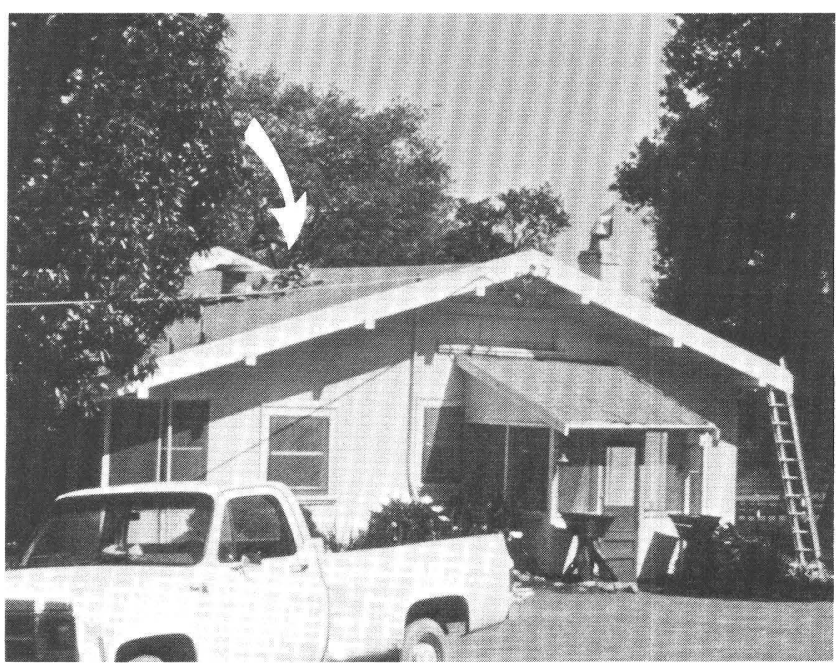

Figure 11.15. Damaged wood-frame house (built about 1914) in the San Felipe Valley. Chimney toppled (arrow) and stemwall cracks developed in perimeter foundation. View east-southeastward.

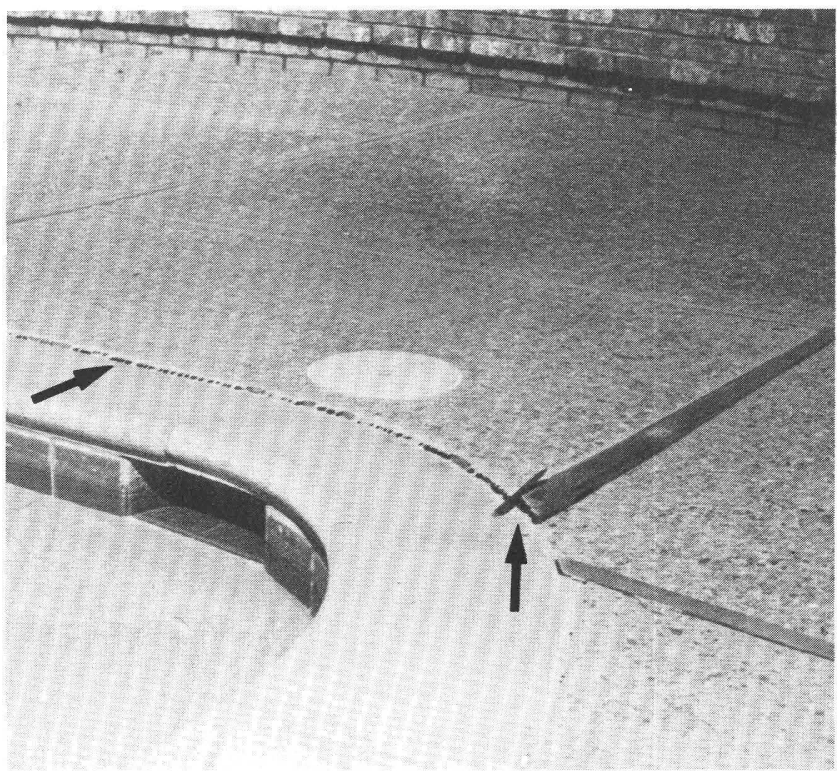

Figure 11.16. Concrete swimming-pool apron in the San Felipe Valley (loc. 9-west, fig. 11.14) that has settled differentially owing to minor lateral spreading of Holocene and late Pleistocene stream deposits. Arrows show different levels of slab surfaces and stretched caulking material. 


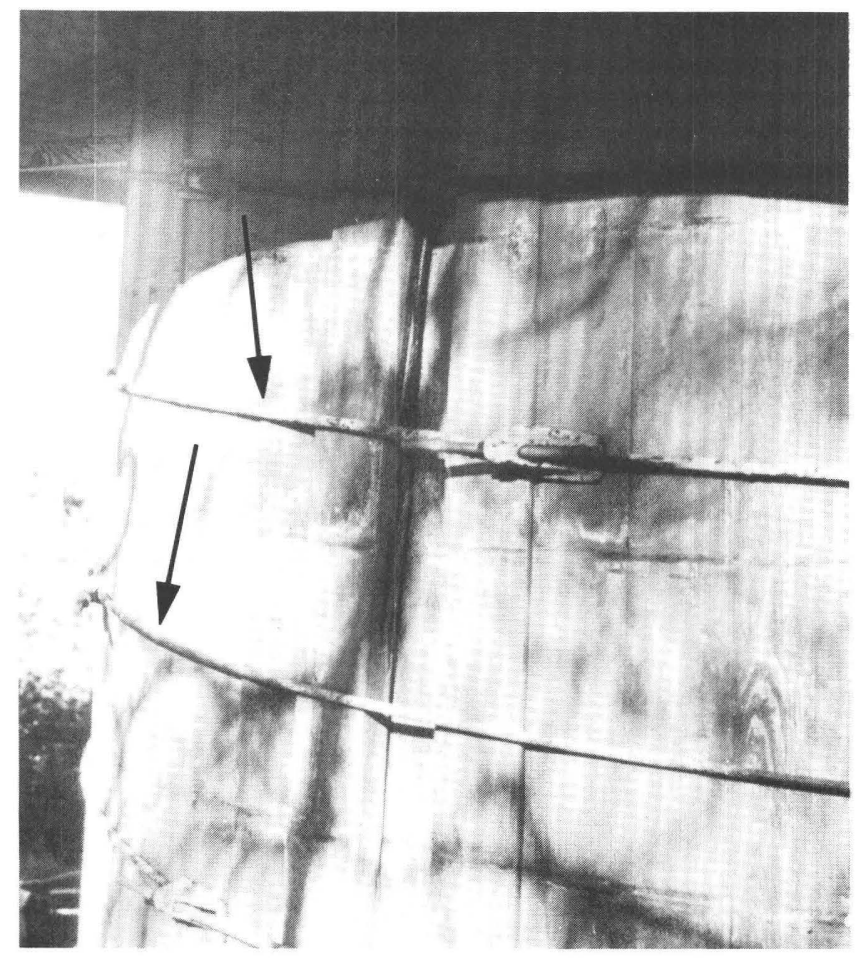

Figure 11.17. Shifted water-tank hoops in Halls Valley (loc. 12, fig. 11.13). Hoops are down to the west; arrows show direction of travel. View eastsoutheastward.

\section{REFERENCES CITED}

Harms, K.K., Clark, M.M., Rymer, M.J., Bonilla, M.G., Harp, E.L., Herd, D.G., Lajoie, K.R. Lienkaemper, J.J., Mathieson, S.A., Perkins, J.A., Wallace, R.E., and Ziony, J.I., 1984, The April 24, 1984 Morgan Hill, California, earthquake: The search for surface faulting, in Hoose, S.N., compiler, The Morgan Hill, California, earthquake of April 24, 1984 (a preliminary report), volume I: U.S. Geological Survey Open-File Report 84-498-A, p. 92-108.

Mathieson, S.A., 1984, Damage to engineered structures associated with the April 24, 1984 Morgan Hill earthquake, Santa Clara County, California, in Hoose, S.N., compiler, The Morgan Hill, California, earthquake of April 24, 1984 (a preliminary report), volume I: U.S. Geological Survey Open-File Report 84-498-A, p. 128-148. 


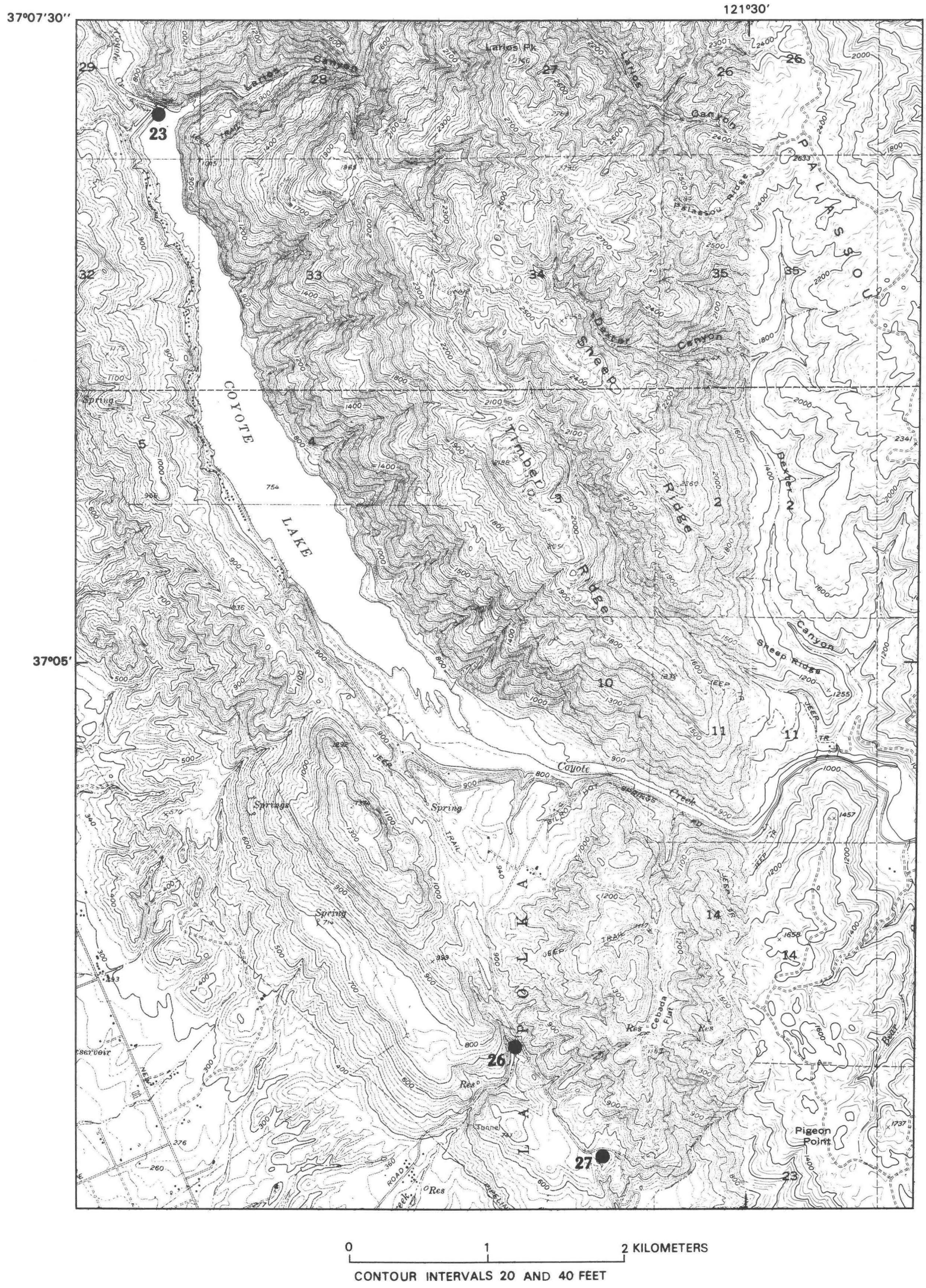

Figure 11.18. Coyote Lake area, Calif., showing localities in vicinity of the Coyote Reservoir. 


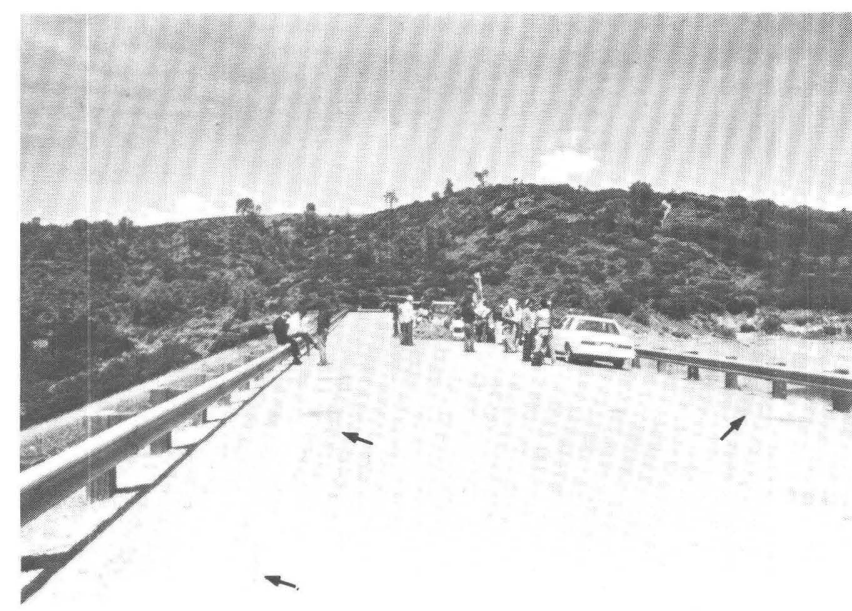

Figure 11.19. Longitudinal cracks developed along crest of the Anderson Dam (loc. 22, fig. 11.7). Trench used to investigate behavior of cracks at depth was excavated parallel to longitudinal upstream crack at right center. Arrows point to crack sets. Upstream is to right. View north-northwestward.

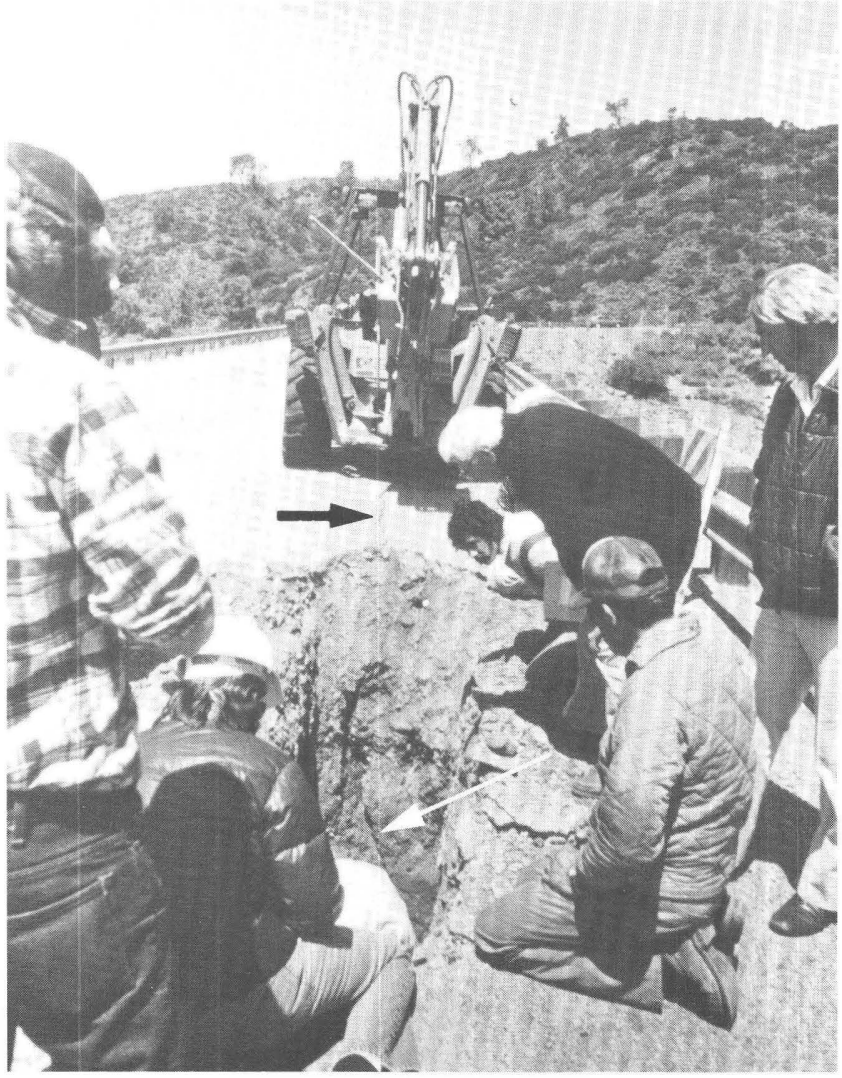

Figure 11.20. Soil-pit-type trench through crest of the Anderson Dam (loc. 22, fig. 11.7). Crack in pavement, visible in north vertical trenchwall, appears to curve outward toward upstream face of dam, to right near bottom of excavation. Arrows point to cracks at surface and at depth. View north-northwestward.

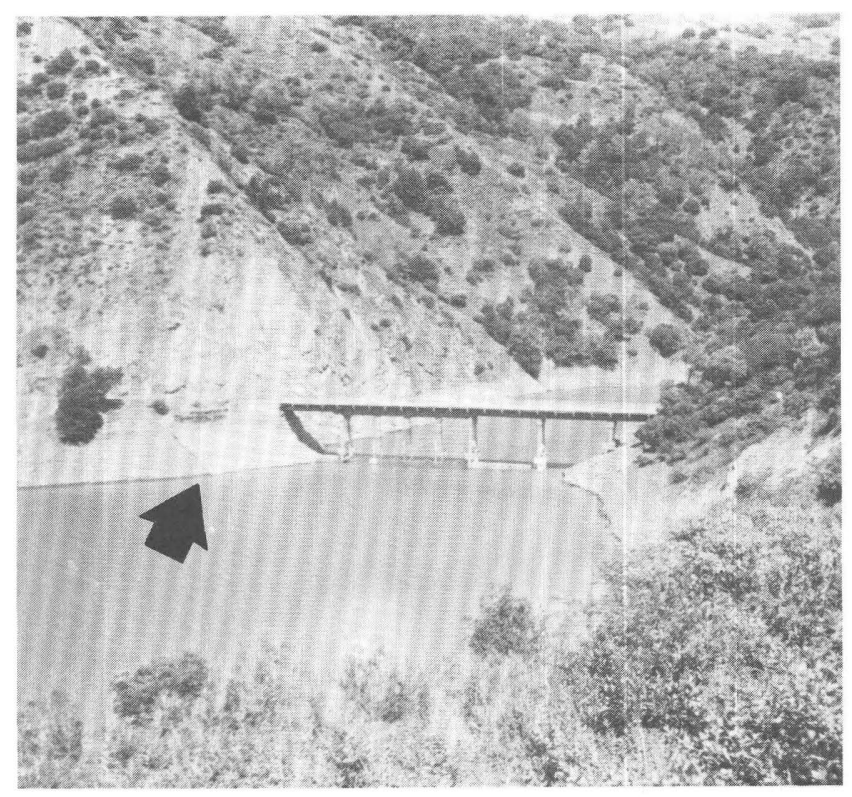

Figure 11.21. Cochrane Bridge over the Anderson Reservoir (loc. 25, fig. 11.7). Bridge has been shortened by telescoping of timbers that support paved roadbed. Rock fall (arrow) covers East Dunne Avenue east of the bridge. View east-southeastward.

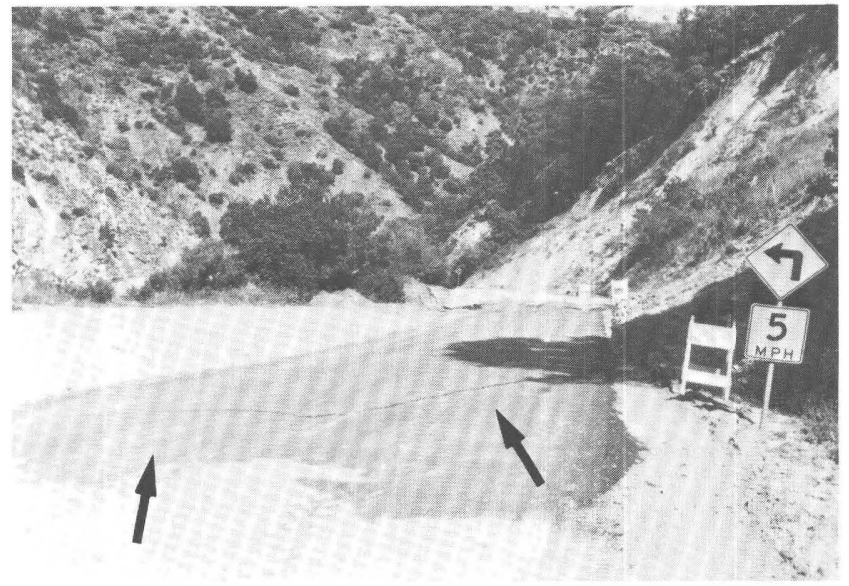

Figure 11.22. Large complex landslide within $0.2 \mathrm{~km}$ of the Cochrane Bridge disrupts East Dunne Avenue right-of-way (adjacent to loc. 24, fig. 11.7) and obscures trace of the Calaveras fault. Arrows point to crack caused by landslide. Note repeated patching of pavement. Rock fall at left is same one shown in figure 11.21. View southeastward. 


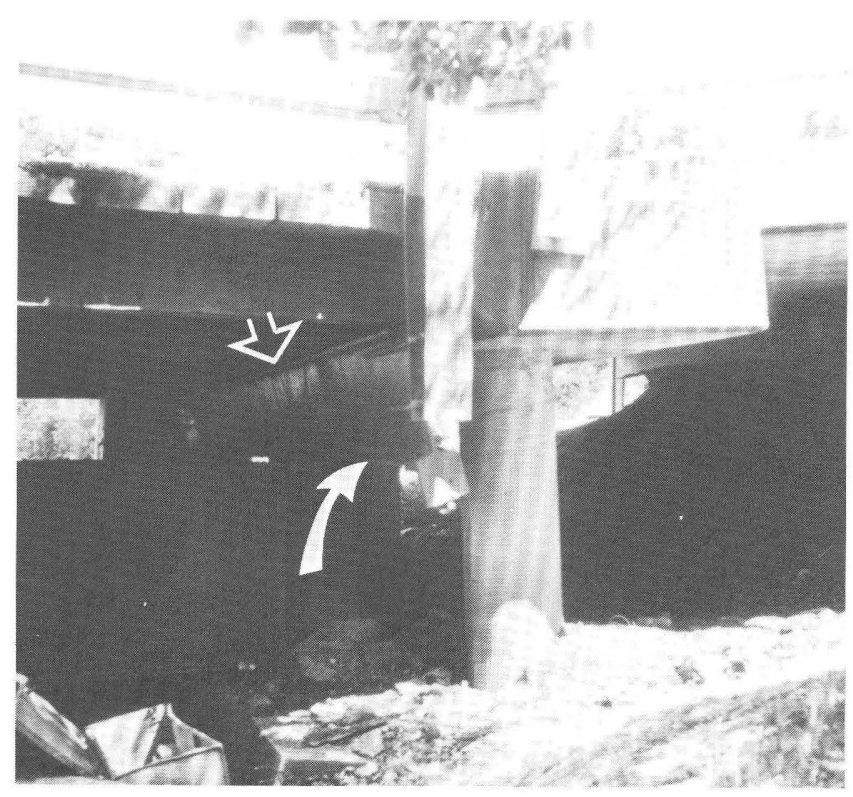

Figure 11.23. Rotated I-beam beneath the Cochrane Bridge (loc. 24, fig. 11.7) and bridge-support timbers (see arrows). Rivets were torn out in several places. View eastward.

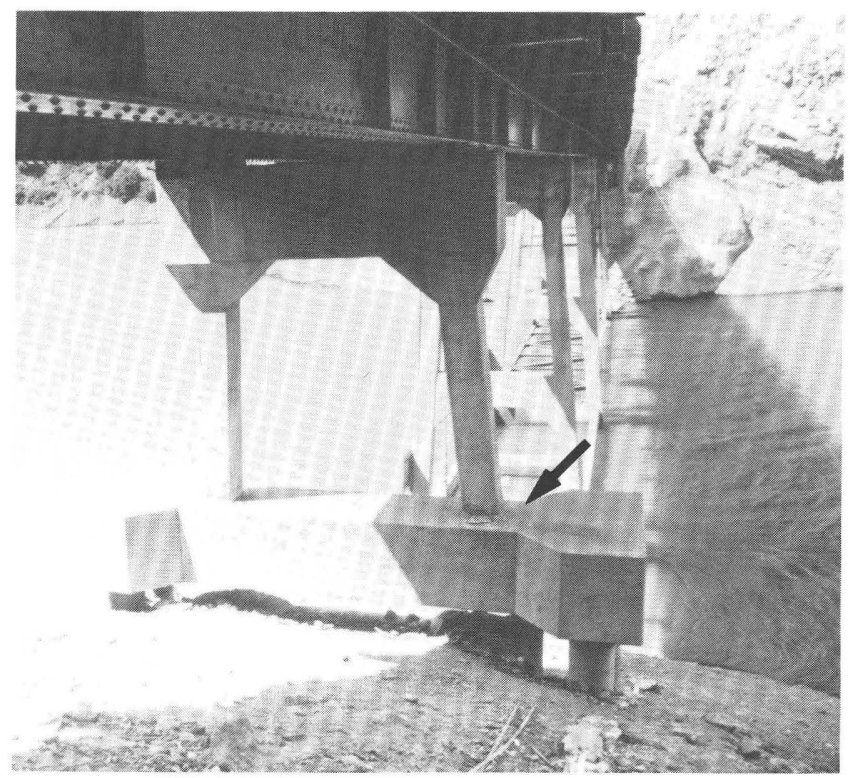

Figure 11.24. Bent bracing, added years ago to strengthen the Cochrane Bridge (loc. 24, fig. 11.7) after distortion of bridge by either fault creep or landslide displacement was discovered. Bent pillar bases (arrow) spalled during main shock. View northward.

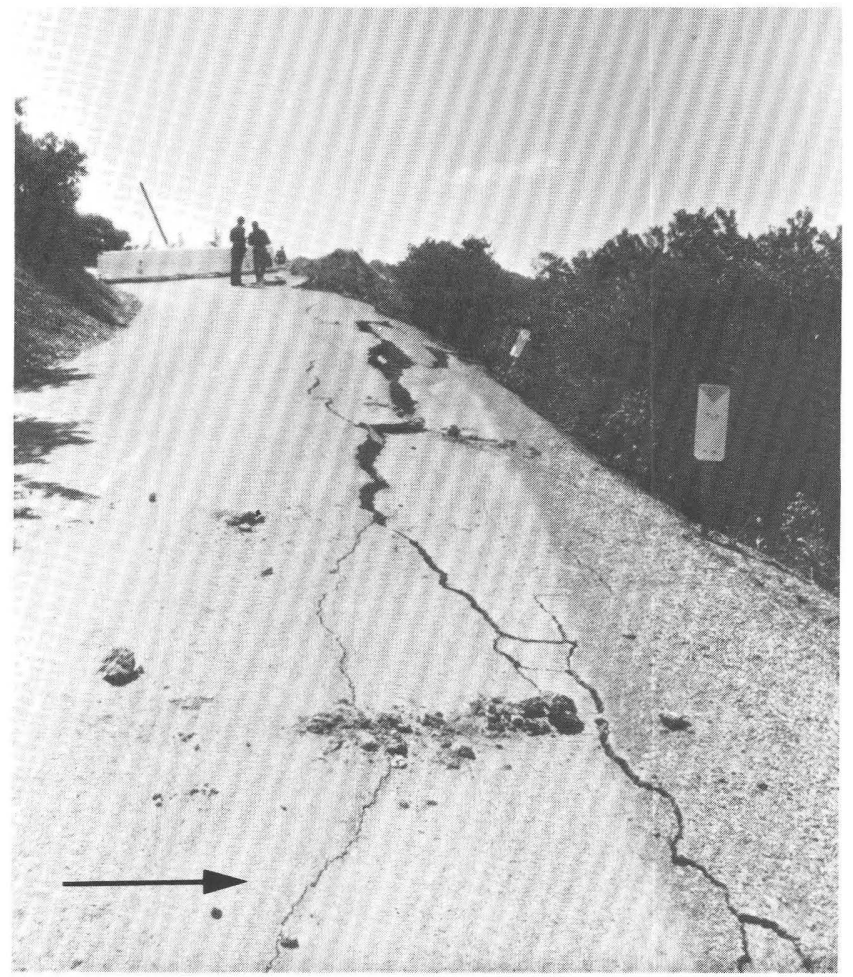

Figure 11.25. One of many fill failures along East Dunne Avenue within $0.8 \mathrm{~km}$ of the Cochrane Bridge (west of loc. 24, fig. 11.7). These failures were typically down toward reservoir, to right (arrow). View northwestward. 


\title{
Distant Resonance Effects of the Earthquake- a Preliminary Study
}

\author{
By Mehmet Celebi
}

\section{CONTENTS}

\author{
Abstract 105 \\ Introduction $\mathbf{1 0 5}$ \\ Description of the buildings $\mathbf{1 0 6}$ \\ Foundations of the buildings $\mathbf{1 0 6}$ \\ Observed damage $\mathbf{1 0 6}$ \\ Engineering analysis $\mathbf{1 0 7}$ \\ Building periods (calculated) $\mathbf{1 0 7}$ \\ Building periods (measured) $\mathbf{1 0 7}$ \\ Soil considerations 107 \\ Conclusions and recommendations $\quad 108$ \\ Acknowledgments $\mathbf{1 0 9}$ \\ References cited $\mathbf{1 0 9}$
}

\section{Abstract}

This chapter presents a preliminary earthquakeengineering evaluation of two adjacent buildings in the west end of San Francisco, approximately $100 \mathrm{~km}$ from the epicenter of the earthquake, that sustained minor nonstructural damage. I explain the damage in terms of possible amplification of ground motions in the layered sedimentary deposits and the resonance effects of these motions. These possibilities are substantiated by simple calculations and measurements.

\section{INTRODUCTION}

This chapter presents a preliminary earthquakeengineering evaluation of the performance of two buildings on the San Francisco State University campus in the west end of Sun Francisco near Lake Merced, approximately $100 \mathrm{~km}$ north of the epicenter of the earthquake. Although other buildings in the vicinity or the tall buildings in San Francisco were not damaged, these two buildings sustained minor nonstructural damage. However, in Palo Alto, Redwood City, and San Mateo, which are the main population centers between the epicenter and San Francisco, there were no reports of distress in structures.

The two buildings, similar in geometry but different in design, are located orthogonal to one another with respect to their lengths in plan. They are connected by an external, partly framed structure that supports a terrace walkway at the third level. Also, a "skywalk" connects both buildings at the sixth-floor level. Figure 12.1 shows a general layout of the two buildings.

During the earthquake, occupants of both buildings were shaken considerably. The earthquake shaking inflicted cracks in both buildings, particularly at the fifth and sixth floors; these cracks were nonstructural. Other buildings, ranging from single story to four story in size, in the vicinity of these two buildings were not damaged.

At the time of the April 24 earthquake, no accelerographs or accelerometers were located in either of the buildings, in the free field, or in the immediate vicinity. Early reports of the earthquake by Hoose (1984) and Shakal and others (1984) indicate that in San Francisco the ground motions recorded in the basements of some buildings had peaks in the range $0.01-0.03 \mathrm{~g}$. The peak acceleration in the basement of one tall building in San Francisco was $0.03 \mathrm{~g}$. At the San Francisco International Airport, the peak acceleration recorded at a one-story building (sta. $58223)$, described to be on alluvial foundation material, was $0.05 \mathrm{~g}$ (Shakal and others, 1984).

The two campus buildings are less than $5 \mathrm{~km}$ from the San Andreas fault. The most recent important earthquake with an epicenter close to these two buildings was the March 22, 1957, San Francisco $(\mathbf{M}=5.3)$ earthquake, which caused $0.13-\mathrm{g}$ peak accelerations in San Francisco. The previous, 1906 San Francisco earthquake had a magnitude of 8.3. Lindh (1983) estimated an 8-percent probability that an $\mathbf{M}=7$ 
earthquake will occur in the San Francisco area within the next 30 years.

\section{DESCRIPTION OF THE BUILDINGS}

Figure 12.1 depicts the general plan layout of the two buildings; both were constructed in 1972. The nine-story building $\mathrm{A}$, with plan dimensions of 75 by $237 \mathrm{ft}$, is of reinforced-concrete frame and shear-wall construction. Numerous infill walls and separation walls also exist in the building.

The eight-story building $\mathrm{B}$, with plan dimensions of 78 by $333 \mathrm{ft}$, is of steel-frame construction with shear walls. Up to the third-floor level, both buildings are rigid, with long continuous shear walls in both directions. The balcony walkway on the exterior of the third-floor level serves as the entrance level to both buildings.

\section{FOUNDATIONS OF THE BUILDINGS}

Buildings $\mathrm{A}$ and $\mathrm{B}$ both have continuous wall footings. In addition, under the columnlines, building A has single footings integrated with the continuous wall footings. Some of the footings on the north end of this building are constructed on cast-in-place concrete piles encased in 2-ft-diameter steel pipes. The foundations of both buildings lie on moist sandy sediment layers, more than $50 \mathrm{ft}$ deep. Figure 12.2 shows typical soil logs. The exact depth to bedrock was not determined during this study. However, a map by Bonilla (1964) indicates that the elevation of bedrock (Franciscan Complex) at the site of these two buildings could be from 50 to $90 \mathrm{ft}$ below the surface elevation.

\section{OBSERVED DAMAGE}

As previously mentioned, no structural damage was visible. Generally, the nonstructural minor cracks consisted of: (1) separation cracks between infill walls and main structual frames, (2) cracks in the vicinity of door openings, (3) diagonal cracks in some infill walls, (4) cracks in some of the architectural panels at the exterior of both buildings, and (5) cracks in the plaster in several places. Typical cracks observed after the earthquake are shown in figure 12.3. Shortly after the earthquake, all cracks were simply plastered and painted.

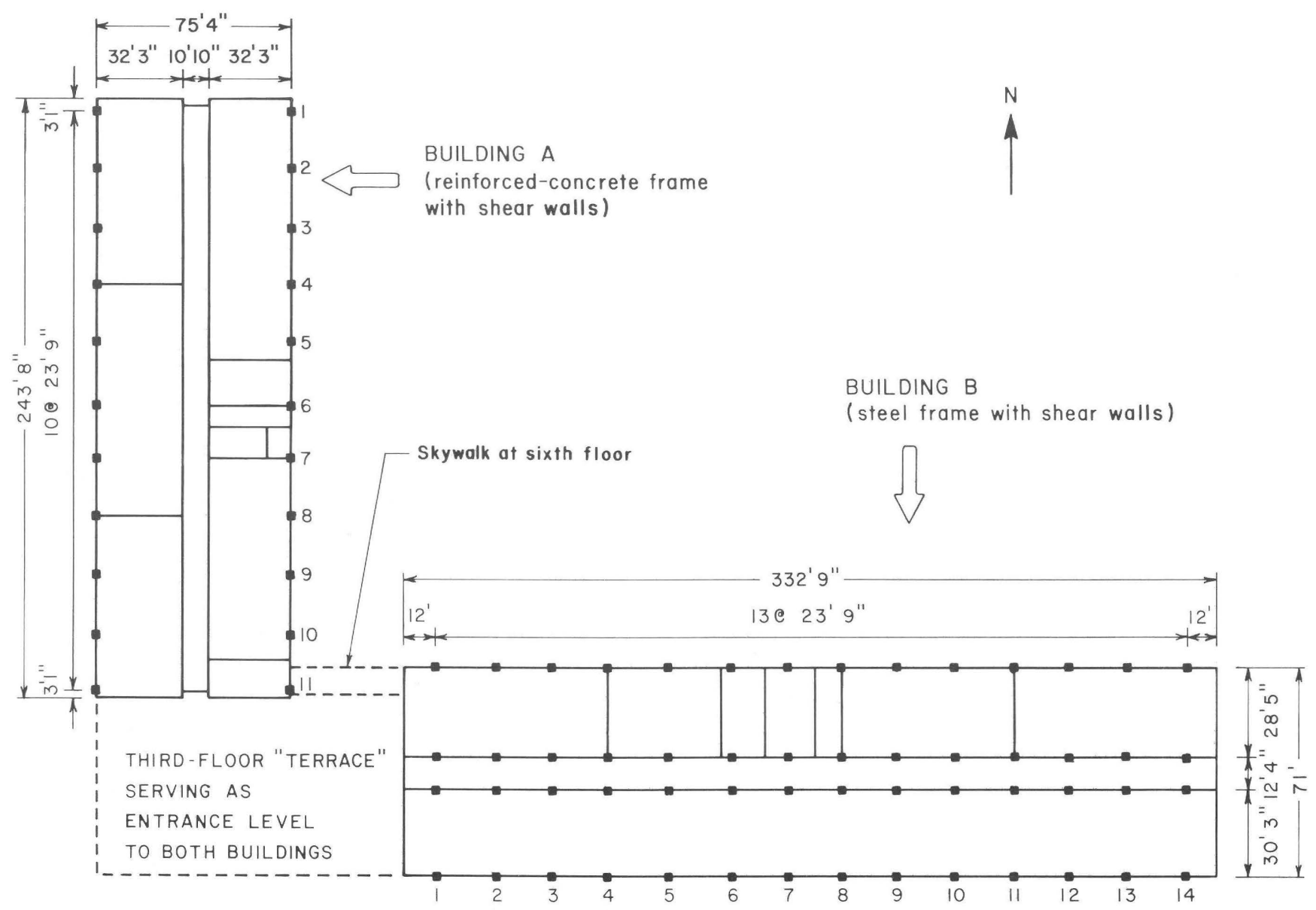

Figure 12.1. Typical plan view of fourth floor and above floors for buildings A and B. Not to scale. 


\section{ENGINEERING ANALYSIS}

The two buildings, constructed on granular media, possibly have dominant frequencies close to that of the underlying soil media.

In the past, long-distance resonance effects during earthquakes have caused extensive damage and (or) collapse of buildings. During the 1970 Gediz, Turkey, earthquake, several buildings of an industrial plant located approximately $85 \mathrm{~km}$ from the epicenter were severely damaged and (or) collapsed (Tezcan and Ipek, 1973; Tezcan and others, 1977). During other earthquakes, such as the 1967 Venezuela earthquake, similar phenomena have been observed and reported (Degenkolb and Hanson, 1969).

Thus, in seismically active zones it is essential to carry out investigations of buildings where rule-ofthumb tendencies and (or) formulations may indicate building-resonance possibilities, especially in combination with observations of minor damage.

I attempt below to obtain quick estimates of the vibrational parameters relevant to the two buildings and the site.

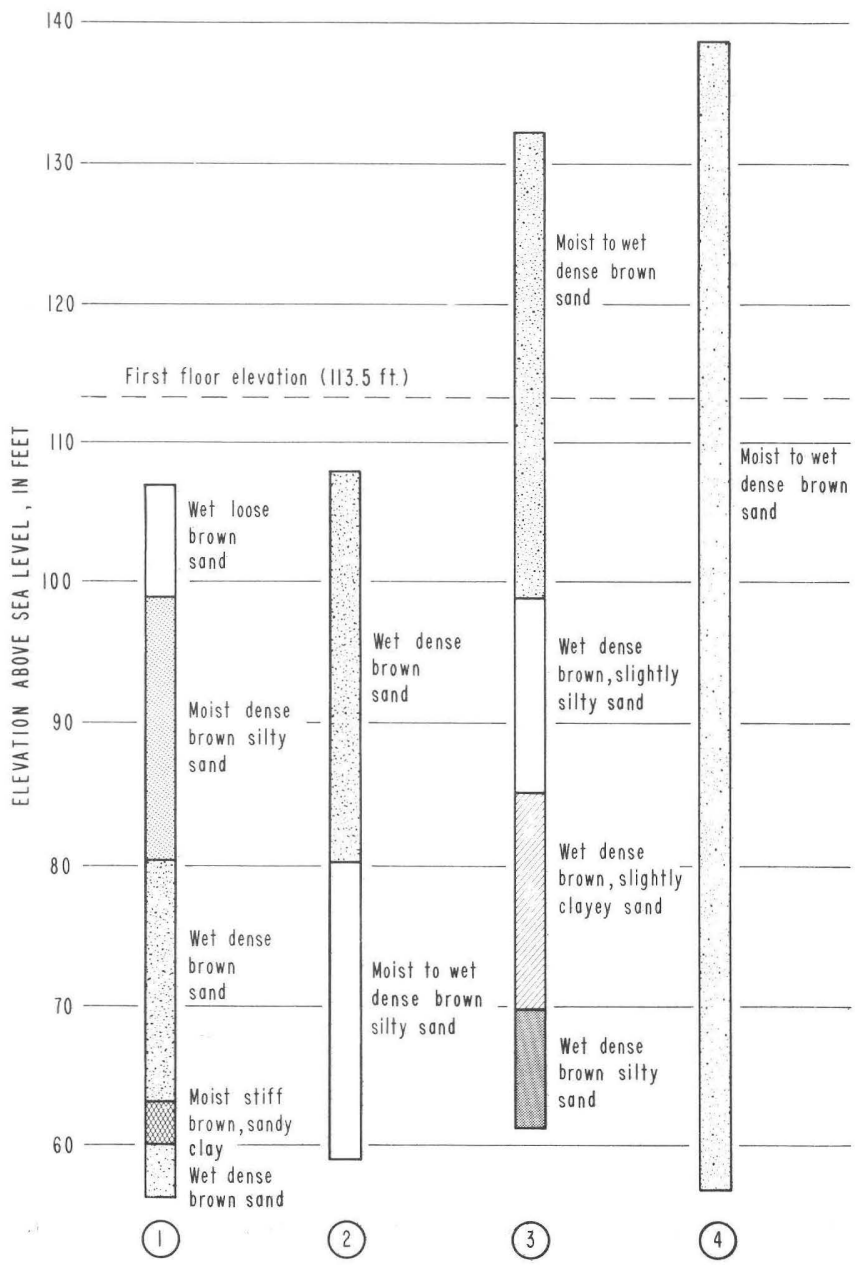

Figure 12.2. Typical soil logs taken from site of building $\mathrm{B}$ before construction.

\section{Building Periods (Calculated)}

$\underline{\mathrm{T}}$

Using the well-known formula for building period

$$
\underline{T}=\frac{0.05 \underline{H}}{\sqrt{\bar{D}}}
$$

where $\underline{H}$ is the height of the building (in feet) and $\underline{D}$ is the dimension (in feet) in the direction of the earthquake considered. The periods culculated for the two buildings are listed in Table 12.1.

\section{Building Periods (Measured)}

After the earthquake, the fundamental period of vibration of each building was measured with a vibration monitor (Kinemetrics model VM-1). From these measurements, using an averuge of 10 cycles, the periods, summarized in table 12.2, were determined.

\section{Soil Considerations}

In general, the underlying soil at the site of the two buildings is dominantly slightly plastic to nonplastic, moist to wet brown sand showing slight variations with mixtures of silt or clay (California Department of Public Works, 1964). The range of shear-wave velocities $\left(\underline{V}_{S}\right)$ typical of this type of soil can be approximated at 600 to $1,200 \mathrm{ft} / \mathrm{s}$. Using the general formula for the fundumental period $\underline{T}_{0}$ of a soil layer,

$$
\underline{\mathrm{T}}_{0} \approx \frac{4 \mathrm{H}}{\underline{\mathrm{V}}},
$$

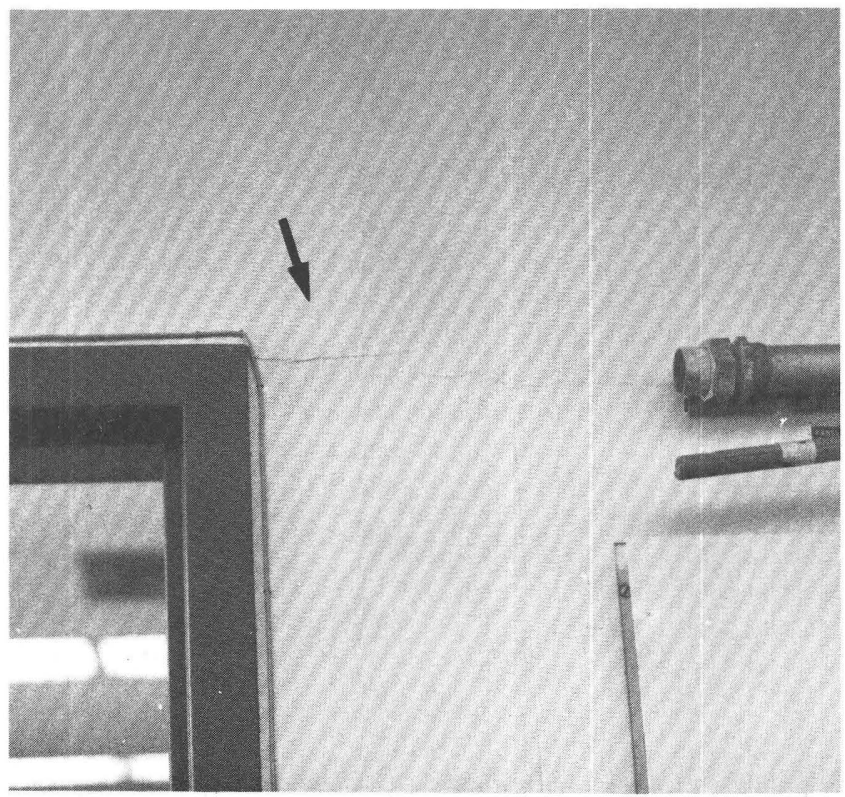

Figure 12.3. Typical nonstructural cracks in walls of building $A$. 
Table 12.1. Calculated periods of buildings

\begin{tabular}{|c|c|c|c|c|c|}
\hline \multirow{2}{*}{ Building } & \multirow{2}{*}{$\begin{array}{l}\underline{H} \\
(f t)\end{array}$} & \multicolumn{2}{|c|}{$\underline{D}(f t)$} & \multicolumn{2}{|c|}{$\underline{T}(\mathrm{~s})$} \\
\hline & & $\mathrm{N}-\mathrm{S}$ & E-W. & $\mathrm{N}-\mathrm{S}$. & $E-W$ \\
\hline A & 114 & 237 & 71 & 0.37 & 0.67 \\
\hline B & 100 & 75 & 333 & .58 & .27 \\
\hline
\end{tabular}

Table 12.2. Measured fundamental periods of vibration

\begin{tabular}{crr}
\hline \multirow{2}{*}{ Building } & \multicolumn{2}{c}{ Period (s) } \\
\cline { 2 - 3 } & N-S. & E-W. \\
\hline A & & \\
B & .35 & 0.5 \\
& .56 & .6 \\
\hline
\end{tabular}

and assuming uniform media with a depth $\left(\underline{\mathrm{H}}_{\mathrm{S}}\right)$ of 100 $\mathrm{ft}$, the fundamental period of the soil can be estimated to be in the range $0.33-0.67 \mathrm{~s}$. For $\mathrm{H}_{\mathrm{S}}=60 \mathrm{ft}$ and $\mathrm{T}_{0}=0.4 \mathrm{~s}$, the shear-wave velocity $\left(\underline{\mathrm{V}}_{\mathrm{S}}\right)$ is $600 \mathrm{ft} / \mathrm{s}$. These values, which represent the approximate range in the fundumental periods of homogeneous soil media, clearly indicate that the structural fundamental frequencies and the soil fundamental frequencies are nearly identical, and thus indicate the likelihood of resonance.

This case is also examined by using the wavepropagation approach to determine the amplification in layered soil media above a bedrock. Roensset (1977, p. 648) defined "amplification ratio" as the ratio of the amplitude of motion at a free surface of soil to the amplitude of motion at bedrock (half-space) if there is no soil on it. Kanai (1952), Haskell (1953, 1960), and Idriss and Seed (1968) developed formulations to study the propagation of shear waves in layered media. Joyner and Chen (1975) further developed this method by incorporating the nonlinear characteristics of soils.

Using this approach and a computer program developed by Charles Mueller (written commun., 1984), based on the formulations by Haskell (1953) and Joyner and Chen (1975), amplification ratios for parameters relevant to the site were obtained. The parameters varied in this approach were the depth of two or three layers of soil above the bedrock, the shear-wave velocity, and the half-space shear-wave velocity (corresponding to the Franciscan Complex, the $V_{S}$ assumed was $0.5-1.0 \mathrm{~km} / \mathrm{s}$; figs. $12.4,12.5)$. In these calculations, the specific dissipation constant $(\underline{Q})$ was assumed to be 16 , a value that approximately trunslates to a damping ratio (D) of 3 percent, because $\underline{D}=\frac{1}{2} \underline{Q}$.

These calculations indicate that for shear-wave velocities of from $600 \mathrm{ft} / \mathrm{s}(0.2 \mathrm{~km} / \mathrm{s})$ to $1,200 \mathrm{ft} / \mathrm{s}(0.4$ $\mathrm{km} / \mathrm{s})$, assumed depths of from $60 \mathrm{ft}(20 \mathrm{~m})$ to $90 \mathrm{ft}(30$ $\mathrm{m})$, and assumed shear-wave velocities for a half-space (Franciscan Complex) of 0.5 to $1.0 \mathrm{~km} / \mathrm{s}$, amplification ratios of 2 to 4 can be realized. Furthermore, these amplifications correspond to frequencies of 2.2 to 3.2 $\mathrm{Hz}$ (periods of 0.31-0.45 s). Therefore, there is a strong likelihood of amplification of surface motions for the type of soil layers beneath the two buildings investiguted.

\section{CONCLUSIONS AND RECOMMENDATIONS}

This analysis reveals that: (1) amplification of surface motions occurs for the type and depth of layered soil media below the foundations of the two buildings, and (2) the similarity in the fundamental frequencies of the buildings to that of the underlying media results in resonance effects that possibly caused the damage described.

Because the buildings were constructed in 1972 and designed before that, the effect of soils probably was not considered because the soil factor was first introduced into the building code in 1976. The existing soil studies of the buildings are related to determination of bearing capacities only.

The preliminary results presented in this chapter are for a case study of the possible resonance effects in two buildings constructed on layered granular media. In San Francisco and other seismically active areas, other buildings similar to the two discussed here
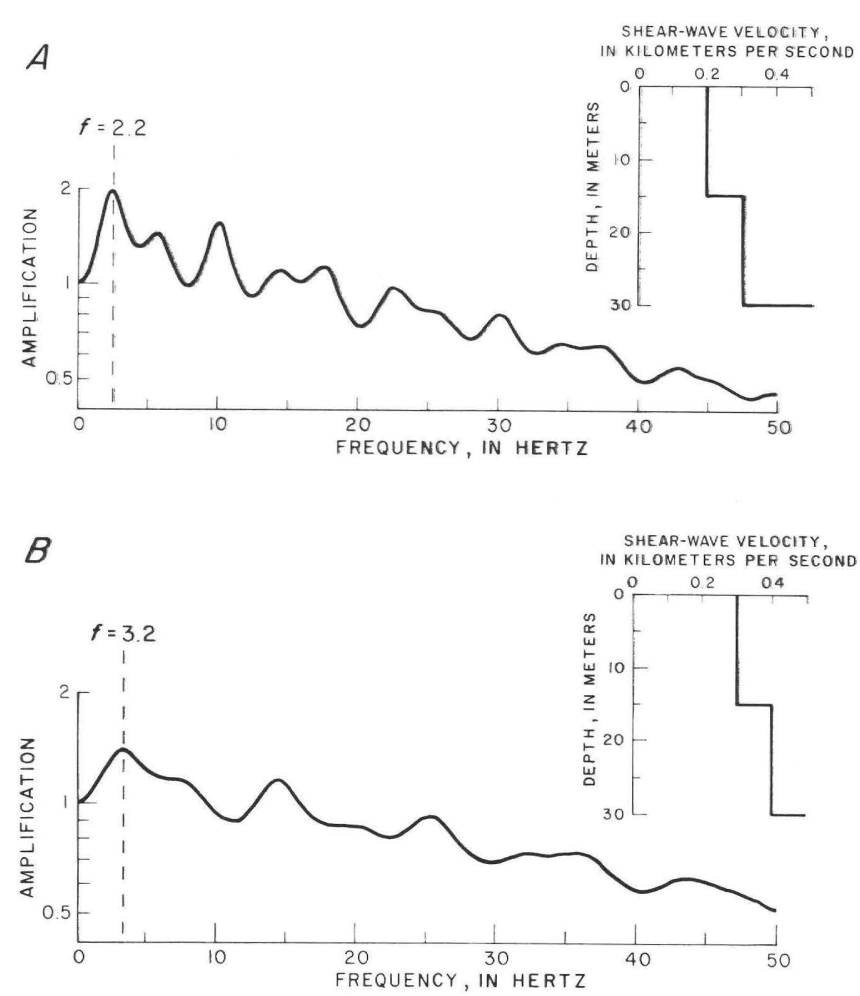

Figure 12.4. Soil amplification of two-layered media on bedrock at a depth of $30 \mathrm{~m}$ (approx $90 \mathrm{ft}$ ), with an assumed half-space $\underline{V}_{s}$ of $0.5 \mathrm{~km} / \mathrm{s}(1,500 \mathrm{ft} / \mathrm{s}) . \quad \underline{A}$, Shear-wave velocities of 0.2 and $0.3 \mathrm{~km} / \mathrm{s}$. B, Shearwave velocities of 0.3 and $0.4 \mathrm{~km} / \mathrm{s}$. 
are located on granular soil deposits of varying depth. Therefore, the following recommendations are strongly made:

1. In seismically active areas, earthquake-risk studies should be performed for buildings constructed on sedimentary deposits (and designed without consideration of the vibrational characteristics of soils). Such studies should include dynamic analysis of the structures, including soil-structure interaction and, if applicable, building-to-building interaction. Actual earthquake-design levels should be compared with current Uniform Building Code and Applied Technology Council (1978) recommendations. Furthermore, the consequences of a major earthquake caused by active faults in the proximity of the buildings, and the longdistance effects of such an earthquake, should be assessed.

2. 'These studies should be supplemented by: (d) instrumenting selected buildings in selected areas that are constructed on soil deposits which have proinise of exhibiting significant amplifications of motions, where the response of the structural systems can then be recorded during a real strong-
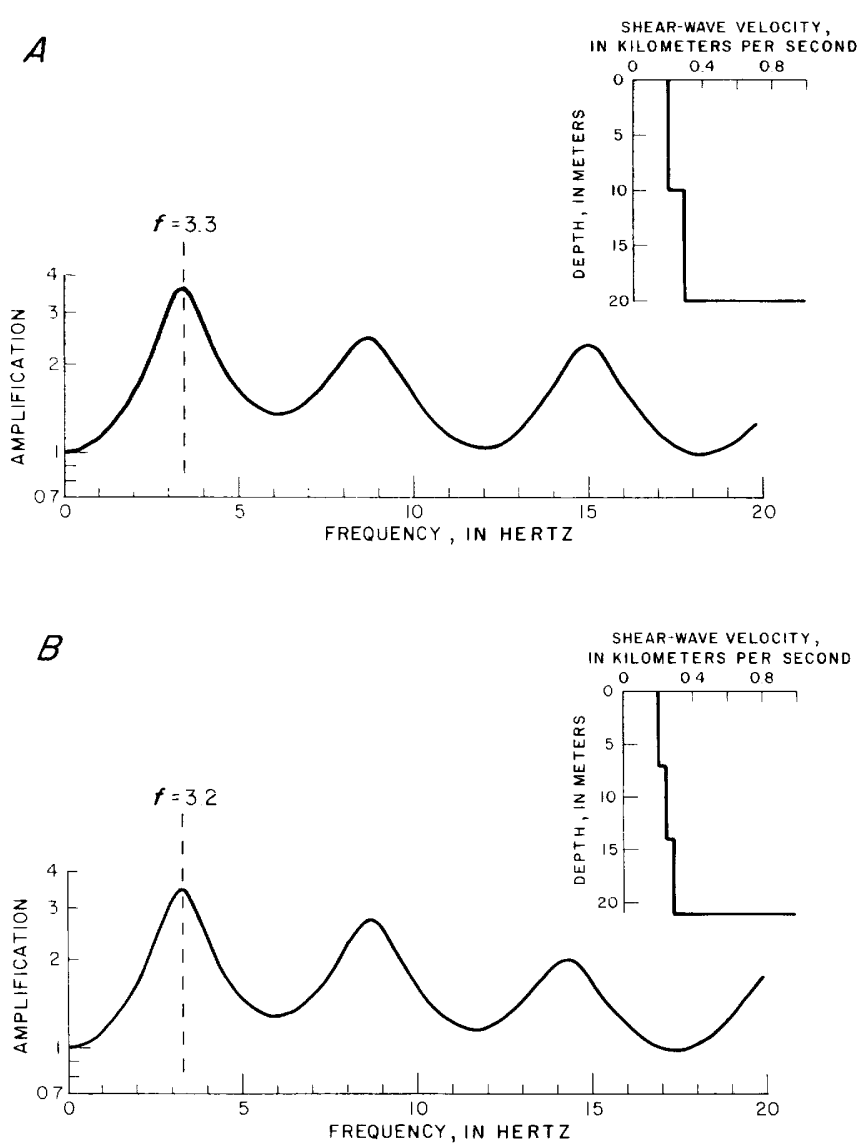

Figure 12.5. Soil amplification of two- and threelayered media on bedrock at a depth of $20 \mathrm{~m}$ (approx $60 \mathrm{ft}$ ), with an assumed half-space $V_{s}$ of $1 \mathrm{~km} / \mathrm{s}$ $(3,000 \mathrm{ft} / \mathrm{s})$. A, Shear-wave velocities of 0.2 and 0.3 $\mathrm{km} / \mathrm{s}$. B, Shear-wave velocities of $0.2,0.25$, and 0.3 $\mathrm{km} / \mathrm{s}$. motion event; and (b) investigations of the amplification of ground motions by soil deposits on bedrock, conducted by borehole sampling in the vicinity of selected structures that are to be instrumented.

\section{ACKNOWLEDGMENTS}

I am indebted to the personnel of the Sun Francisco State University's Office of Buildings and Grounds for providing some of the data, to W.B. Joyner and Erdal Safak for discussions, to Charles Mueller for the use of his computer program and assistance in running it, and to R.D. Forshee for his help with the ambient-vibration measurements.

\section{REFERENCES CITED}

Applied Technology Council, 1978, Tentative provisions for the development of seismic regulations for buildings: A cooperative effort with the design professions, building code interests and the research community: Report ATC-3-06 (U.S. National Bureau of Standards Special Publication 510), 505 p.

Bonilla, M.G., 1964, Bedrock-surface map of the San Francisco South quadrangle, California: U.S. Geological Survey open-file map, scale 1:20,000.

California Department of Public Works, 1964, Report of foundation investigation: Materials and Research Department report, 6 p.

Degenkolb, H.J., and Hanson, R.D., 1969, The July 29, 1967 Venezuela earthquake: Lessons for the structural engineer: World Conference on Earthquake Engineering, 4th, Santiago, Chile, 1969 , Proceedings, v. 3, p. J-2-90 to J-2-106.

Haskell, N.A., 1953, The dispersion of surface waves on multilayered media: Seismological Society of America Bulletin, v. 43, no. 1, p. 17-34.

--- 1960, Crustal reflection of plane $\mathrm{SH}$ waves: Journal of Geophysical Research, v. 65, no. 12, p. 4147-4150.

Hoose, S.N., compiler, 1984, The Morgan Hill, California, earthquake of April 24, 1984 (a preliminary report): U.S. Geological Survey Open-File Report 84-489, 2 v.

Idriss, I.M., and Seed, H.B., 1968, Seismic response of horizontal soil layers: American Society of Civil Engineers Proceedings, Soil Mechanics and Foundations Journal, v. 94, no. SM4, p. 10031031.

Joyner, W.B., and Chen, A.T.F., 1975, Calculation of nonlinear ground response in earthquakes: Seismological Society of America Bulletin, v. 65, no. 5 , p. $1315-1336$.

Kanai, Kiyoshi, 1952, Relation between the nature of surface layer and the amplitudes of earthquake motions: Tokyo University, Earthquake Research Institute Bulletin, v. 30, no. 1, p. 31-37.

Lindh, A.G., 1983, Preliminary assessment of longterm probabilities for large earthquakes along selected fault segments of the San Andreas fault system, California: U.S. Geological Survey 
Open-File Report 83-63, 15 p.

Roelsset, J.M., 1977, Soil amplification of earthquakes, chap. 19 of Desai, C.S., and Christian, J.T., eds., Numerical methods in geotechnical engineering: New York, McGraw-Hill, p. 639-682.

Seed, H.B., and Idriss, I.M., 1982, Ground motions and soil liquefaction during earthquakes: Berkeley, Calif., Earthquake Engineering Research Institute, $134 \mathrm{p}$.

Shakal, A.F., Sherburne, R.W., and Parke, D.L., 1984, CDMG strong-motion records from the Morgan Hill, California earthquake of 24 April 1984 : California Division of Mines and Geology, Office of Strong-Motion Studies Report 84-7, 64 p.

Tezcan, S.S., Seed, H.B., Whitman, R.V., Serff, Norman, Christian, J.T., Durgunoglu, H.T., and Yegian, Mishac, 1977, Resonant period effects in the Gediz, Turkey earthquake of 1970: Earthquake Engineering and Structural Dynamics, v. 5, no. 2, p. 157-179.

Tezcan, S.S., and Ipek, Muzaffer, 1973, Long distance effects of the 28 March 1975 Gediz Turkey earthquake: International Journal of Earthquake Engineering and Structural Dynamics, v. 1, no. 3, p. 203-215. 


\title{
Response of U.S. Geological Survey Creepmeters near Hollister, California
}

\author{
By Sandra S. Schulz
}

\section{CONTENTS}

Abstract $\mathbf{1 1 1}$

Triggered creep at Shore Roud $\mathbf{1 1 1}$

Observed postearthquake surface displacement 111

Summury 112

References cited $\mathbf{1 1 5}$

\section{Abstract}

The earthquake along the Calaveras fault near Halls Valley caused $12.9 \mathrm{~mm}$ of afterslip with associated ground breakage at U.S. Geological Survey (USGS) creepmeter station SHR1, $50 \mathrm{~km}$ southeast on the same fault. No other surface evidence of triggered creep was found on recognized traces of the Calaveras fault from station SHR $110 \mathrm{~km}$ southeast to Hollister. In downtown Hollister, three creepmeters showed only normal activity since January 1984 . Surface inspection and instrument readings indicate that the triggered creep at station SHR1 did not propagate as far as Hollister. After the earthquake, station SHR1 recorded accelerated creep for 1 month. On May 26, a 7.9-mm creep event occurred, followed by accelerated creep to August 1984.

\section{TRIGGERED CREEP AT SHORE ROAD}

The USGS creepmeter network monitoring the Calaveras fault near Hollister has its north terminus at station SHR1 (Shore Roud), $50 \mathrm{~km}$ southeast of the earthquake epicenter (fig. 13.1). The Invar-rod creepmeter at Shore Roud was installed in 1971. The 6-m-long rod is buried 0.5 deep; one end is anchored under Shore Road, and the other end is connected under tension to a sensor and dial gage accessible in a vault on the road shoulder. The rod lies at $45^{\circ}$ to the fault strike and monitors approximately $4 \mathrm{~m}$ of the total width of the fault zone (Nason and others, 1984). During the $M=6.2$ earthquake of 2115 G.m.t. April 24, 1984, sta. SHR1 recorded a coseismic rightlateral step of $0.11 \mathrm{~m}$, followed by onset of a single afterslip event that reached $12.9 \mathrm{~mm}$ after 18 hours (figs. 13.2A, 13.2B). Previously, no single creep event greater than $9 \mathrm{~mm}$ had been recorded at station SHR1 since its installation. Station SHR1 did not record coseismic steps during two $\mathbf{M}=3+$ aftershocks on May 3, 1984. After recording accelerated creep for 32 days after the earthquake, station SHR1 recorded a 7.9-mrn creep event, followed by accelerated creep to August 1974 (see chap. 1 for location of sta. SHR1 with respect to the rupture zone). It is interesting to compare station SHR1's reaction to the August 6, 1979 Coyote Lake, Calif., earthquake ( $M=5.9$ ) (fig. 13.2C). Located $20 \mathrm{~km}$ southeast of that epicenter, station SHR1 recorded a $4.2-\mathrm{mm}$ right-lateral coseismic step and two afterslip events in the next 24 hours, for a total slip of $8.3 \mathrm{~mm}$ (fig. 13.2). The Coyote Lake earthquake ended a 3-year creep lag at station SHR1 (Raleigh, 1979; Schulz and others, 1983). An 18-month lag occurred at Shore Road before the April 24 event (fig. 13.3).

\section{OBSERVED POSTEARTHQUAKE SURFACE DISPLACEMENT}

The creep rate at station SHR1 averages 9 to $12 \mathrm{~mm} / \mathrm{yr}$ (Schulz and others, 1982), and tension crucks across Shore Road are common. The present cracks have been forming since repaving in 1982, and it was unclear whether the triggered creep on April 24 widened them (fig. 13.4). However, a fresh crack $1 \mathrm{~m}$ long and $0.5 \mathrm{~cm}$ wide at its center was observed on April 25 in the southeast dirt shoulder of Shore Road (fig. 13.5), and huirline cracks extended from the northwest dirt shoulder into the pavement (figure 13.6).

A search on April 25 along the known creeping trace of the Calaveras fault between Shore Road and Hollister yielded no further surface evidence of triggered creep. However, the fault geometry appears to change in this area (Radbruch-Hall, 1974; Slater and Burford, 1979), and so not all potential moving traces have been located. 
An active trace of the fault has been identified on Wright Road, $8.5 \mathrm{~km}$ southeast of station SHR1 (fig. 13.1). A USGS creepmeter station (WRT1) operating here until 1983 recorded a creep rate of 11 to $13 \mathrm{~mm} / \mathrm{yr}$, and a San Francisco State University survey across the trace has measured a similar rate (J.S. Galehouse, orul commun., 1984). A resurvey by Jon S. Galehouse and Beth D. Brown on April 25, 1984 showed no significant change in creep rate since January 1984 (see chap. 15). Also, no surface cracks were visible in the fields on either side of Wright Road or next to the previous creepmeter site.

Although the three USGS creepmeters in Hollister no longer record on site, dial readings on April 25 showed $1.5 \mathrm{~mm}$ of left-lateral movement (contraction) at the base of Park Hill since January 24, 1984, and approximately $1 \mathrm{~mm}$ of right-laterul movement (extension) at the two instruments in central Hollister--all normul amounts for this time of year. Cumulative creep amounts for the three Hollister creepmeters from January 1984 to July 30 , 1984, are listed in table 13.1.

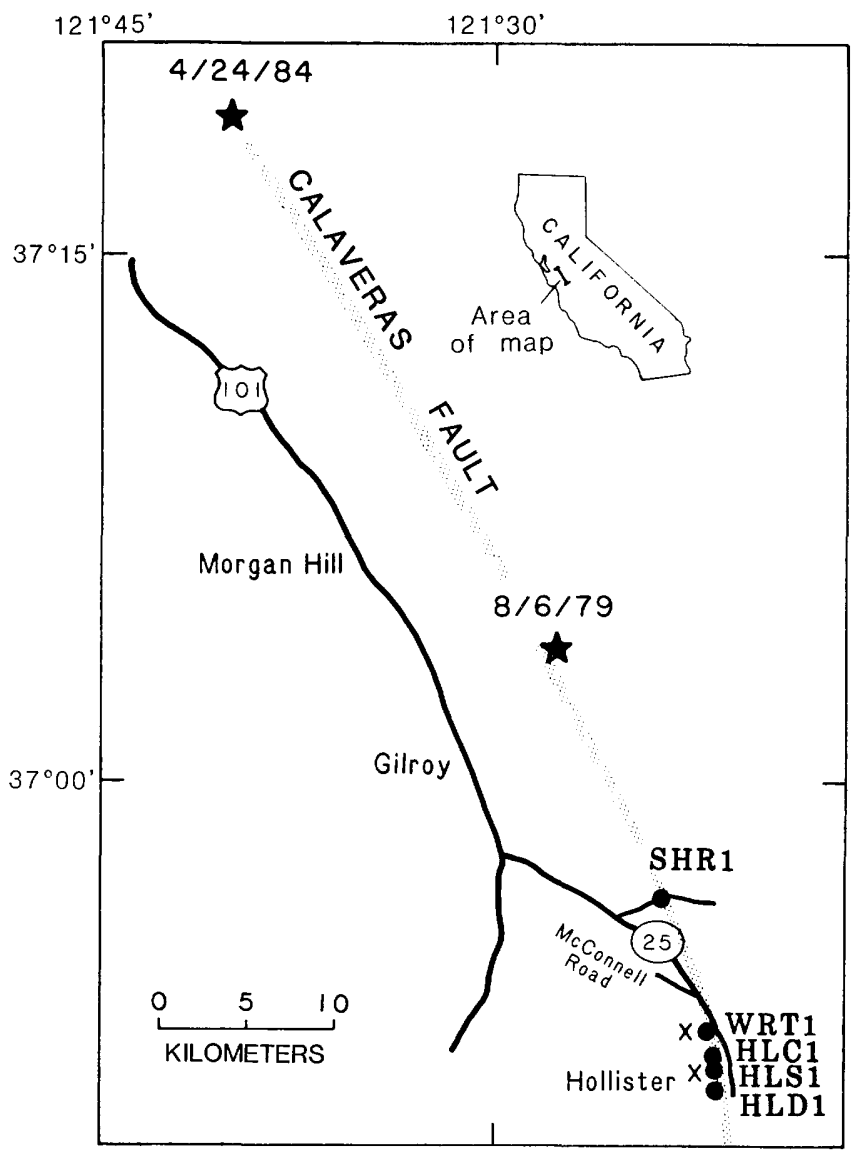

Figure 13 1. Locations of epicenters of April 24, 1984, Morgan Hill and August 6, 1979, Coyote Lake earthquakes (stars) along Calaveras fault, central California. Circles, USGS creepmeters; X's, San Francisco State University survey lines.

\section{SUMMARY}

On the busis of creepmeter-dial reudings in Hollister and the San Francisco State University survey at Wright Road, the surface displacement recorded at station SHR1 on April 24 may not have extended farther southeastward. Chapter 7 reports on surface fractures $10 \mathrm{~km}$ northwest of station SHR1 on the fault trace across Culifornia Highway 152. However, no surface fractures of unequivocal tectonic origin were found in the vicinity of the epicenter, 50 $\mathrm{km}$ northwest (see chup. 6). Thus, the large triggered creep at Shore Road is one of the more unusual phenomena of the earthquake.
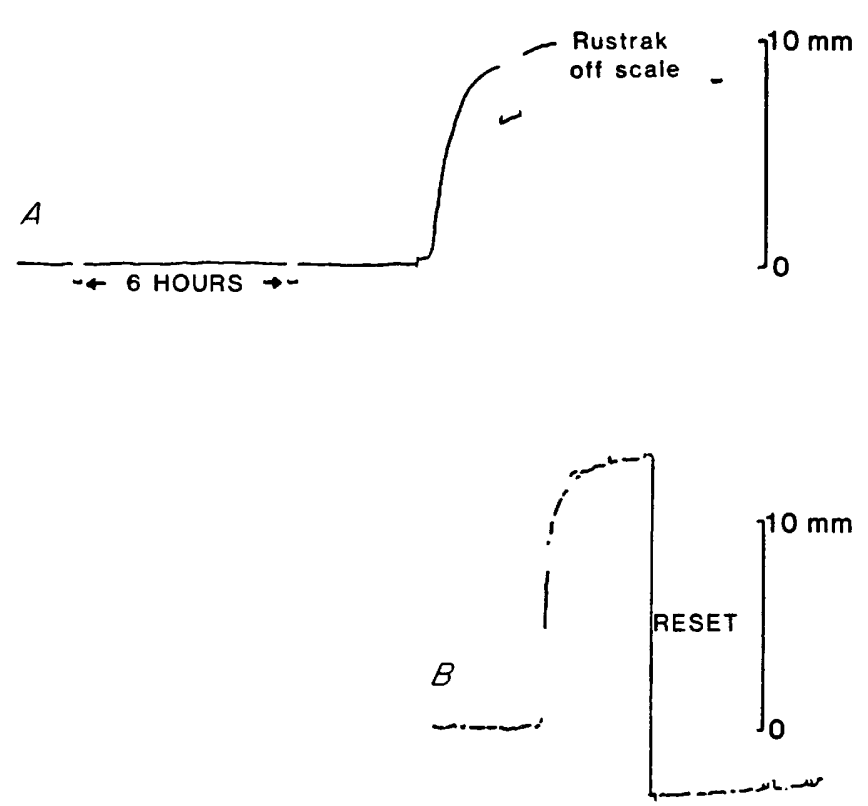

24 HOURS

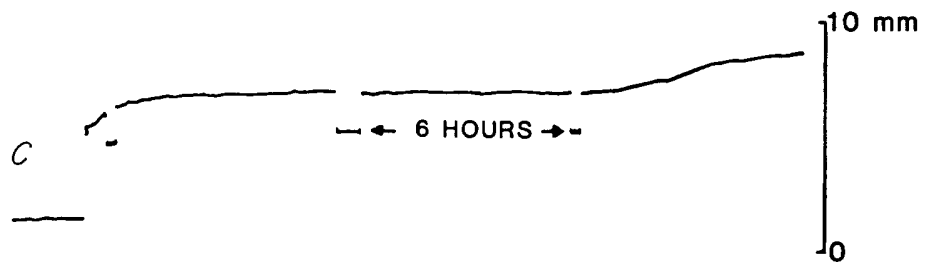

Figure 13.2. Records of the April 24 earthquake. A, Rustrak trace showing station SHRl's response to the April 24, 1984, Morgan Hill earthquake. A $0.11-\mathrm{mm}$ coseismic step was followed within 23 minutes by $12.0 \mathrm{~mm}$ of afterslip over the next 18 hours. Recorder went of $f$ scale after 4 hours. $B$, Telemetry trace showing entire event (10-minute samples). Left-lateral step was due to mechanical reset on April 25 to prevent instrumental range being exceeded. $C$, Rustrak trace showing station SHRl's response to the August 6, 1979, Coyote Lake earthquake. A $4.2-\mathrm{mm}$ coseismic step was followed by $4.1-\mathrm{mm}$ of afterslip in two events over the next 24 hours. 


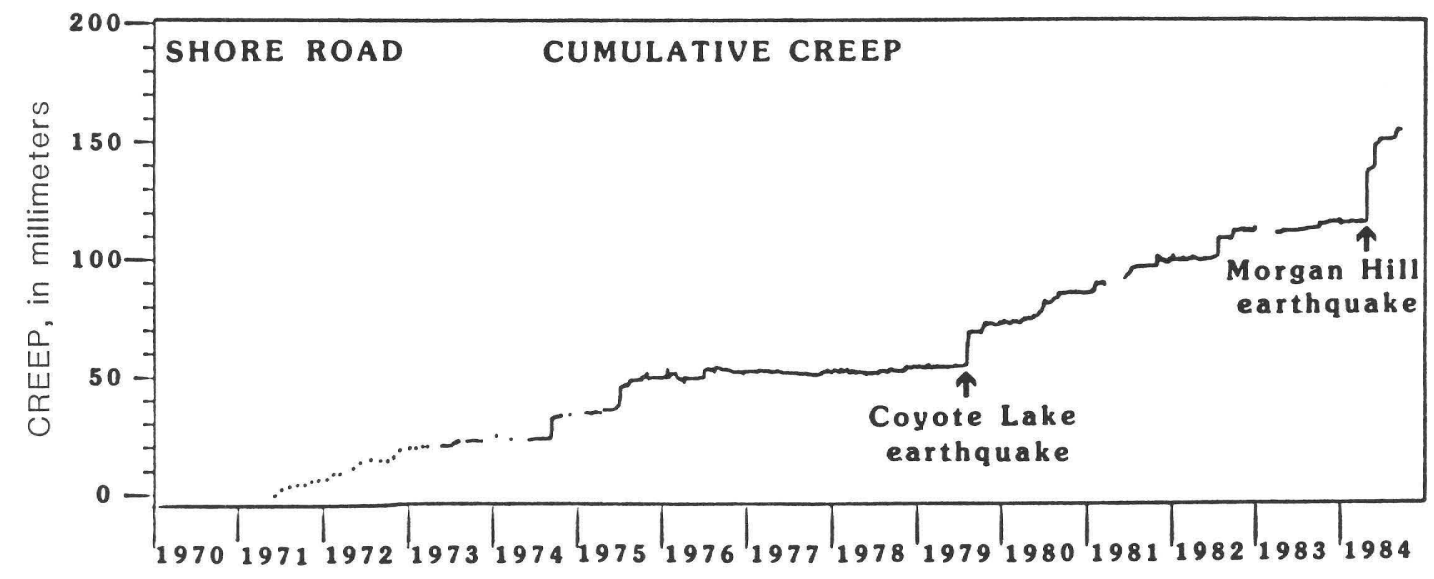

TIME, in years

Figure 13.3. Long-term cumulative creep recorded at station SHR1. Step that begins at time of the Coyote Lake earthquake consists of four separate events over a 5-day period.

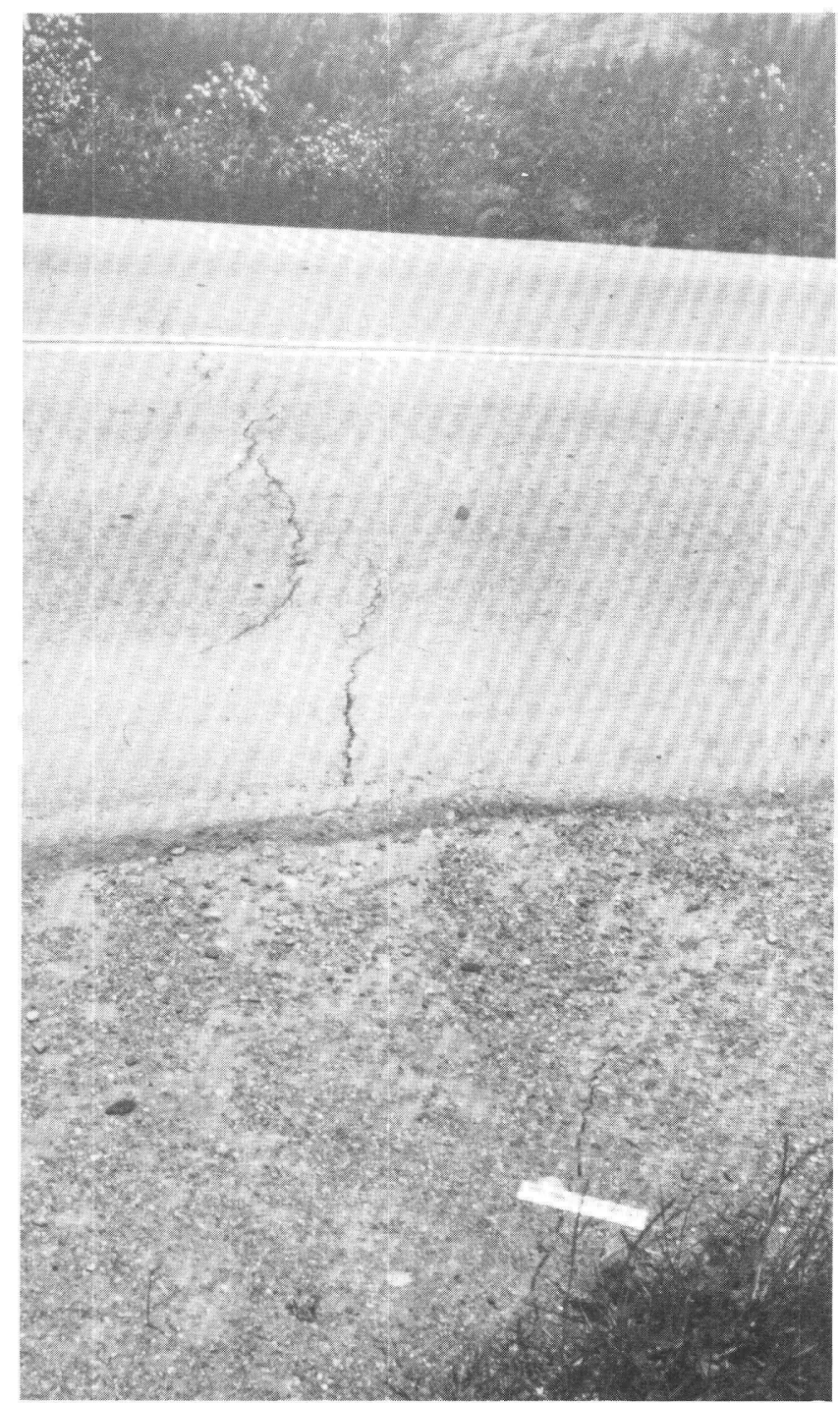

Although the Shore Road creepmeter has recorded no eventlike response during aftershocks as of August 1984, postearthquake acceleration and a 7.9min ereep event on May 26, 1 month after the earthquake, may be related to heightened seismicity, as was suggested for the activity following the 1966 Parkfield, Calif., earthquake (Smith and Wyss, 1968). This creep event occurred independently of the two af tershocks within that time period--an $\mathbf{M}=0.5$ event 2 hours earlier and an $\mathbf{M}=1.4$ event 4 hours later (F.W. Lester, oral commun., 1984). However, the May 26 creep event may also be the movement of ten recorded in late summer at Shore Road (Schulz and others, 1983), reflecting local slip conditions only.

The 3-year creep lag recorded at Shore Road before the 1979 Coyote Lake earthquake, and the 18month lag before und the large triggered creep in reaction to the 1984 Morgan Hill earthquake $50 \mathrm{~km}$ distant, show that the fault near Shore Road is sensitive to changes in regional strain and stress.

Figure 13.4. Calaveras fault trace at Shore Road, $10 \mathrm{~km}$ northwest of Hollister. Station SHR1 lies in road shoulder off to right, crossing the trace at an angle of $45^{\circ}$. Cracks in road began after repaving in 1982. $15-\mathrm{cm}$ scale indicates location of fresh crack in road shoulder, apparently caused by afterslip following the April 24 earthquake (see fig. 13.5). View northwestward. 


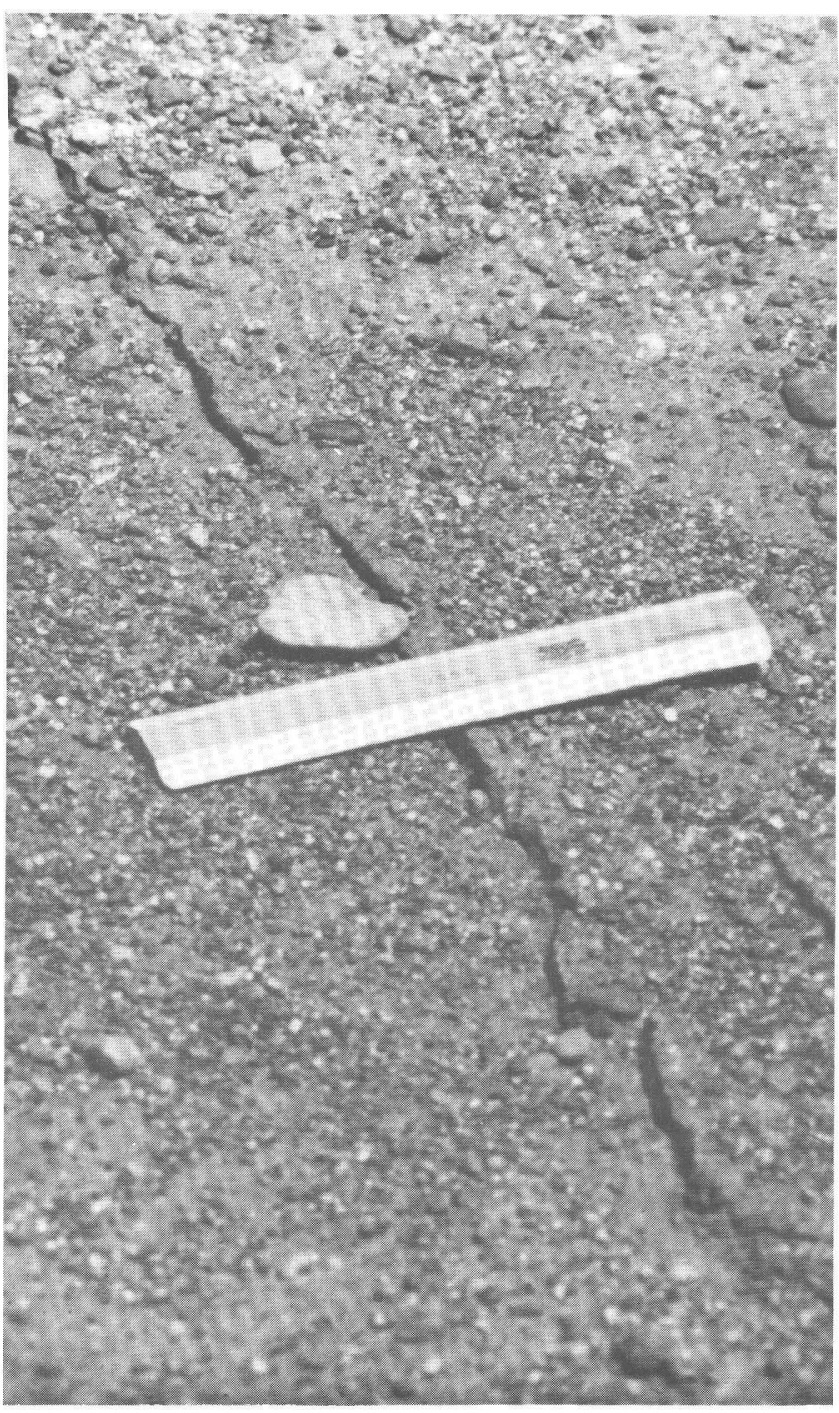

Figure 13.5. Closeup of fresh crack, $1 \mathrm{~m}$ long by as much as $0.5 \mathrm{~cm}$ wide, beside Shore Road. Scale is $15 \mathrm{~cm}$ long.
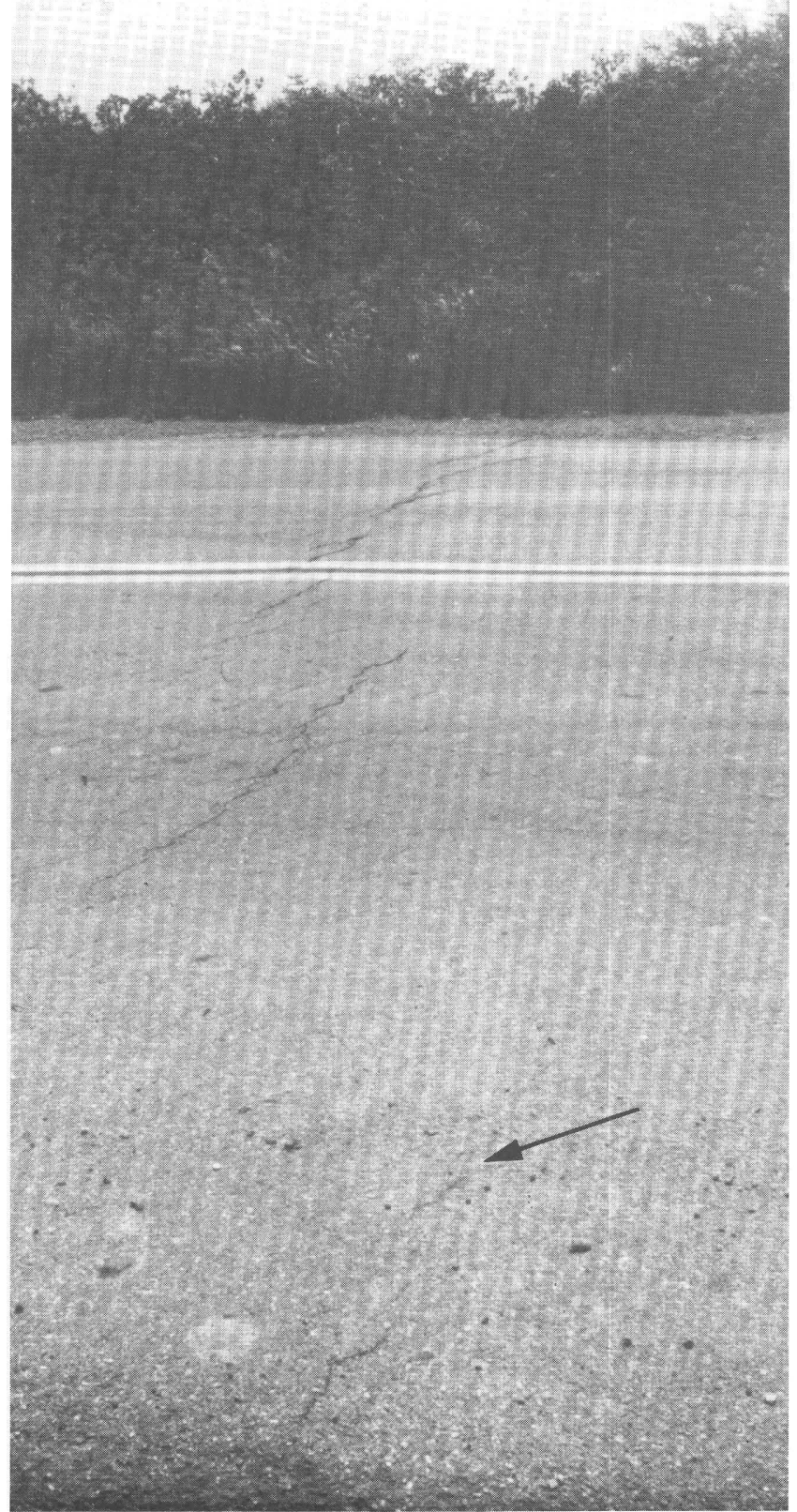

Figure 13.6. Calaveras fault trace at Shore Road. Station SHR1 is in shoulder in upper left center. Arrow denotes hairline crack extending from dirt shoulder into roadway. View southeastward. 
Table 13.1. Right-lateral creep accumulated since April 1970 at sites in Hollister

\begin{tabular}{|c|c|c|c|}
\hline \multirow{2}{*}{$\begin{array}{l}\text { [All values in milli } \\
\text { crosses only a smal] } \\
\text { trace. Ranges of } \\
\text { ods when stations we } \\
\text { others, 1974; Schulz } \\
\text { Date of dial } \\
\text { reading (1984) }\end{array}$} & \multicolumn{3}{|c|}{ Station } \\
\hline & HLC 1 & HLS1 & HLD1 \\
\hline January & 133.5 & 94.63 & 24.61 \\
\hline April 25 & 132.05 & 95.72 & 25.58 \\
\hline May 4 & 134.07 & 99.50 & 27.10 \\
\hline June 6 & 134.27 & $100 \cdot 54$ & $\mathrm{~N}$ \\
\hline July 6 & 140.28 & 103.68 & 27.15 \\
\hline July 30 & 140.57 & 103.80 & $\mathrm{~N}$ \\
\hline $\begin{array}{l}\text { Range of creep-event } \\
\text { amplitude. }\end{array}$ & $1-.23-9.5$ & $.1-9 \cdot 2$ & $.2-5 \cdot 0$ \\
\hline
\end{tabular}

${ }^{1}$ Minus sign indicates left-lateral movement.

\section{REFERENCES CITED}

Bakun, W.H., Clark, M.M., Cockerham, R.S., Ellsworth, W.L., Lindh, A.G., Prescott, W.H., Shakal, A.F., and Spudich, Paul, 1984, The 1984 Morgan Hill, California, earthquake: Science, v. 225, no. 4659, p. 288-291.

Nason, R.D., Philippsborn, F.R., and Yamashita, P.A., 1984, Catalog of creepmeter measurements in central California from 1968 to 1972: U.S. Geological Survey Open-File Report 74-31, 287 p.

Radbruch-Hall, D.H., 1984, Map showing recently active breaks along the Hayward fault zone and the southern part of the Calaveras fault zone, California: U.S. Geological Survey Miscellaneous Investigations Series May I-813, scale 1:24,000, 2 sheets.

Raleigh, C.B., Stuart, W.D., and Harsh, P.W., 1979, Creep on the Calaveras fault near Coyote Lake Calif. [abs.]: Eos (American Geophysical Union Transactions), v. 60 , no. 46, p. 890 .

Schulz, S.S., Burford, R.O., and Mavko, Barbara, 1983, Influence of seismicity and rainfall on episodic creep on the San Andreas fault system in central California: Journal of Geophysical Research, v. 88, B9, p. 7475-7484.

Schulz, S.S., Mavko, G.M., Burford, R.O., 1979, and Stuart, W.D., 1982, Long-term fault creep observations in central California: Journal of Geophysical Research, v. 87, B8, p. 6977-6982.

Slater, L.E., and Burford, R.O., 1979, A comparison of long-baseline strain data and fault creep records obtained near Hollister, California in Whitten, C.A., Green, Ronald, and Meade, B.K., eds., Recent crustal movements, 1977: Tectonophysics, v. 52, no. 1-4 (special issue), p. 481-496.

Smith, S.W., and Wyss, Max, 1968, Displacement on the San Andreas fault subsequent to the 1966 Parkfield earthquake: Seismological Society of America Bulletin, v. 58, no. 6, p. 1955-1973. 


\title{
Alignment-Array Measurements in the San Felipe Valley, California
}

\author{
By Beth D. Brown
}

\section{CONTENTS}

\begin{tabular}{|c|c|}
\hline Abstract & 17 \\
\hline Introduction & 117 \\
\hline Observations & 117 \\
\hline $\begin{array}{l}\text { Conclusion } \\
\text { Acknowledon }\end{array}$ & 117 \\
\hline $\begin{array}{l}\text { Acknowledgn } \\
\text { References }\end{array}$ & ited \\
\hline
\end{tabular}

Abstract

On April 26, 1984, an alignment array was installed in the San Felipe Valley to measure any afterslip associated with the Morgan Hill earthquake. After 2 months, measurements showed no significant af terslip.

\section{INTRODUCTION}

Bakun and others (1984) located the epicenter of the April 24, 1984, earthquake $5 \mathrm{~km}$ west-southwest of Mount Hamilton near the Calaveras fault; nearly all aftershocks were located within a 26-km-long section southeast of the epicenter, concentrated near the San Felipe Valley und the Anderson Reservoir. On April 26 , just 2 days after the earthquake, the San Felipe Ranch alignment array (SFR4, fig. 14.1) was installed to measure af terslip $4 \mathrm{~km}$ south of the epicenter. This array, which is located at the north end of the San Felipe Valley (figs. 14.1, 14.2), spans both of the fault traces identified by Radbruch-Hall (1974) and D.G. Herd (unpub. data, 1982). Slip along one or both traces would be reflected by a change in the angle $\phi$ (fig. 14.2), as determined by remeasurement of the targets. Calculation of slip follows the formula $\underline{\mathrm{s}}=\mathrm{d} \tan \Delta / \mathrm{h}$, where $\underline{\mathrm{s}}$ is the slip, $\mathrm{d}$ is the distance from Theodolite to end target (in meters), $\Delta$ is the change in the angle $\phi$, and $h$ is the correction factor (cosine of the difference from $90^{\circ}$ of the Theodolite-to-endtarget azimuth and the fault azimuth). The measurements primarily followed the surveying procedure described by Burford and Harsh (1980), with additional techniques from Galehouse and others (1982).

\section{OBSERVATIONS}

An initial measurement of the San Felipe Ranch array was completed on April 26, 1984. A remeasurement on April 28 indicated left-lateral movement of $1.89 \pm 0.78 \mathrm{~mm}$. Further remeusurements on May 3 and May 30 showed right-lateral movements of $0.48 \pm 0.58$ and $0.44 \pm 1.07 \mathrm{~mm}$, respectively, and an additional measurement on June 25 showed a leftlateral movement of $0.39 \pm 0.48 \mathrm{~mm}$. Cumulative total slip after four measurements of the array indicates no appreciable movement beyond our error limits.

\section{CONCLUSION}

Although the alignment array is located well within the aftershock zone, no evidence of afterslip associated with the April 24 earthquake was found as of June 25, 1984, within the zone covered by the array. This zone may not include any currently active trace, or it may be complex, with multiple traces interacting to ef fectively zero out the total slip. The San Felipe Valley site will continue to be monitored, and additional deflection monuments will be installed as soon as possible to delineate any actual fault traces.

\section{ACKNOWLEDGMENTS}

I thank Brett Baker and Kate Breckenridge, who assisted with the field measurements. 


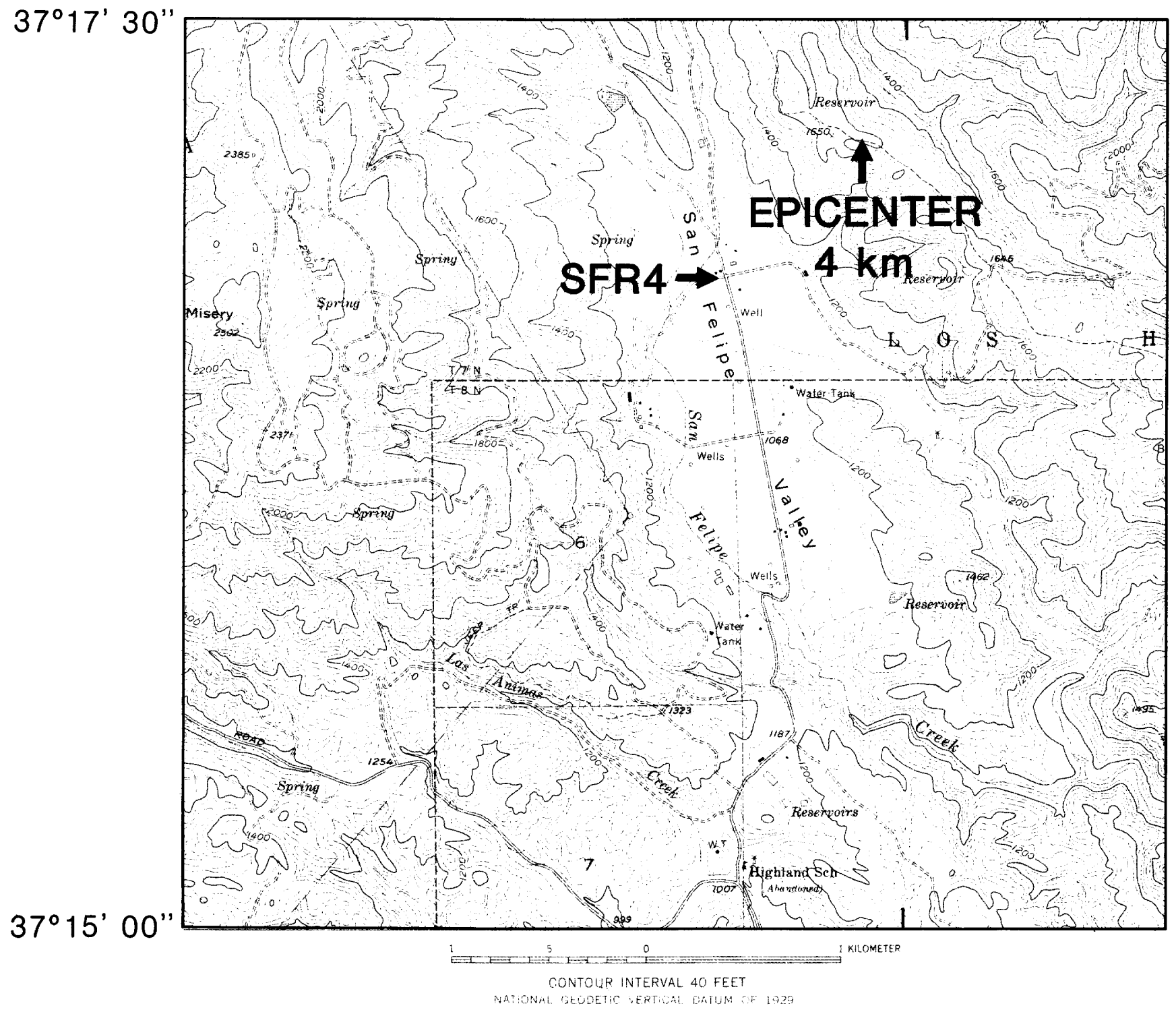

Figure 14.1. Location of U.S. Geological Survey San Felipe Ranch alignment array (SFR4), San Felipe Valley. Topography from Lick Observatory 7.5-minute quadrangle, scale 1:24,000.

\section{REFERENCES CITED}

Bakun, W.H., Clark, M.M., Cockerham, R.S., Ellsw orth, W.L., Lindh, A.G., Prescott, W.H., Shakal, A.F., and Spudich, Paul, 1984, The 1984 Morgan Hill, California, earthquake: Science, v. 225, no. 4659, p. 288-291.

Burford, R.O., and Harsh, P.W., 1980, Slip on the San Andreas Fault in central California from alinement array surveys: Seismological Society of America Bulletin, v. 70, no. 4, p. 1233-1261.

Galehouse, J.S., Brown, B.D., Pierce, Brian, and Thordson, J.J., 1982, Changes in movement rates on certain East Bay faults, in Hart, E.W., Hirschfeld, S.E., and Schulz, S.S., eds., Conference on Earthquake Hazards in the Eastern San Francisco Bay Area, Hayward, Calif., 1982, Proceedings: California Division of Mines and Geology Special Publication 62, p. 239-250.

Radbruch-Hall, D.H., 1974, Map showing recently active breaks along the Hayward fault zone and the southern part of the Calaveras fault zone, California: U.S. Geological Survey Miscellaneous Investigations Series Map I-813, scale 1:24,000, 2 sheets. 


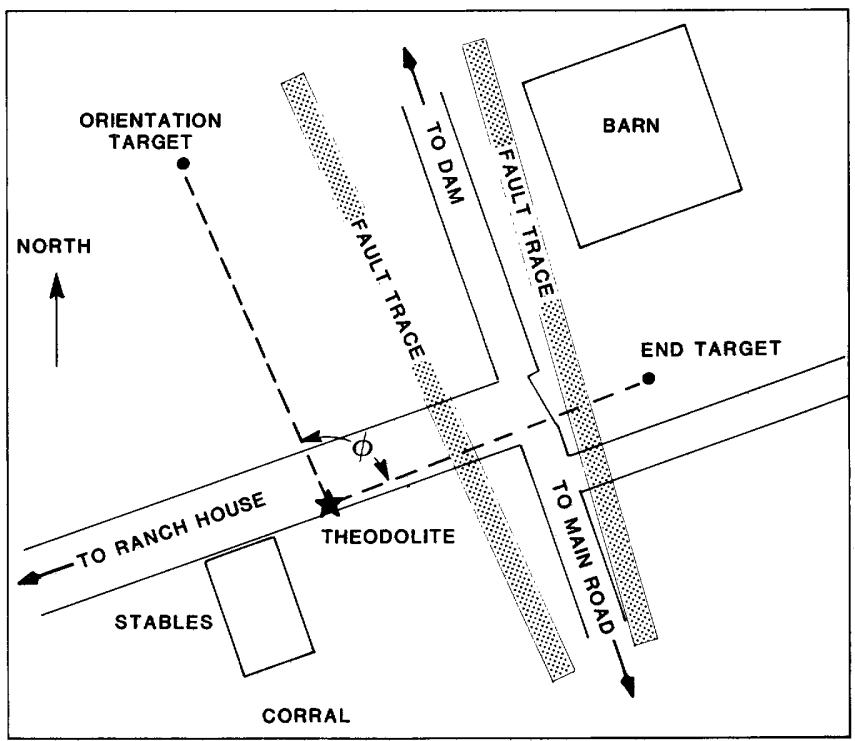

Figure 14.2. Geometry of San Felipe Ranch alignment array. Not to scale. 


\title{
Theodolite Measurements
}

\author{
By Jon S. Galehouse ${ }^{1}$
}

\section{CONTENTS}

Abstract 121

Observations 121

Conclusion 123

References cited $\mathbf{1 2 3}$

\section{Abstract}

Theodolite triangulation measurements on the Calaveras, Hayward, and San Andreas faults indicate that no unusual or significant changes in creep rates can be unequivocally related to the Morgan Hill earthquake.

\section{OBSERVATIONS}

Three San Francisco State University (SFSU) Theodolite triangulation-measurement sites are located astride the Calaveras fault (fig. 15.1). One site is in San Ramon near the northwest terminus of the Calaveras fault, about $60 \mathrm{~km}$ northwest of the earthquake epicenter as determined by Bakun and others (1984); and two sites are in the Hollister area, about $60 \mathrm{~km}$ southeast of the epicenter. Theodolite data indicate no significant changes in creep rates before the earthquake and no surface displacement associated with the earthquake at any of these three sites. Figure 15.2 shows a typical measurement site.

The SFSU has been monitoring the site in San Ramon (SF-19) since November 1980. The average rate of right-lateral movement has been about $1 \mathrm{~mm} / \mathrm{yr}$ for the past 4.2 years (fig. 15.3). The last measurement before the April 24 earthquake was on January 19, 1984, 96 days before the event. The site was remeasured on April 29, June 3, August 24, and October 13, 1984, and on February 18, 1985. All measurements were normal in comparison with the overall average, and no signs of surface rupture were observed at the site.

\footnotetext{
${ }^{1}$ San Francisco State University, San Francisco,
} CA 94132.
Monitoring of the site on Wright Road, about $1.5 \mathrm{~km}$ north of Hollister (SF-06), began in October 1979, about 2.5 months af ter the nearby Coyote Lake, Calif., earthquake. Slip along this segment of the Calaveras fault is fairly uniform, averaging about $14 \mathrm{~mm} / \mathrm{yr}$ for the 4.5 years before the April 24 earthquake (fig. 15.3)--the fastest rate of movement of any of the 20 SFSU sites on 10 active faults in the San Francisco Bay region. The last measurement at Wright Road before the April 24 earthquake was on January 28, 1984, 87 days before the event. The site was remeasured on April 25, the day after the earthquake, and again on June 2, June 23, July 8, August 10, October 7, and December 8, 1984, and on January 26, 1985. Measurements indicate a net rightlateral slip of about $13 \mathrm{~mm}$ in the 9 months following the earthquake--only a few millimeters more than would be expected if the fault at this site had moved at its long-term-average rate. It is unlikely that this slightly higher than average rate of movement is related to the April 24 earthquake. In mid-1981, the Calaveras fault at this site moved more than $10 \mathrm{~mm}$ in a 2-month interval not associated with any nearby significant earthquakes (fig. 15.3).

Monitoring of the site on Seventh Street in Hollister (SF-04) began in September 1979, 54 days af ter the Coyote Lake, Calif., earthquake. This site is about $2.3 \mathrm{~km}$ southeast of the site on Wright Road and is on a different segment of the Calaveras fault (Radbruch-Hall, 1974). Slip on Seventh Street is much more episodic than at Wright Road; times of relatively rapid right-lateral movement alternate with times of little net movement (fig. 15.3). The overall average rate of right-lateral displacement for the 4.5 years before the April 24 earthquake was about $7 \mathrm{~mm} / \mathrm{yr}$.

At the time of the April 24 earthquake, the Calaveras fault at Seventh Street was in an overall phase of slight left-lateral movement that had lasted about a year (fig. 15.3). The measurement on April 25, the day after the earthquake, was virtually the same 
as the last previous measurement on January 28 , 1984. In the 9 months after the earthquake, the fault at this site had net movement of about $8 \mathrm{~mm}$ in a right-lateral sense, a few millimeters more than would have occurred at the long-term-average rate. This pattern of movement is not unusual for this site, inasmuch as virtually the same thing occurred from mid-1981 to mid-1982. About a year of slight leftlateral movement was followed by relatively rapid right-lateral movement of about $10 \mathrm{~mm}$. This change in direction and rate in 1982 occurred without

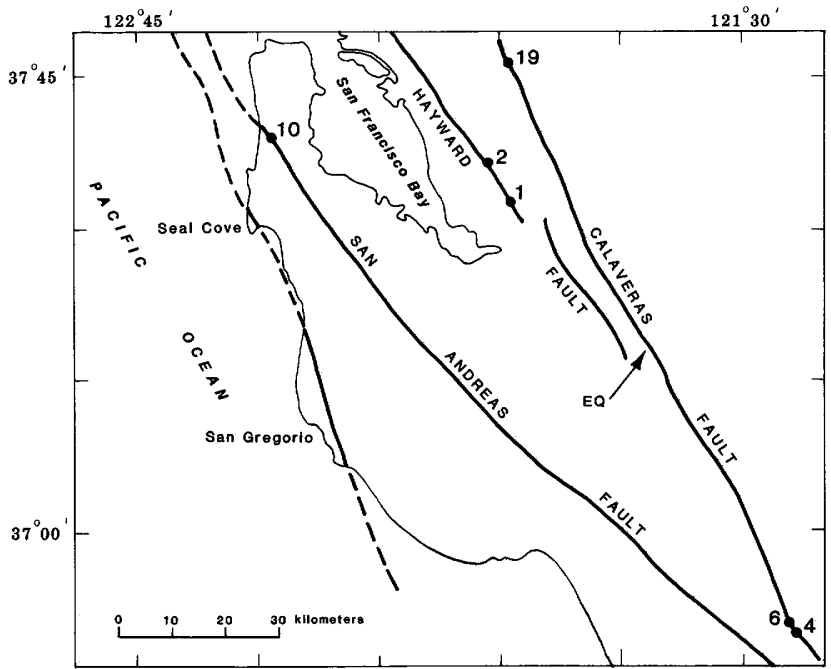

Figure 15.1. Locations of San Francisco State University Theodolite triangulation-measurement sites in the southern San Francisco Bay region. Arrow EQ denotes epicenter of April 24 earthquake as determined by Bakun and others (1984).

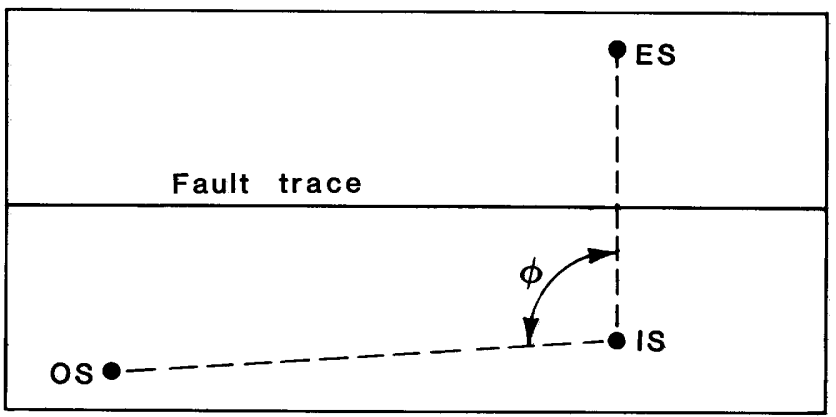

Figure 15.2. Typical positions of stations for Theodolite triangulation measurements. ES, end station; IS, instrument station; OS, orientation station. A change in the angle $\phi$ determined by remeasuring these stations indicates displacement (slip) of ES relative to IS, where the amount of slip is given by the product of the IS-ES distance times the tangent of the change in $\phi$ divided by the sine of the angle between the fault trend and the IS-ES trend. association with any neurby earthquakes. Thus, the change at Seventh Street shortly after the April 24 earthquake is probably only coincidental and not a result of the earthquake.

The Theodolite results at Seventh Street in Hollister are quite comparable to U.S. Geological Survey creepmeter results from the same site (S.S. Schulz, oral commun., 1984). Both measurement methods indicate that displacement at this site is episodic and that little net displacement occurred for several months before the eurthquake. Both methods also show that relatively rapid right-lateral displacement occurred for 2 to 3 months after the earthquake, with little net displacement since.

The measurement site in Fremont (SF-01) on the Hayward fault, about $38 \mathrm{~km}$ northwest of the April 24 epicenter (fig. 15.1), showed no significant change in creep rate either before or after the earthquake (through early February 1985). The average rate of creep at this site has been about $5 \mathrm{~mm} / \mathrm{yr}$ for the past 5.4 years. Similarly, the measurement site in Union City (SF-02) on the Hayward fault, about $45 \mathrm{~km}$ northwest of the epicenter, also showed no unusual behavior. The creep rate there has been about $4 \mathrm{~mm} / \mathrm{yr}$ for the past 5.4 years.

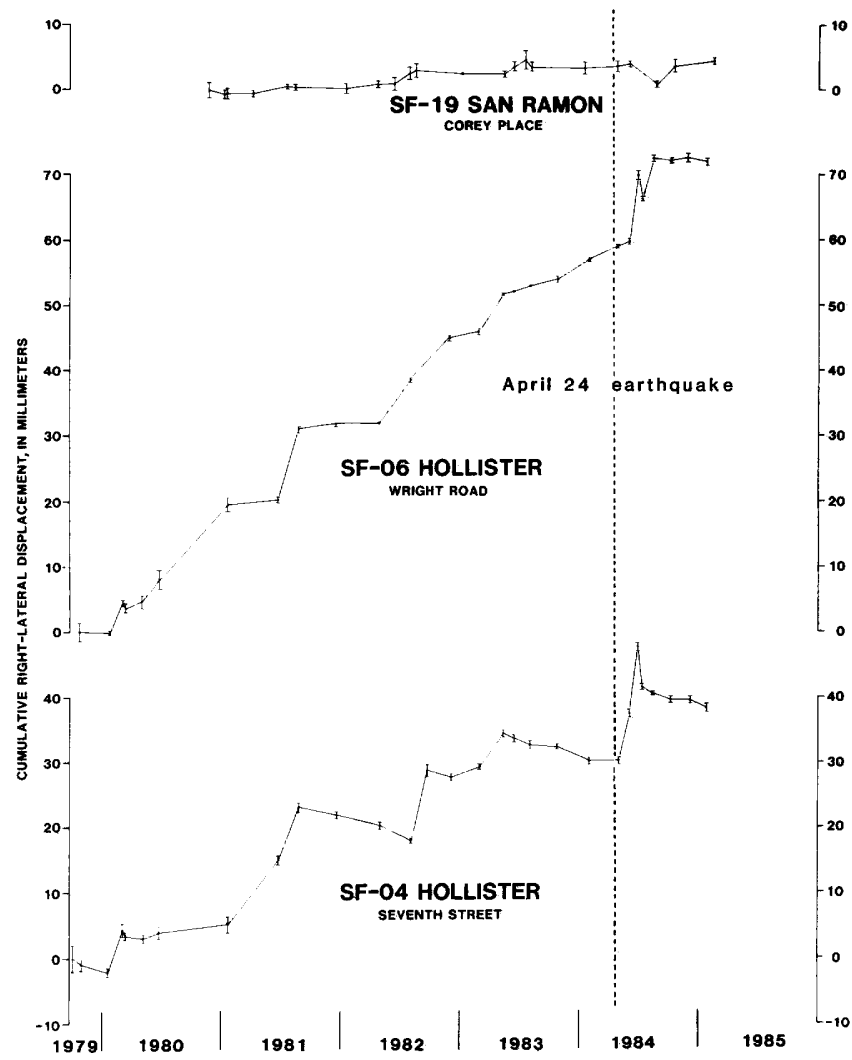

Figure 15.3. Data from San Francisco State University Theodolite triangulation-measurement sites on the Calaveras fault. Upward-sloping part of curve indicates right-lateral slip, and downward-sloping part indicates left-lateral slip. Error bars indicate one standard deviation on either side of plotted points. 
Finally, the measurement site in South San Francisco (SF-10) on the San Andreas fault, about $80 \mathrm{~km}$ northwest of the epicenter (fig. 15.1), remained virtually locked, as it has been since measurements began about 5 years ago.

\section{CONCLUSION}

In summary, no unusual or significant changes in creep rates measured at sites on the Calaveras, Hayward, and San Andreas faults can be unequivocally related to the April 24 earthquake, either before the earthquake or for about 9 months af ter.

\section{REFERENCES CITED}

Bakun, W.H., Clark, M.M., Cockerham, R.S., Ellsworth, W.L., Lindh, A.G., Prescott, W.H., Shakal, A.F., and Spudich, Paul., 1984, The 1984 Morgan Hill, California, earthquake: Science, v. 225, no. 4659, p. 288-291.

Radbruch-Hall, D. H., 1974, Map showing recently active breaks along the Hayward fault zone and the southern part of the Calaveras fault zone, California: U.S. Geological Survey Miscellaneous Investigations Series Map I-813, scale 1:24,000, 2 sheets. 


\title{
Tiltmeter Observations
}

\author{
By C.E. Mortensen and R.P. Liechti
}

\section{CONTENTS}

Abstract 125

Introduction $\mathbf{1 2 5}$

Recent observations $\mathbf{1 2 6}$

Conclusion 127

References cited $\mathbf{1 2 7}$

\section{Abstract}

A bubble-level tiltmeter located near Mount Hamilton, about $1.5 \mathrm{~km}$ east of the epicenter of the earthquake, recorded large changes in ground tilt between November 21, 1983, and April 5, 1984, when the instrument stopped recording data. Although these signals resembled tilt events that preceded earthquakes in 1978 and 1981, they are most likely related to rainfall. Between the time of the last recorded tilt measurement and the first measurement a few hours after the earthquake, the instrument tilted 9.4 microradians ESE. It cannot be determined whether this tilt was preseismic or coseismic.

\section{INTRODUCTION}

Two previous reports (Mortensen and Iwatsubo, 1980; Mortensen, 1982) presented observations of anomalous tilt events of short duration preceding the earthquakes of August 29, 1978, and January 5, 1981. The similarity of these tilt events in form and time scale to signals recorded by tiltmeters installed along the Sun Andreas fault south of Hollister, Calif., at the times of creep events recorded by neurby creepmeters suggested fitting the data with models of aseismic slip propagating along a nearby fault (Johnston and others, 1976; Mortensen and others, 1977).

In the 1978 observations, a change in tilt with a maximum peak-to-peak amplitude of 10.6 microradians down to the northeast preceded a pair of earthquakes $(\mathbf{M}=4.2$, with an origin time of 0014 G.m.t., and $\mathbf{M}=3.9$, with an origin time of 0018 G.m.t., both on August 29, 1978) with epicenters 6.7 and $5.2 \mathrm{~km}$, respectively, northwest of the Mount Hamilton tiltmeter site (MTH, fig. 16.1). The signal began about 40 hours before the earthquake pair and persisted for about 35 hours. The record was uneventful except for this anomalous change.

In the 1981 observations, a similar signal, with a maximum peak-to-peak amplitude of 8.2 microradians down to the southeast, preceded an $M=4.6$ earthquake on January 15, 1981. The onset of this signal was about 7 days before the earthquake, and the signal lasted for about 1 day. Several other, smaller signals were recorded during the month before the January 15 , 1981, earthquake. The epicenter for this earthquake was $7.8 \mathrm{~km}$ north west of station MTH.

In contrast to these previous results, an $\mathbf{M}=4.5$ earthquake on May 8, 1979, occurred without any accompanying anomalous tilt events observed at MTH. The epicenter of this earthquake was $3.2 \mathrm{~km}$ south of the tiltmeter near Panochita Hill, the eventual epicenter of the April 24, 1984, earthquake.

Figure 16.1 shows the locations of $\mathbf{M}>\mathbf{3 . 5}$ earthquakes that have occurred in Halls Valley while station MTH has been in operation. Figures 16.2 and 16.3 show the E-W. and N-S. record traces of the MTH tilt meter data spanning the times of the 1978 and 1981 earthquakes and anomalous tilt signals. Figures $\mathbf{1 6 . 2}$ and 16.3 include theoretical tilt wave forms generated by models of dislocation loops, propagating quasistatically, with the geometry depicted. These models use the equations of Press (1965) and the programs of McHugh (1976) to generate tilt waveforms. The model geometries were then determined simply by successive fitting by inspection of many waveforms. These models determine possible slip amplitudes and geometries that satisfy the observed data. From the smaller signals present in the record in Figure 16.3, the model results clearly do not adequately represent the complexities in the data and thus do not depict the complexity of the mechanism. For further discussion, the reader is referred to the report by Mortensen (1982). 


\section{RECENT OBSERVATIONS}

Figure 16.4 plots the station MTH data before the April 24 earthquake. In comparison with rainfall data (available through February 29, 1984), the large signals evident in the record appear to occur at the times of greatest ra in fall. Instrumental and site noise is typically high for MTH.

The data plotted in figure 16.4 were taken from digitized strip-chart records. The telephone telemetry became unreliable and difficult to maintain after December 1983. Reliance on the onsite strip-chart recorder resulted in missing the 19 days of data immediately before the earthquake. A tilt measurement was taken on the afternoon of the earthquake. The difference between the last recorded tilt value and the measurement immediately (less than 2 hours) after the earthquake indicates that a tilt change of about 9 microradians down to the ESE. occurred between April 5 and 24. It cannot be determined whether this change was preseismic or coseismic. The tilt sensor at station MTH is held by a rugged stainless-steel clamp that is grouted firmly into the borehole, whereas at most U.S. Geological Survey tiltmeter sites, sensors are typically packed in fine silica sand. The coseismic-tilt of fset expected at MTH from a simple dislocation model of the earthquake source is 1.5 microradians down to the north, calculated using a moment of $2 \times 10^{25}$ dyne-cm (M.J.S. Johnston, written communication, 1984).

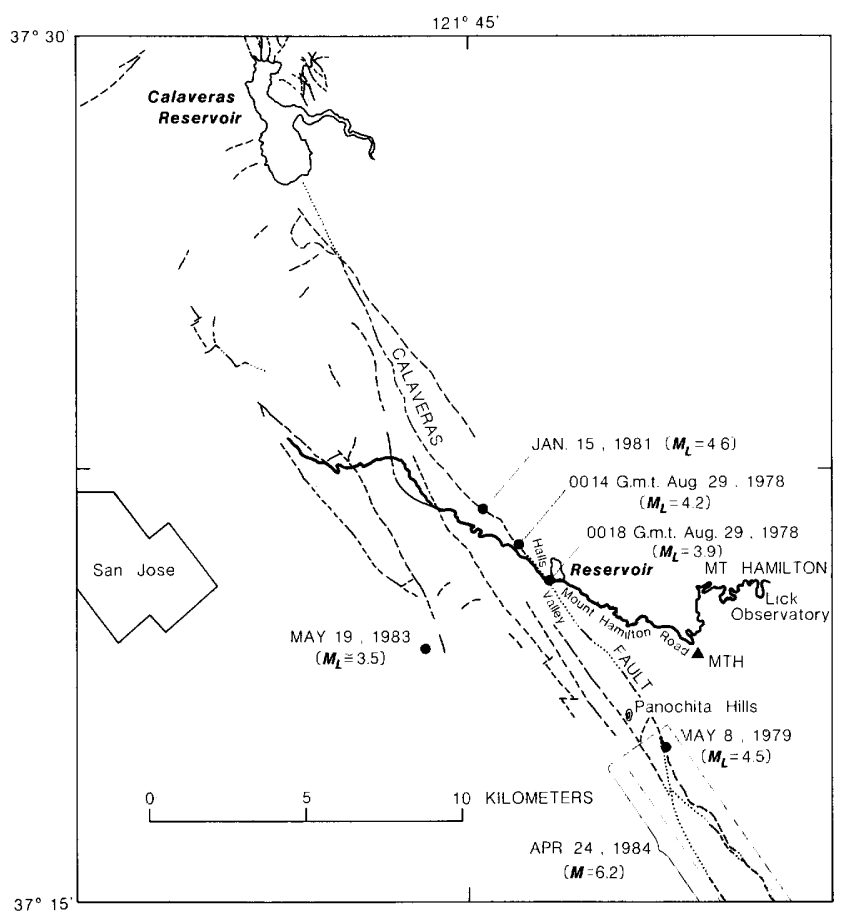

Figure 16.1. Sketch map of the Calaveras fault in northern California, showing locations of Mount Hamilton tiltmeter site (MTH), epicenters of recent earthquakes (dots), and fault segment that ruptured on April 24 (stippling). Modified from Mortensen (1982, fig. 1).

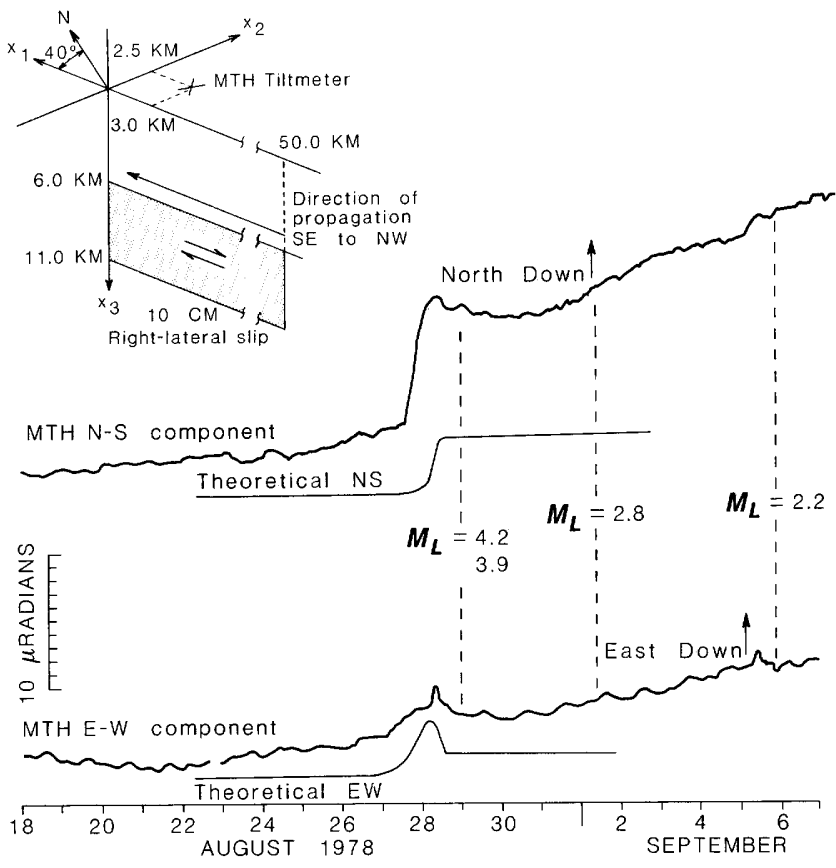

Figure 16.2. Short-term tilt signals recorded by the Mount Hamilton tiltmeter (MTH) before the August 29, 1978, earthquake pair and September 5 aftershock, in comparison with theoretical tilt waveforms generated by propagating-slip model shown in upper left. Tilt components are sampled every 10 minutes; curve MTH $\mathrm{N}-\mathrm{S}$. component has been smoothed with a six-point running mean to eliminate noise. From Mortensen and Iwatsubo (1980, fig. 2).

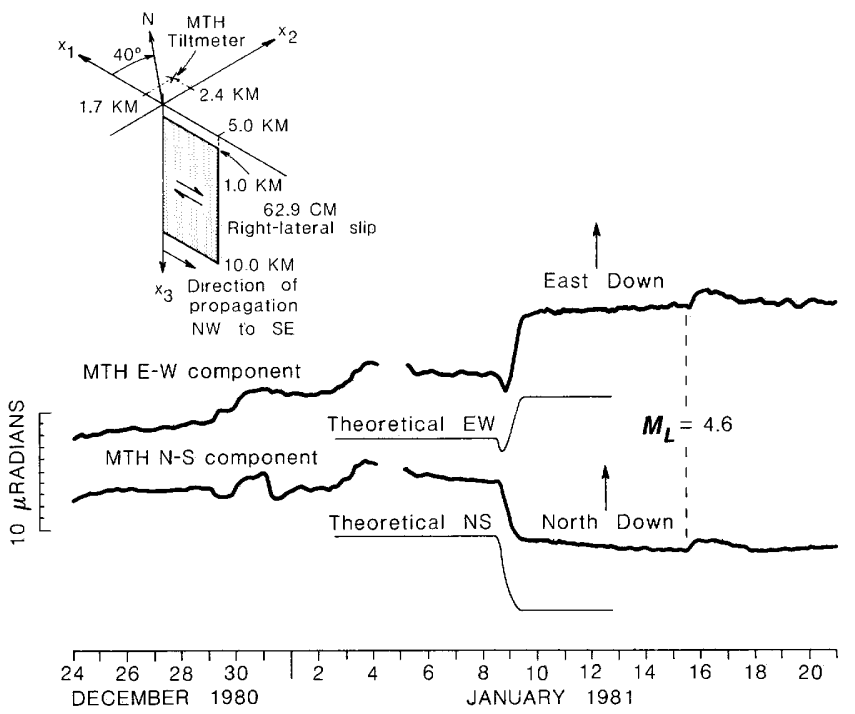

Figure 16.3. Short-term tilt signals recorded by the Mount Hamilton tiltmeter (MTH) before the January 15, 1981, earthquake. Theoretical tilt waveforms generated by propagating-slip model shown in upper left. From Mortensen (1982, fig. 2). 


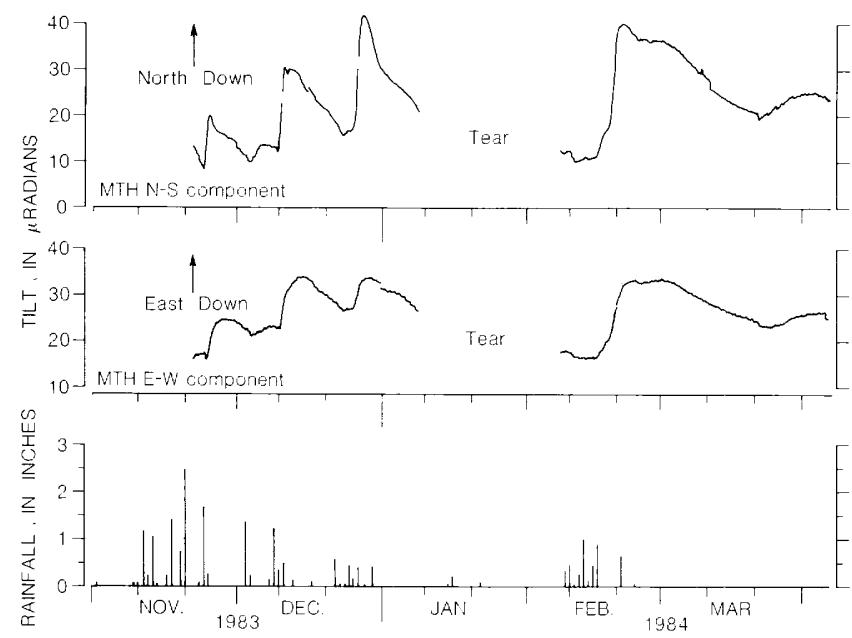

Figure 16.4. Mount Hamilton tiltmeter (MTH) data for the period November 21, 1983-April 5, 1984, digitized from strip-chart record at 1 -hour intervals.

\section{CONCLUSION}

Bakun (1980) suggested that the Calaveras fault between the Anderson Reservoir and Halls Valley is creeping and that the fault segment juxtaposed to station MTH may serve as an "unpinned" patch where normal stress tends to be relieved by adjacent rightlateral shear, so that it is a likely place for rupture to initiute, as it did in the April 24 earthquake. The 1978,1981 , and 1983 observations are consistent with that model and further suggest that episodic creep at depth may occur in the region, possibly related to seismicity (Mortensen and Iwatsubo, 1980; Mortensen, 1982). The observations presented here for the April 24 earthquake neither confirm nor contradict that conclusion.

\section{REFERENCES CITED}

Bakun, W.H., 1980, Seismic activity on the southern Calaveras Fault in central California: Seismological Society of America Bulletin, v. 70, no. 4, p. 1181-1197.

Crittenden, M.D., Jr., 1951, Geology of the San JoseMount Hamilton area, California: California Division of Mines Bulletin 157, $74 \mathrm{p}$.

Johnston, M.J.S., McHugh, Stuart, and Burford, R.O., 1976, On simultaneous tilt and creep observations on the San Andreas Fault California : Nature, v. 260, no. 5553, p. 691-693.

McHugh, Stuart, 1976, Documentation of programs that compute (1) static tilts for a spatially variable slip distribution, and (2) quasistatic tilts produced by an expanding dislocation loop with a spatially variable slip distribution: U.S. Geological Survey Open-File Report 76-578, $149 \mathrm{p}$.

Mortensen, C.E., 1982, Short-term tilt events preceding some local earthquakes on the central Calaveras Fault: Additional evidence, in Hart, E.W., Hirschfeld, S.E., and Schulz, S.S., eds., Conference on Earthquake Hazards in the Eastern San Francisco Bay Area, Hayward, Calif., 1982, Proceedings: California Division of Mines and Geology Special Publication 62, p. 289-298.

Mortensen, C.E., and Iwatsubo, E.Y., 1980, Short-term tilt anomalies preceding local earthquakes near San Jose, California: Seismological Society of America Bulletin, v. 70, no. 6, p. 2221-2228.

Mortensen, C.E., Lee, R.C., and Burford, R.O., 1977, Observations of creep-related tilt, strain, and water-level changes on the central San Andreas Fault: Seismological Society of America Bulletin, v. 67, no. 3, p. 641-649.

Press, Frank, 1965, Displacements, strains, and tilts at teleseismic distances: Journal of Geophysical Research, v. 70, no. 10, p. 2395-2412. 


\title{
Magnetic-Field Measurements
}

\author{
By R.J. Mueller and M.J.S. Johnston
}

\section{CONTENTS}

\author{
Abstract 129 \\ Introduction \\ Data 129 \\ Discussion 130 \\ Conclusions 131

\section{9}

13

References cited

\section{Abstract}

The magnetometer stations located along the Calaveras fault were not operational at the time of the earthquake or for the 16-month period before, but were reinstalled within hours of the main shock. Comparison of the magnetic-field differences after the earthquake with those 16 months before indicates no significant variations greater than $0.75 \mathrm{nT}$. Analysis of hourly magnetic-field differences for the 12-day period after the earthquake indicates no significant variations greater than $1.0 \mathrm{nT}$ associated with the aftershock activity. A seismomagnetic model of the earthquake, assuming uniform magnetization, indicates that the magnetometer stations along the Calaveras fault are poorly located to detect stressgenerated magnetic-field changes. The same model, using a distribution of magnetic material on only the west side of the fault, indicates that station C1Y was located near the point of maximum expected field changes. The absence of any magnetic-field changes greater than $1.0 \mathrm{nT}$ at station C1Y requires a stress change of less than $1.2 \mathrm{MPa}$ for the 12-day period after the earthquake.

\section{INTRODUCTION}

The U.S. Geological Survey (USGS) operates a network of magnetometer stations in central California to detect local magnetic-field perturbations generated by changes in tectonic stress (fig. 17.1). Previous studies of magnetic-field perturbations associated with earthquakes in this region are inconclusive. A 2-nT variation in the local magnetic field was observed during the 2-month period before an $\mathrm{M}_{\mathrm{L}}=5.2$ earthquake in November 1974 (Smith and Johnston, 1976). However, no significant magneticfield variation was observed before or during the
August 6, 1979, Coyote Lake, Calif., earthquake (Johnston and others, 1981).

Station MTH, the nearest station in the USGS magnetometer network, is located $2 \mathrm{~km}$ east of the epicenter of the earthquake (fig. 17.1). Both stations MTH and COY have not been operational since January 1983 , but they were reinstalled with portable onsite recording systems after the earthquake. Station MTH was operational within 3 hours, and station COY within 24 hours, of the main shock. In addition, station C1Y, which was established after the Coyote Lake earthquake, was reoccupied; and a new station (EMT) was established as a reference for station MTH (fig. 17.1). In this chapter, we examine the data collected with the onsite recording systems at these four stations and the data from two telemetered magnetometer stations (EUC, SAR, fig. 17.1), in an attempt to isolate any local magnetic-field variations associated with the April 24 earthquake.

\section{DATA}

The four onsite recording systems measure total magnetic-field intensity at $0.25-\mathrm{nT}$ sensitivity and the duta from the two telemetered stations at $0.125-\mathrm{nT}$ sensitivity. The field at all stations is synchronously sampled at a $10-$ minute sampling interval. All stations use an E.G.\& G. Geometrics, Inc., model G-816 or G-826 proton-precession magnetometer. Instrumental details were described by Mueller and others (1981).

Because none of the magnetometer stations was in operation along the Calaveras fault at the time of, or 16 months before, the April 24 earthquake, observation of coseismic and preseismic effects with periods of less than 16 months is not possible. What may be investigated are the long-term net of fsets that accumulated during this period, and the postseismic local magnetic-field variations related to af tershocks. 
The simplest method of isoluting magnetic-field changes and of reducing the effects of ionospheric and magnetospheric disturbances is to difference the magnetic-field observations between adjacent stations. Figure 17.2 shows 3-day averages of differenced 10-minute magnetic-field data for stations near the epicenter of the earthquake. The top three plots include data from stations along the Calaveras fault, and the bottom reference plot includes duta from two stations located of $f$ the Calaveras fault. An annual cycle is apparent in the two middle plots. We suspect that this cycle is due to a temperature-related response at station $\mathrm{COY}$, although we have no good evidence. Thermal testing of the electronic equipment at station $\mathrm{COY}$ when it was operational indicates no response to temperature over the range $5^{\circ}-30^{\circ} \mathrm{C}$.

No significant offsets greater than $0.75 \mathrm{nT}$ are observable in these data from magnetometer stations along the Calaveras fault after the April 24 earthquake relative to data from $1 \hat{0}$ months before. In addition to these data, comparison of the averaged magnetic-field differences for difference plot $\mathrm{C} 1 \mathrm{Y}$ $\mathrm{COY}$ in August 1979 with April 1984 indicates only a $-0.16 \pm 0.25-n T$ change for this 56 -month period.

Figure 17.3 shows hourly averages of 10-minute differenced magnetic-field data for stations along the Calaveras fault during the 12 days after the April 24 earthquake. The tickmarks at the bottom of figure 17.3 represent the logarithm of hourly averaged moment, where $\log \mathrm{M}_{0}=1.5 \mathrm{M} \mathrm{L}^{+16}$ ('Thatcher and Hanks, 1973). This quantity is intended to indicate the seismic energy released during the aftershock period.

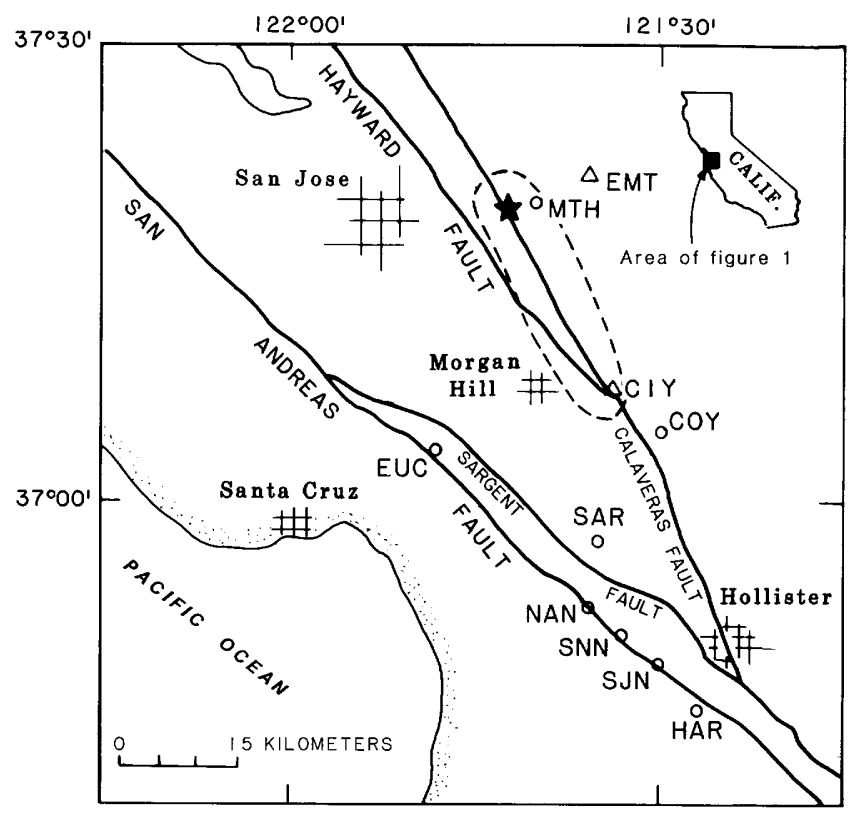

Figure 17.1. Locations of telemetered (circles) and portable (triangles) magnetometer stations in central California. Star, epicenter of $M=6.2$ main shock of April 24 earthquake; dashed line, approximate boundary of aftershock zone.
To further complicate interpretation of these differenced magnetic-field data, storm-level conditions existed in the geomagnetic field beginning at 1200 G.m.t. April 25 and continuing to the end of April 20 . These geomagnetic-field storm conditions are suspected to be responsible for the $3-n$ ' $T$ positive spike on April 26 shown on difference plot EMT-MTH and the changes at the beginning of difference plots EMT-COY and $\mathrm{C} 1 \mathrm{Y}-\mathrm{C} 0 \mathrm{Y}$ (fig. 17.3). The increasing noise level of the differenced data for difference plot EMT-COY $(\sigma=0.92 \mathrm{nT})$ is due to a greater station-separation distance of $34 \mathrm{~km}$ versus station-separation distances of approximately $8 \mathrm{~km}$ for difference plots EVIT-MTH $(\sigma=0.60 \mathrm{nT})$ and $\mathrm{C} 1 \mathrm{Y}-\mathrm{COY}(\sigma=0.25 \mathrm{nT})$. No significant changes greater than 1 to $2 \mathrm{nT}$ are observed in these magnetic-field data that relate to seismicity during the 12-day period after the April 24 earthquake.

\section{DISCUSSIO N}

Local magnetic-field perturbations are expected to result from stress drops before and during moderate to large earthquakes. These se ismomagnetic effects (Stacey, 1964) are derived from the stress dependence of the magnetic properties of crustal rocks near active faults. Models used to calculate the form and amplitude of magnetic-field changes on the Calaveras Fault for the Coyote Lake earthquake (Johnston and others, 1981) can also be applied to the Morgan Hill earthquake. These models calculate the seismomarnetic anomaly on the Earth's surface as a function of fault geometry, the distribution of magnetic material, and the stress change in the region.

Figure 17.4 illustrates the calculation of the seismomagnetic effect, using a vertical finite-slip patch, 1 to $11 \mathrm{~km}$ deep and $21 \mathrm{~km}$ long, with $10 \mathrm{~cm}$ of fault slip, assuming a uniform magnetization of $1 \mathrm{~A} / \mathrm{m}$ on both sides of the fuult. This solution indicates that the three magnetometer stations near the Calaveras fault are poorly located for detection of local magnetic-field changes and that the amount of slip would have to triple to produce a change greater than $1 \mathrm{nT}$ at any of these stations.

Aeromagnetic surveys (U.S. Geological Survey, 1974) indicate that more magnetic material is located on the west side of the Calaveras fault in this area. Figure 17.5 illustrates the calculation of the seismomagnetic effect, using the same fault geometry as in figure 17.4 , but with a magnetization of $1 \mathrm{~A} / \mathrm{m}$ on only the west side and of $0.1 \mathrm{~A} / \mathrm{m}$ on the east side of the fault. For this solution, station $\mathrm{C} 1 \mathrm{Y}$ is best located to detect magnetic-field changes from the April 24 earthquake. The differenced data for difference plot $\mathrm{C} 1 \mathrm{Y}-\mathrm{COY}$ (fig. 17.3) indicate no significant magnetic-field changes greater than $1 \mathrm{nT}$ during the aftershock period from April 26 to May 6. For this solution, if the signal were at the level of the noise, these data require a stress change no greater than 1.2 MPa for the period April 26-May 6.

The two solutions using the seismomagnetic model indicate that the optimum array of magnetometers for an earthquake of this magnitude would consist of pairs of stations located about 1 to 2 $\mathrm{km}$ on either side of the fault, at approximately $5-\mathrm{km}$ intervals along the fault. 


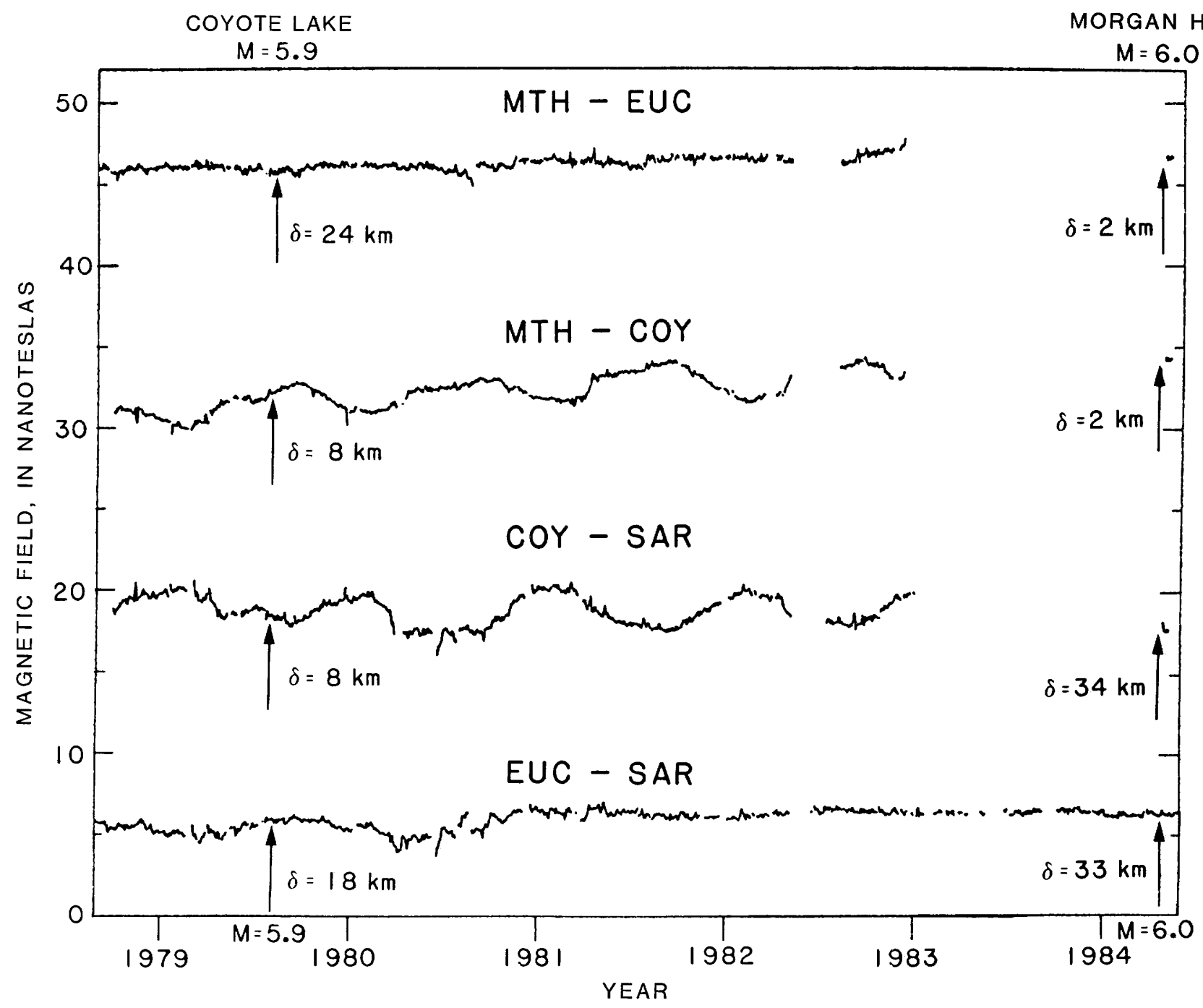

Figure 17.2. Three-day averages of differenced magnetic-field data between 1978 and 1984. Three upper plots include data from stations located along the Calaveras fault. $\delta$, distance from epicenter to nearest station used in the difference. Arrows mark times of two moderate earthquakes that occurred on the Calaveras fault during this period.

\section{CONCLUSIONS}

Analysis of magnetic-field data from stations located near Morgan Hill indicate no anomulous preseismic variations larger than $0.75 \mathrm{nT}$ with periods longer than 16 months. For the 12 days after the April 24 earthquake, no magnetic-field variations larger than $1.0 \mathrm{nT}$ were associated with the postseismic activity. Seismomagnetic models indicate either that the magnetometer stations are poorly located for this earthquake or that any stress changes during the 12duy period after the earthquake were no greater than $1.2 \mathrm{MPa}$. The absence of data at the time of, and for the 16-month period before, the earthquake preclude the identification of magnetic-field perturbations during this period. 

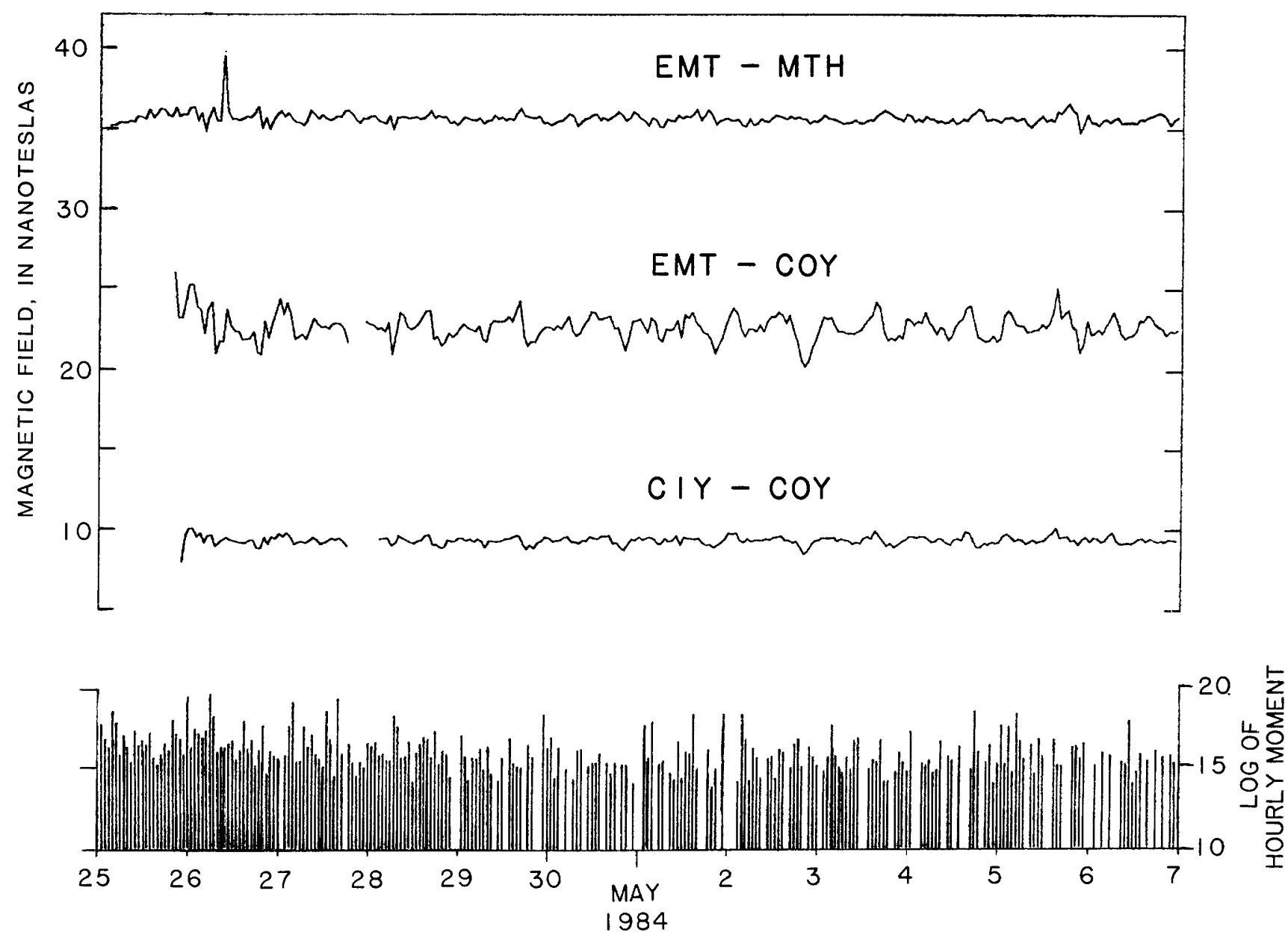

Figure 17.3. Hourly averages of differenced magnetic-field data from stations along the Calaveras fault during 12-day period after the April 24 earthquake. Tickmarks represent logarithms of hourly averaged seismic moment $\left(\log \underline{M}_{0}=1.5 \underline{M}_{L}+16\right)$.

\section{REFERENCES CITED}

Johnston, M.J.S., Mueller, R.J., and Keller, Vincent, 1981, Preseismic and coseismic magnetic field measurements near the Coyote Lake, California, earthquake of August 6, 1979: Journal of Geophysical Research, v. 86, no. B2, p. 921-926.

Mueller, R.J., Johnston, M.J.S., Smith, B.E., and Keller, Vincent, 1981, U.S. Geological Survey magnetometer network and measurement techniques in Western U.S.A.: U.S. Geological Survey Open-File Report 81-1346, 44 p.

Smith, B.E., and Johnston, M.J.S., 1976, A tectonomagnetic effect observed before a magnitude 5.2 earthquake near Hollister, California: Journal of Geophysical Research, v. 81 , no. 20 , p. 3556-3560.

Stacey, F.D., 1964, The seismomagnetic effect: Pure and Applied Geophysics, v. 58, p. 5-22.

Thatcher, Wayne, and Hanks, T.C., 1973, Source parameters of southern California earthquakes: Journal of Geophysical Research, v. 78, no. 35, p. 8547-8576.

U.S. Geological Survey, 1971, Aeromagnetic map of parts of the San Jose, Santa Clara, and San Francisco $1^{\circ}$ by $2^{\circ}$ quadrangles, California: Open-File Report 74-79, scale 1:125,000. 


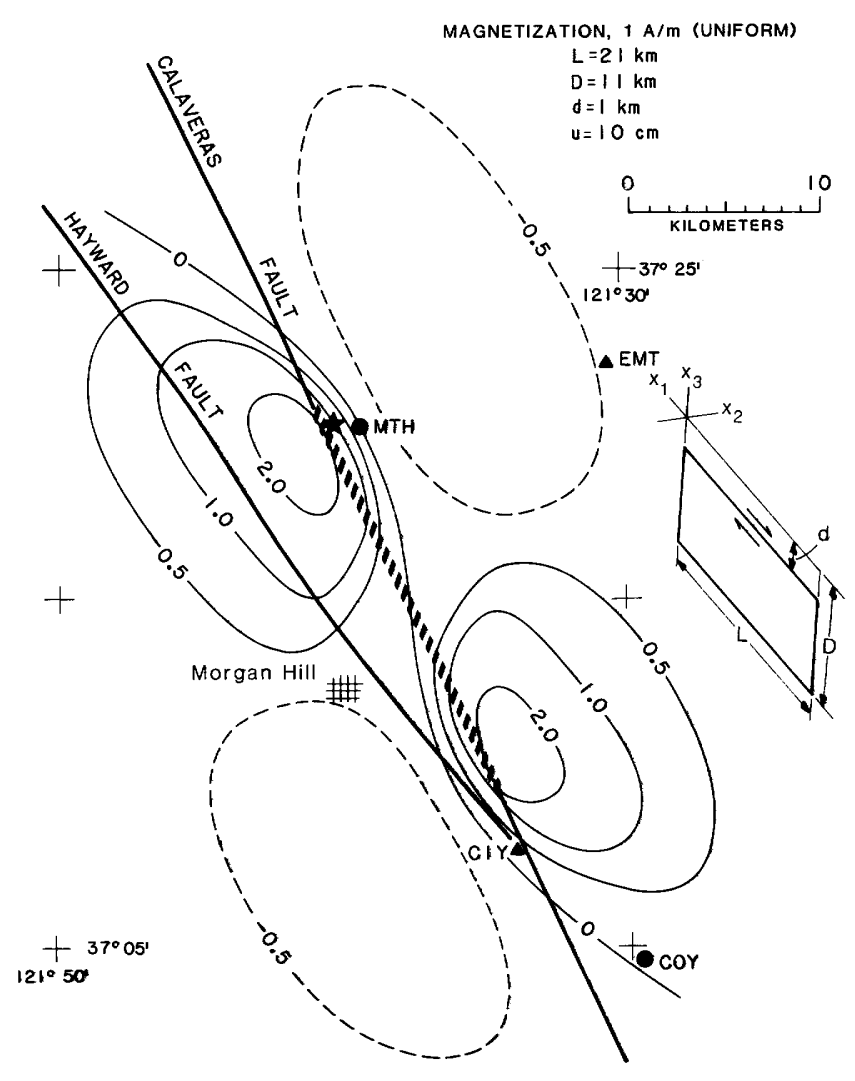

Figure 17.4. Locations of magnetometer stations and epicenter of the April 24 earthquake (star) in relation to magnetic-anomaly contours (in nanoteslas). Magnetic-anomaly contours represent $10 \mathrm{~cm}$ of slip on a fault plane $10 \mathrm{~km}$ by $21 \mathrm{~km}$, with a uniform magnetization of $1 \mathrm{~A} / \mathrm{m}$. Dashed-outlined area denotes rupture zone.

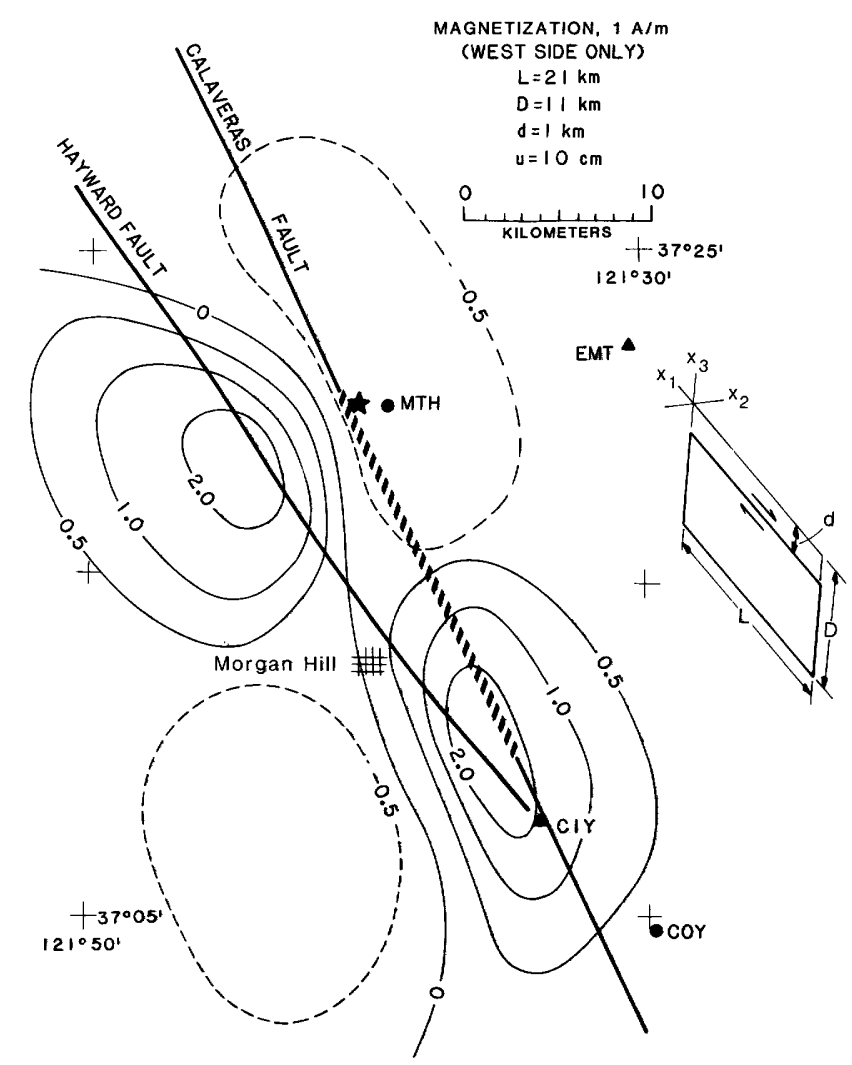

Figure 17.5. Magnetic-anomaly contours (in nanoteslas), using same model as in figure 17.4 but with magnetic material on only the west side of the fault. 


\title{
Ground-Water Observations
}

\author{
By Chi-Yu King and David Basler
}

\section{CONTENTS}

\author{
Abstract 135 \\ Observations 135 \\ Conclusion 136 \\ References cited
}

\section{6}

\section{Abstract}

A gradual decrease in conductivity and salinity was recorded at two springs in Alum Rock Park, about $15 \mathrm{~km}$ from the epicenter of the earthquake, beginning about $2-1 / 2$ years before the event. The flow rates of these springs showed a large, possibly coseismic increase.

\section{OBSERVATIONS}

This chapter presents some preliminary data recorded at two springs and two shallow wells situated along the Hayward fault, where the ground water seems to have shown some anomalous changes in quality beginning 2 years before the earthquake. The temperature, salinity, and conductivity of ground water were measured with a portable instrument (Yellow Springs Instrument Co. model 33) about once a month since late 1975 at two springs in Alum Rock Park east of San Jose, and approximately $15 \mathrm{~km}$ from the epicenter of the earthquake (fig. 18.1). Waterflow rate was also recorded at the orifice of one of the springs (Sulfur Spring 11). Both springs are located within the middle member of the Monterey Formation, which consists of thin-bedded opaline chert and cherty shale (Crittenden, 1951).

The measured conductivity and salinity values show a gradual decline of 40 percent from about the end of 1981 to April 9, 1984 (fig. 18.2). This result was corroborated by an independent study by William $\mathrm{C}$. Evans of the U.S. Geological Survey, who has been regularly collecting water samples from one of the springs (Sulfur Spring 4) for chemical analysis. Evans' data show a similar decline in $\mathrm{HCO}_{3}^{-}$content in the water. Our postearthquake measurements, taken on May 9 and June 8, 1984, show a small recovery of conductivity (and salinity) at both springs (fig. 18.2).

One of us (D.B.) visited the springs on April 25, the day after the earthquake; he observed an appreciable increase of flow at Sulfur Spring 4 and

recorded a large increase in flow rate at Sulfur Spring 11 (more than twice that measured on April 9 and the highest since our study began in 1975). This flow increase cannot be attributed to rainfall, which has been extremely small for winter 1983-84, but may have been induced by stress-field changes associated with the earthquake, because the springs are situated in a compressional quadrant of the earthquake, as observed by Wakita (1975). Furthermore, the color of

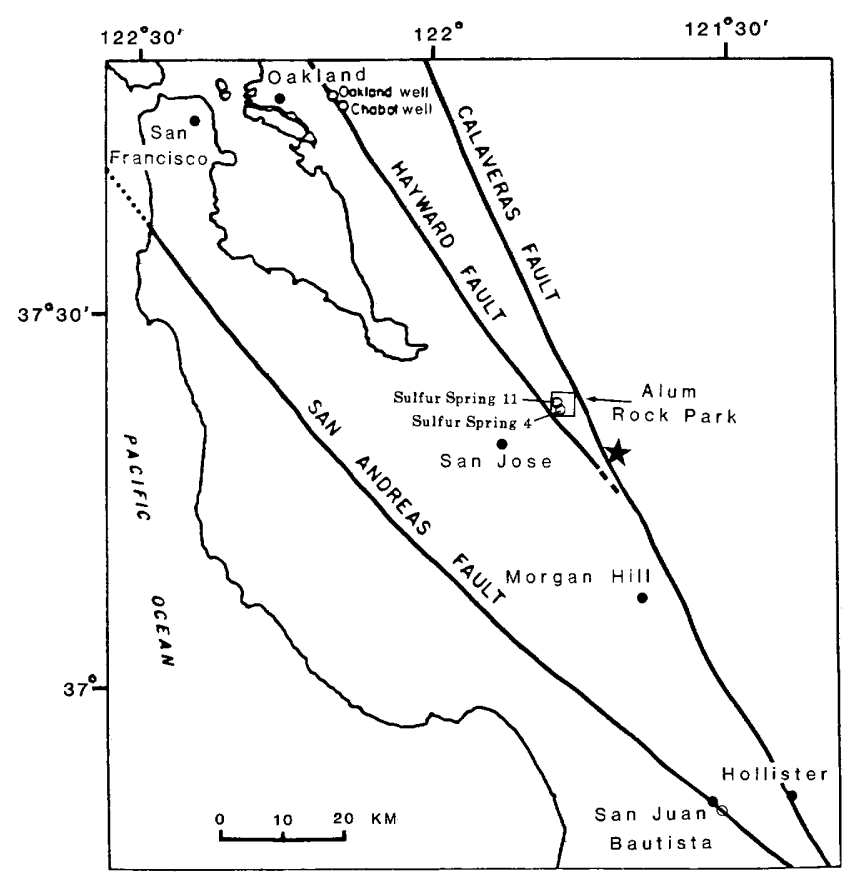

Figure 18.1. Sketch map of San Francisco Bay region, Calif., showing locations of ground-watermeasurement sites (circles) and epicenter of the April 24 earthquake (star). 


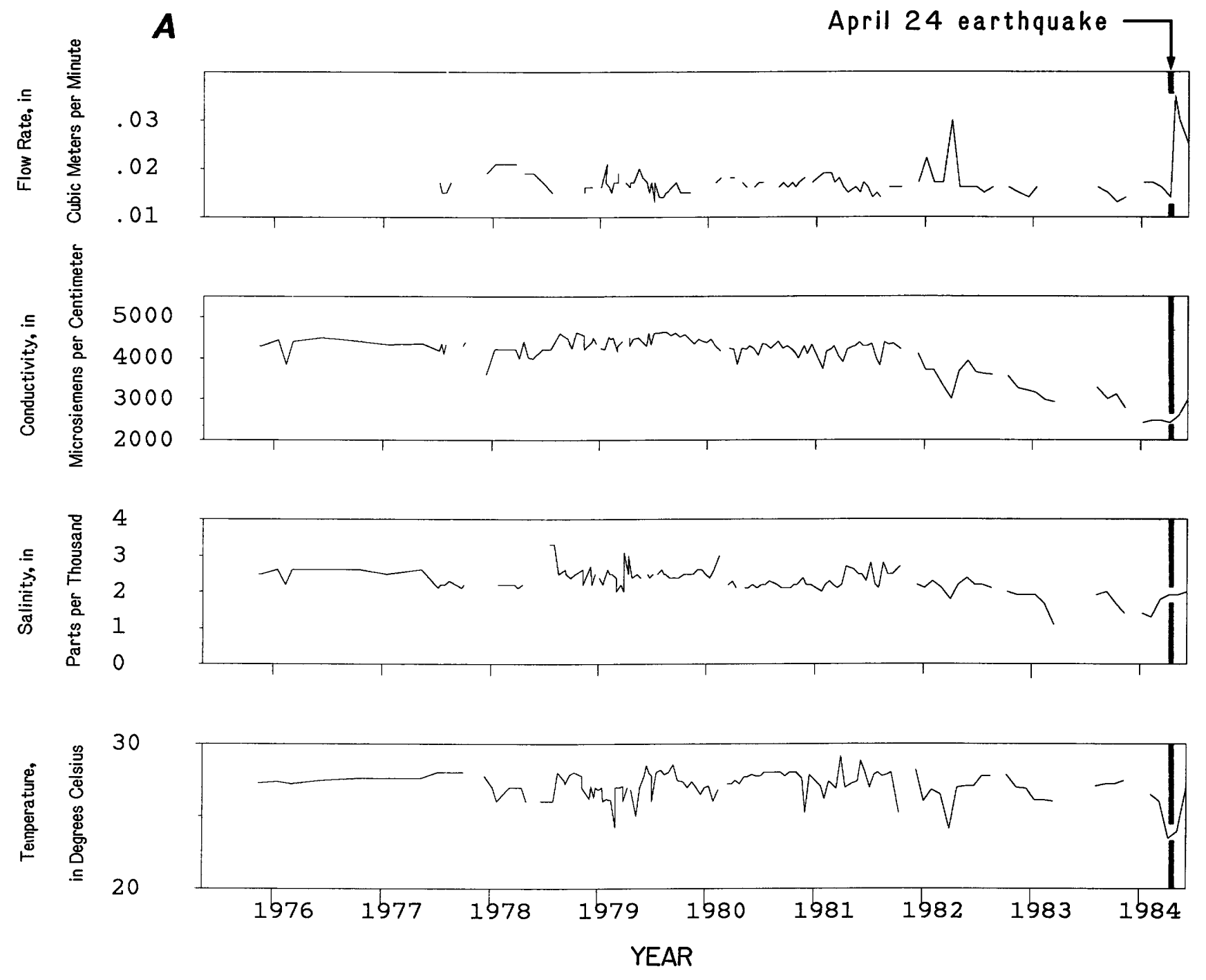

Figure 18.2. Flow rate, conductivity, salinity, and temperature data from two springs in Alum Rock Park. A, Sulfur Spring 11. B, Sulfur Spring 4.

the water in the springs changed from white to greyish brown because of the large amount of sediment in the water. The flow rate at Sulfur Spring 11 was measured again on May 9 and June 8, when it was found to have decreased considerably but was still higher than normal (fig. 18.2A). The water color had returned to normal (white) by May 9.

Measurements were also made at two shallow wells in East Oakland, Calif., near the Hayward fault (Oakland and Chabot, fig. 18.1). A gradual decline in conductivity and temperature during the past 2 years $(1982-83)$ is noticeable in the data, although it is dominated by seasonal variations (fig. 18.3).

\section{CONCLUSION}

It is unclear at present whether the observed ground-water changes are due to tectonic or climatic effects (the winters of 1981-82 and 1982-83 had an above-normal amount of rainfall). The radon content of ground water has been continuously monitored for several years at an artesian well south of San Juan Bautista near the San Andreas fault (fig. 18.1). These radon data show no significant changes.

\section{REFERENCES CITED}

Crittenden, M.D., Jr., 1951, Geology of the San JoseMount Hamilton area, California: California Division of Mines Bulletin 157, 74 p.

Wakita, Hiroshi, 1975, Water wells as possible indicators of tectonic strain: Science, v. 189, no. 4202 , p. 553-555. 

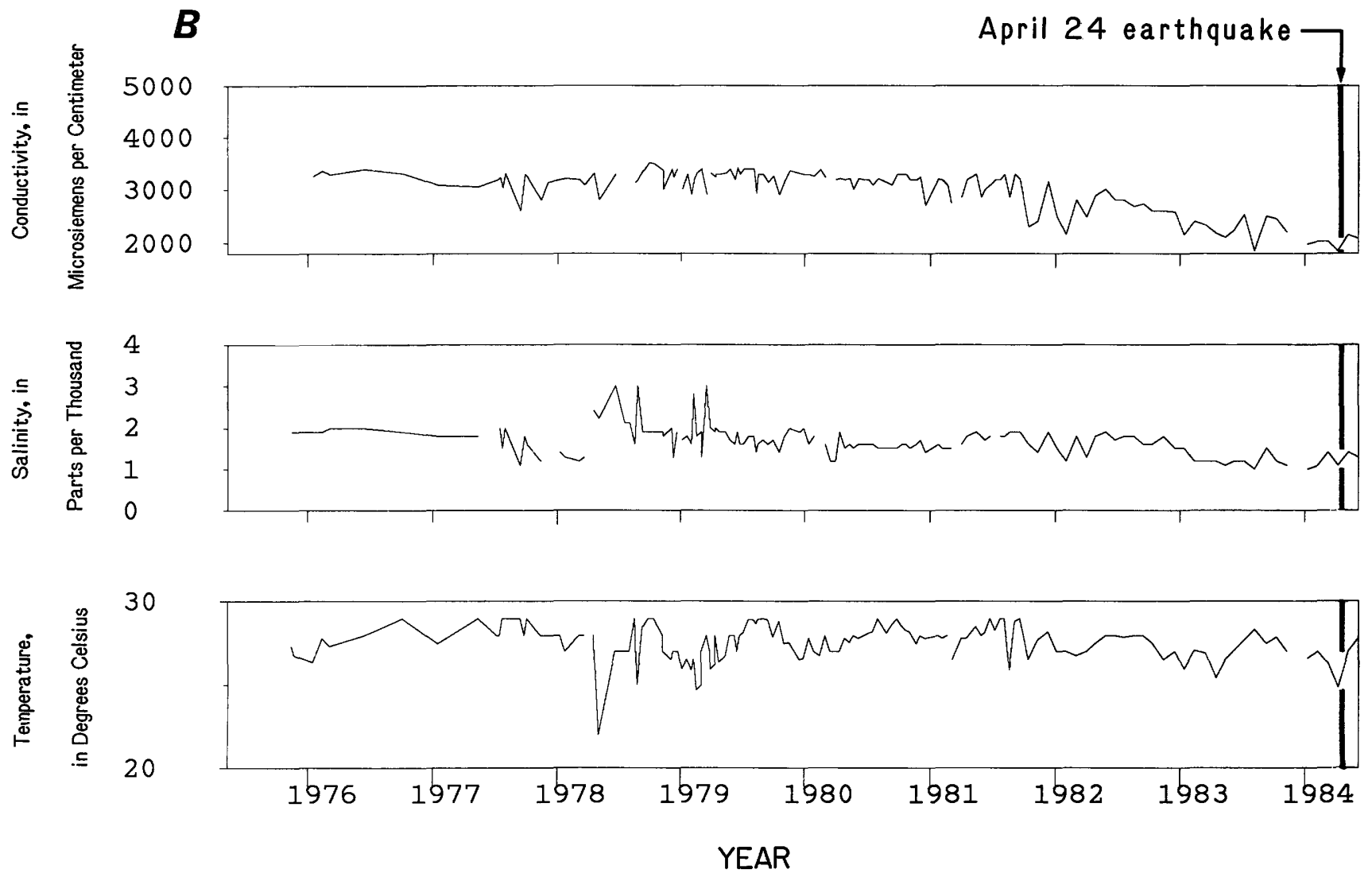

Figure 18.2. Continued 

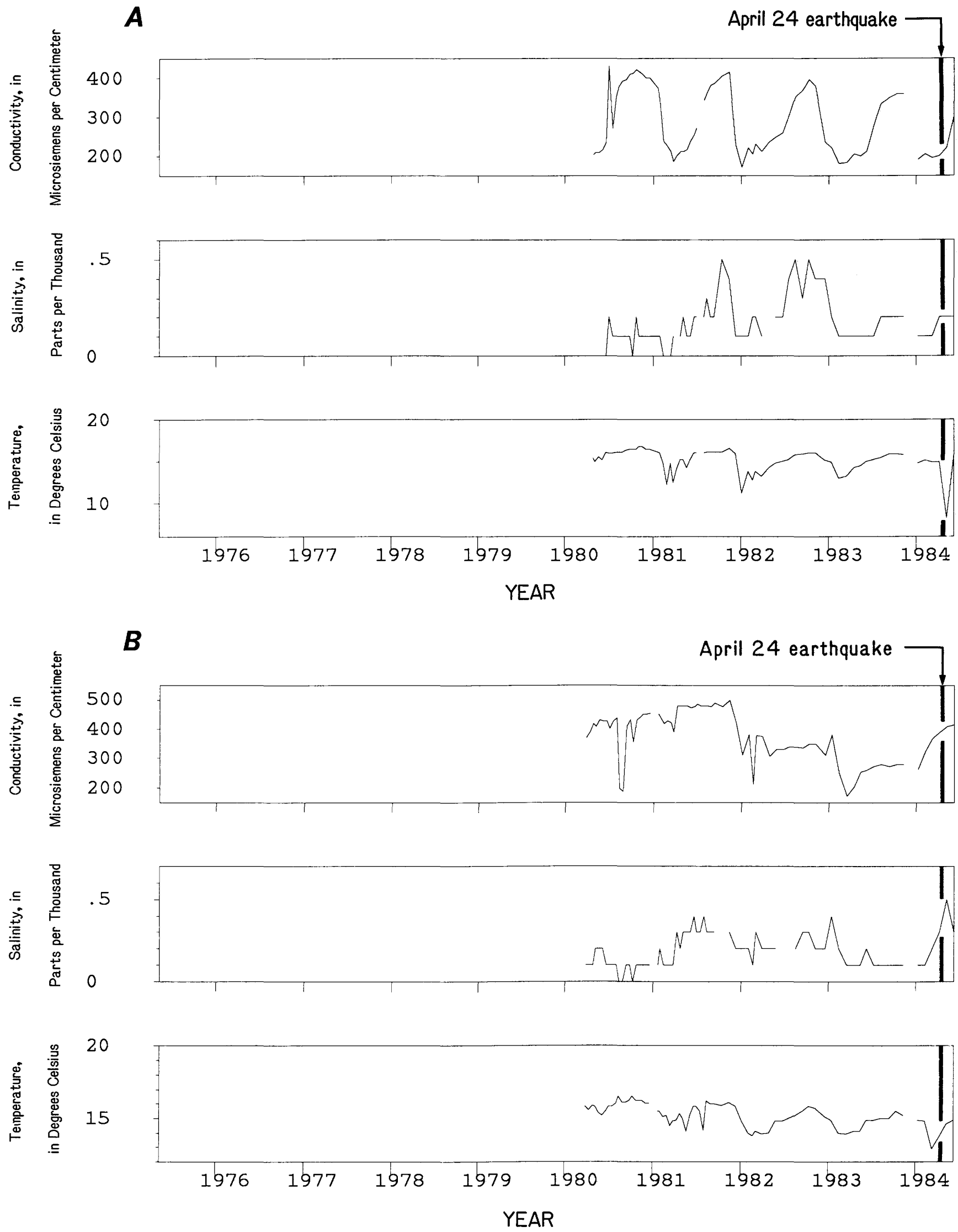

Figure 18.3. Conductivity, salinity, and temperature data from two wells in East Oakland, Calif. A, Oakland. $\underline{B}$, Chabot. 


\title{
Computer Plots of Strong-Motion Results from the Main Shock
}

\author{
By A.G. Brady, R.L. Porcella, G.N. Bycroft, E.C. Etheredge, P.N. Mork, \\ Barry Silverstein, and A.F. Shakal ${ }^{1}$
}

The computer plots included in this chapter (fig. 19.1-19.116) serve two purposes. First, they provide a visual description of the recorded accelerations from the April 24 main shock and their processed results, so that specific records can be selected for further study, using the available digital data. Second, they permit specific earthquake or record parameters to be read, measured, or scaled directly.
The stations to which the computer plots in figures 19.1 through 19.116 refer are listed in tuble 19.1. The digital data from which these plots were produced are available on tape from the National Geophysical Data Center of the U.S. National Oceanic and Atmospheric Administration, Mail Stop E/GC11, 325 Broadway, Boulder, CO 80303.

Table 19.1. Index to computer plots of the Morgan Hill, Calif., earthquake of 2115 G.m.t. April 24, 1984

[Processing steps: 1, uncorrected accelerogram; 2, corrected acceleration, velocity, and displacement; 3 , relative-velocityresponse spectrum; 4, pseudovelocity-response spectrum; 5, Fourier amplitude spectrum of acceleration (linear plot); 6, Fourier amplitude spectrum of acceleration (log plot)]

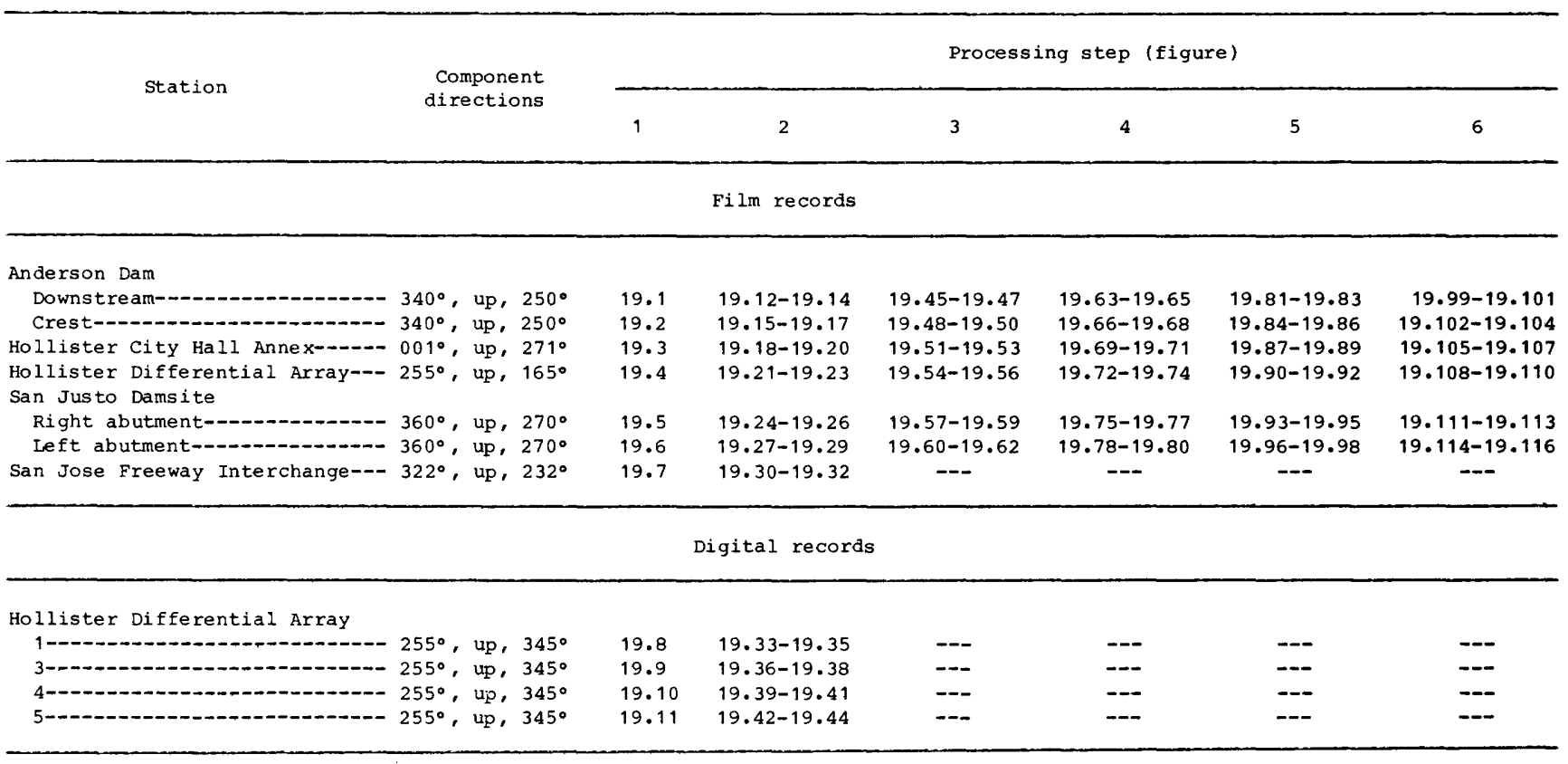

${ }^{1}$ California Division of Mines and Geology, Sacramento, CA 95812 . 


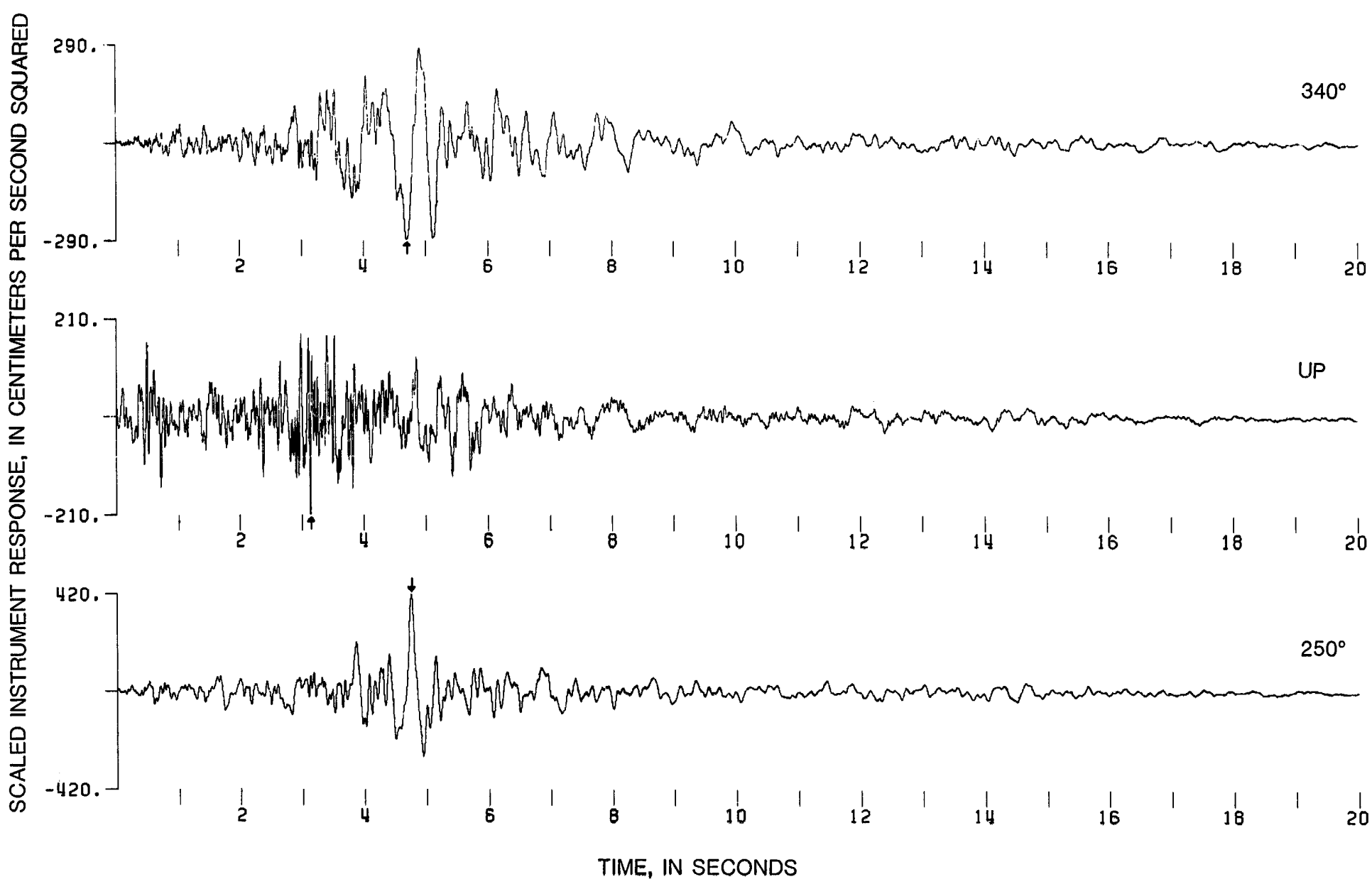

Figure 19.1. Uncorrected accelerogram at the Anderson Dam, downstream, for the April 24 earthquake. Peak values (arrows) of components: $-285.95\left(340^{\circ}\right),-209.65$ (up), and $415.79\left(250^{\circ}\right) \mathrm{cm} / \mathrm{s}^{2}$. 

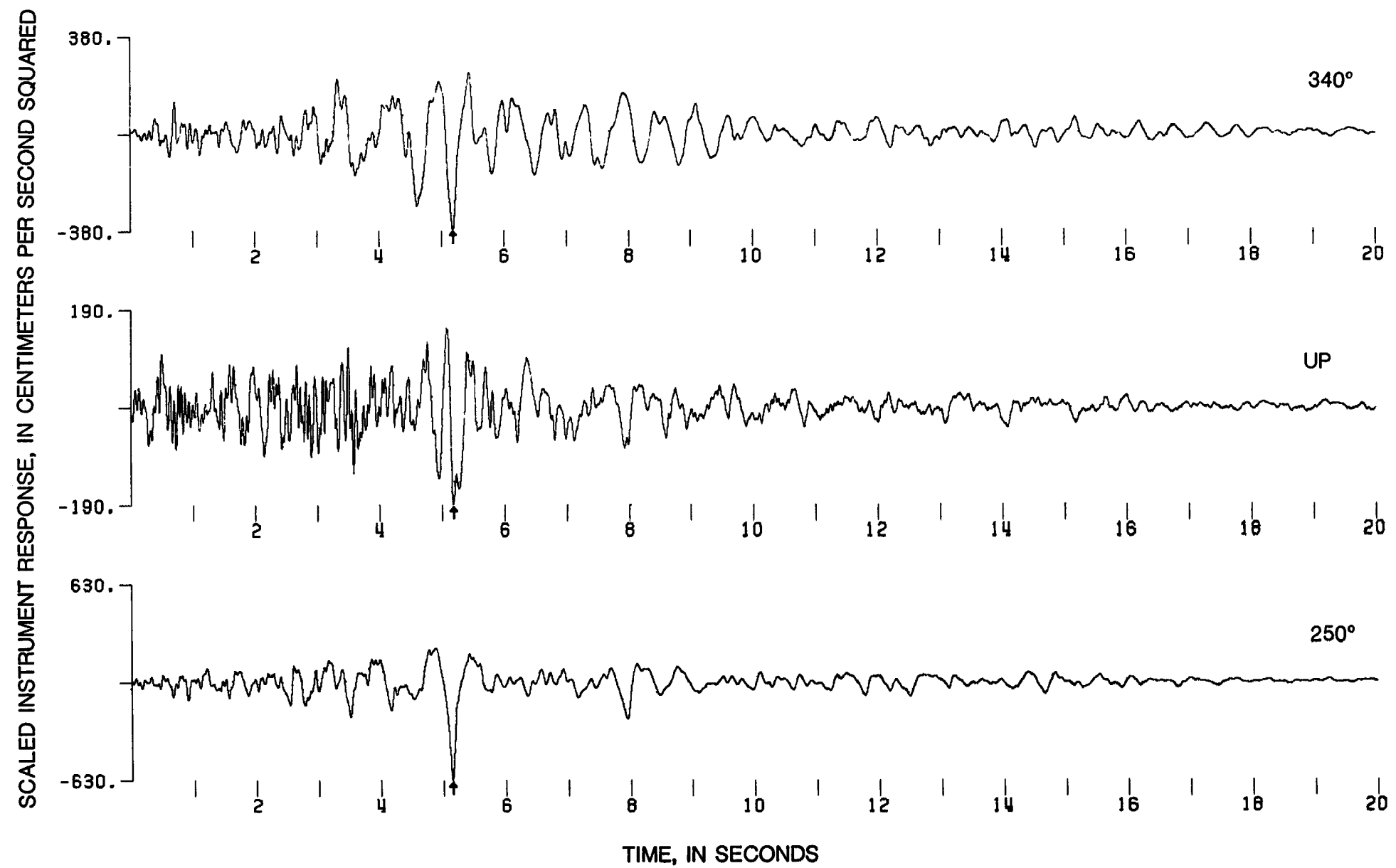

Figure 19.2. Uncorrected accelerogram at the Andrerson Dam, crest, for the April 24 earthquake. Peak values (arrows) of components: $-371.53\left(340^{\circ}\right),-189.09$ (up), and $-627.00\left(250^{\circ}\right) \mathrm{cm} / \mathrm{s}^{2}$. 


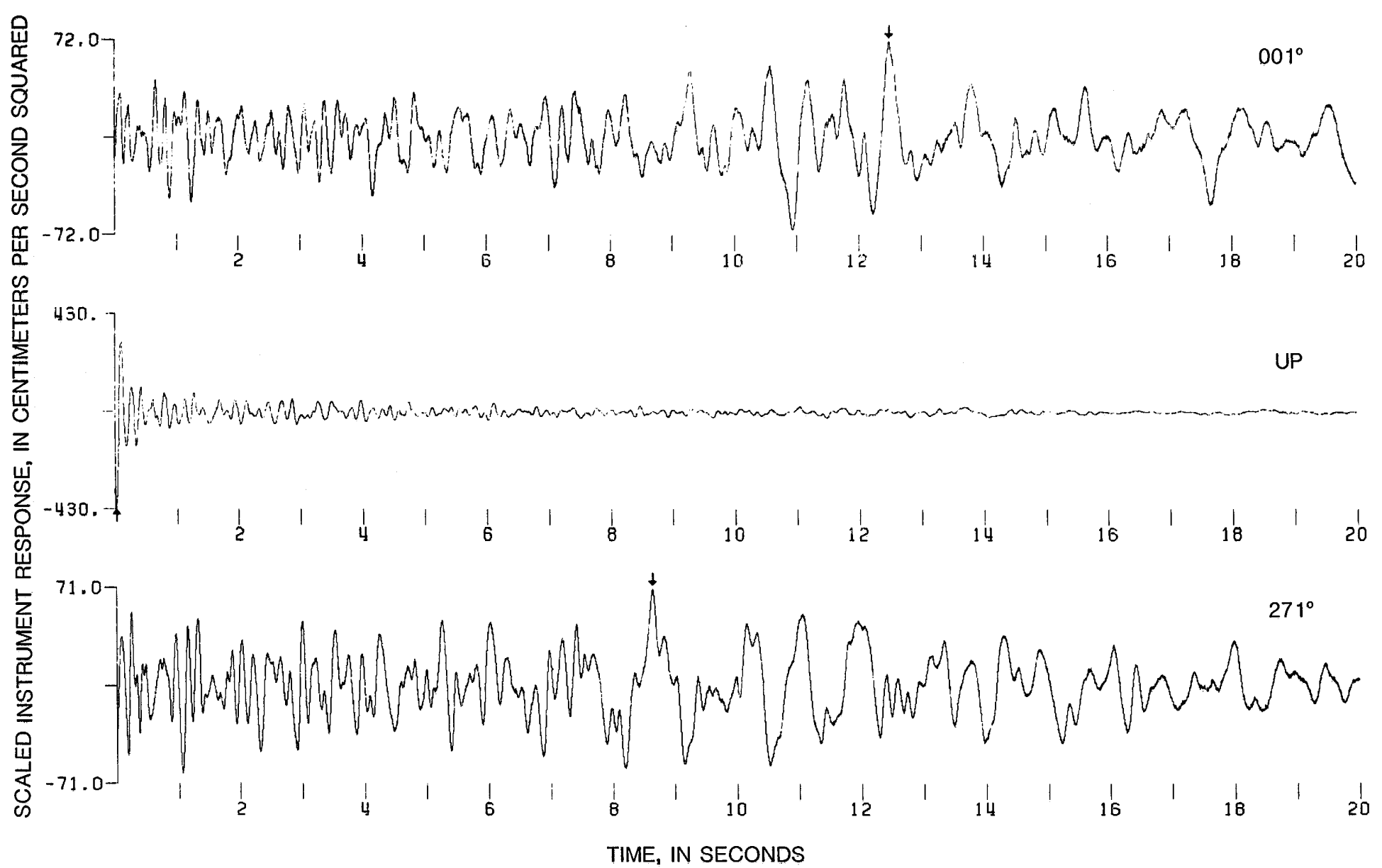

Figure 19.3. Uncorrected accelerogram at the Hollister City Hall Annex basement, for the April 24 earthquake. Peak values (arrows) of components: $71.26\left(001^{8}\right),-424.41$ (up), and $70.26\left(271^{\circ}\right) \mathrm{cm} / \mathrm{s}^{2}$. 

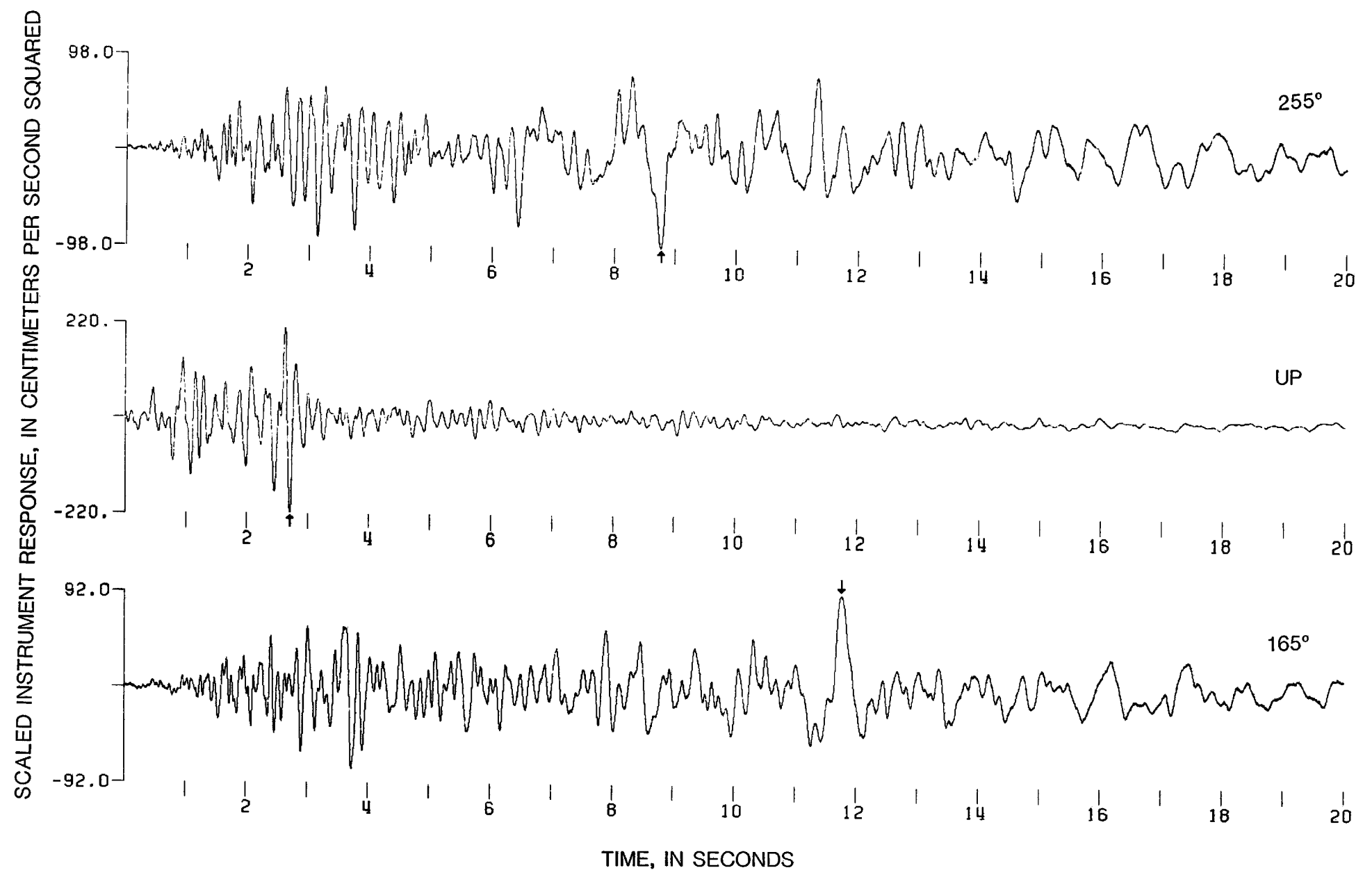

TIME, IN SECONDS

Figure 19.4. Uncorrected accelerogram at the Hollister Differential Array (SMA-1T) for the April 24 earthquake. Peak values (arrows) of components: $-97.62\left(255^{\circ}\right),-217.78$ (up), and $91.78\left(165^{\circ}\right) \mathrm{cm} / \mathrm{s}^{2}$. 


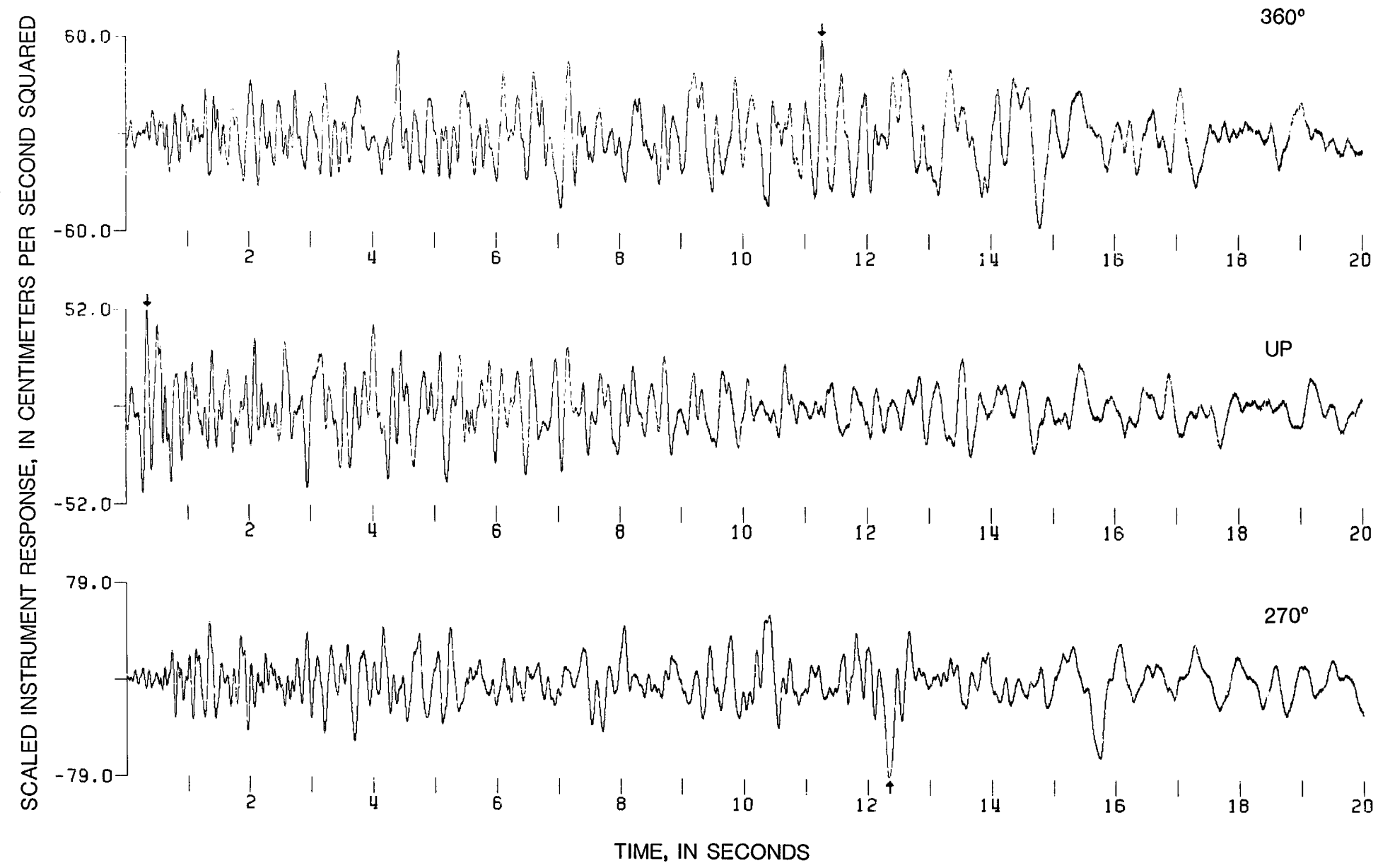

Figure 19.5. Uncorrected accelerogram at the San Justo Damsite, right abutment (dike), for the April 24 earthquake. Peak values (arrows) of components: $59.63\left(360^{\circ}\right), 51.63$ (up), and $-78.03\left(270^{\circ}\right) \mathrm{cm} / \mathrm{s}^{2}$. 


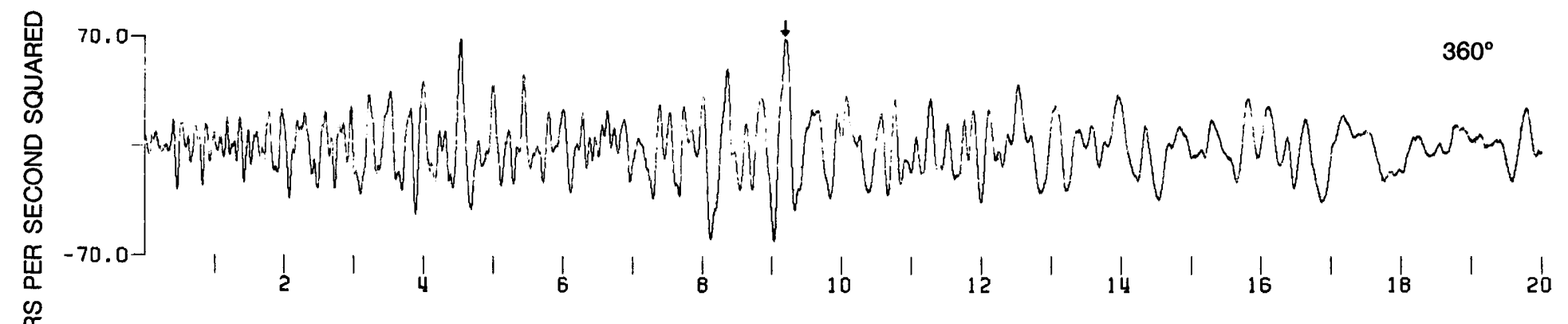

37.0-

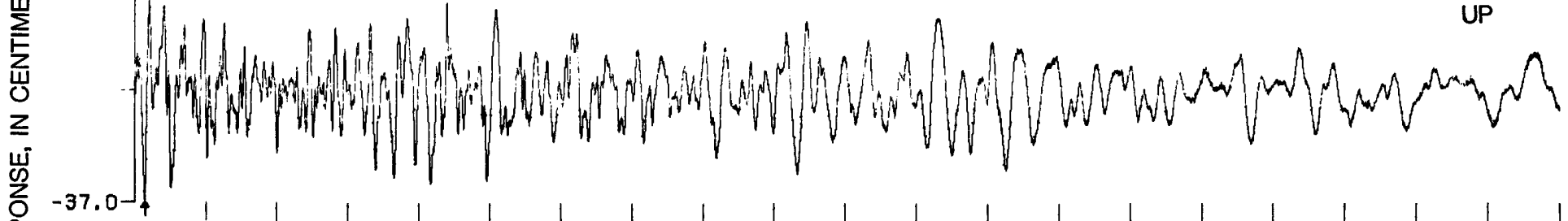

㽞

580.07

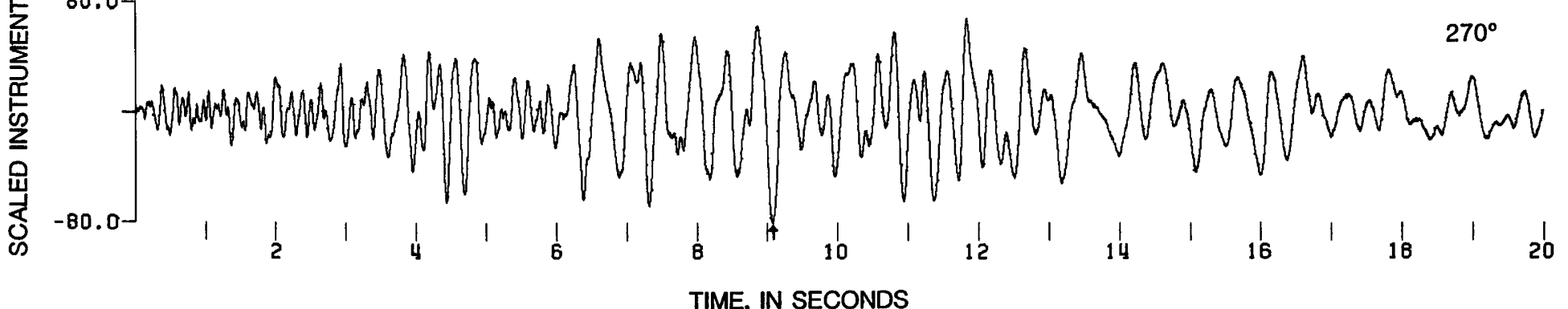

Figure 19.6. Uncorrected accelerogram at the San Justo Damsite, left abutment, for the April 24 earthquake. Peak values (arrows) of components: $69.38\left(360^{\circ}\right),-36.28$ (up), and $-79.71\left(270^{\circ}\right) \mathrm{cm} / \mathrm{s}^{2}$. 
点

官

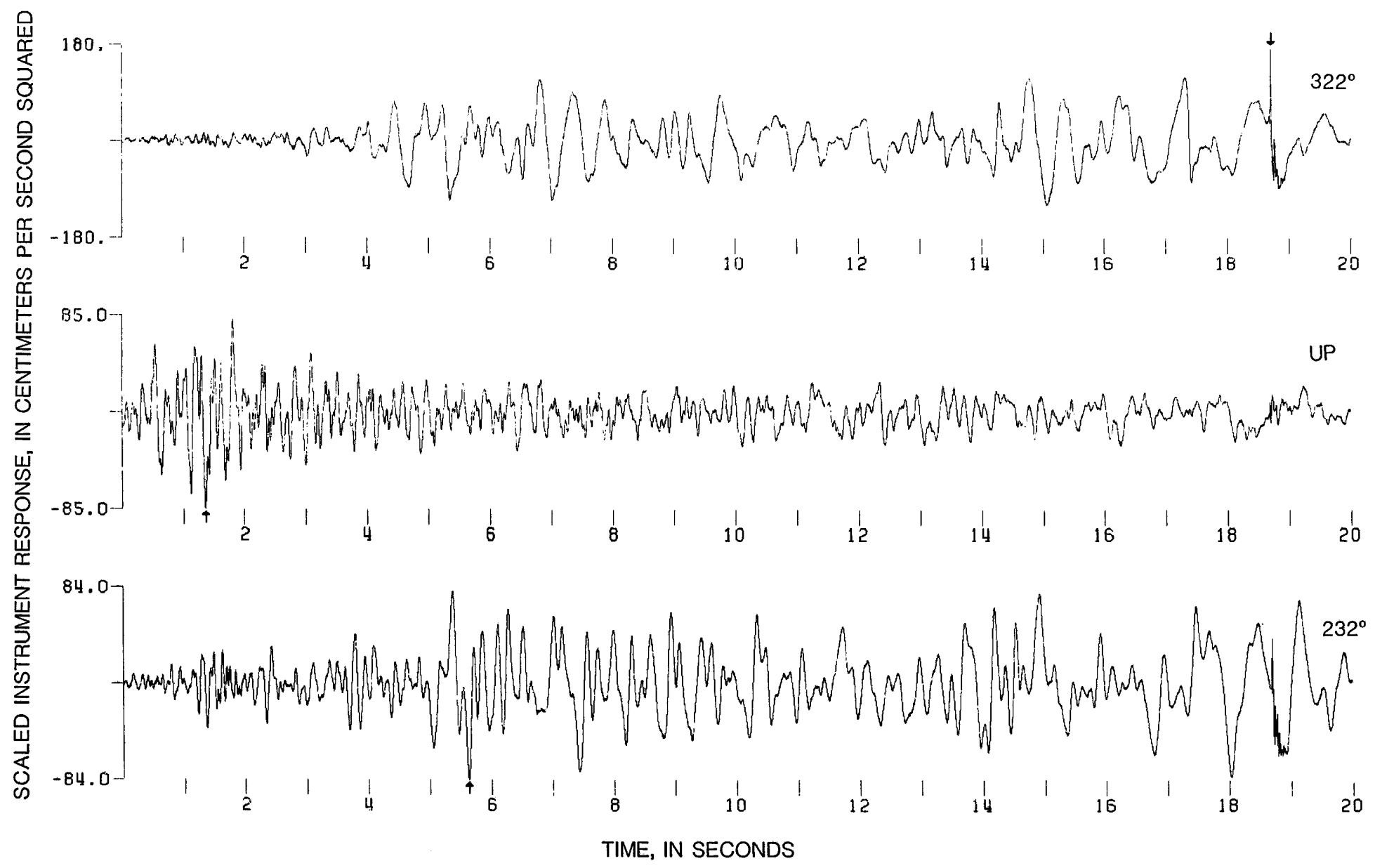

Figure 19.7. Uncorrected accelerogram at the San Jose Freeway Interchange for the April 24 earthquake. Peak values (arrows) of components: $173.06\left(322^{\%}\right),-84.77$ (up), and $-83.82\left(232^{\circ}\right) \mathrm{cm} / \mathrm{s}^{2}$. 


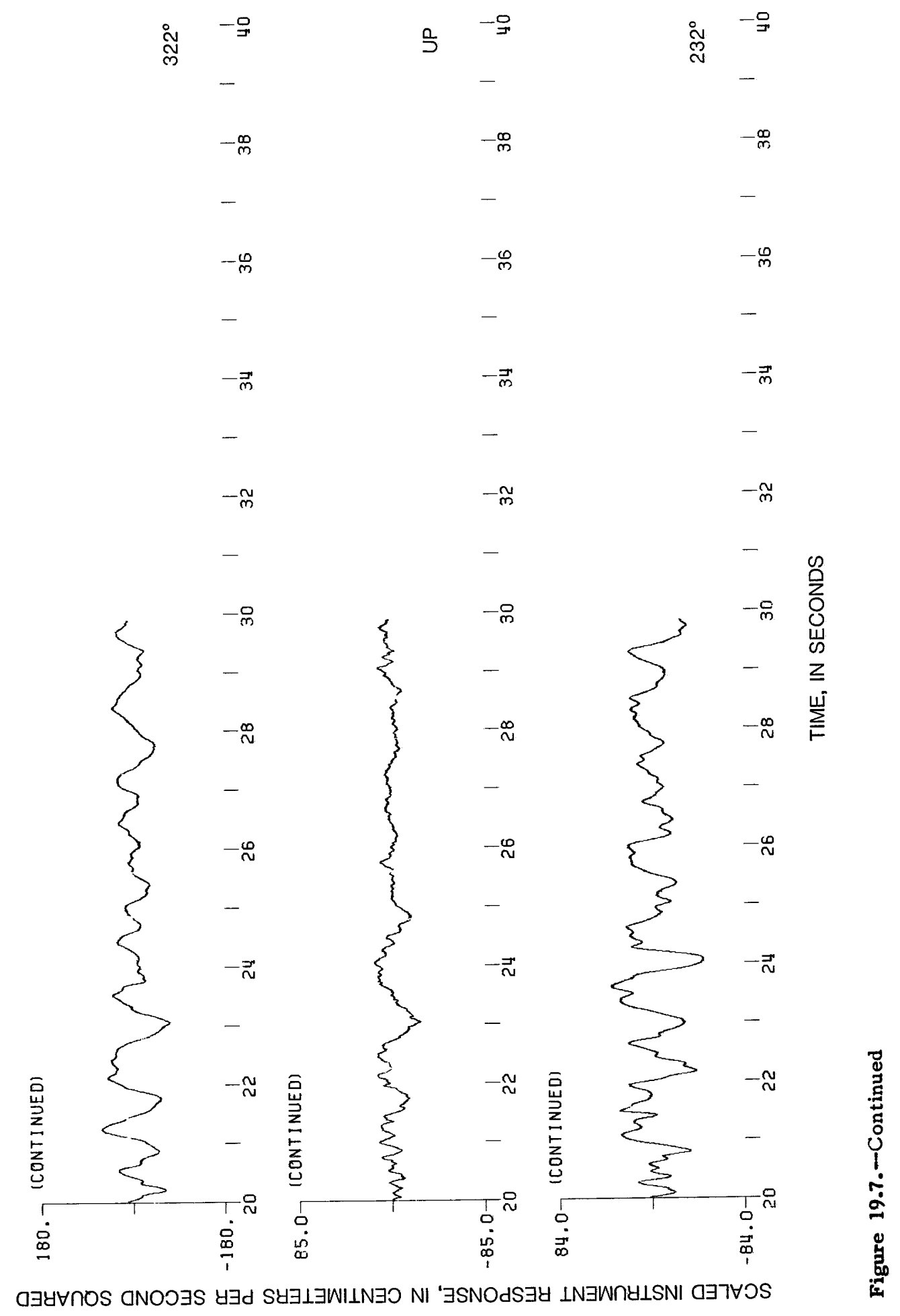




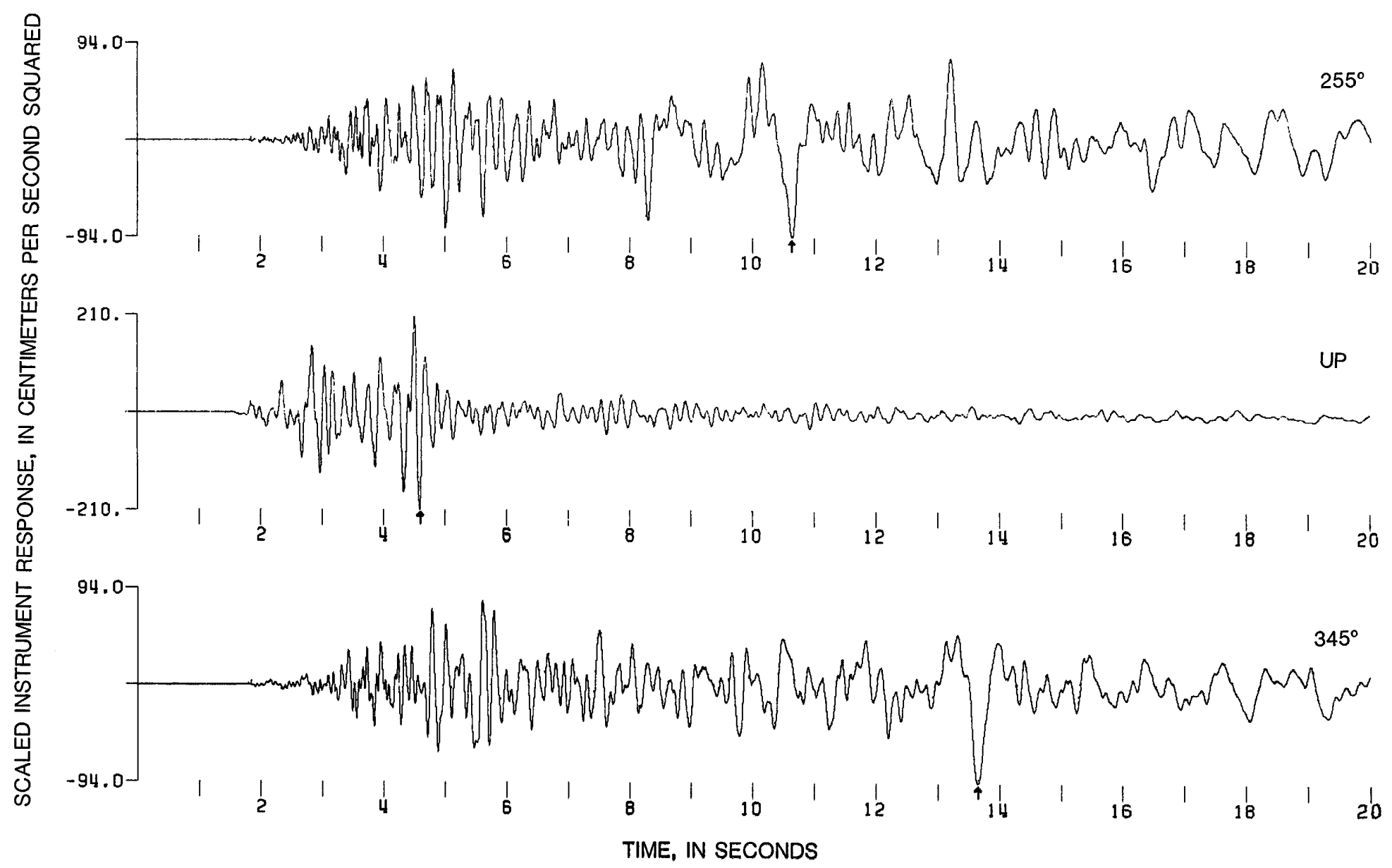

Figure 19.8. Uncorrected accelerogram at Hollister Differential Array 1 for the April 24 earthquake. Peak values (arrows) of components: $-93.50\left(255^{\circ}\right),-209.34$ (up), and $-93.48(345 \%) \mathrm{cm} / \mathrm{s}^{2}$. 

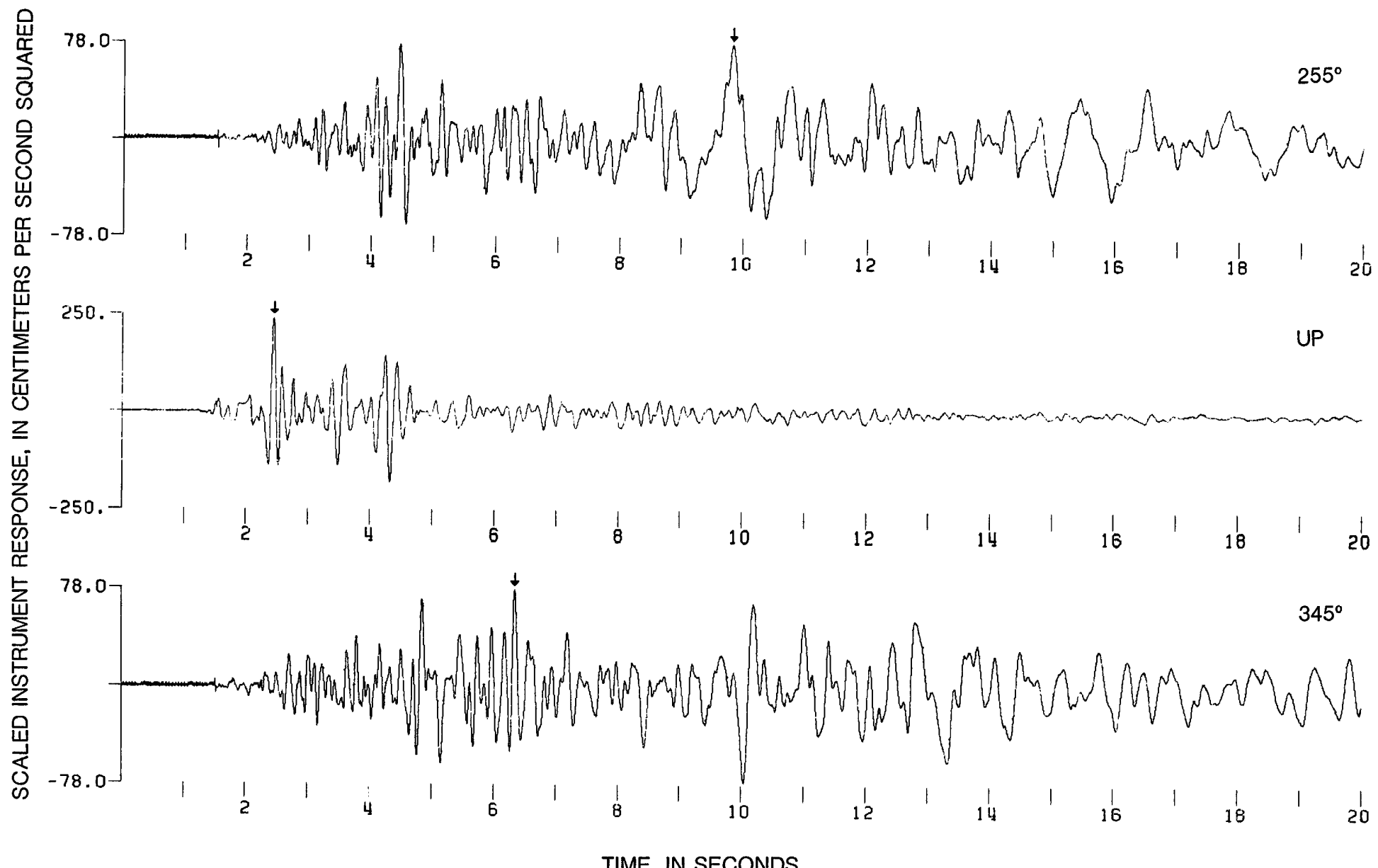

TIME, IN SECONDS

Figure 19.9. Uncorrected accelerogram at Hollister Differential Array 3 for the April 24 earthquake. Peak values (arrows) of components: $77.79\left(255^{\circ}\right), 240.24$ (up), and $77.68\left(345^{\circ}\right) \mathrm{cm} / \mathrm{s}^{2}$. 


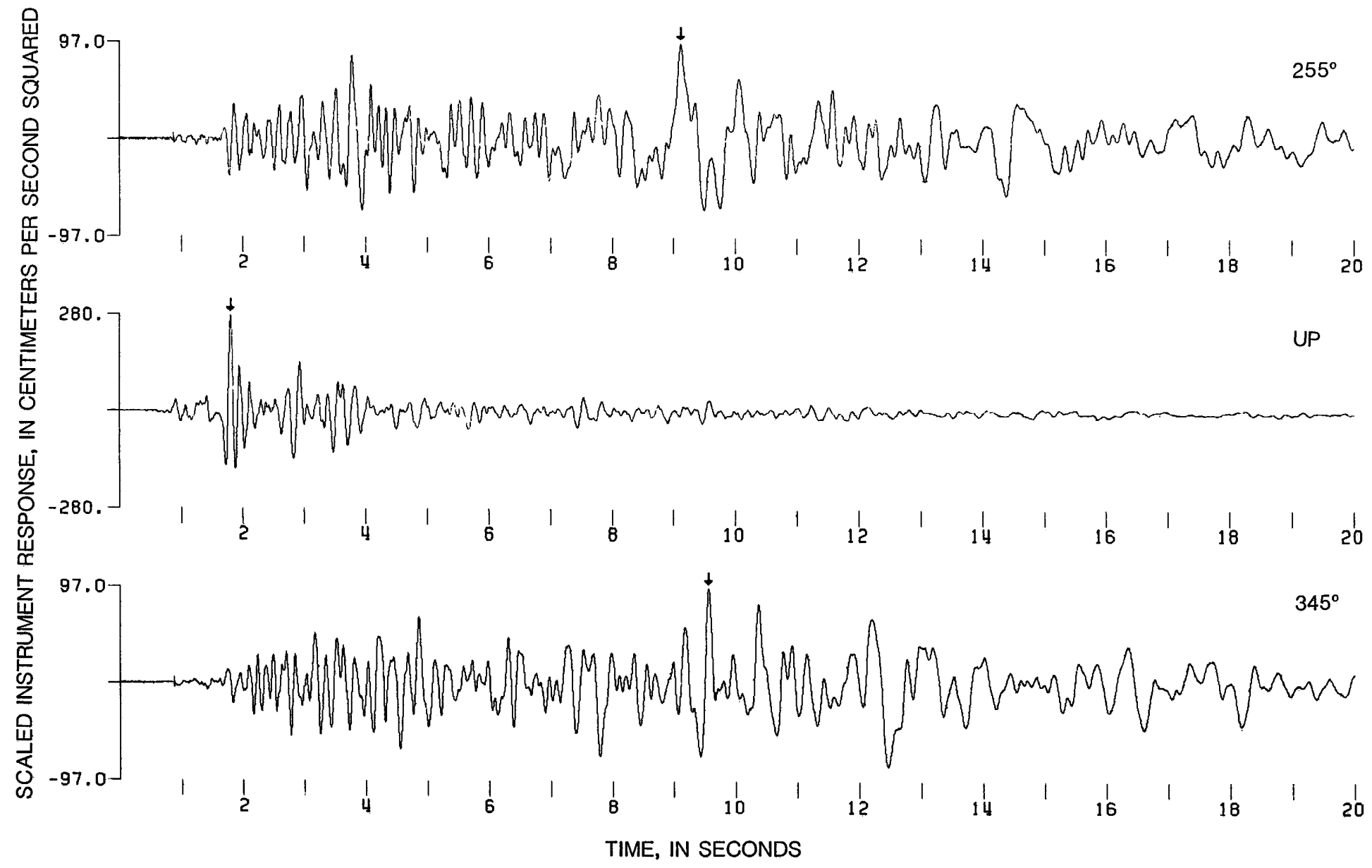
Figure 19.10. Uncorrected accelerogram at Hollister Differential Array 4 for the April 24 earthquake. Peak values (arrows)
of components: $96.88\left(255^{\circ}\right), 278.54$ (up), and $96.48\left(345^{\circ}\right) \mathrm{cm} / \mathrm{s}^{2}$. 


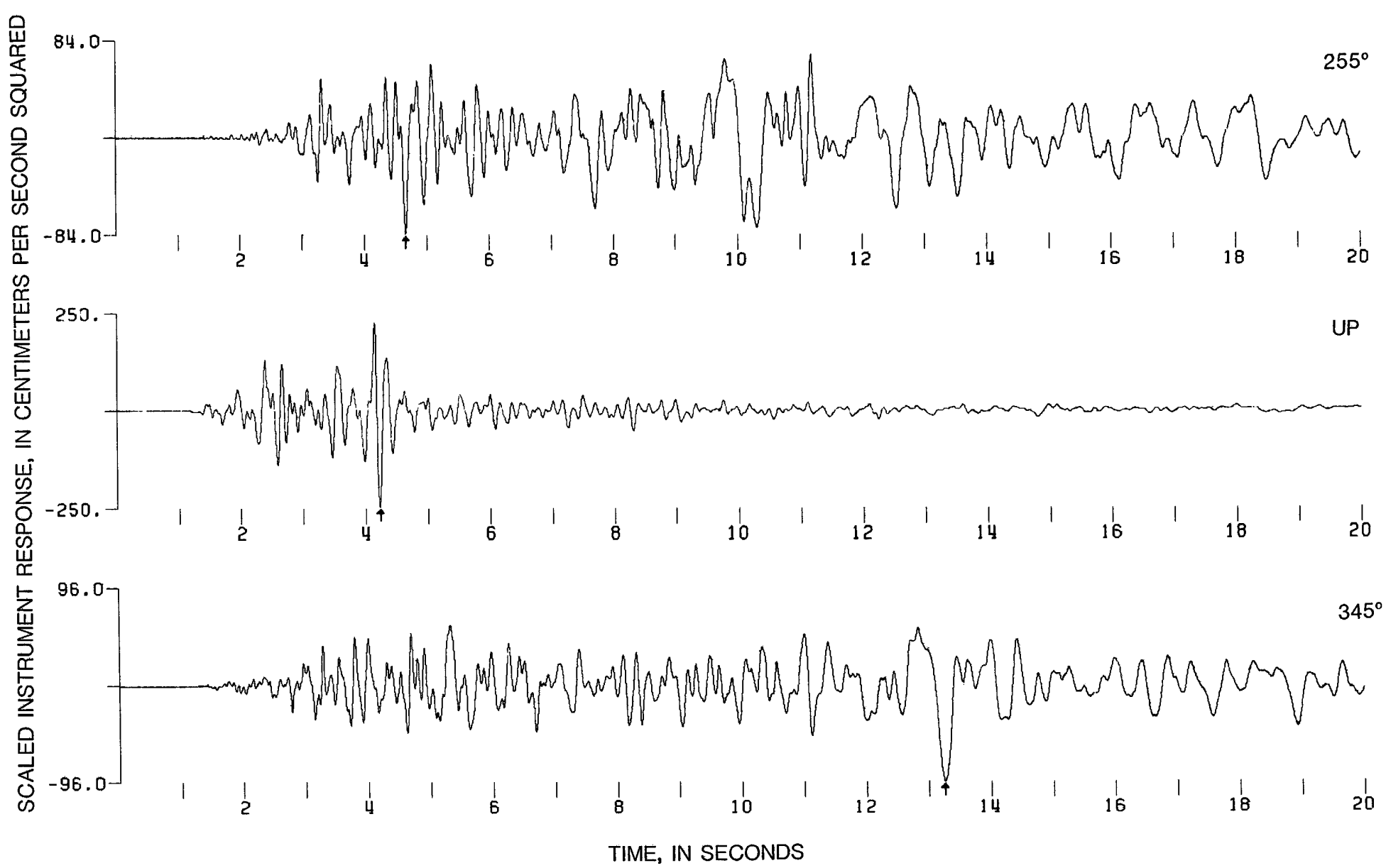

Figure 19.11. Uncorrected accelerogram at Hollister Differential Array 5 for the April 24 earthquake. Peak values (arrows) of components: $-83.42\left(255^{\circ}\right),-246.01$ (up), and $-95.85\left(345^{\circ}\right) \mathrm{cm} / \mathrm{s}^{2}$. 

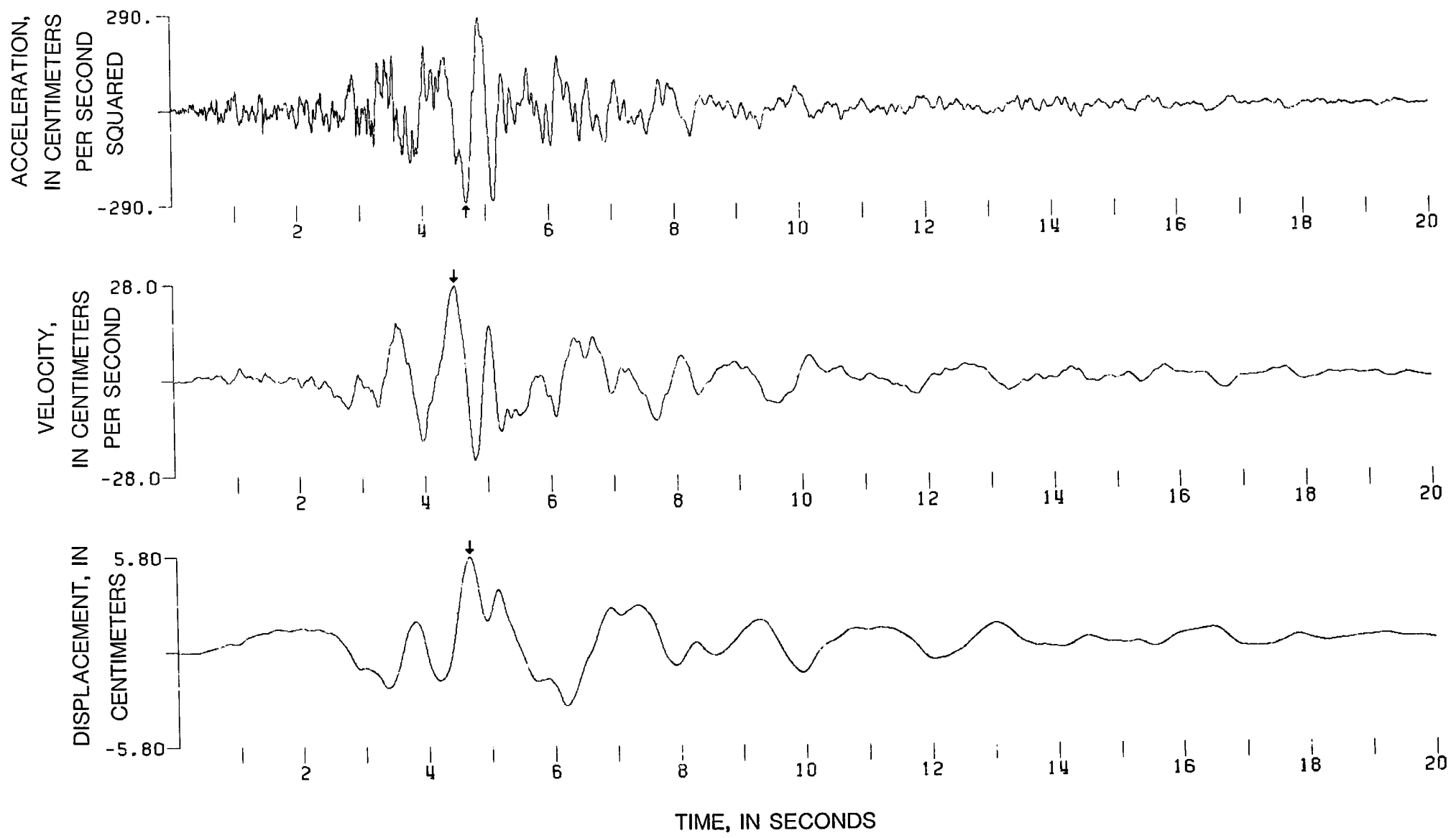

Figure 19.12. Corrected acceleration, velocity, and displacement at the Anderson Dam, downstream ( $340^{\circ}$ component), for the April 24 earthquake, using a Butterworth filter $(0.25 \mathrm{~Hz}$, order 8) at 200 samples per second. Peak values (arrows): acceleration, $-283.43 \mathrm{~cm} / \mathrm{s}^{2}$; velocity, $27.59 \mathrm{~cm} / \mathrm{s}$; displacement, $5.75 \mathrm{~cm}$. 

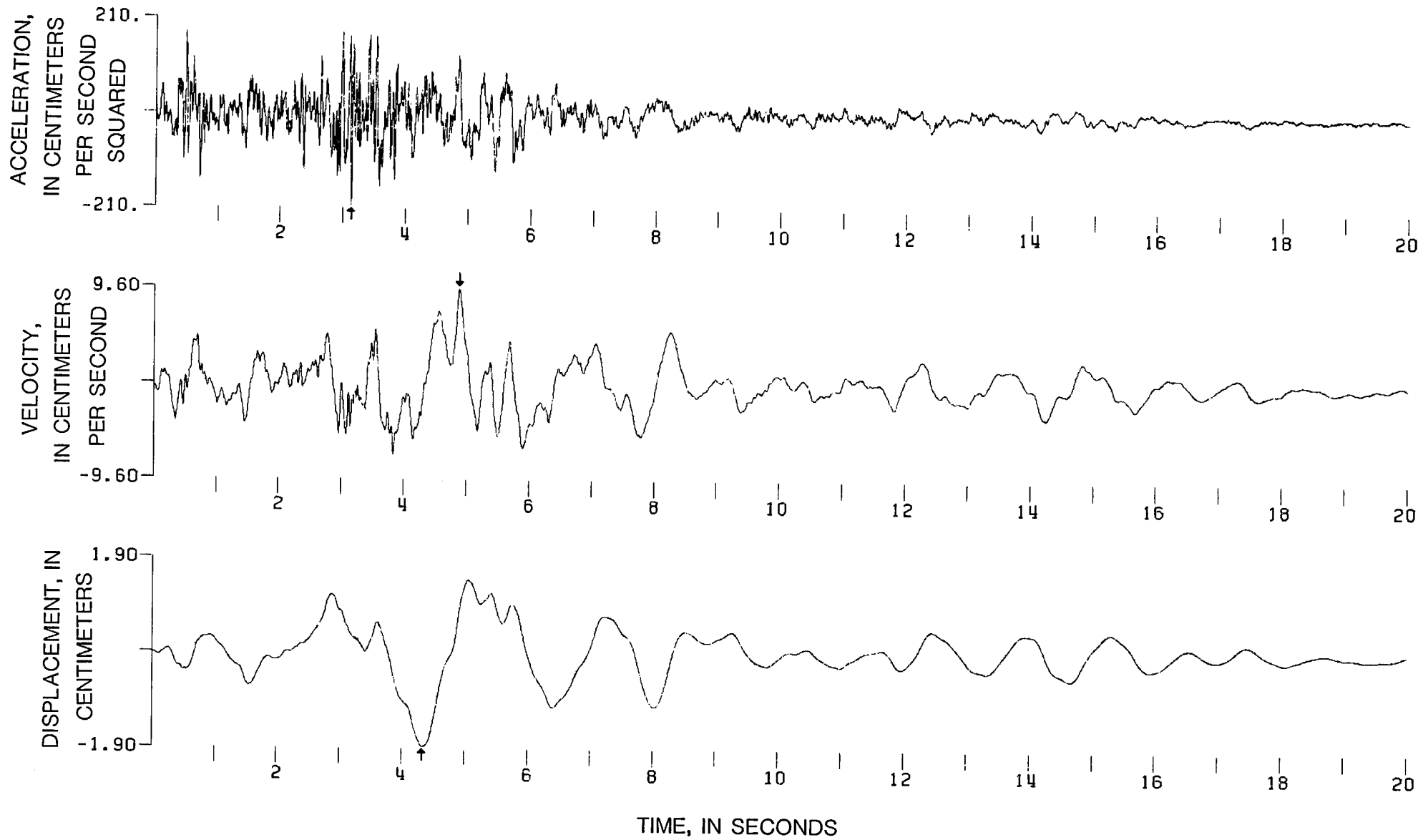

Figure 19.13. Corrected acceleration, velocity, and displacement at the Anderson Dam, downstream (up component), for the April 24 earthquake, using a Butterworth filter $(0.25 \mathrm{~Hz}$, order 8) at 200 samples per second. Peak values (arrows): acceleration, $-203.50 \mathrm{~cm} / \mathrm{s}^{2}$; velocity, $9.56 \mathrm{~cm} / \mathrm{s}$; displacement, $-1.85 \mathrm{~cm}$. 

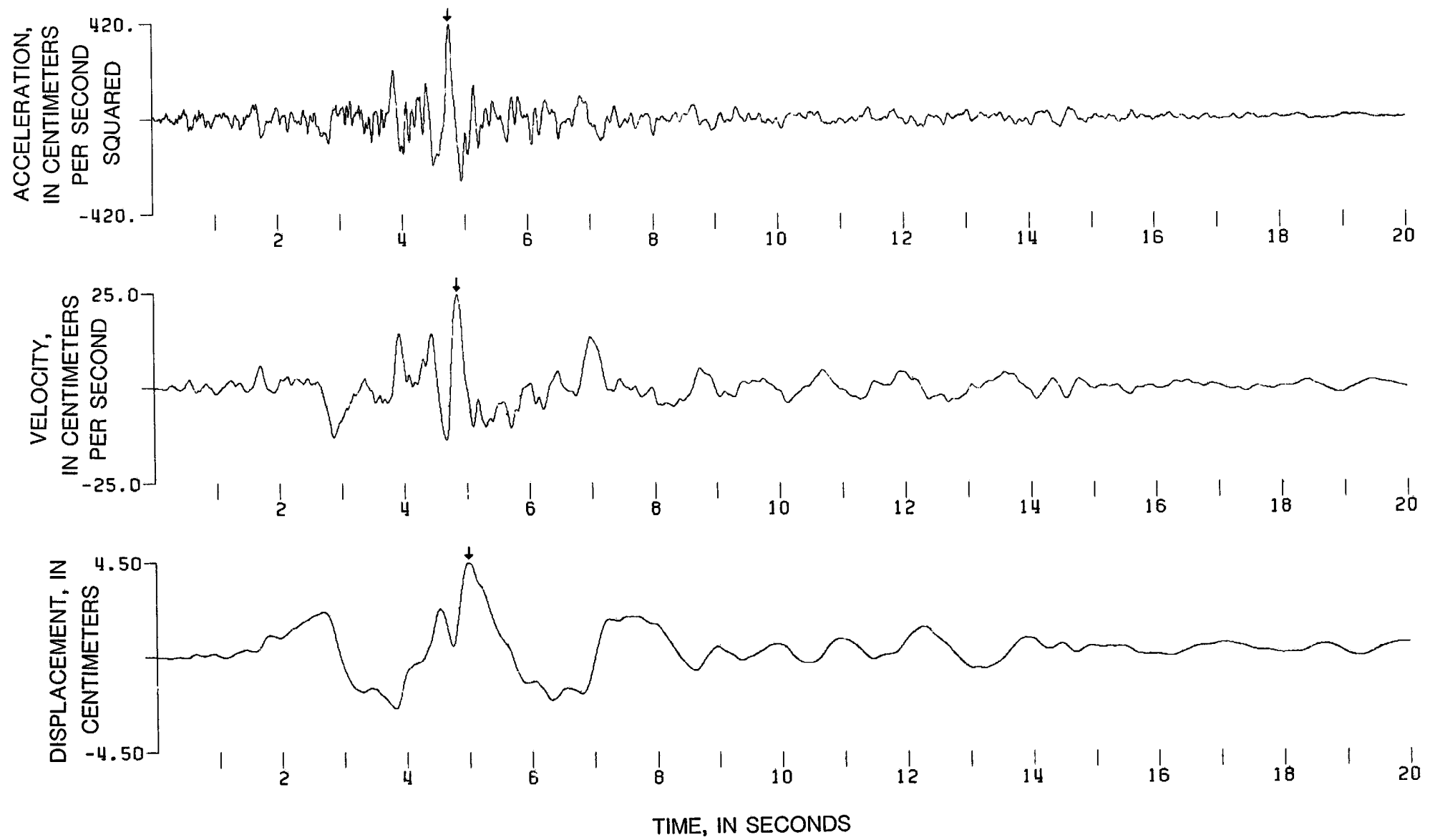

Figure 19.14. Corrected acceleration, velocity, and displacement at the Anderson Dam, downstream (250 $0^{\circ}$ component), for the April 24 earthquake, using a Butterworth filter $(0.25 \mathrm{~Hz}$, order 8) at 200 samples per second. Peak values (arrows): acceleration, $415.90 \mathrm{~cm} / \mathrm{s}^{2}$; velocity, $24.69 \mathrm{~cm} / \mathrm{s}$; displacement, $4.47 \mathrm{~cm}$. 

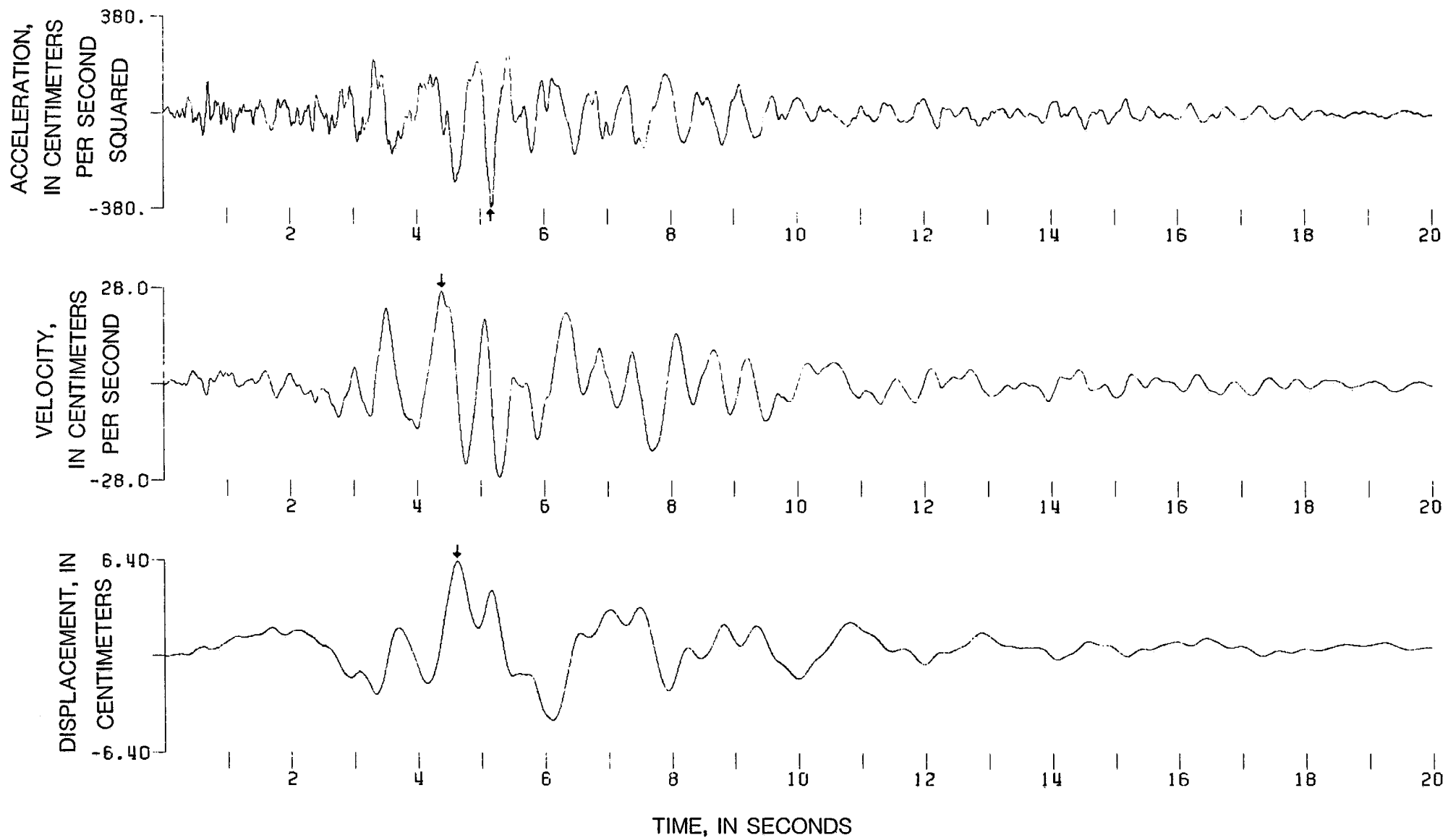

Figure 19.15. Corrected acceleration, velocity, and displacement at the Anderson Dam, crest ( $340^{\circ}$ component), for the April 24 earthquake, using a Butterworth filter $(0.25 \mathrm{~Hz}$, order 8) at 200 samples per second. Peak values (arrows): acceleration, $-372.11 \mathrm{~cm} / \mathrm{s}^{2}$; velocity, $27.25 \mathrm{~cm} / \mathrm{s}$; displacement, $6.33 \mathrm{~cm}$. 

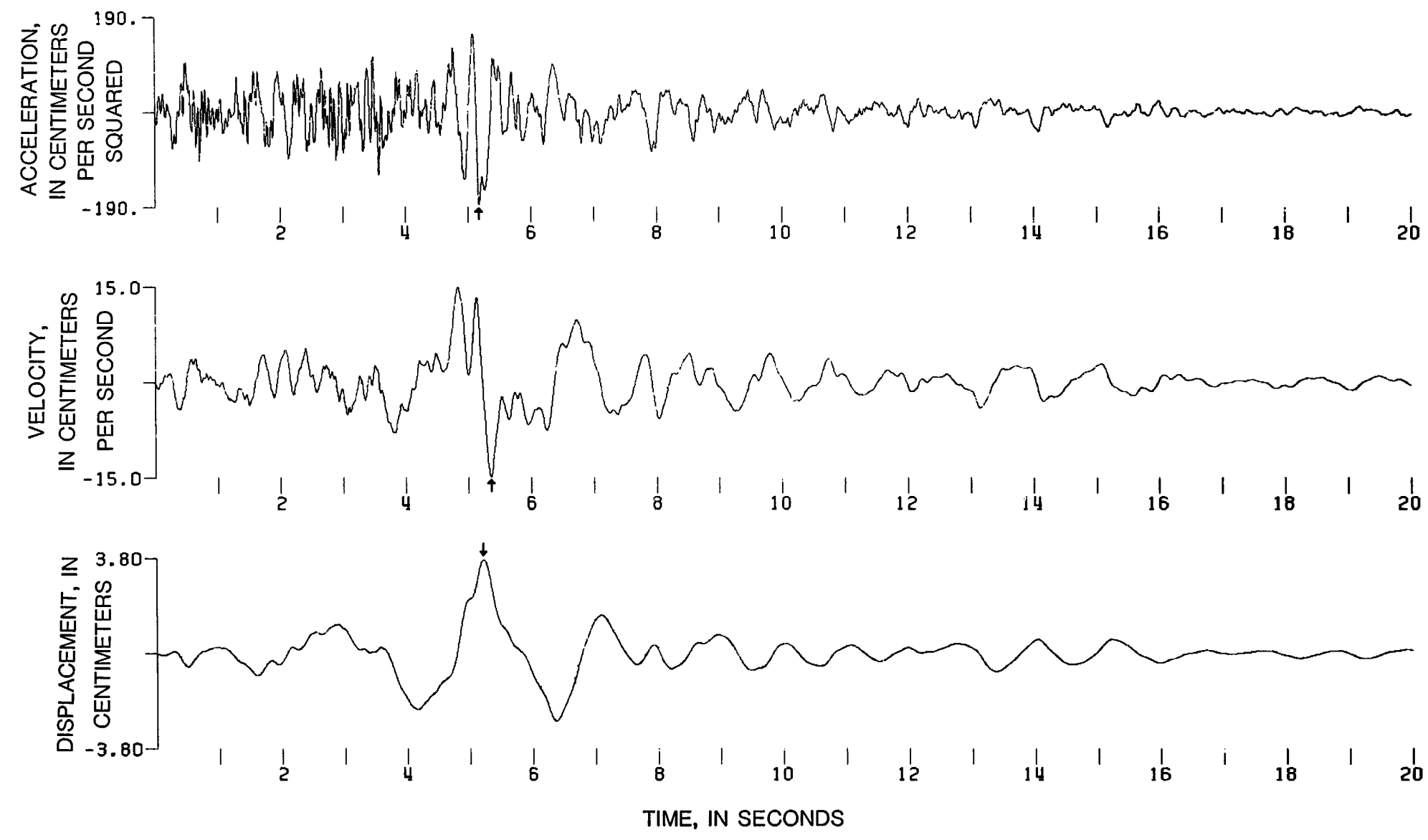

Figure 19.16. Corrected acceleration, velocity, and displacement at the Anderson Dam, crest (up component), for the April 24 earthquake, using a Butterworth filter $(0.25 \mathrm{~Hz}$, order 8) at 200 samples per second. Peak values (arrows): acceleration, $-185.78 \mathrm{~cm} / \mathrm{s}^{2}$; velocity, $-14.93 \mathrm{~cm} / \mathrm{s}$; displacement, $3.72 \mathrm{~cm}$. 

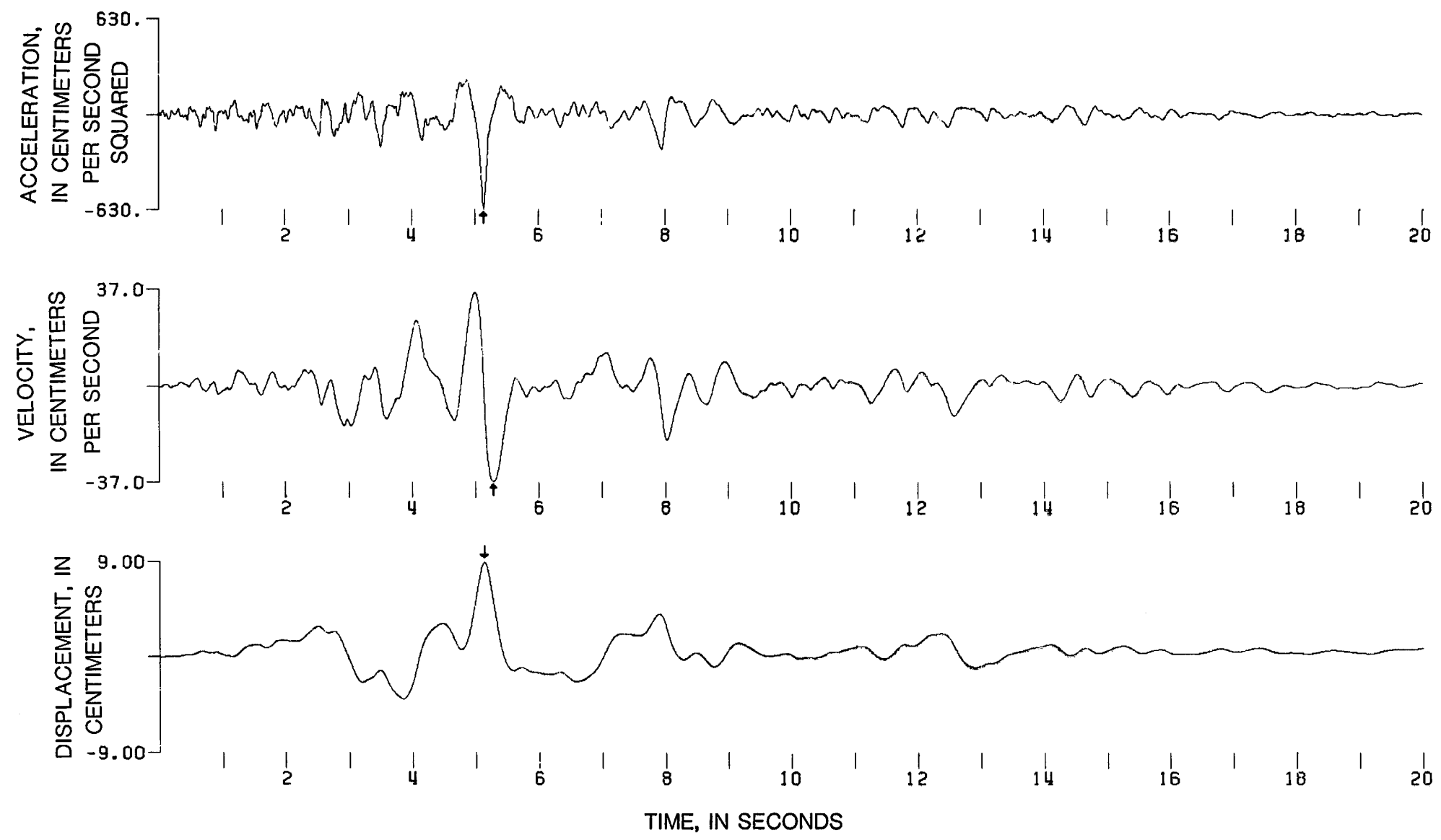

Figure 19.17. Corrected acceleration, velocity, and displacement at the Anderson Dam, crest ( $250^{\circ}$ component), for the April 24 earthquake, using a Butterworth filter $(0.25 \mathrm{~Hz}$, order 8) at 200 samples per second. Peak values (arrows): acceleration, $-627.88 \mathrm{~cm} / \mathrm{s}^{2}$; velocity, $-36.75 \mathrm{~cm} / \mathrm{s}$; displacement, $8.92 \mathrm{~cm}$. 

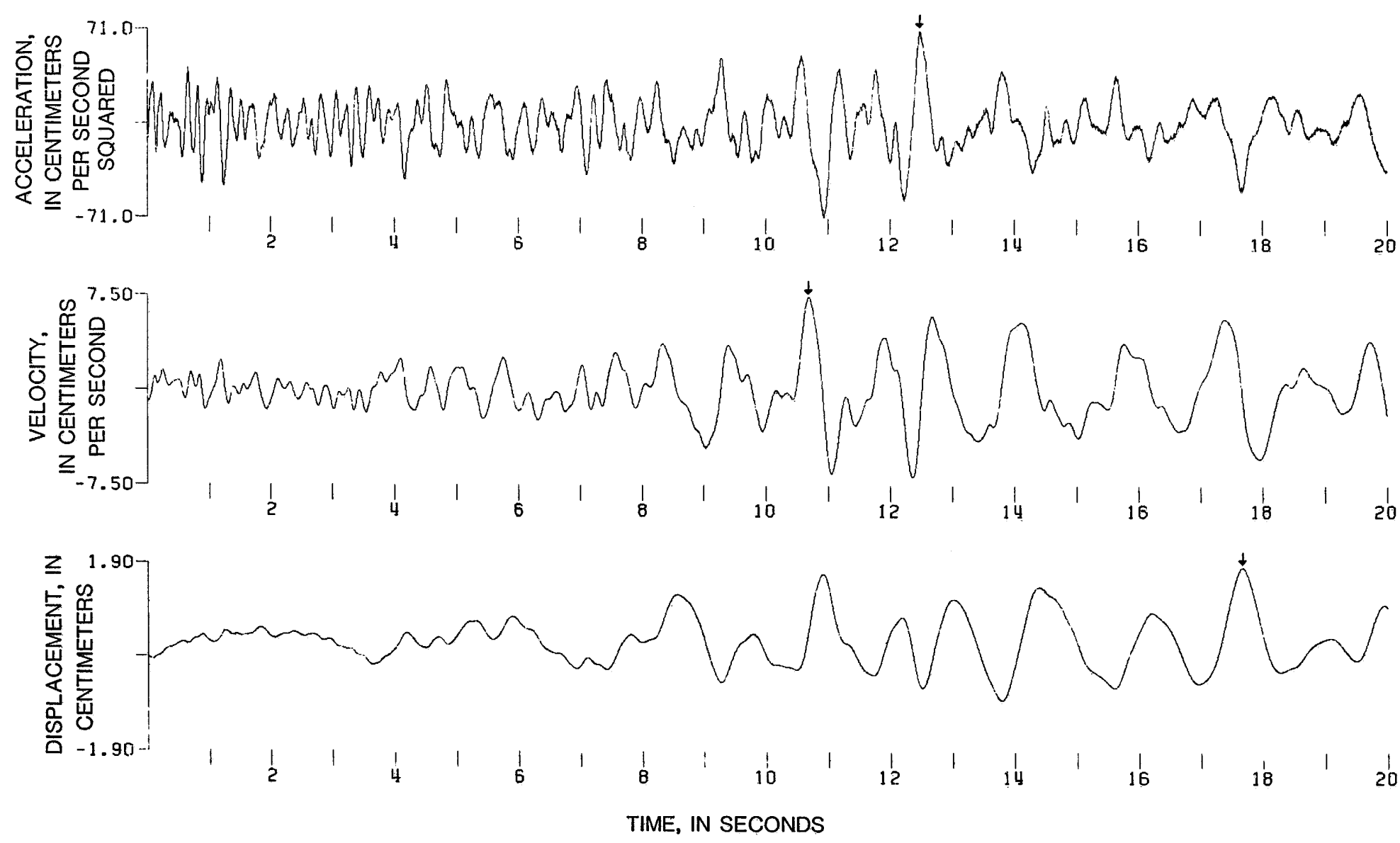

Figure 19.18. Corrected acceleration, velocity, and displacement at the Hollister City Hall Annex, basement $\left(001^{\circ}\right.$ component), for the April 24 earthquake, using a Butterworth filter $(0.25 \mathrm{~Hz}$, order 8$)$ at 200 samples per second. Peak values (arrows): acceleration, $70.94 \mathrm{~cm} / \mathrm{s}^{2}$; velocity, $7.46 \mathrm{~cm} / \mathrm{s}$; displacement, $1.83 \mathrm{~cm}$. 

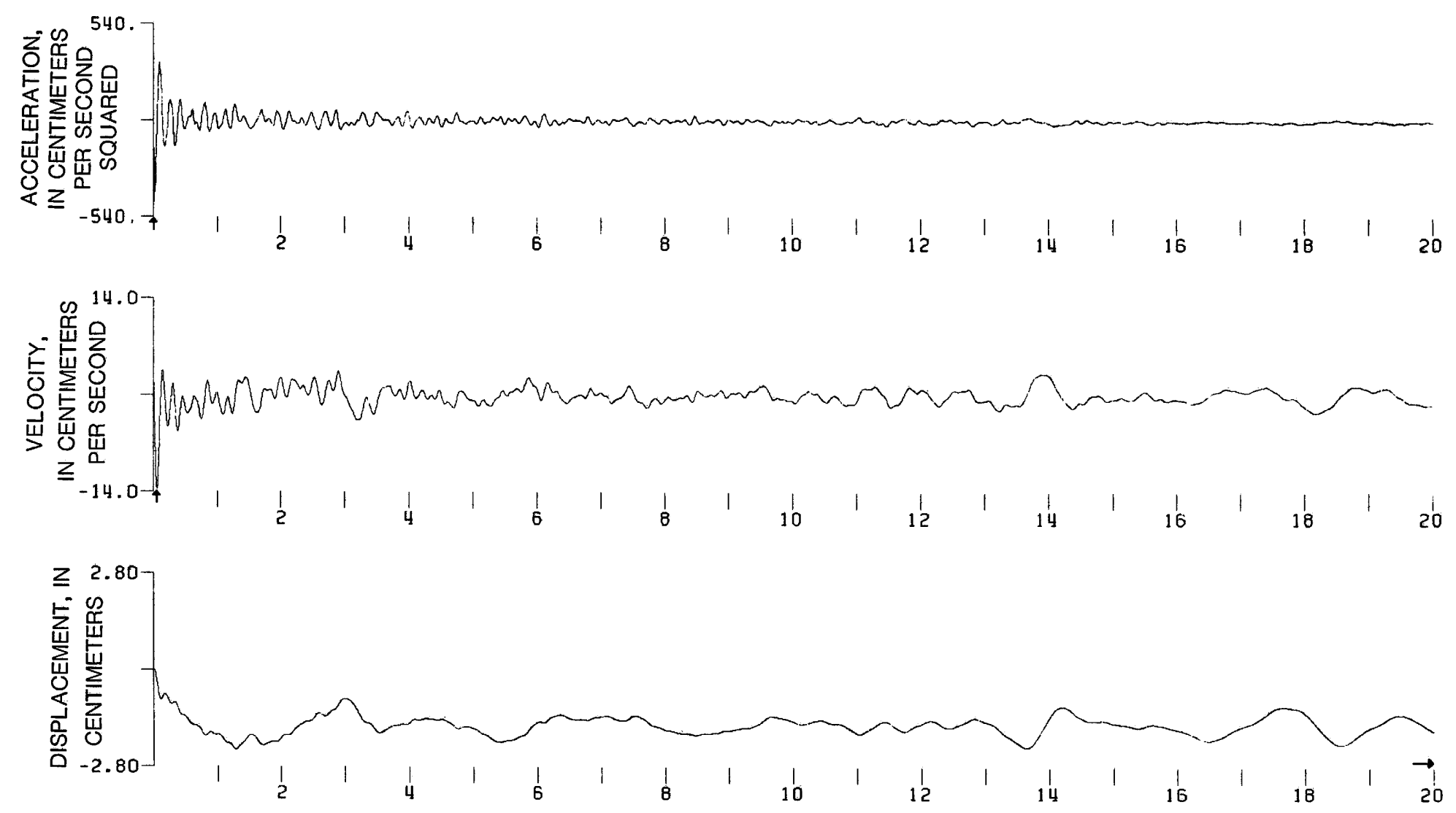

TIME, IN SECONDS

Figure 19.19. Corrected acceleration, velocity, and displacement at the Hollister City Hall Annex, basement (up component), for the April 24 earthquake, using a Butterworth filter $(0.25 \mathrm{~Hz}$, order 8) at 200 samples per second. Peak values (arrows): acceleration, $-532.85 \mathrm{~cm} / \mathrm{s}^{2}$; velocity, $-13.59 \mathrm{~cm} / \mathrm{s}$; displacement, $-2.73 \mathrm{~cm}$. 

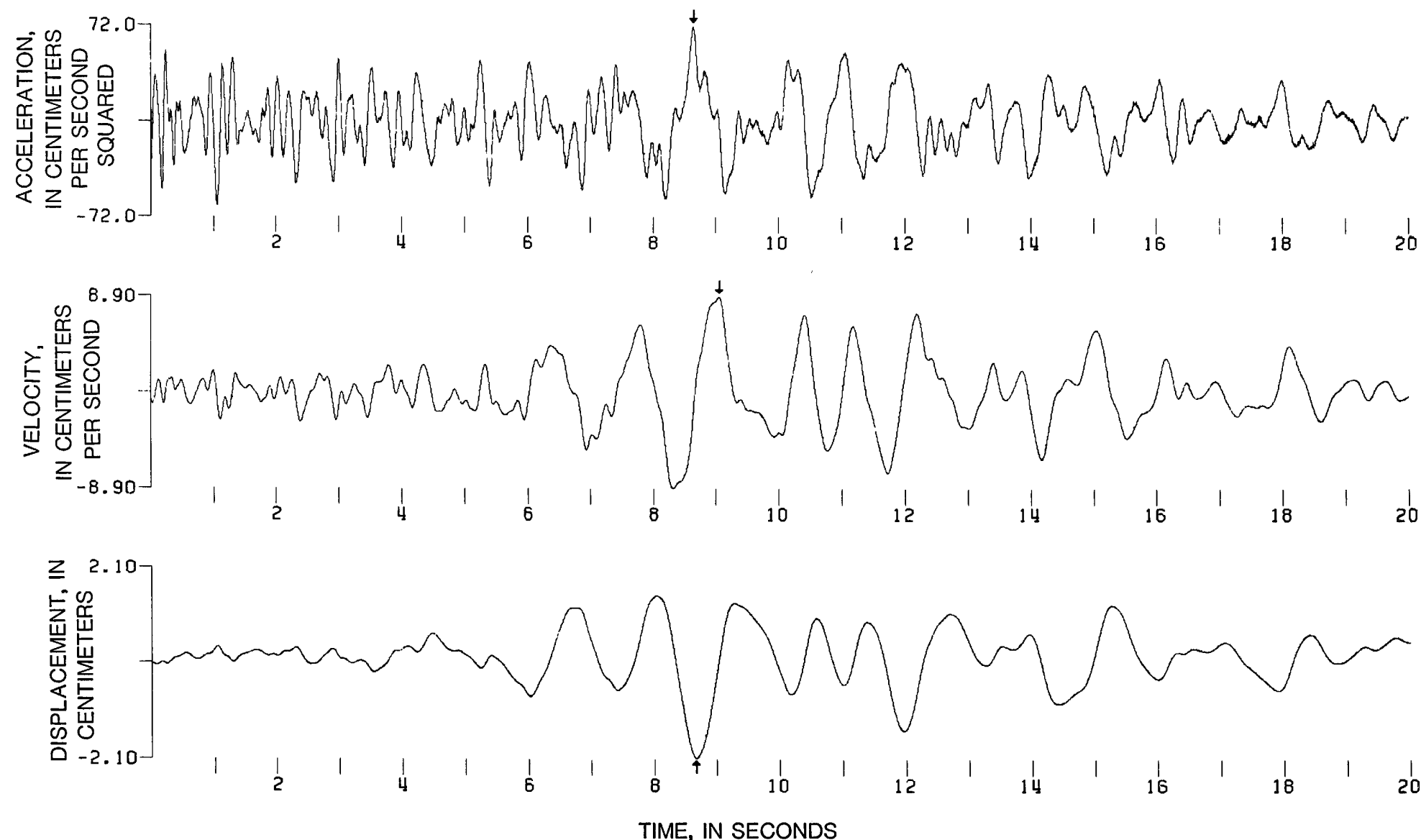

Figure 19.20. Corrected acceleration, velocity, and displacement at the Hollister City Hall Annex, basement (271 ${ }^{\circ}$ component), for the April 24 earthquake, using a Butterworth filter $(0.25 \mathrm{~Hz}$, order 8$)$ at 200 samples per second. Peak values (arrows): acceleration, $71.06 \mathrm{~cm} / \mathrm{s}^{2}$; velocity, $8.86 \mathrm{~cm} / \mathrm{s}$; displacement, $-2.07 \mathrm{~cm}$. 

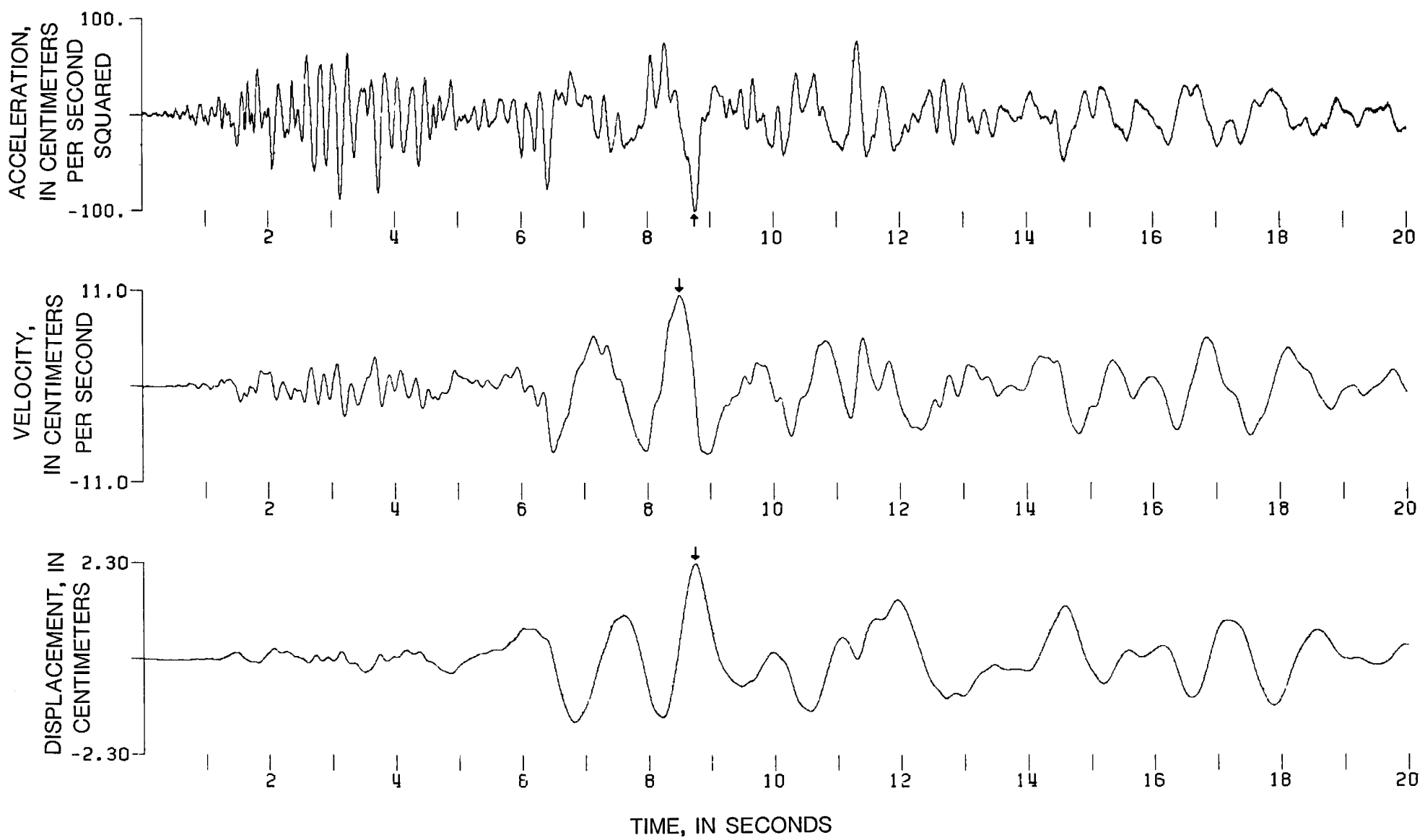

Figure 19.21. Corrected acceleration, velocity, and displacement at the Hollister Differential Array (SMA-1T, 255 ${ }^{\circ}$ component) for the April 24 earthquake, using a Butterworth filter $(0.25 \mathrm{~Hz}$, order 8$)$ at 200 samples per second. Peak values (arrows): acceleration, $-99.37 \mathrm{~cm} / \mathrm{s}^{2}$; velocity, $10.61 \mathrm{~cm} / \mathrm{s}$; displacement, $2.30 \mathrm{~cm}$. 

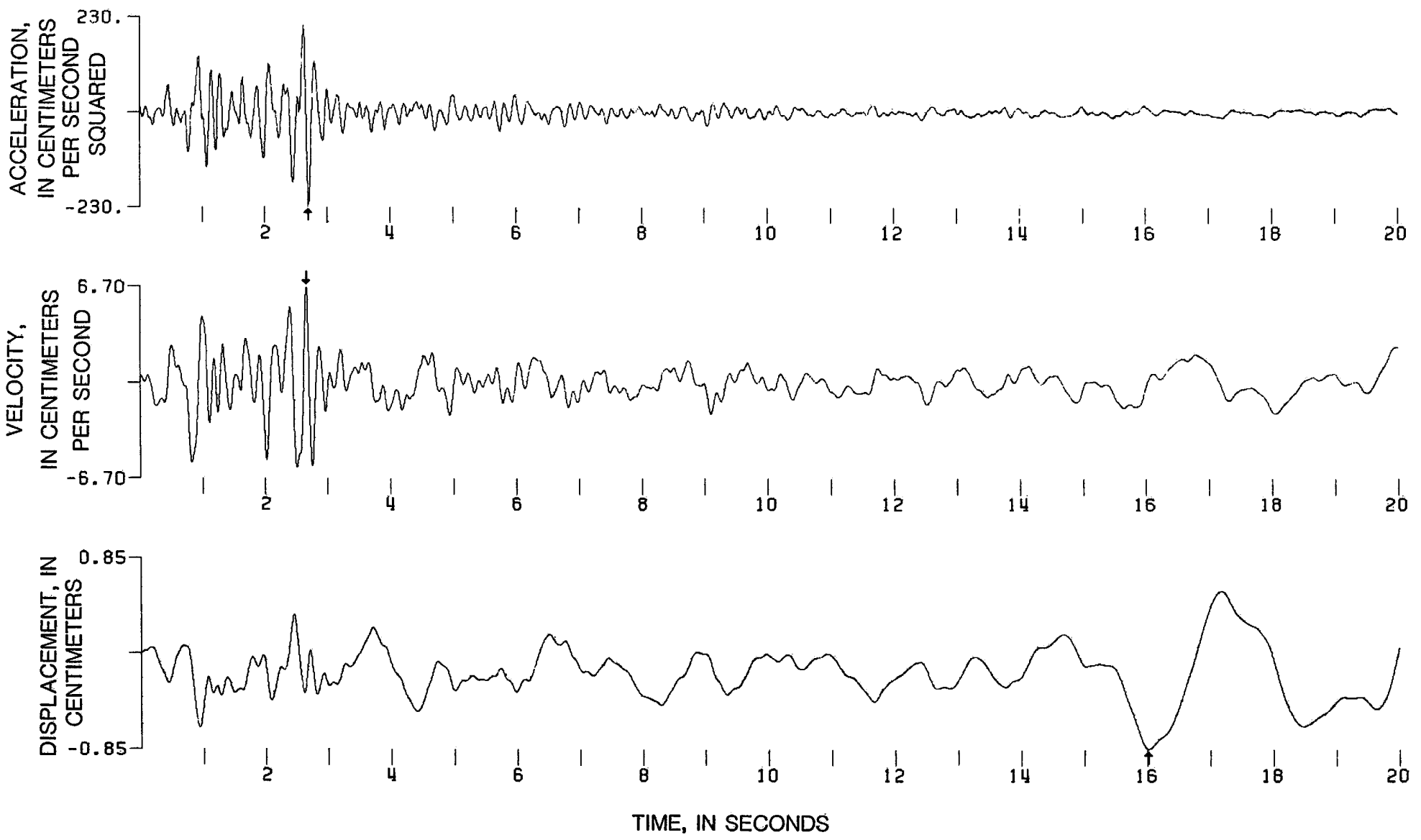

Figure 19.22. Corrected acceleration, velocity, and displacement at the Hollister Differential Array (SMA-1T, up component) for the April 24 earthquake, using a Butterworth filter (0.25 Hz, order 8) at 200 samples per second. Peak values (arrows): acceleration, $-227.24 \mathrm{~cm} / \mathrm{s}^{2}$; velocity, $6.62 \mathrm{~cm} / \mathrm{s}$; displacement, $-0.84 \mathrm{~cm}$. 

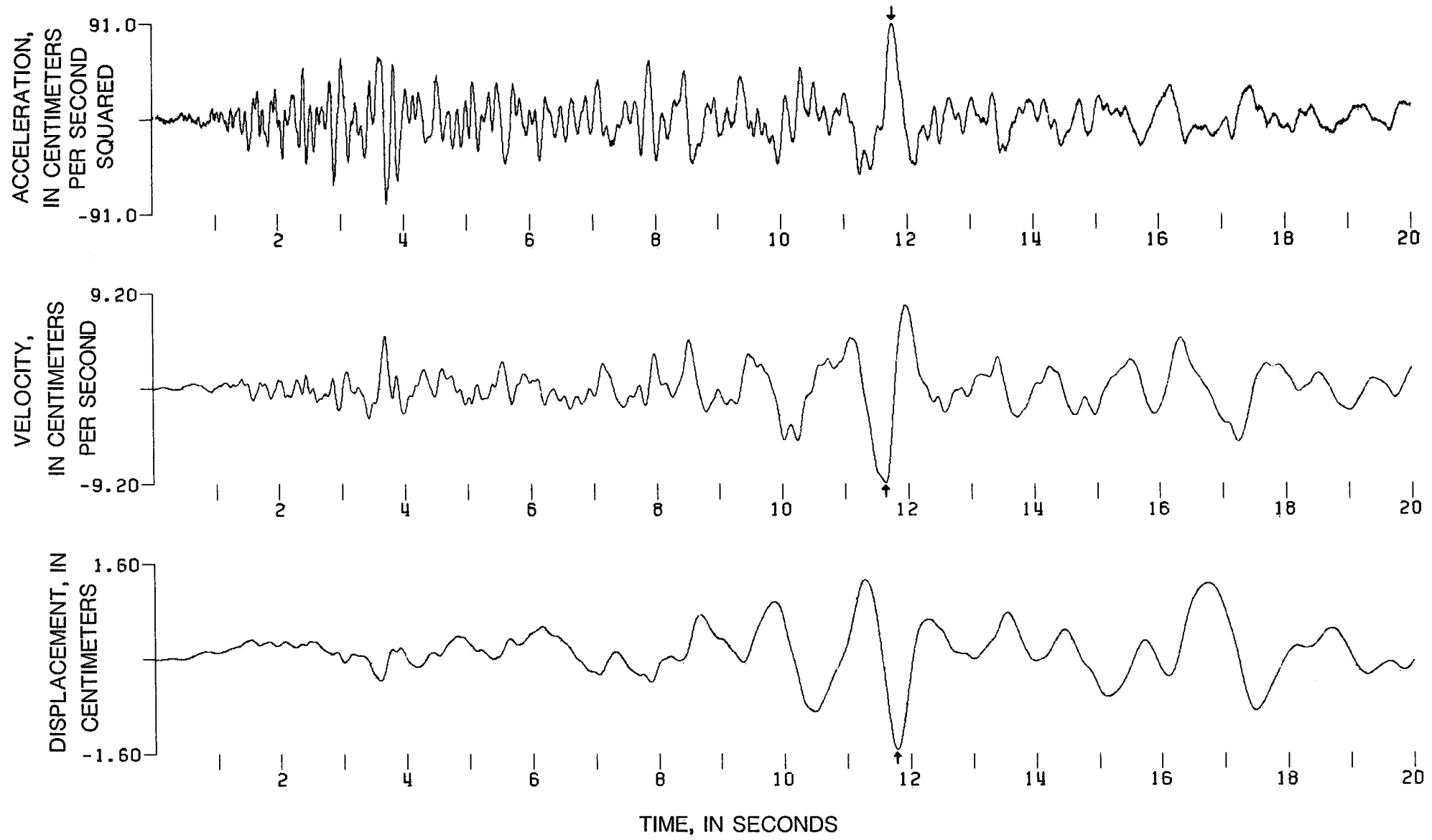

Figure 19.23. Corrected acceleration, velocity, and displacement at the Hollister Differential Array (SMA-1T, $165^{\circ}$ component) for the April 24 earthquake, using a Butterworth filter $(0.25 \mathrm{~Hz}$, order 8$)$ at 200 samples per second. Peak values (arrows): acceleration, $90.95 \mathrm{~cm} / \mathrm{s}^{2}$; velocity, $-9.15 \mathrm{~cm} / \mathrm{s}$; displacement, $-1.53 \mathrm{~cm}$. 

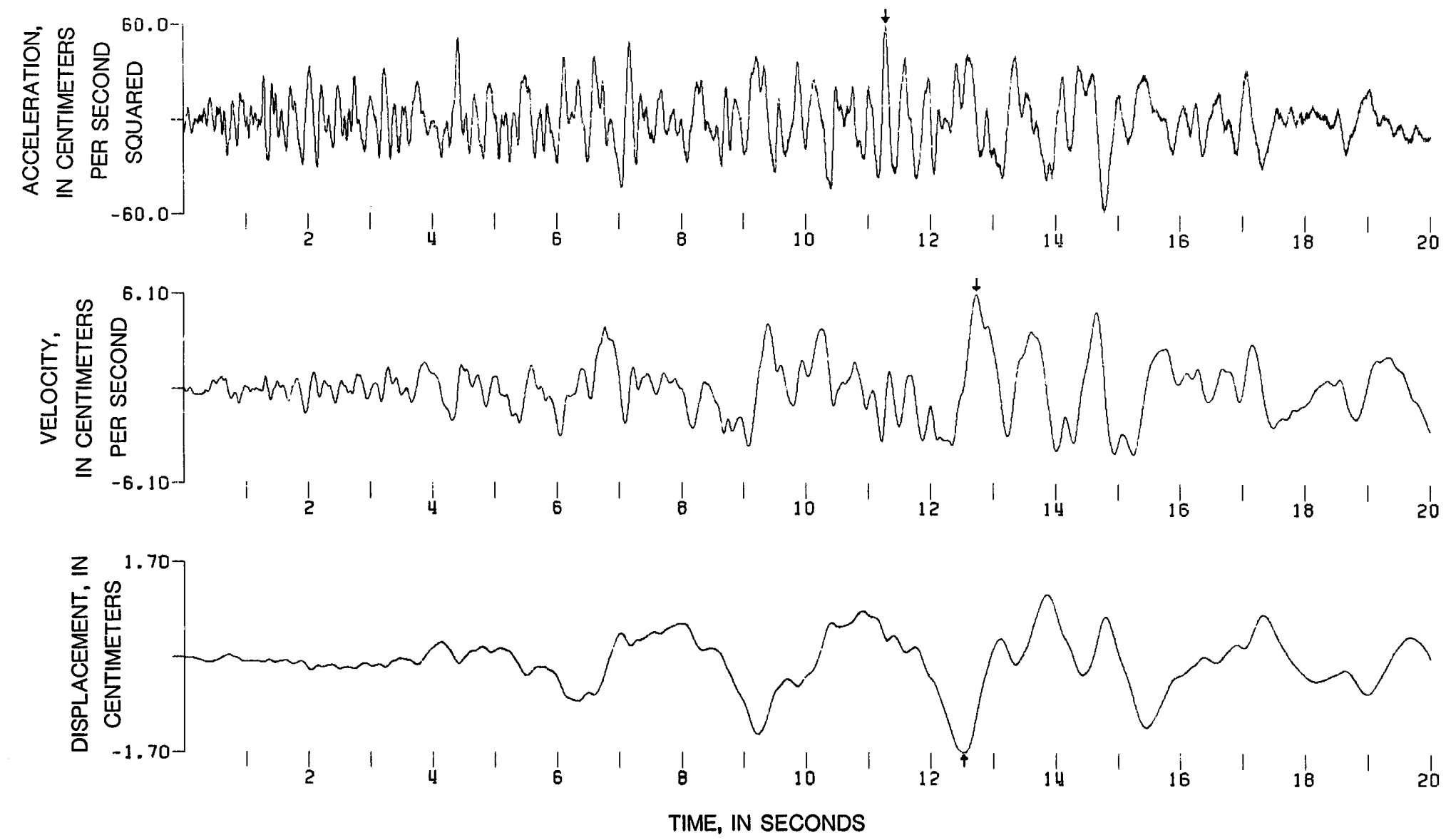

Figure 19.24. Corrected acceleration, velocity, and displacement at the San Justo Damsite, right abutment (dike, $360^{\circ}$ component), for the April 24 earthquake, using a Butterworth filter $(0.25 \mathrm{~Hz}$, order 8$)$ at 200 samples per second. Peak values (arrows): acceleration, $59.48 \mathrm{~cm} / \mathrm{s}^{2}$; velocity, $6.08 \mathrm{~cm} / \mathrm{s}$; displacement, $-1.69 \mathrm{~cm}$. 

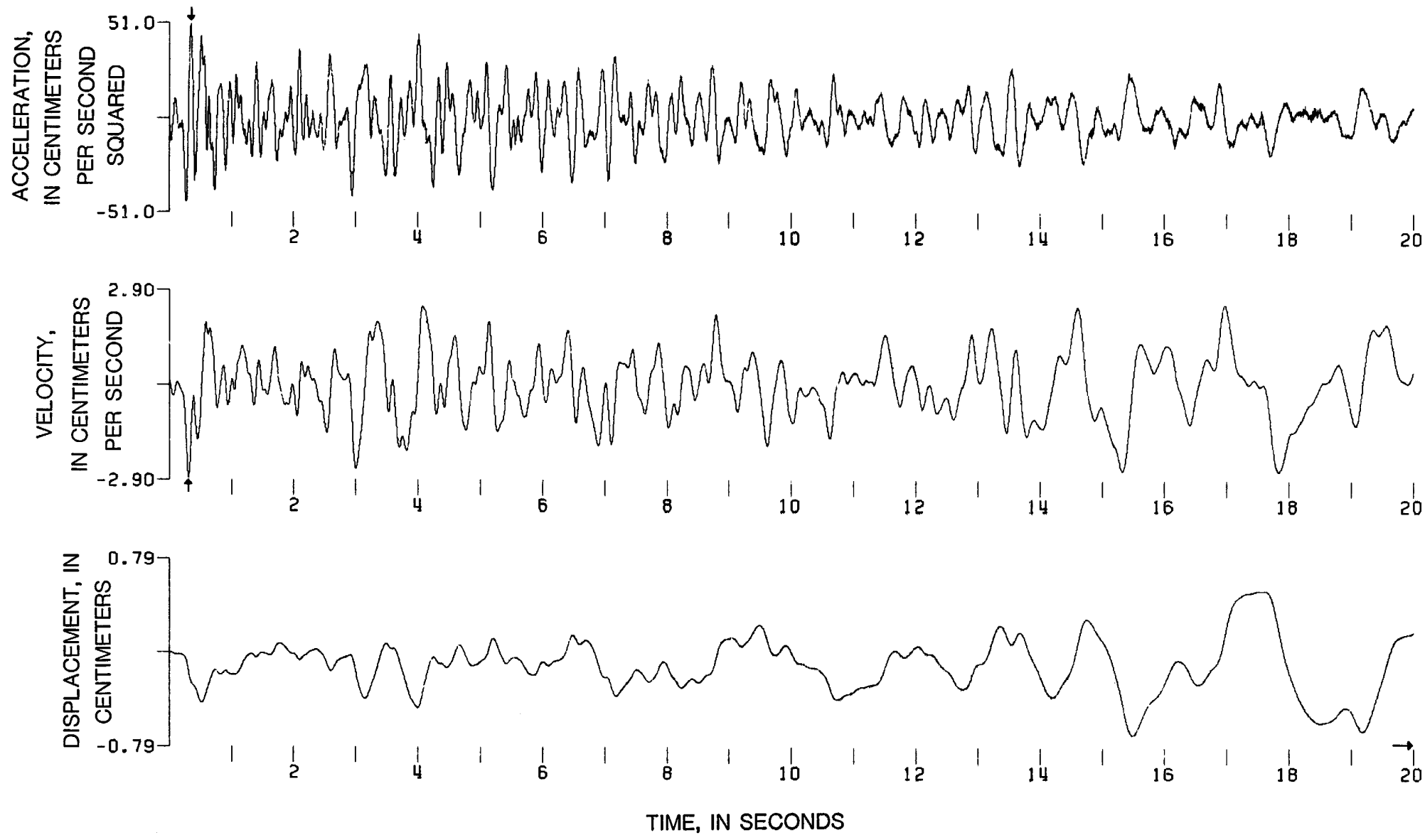

Figure 19.25. Corrected acceleration, velocity, and displacement at the San Justo Damsite, right abutment (dike, up component), for the April 24 earthquake, using a Butterworth filter $(0.25 \mathrm{~Hz}$, order 8$)$ at 200 samples per second. Peak values (arrows): acceleration, $50.20 \mathrm{~cm} / \mathrm{s}^{2}$; velocity, $-2.84 \mathrm{~cm} / \mathrm{s}$; displacement, $-0.78 \mathrm{~cm}$. 

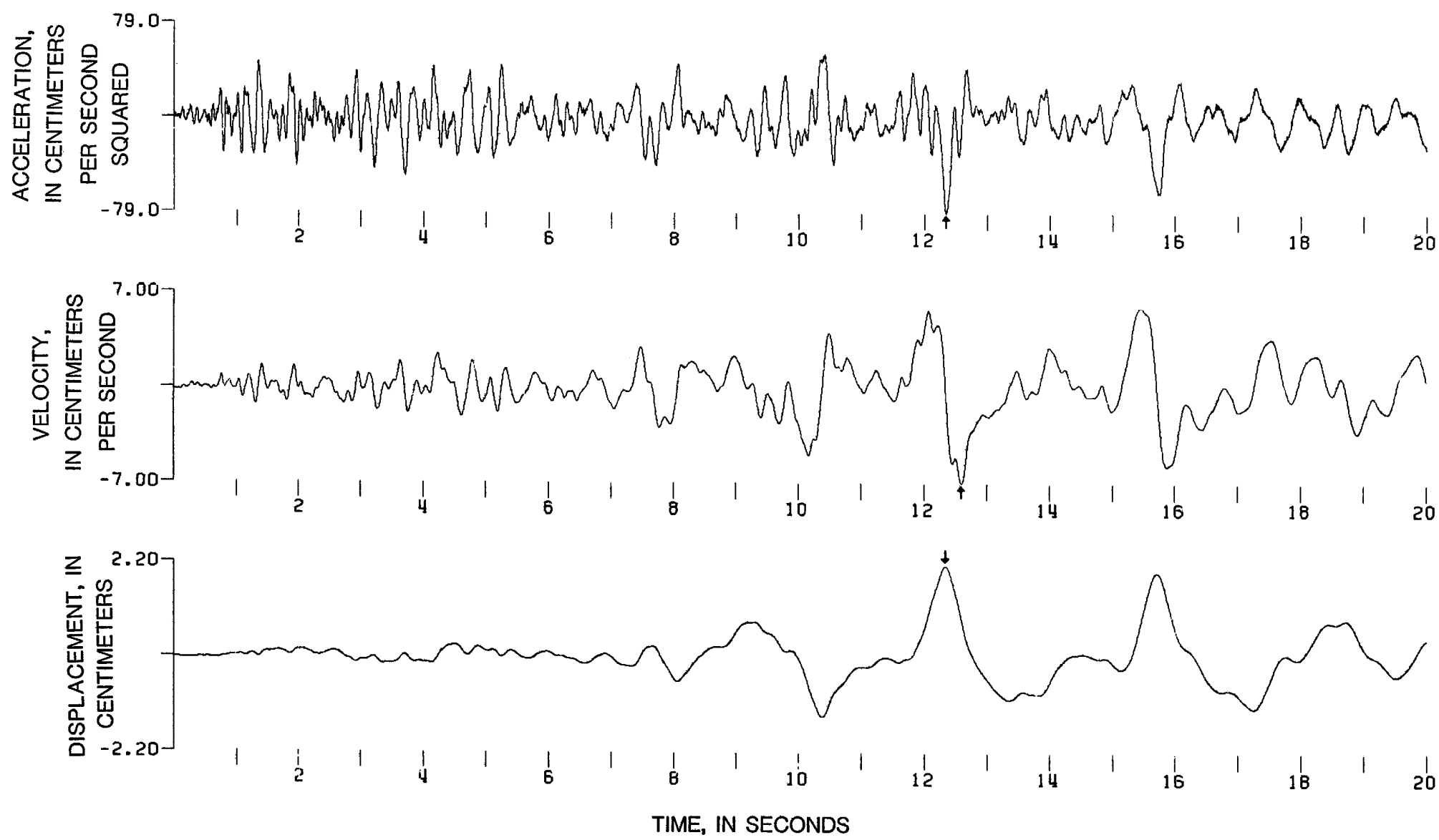

Figure 19.26. Corrected acceleration, velocity, and displacement at the San Justo Damsite, right abutment (dike, $270^{\circ}$ component), for the April 24 earthquake, using a Butterworth filter $(0.25 \mathrm{~Hz}$, order 8$)$ at 200 samples per second. Peak values (arrows): acceleration, $-78.16 \mathrm{~cm} / \mathrm{s}^{2}$; velocity, $-6.94 \mathrm{~cm} / \mathrm{s}$; displacement, $2.14 \mathrm{~cm}$. 

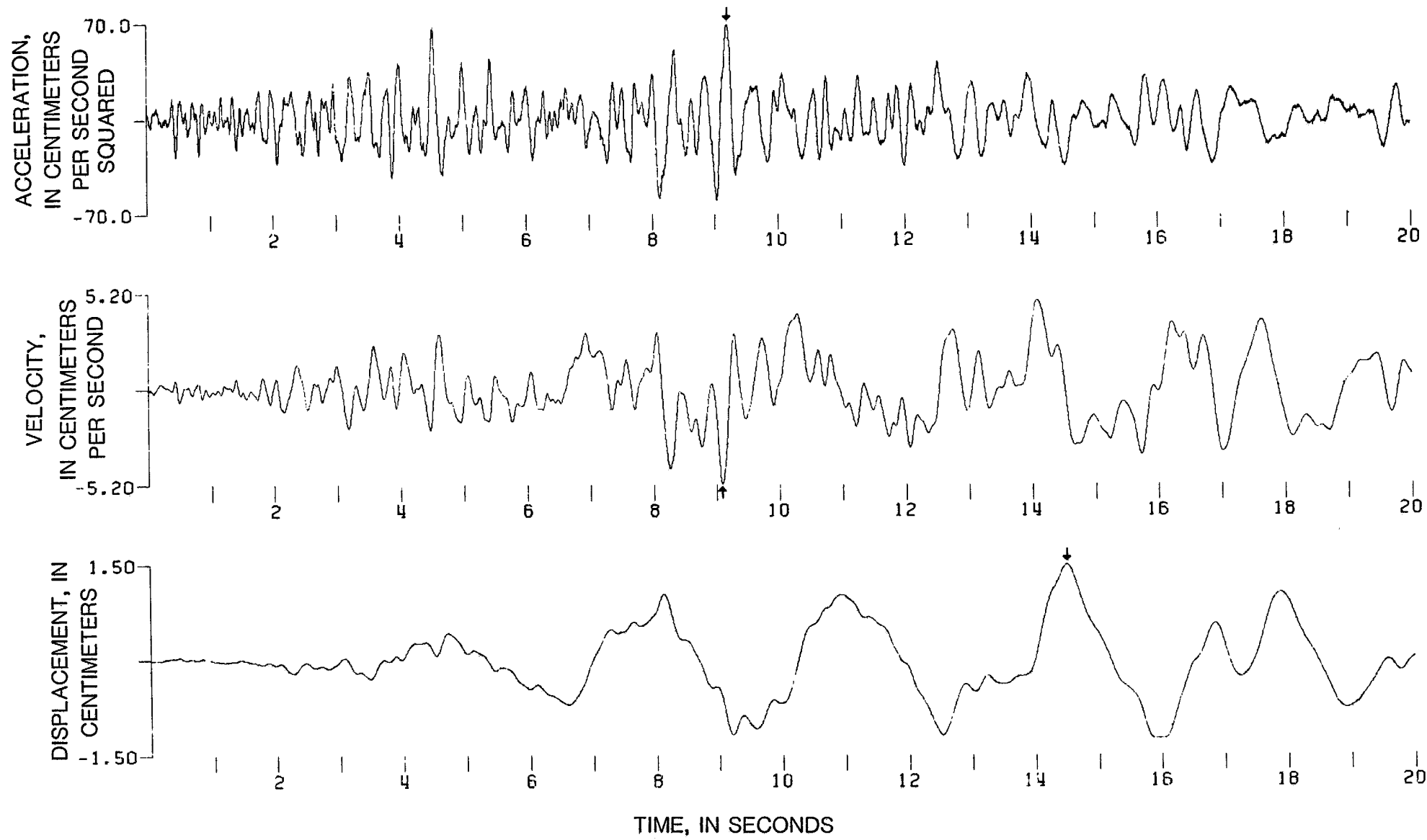

Figure 19.27. Corrected acceleration, velocity, and displacement at the San Justo Damsite, left abutment ( $360^{\circ}$ component), for the April 24 earthquake, using a Butterworth filter $(0.25 \mathrm{~Hz}$, order 8) at 200 samples per second. Peak values (arrows): acceleration, $69.18 \mathrm{~cm} / \mathrm{s}^{2}$; velocity, $-5.16 \mathrm{~cm} / \mathrm{s}$; displacement, $1.48 \mathrm{~cm}$. 

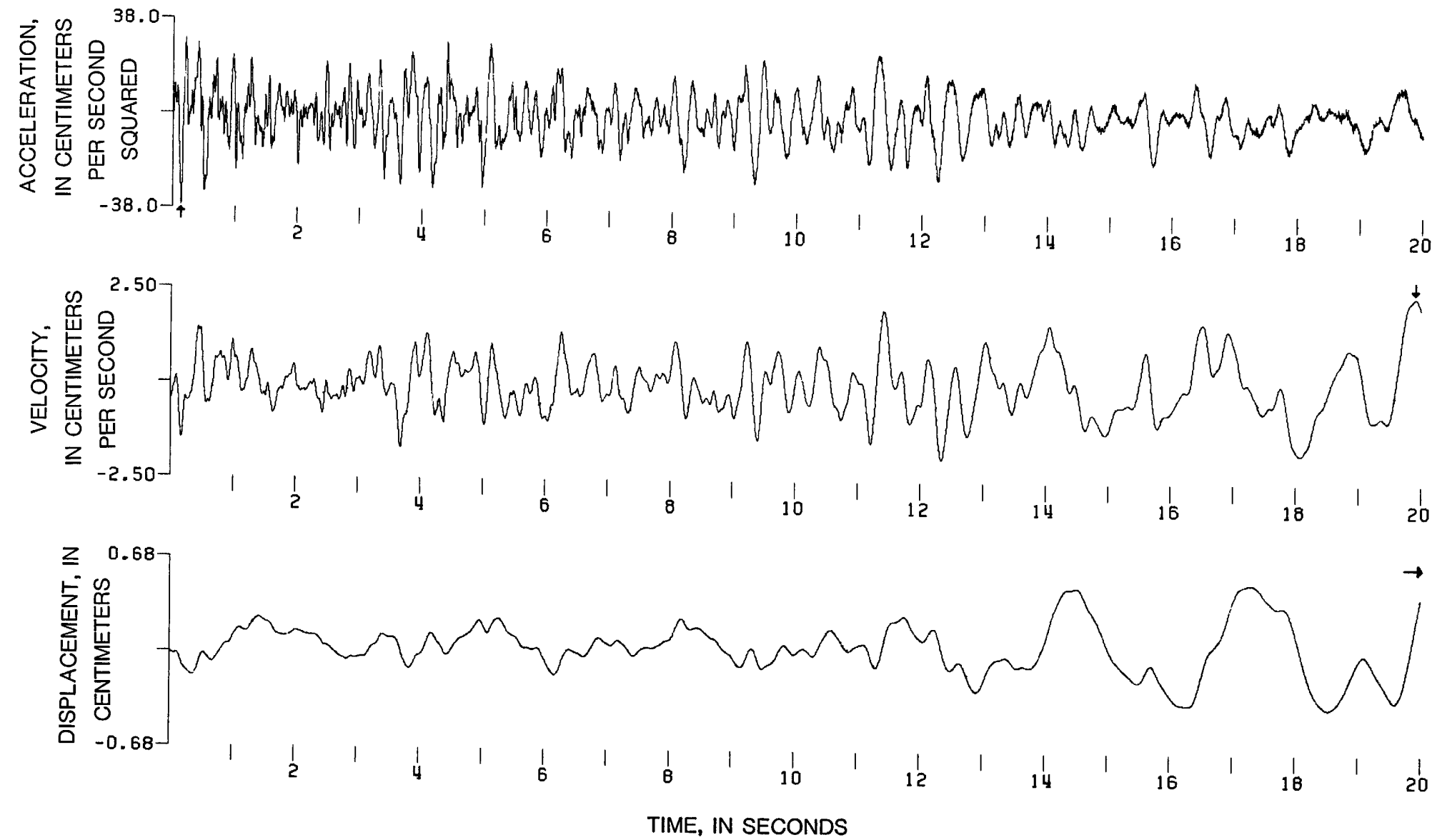

Figure 19.28. Corrected acceleration, velocity, and displacement at the San Justo Damsite, left abutment (up component), for the April 24 earthquake, using a Butterworth filter (0.25 Hz, order 8) at 200 samples per second. Peak values (arrows): acceleration, $-37.06 \mathrm{~cm} / \mathrm{s}^{2}$; velocity, $2.45 \mathrm{~cm} / \mathrm{s}$; displacement, $0.68 \mathrm{~cm}$. 

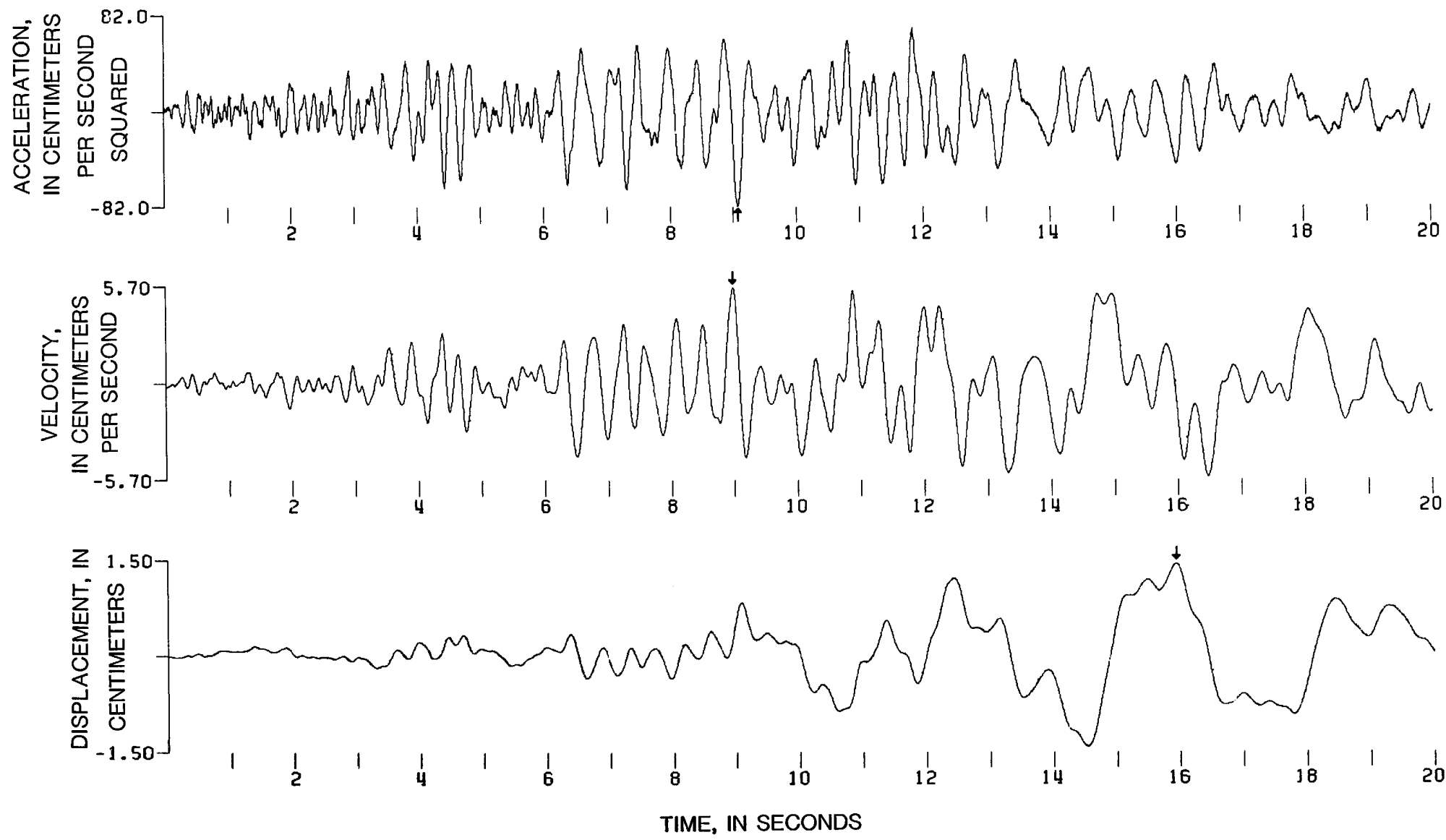

Figure 19.29. Corrected acceleration, velocity, and displacement at the San Justo Damsite, left abutment (270 component), for the April 24 earthquake, using a Butterworth filter $(0.25 \mathrm{~Hz}$, order 8) at 200 samples per second. Peak values (arrows): acceleration, $-81.40 \mathrm{~cm} / \mathrm{s}^{2}$; velocity, $5.64 \mathrm{~cm} / \mathrm{s}$; displacement, $1.43 \mathrm{~cm}$. 

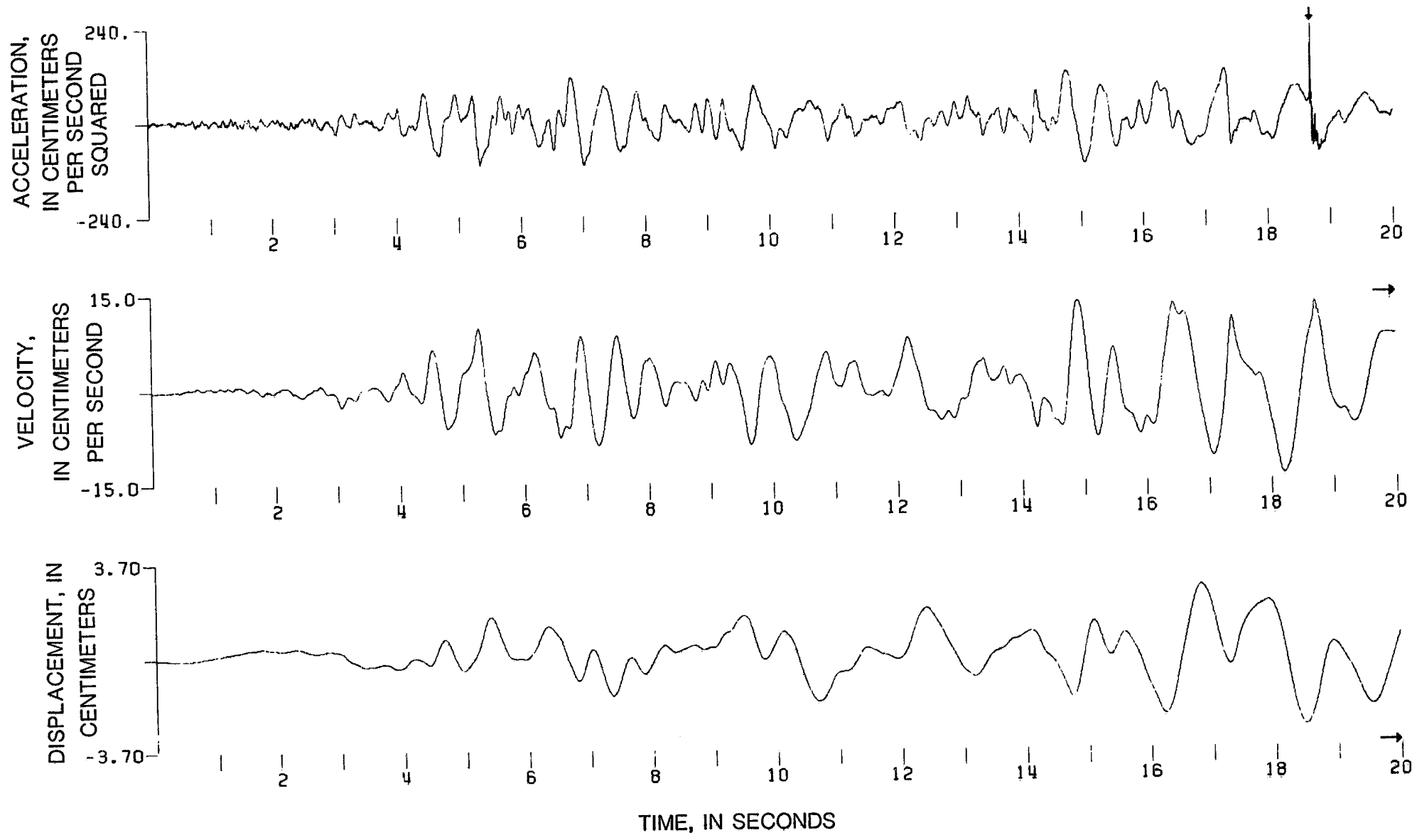

Figure 19.30. Corrected acceleration, velocity, and displacement at the San Jose Freeway Interchange $\left(322^{\circ}\right.$ component) for the April 24 earthquake, using a Butterworth filter $(0.25 \mathrm{~Hz}$, order 8$)$ at 200 samples per second. Peak values (arrows): acceleration, $230.17 \mathrm{~cm} / \mathrm{s}^{2}$; velocity, $14.42 \mathrm{~cm} / \mathrm{s}$; displacement, $-3.68 \mathrm{~cm}$. 

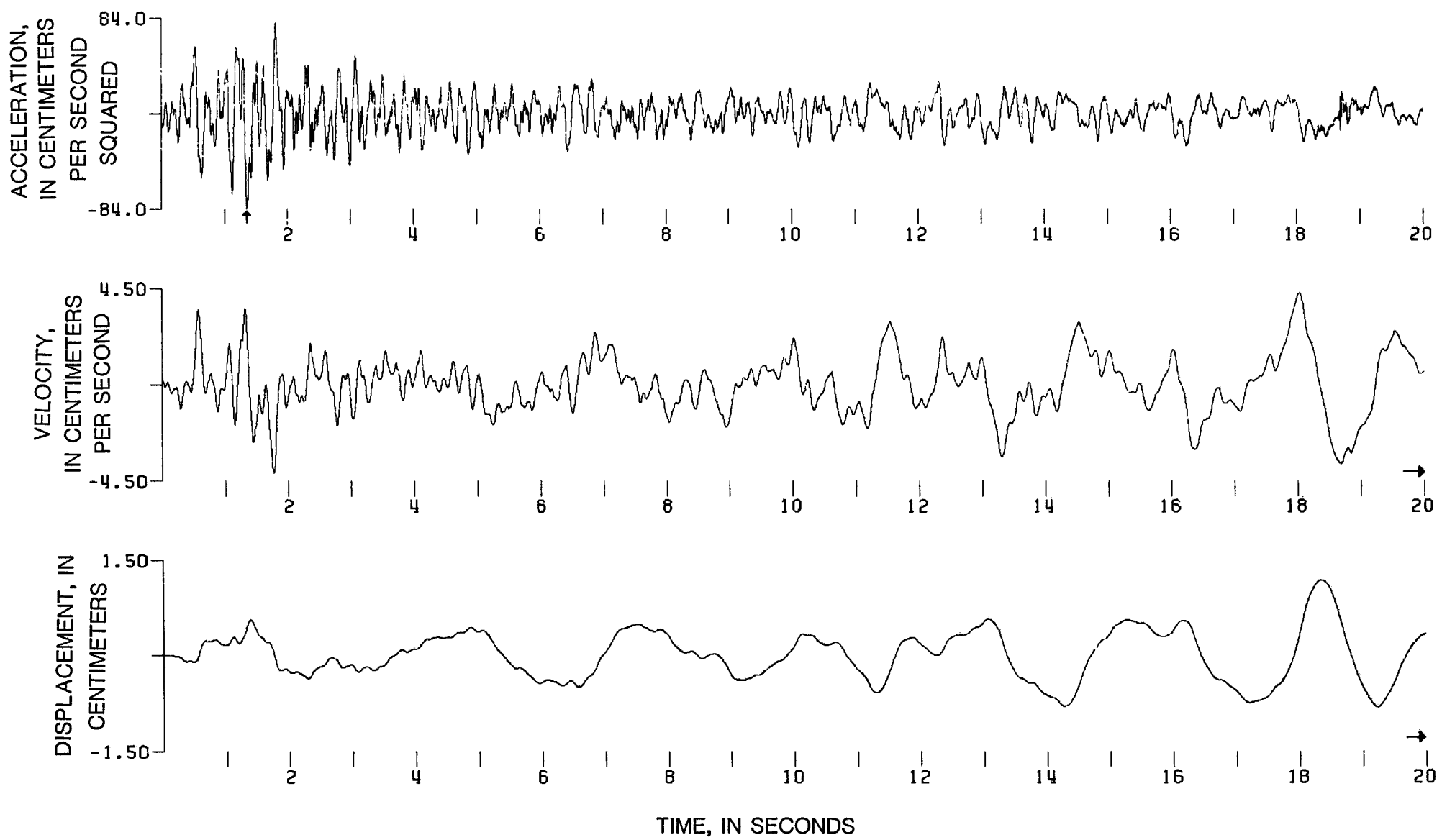

Figure 19.31. Corrected acceleration, velocity, and displacement at the San Jose Freeway Interchange (up component) for the April 24 earthquake, using a Butterworth filter $(0.25 \mathrm{~Hz}$, order 8) at 200 samples per second. Peak values (arrows): acceleration, $-83.53 \mathrm{~cm} / \mathrm{s}^{2}$; velocity, $-4.43 \mathrm{~cm} / \mathrm{s}$; displacement, $-1.4 \mathrm{~cm}$. 

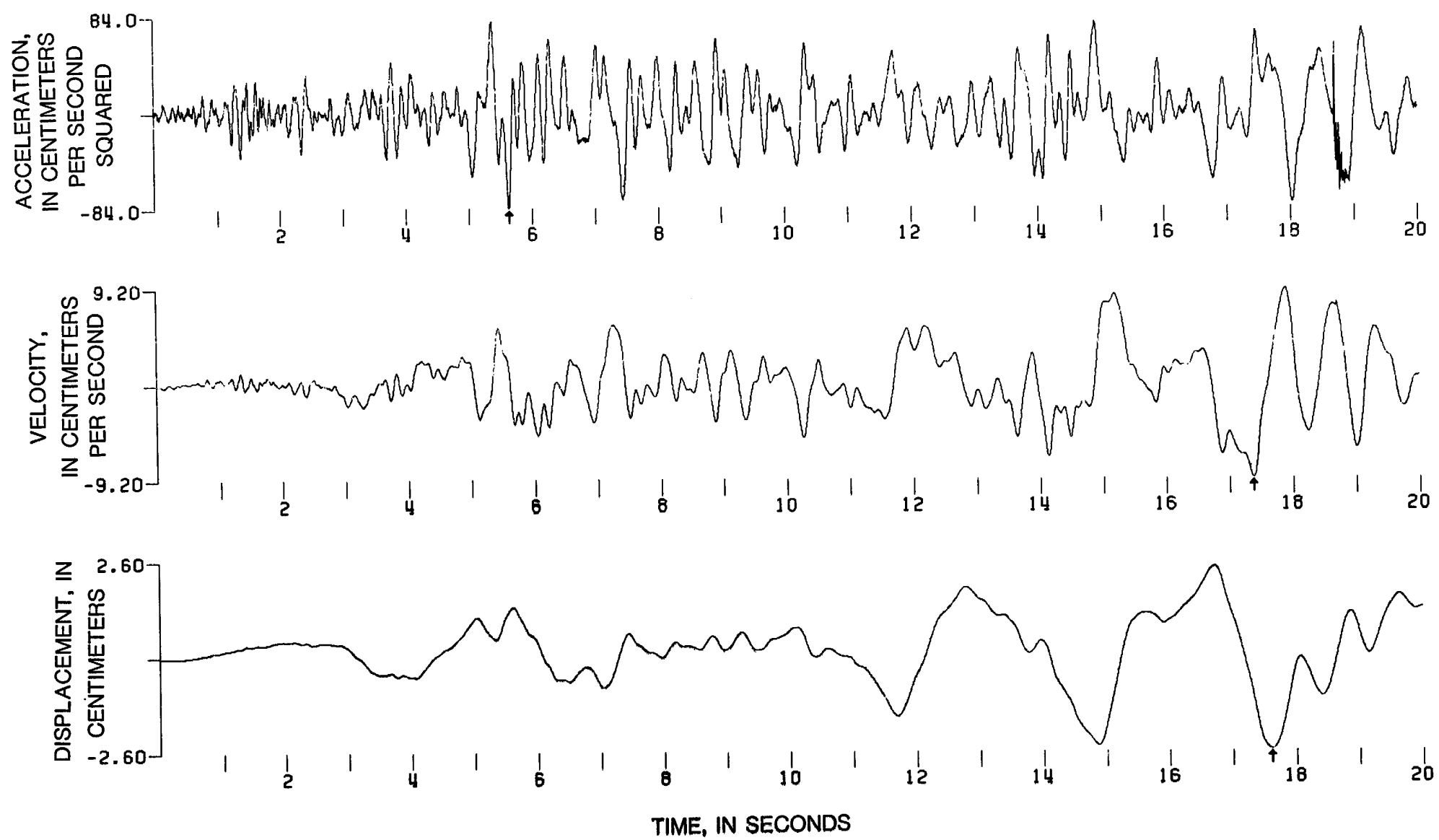

Figure 19.32. Corrected acceleration, velocity, and displacement at the San Jose Freeway Interchange (232 ${ }^{\circ}$ component) for the April 24 earthquake, using a Butterworth filter $(0.25 \mathrm{~Hz}$, order 8 ) at 200 samples per second. Peak values (arrows): acceleration, $-83.92 \mathrm{~cm} / \mathrm{s}^{2}$; velocity, $-9.15 \mathrm{~cm} / \mathrm{s}$; displacement, $-2.55 \mathrm{~cm}$. 

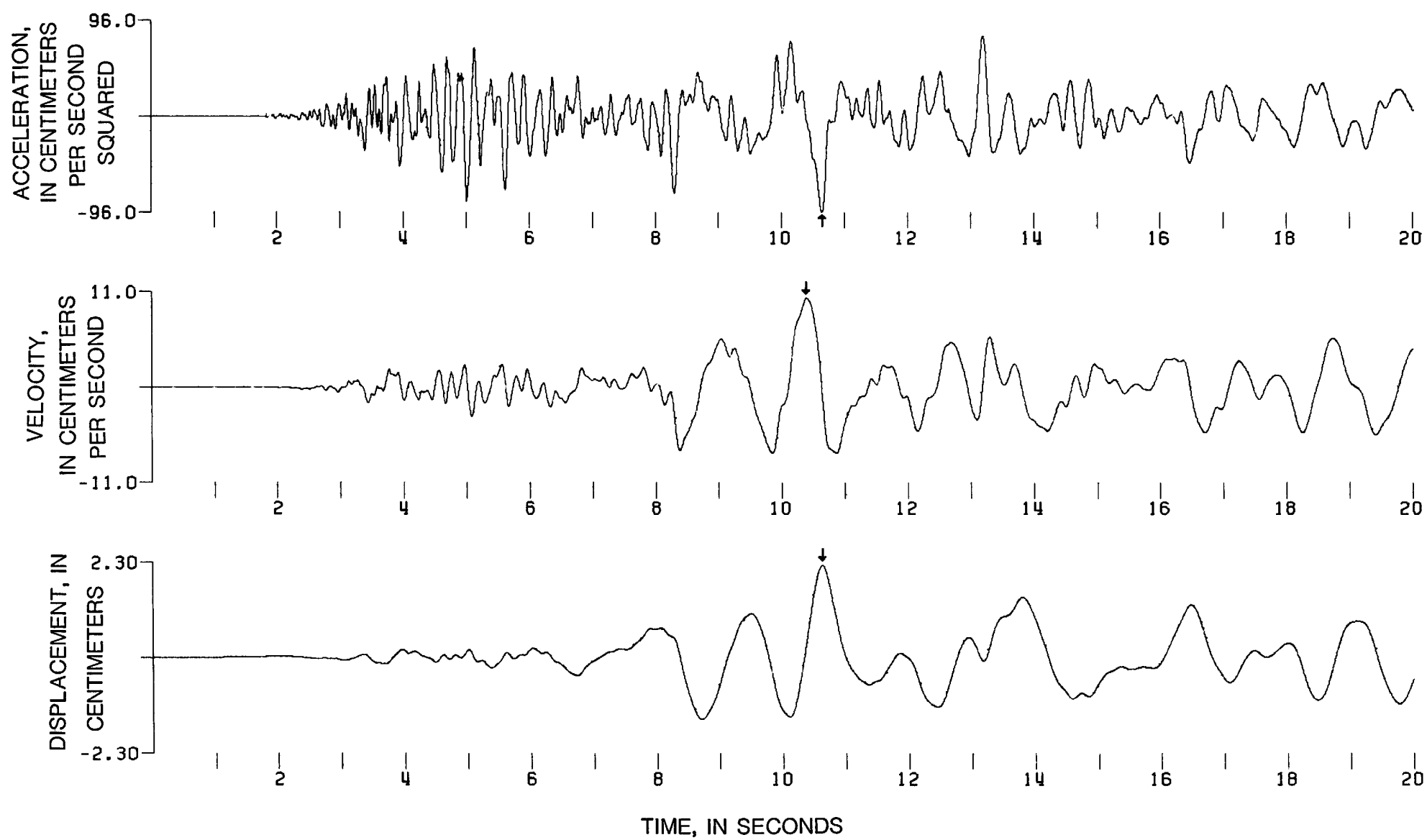

Figure 19.33. Corrected acceleration, velocity, and displacement at Hollister Differential Array 1 ( $255^{\circ}$ component) for the April 24 earthquake, using a Butterworth filter $(0.25 \mathrm{~Hz}$, order 8) at 200 samples per second. Peak values (arrows): acceleration, $-95.29 \mathrm{~cm} / \mathrm{s}^{2}$; velocity, $10.35 \mathrm{~cm} / \mathrm{s}$; displacement, $2.23 \mathrm{~cm}$. 

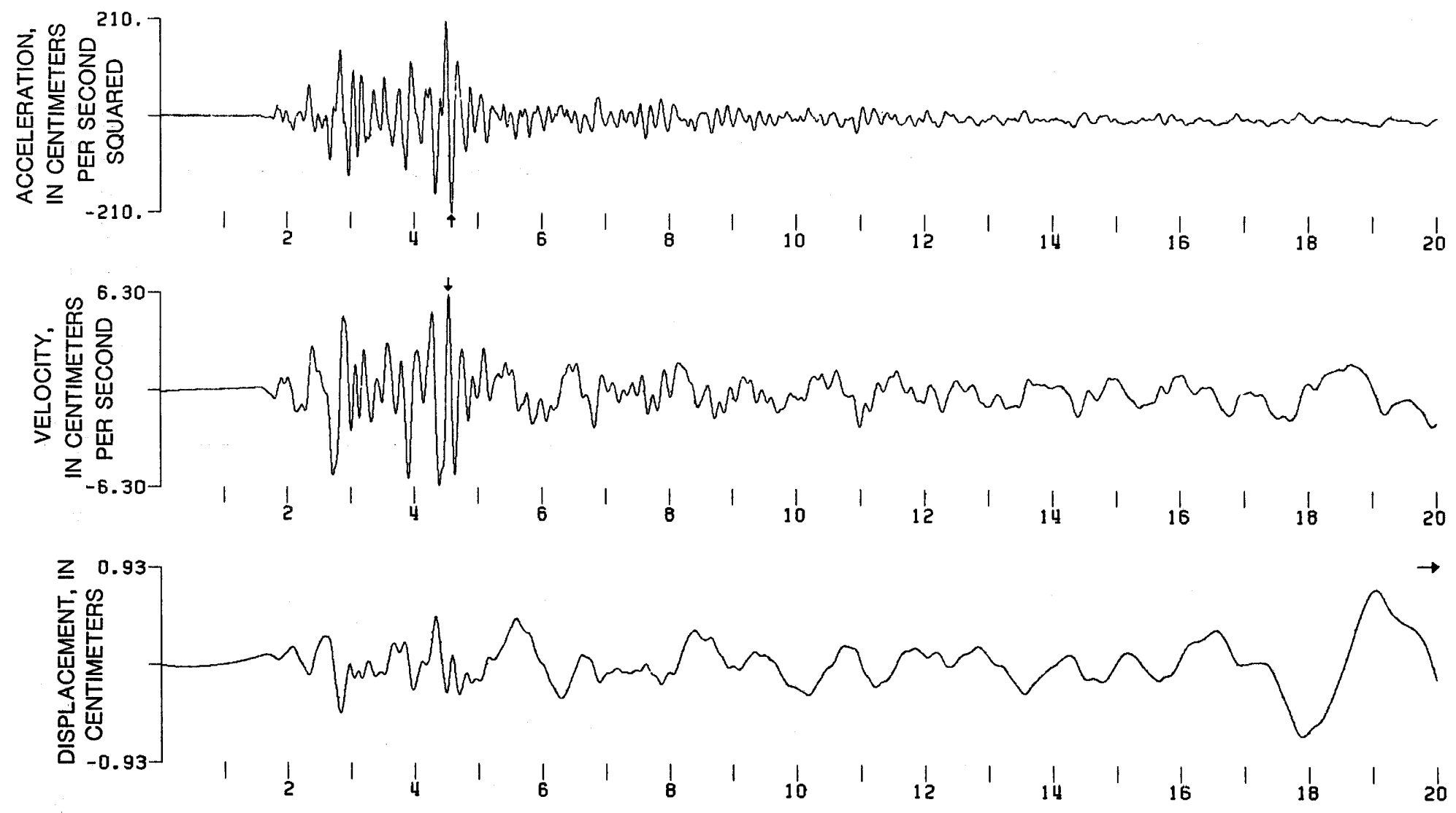

TIME, IN SECONDS

Figure 19.34. Corrected acceleration, velocity, and displacement at Hollister Differential Array 1 (up component) for the April 24 earthquake, using a Butterworth filter $(0.25 \mathrm{~Hz}$, order 8) at 200 samples per second. Peak values (arrows): acceleration, $-208.63 \mathrm{~cm} / \mathrm{s}^{2}$; velocity, $6.24 \mathrm{~cm} / \mathrm{s}$; displacement, $0.93 \mathrm{~cm}$. 

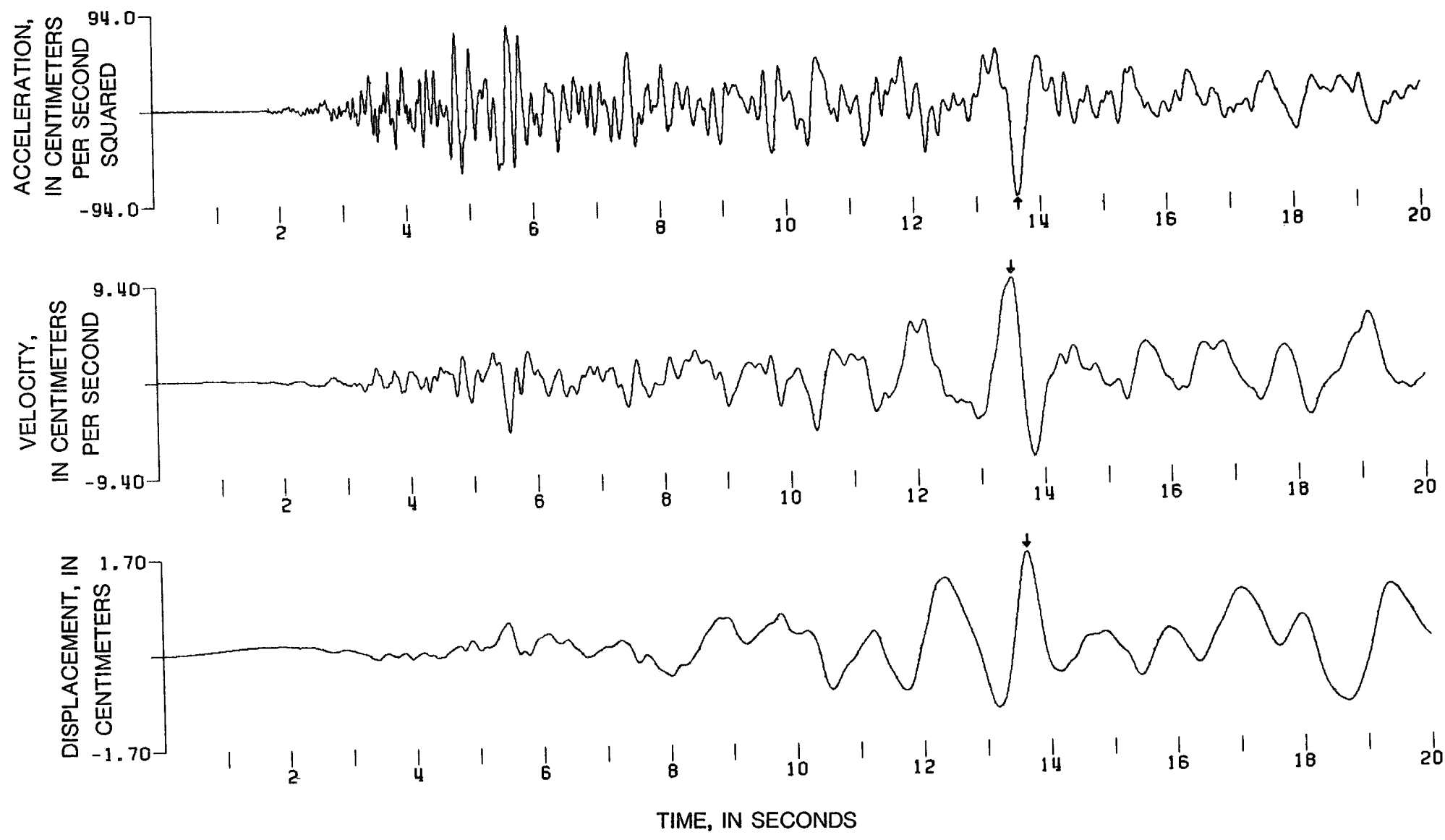

Figure 19.35. Corrected acceleration, velocity, and displacement at Hollister Differential Array 1 ( $345^{\circ}$ component) for the April 24 earthquake, using a Butterworth filter $(0.25 \mathrm{~Hz}$, order 8) at 200 samples per second. Peak values (arrows): acceleration, $-93.11 \mathrm{~cm} / \mathrm{s}^{2}$; velocity, $9.32 \mathrm{~cm} / \mathrm{s}$; displacement, $1.65 \mathrm{~cm}$. 

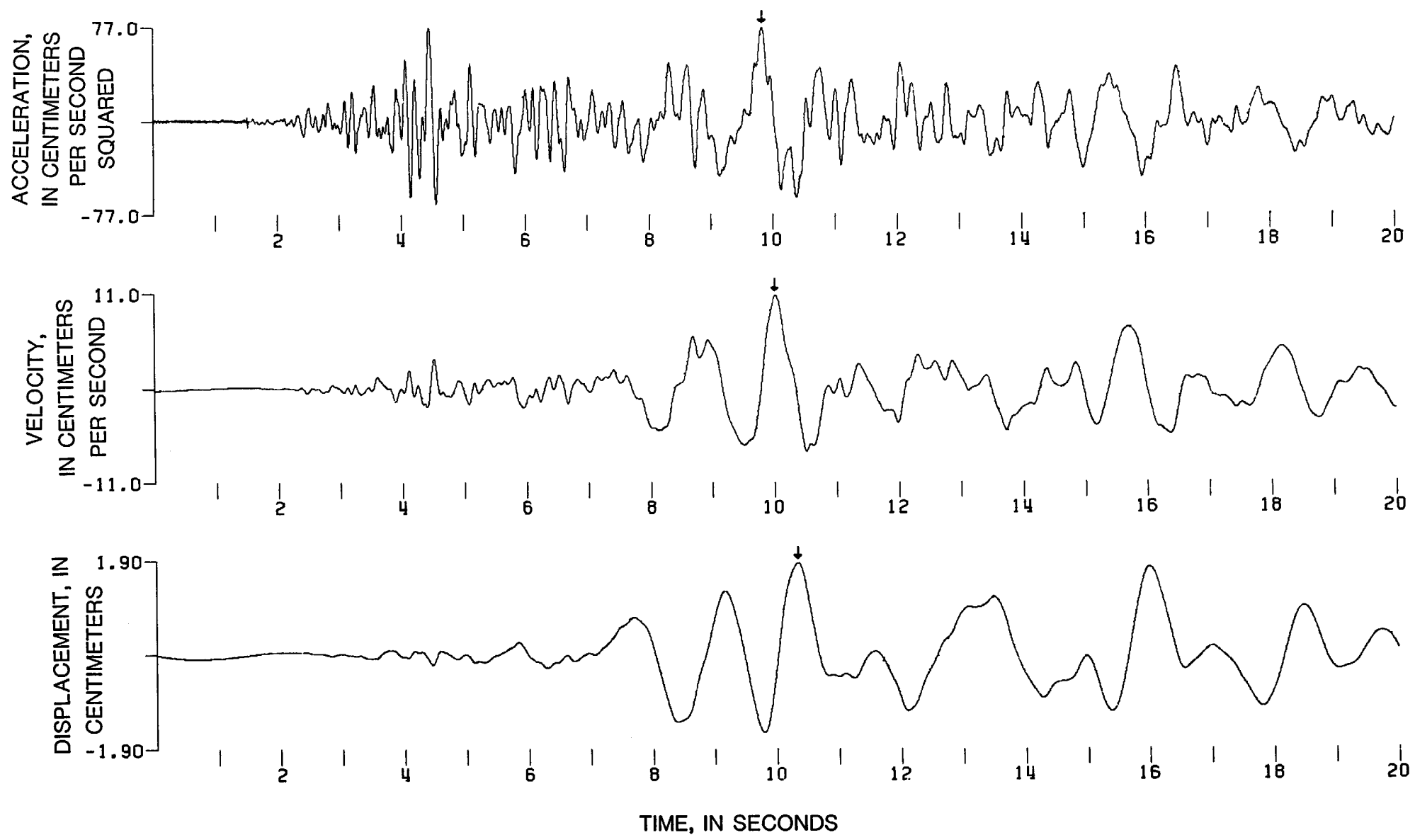

Figure 19.36. Corrected acceleration, velocity, and displacement at Hollister Differential Array 3 ( $255^{\circ}$ component) for the April 24 earthquake, using a Butterworth filter $(0.25 \mathrm{~Hz}$, order 8) at 200 samples per second. Peak values (arrows): acceleration, $76.45 \mathrm{~cm} / \mathrm{s}^{2}$; velocity, $10.79 \mathrm{~cm} / \mathrm{s}$; displacement, $1.84 \mathrm{~cm}$. 

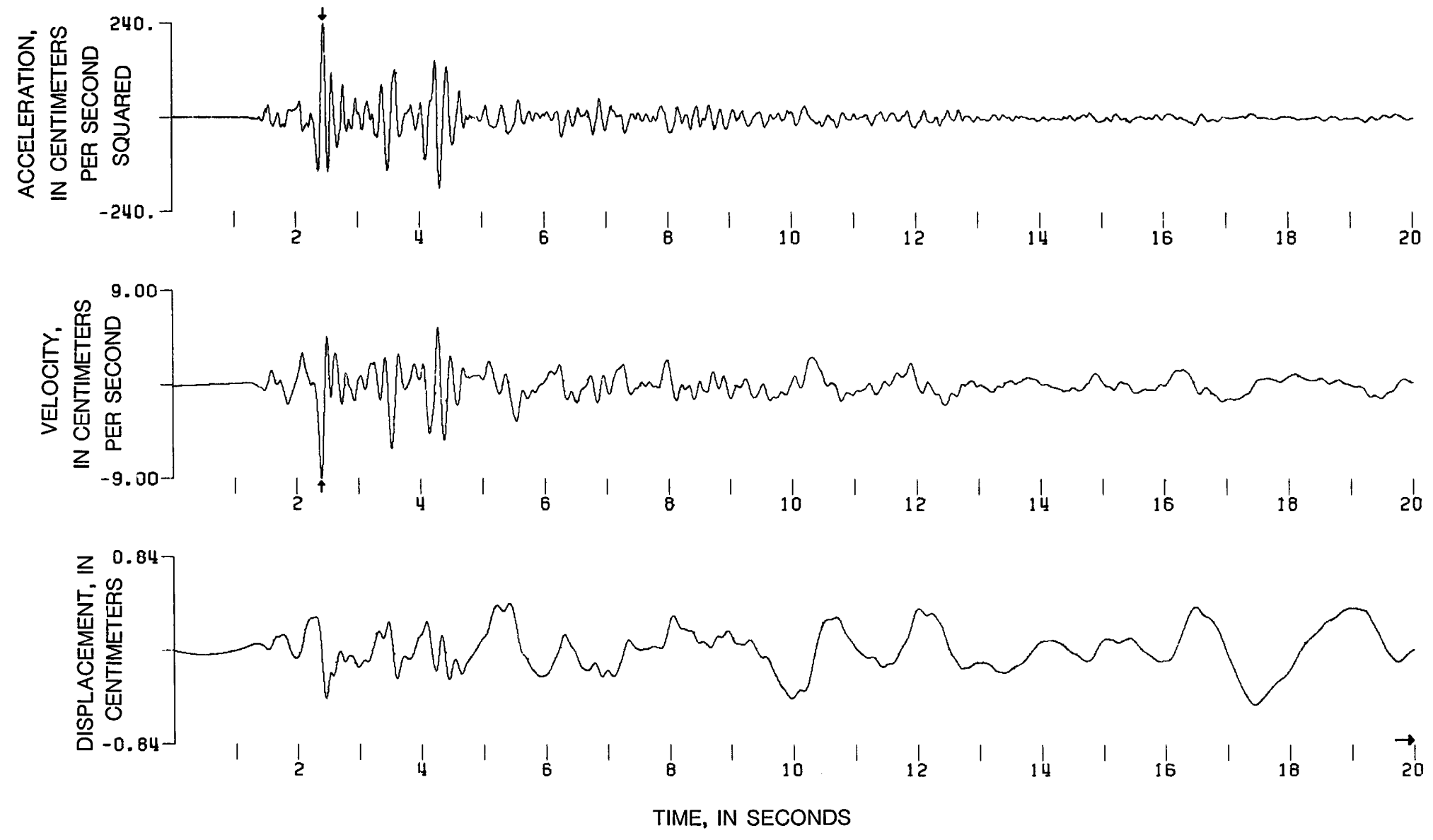

Figure 19.37. Corrected acceleration, velocity, and displacement at Hollister Differential Array 3 (up component) for the April 24 earthquake, using a Butterworth filter $(0.25 \mathrm{~Hz}$, order 8) at 200 samples per second. Peak values (arrows): acceleration, $239.40 \mathrm{~cm} / \mathrm{s}^{2}$; velocity, $-8.99 \mathrm{~cm} / \mathrm{s}$; displacement, $-0.83 \mathrm{~cm}$. 

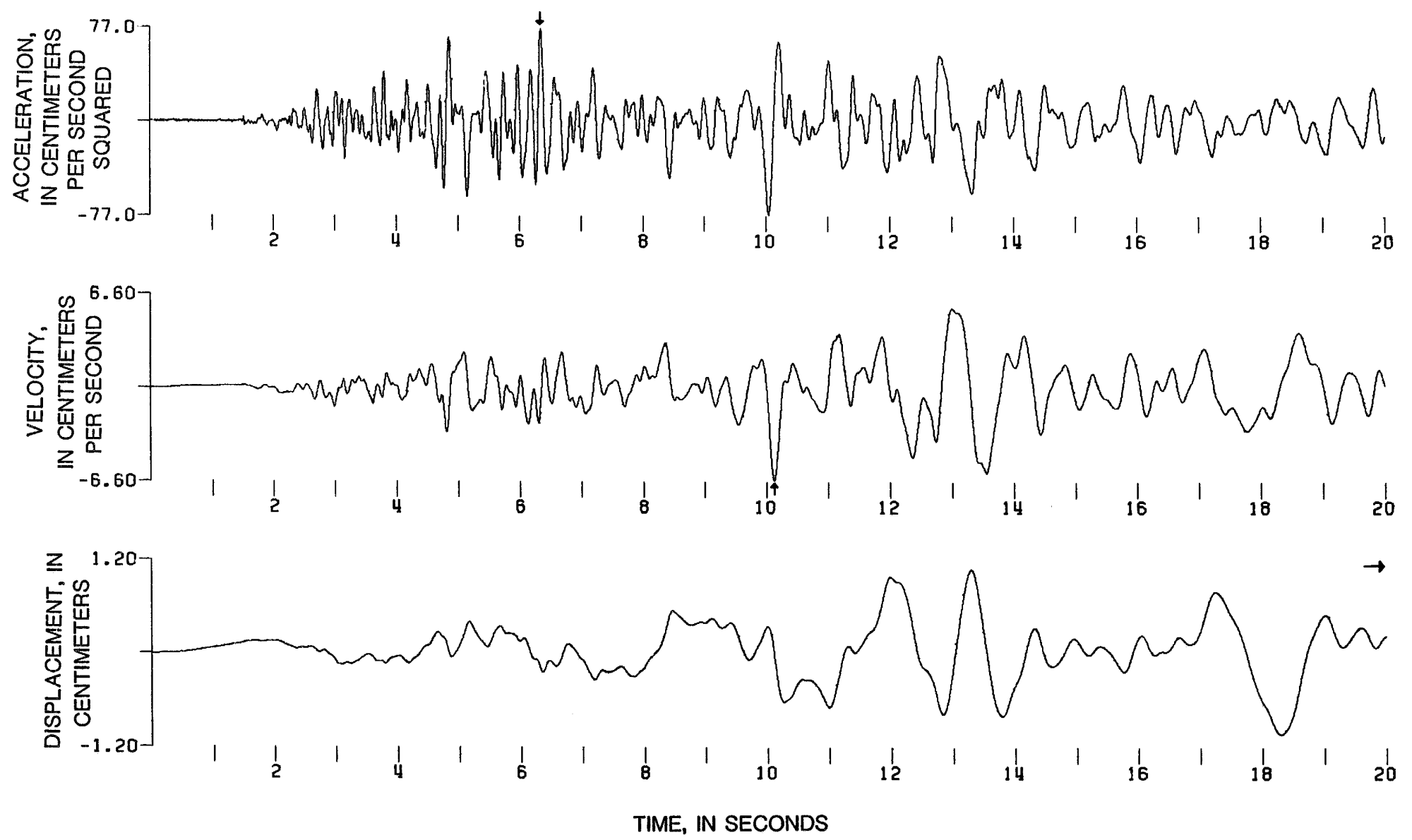

Figure 19.38. Corrected acceleration, velocity, and displacement at Hollister Differential Array 3 ( $345^{\circ}$ component) for the April 24 earthquake, using a Butterworth filter $(0.25 \mathrm{~Hz}$, order 8) at 200 samples per second. Peak values (arrows): acceleration, $76.37 \mathrm{~cm} / \mathrm{s}^{2}$; velocity, $-6.51 \mathrm{~cm} / \mathrm{s}$; displacement, $1.12 \mathrm{~cm}$. 

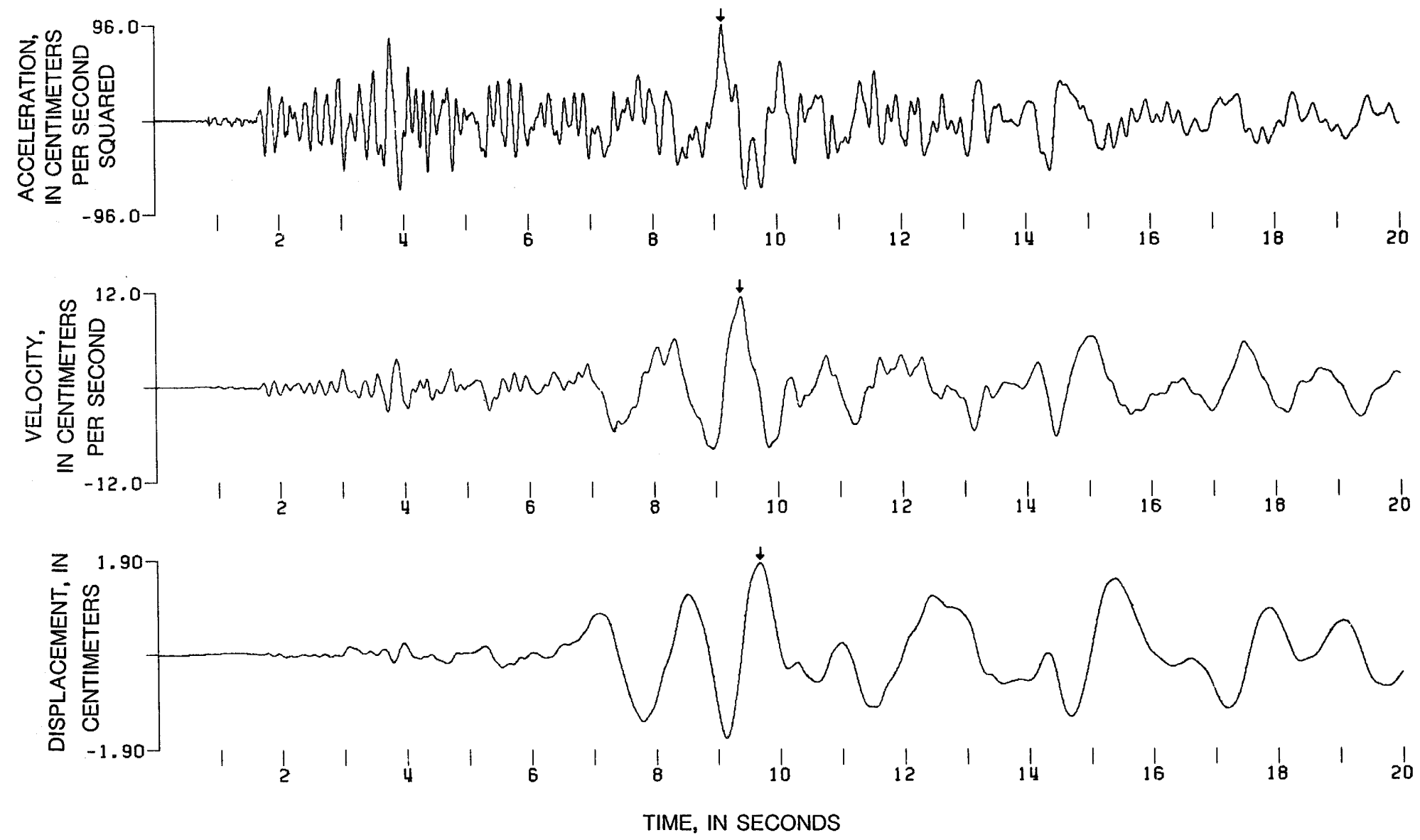

Figure 19.39. Corrected acceleration, velocity, and displacement at Hollister Differential Array 4 (255 $5^{\circ}$ component) for the April 24 earthquake, using a Butterworth filter $(0.25 \mathrm{~Hz}$, order 8) at 200 samples per second. Peak values (arrows): acceleration, $95.65 \mathrm{~cm} / \mathrm{s}^{2}$; velocity, $11.51 \mathrm{~cm} / \mathrm{s}$; displacement, $1.84 \mathrm{~cm}$. 

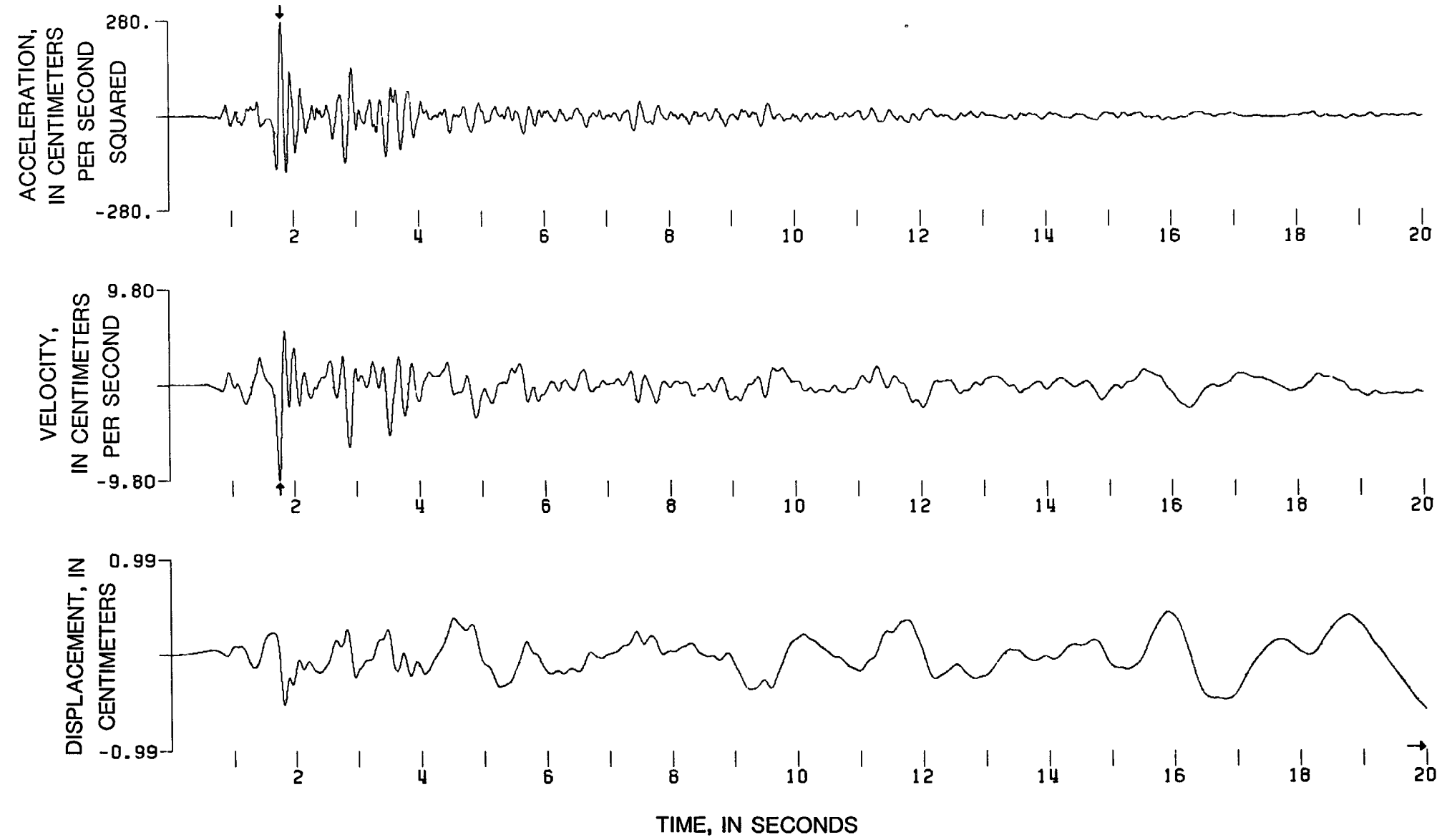

Figure 19.40. Corrected acceleration, velocity, and displacement at Hollister Differential Array 4 (up component) for the April 24 earthquake, using a Butterworth filter $(0.25 \mathrm{~Hz}$, order 8) at 200 samples per second. Peak values (arrows): acceleration, $276.56 \mathrm{~cm} / \mathrm{s}^{2}$; velocity, $-9.80 \mathrm{~cm} / \mathrm{s}$; displacement, $-0.99 \mathrm{~cm}$. 

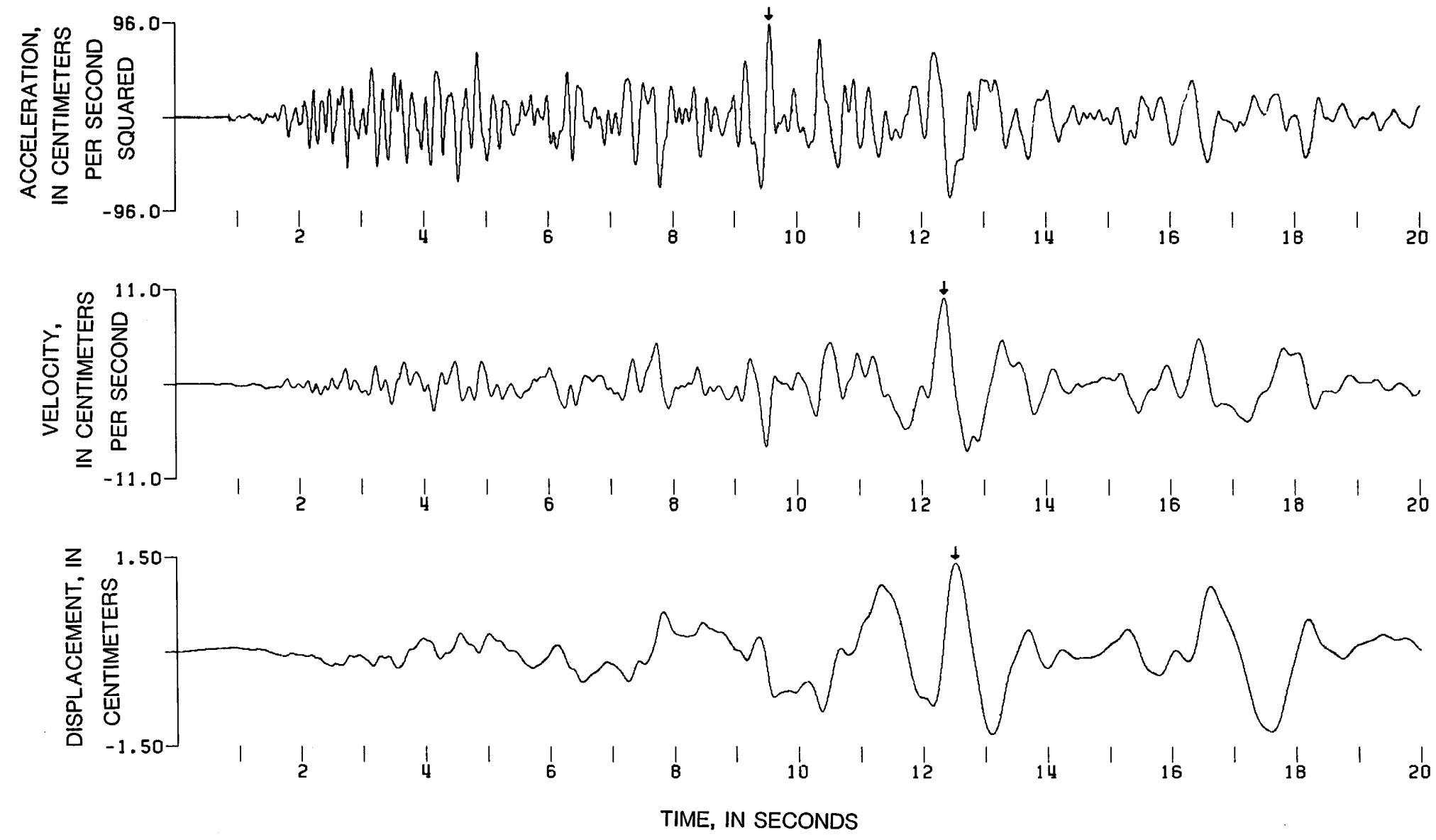

Figure 19.41. Corrected acceleration, velocity, and displacement at Hollister Differential Array $4\left(345^{\circ}\right.$ component) for the April 24 earthquake, using a Butterworth filter $(0.25 \mathrm{~Hz}$, order 8) at 200 samples per second. Peak values (arrows): acceleration, $95.54 \mathrm{~cm} / \mathrm{s}^{2}$; velocity, $10.19 \mathrm{~cm} / \mathrm{s}$; displacement, $1.42 \mathrm{~cm}$. 

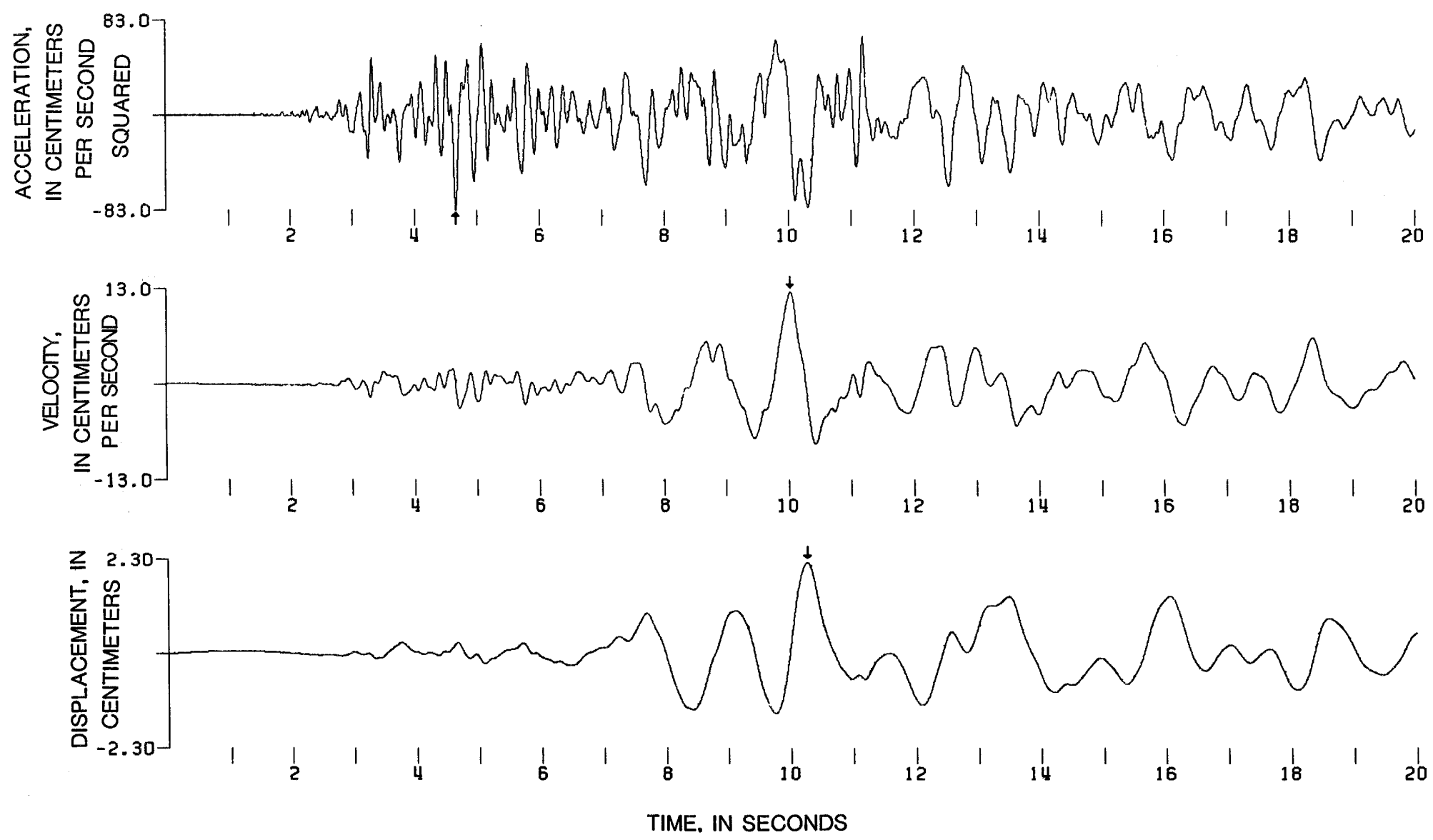

Figure 19.42. Corrected acceleration, velocity, and displacement at Hollister Differential Array 5 (255 component) for the April 24 earthquake, using a Butterworth filter $(0.25 \mathrm{~Hz}$, order 8) at 200 samples per second. Peak values (arrows): acceleration, $-82.91 \mathrm{~cm} / \mathrm{s}^{2}$; velocity, $12.62 \mathrm{~cm} / \mathrm{s}$; displacement, $2.21 \mathrm{~cm}$. 

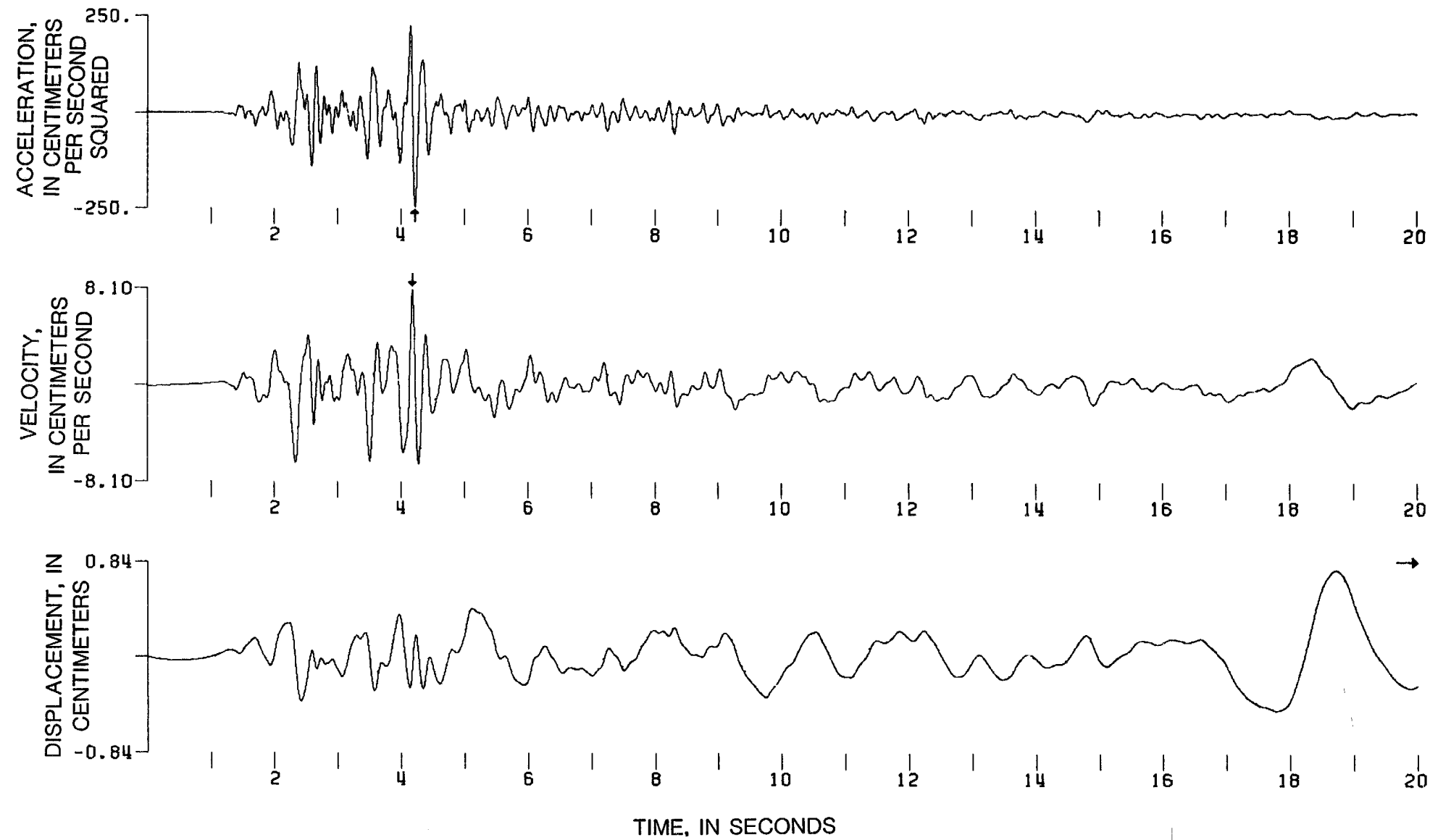

Figure 19.43. Corrected acceleration, velocity, and displacement at Hollister Differential Array 5 (up component) for the April 24 earthquake, using a Butterworth filter $(0.25 \mathrm{~Hz}$, order 8) at 200 samples per second. Peak values (arrows): acceleration, $-244.26 \mathrm{~cm} / \mathrm{s}^{2}$; velocity, $8.03 \mathrm{~cm} / \mathrm{s}$; displacement, $0.83 \mathrm{~cm}$. 

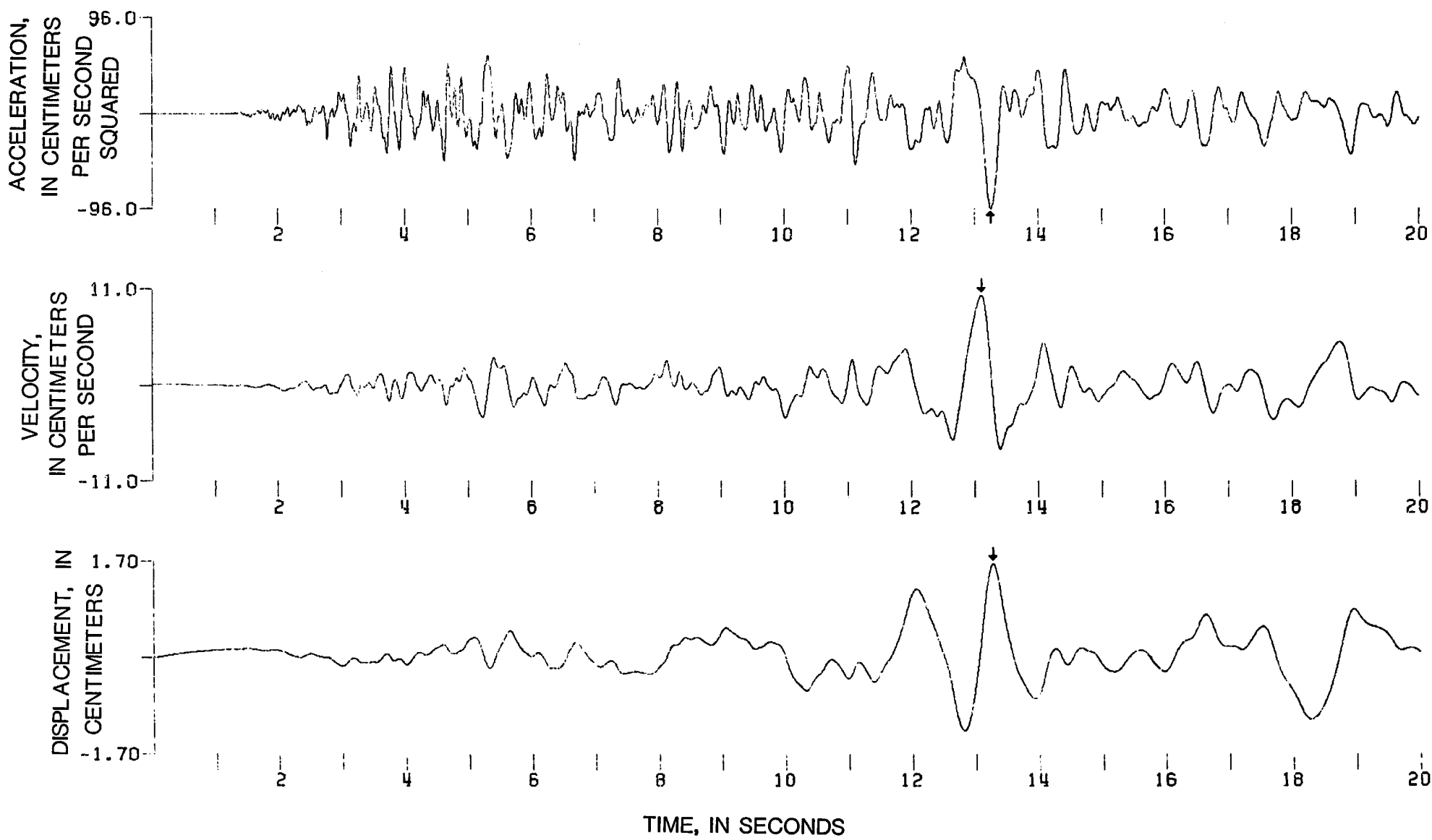

Figure 19.44. Corrected acceleration, velocity, and displacement at Hollister Differential Array 5 ( $345^{\circ}$ component) for the April 24 earthquake, using a Butterworth filter $(0.25 \mathrm{~Hz}$, order 8) at 200 samples per second. Peak values (arrows): acceleration, $-95.45 \mathrm{~cm} / \mathrm{s}^{2}$; velocity, $10.28 \mathrm{~cm} / \mathrm{s}$; displacement, $1.65 \mathrm{~cm}$. 

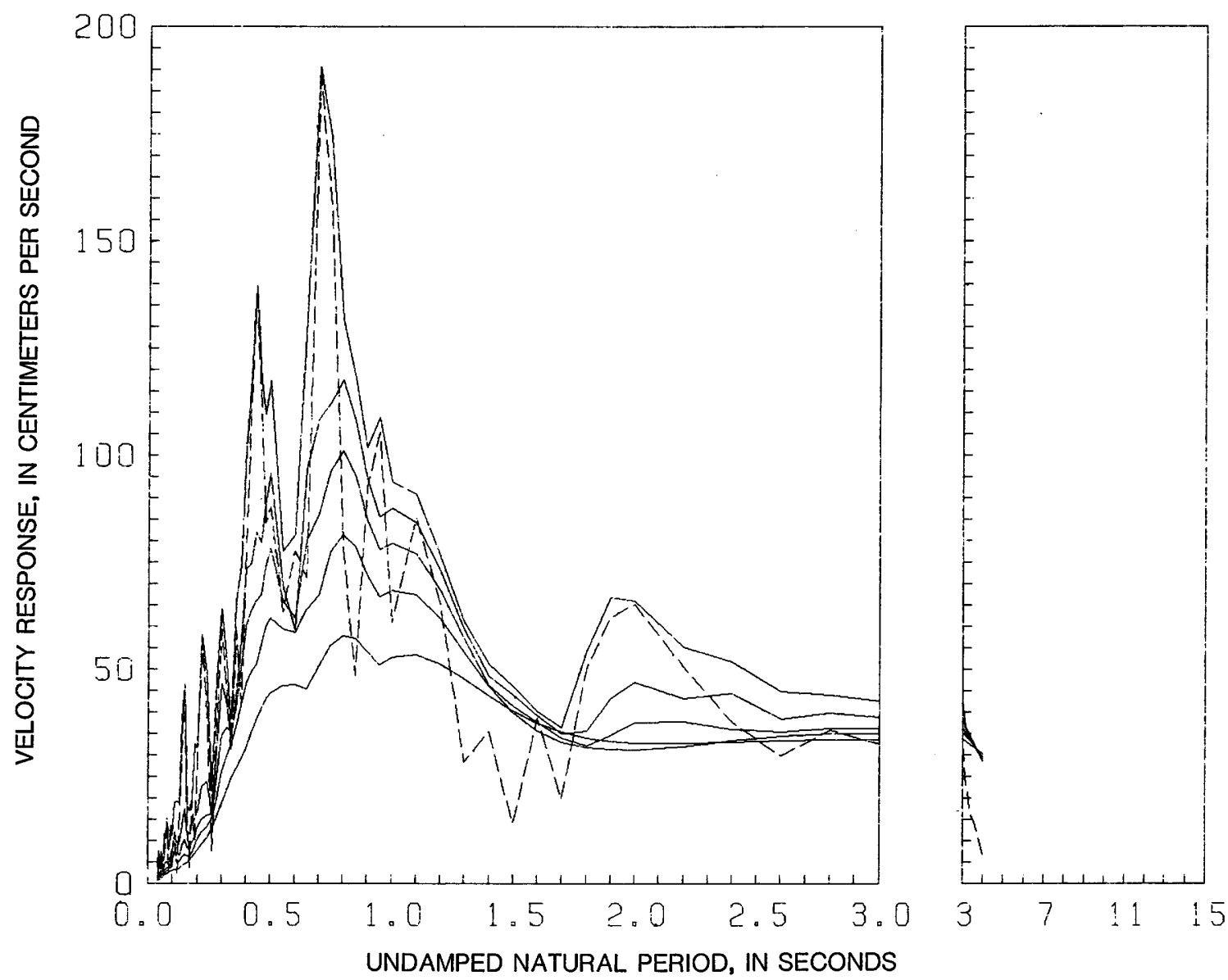

Figure 19.45. Response spectra at the Anderson Dam, downstream $\left(340^{\circ}\right.$ component), for the April 24 earthquake, using a Butterworth filter $(0.25 \mathrm{~Hz}$, order 8) with an antialias of 50 to $100 \mathrm{~Hz}$. Solid curves, relative velocity, at $0,2,5,10$, and 20 percent critical damping; dashed curve, Fourier amplitude. 

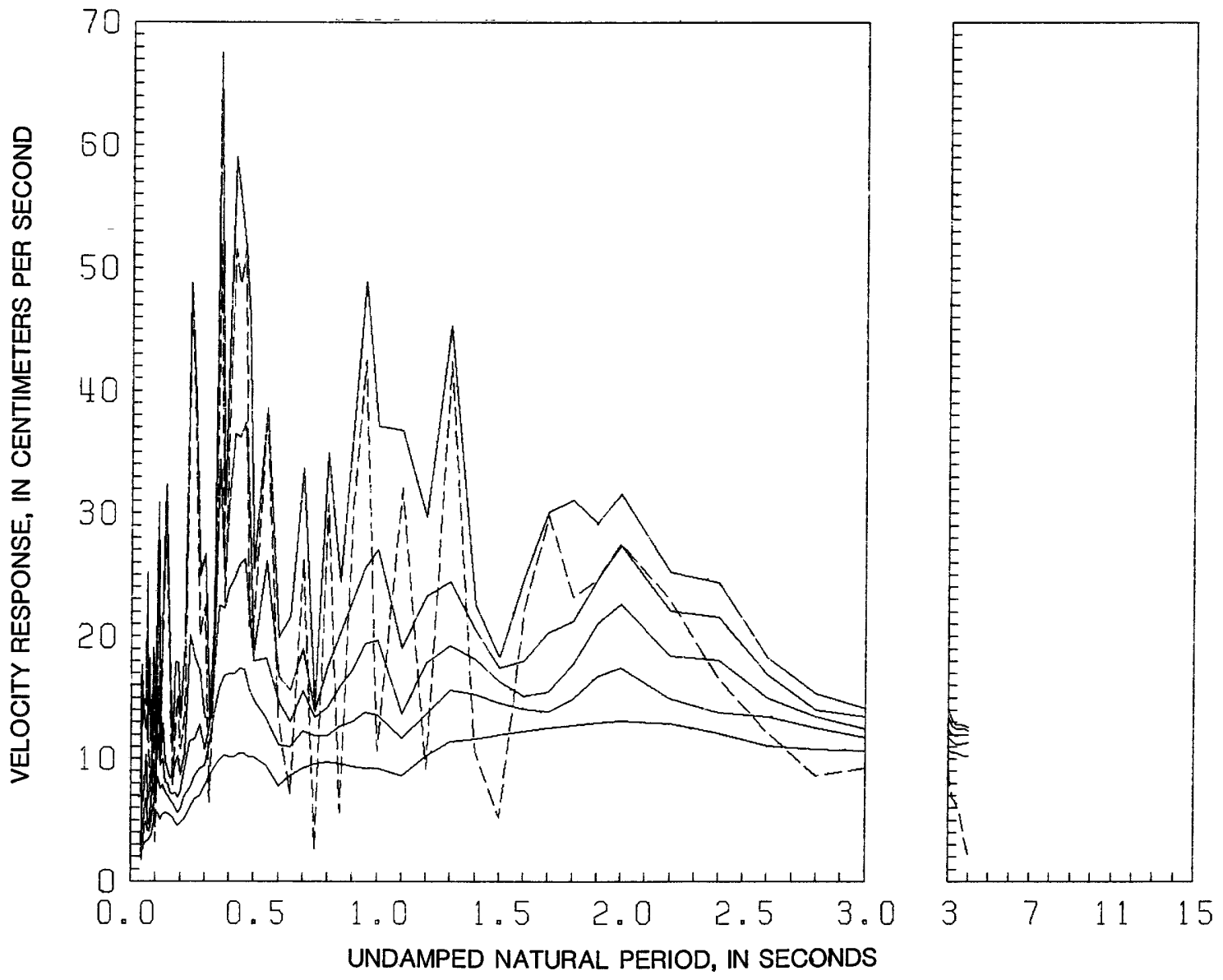

Figure 19.46. Response spectra at the Anderson Dam, downstream (up component), for the April 24 earthquake, using a Butterworth filter $(0.25 \mathrm{~Hz}$, order 8) with an antialias of 50 to $100 \mathrm{~Hz}$. Solid curves, relative velocity, at $0,2,5,10$, and 20 percent critical damping; dashed curve, Fourier amplitude. 

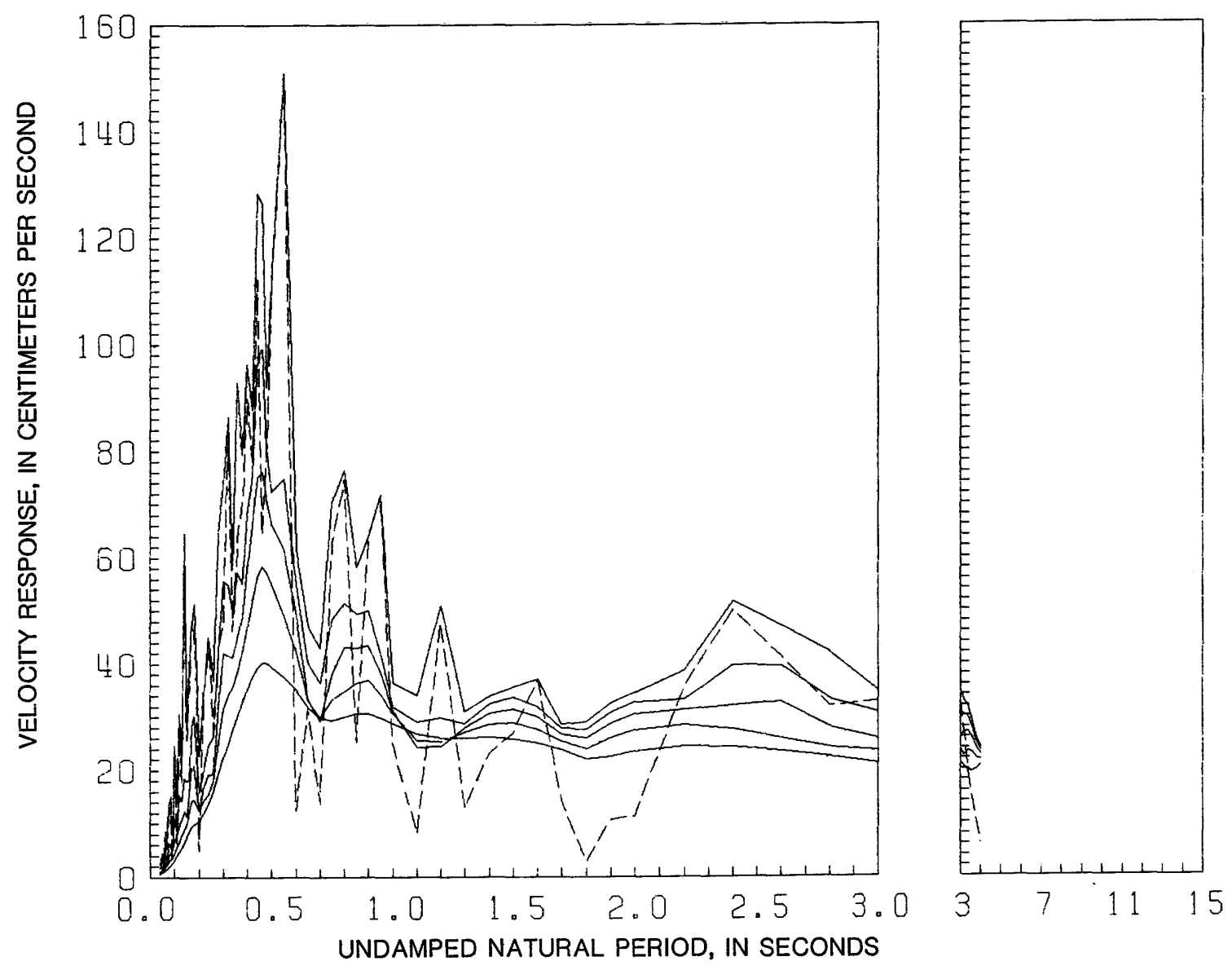

Figure 19.47. Response spectra at the Anderson Dam, downstream ( $250^{\circ}$ component), for the April 24 earthquake, using a Butterworth filter $(0.25 \mathrm{~Hz}$, order 8) with an antialias of 50 to $100 \mathrm{~Hz}$. Solid curves, relative velocity, at $0,2,5,10$, and 20 percent critical damping; dashed curve, Fourier amplitude. 

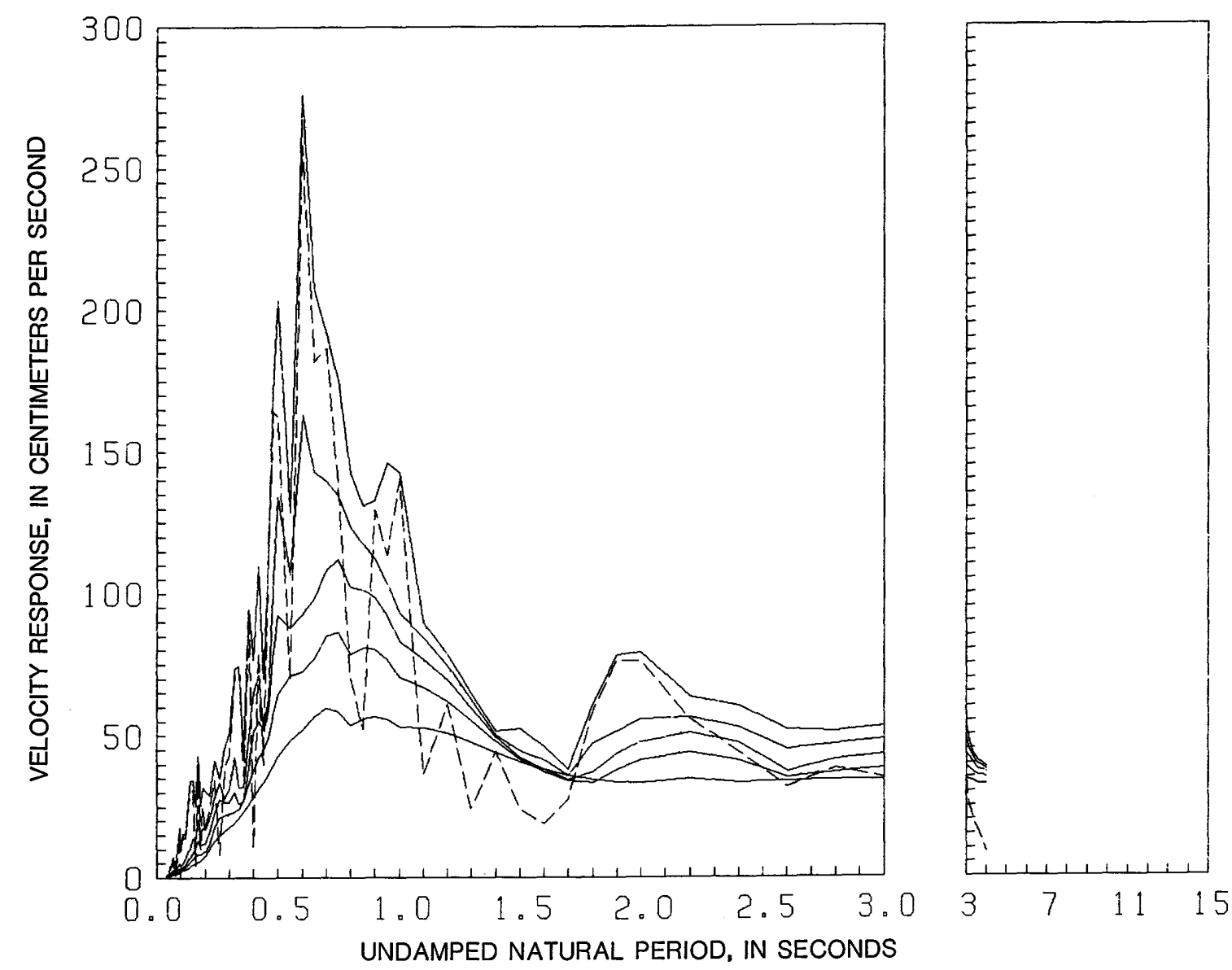

Figure 19.48. Response spectra at the Anderson Dam, crest $\left(340^{\circ}\right.$ component), for the April 24 earthquake, using a Butterworth filter $(0.25 \mathrm{~Hz}$, order 8$)$ with an antialias of 50 to $100 \mathrm{~Hz}$. Solid curves, relative velocity, at $0,2,5,10$, and 20 percent critical damping; dashed curve, Fourier amplitude. 


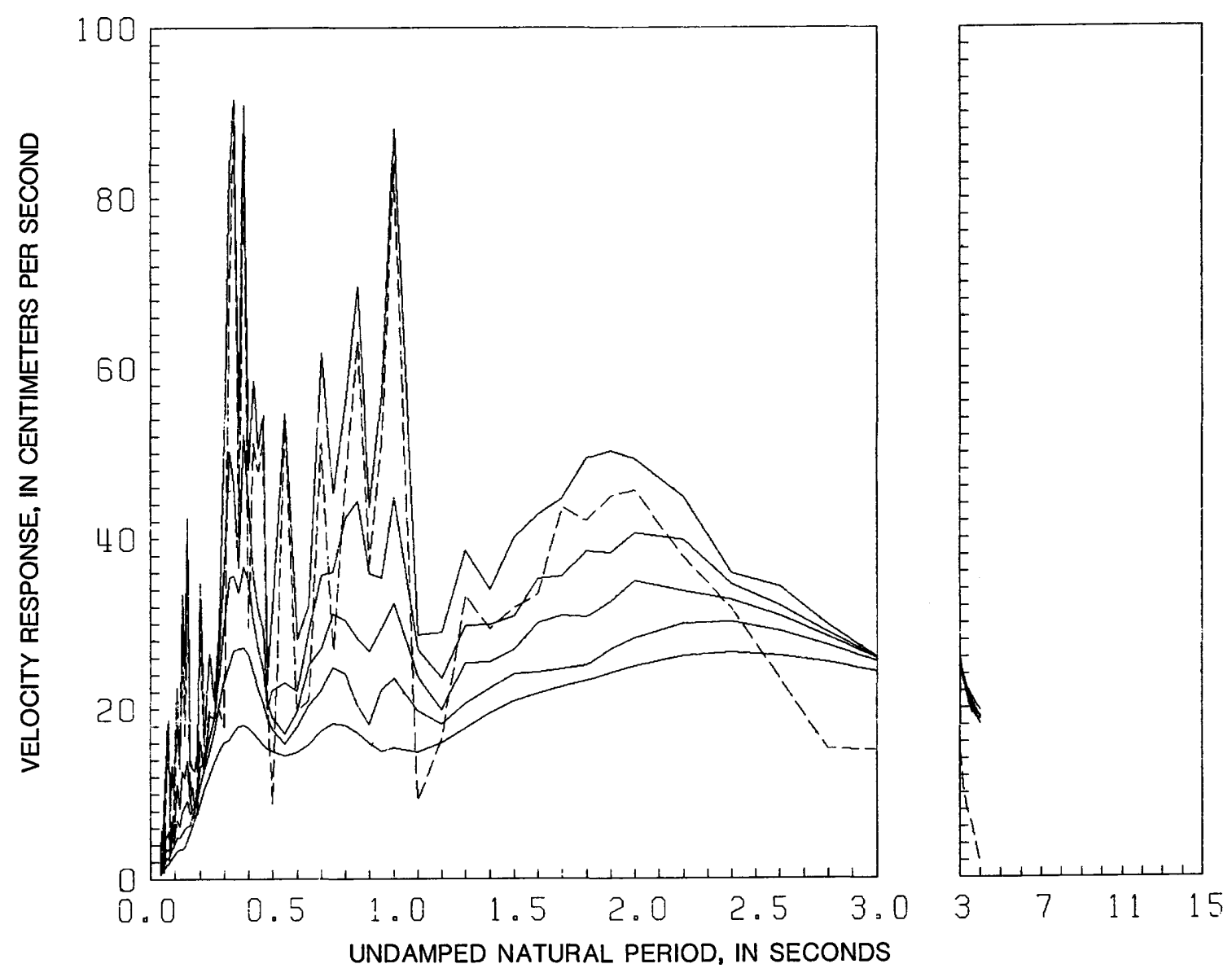

Figure 19.49. Response spectra at the Anderson Dam, crest (up component), for the April 24 earthquake, using a Butterworth filter $(0.25 \mathrm{~Hz}$, order 8$)$ with an antialias of 50 to $100 \mathrm{~Hz}$. Solid curves, relative velocity, at $0,2,5,10$, and 20 percent critical damping; dashed curve, Fourier amplitude. 

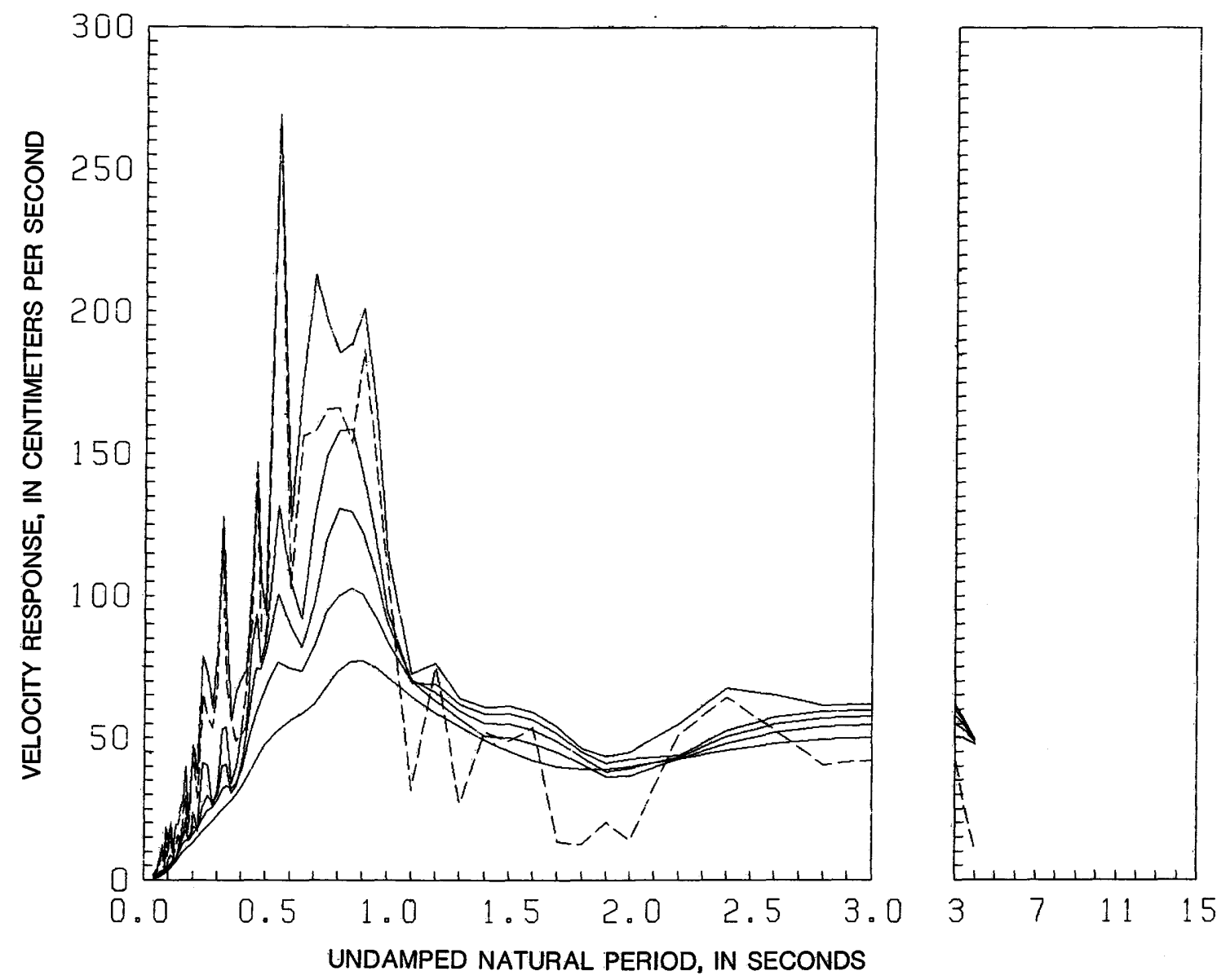

Figure 19.50. Response spectra at the Anderson Dam, crest ( $250^{\circ}$ component), for the April 24 earthquake, using a Butterworth filter $(0.25 \mathrm{~Hz}$, order 8) with an antialias of 50 to $100 \mathrm{~Hz}$. Solid curves, relative velocity, at $0,2,5,10$, and 20 percent critical damping; dashed curve, Fourier amplitude. 

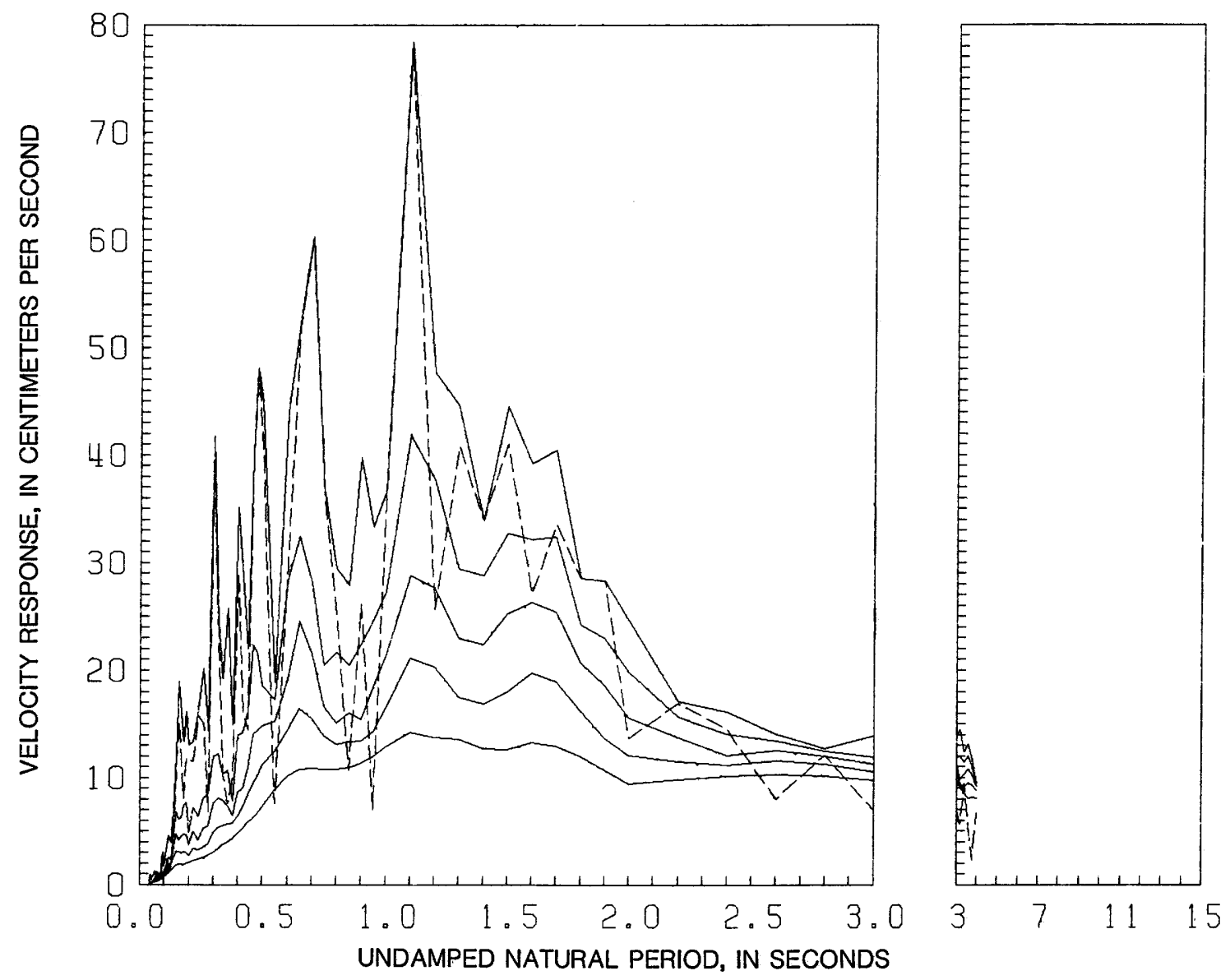

Figure 19.51. Response spectra at the Hollister City Hall Annex, basement $\left(001^{\circ}\right.$ component), for the April 24 earthquake, using a Butterworth filter $(0.25 \mathrm{~Hz}$, order 8) with an antialias of 50 to 100 Hz. Solid curves, relative velocity, at $0,2,5,10$, and 20 percent critical damping; dashed curve, Fourier amplitude. 

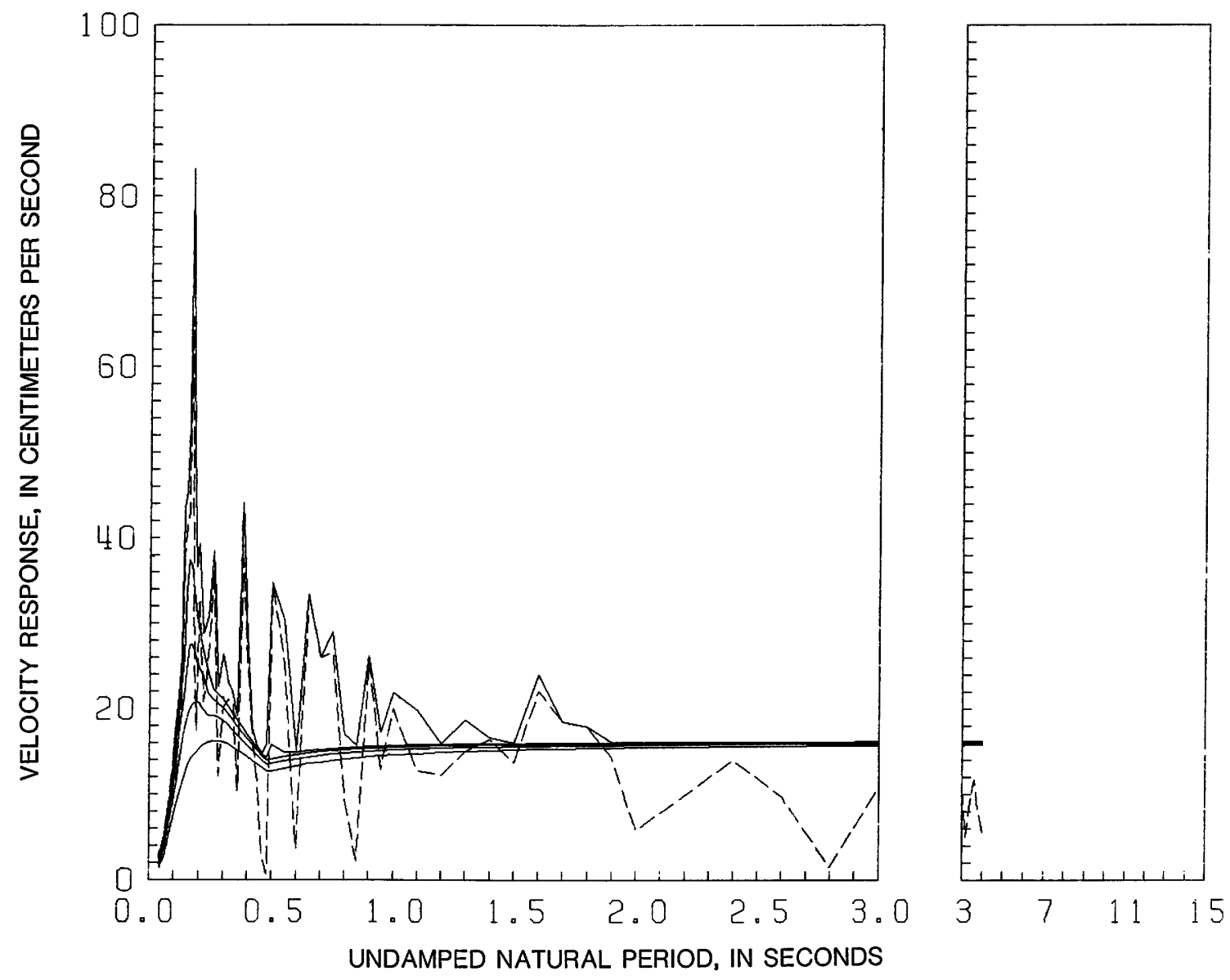

Figure 19.52. Response spectra at the Hollister City Hall Annex, basement (up component), for the April 24 earthquake, using a Butterworth filter $(0.25 \mathrm{~Hz}$, order 8) with an antialias of 50 to 100 $\mathrm{Hz}$. Solid curves, relative velocity, at $0,2,5,10$, and 20 percent critical damping; dashed curve, Fourier amplitude. 


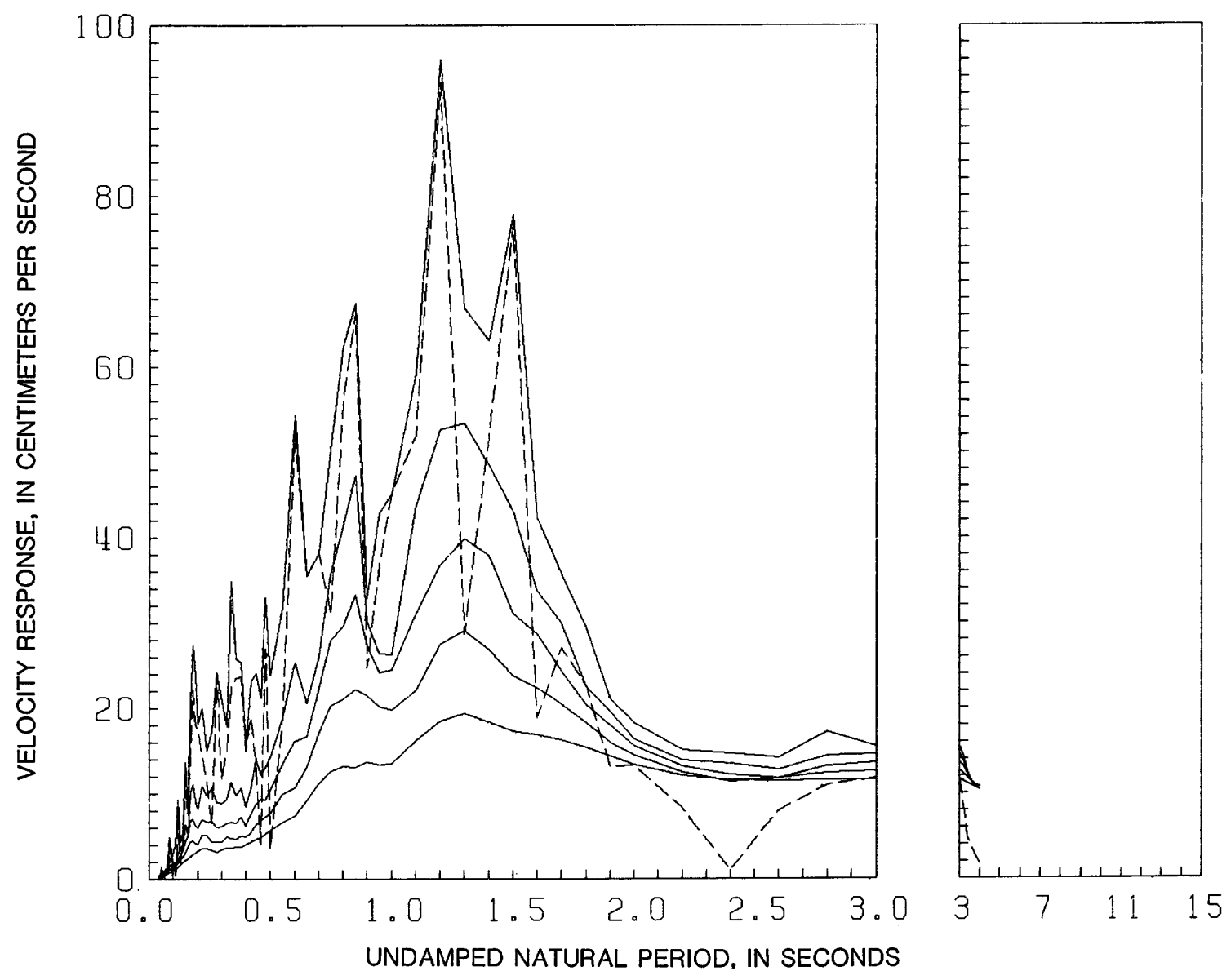

Figure 19.53. Response spectra at the Hollister City Hall Annex, basement ( $271^{\circ}$ component), for the April 24 earthquake, using a Butterworth filter $(0.25 \mathrm{~Hz}$, order 8) with an antialias of 50 to 100 $\mathrm{Hz}$. Solid curves, relative velocity, at $0,2,5,10$, and 20 percent critical damping; dashed curve, Fourier amplitude. 

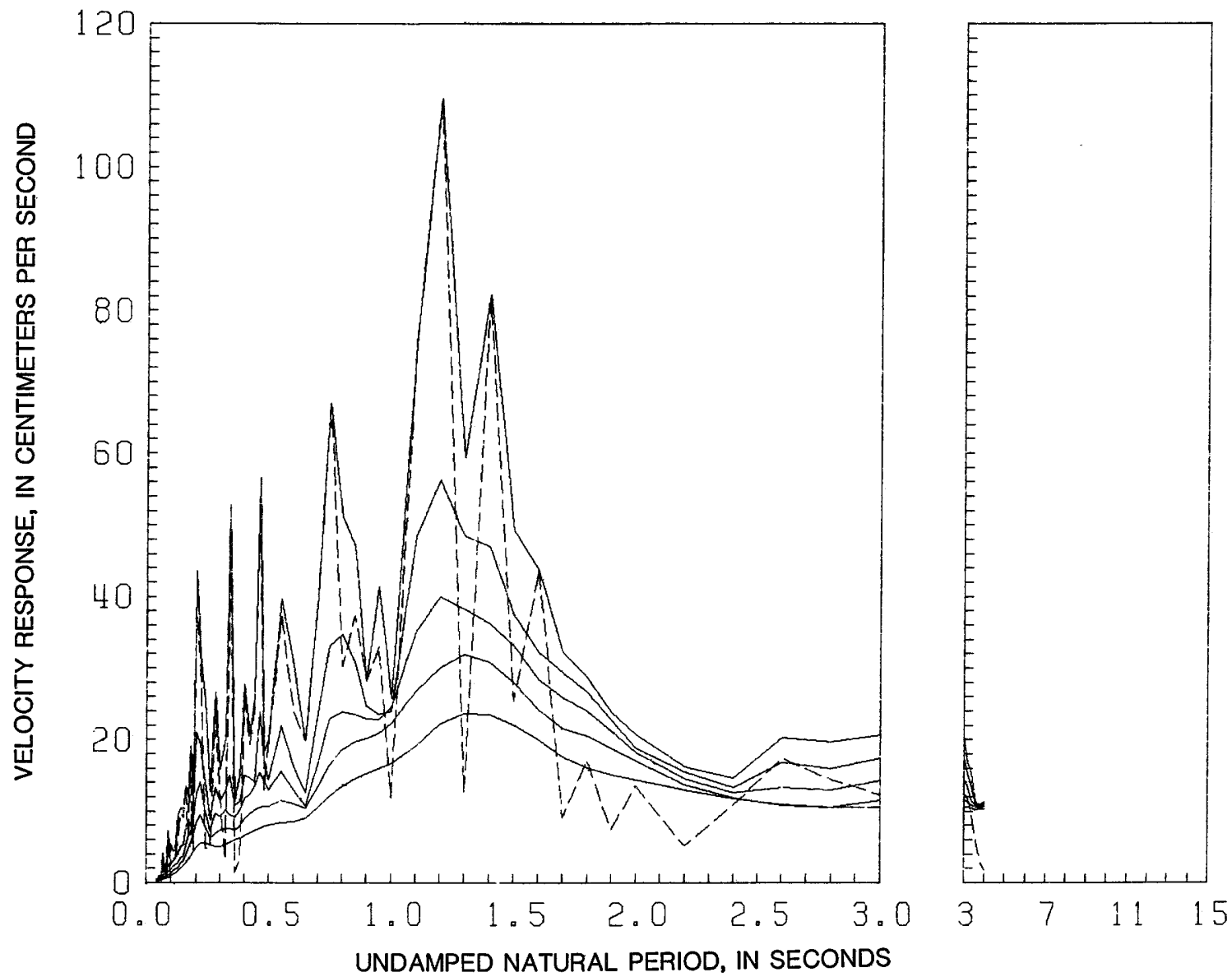

Figure 19.54. Response spectra at the Hollister Differential Array (SMA-1T, $255^{\circ}$ component) for the April 24 earthquake, using a Butterworth filter $(0.25 \mathrm{~Hz}$, order 8) with an antialias of 50 to 100 Hz. Solid curves, relative velocity, at $0,2,5,10$, and 20 percent critical damping; dashed curve, Fourier amplitude. 

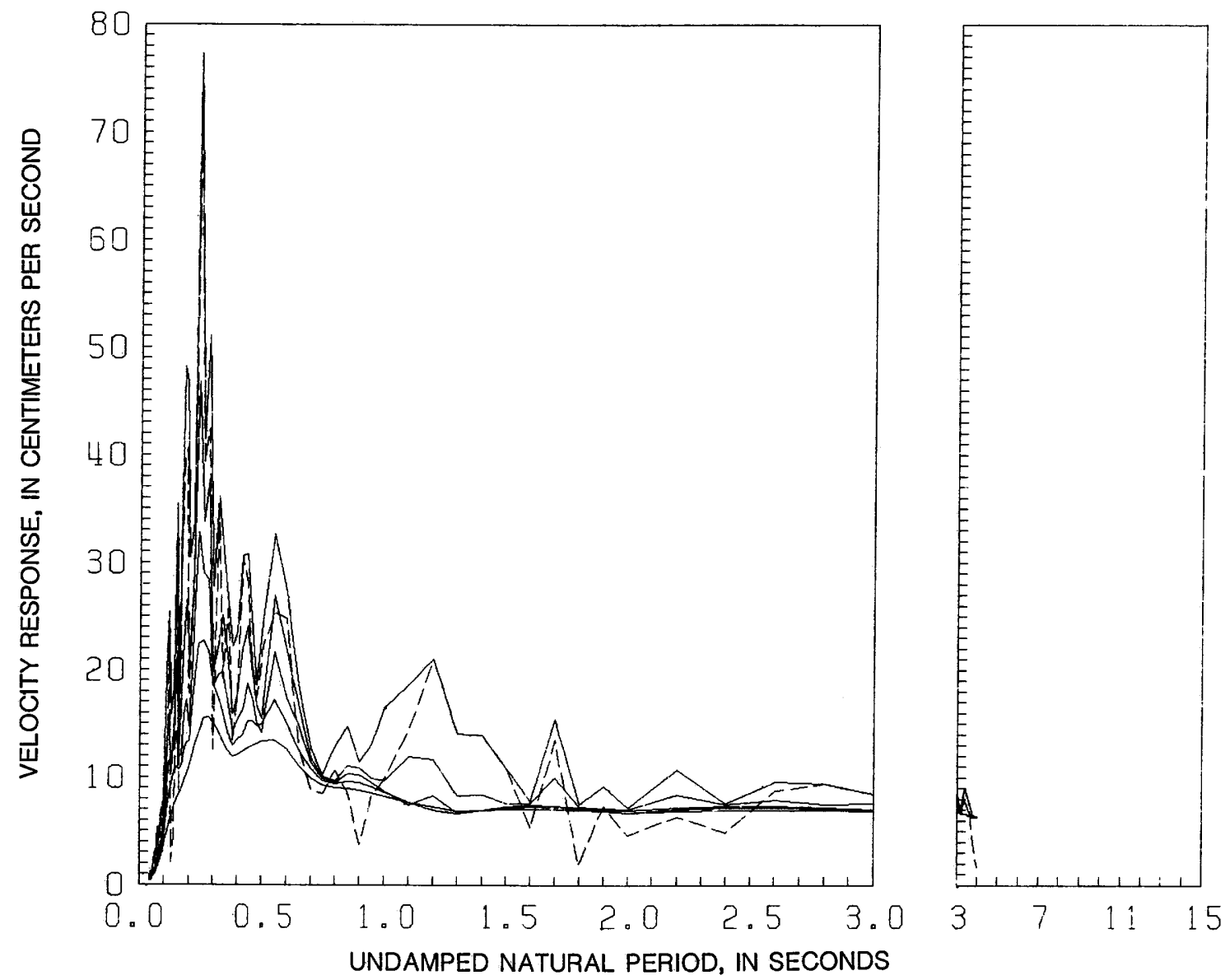

Figure 19.55. Response spectra at the Hollister Differential Array (SMA-1T, up component) for the April 24 earthquake, using a Butterworth filter $(0.25 \mathrm{~Hz}$, order 8) with an antialias of 50 to 100 Hz. Solid curves, relative velocity, at $0,2,5,10$, and 20 percent critical damping; dashed curve, Fourier amplitude. 

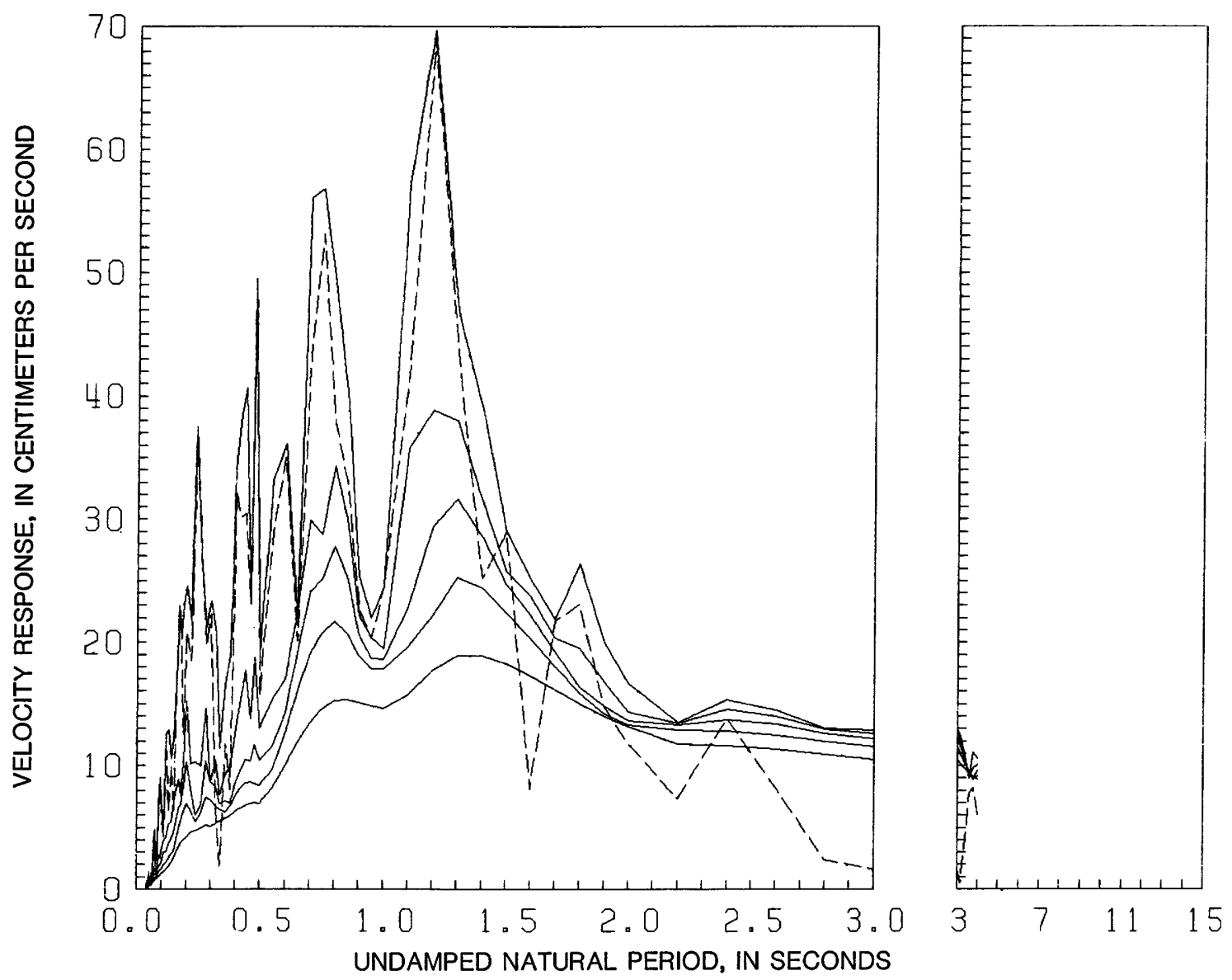

Figure 19.56. Response spectra at the Hollister Differential Array (SMA-1T, $165^{\circ}$ component) for the April 24 earthquake, using a Butterworth filter $(0.25 \mathrm{~Hz}$, order 8) with an antialias of 50 to 100 $\mathrm{Hz}$. Solid curves, relative velocity, at $0,2,5,10$, and 20 percent critical damping; dashed curve, Fourier amplitude. 


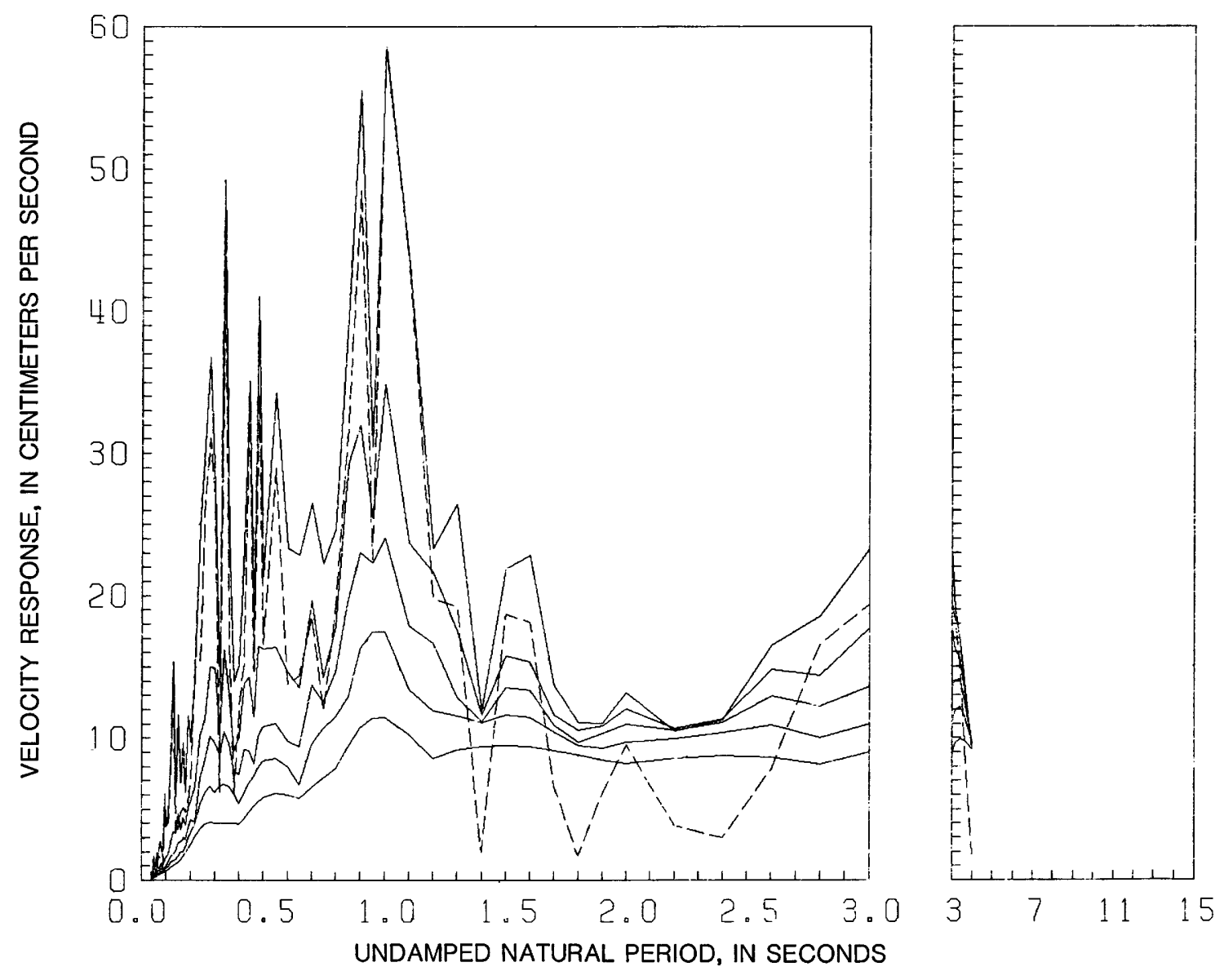

Figure 19.57. Response spectra at the San Justo Damsite, right abutment (dike, $360^{\circ}$ component), for the April 24 earthquake, using a Butterworth filter $(0.25 \mathrm{~Hz}$, order 8) with an antialias of 50 to $100 \mathrm{~Hz}$. Solid curves, relative velocity, at $0,2,5,10$, and 20 percent critical damping; dashed curve, Fourier amplitude. 

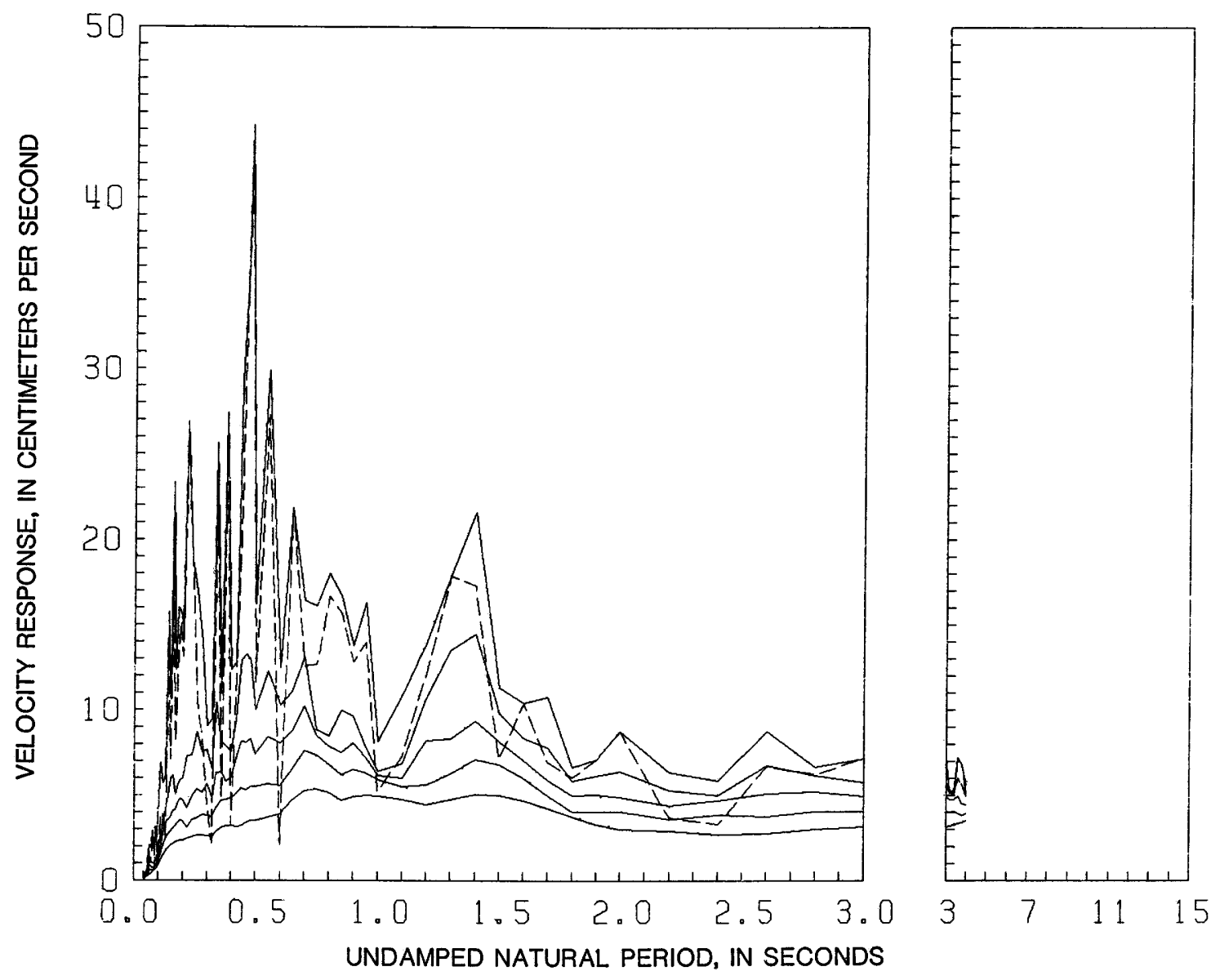

Figure 19.58. Response spectra at the San Justo Damsite, right abutment (dike, up component), for the April 24 earthquake, using a Butterworth filter $(0.25 \mathrm{~Hz}$, order 8) with an antialias of 50 to $100 \mathrm{~Hz}$. Solid curves, relative velocity, at $0,2,5,10$, and 20 percent critical damping; dashed curve, Fourier amplitude. 


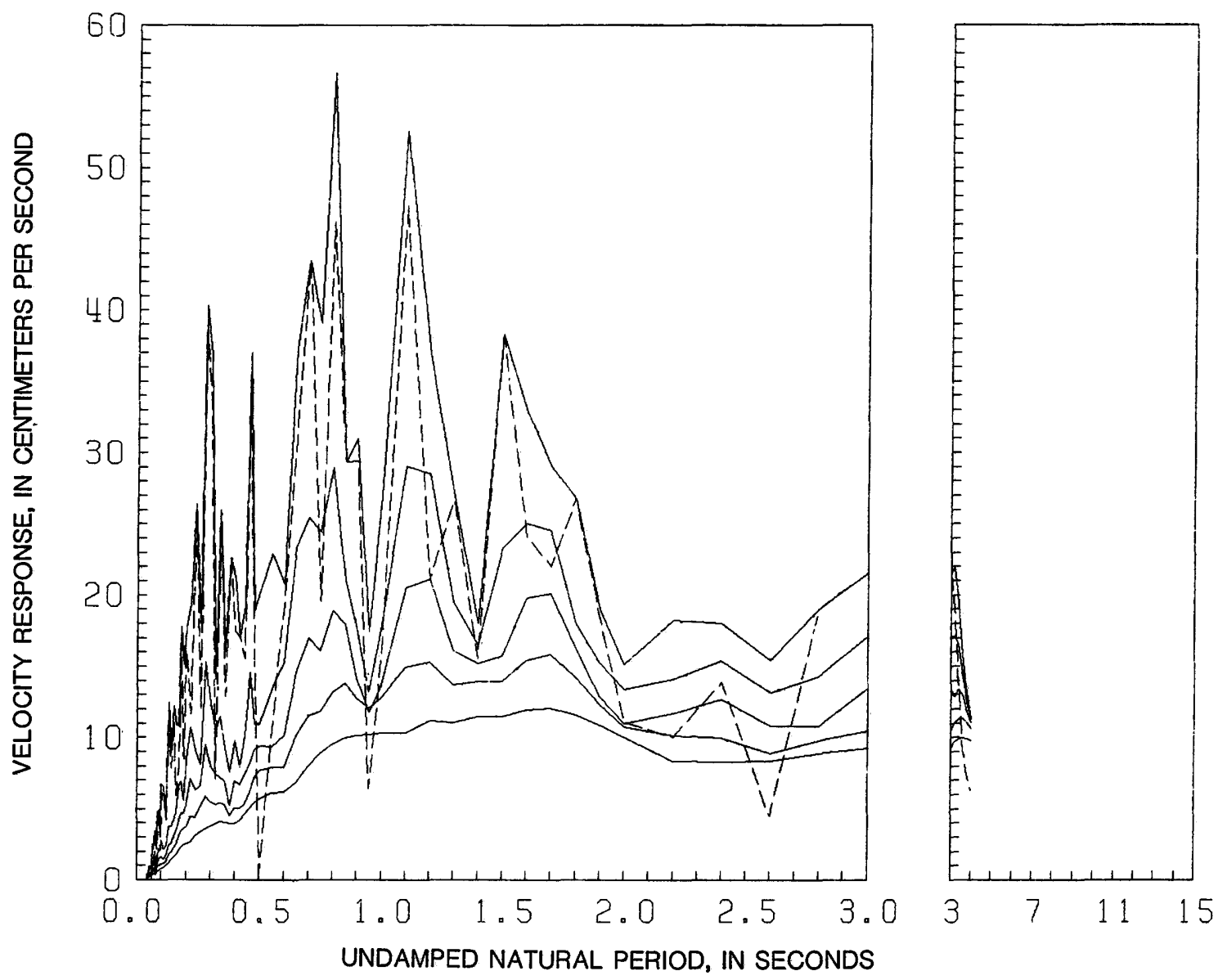

Figure 19.59. Response spectra at the San Justo Damsite, right abutment (dike, $270^{\circ}$ component), for the April 24 earthquake, using a Butterworth filter $(0.25 \mathrm{~Hz}$, order 8) with an antialias of 50 to $100 \mathrm{~Hz}$. Solid curves, relative velocity, at $0,2,5,10$, and 20 percent critical damping; dashed curve, Fourier amplitude. 

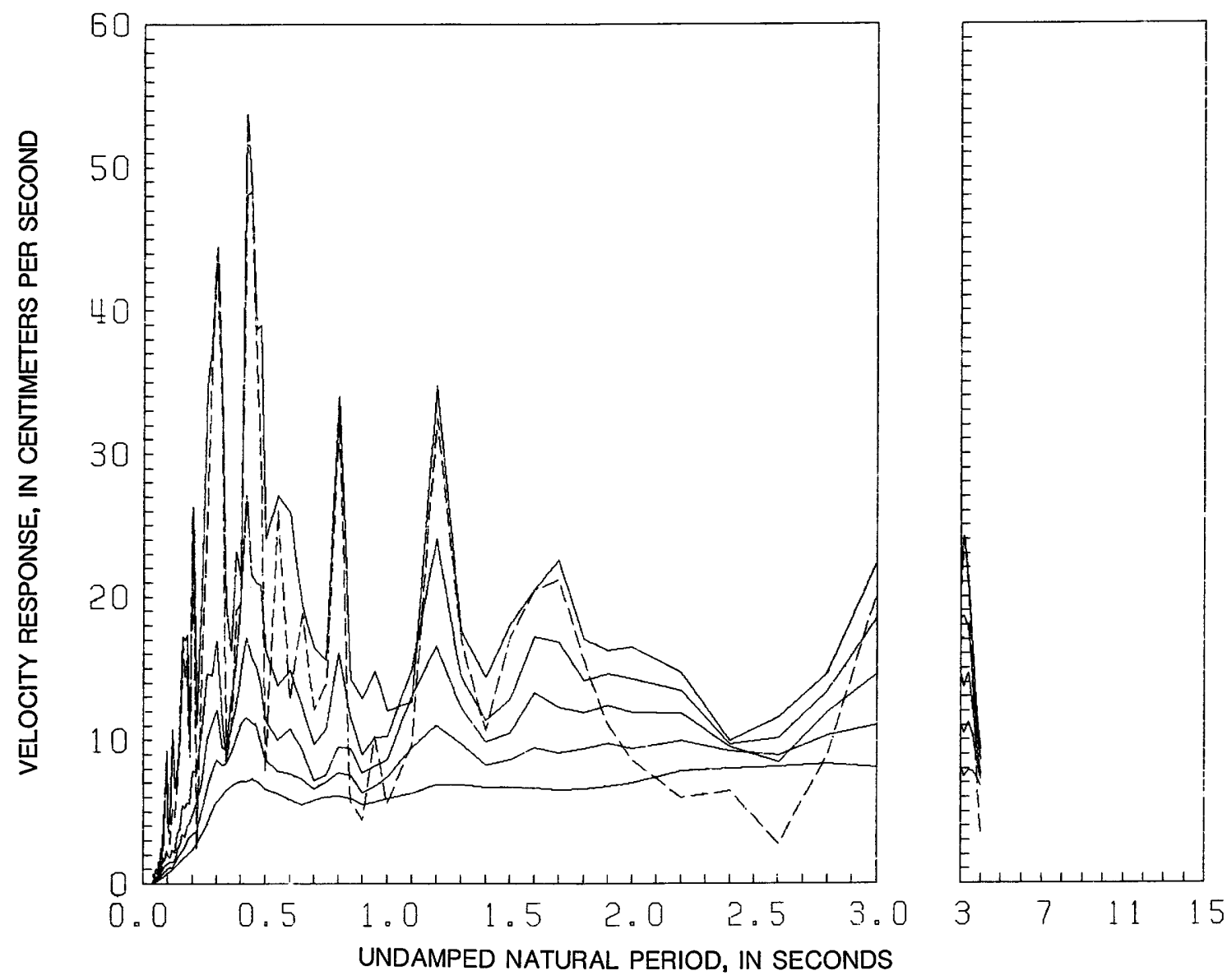

Figure 19.60. Response spectra at the San Justo Damsite, left abutment $\left(360^{\circ}\right.$ component), for the April 24 earthquake, using a Butterworth filter $(0.25 \mathrm{~Hz}$, order 8) with an antialias of 50 to 100 $\mathrm{Hz}$. Solid curves, relative velocity, at $0,2,5,10$, and 20 percent critical damping; dashed curve, Fourier amplitude. 

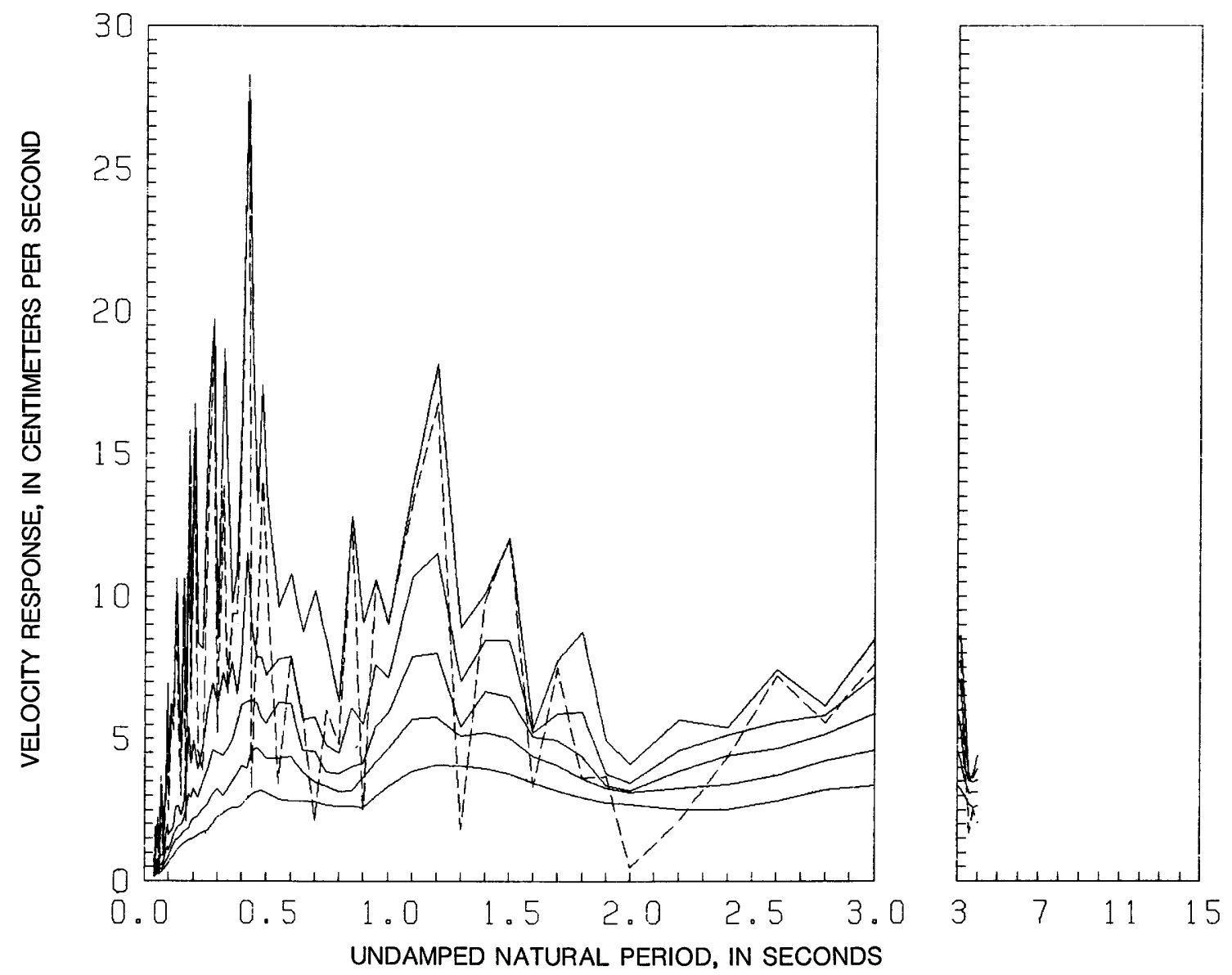

Figure 19.61. Response spectra at the San Justo Damsite, left abutment (up component), for the April 24 earthquake, using a Butterworth filter $(0.25 \mathrm{~Hz}$, order 8) with an antialias of 50 to 100 Hz. Solid curves, relative velocity, at $0,2,5,10$, and 20 percent critical damping; dashed curve, Fourier amplitude. 

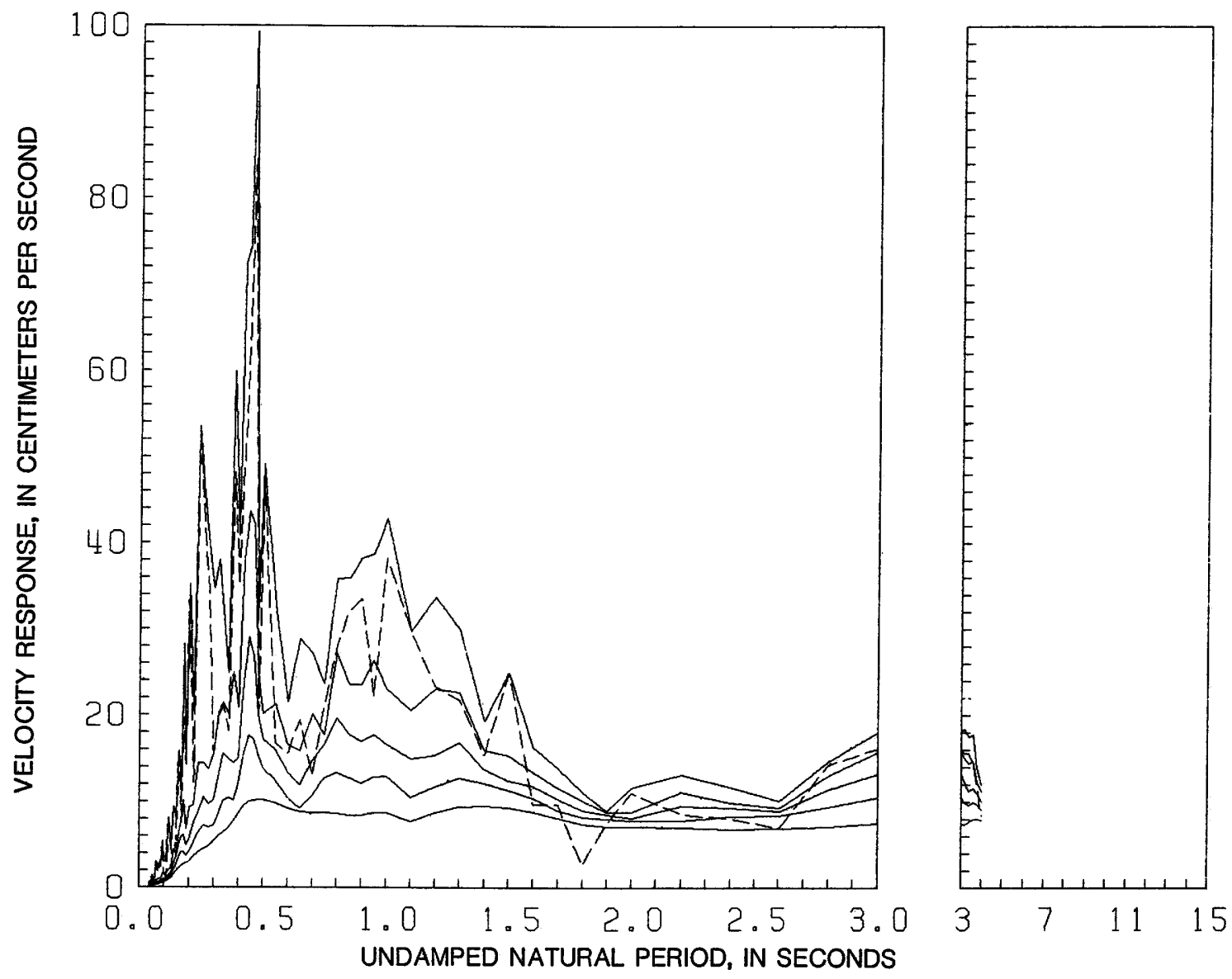

Figure 19.62. Response spectra at the San Justo Damsite, left abutment $\left(270^{\circ}\right.$ component), for the April 24 earthquake, using a Butterworth filter $(0.25 \mathrm{~Hz}$, order 8) with an antialias of 50 to 100 Hz. Solid curves, relative velocity, at $0,2,5,10$, and 20 percent critical damping; dashed curve, Fourier amplitude. 


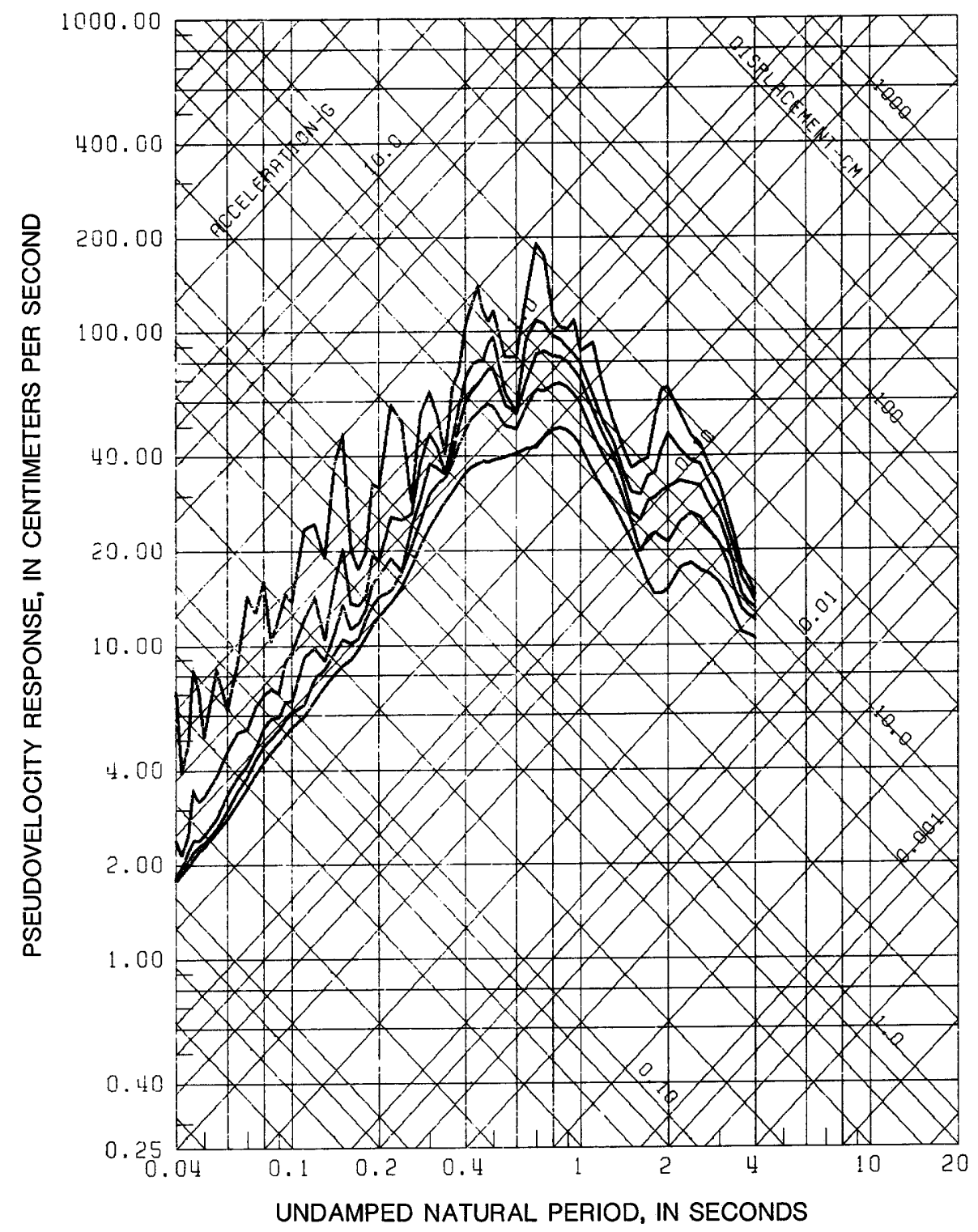

Figure 19.63. Pseudovelocity-response spectra at the Anderson Dam, downstream $\left(340^{\circ}\right.$ component), for the April 24 earthquake, using a Butterworth filter $(0.25 \mathrm{~Hz}$, order 8) with an antialias of 50 to $100 \mathrm{~Hz}$ at $0,2,5,10$, and 20 percent critical damping. 


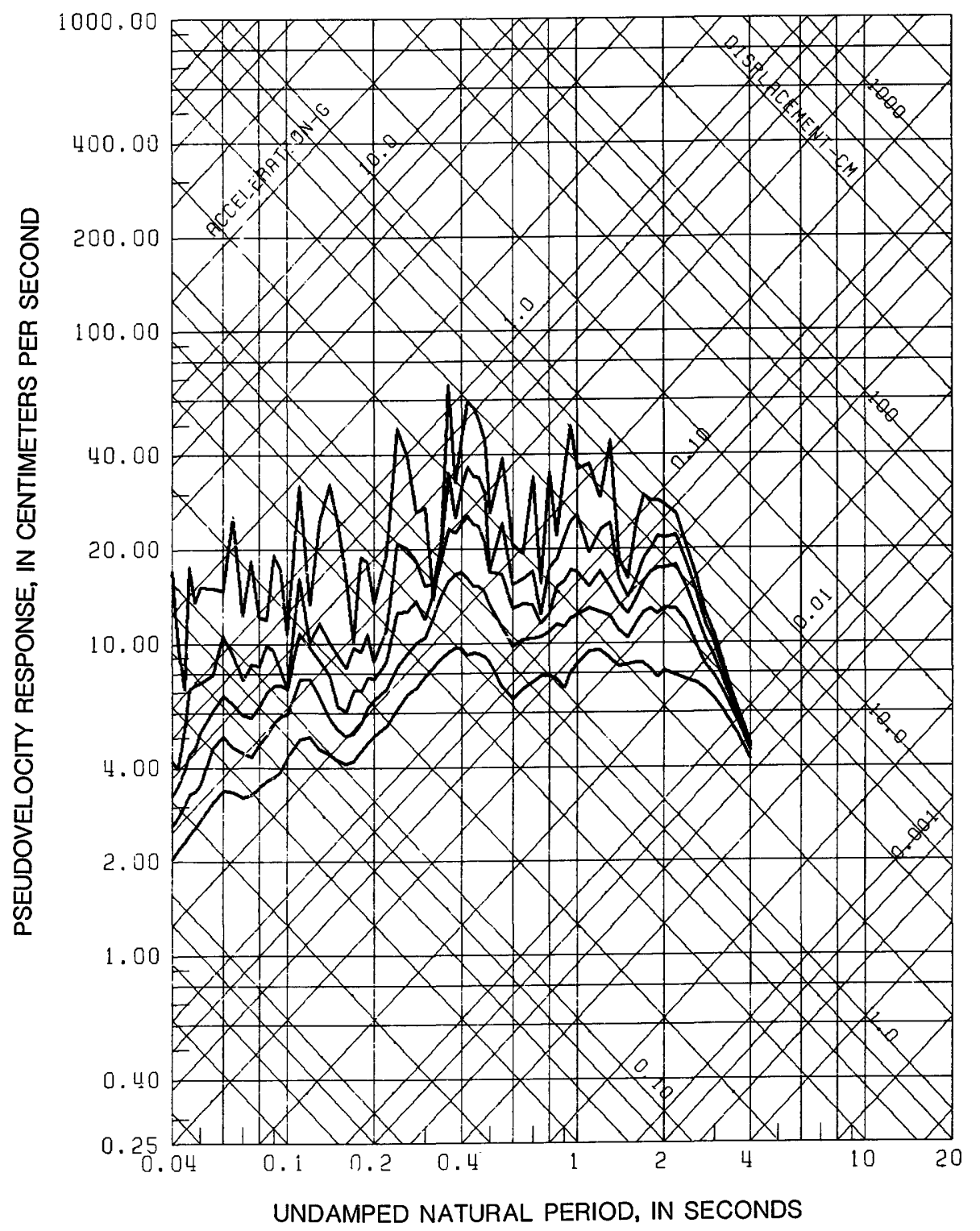

Figure 19.64. Pseudovelocity-response spectra at the Anderson Dam, downstream (up component), for the April 24 earthquake, using a Butterworth filter $(0.25 \mathrm{~Hz}$, order 8) with an antialias of 50 to $100 \mathrm{~Hz}$ at $0,2,5,10$, and 20 percent critical damping. 


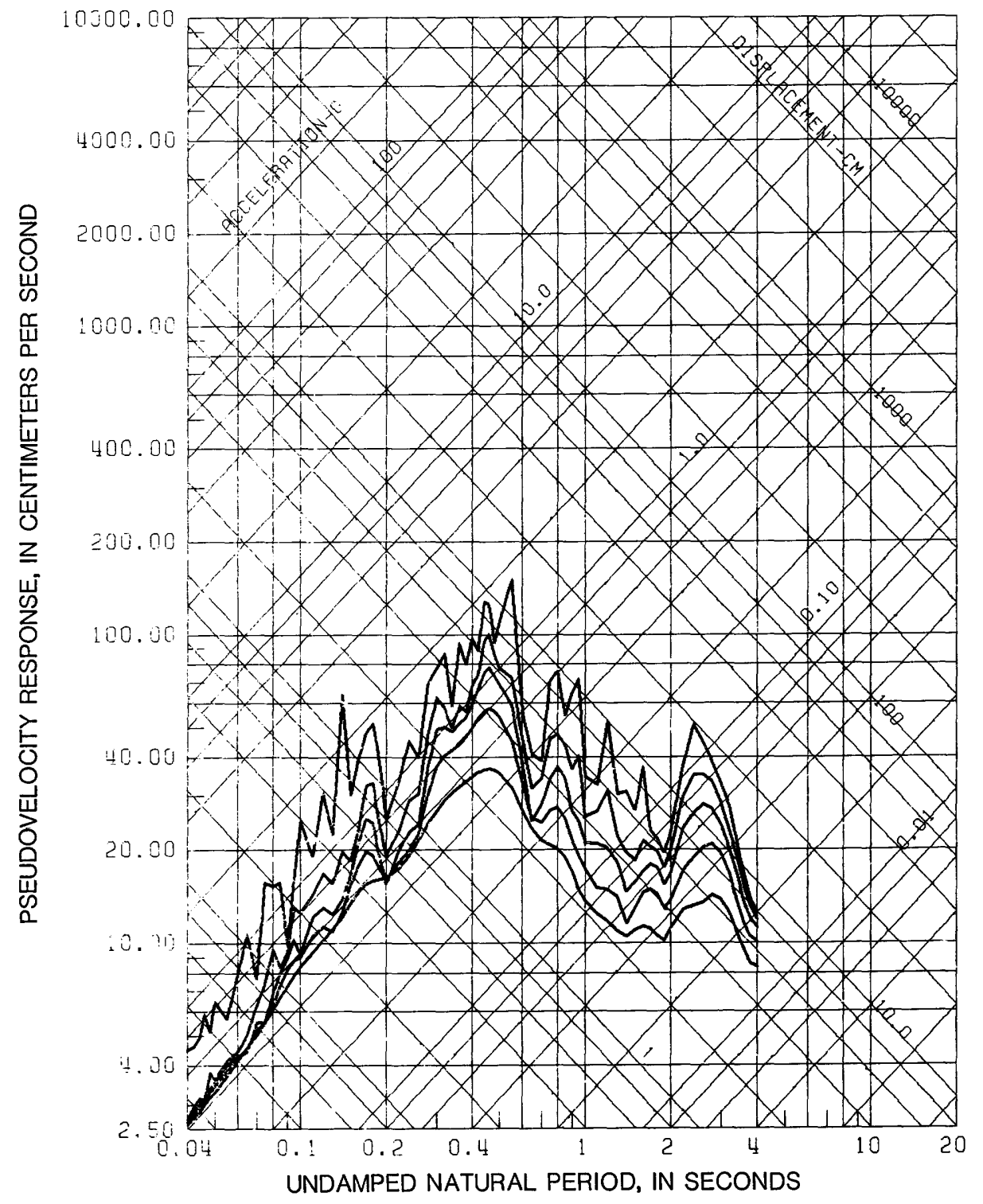

Figure 19.65. Pseudovelocity-response spectra at the Anderson Dam, downstream $\left(250^{\circ}\right.$ component), for the April 24 earthquake, using a Butterworth filter $(0.25 \mathrm{~Hz}$, order 8) with an antialias of 50 to $100 \mathrm{~Hz}$ at $0,2,5,10$, and 20 percent critical damping. 


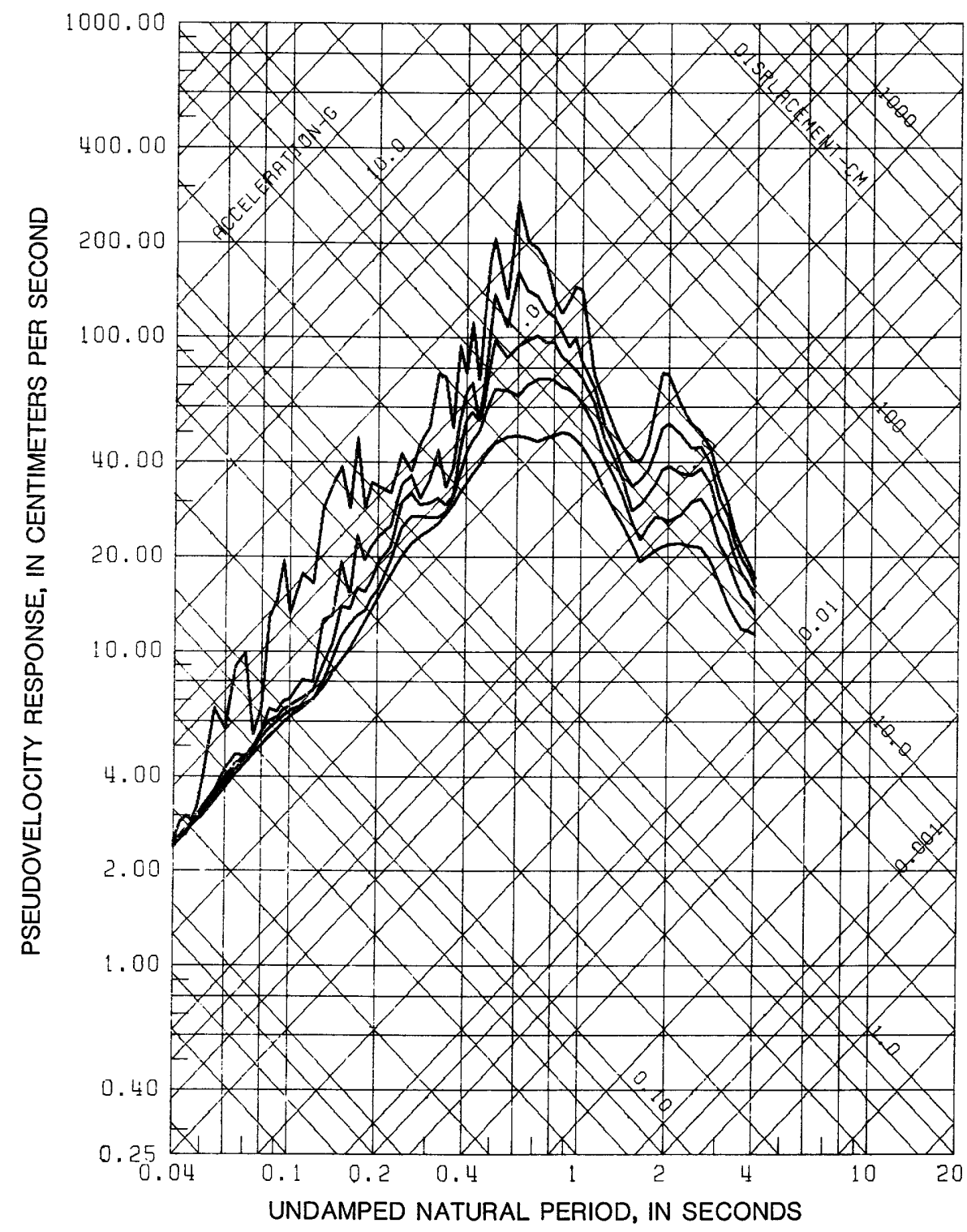

Figure 19.66. Pseudovelocity-response spectra at the Anderson Dam, crest $\left(340^{\circ}\right.$ component), for the April 24 earthquake, using a Butterworth filter $(0.25 \mathrm{~Hz}$, order 8) with an antialias of 50 to $100 \mathrm{~Hz}$ at $0,2,5,10$, and 20 percent critical damping. 


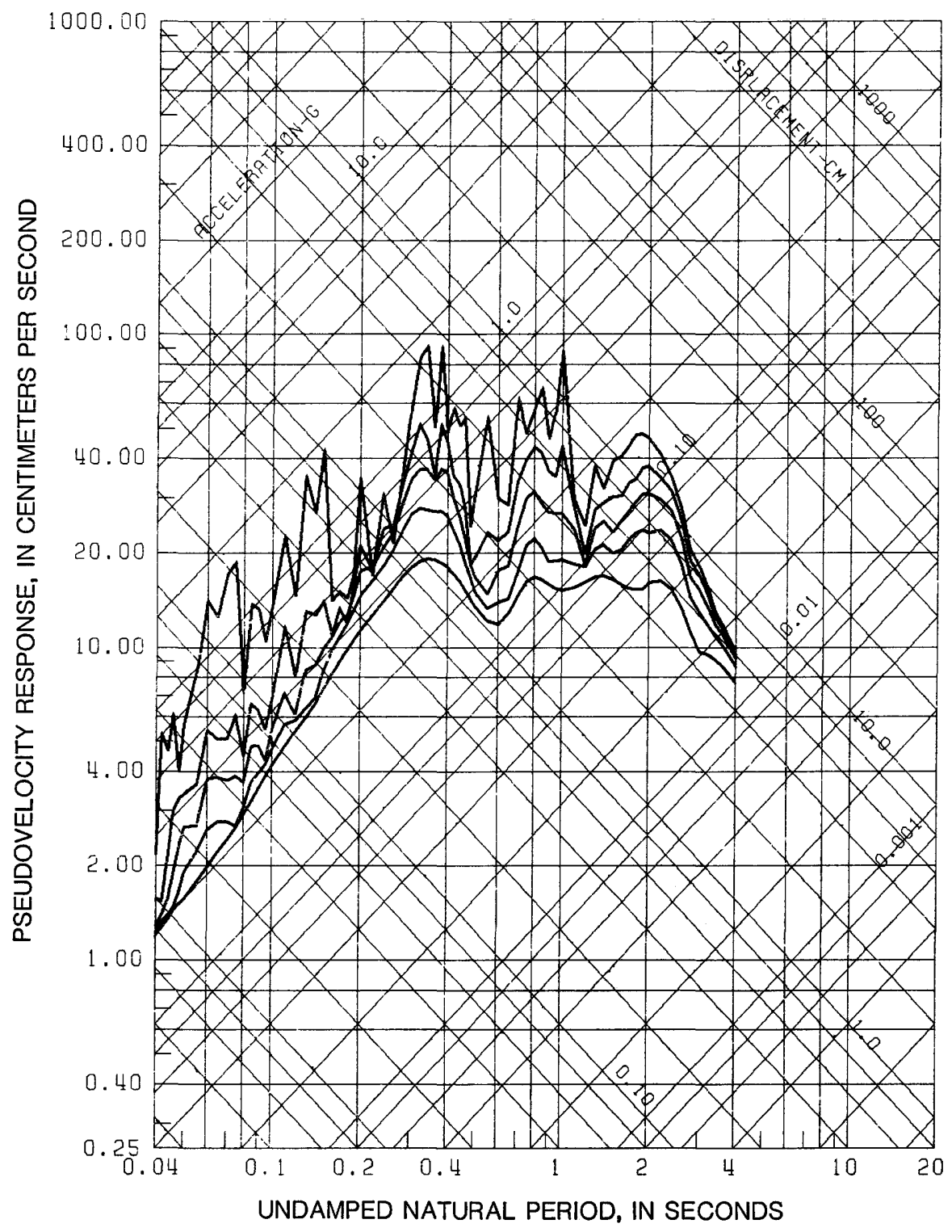

Figure 19.67. Pseudovelocity-response spectra at the Anderson Darn, crest (up component), for the April 24 earthquake, using a Butterworth filter $(0.25$ $\mathrm{Hz}$, order 8) with an antialias of 50 to $100 \mathrm{~Hz}$ at $0,2,5,10$, and 20 percent critical damping. 


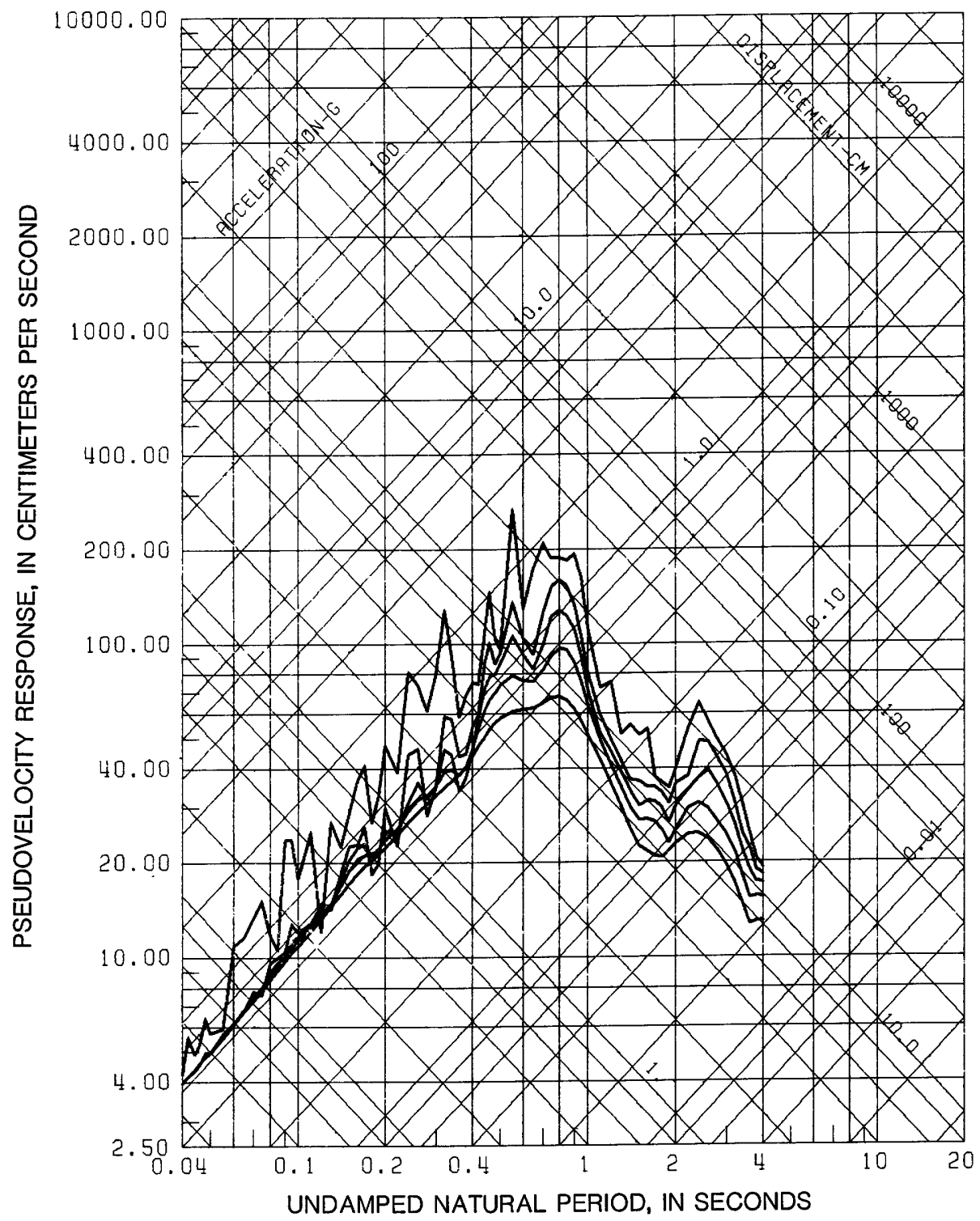

Figure 19.68. Pseudovelocity-response spectra at the Anderson Dam, crest ( $250^{\circ}$ component), for the April 24 earthquake, using a Butterworth filter $(0.25 \mathrm{~Hz}$, order 8) with an antialias of 50 to $100 \mathrm{~Hz}$ at $0,2,5,10$, and 20 percent critical damping. 


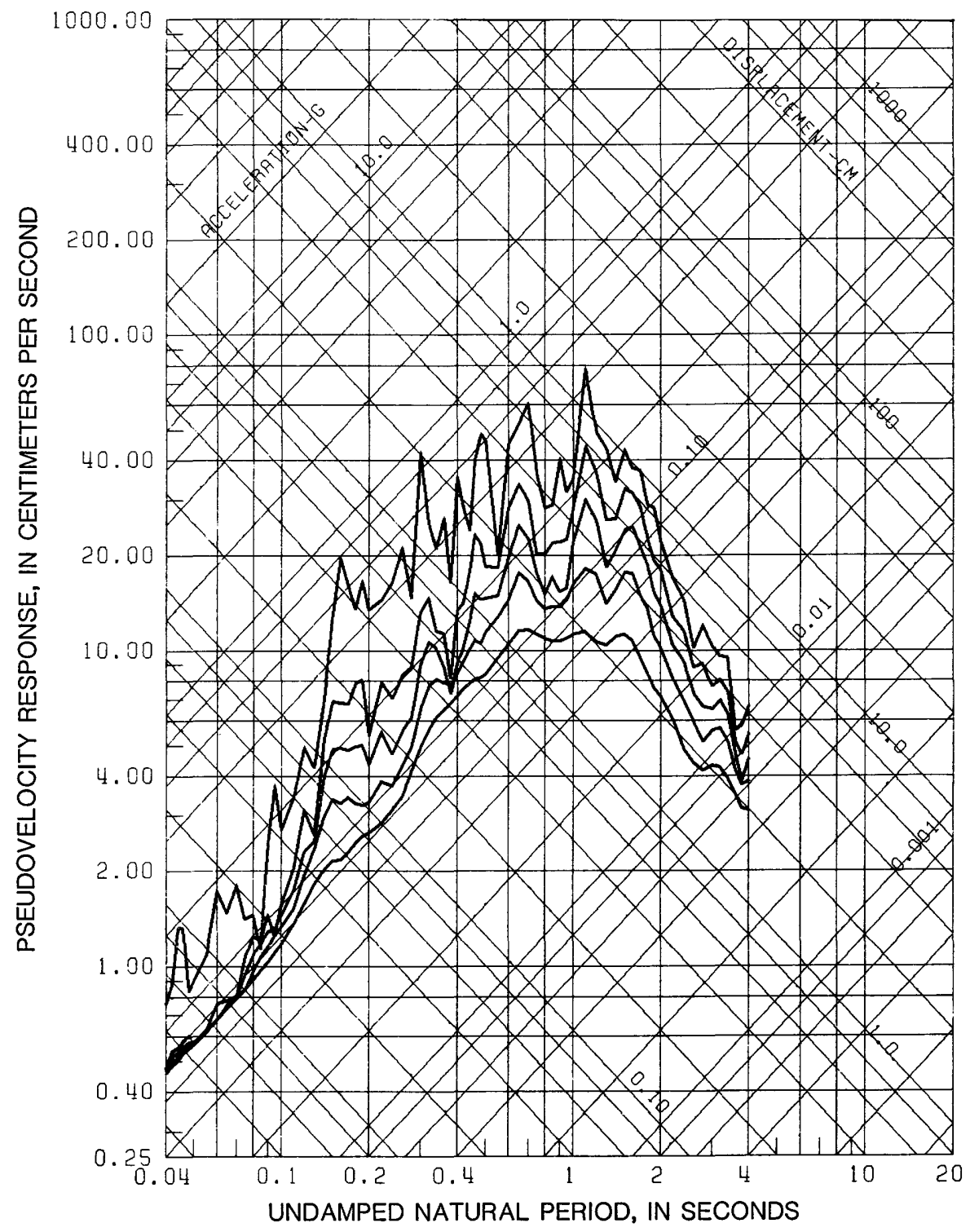

Figure 19.69. Pseudovelocity-response spectra at the Hollister City Hall Annex, basement $\left(001^{\circ}\right.$ component), for the April 24 earthquake, using a Butterworth filter $(0.25 \mathrm{~Hz}$, order 8) with an antialias of 50 to $100 \mathrm{~Hz}$ at 0,2 , 5,10 , and 20 percent critical damping. 


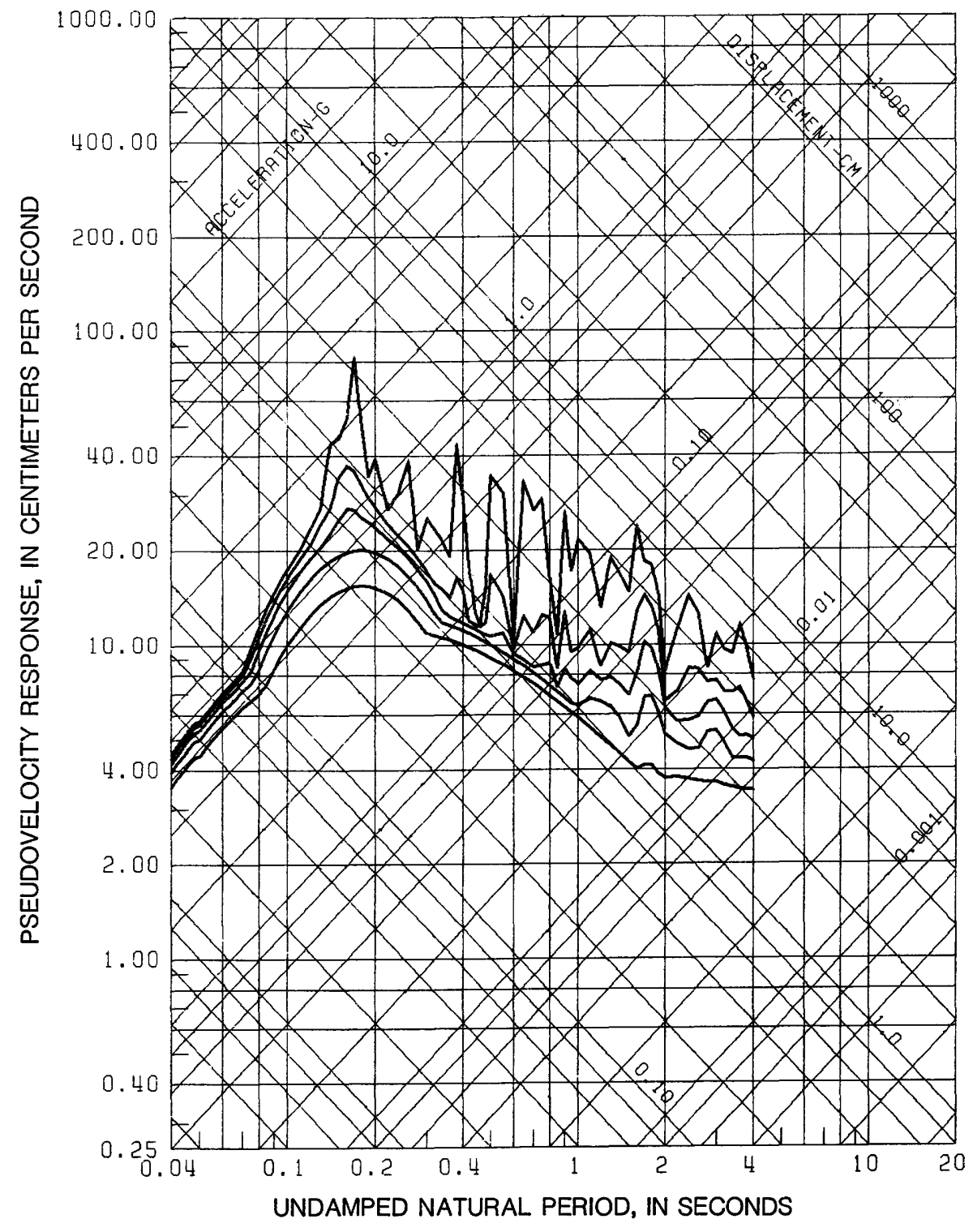

Figure 19.70. Pseudovelocity-response spectra at the Hollister City Hall Annex, basement (up component), for the April 24 earthquake, using a Butterworth filter $(0.25 \mathrm{~Hz}$, order 8) with an antialias of 50 to $100 \mathrm{~Hz}$ at $0,2,5,10$, and 20 percent critical damping. 


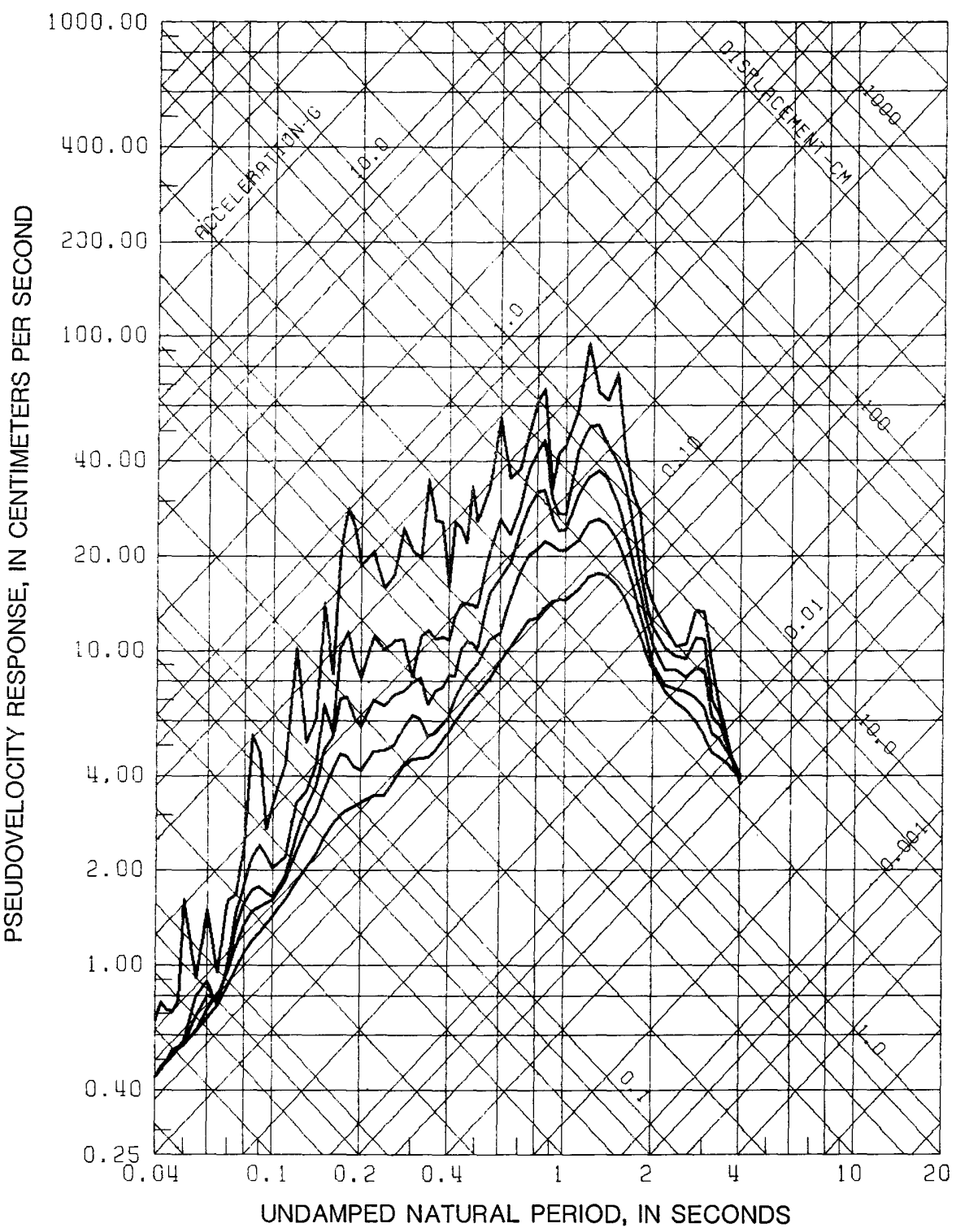

Figure 19.71. Pseudovelocity-response spectra at the Hollister City Hall Annex, basement $\left(271^{\circ}\right.$ component), for the April 24 earthquake, using a Butterworth filter $(0.25 \mathrm{~Hz}$, order 8$)$ with an antialias of 50 to $100 \mathrm{~Hz}$ at 0,2 , 5,10 , and 20 percent critical damping. 


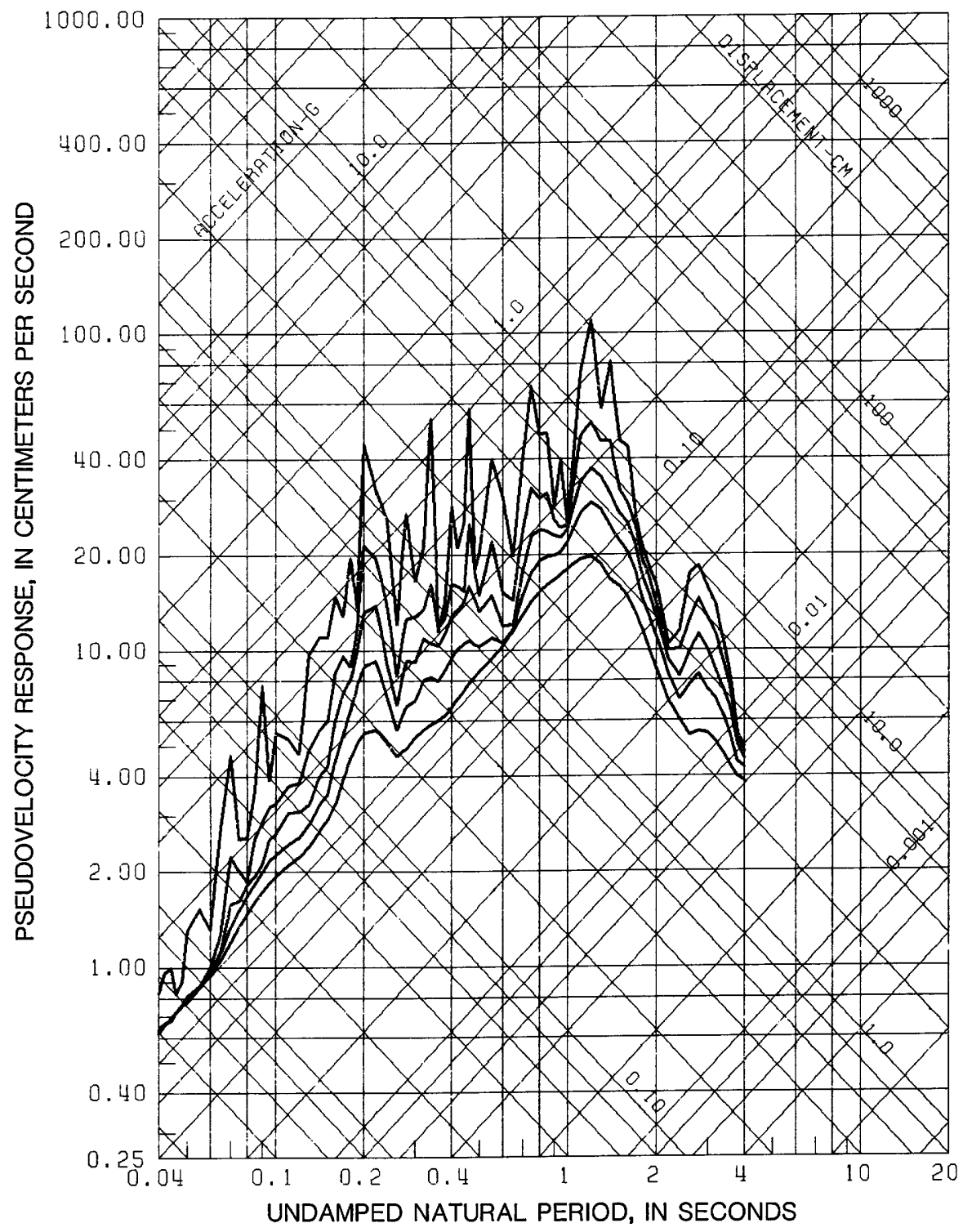

Figure 19.72. Pseudovelocity-response spectra at the Hollister Differential Array (SMA-1T, $255^{\circ}$ component) for the April 24 earthquake, using a Butterworth filter $(0.25 \mathrm{~Hz}$, order 8) with an antialias of 50 to $100 \mathrm{~Hz}$ at $0,2,5,10$, and 20 percent critical damping. 


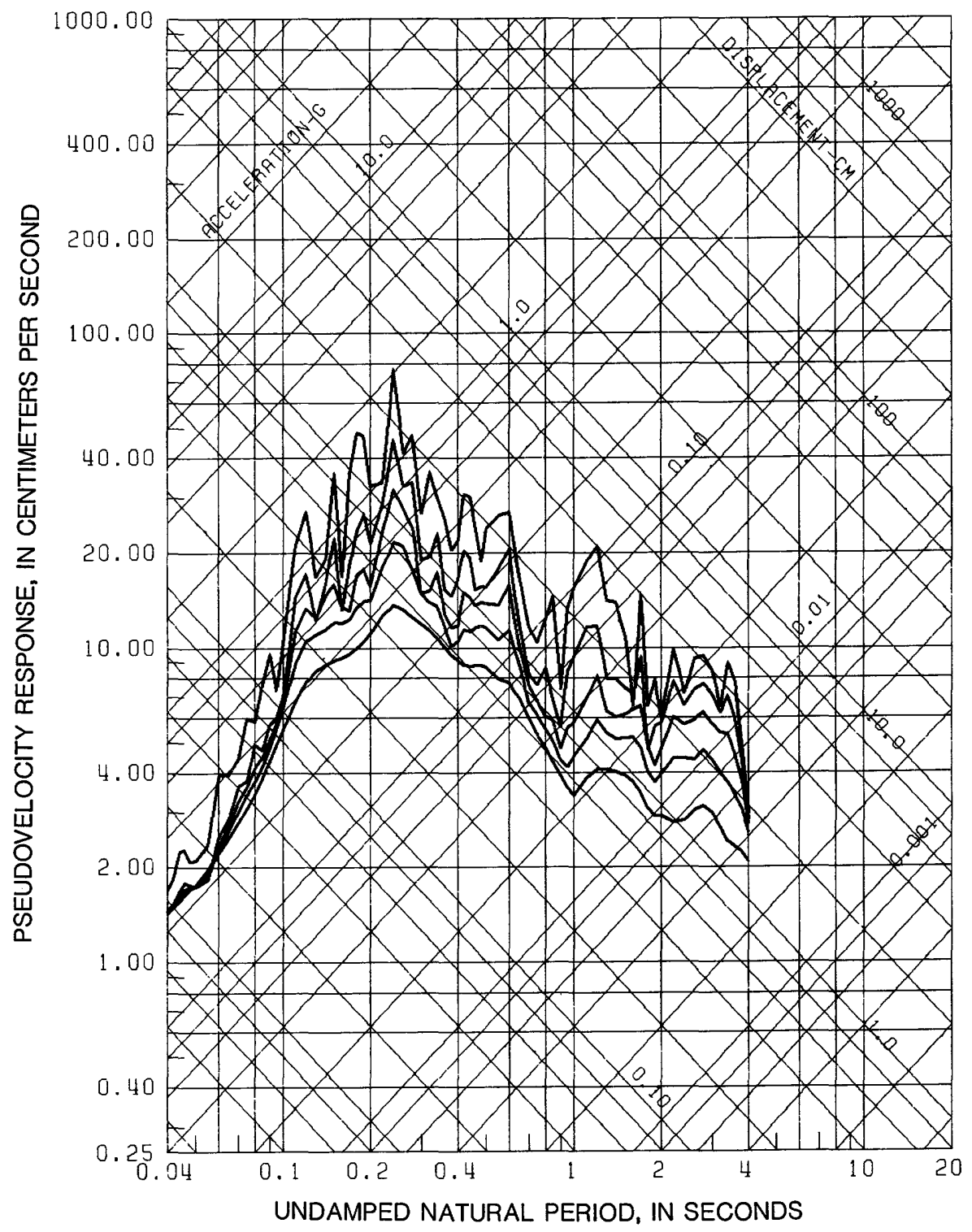

Figure 19.73. Pseudovelocity-response spectra at the Hollister Differential Array (SMA-1T, up component) for the April 24 earthquake, using a Butterworth filter $(0.25 \mathrm{~Hz}$, order 8) with an antialias of 50 to $100 \mathrm{~Hz}$ at $0,2,5,10$, and 20 percent critical damping. 


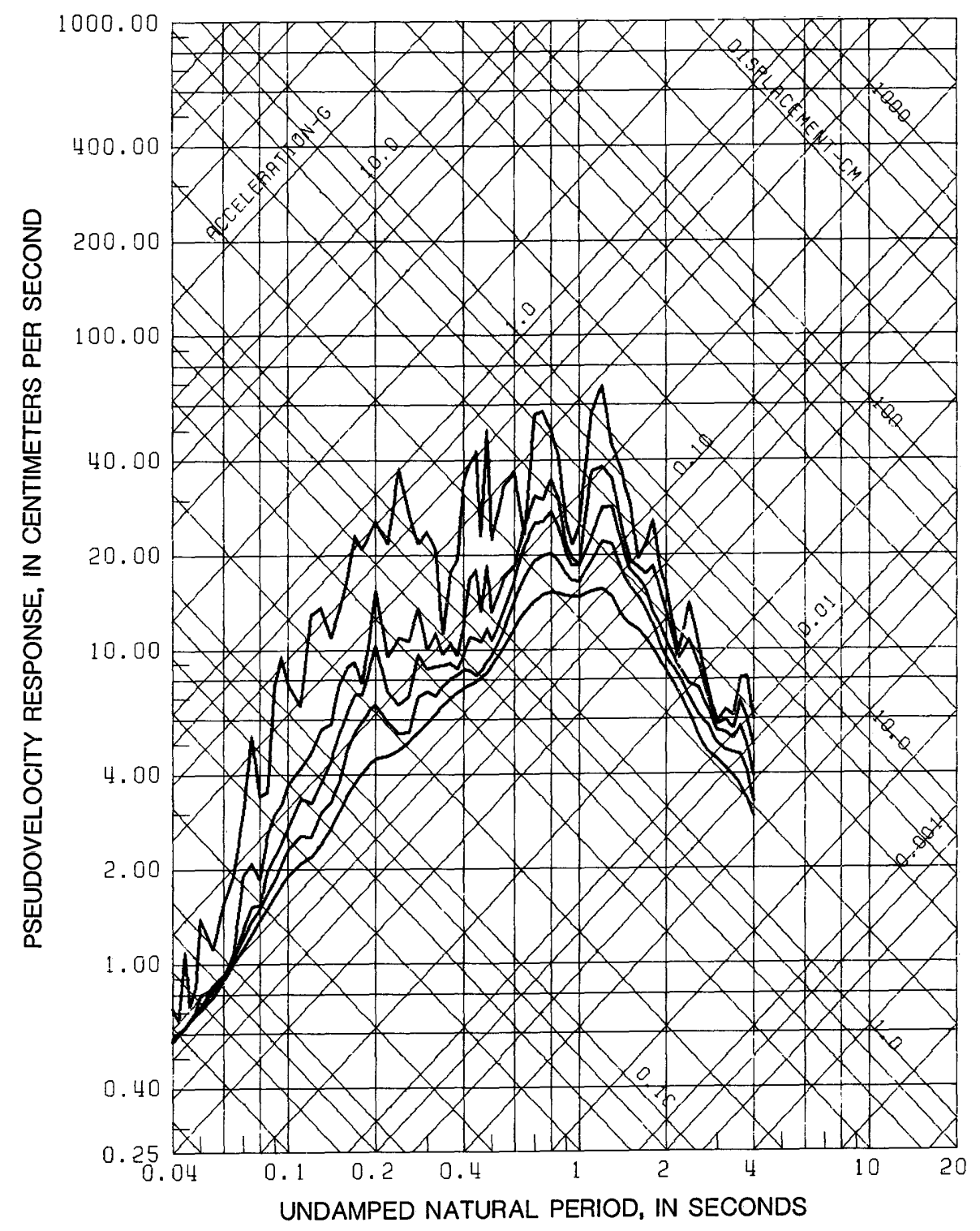

Figure 19.74. Pseudovelocity-response spectra at the Hollister Differential Array (SMA-1T, $165^{\circ}$ component) for the April 24 earthquake, using a Butterworth filter $(0.25 \mathrm{~Hz}$, order 8) with an antialias of 50 to $100 \mathrm{~Hz}$ at $0,2,5,10$, and 20 percent critical damping. 


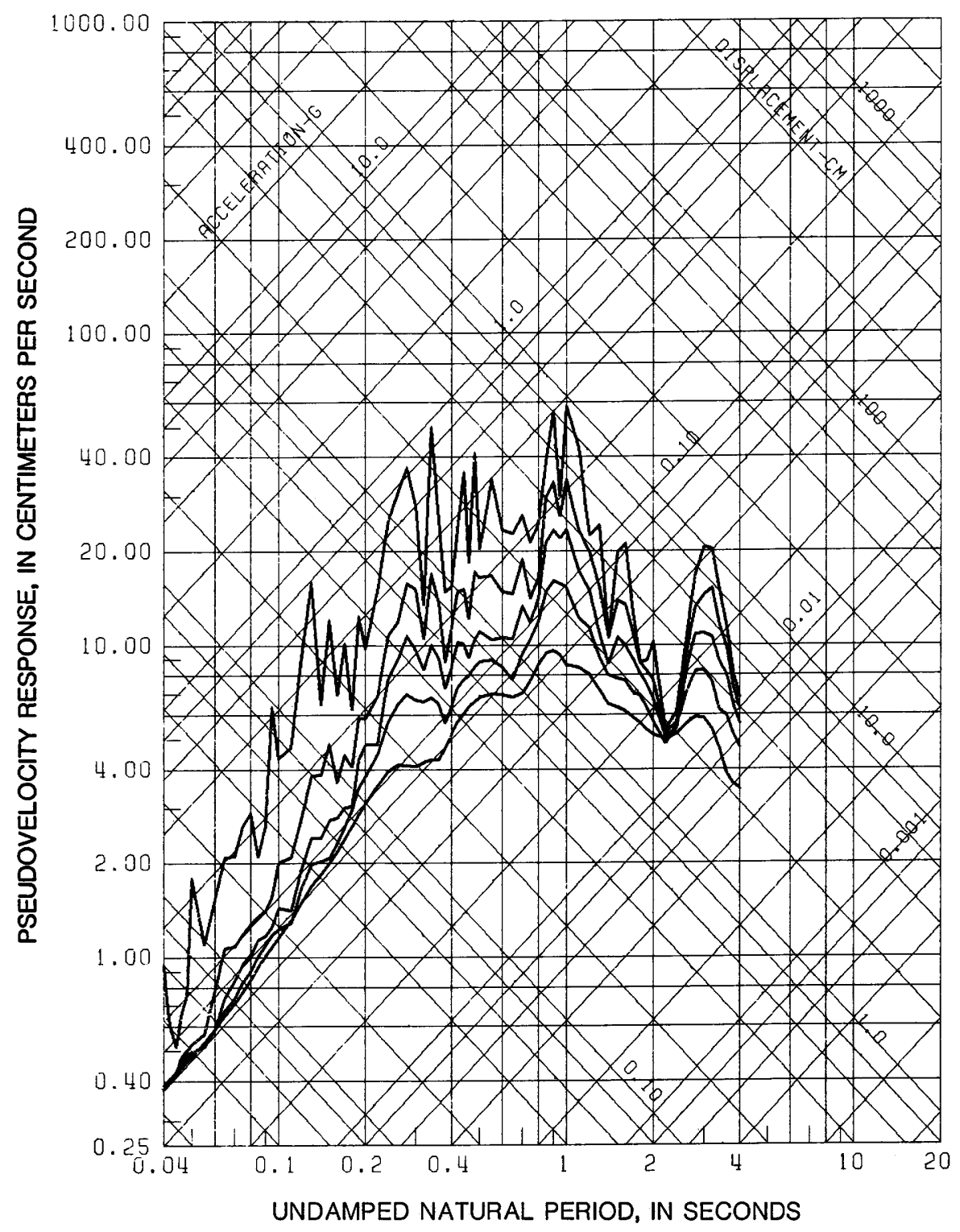

Figure 19.75. Pseudovelocity-response spectra at the San Justo Damsite, right abutment (dike, $360^{\circ}$ component), for the April 24 earthquake, using a Butterworth filter $(0.25 \mathrm{~Hz}$, order 8) with an antialias of 50 to $100 \mathrm{~Hz}$ at 0,2 , 5,10 , and 20 percent critical damping. 


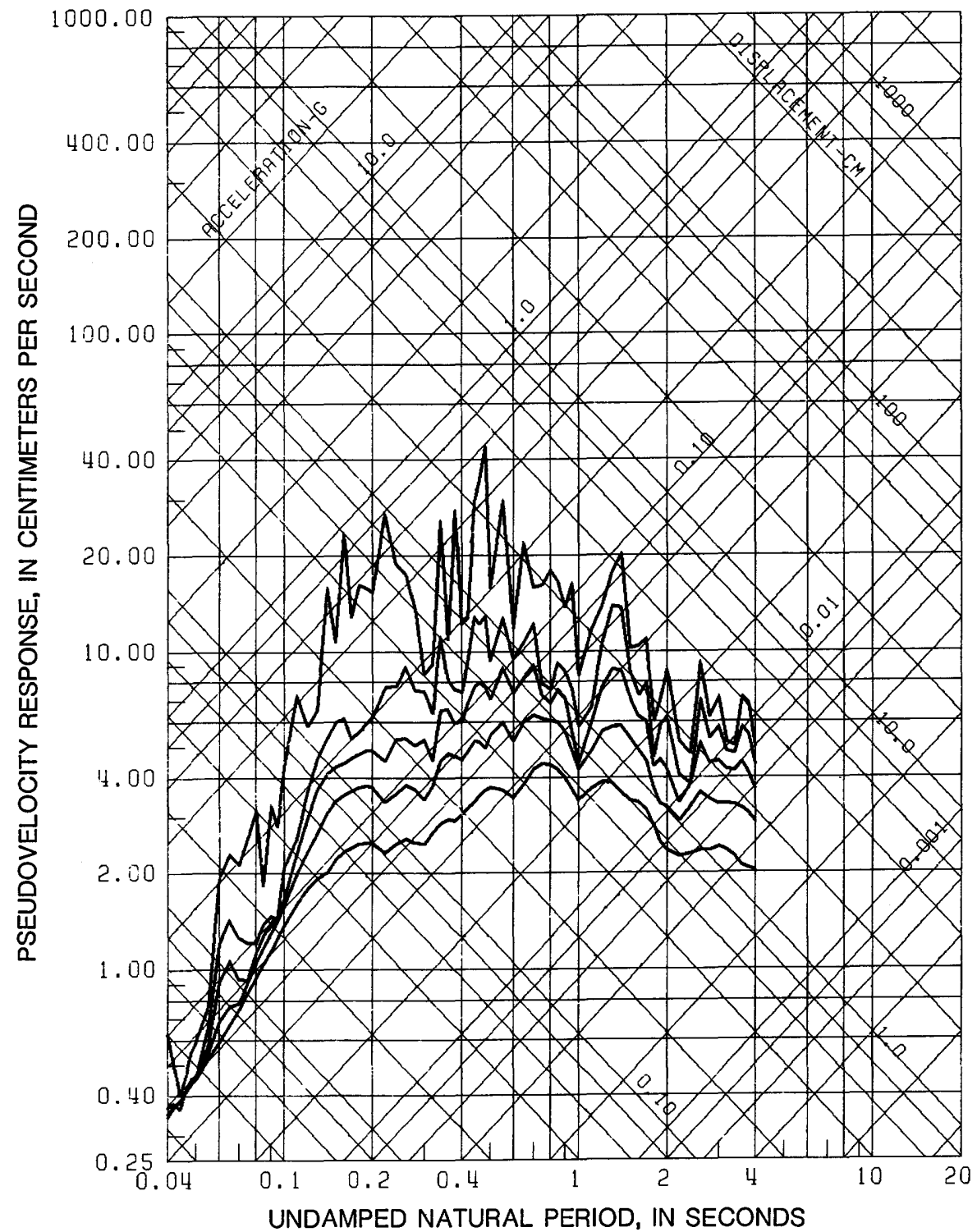

Figure 19.76. Pseudovelocity-response spectra at the San Justo Damsite, right abutment (dike, up component), for the April 24 earthquake, using a Butterworth filter $(0.25 \mathrm{~Hz}$, order 8) with an antialias of 50 to $100 \mathrm{~Hz}$ at 0,2 , 5,10 , and 20 percent critical damping. 


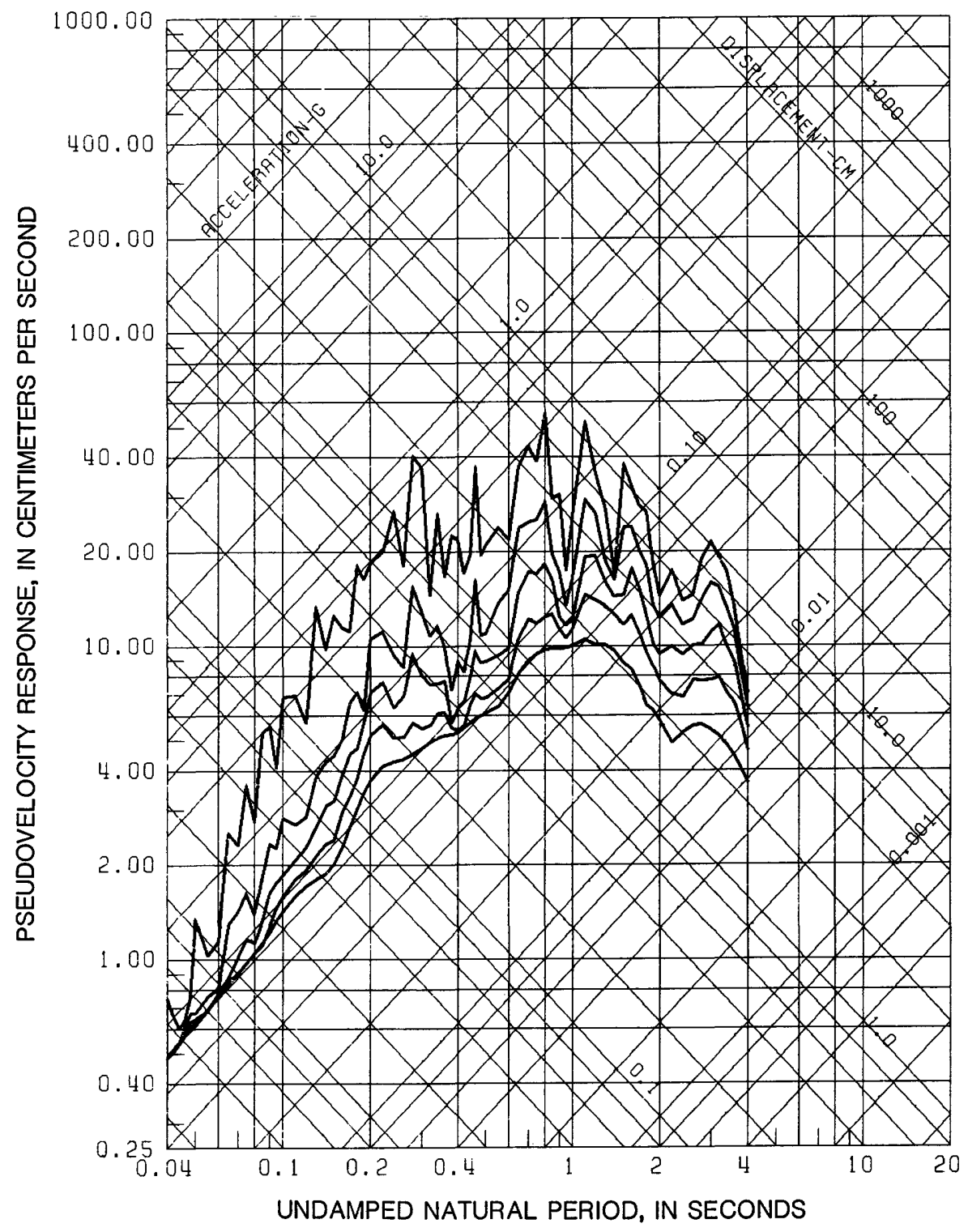

Figure 19.77. Pseudovelocity-response spectra at the San Justo Damsite, right abutment (dike, $270^{\circ}$ component), for the April 24 earthquake, using a Butterworth filter $(0.25 \mathrm{~Hz}$, order 8) with an antialias of 50 to $100 \mathrm{~Hz}$ at 0,2 , 5,10 , and 20 percent critical damping. 


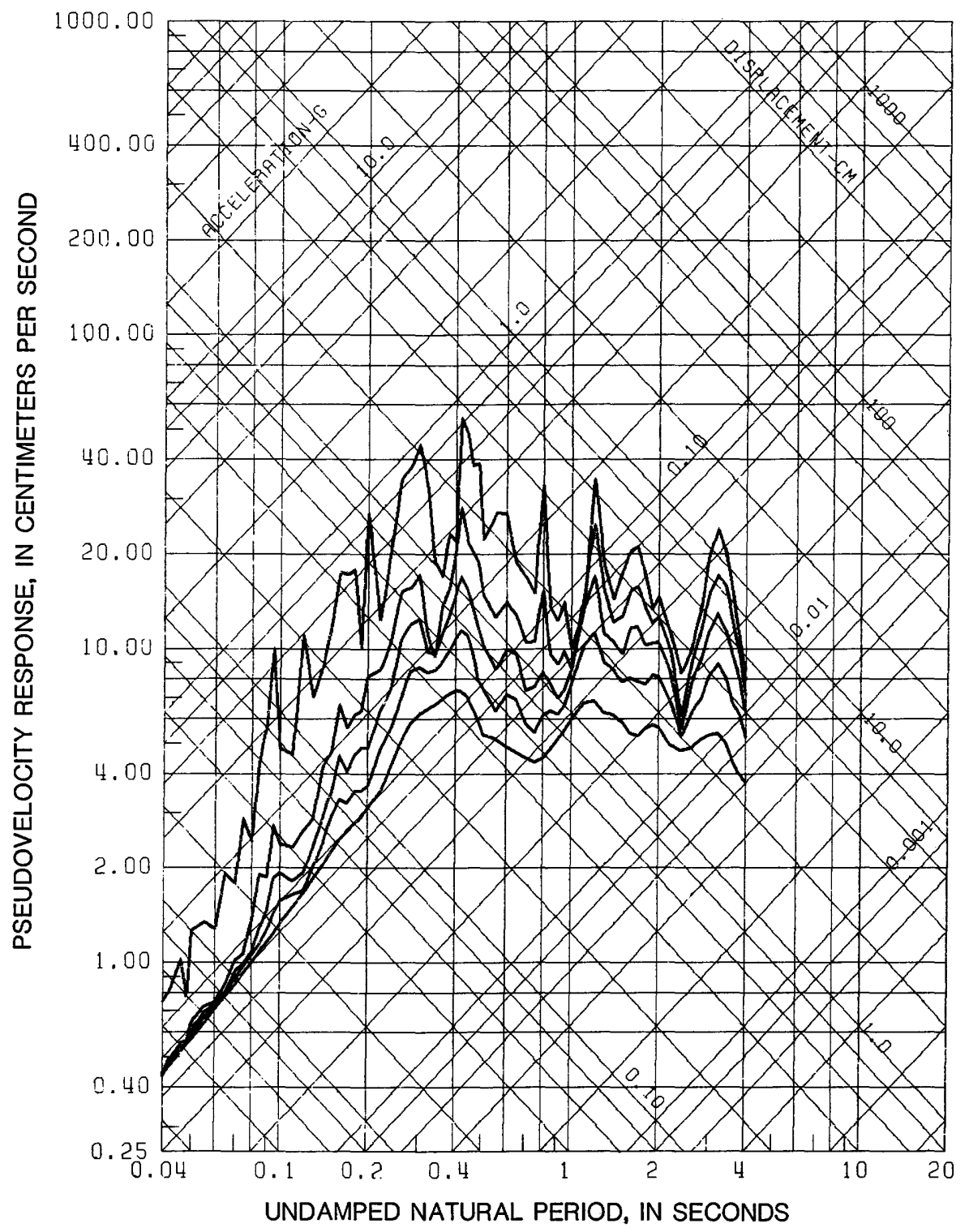

Figure 19.78. Pseudovelocity-response spectra at the San Justo Damsite, left abutment $\left(360^{\circ}\right.$ component), for the April 24 earthquake, using a Butterworth filter $(0.25 \mathrm{~Hz}$, order 8) with an antialias of 50 to $100 \mathrm{~Hz}$ at $0,2,5,10$, and 20 percent critical damping. 


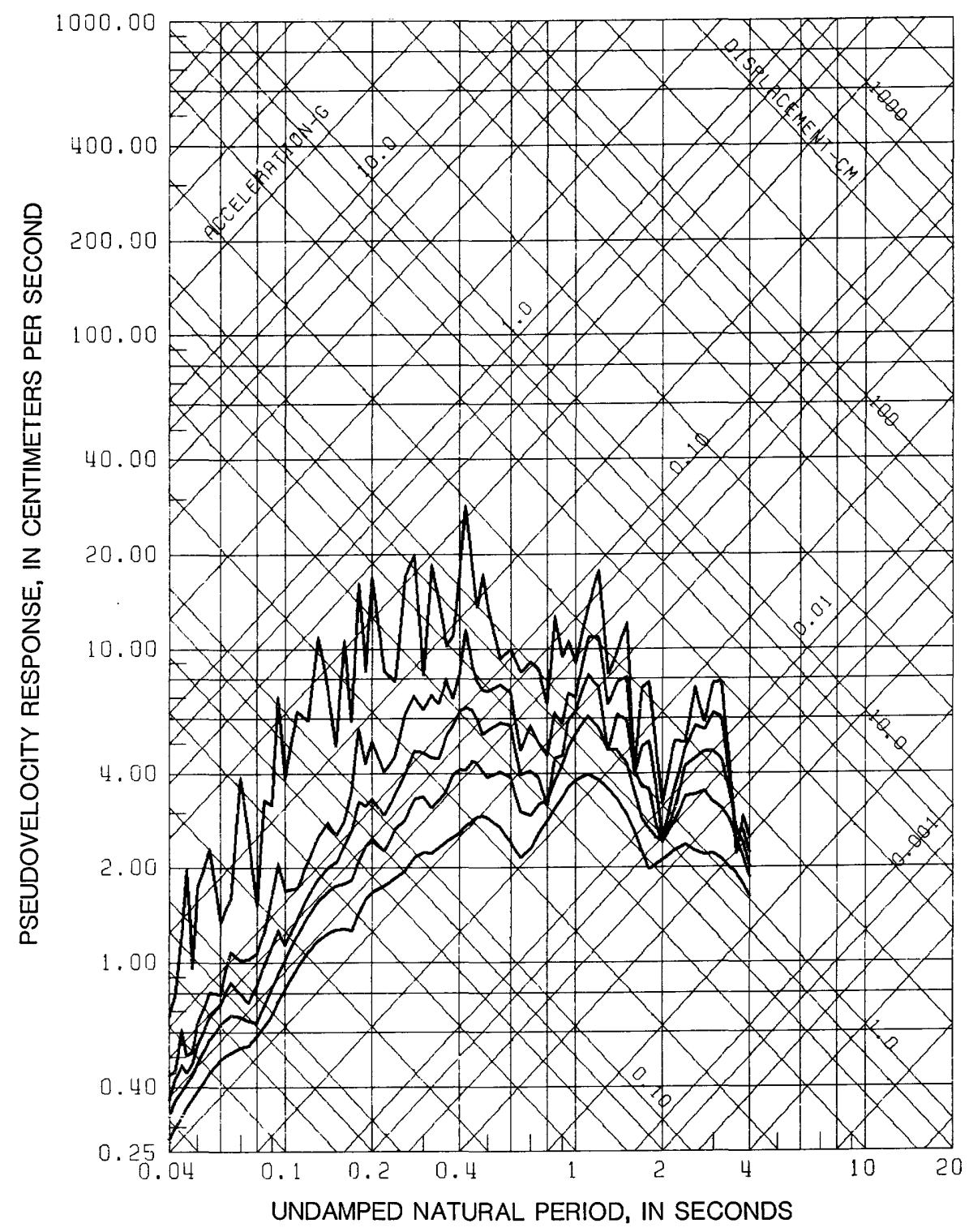

Figure 19.79. Pseudovelocity-response spectra at the San Justo Damsite, left abutment (up component), for the April 24 earthquake, using a Butterworth filter $(0.25 \mathrm{~Hz}$, order 8 ) with an antialias of 50 to $100 \mathrm{~Hz}$ at $0,2,5,10$, and 20 percent critical damping. 


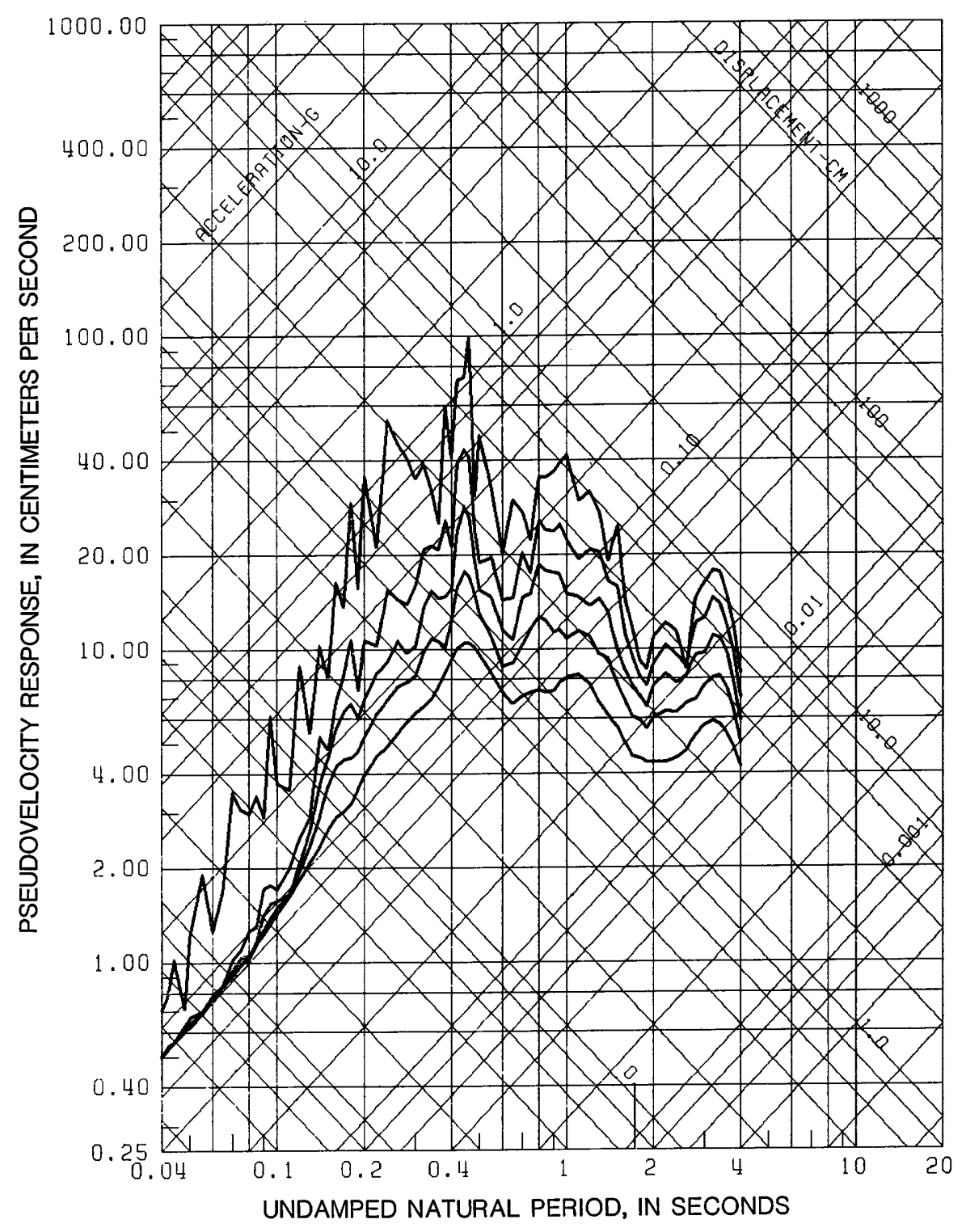

Figure 19.80. Pseudovelocity-response spectra at the San Justo Damsite, left abutment $\left(270^{\circ}\right.$ component), for the April 24 earthquake, using a Butterworth filter $(0.25 \mathrm{~Hz}$, order 8) with an antialias of 50 to $100 \mathrm{~Hz}$ at $0,2,5,10$, and 20 percent critical damping. 


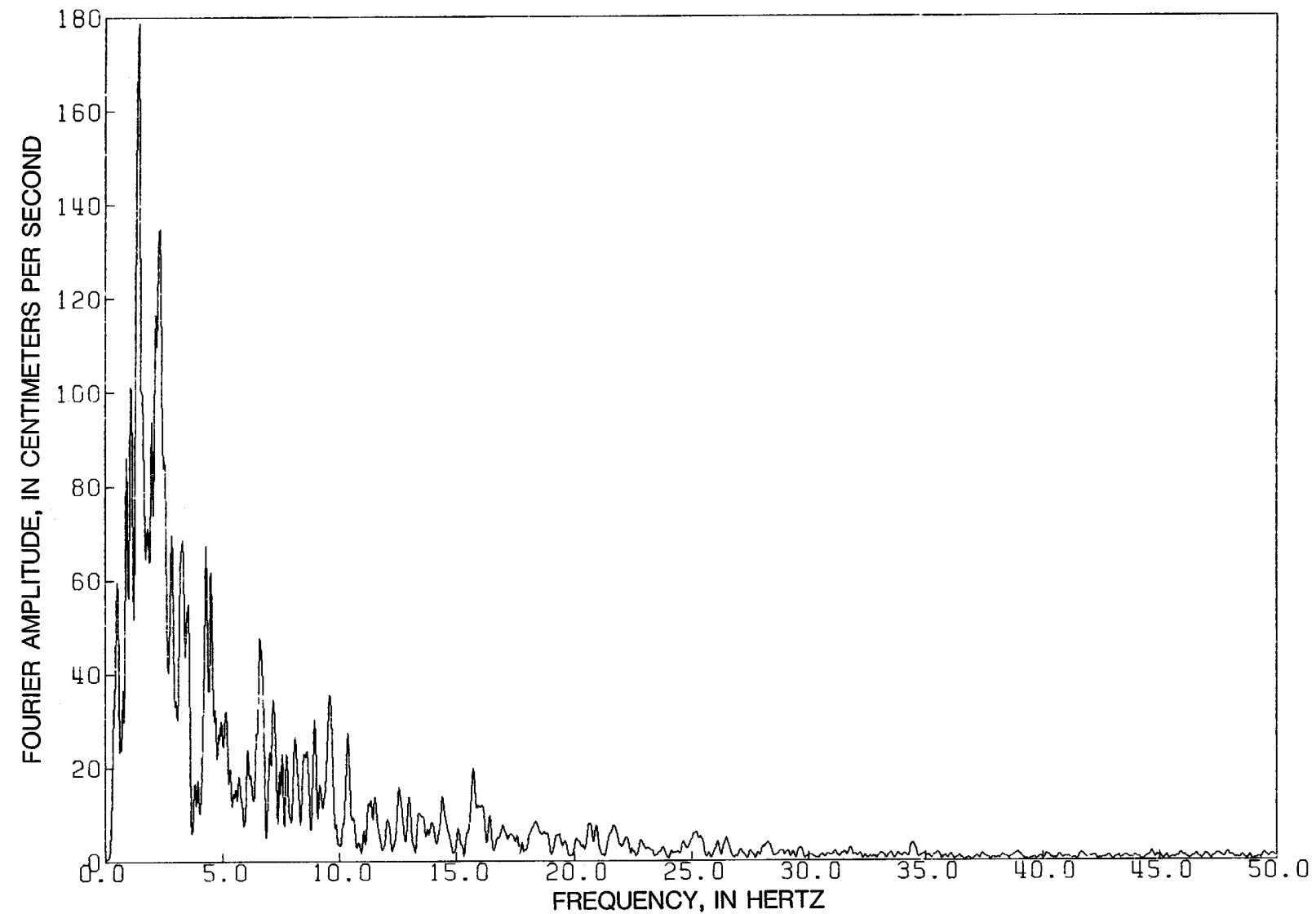

Figure 19.81. Fourier amplitude spectrum of acceleration at the Anderson Dam, downstream $\left(340^{\circ}\right.$ component), for the April 24 earthquake, using a Nyquist filter $(0.25 \mathrm{~Hz}$, order 8) bandpassed with a cosine taper from 50 to $100 \mathrm{~Hz}$. 


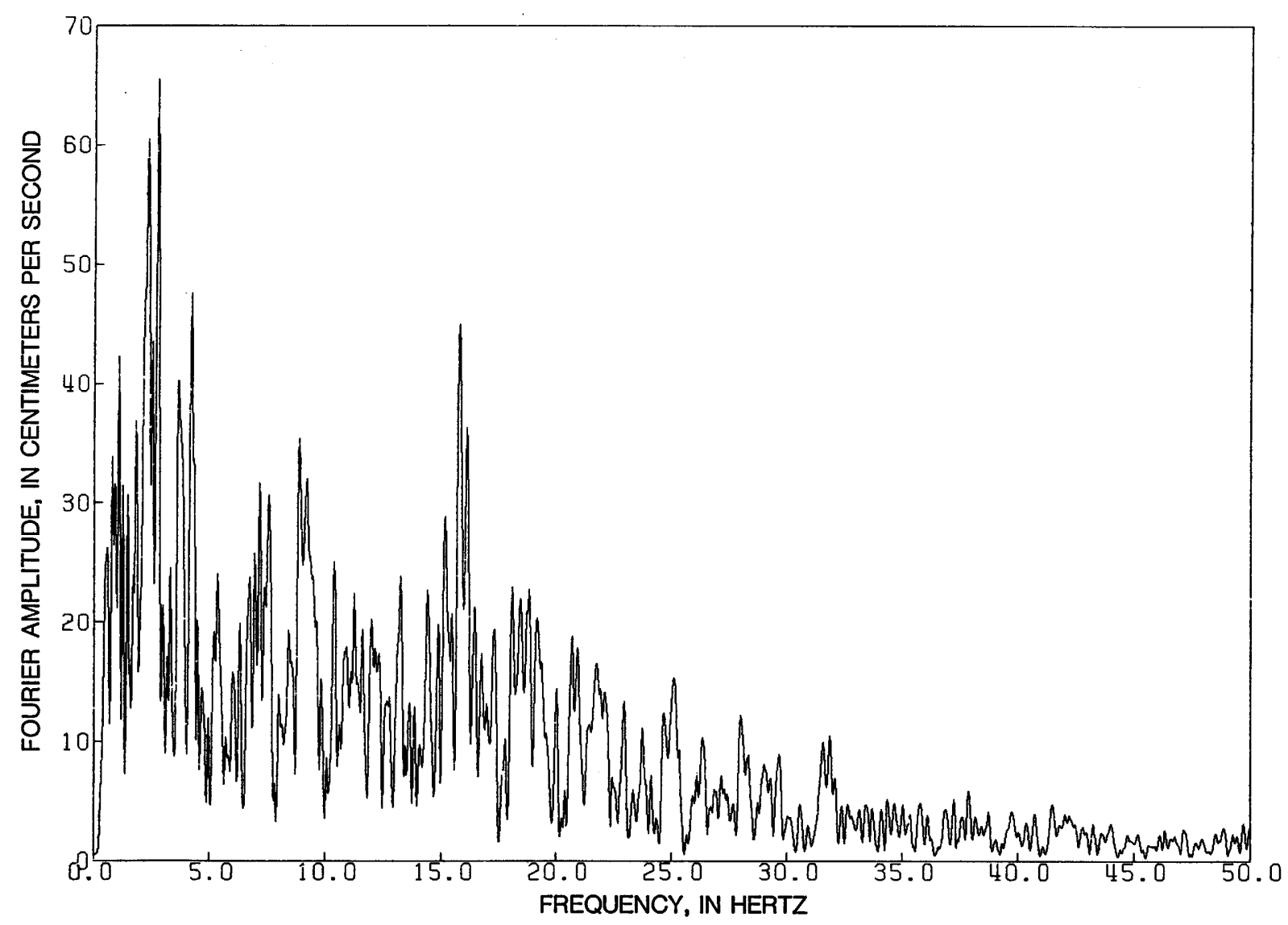

Figure 19.82. Fourier amplitude spectrum of acceleration at the Anderson Dam, downstream (up component), for the April 24 earthquake, using a Nyquist filter $(0.25 \mathrm{~Hz}$, order 8$)$ bandpassed with a cosine taper from 50 to $100 \mathrm{~Hz}$. 


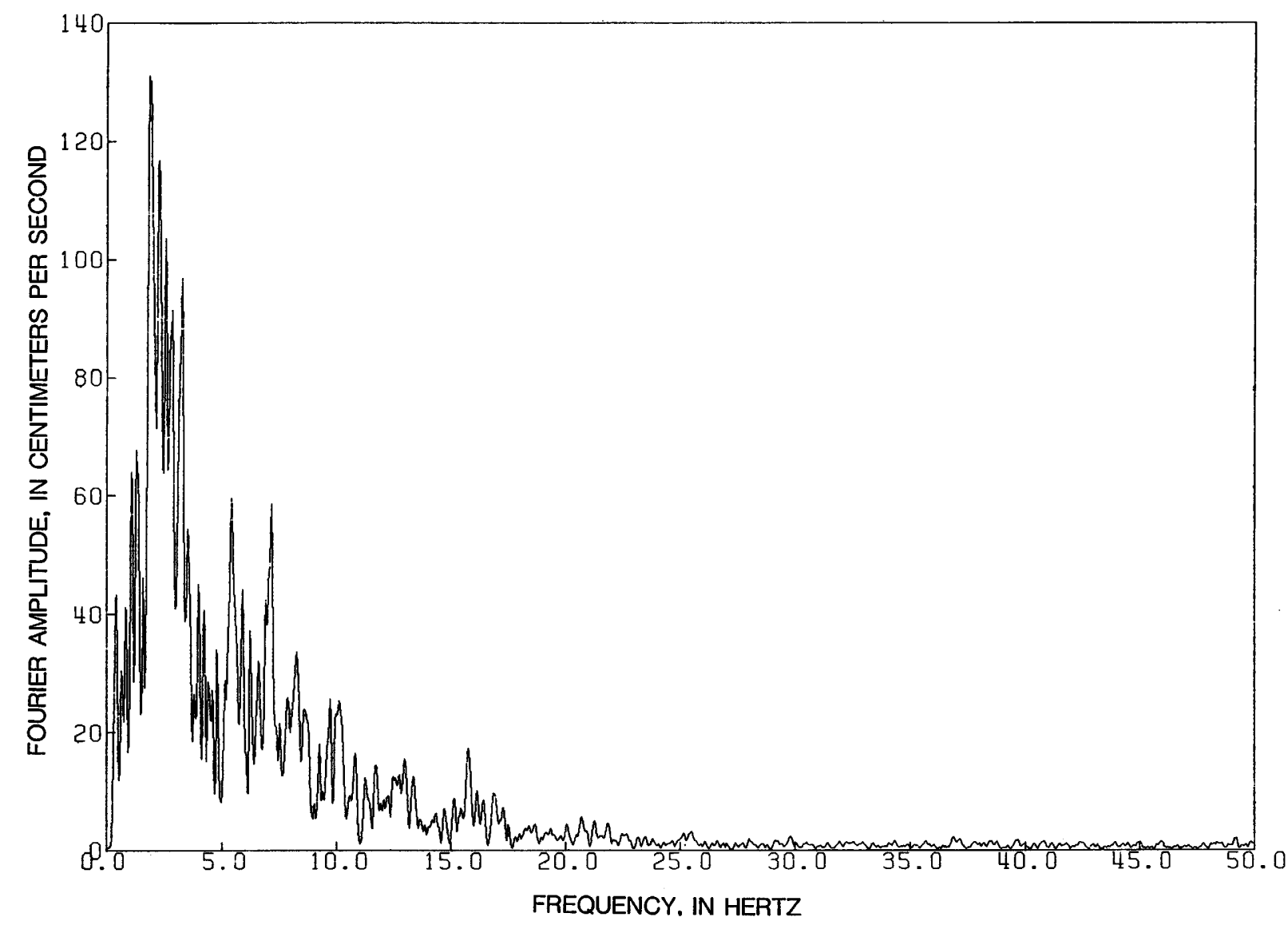

Figure 19.83. Fourier amplitude spectrum of acceleration at the Anderson Dam, downstream $\left(250^{\circ}\right.$ component), for the April 24 earthquake, using a Nyquist filter $(0.25 \mathrm{~Hz}$, order 8) bandpassed with a cosine taper from 50 to $100 \mathrm{~Hz}$. 


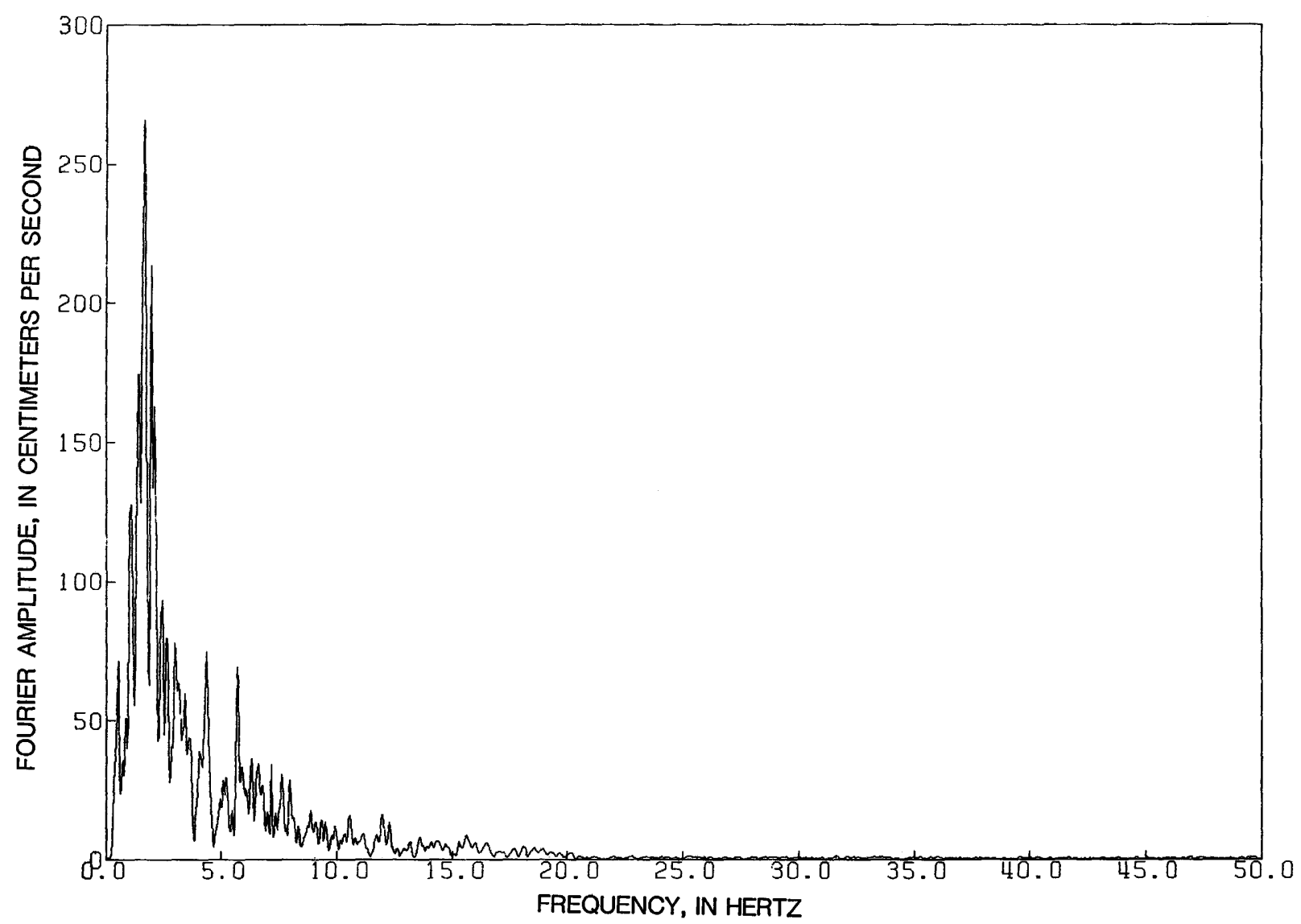

Figure 19.84. Fourier amplitude spectrum of acceleration at the Anderson Dam, crest ( $340^{\circ}$ component), for the April 24 earthquake, using a Nyquist filter $(0.25 \mathrm{~Hz}$, order 8$)$ bandpassed with a cosine taper from 50 to $100 \mathrm{~Hz}$. 


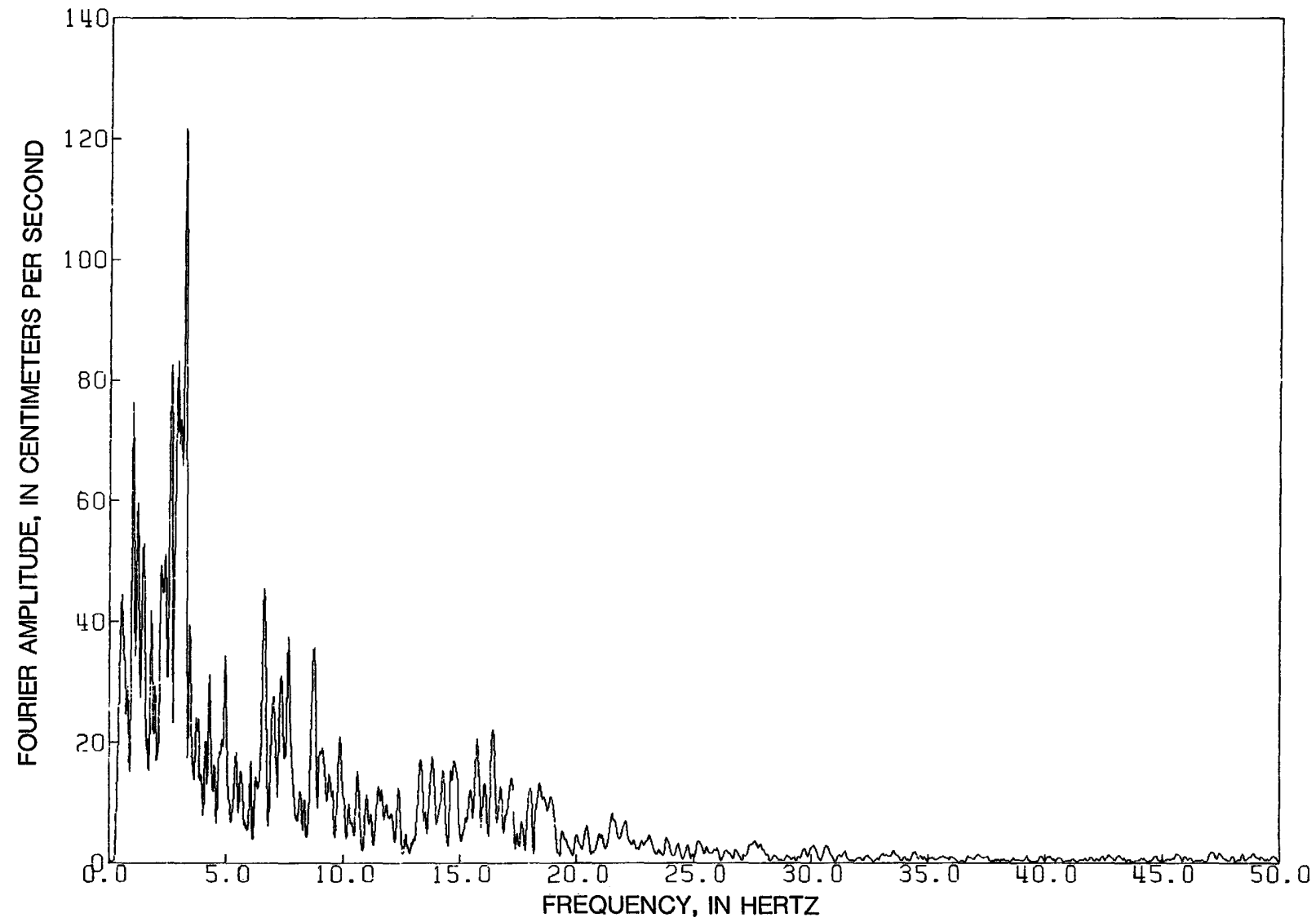

Figure 19.85. Fourier amplitude spectrum of acceleration at the Anderson Dam, crest (up component), for the April 24 earthquake, using a Nyquist filter $(0.25 \mathrm{~Hz}$, order 8$)$ bandpassed with a cosine taper from 50 to $100 \mathrm{~Hz}$. 


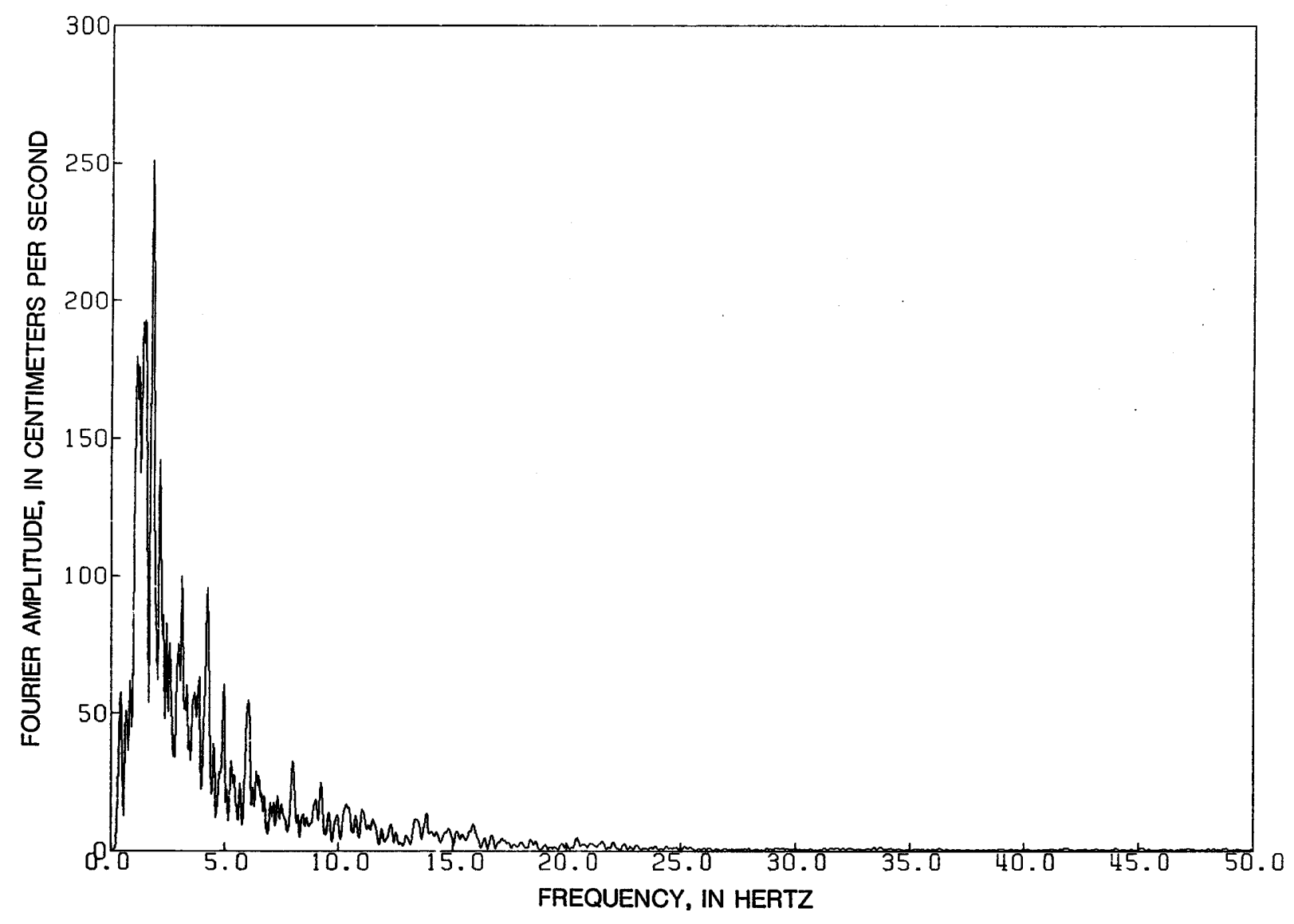

Figure 19.86. Fourier amplitude spectrum of acceleration at the Anderson Dam, crest $\left(250^{\circ}\right.$ component), for the April 24 earthquake, using a Nyquist filter $(0.25 \mathrm{~Hz}$, order 8$)$ bandpassed with a cosine taper from 50 to $100 \mathrm{~Hz}$. 


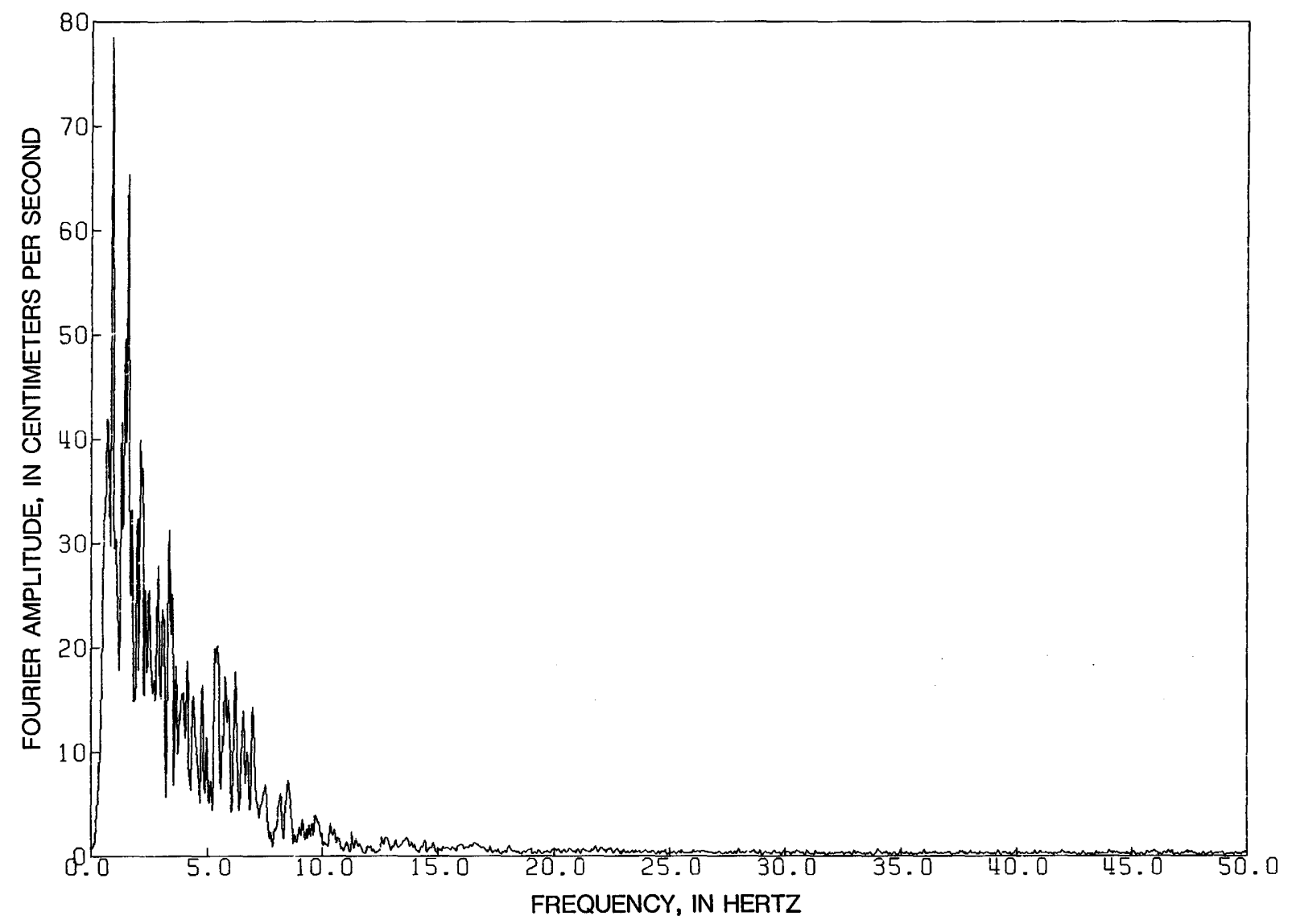

Figure 19.87. Fourier amplitude spectrum of acceleration at the Hollister City Hall Annex, basement $\left(001^{\circ}\right.$ component), for the April 24 earthquake, using a Nyquist filter $(0.25 \mathrm{~Hz}$, order 8$)$ bandpassed with a cosine taper from 50 to $100 \mathrm{~Hz}$. 


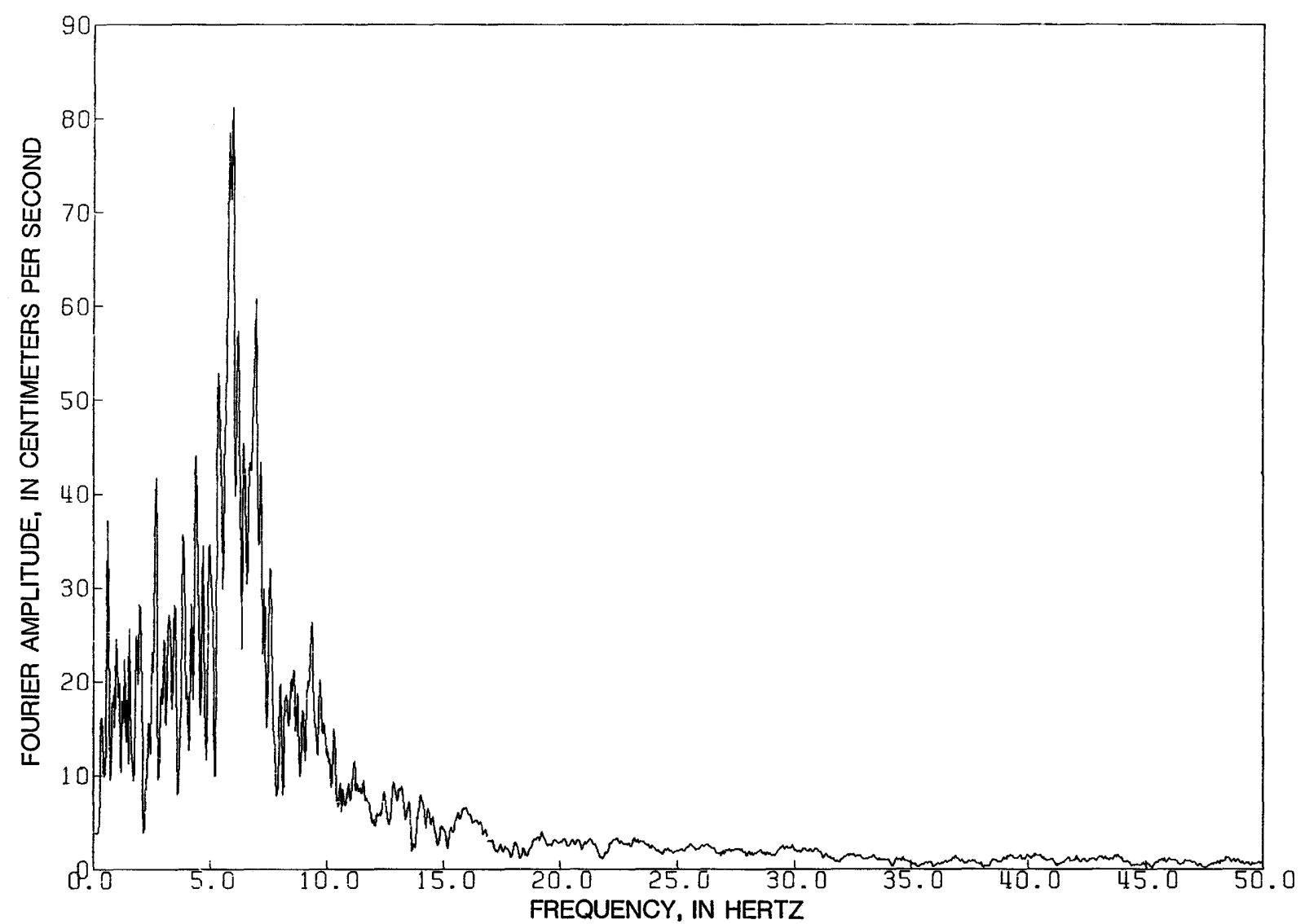

Figure 19.88. Fourier amplitude spectrum of acceleration at the Hollister City Hall Annex, basement (up component), for the April 24 earthquake, using a Nyquist filter $(0.25 \mathrm{~Hz}$, order 8) bandpassed with a cosine taper from 50 to $100 \mathrm{~Hz}$. 


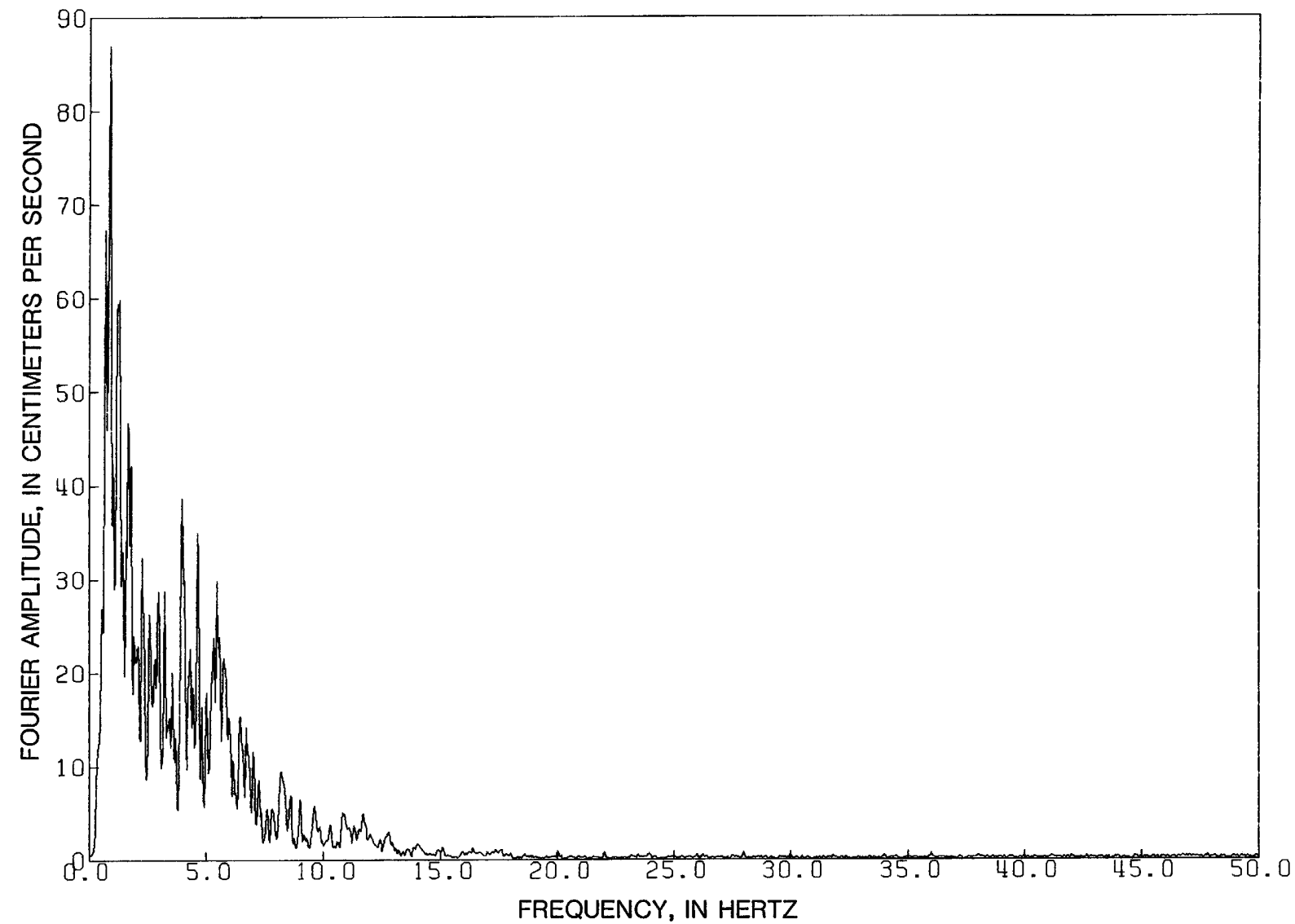

Figure 19.89. Fourier amplitude spectrum of acceleration at the Hollister City Hall Annex, basement $\left(271^{\circ}\right.$ component), for the April 24 earthquake, using a Nyquist filter $(0.25 \mathrm{~Hz}$, order 8) bandpassed with a cosine taper from 50 to $100 \mathrm{~Hz}$. 


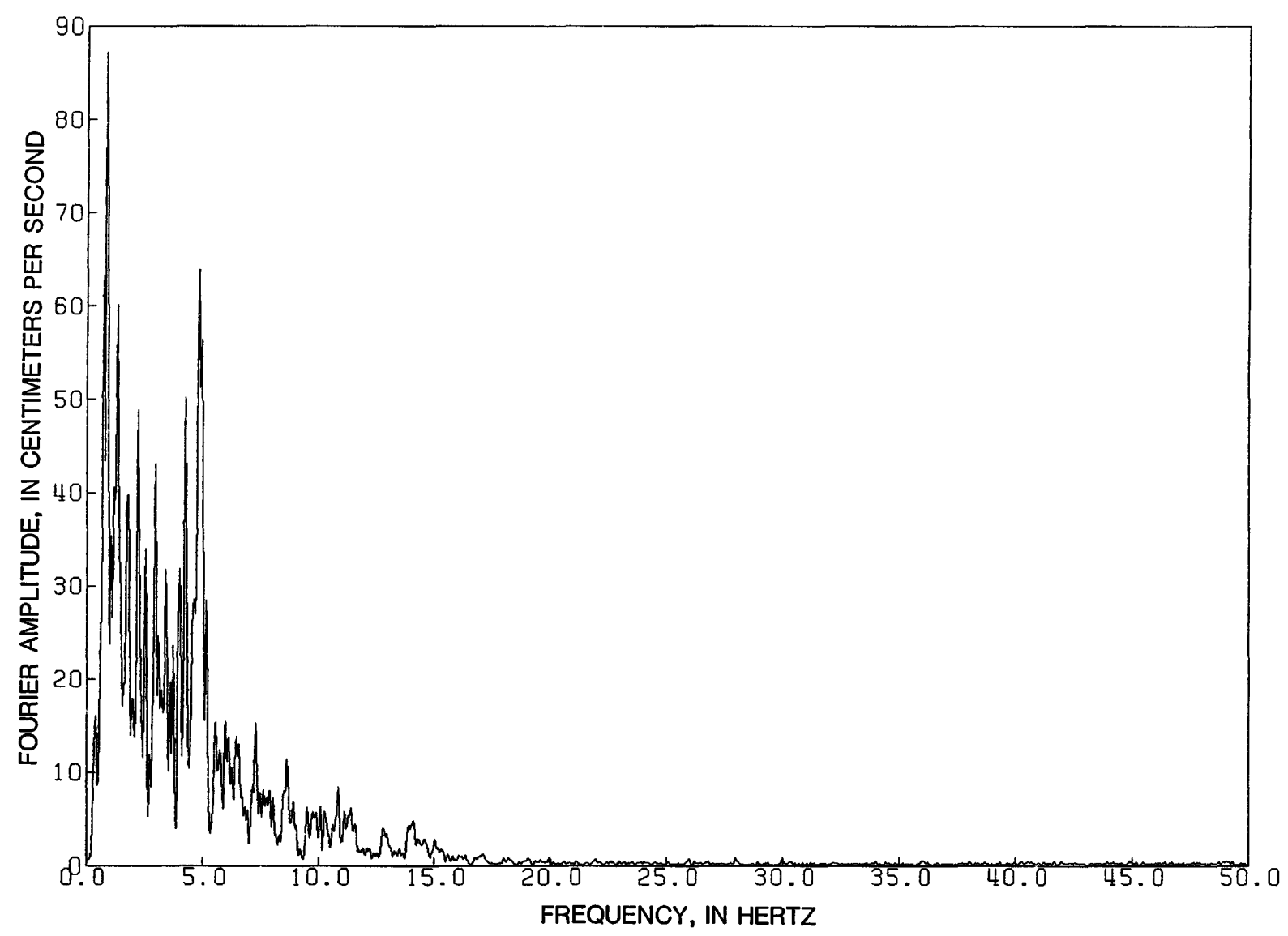

Figure 19.90. Fourier amplitude spectrum of acceleration at the Hollister Differential Array (SMA-1T, $255^{\circ}$ component) for the April 24 earthquake, using a Nyquist filter $(0.25 \mathrm{~Hz}$, order 8 ) bandpassed with a cosine taper from 50 to $100 \mathrm{~Hz}$. 


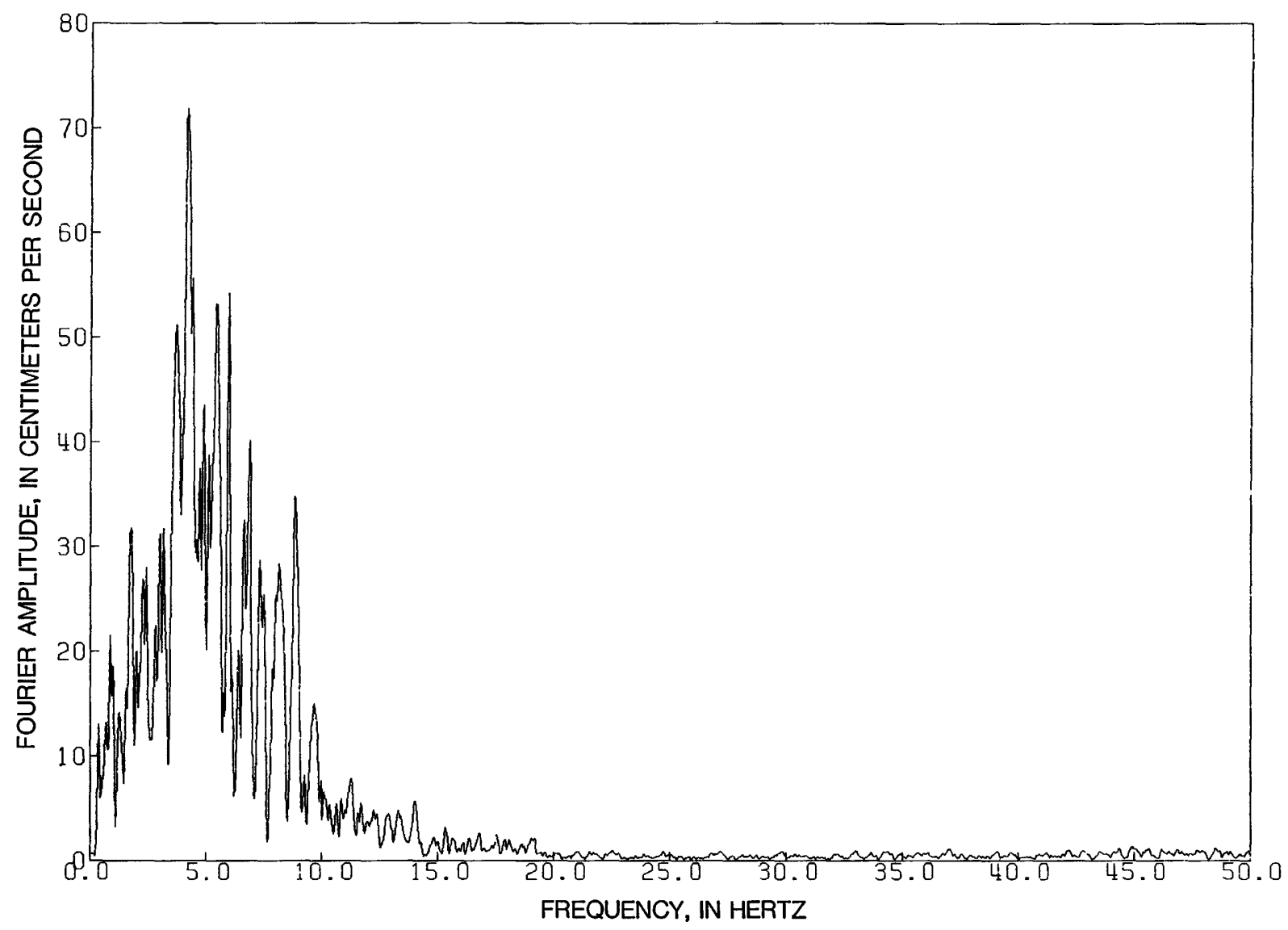

Figure 19.91. Fourier amplitude spectrum of acceleration at the Hollister Differential Array (SMA-1T, up component) for the April 24 earthquake, using a Nyquist filter $(0.25 \mathrm{~Hz}$, order 8) bandpassed with a cosine taper from 50 to $100 \mathrm{~Hz}$. 
$\tilde{\sim}$

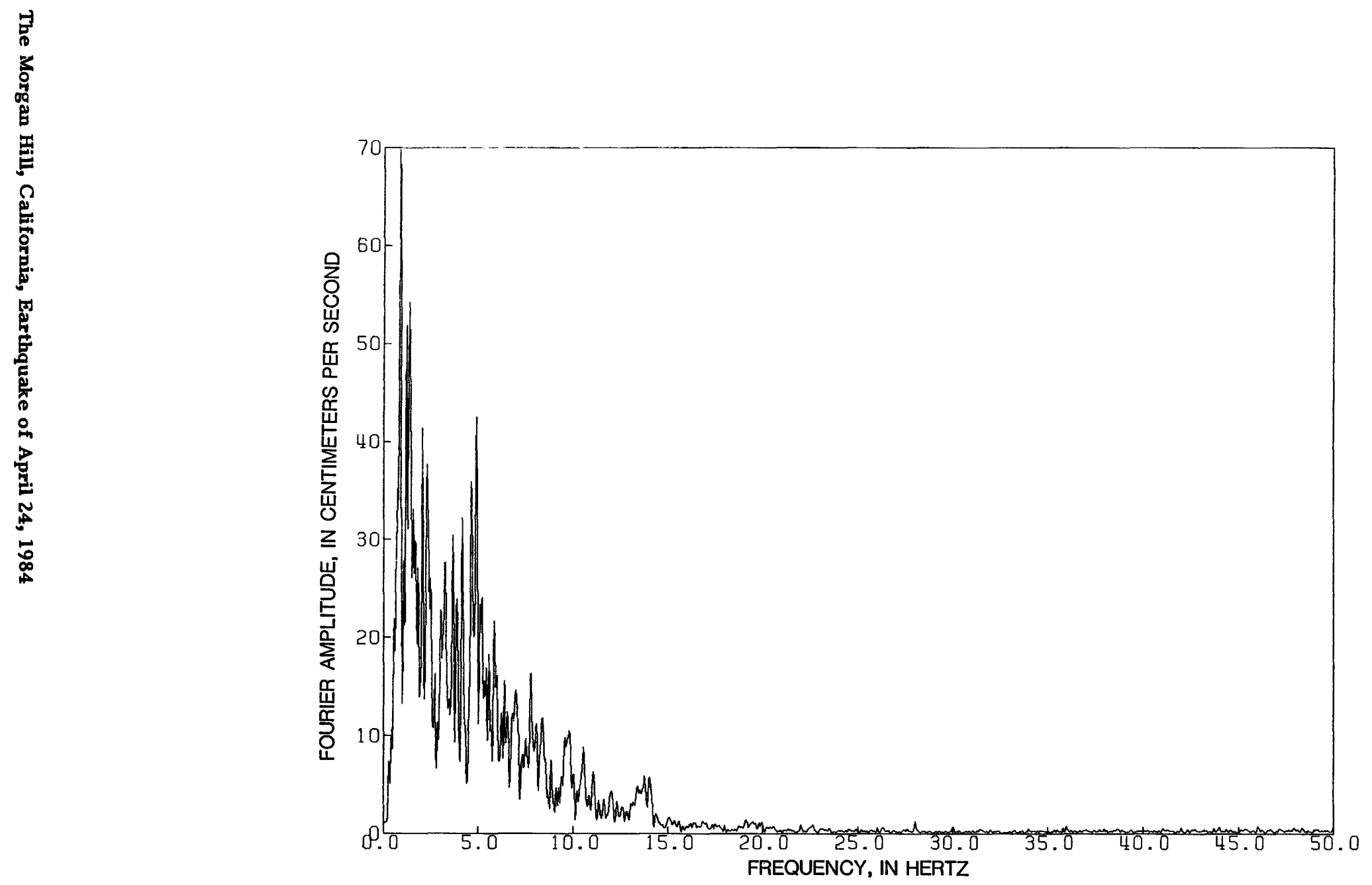

Figure 19.92. Fourier amplitude spectrum of acceleration at the Hollister Differential Array (SMA-1T, $165^{\circ}$ component) for the April 24 earthquake, using a Nyquist filter $(0.25 \mathrm{~Hz}$, order 8) bandpassed with a cosine taper from 50 to $100 \mathrm{~Hz}$. 


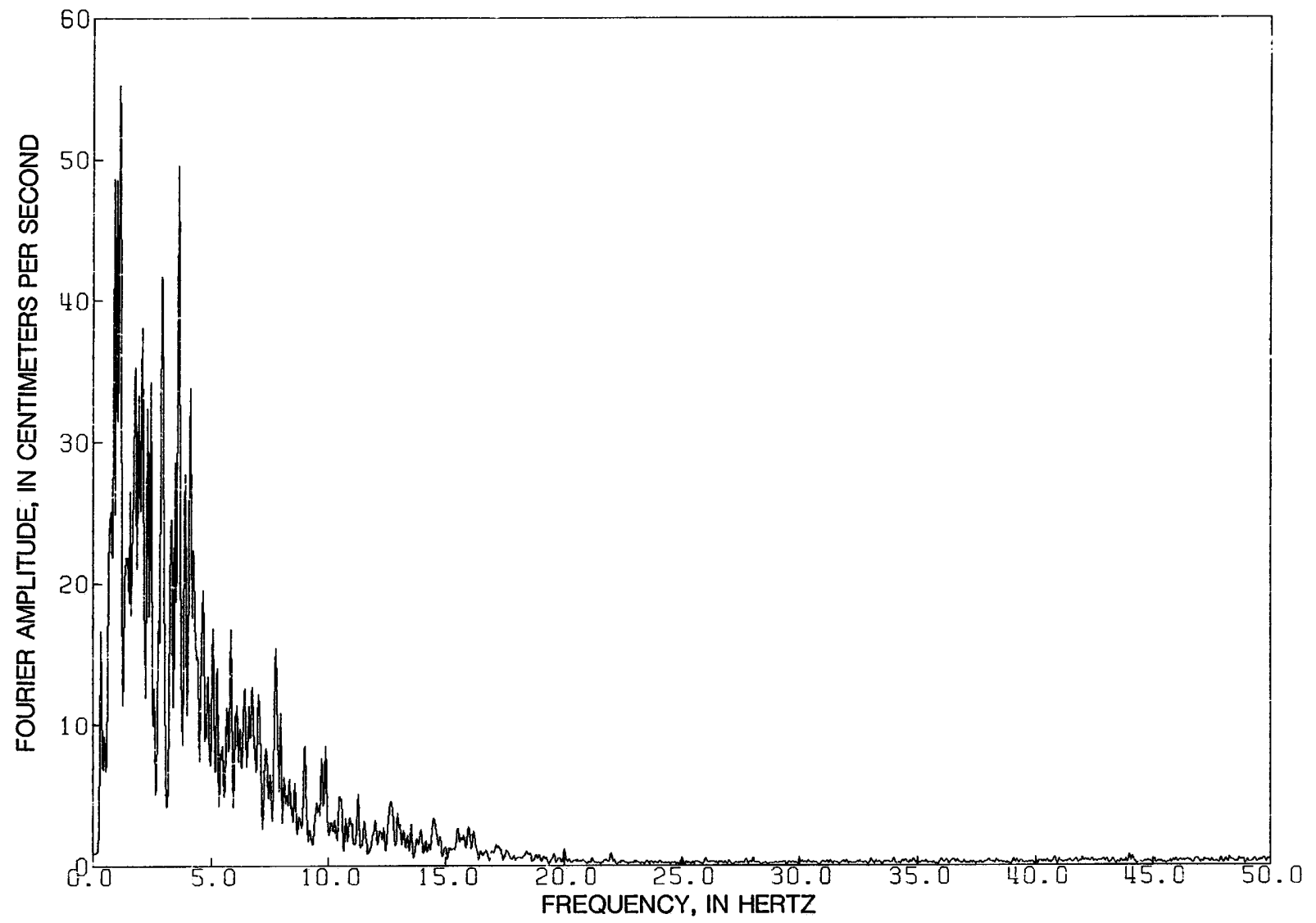

Figure 19.93. Fourier amplitude spectrum of acceleration at the San Justo Damsite, right abutment (dike, $360^{\circ}$ component), for the April 24 earthquake, using a Nyquist filter $(0.25 \mathrm{~Hz}$, order 8$)$ bandpassed with a cosine taper from 50 to $100 \mathrm{~Hz}$. 


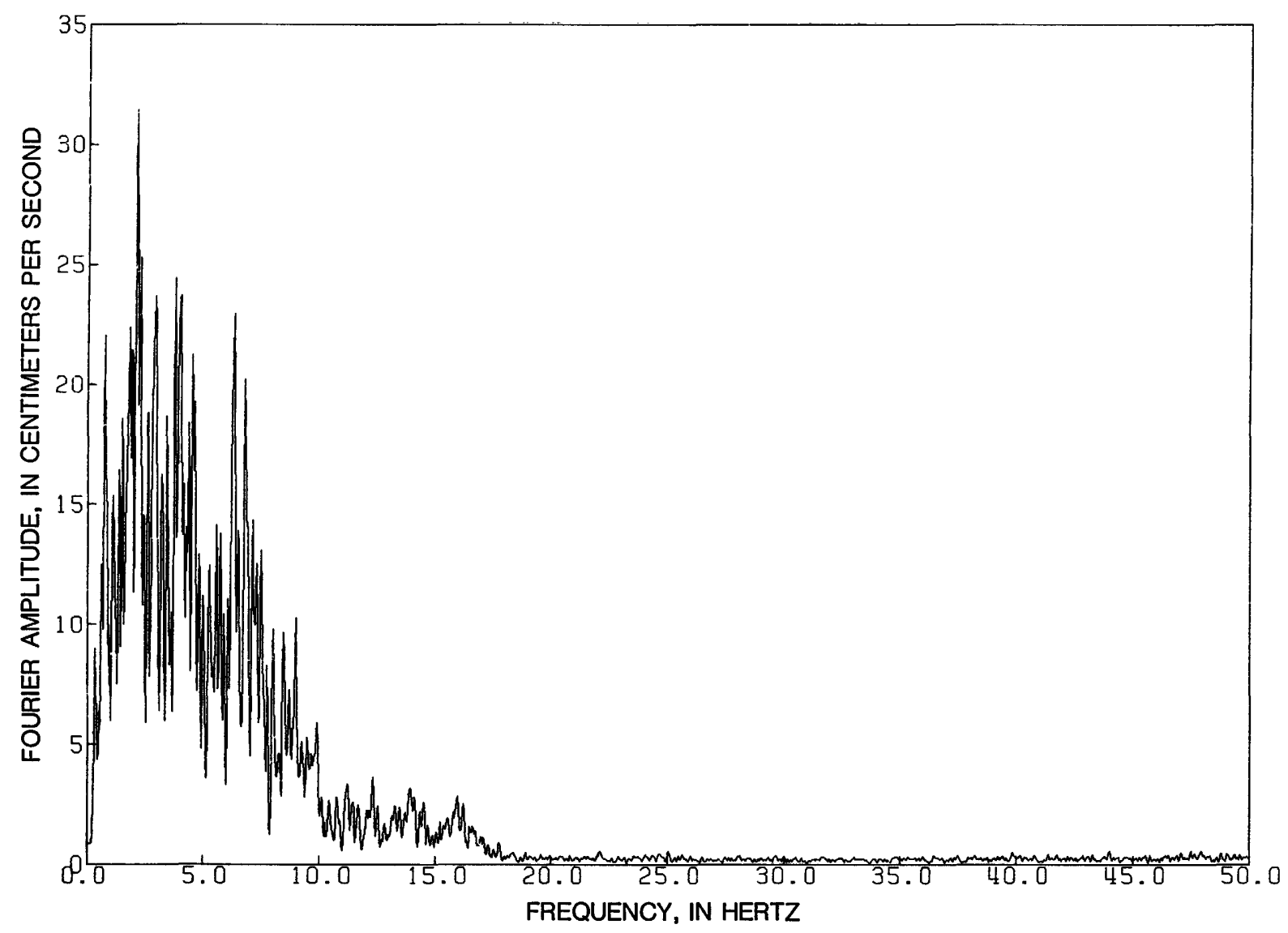

Figure 19.94. Fourier amplitude spectrum of acceleration at the San Justo Damsite, right abutment (dike, up component), for the April 24 earthquake, using a Nyquist filter $(0.25 \mathrm{~Hz}$, order 8 ) bandpassed with a cosine taper from 50 to $100 \mathrm{~Hz}$. 



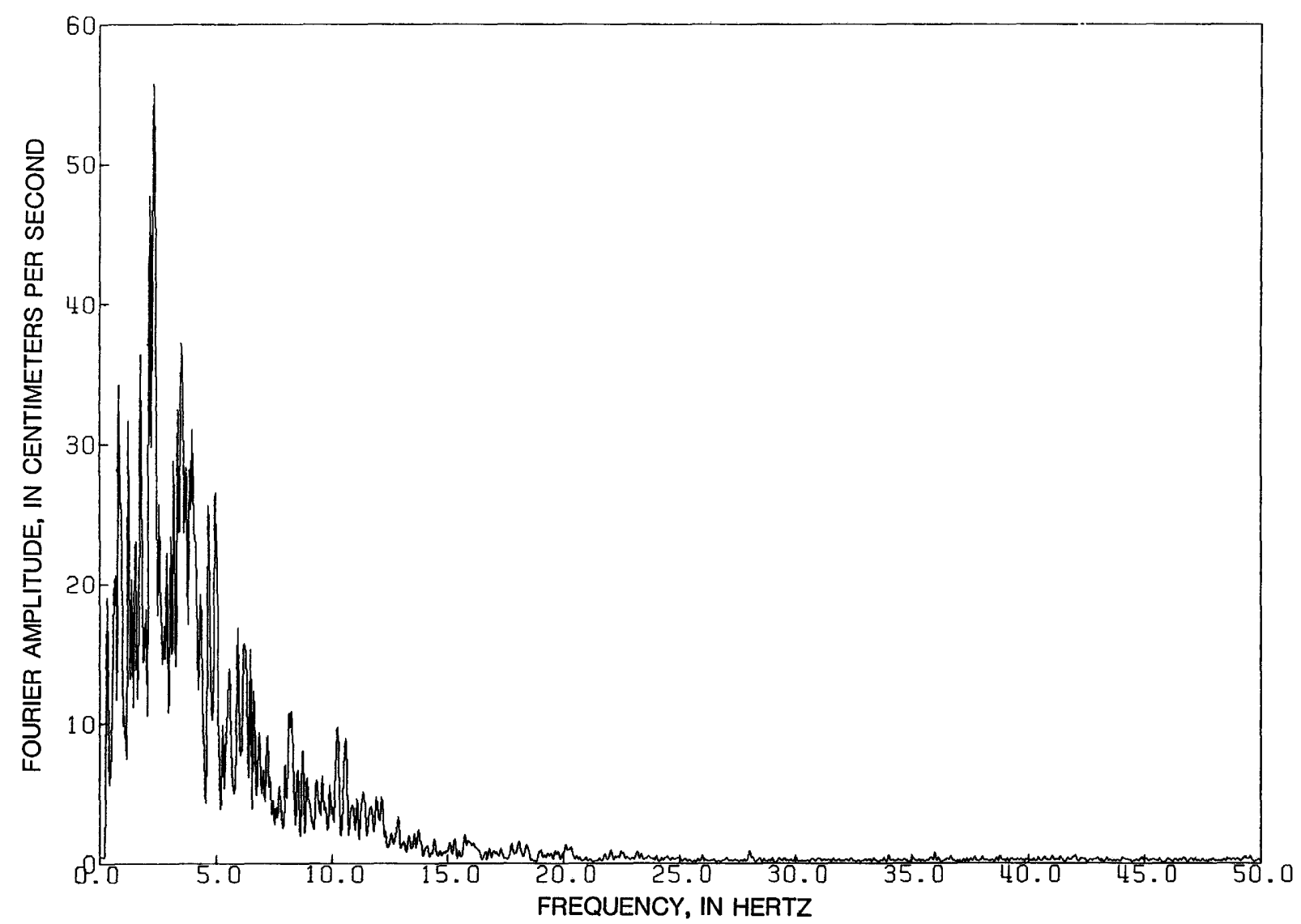

Figure 19.96. Fourier amplitude spectrum of acceleration at the San Justo Damsite, left abutment $\left(360^{\circ}\right.$ component), for the April 24 earthquake, using a Nyquist filter $(0.25 \mathrm{~Hz}$, order 8) bandpassed with a cosine taper from 50 to $100 \mathrm{~Hz}$. 



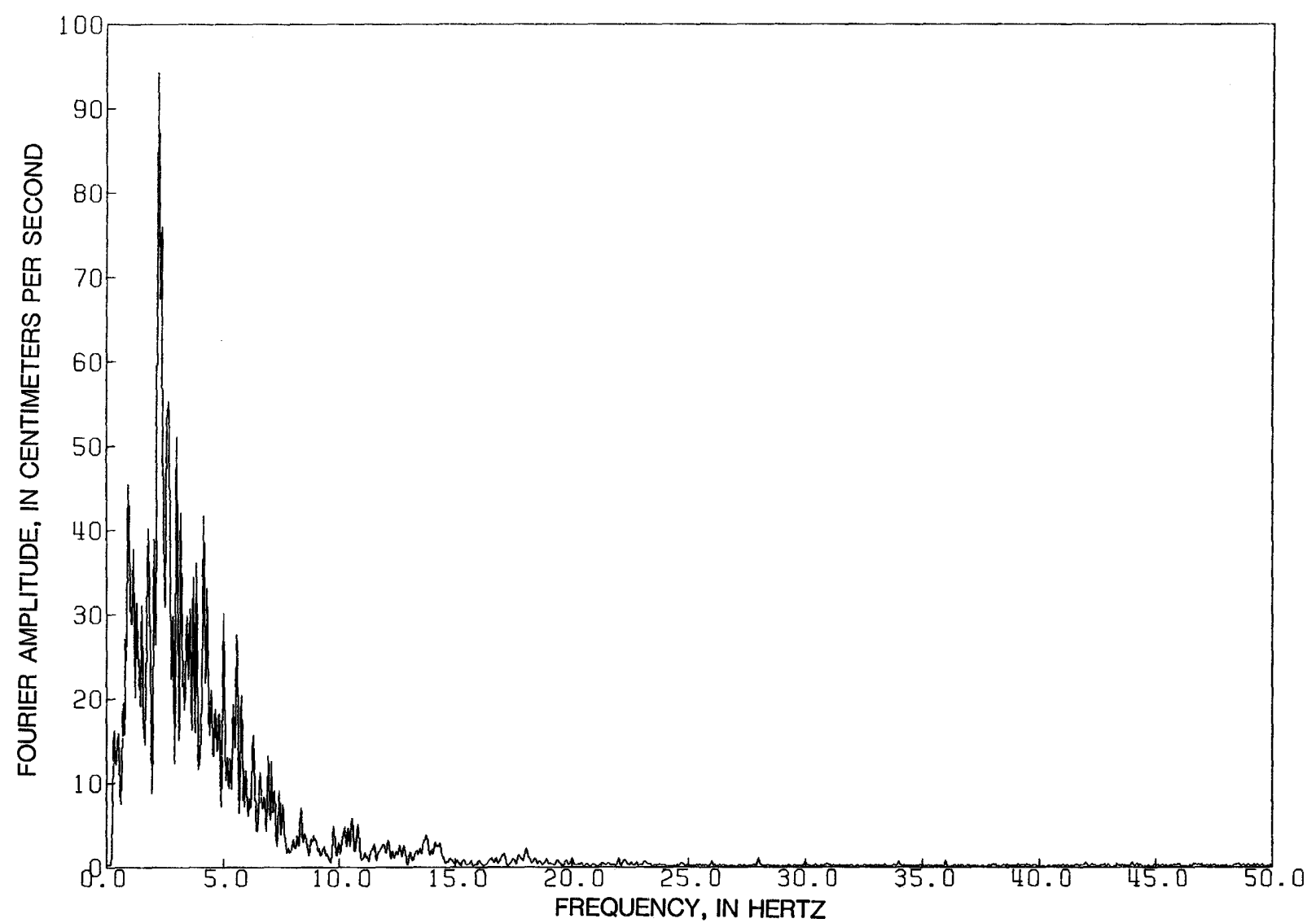

Figure 19.98. Fourier amplitude spectrum of acceleration at the San Justo Damsite, left abutment $\left(270^{\circ}\right.$ component), for the April 24 earthquake, using a Nyquist filter $(0.25 \mathrm{~Hz}$, order 8) bandpassed with a cosine taper from 50 to $100 \mathrm{~Hz}$. 


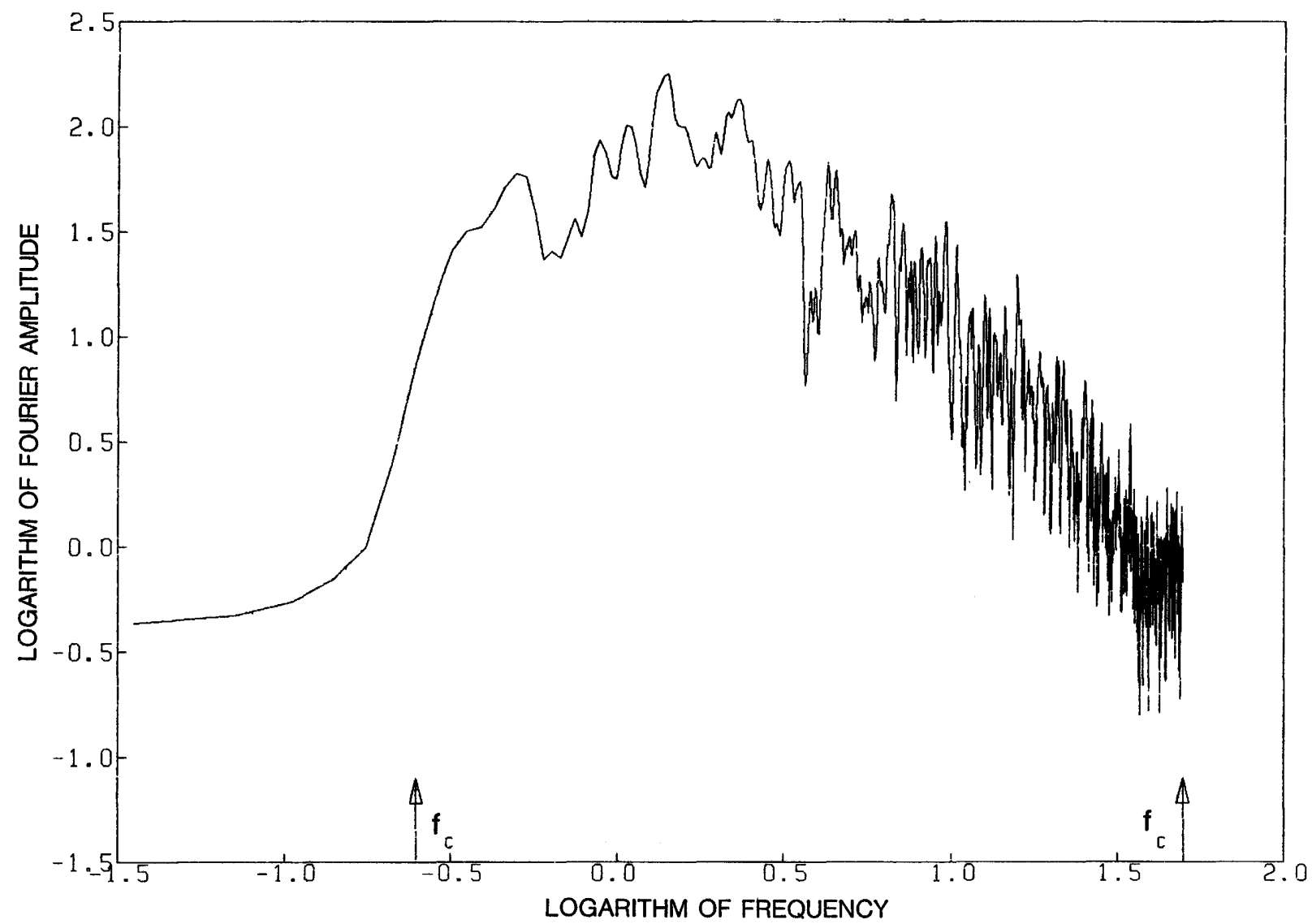

Figure 19.99. Log-log plot of Fourier amplitude spectrum of acceleration at the Anderson Dam, downstream $\left(340^{\circ}\right.$ component), for the April 24 earthquake, using a Nyquist filter $(0.25 \mathrm{~Hz}$, order 8) bandpassed with a cosine taper from 50 to $100 \mathrm{~Hz}$. $\underline{f}_{c}$, corner frequency. 


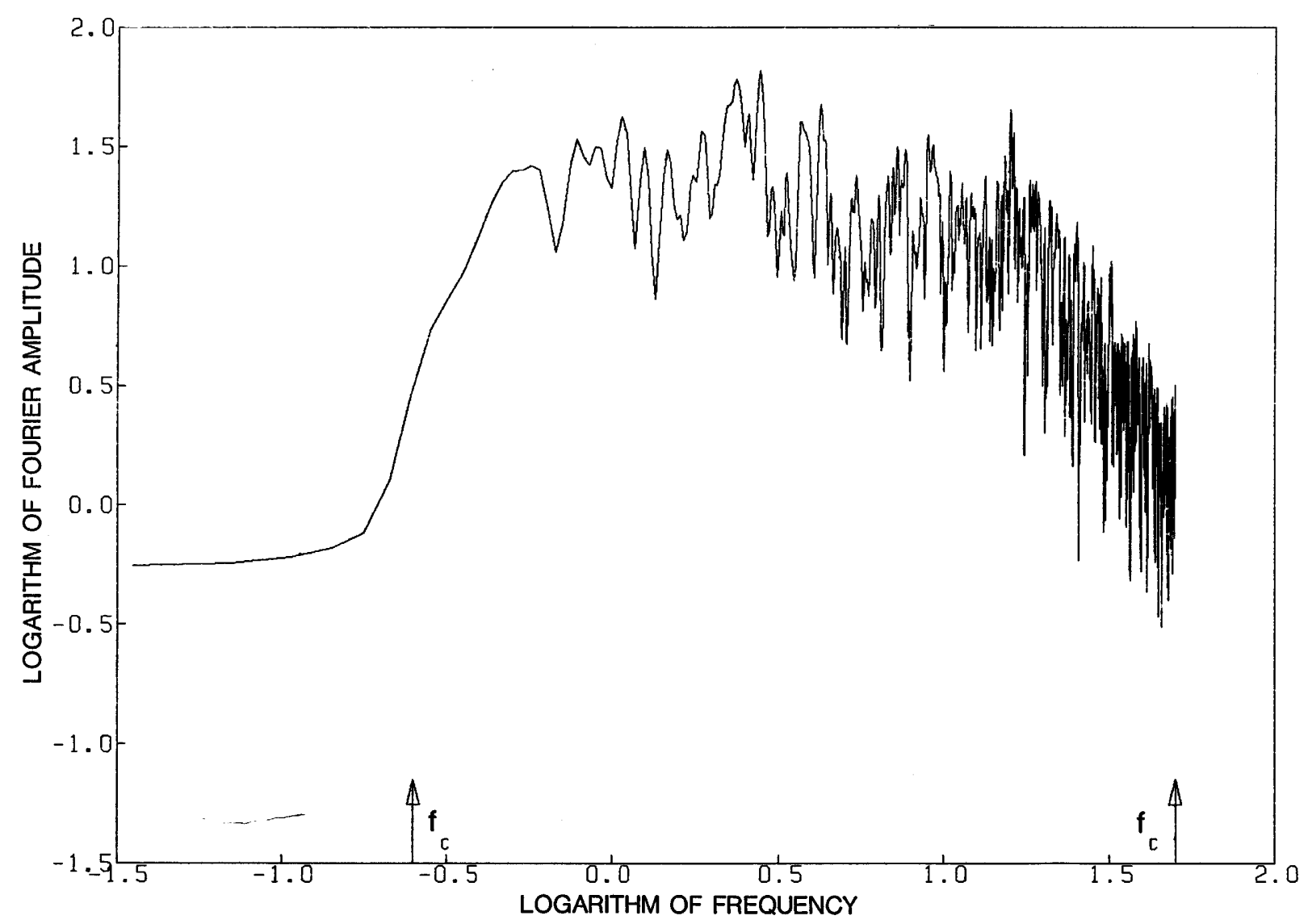

Figure 19.100. Log-log plot of Fourier amplitude spectrum of acceleration at the Anderson Dam, downstream (up component), for the April 24 earthquake, using a Nyquist filter $(0.25 \mathrm{~Hz}$, order 8) bandpassed with a cosine taper from 50 to $100 \mathrm{~Hz}$. $\underline{f}_{c}$, corner frequency. 


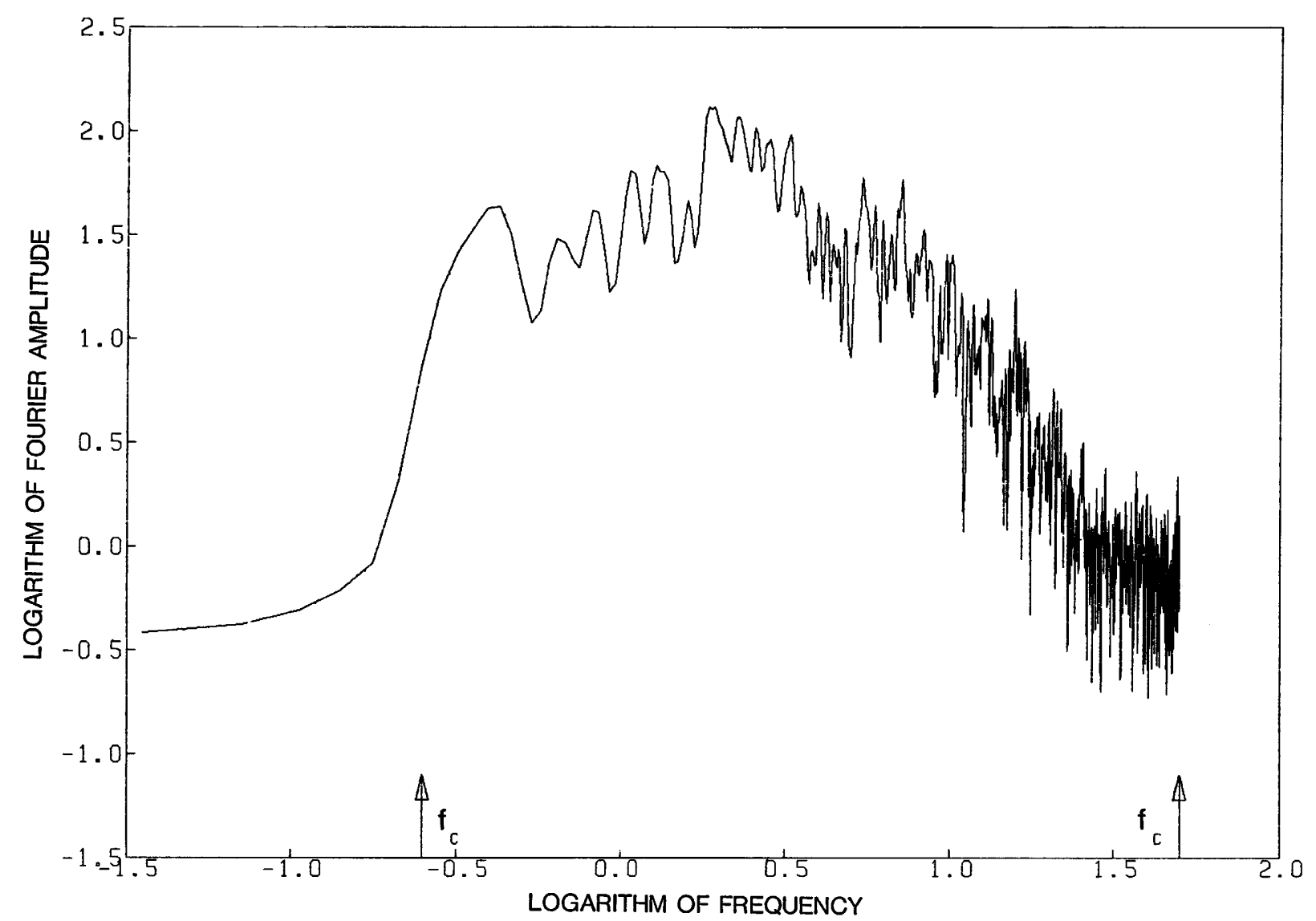

Figure 19.101. Log-log plot of Fourier amplitude spectrum of acceleration at the Anderson Dam, downstream $\left(250^{\circ}\right.$ component), for the April 24 earthquake, using a Nyquist filter $(0.25 \mathrm{~Hz}$, order 8$)$ bandpassed with a cosine taper from 50 to $100 \mathrm{~Hz}$. $\underline{f}_{c}$, corner frequency. 


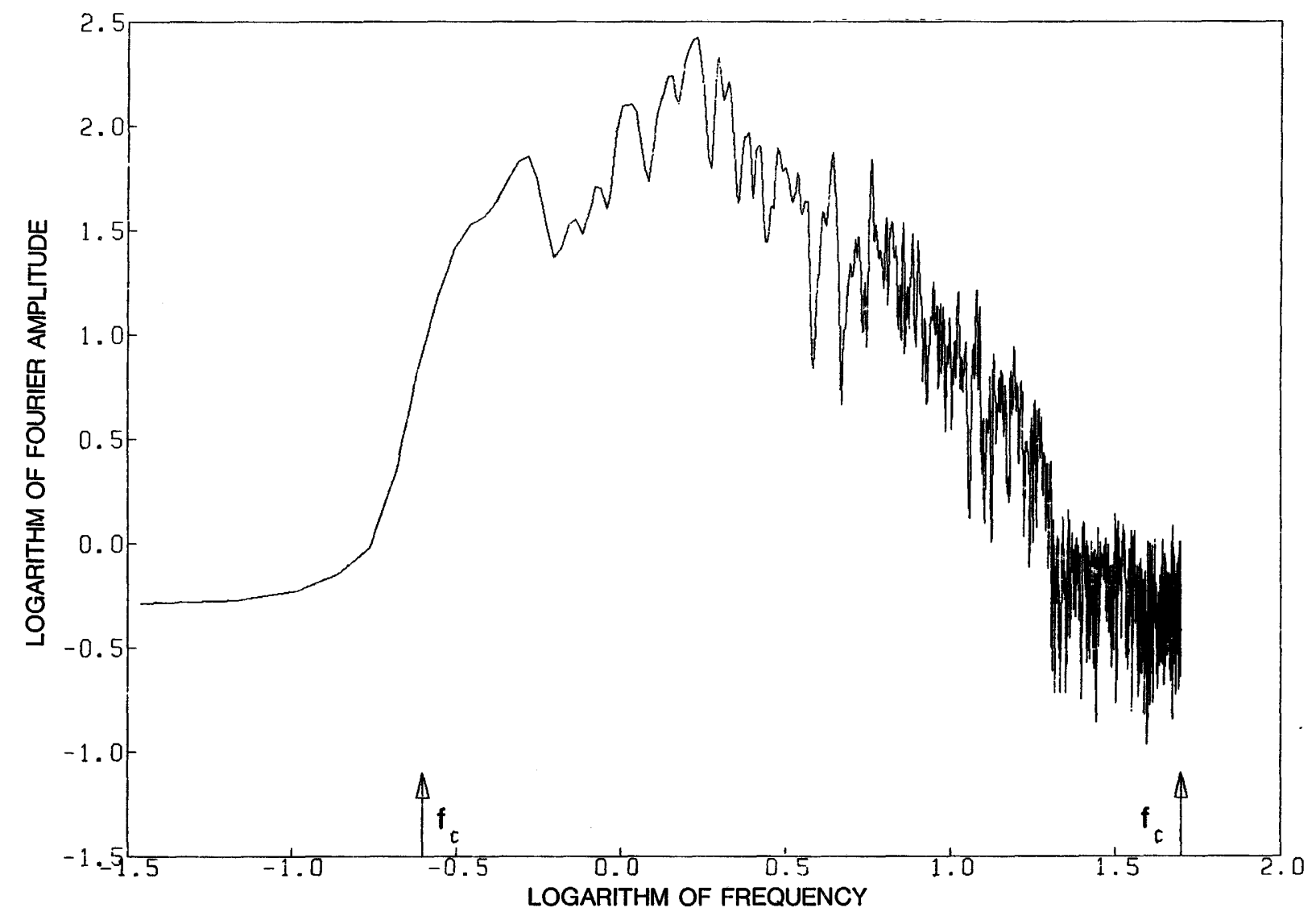

Figure 19.102. Log-log plot of Fourier amplitude spectrum of acceleration at the Anderson Dam, crest $\left(340^{\circ}\right.$ component), for the April 24 earthquake, using a Nyquist filter $(0.25 \mathrm{~Hz}$, order 8$)$ bandpassed with a cosine taper from 50 to $100 \mathrm{~Hz}$. $\underline{f}_{c}$, corner frequency. 


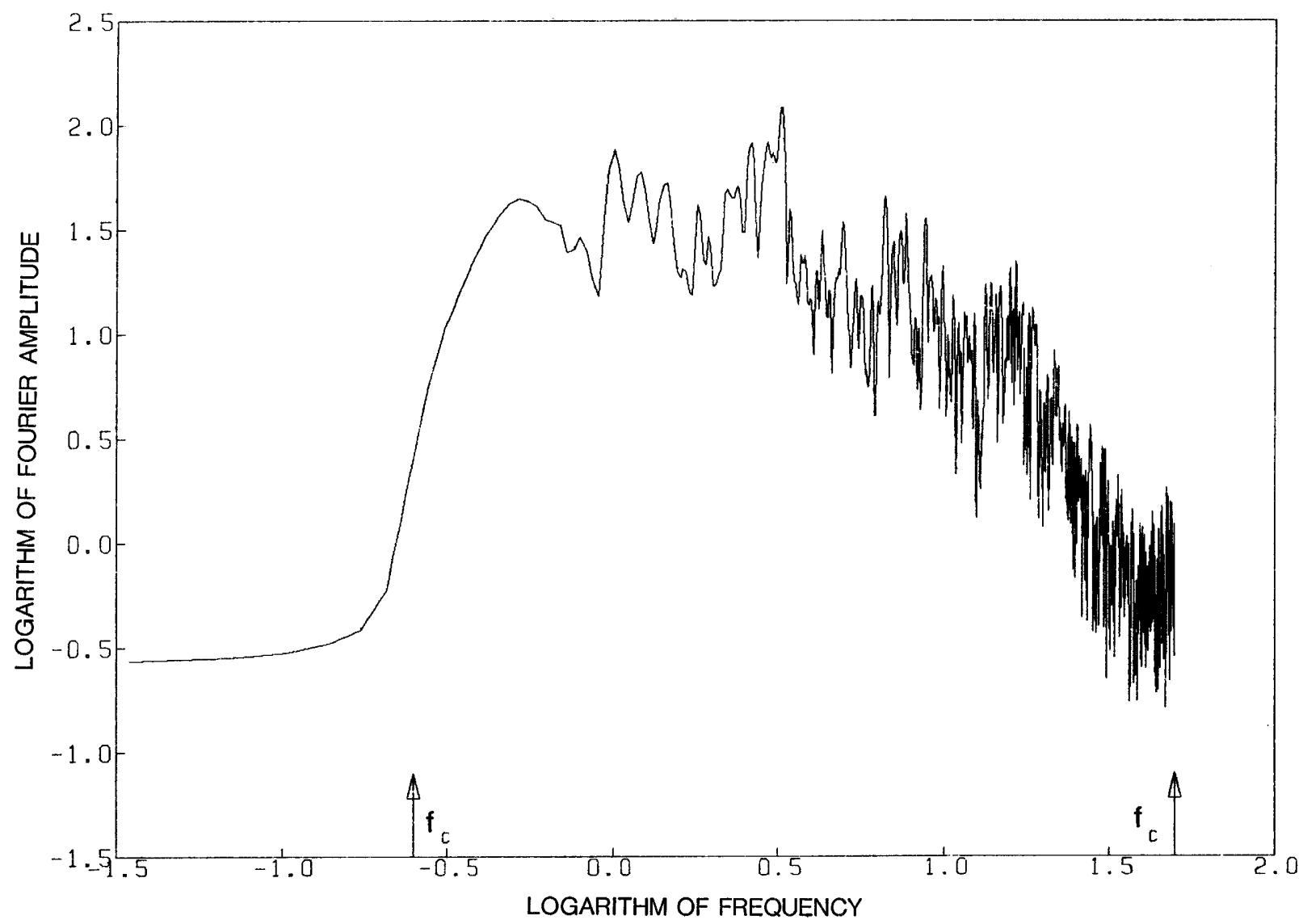

Figure 19.103. Log-log plot of Fourier amplitude spectrum of acceleration at the Anderson Dam, crest (up component), for the April 24 earthquake, using a Nyquist filter $(0.25 \mathrm{~Hz}$, order 8 ) bandpassed with a cosine taper from 50 to $100 \mathrm{~Hz}$. $\underline{f}_{c}$, corner frequency. 


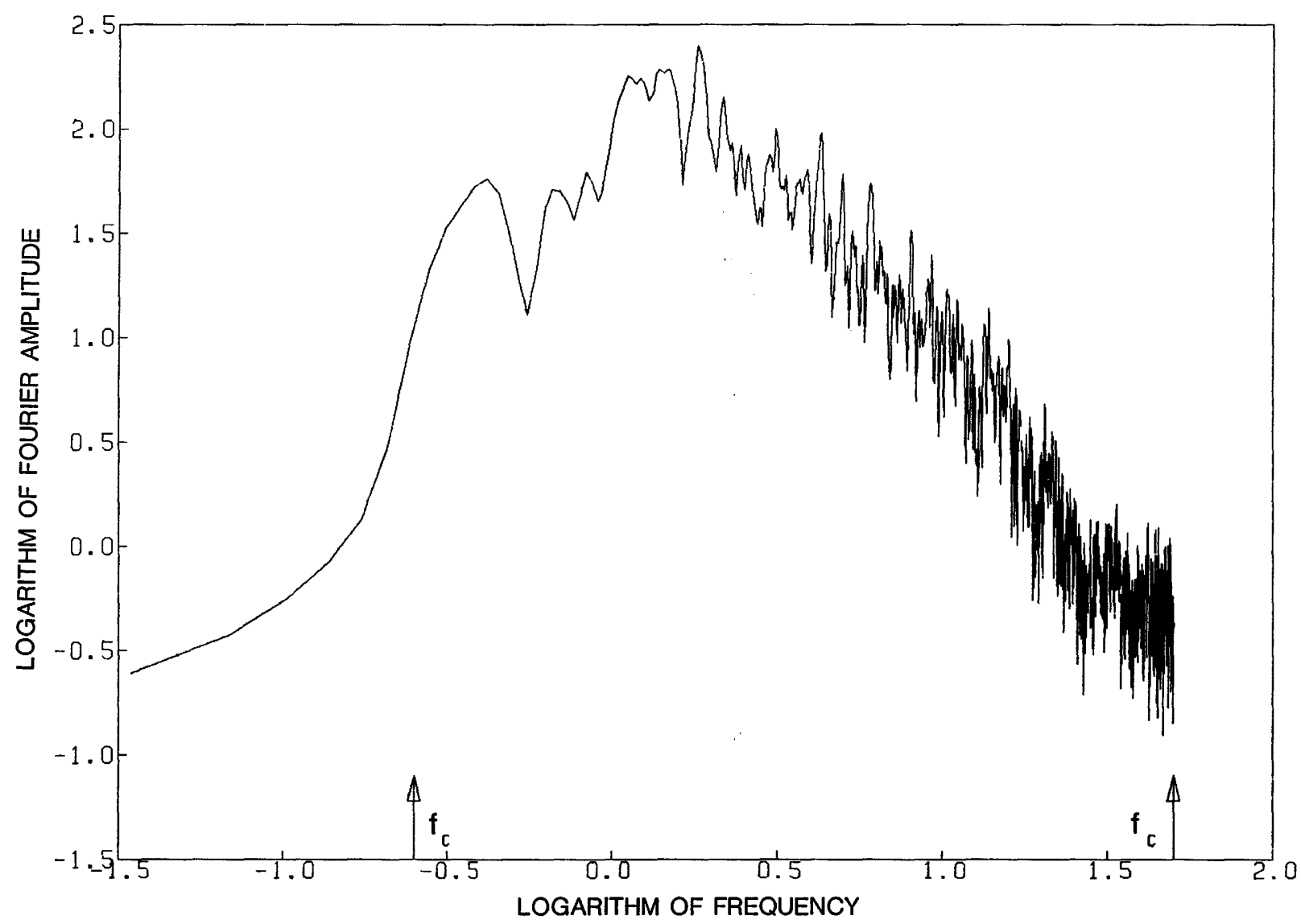

Figure 19.104. Log-log plot of Fourier amplitude spectrum of acceleration at the Anderson Dam, crest $\left(250^{\circ}\right.$ component), for the April 24 earthquake, using a Nyquist filter $(0.25 \mathrm{~Hz}$, order 8$)$ bandpassed with a cosine taper from 50 to $100 \mathrm{~Hz}$. $\underline{f}_{C}$, corner frequency. 


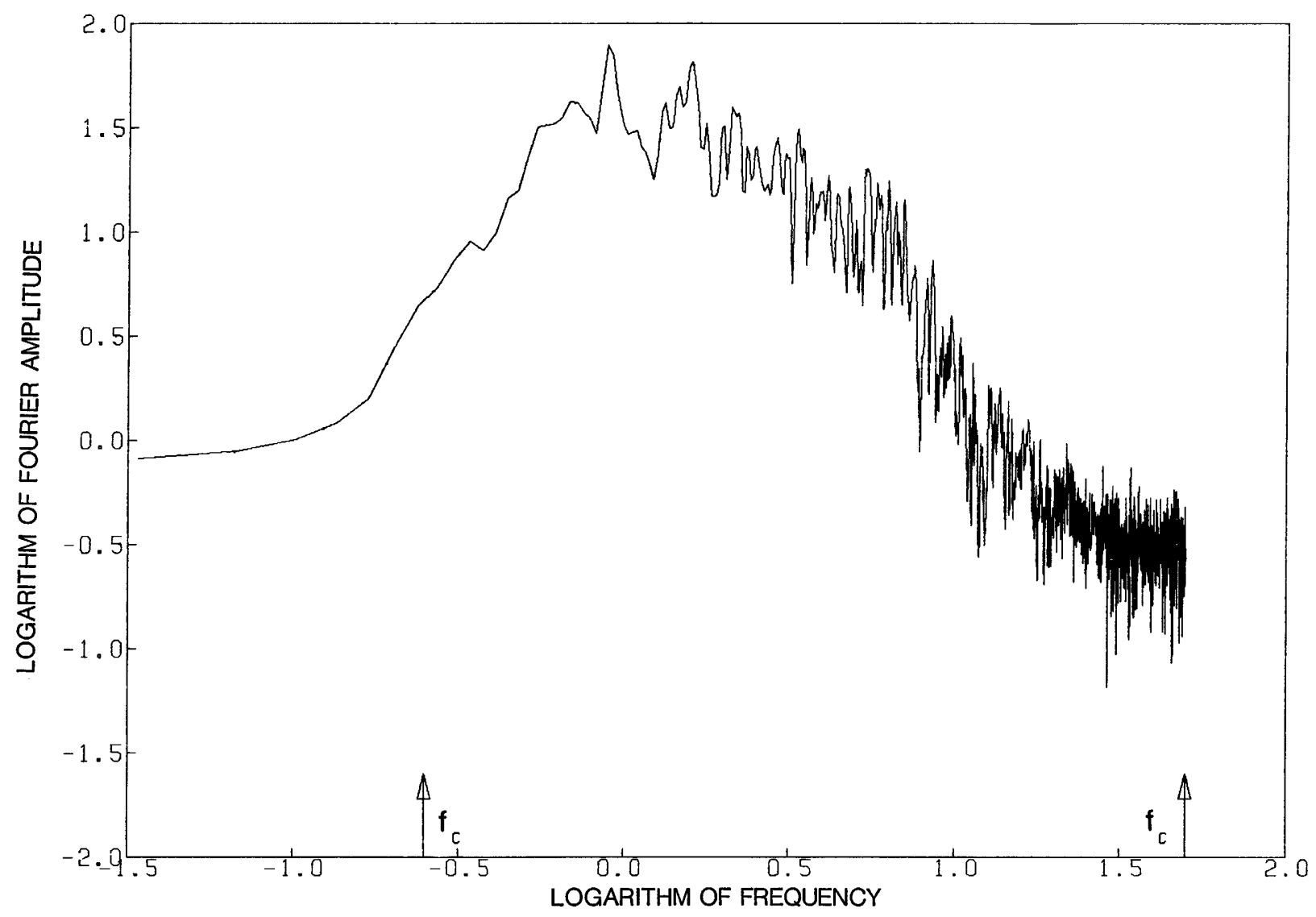

Figure 19.105. Log-log plot of Fourier amplitude spectrum of acceleration at the Hollister City Hall Annex, basement $\left(001^{\circ}\right.$ component), for the April 24 earthquake, using a Nyquist filter $(0.25 \mathrm{~Hz}$, order 8 ) bandpassed with a cosine taper from 50 to $100 \mathrm{~Hz}$. $\underline{f}_{c}$, corner frequency. 


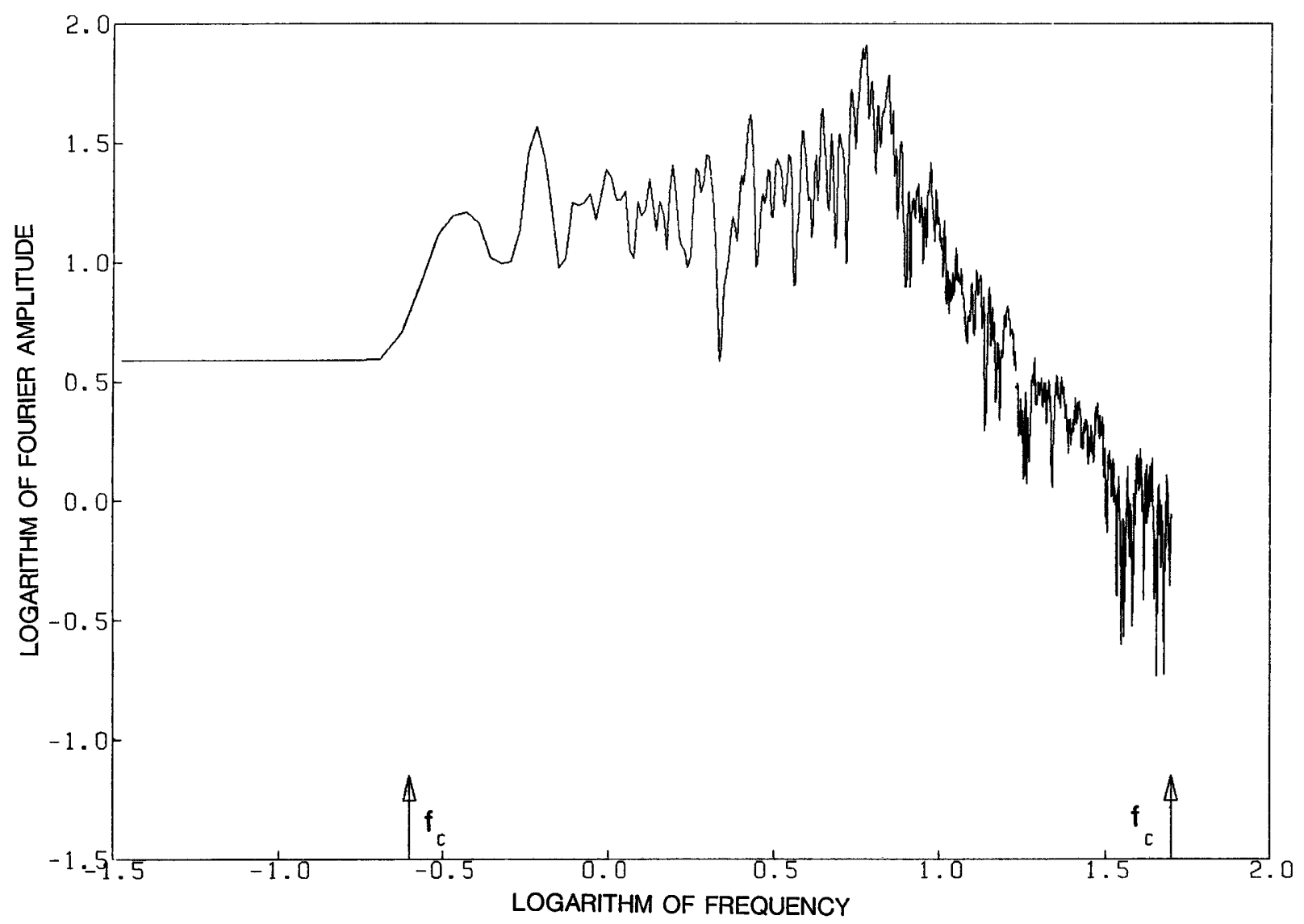

Figure 19.106. Log-log plot of Fourier amplitude spectrum of acceleration at the Hollister City Hall Annex, basement (up component), for the April 24 earthquake, using a Nyquist filter $(0.25 \mathrm{~Hz}$, order 8) bandpassed with a cosine taper from 50 to $100 \mathrm{~Hz}$. $\underline{f}_{-}$, corner frequency. 


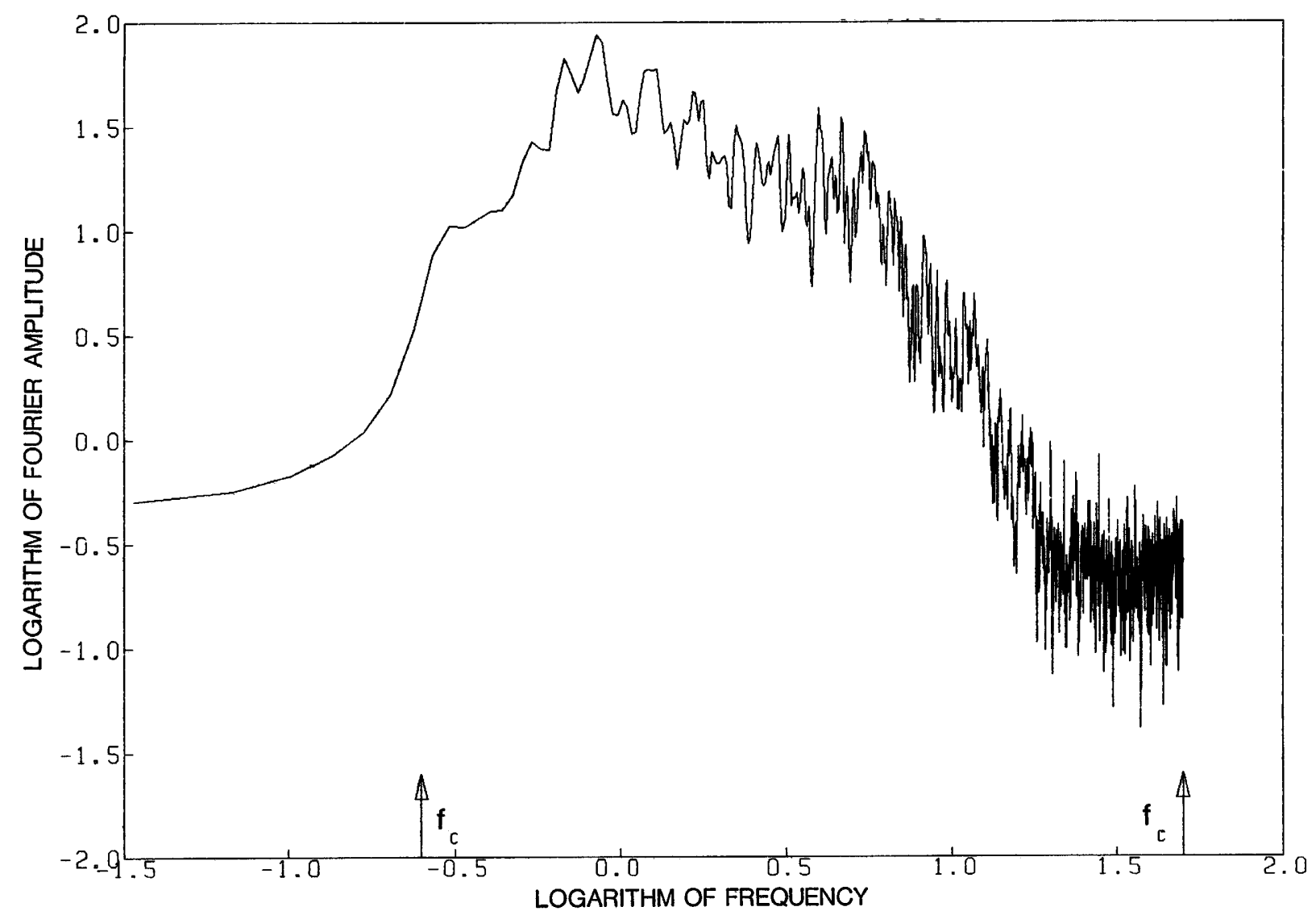

Figure 19.107. Log-log plot of Fourier amplitude spectrum of acceleration at the Hollister City Hall Annex, basement $\left(271^{\circ}\right.$ component), for the April 24 earthquake, using a Nyquist filter $(0.25 \mathrm{~Hz}$, order 8) bandpassed with a cosine taper from 50 to $100 \mathrm{~Hz}$. $\underline{f}_{-}$, corner frequency. 


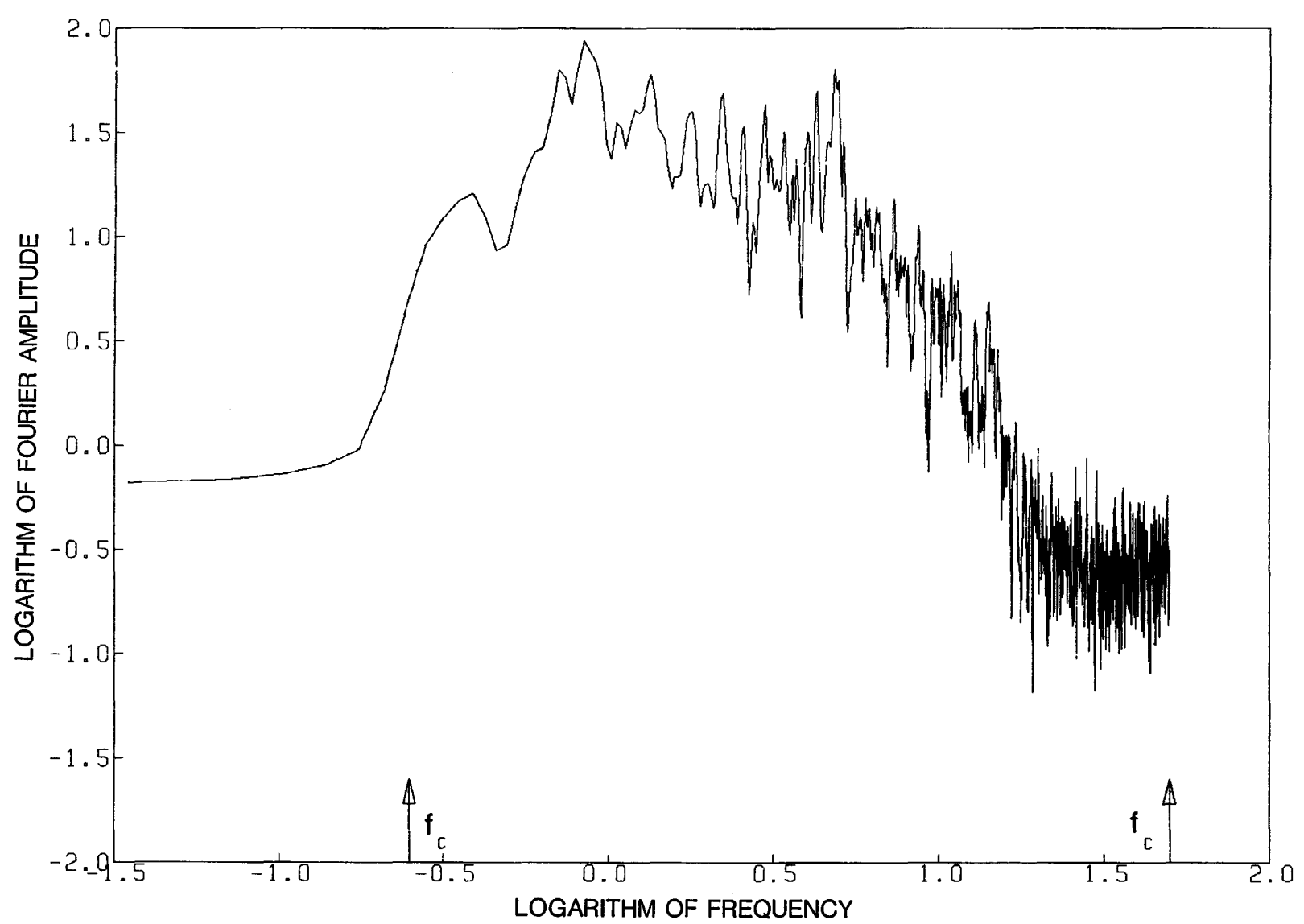

Figure 19.108. Log-log plot of Fourier amplitude spectrum of acceleration at the Hollister Differential Array (SMA-1T, $255^{\circ}$ component) for the April 24 earthquake, using a Nyquist filter $(0.25 \mathrm{~Hz}$, order 8) bandpassed with a cosine taper from 50 to $100 \mathrm{~Hz}$. $\underline{f}_{C}$, corner frequency. 


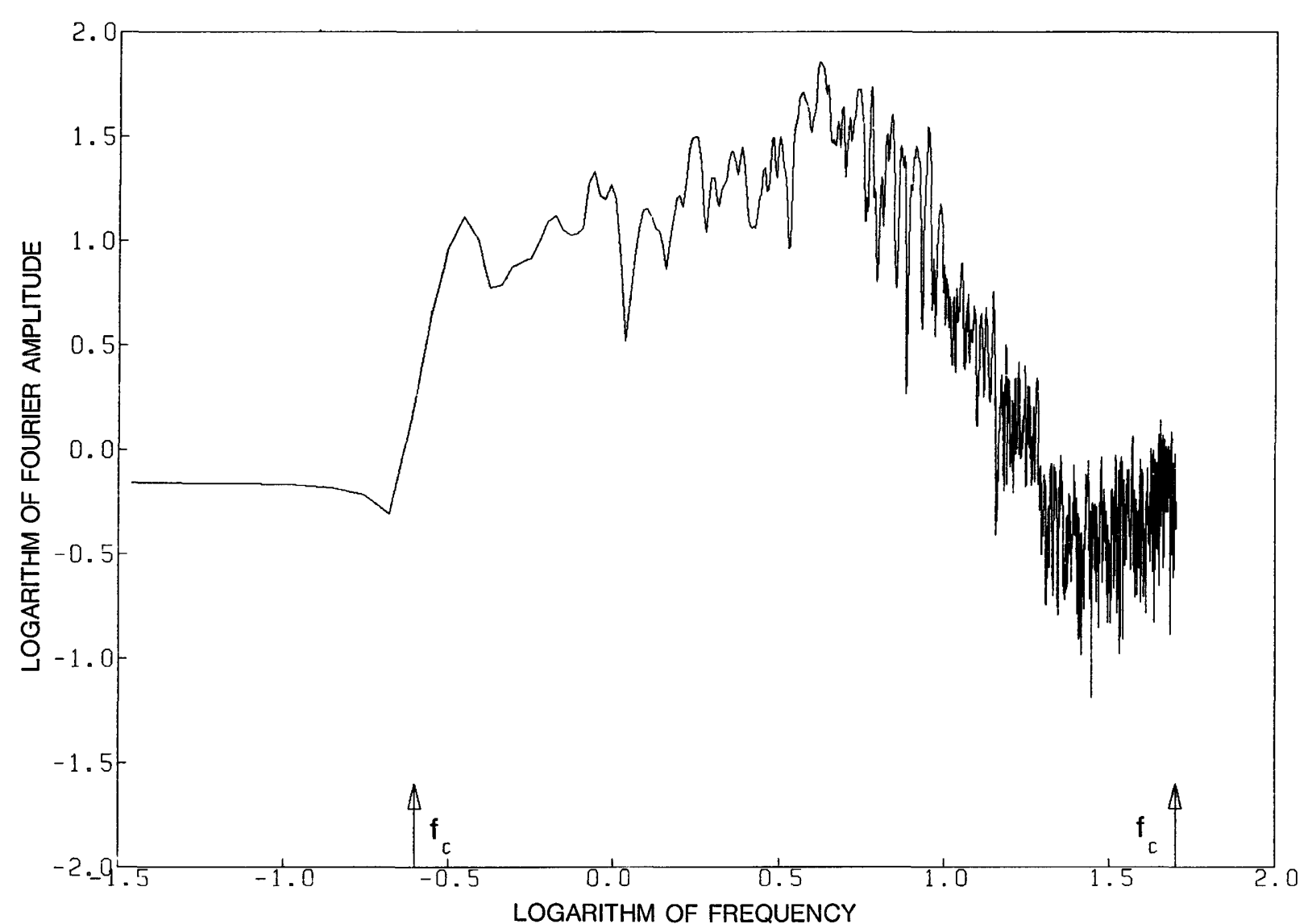

Figure 19.109. Log-log plot of Fourier amplitude spectrum of acceleration at the Hollister Differential Array (SMA-1T, up component) for the April 24 earthquake, using a Nyquist filter $(0.25 \mathrm{~Hz}$, order 8) bandpassed with a cosine taper from 50 to $100 \mathrm{~Hz}$. $\underline{f}_{c}$, corner frequency. 


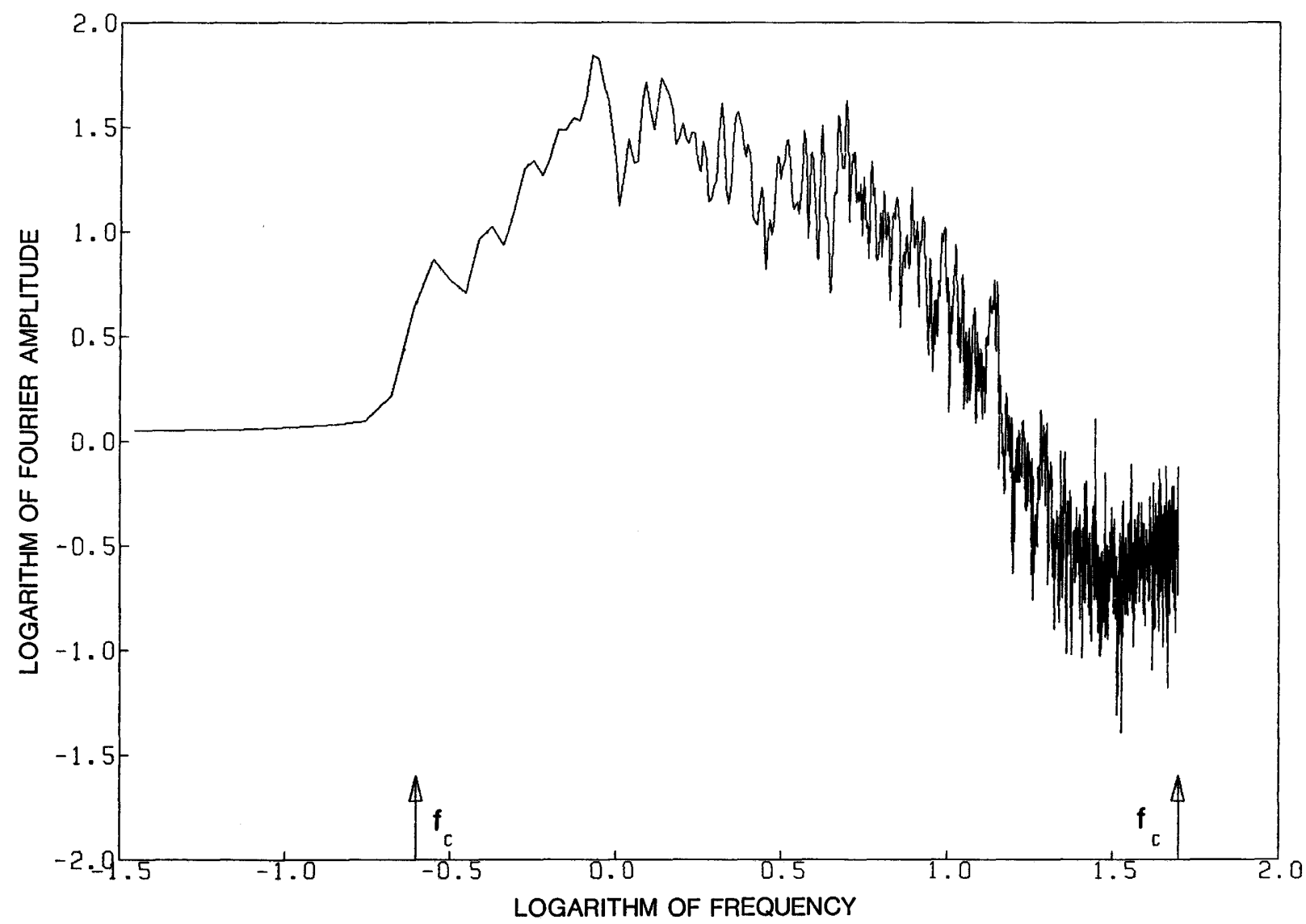

Figure 19.110. Log-log plot of Fourier amplitude spectrum of acceleration at the Hollister Differential Array (SMA-1T, $165^{\circ}$ component) for the April 24 earthquake, using a Nyquist filter $(0.25 \mathrm{~Hz}$, order 8 ) bandpassed with a cosine taper from 50 to $100 \mathrm{~Hz}$. $\underline{f}_{c}$, corner frequency. 


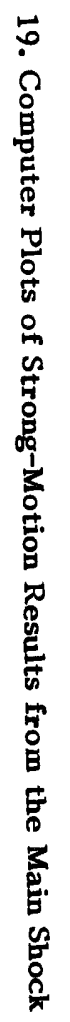

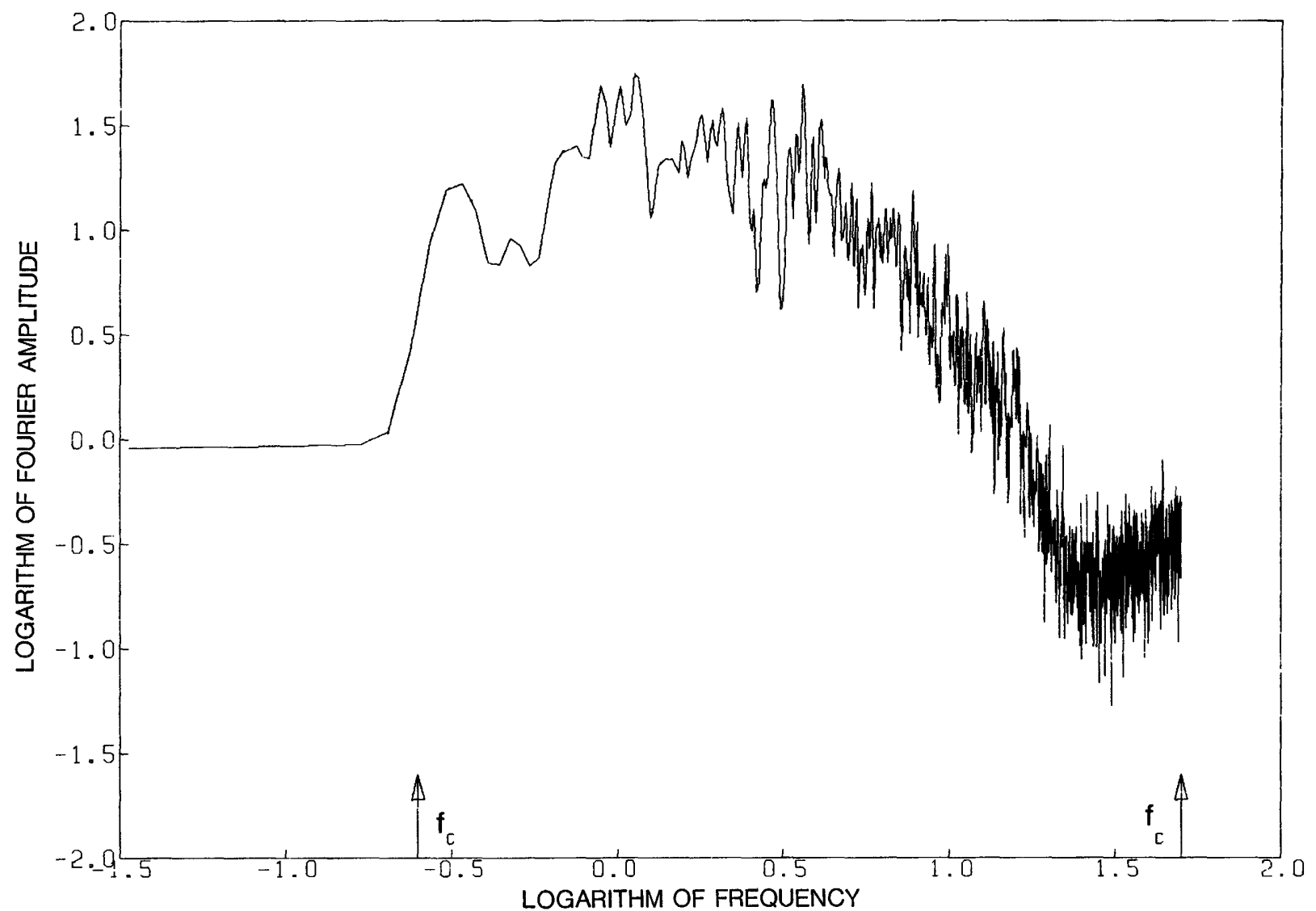

Figure 19.111. Log-log plot of Fourier amplitude spectrum of acceleration at the San Just Damsite, right abutment (dike, $360^{\circ}$ component), for the April 24 earthquake, using a Nyquist filter $(0.25 \mathrm{~Hz}$, order 8) bandpassed with a cosine taper from 50 to $100 \mathrm{~Hz}$. $f_{C}$, corner frequency.

$\mathfrak{N}$ 


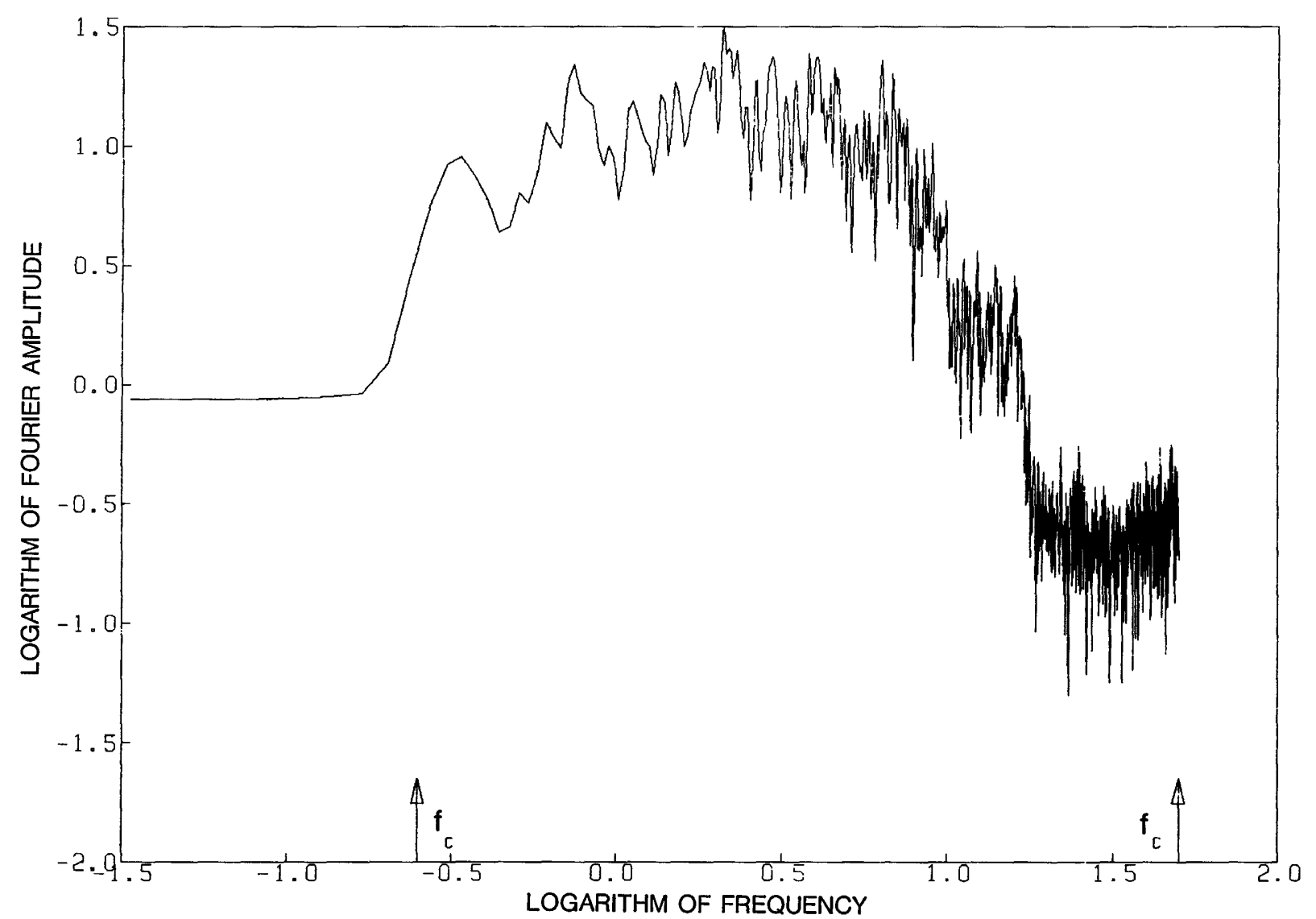

Figure 19.112. Log-log plot of Fourier amplitude spectrum of acceleration at the San Justo Damsite, right abutment (dike, up component), for the April 24 earthquake, using a Nyquist filter $(0.25 \mathrm{~Hz}$, order 8) bandpassed with a cosine taper from 50 to $100 \mathrm{~Hz}$. $\underline{f}_{c}$, corner frequency. 


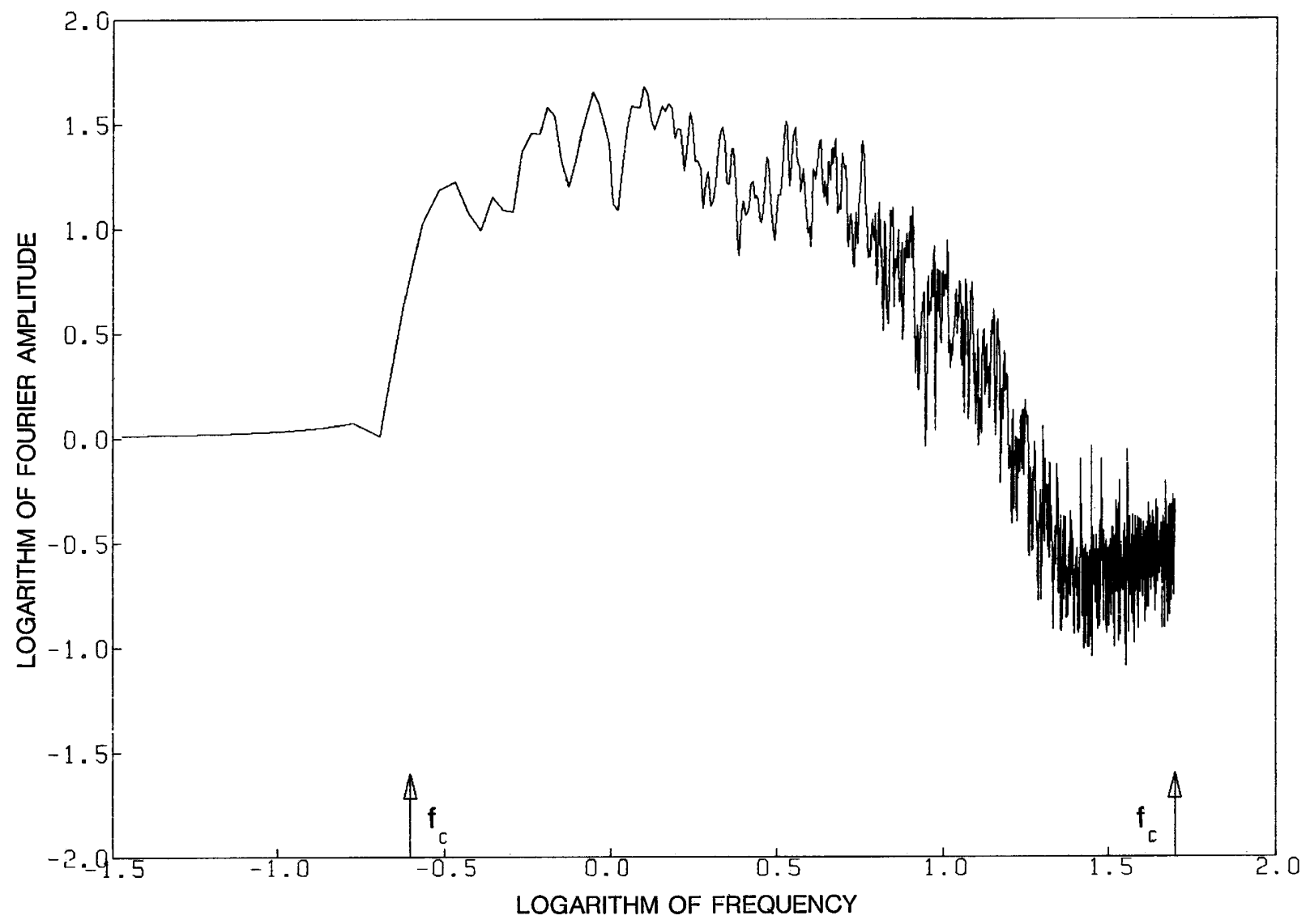

Figure 19.113. Log-log plot of Fourier amplitude spectrum of acceleration at the San Justo Damsite, right abutment (dike, $270^{\circ}$ component), for the April 24 earthquake, using a Nyquist filter $(0.25 \mathrm{~Hz}$, order 8) bandpassed with a cosine taper from 50 to $100 \mathrm{~Hz}$. $\underline{f}_{c}$, corner frequency. 


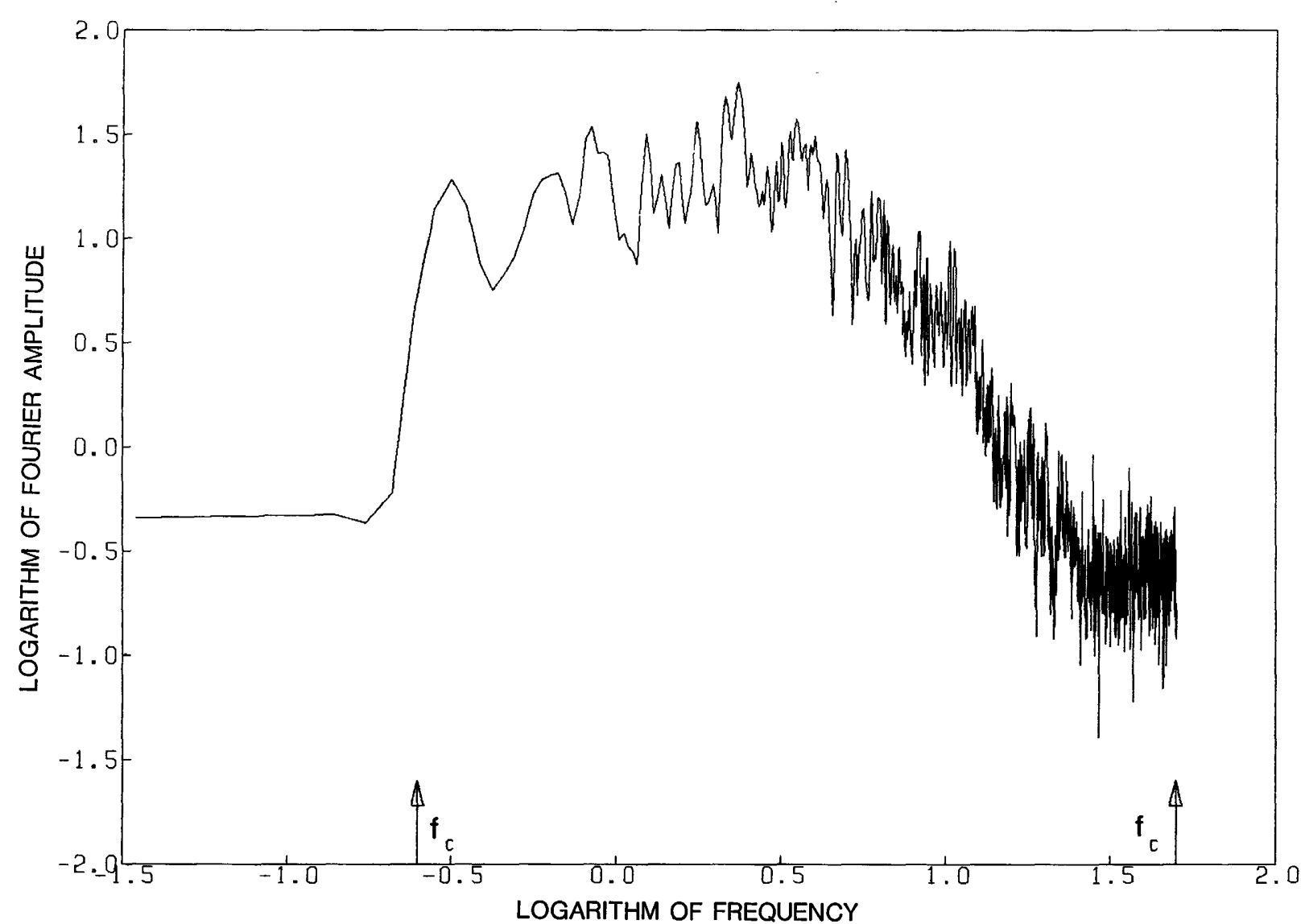

Figure 19.114. Log-log plot of Fourier amplitude spectrum of acceleration at the San Justo Damsite, left abutment $\left(360^{\circ}\right.$ component), for the April 24 earthquake, using a Nyquist filter $(0.25 \mathrm{~Hz}$, order 8) bandpassed with a cosine taper from 50 to $100 \mathrm{~Hz}$. $\underline{f}_{c}$, corner frequency. 


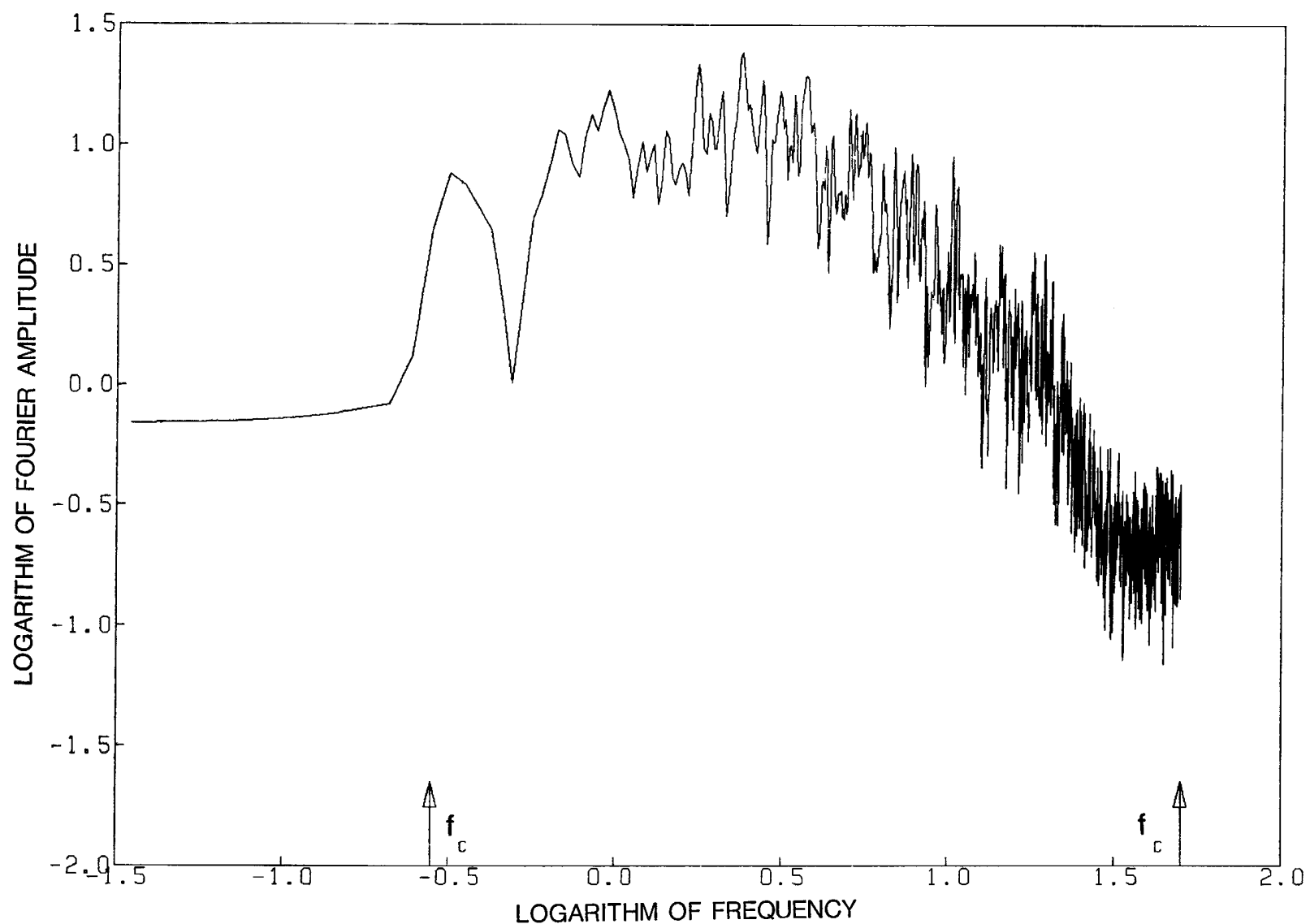

Figure 19.115. Log-log plot of Fourier amplitude spectrum of acceleration at the San Justo Damsite, left abutment (up component), for the April 24 earthquake, using a Nyquist filter $(0.25 \mathrm{~Hz}$, order 8) bandpassed with a cosine taper from 50 to $100 \mathrm{~Hz}$. $\underline{f}_{c}$, corner frequency. 


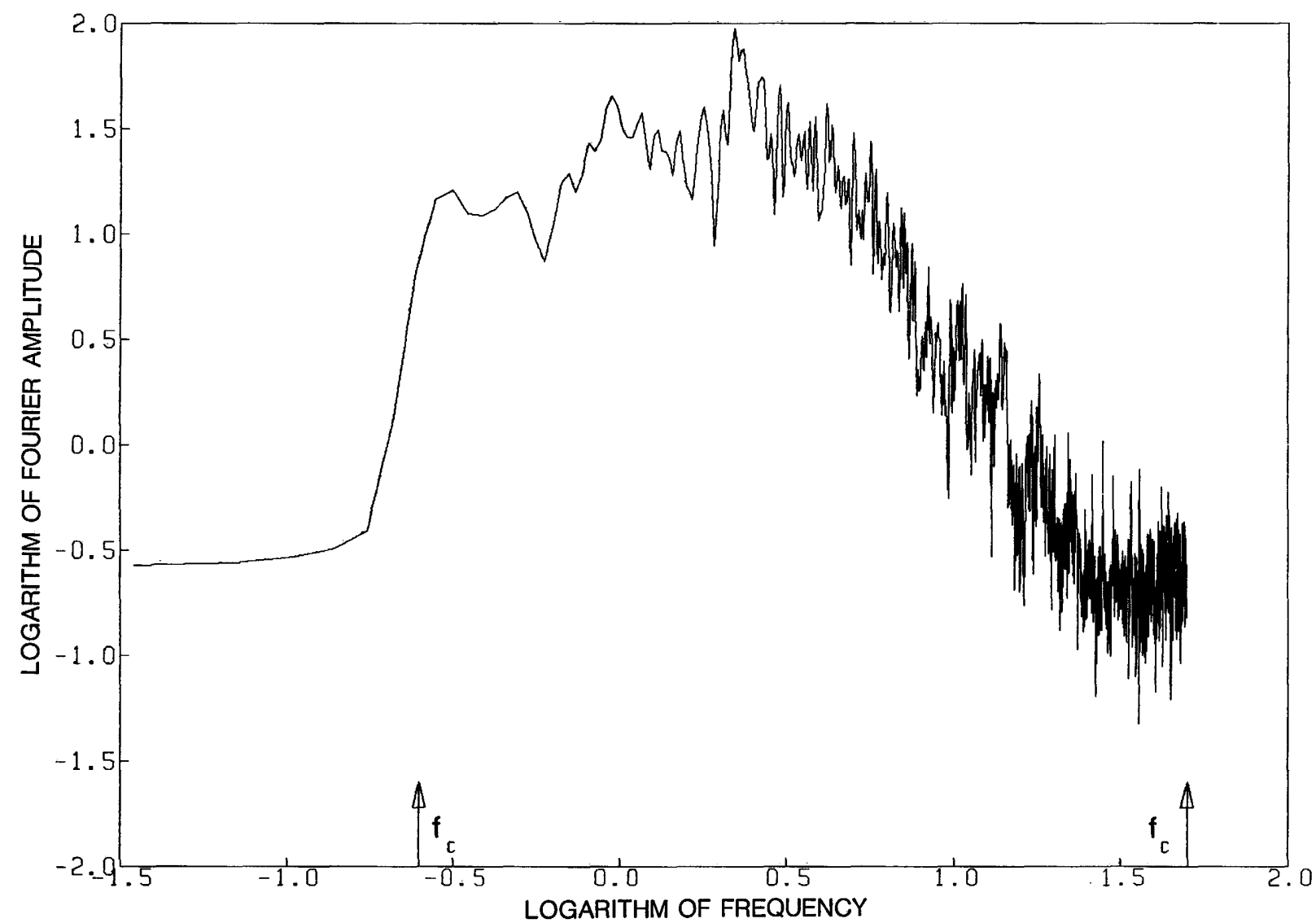

Figure 19.116. Log-log plot of Fourier amplitude spectrum of acceleration at the San Justo Damsite, left abutment $\left(270^{\circ}\right.$ component), for the April 24 earthquake, using a Nyquist filter $(0.25 \mathrm{~Hz}$, order 8$)$ bandpassed with a cosine taper from 50 to $100 \mathrm{~Hz}$. $\underline{f}_{c}$, corner frequency. 